FORDING THE SEVERN: THE INFLUENCE OF INTERMARRIAGE AND JUDICIAL PARTICIPATION ON WELSH IDENTITY AND SELF-IDENTIFICATION IN SHROPSHIRE AND THE CENTRAL MARCH OF WALES IN THE TWELFTH AND THIRTEENTH CENTURIES

A Dissertation
presented to
the Faculty of the Graduate School
at the University of Missouri-Columbia
In Partial Fulfillment
of the Requirements for the Degree
Doctor of Philosophy
ALEXIS MILLER
Dr. Lois Huneycutt, Dissertation Supervisor
MAY, 2018




\section{APPROVAL}

The undersigned, appointed by the dean of the Office of Graduate Studies, have examined the thesis entitled

Fording the Severn: The Influence of Intermarriage and Judicial Participation on Welsh Identity and Self-Identification in Shropshire and the Central March of Wales in the Twelfth and Thirteenth Centuries

presented by Alexis Michele Miller, a candidate for the degree of doctor of philosophy and hereby certify that, in their opinion, it is worthy of acceptance.

Professor Lois Huneycutt

Professor A. Mark Smith

Professor Russell Zguta

Professor John Frymire

Professor Emma Lipton 


\section{ACKNOWLEDGEMENTS}

This dissertation would not have been possible without the financial and academic support of a multitude of people and organizations. I would like to begin by thanking the Department of History at the University of Missouri for their willingness to support my research and aid me in my journey through the $\mathrm{PhD}$ process. I am very grateful to the William A. Wilcher and the Charles and Jean Nauert endowments for their willingness to financially support me as I traveled to England and Wales for research. I would like to also express my gratitude for the financial support of the Medieval Academy of America and the Kinder Institute of Constitutional Democracy. Without their generous support I would not have been able to complete research at the Shropshire Archive and the National Library of Wales.

Many people have helped me along the way at conferences and I am very grateful for their offers to read my work and send me sources. Specifically I would like to thank Linda Mitchell from the University of Missouri - Kansas City for her guidance in navigating the Shropshire Archives and her willingness, as a fellow historian of the Welsh Marches, to read my work and supply feedback. I must thank my professors at the University of Missouri from the History, English, Religious Studies, and Classics departments for their excellent teaching and mentoring over the last nine years. In particular the members of my dissertation committee: Dr. Lois Huneycutt, Dr. A. Mark Smith, Dr. Russell Zguta, Dr. John Frymire, and Dr. Emma Lipton. Their patience and willingness to support me throughout the dissertation process is much appreciated.

Finally, I would like to thank Dr. Lois Huneycutt for her unfailing support from the time I entered the master's program to today and beyond. She has pushed me to 
develop my research and improve my writing and provided key feedback for my work. She has also taken the time to mentor me as both a teacher and an academic. I am forever grateful for her help in directing me to conferences and making it possible for me to present my work professionally. Over the years we have also become friends and I look forward to seeing her at conferences in the future.

To my family and friends, thank you for your emotional and material support throughout this long process. You have been a blessing to me.

Alexis Miller, May 2018 
TABLE OF CONTENTS

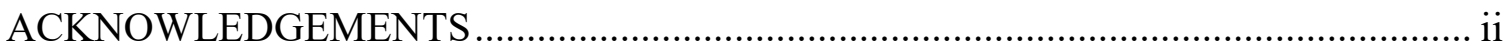

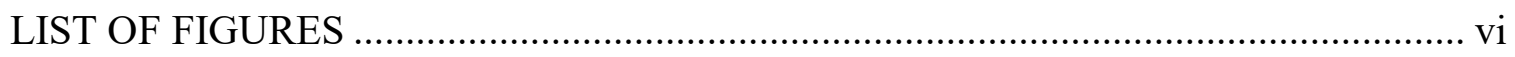

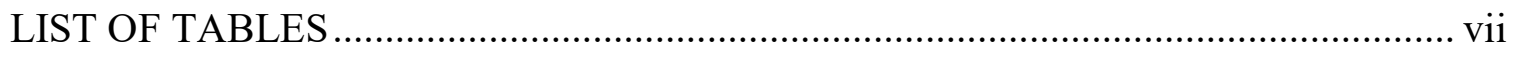

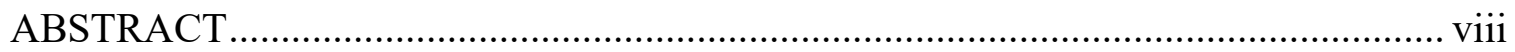

CHAPTERS:

1. INTRODUCTION: CONTEMPORARY CONCEPTS OF 'BEING WELSH' ........1

2. HISTORIOGRAPHY OF THE WELSH MARCHES............................16

3. ENGLISH-WELSH MARRIAGES ON THE CENTRAL MARCH...............34

4. WELSH LAW: PROPERTY, INHERITANCE, AND KIN-GROUP RELATIONSHIPS IN THEORY AND PRACTICE...........................52

5. THIS IS MY COMMUNITY, IS IT MY COURT? A CASE STUDY OF MULTICULTURAL COMMUNITIES AND LEGAL PARTICIPATION IN THE ROLL OF THE SHROPSHIRE EYRE OF 1256. .80

6. THIS LAND IS MY LAND: A CASE STUDY OF MIXED-ETHNICITY COUPLES AND LEGAL PARTICIPATION IN THE WELSH ASSIZE ROLL $1277-1284$

7. CONCLUSION: THE CENTRAL MARCH AND USING LEGAL STUDY AS A SOURCE FOR CULTURAL HISTORY ...................................157

APPENDIXES

1. FAMILY/KIN-GROUP/LOCATION DATABASE FROM WELSH GENEALOGIES: AD 300-1400 . .161

2. TOWNSHIP/COUNTY/HUNDRED DATABASE FROM THE SHROPSHIRE GAZETEER: WITH AN APPENDIX INCLUDING A SURVEY OF THE COUNTY, AND VALUABLE MISCELLANEOUS INFORMATION, WITH PLATES .201

3. WELSH LEGAL MANUSCRIPTS .214

4. THE ROLL OF THE SHROPSHIRE EYRE OF 1256 DEMOGRAPHIC DATABASE. .215 
5. THE ROLL OF THE SHROPSHIRE EYRE OF $1256 \mathrm{WELSH}$

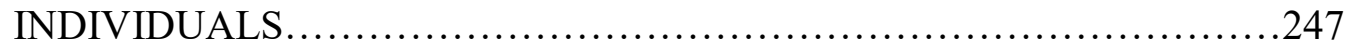

6. THE WELSH ASSIZE ROLL 1277-1284 BY NAME...........................252

7. THE WELSH ASSIZE ROLL 1277-1884 BY DATE.............................289

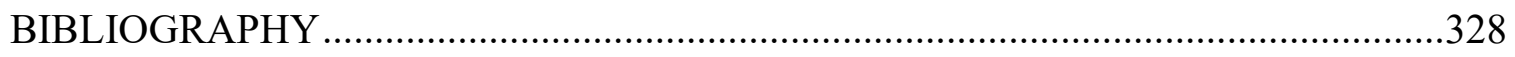

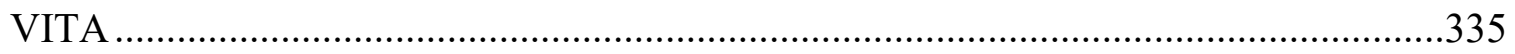




\section{LIST OF FIGURES:}

FIG. 2.1 LOCATION OF LIMINAL BOUNDARIES BETWEEN ENGLAND AND

WALES IN THE CENTRAL MARCH..................................... 18

FIG 3.1 CORBET LANDHOLDING C. 1086, DOMESDAY .....................40

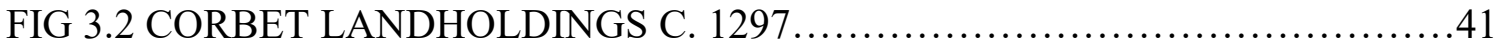

FIG 3.3 CORBET MARRIAGES WITH THE WELSH KIN-GROUPS OF GWYN,

GWENWYS, AND BLEDDYN AP CYNAN ................................44

FIG 5.1 LOCATIONS OF WELSH-INVOLVED CASES IN THE SHROPSHIRE

EYRE

FIG 5.2 THE HUNDREDS OF SHROPSHIRE.

FIG 5.3 THE PARISHES OF SHROPSHIRE..................................116

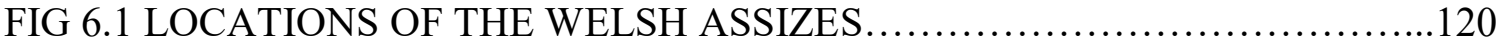

FIG 6.2 LANDS CLAIMED BY GRUFFYDD AB EINION AND HIS BROTHERS..124

FIG 6.3 LANDS CLAIMED BY ANGHARAD f. OWAIN 131

FIG 6.4 COURT APPEARANCES OF ANGHARAD f. OWAIN, WIFE OF WALTER

DE PEDWARDINE BY LOCATION AND DATE. 137

FIG 6.5 LANDS CLAIMED BY RALPH AND MATILDA DE BOTELER ... 143

FIG 6.6 COURT APPEARANCES OF RALPH AND MATILDA DE BOTELER BY

LOCATION AND DATE.............................................. 146

FIG 6.7 LANDS CLAIMED BY JOHN AND MATILDA GIFFARD................148

FIG 6.8 COURT APPEARANCES BT JOHN AND MATILDA GIFFARD IN CASES INVOLVING MORGAN AP MAREDUDD, RHYS AP MAREDUDD, AND RHYS VYCHAN, BY LOCATION AND DATE........................... 152 


\section{LIST OF TABLES:}

TABLE 5.1 INDIVIDUAS SPECIFICALLY IDENTIFIED AS BEING WELSH IN THE

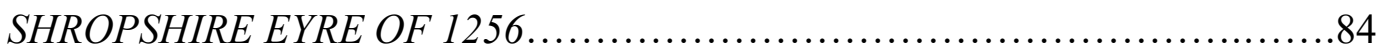

TABLE 5.2 INCIDENCE OF MALE WELSH PERSONAL NAMES IN THE

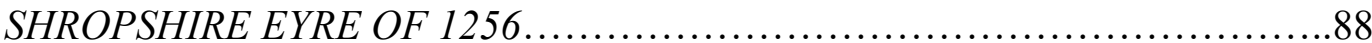

TABLE 5.3 INCIDENCE OF FEMALE WELSH PERSONAL NAMES IN THE

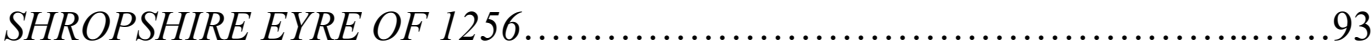

TABLE 5.4 WELSH-INVOLVED DEATHS IN THE SHROPSHIRE EYRE .......102-103

TABLE 6.1 DATES AND LOCATIONS OF THE WELSH ASSIZES................119 


\title{
FORDING THE SEVERN: THE INFLUENCE OF INTERMARRIAGE AND JUDICIAL PARTICIPATION ON WELSH IDENTITY AND SELF-IDENTIFICATION IN SHRIPSHIRE AND THE CENTRAL MARCH OF WALES IN THE TWELFTH AND THIRTEENTH CENTURIES
}

\author{
Alexis Miller \\ Dr. Lois Huneycutt, Dissertation Advisor
}

\begin{abstract}
A study of how intermarriage and the creation of multicultural communities helped to determine the way in which people used their identity along the often-fractious border zone of the Welsh March in the twelfth and thirteenth centuries. This identity can be seen through the ways in which the border inhabitants used concurrent English and Welsh legal systems to their own advantage. This manipulation of the legal system and the fluidity of self-identification stands out in sharp contrast with the view of many historians that the English and Welsh populations lived in self-contained parallel communities according to vastly differing customs and habits. In-depth analysis of primary documents support the assertion that English and Welsh people lived in the same communities and often interacted in legal matters, both as partners and as opponents. Both populations were willing to use the English court system when it was available, but, these individuals were also willing to assert their rights to the legal jurisdiction of English or Welsh law based on which ever would be the most beneficial to their case. These case studies demonstrate the adaptations made to Welsh law and the ways in which Welsh peoples used their legal identity to their own advantage.
\end{abstract}




\section{CHAPTER ONE \\ INTRODUCTION}

In 1188 Gerald of Wales accompanied Baldwin, Archbishop of Canterbury, on a visit through Wales. During this trip he began writing his well-known text The Journey Through Wales. Shortly after, in 1188-1189, he also wrote The Description of Wales, a mirror piece to his earlier The Description of Ireland. Gerald presented the Welsh as a people who had positive qualities, such as hospitality, but had little sense of moderation or self-control, as seen through their willingness to through drop everything and throw a party if visitors appeared. Gerald was known as le waleys but his full name was Gerald de Barri and his 'Welshness' is difficult to determine. ${ }^{1}$ While he writes as an expert on the Welsh, he clearly separates himself from the people about whom he writes.

Gerald describes a Welsh people who are passionate, reckless, and uncivilized in a somewhat endearing fashion. They are like children who will never grow up and enter the real world of adult peoples, clever barbarians who sing and write beautiful music and poetry but remain uncivilized. Gerald of Wales was not alone in the way he describes a people who are in some way different from the majority, in this case the English as the majority while in other medieval ethnographic and travel literature the assumed majority was often Europe as a whole. Familiar language of otherness can be found in descriptions of medieval European Jews and the Muslims of Spain and Sicily. I have chosen to focus specifically on Gerald's writing for two reasons: first, his work was incredibly popular and was not only copied but Gerald himself wrote three versions, the third being

${ }^{1}$ As John Thorpe points out in Gerald of Wales, "The Journey through Wales and the Description of Wales," in Gerald of Wales: The Journey through Wales and The Description of Wales, ed. Lewis Thorpe (New York: Penguin, 1978). 12. 
dedicated to Stephen Langton, Archbishop of Canterbury, in the early years of the thirteenth century. ${ }^{2}$

This is how the Welsh were presented by Gerald and it is easy then for historians to make the following erroneous assumptions. First, that the identity these writers placed upon the Welsh was their only identity. This, of course, is false as we have many examples of Welsh jurists, chroniclers, and poets who paint their own ideas of Welsh identity. Additionally, as I argue throughout this work, Welsh individuals themselves had certain ideas of individual and collective Welsh identity that they embraced at their own choosing. ${ }^{3}$ And secondly, that the English and Anglo-Normans who lived near and with the Welsh throughout the Severn valley shared the prescribed generalized version of Welsh identity. As I argue below, the evidence about daily life on the March presents a somewhat different picture. English and Welsh men and women lived in the same communities, attended the same parish churches, and married into each other's families. Legal documents and court cases, records of marriages and family genealogies, and records of land tenure all point to the Shropshire-Montgomery region as being a place where identity was complex. Mixed marriages led to families of both English and Welsh descent, and there appears to have been no concern on the side of Englishmen that, when

${ }^{2}$ From Thorpe's Introduction in Gerald of Wales, "The Journey through Wales and the Description of Wales," in Gerald of Wales: The Journey through Wales and The Description of Wales, ed. Lewis Thorpe (New York: Penguin, 1978). 38-39.

${ }^{3}$ Here I am using P. G. Klandermans' definition of collective identity as an identity shared by members of a group or category, one that "concerns cognitions shared by members of a single group about the group to which they are a member." P. G. Klandermans, "Presidential Address - Identity Politics and Politicized Identities: Identity Processes and the Dynamics of Protest," Political Psychology 35, no. 1 (2014). 2-4. 
arranging such marriages, they were somehow giving their daughters over into a life of barbarity or bringing wives of questionable character into their own homes.

Through The Description of Wales Gerald promotes and perpetuates the idea that the Welsh were a people alien from the English and the Anglo-Normans. He argued that they lived differently, had different morals and character, and were physically a different race from other men. He was not alone in his views; he and others who wrote about the Welsh, such as John Peckam, Archbishop of Canterbury, and Henry of Huntingdon worked within the inherited concepts of humoral race and barbaric 'otherness' passed down from the ancient world. As J. J. Cohen writes:

When the Greeks and Romans described the Ethiopians, Indians, Germans, and Celts, they were in general not only conveying that these peoples varied from them in language, custom, and geographical origin, but asserting their own cultural, intellectual, and physical superiority. The humoral and environmental model of biological determinism was inherited by the Middle Ages, taking on a renewable vitality as classical texts were translated from Arabic into Latin in the twelfth century. ${ }^{4}$

Using the writings of Gerald, Peckham, and others we can see how these ideas appeared in the English and Anglo-Norman prescriptive perception of Welsh identity.

To understand the medieval construction of 'otherness' and how it was applied to the Welsh, we must begin with the concept of race in the Middle Ages. I have chosen to use the word race when referring to how people thought about difference in the Middle

${ }^{4}$ Jeffrey Jerome Cohen, "Race," in A Handbook of Middle English Studies, ed. Marion Turner (John Wiley \& Sons, 2013), 114. 
Ages while being fully aware of the weight the term inherently contains in modern scholarship. In his article "Medieval and Modern Concepts of Race and Ethnicity” Robert Bartlett argues that the term "race" can trigger unwanted responses when the author is really talking about ethnic groups and ethnicity. By rejecting the biological social construct of race scholars can use the terms race and ethnicity interchangeably. Thus ethnicity can be used without qualms. Bartlett continues with discussion about gens and natio and family lines as an element of ethnicity that people recognized in the Middle Ages and makes a strong argument for the strategic and situational use of ethnic identity. ${ }^{5}$ His argument is clear and logical, and I could have comfortably used ethnicity instead of race in this study. And yet I have chosen not to. Instead I am subscribing to J. J. Cohen's argument for the intentional use of "race". Cohen suggests that the use of the term "race" should be used because it is so loaded, because it is "the product of a discriminatory system of power that intertwines identity and embodiment." ${ }^{9}$ When Gerald wrote about Wales, as an outsider regardless of his Welsh connections, he is describing the Welsh people in a racialized manner. His descriptions are not without the judgement of the taxonomer and the superior. In his writing you can see demonstrated how, as Cohen puts it, "race foregrounds the inextricability of corporal and group identity, as well as the uneven structures of power within which identities are made solid."7 The power structure of English superiority, as a self-defined civilized, economically advanced, and religiously

${ }^{5}$ Robert Bartlett, "Medieval and Modern Concepts of Race and Ethnicity," Journal of Medieval and Early Modern Studies 31 (2001). 40-45 \& 53.

${ }^{6}$ Cohen, "Race." 115.

7 "Race." 112. 
correct society, is ingrained in the way that Gerald compares the Welsh to the English. When I use the word race below I am not talking about conflicting definitions of gens or natio. Instead I am using race is in its current provocative sense; I want readers to see how Gerald's Description of Wales perpetuates a view that the Welsh were different and a group subordinate to the English. ${ }^{8}$

Questions of race and classification of living creatures was not new in the high middle ages. The taxonomy of Aristotle and the use of physiognomy had been used throughout the ancient and early medieval world. In a ninth-century letter to Rimbert, a German missionary to Scandinavia, Ratramnus of Corbie responded to Rimbert's previous query of whether or not he should try to save the cynocephali or dog-headed men of Scandinavia, being unsure if they were men or animals. Ratramnus replied that they indeed had souls in need of saving because they "lived by social laws, they cultivated fields, they wore clothes, and they even had domestic animals." 9 The question of categorization of peoples, whether they were animal or human, whether they had souls, preoccupied medieval societies. They relied upon taxonomy and yet, as Cohen has pointed out, "no taxonomy is neutral. To classify peoples is to judge them, to sort the

${ }^{8}$ I recognize that in this study I am just barely touching on broader discussions of race, ethnicity, and identity in the Middle Ages. The ways in which I have chosen to discuss race here come from a decision to stay specifically in the time and place of this study.

${ }^{9}$ Natalia Lozovsky, "Geography and Ethnography in Medieval Europe: Classical Traditions and Contemporary Concerns," in Geography and Ethnography, Perceptions of the World in Pre-Modern Societies, ed. Kurt and Richard Talbert Raaflaub (Chichester: Wiley-Blackwell, 2010), 320. 
world in ways that typically buttress the privileges of a dominating collective." ${ }^{10}$ It was not the cynocephali who decided that they had souls worth saving, but their taxonomers.

Cohen argues that such practices allow for "strategic inclusions and exclusions" into the dominant group's perception of civilization. ${ }^{11}$ Peoples were classified by the languages they spoke, the foods they ate, common (or perceived common) physical characteristics, physiological humors, and cultural practices. Some of these characteristics were determined through observation by an outside group, in this case the English and Anglo-Normans as they sought to classify the Welsh. Others resulted from a strong medieval reliance on geographical determinism on both body and character, believing, as Albertus Magnus stated, that "everything generated in a place derives its natural properties from that place." 12 These traits together can be referred to as race. Human difference is the driving force behind classification and the formation of the "other". As Geraldine Heng points out, "race is a structural relationship for the articulation and management of human differences, rather than a substantive content."13 Peoples and societies seek to find and emphasize differences between themselves and the peoples around them. It is a catch 22 - in order to define themselves and their own

${ }^{10}$ Cohen, "Race." 111.

11 "Race." 112.

${ }^{12}$ Bartlett, "Medieval and Modern Concepts of Race and Ethnicity." 45-47.

${ }^{13}$ Geraldine Heng, "The Invention of Race in the European Middle Ages I: Race Studies, Modernity, and the Middle Ages," Literature Compass 8, no. 5 (2011). 319 \& 324-325. 
society they must define others as different and inferior. ${ }^{14}$ Distinctions of such characteristics as language, custom, and body can be seen in any culture's written and artistic work. These characteristics themselves hold no bias, but they are rarely presented without a clear sense of superiority versus inferiority. For example, Gerald quotes a letter from Henry II to Emperor Manuel Comnenus of Constantinople saying "In one part of the island there is a race of people called the Welsh that are so brave and untamed that, though unarmed themselves, they do not hesitate to do battle with fully armed opponents. ${ }^{\prime 15}$ While this description may seem flattering it also resonates with the later concept of the 'noble savage' who is to be admired for his primitive skill and bravery, but is clearly less of a man than one from a civilized people who would, no doubt, behave much less recklessly. Gerald follows this up a few pages later by noting that "as was written about the Germans is just as applicable to the Welsh: 'In the first onslaught they are more than men, in the second they are less than women."'16

The bodies of the Welsh themselves posed an interesting conundrum for those writing about the them. The Welsh claimed to be descendants of the Trojans, and this was widely accepted, as can be seen in Geoffrey of Monmouth's popular Historia Britania. Gerald used this Trojan ancestry to explain why the Welsh were physiologically different from the other peoples of the British Isles, explaining that while the Germans, Saxons,

${ }^{14}$ David M. Goldenberg, "The Development of the Idea of Race: Classical Paradigms and Medival Elaborations, a Review of Ivan Hannaford Race: The History of an Idea in the West," International Journal of the Classical Tradition (Spring 1999). 234-235.

${ }^{15}$ Gerald of Wales, "The Journey through Wales and the Description of Wales."

16 "The Journey through Wales and the Description of Wales." 259. 
and other northern Europeans, and thus the English, "derive their cold nature from the polar regions which lie adjacent to them" and "retain their outward fairness of complexion and their inward coldness of disposition from what nature had given them earlier on," the Welsh peoples were "transplanted from the hot and arid regions of the Trojan plain, keep their dark colouring, which reminds one of the earth itself, their natural warmth of personality and their hot temper." 17 Their hot humors dictated their wild and ungovernable behavior. Additionally, both Gerald and Henry of Huntingdon also compared the Welsh to animals, likening them to wolves and eagles "which live by plunder and are never satisfied" 18 and their style of fighting to that of cattle. ${ }^{19}$ In this, the Welsh are bestial rather than human.

Welsh character was often called into question. While Gerald praised the Welsh for their wit he was just as quick to point out their falseness:

They are always prepared to perjure themselves to their own convenience and for any temporary advantage which they hope to gain by concealing the truth. In any lawsuit, civil or ecclesiastic, they are ready to swear anything which seems expedient at the moment, whether they are the accusers or the accused, each side doing all it can to make its point and prove its case. For all that they have laws which have stood the test of time, in which a man's plighted word is held sacred,

17 "The Journey through Wales and the Description of Wales." 245.

18 "The Journey through Wales and the Description of Wales." 262.

${ }^{19}$ Henry of Huntingdon, The Chronicle of Henry of Huntingdon: Comprising the History of England, from the Invasion of Julius Caesar to the Accession of Henry Ii. Also, the Actsof Stephen, King of England and Duke of Normandy, (London: H. G. Bohn, 1853), http://www.archive.org/details/chroniclehenryh01foregoog. Electronic Book - Not in Copywrite. 79. 
truth is revered, honest dealing is highly thought of, the accused is given the benefit of the doubt, the accuser is allowed no advantage, and the onus of proving a case lies with the man who brings it. To a people so cunning and crafty this seems no great burden, for they take it all very lightly. ${ }^{20}$

An anonymous pamphlet written in thirteenth-century Canterbury described the Welsh as "a people of a bad sort. . . if not perhaps outlaws," and "in a nut shell, [men] to be made neither good nor trustworthy if not free from drunkenness, low passions, luxury, murder, passion, or rapine." ${ }^{21}$ The implication being that the Welsh were only able to be good men if kept under strict control. Most likely written under the auspices of Archbishop of Canterbury John Peckham, this pamphlet goes on to support the English conquest of Wales then underway. Gerald had similar sentiments, writing that the Welsh were a people "sunk in sin and in a deep abyss of every vice." ${ }^{22}$ Such literature promoted the idea that Welshmen and women were untrustworthy and given to embracing the negative parts of their character if not carefully managed.

256.

${ }^{20}$ Gerald of Wales, "The Journey through Wales and the Description of Wales."

21 "A people of a bad sort (Gens ista malis huiusmodi) ... if not perhaps outlaws (nisi forsitan utlagatis)" and "in a nut shell, [men] to be made neither good nor trustworthy if not free from drunkenness, low passions, luxury, murder, passion, or rapine (Et breviter bonum facere non credebat nisi dum vacabat ebrietatibus, carnis luxui, homicidiis, incendiis, vel rapinis)" Anon, "Untitled - a Fragment of a History Written Late in the Thirteenth Century and Possibly Drawn up by One of Archbishop Peckham's Clerks at the Time When He Was Occupied with the Welsh Negotiations," in Historical Manuscripts Commission Report on Mss. in various collections (1901). 248. 265.

${ }^{22}$ Gerald of Wales, "The Journey through Wales and the Description of Wales." 
Even more than the character of the Welsh, the portrayals of the ways in which they lived, their rituals and relationships, even their agriculture, seemed to set them apart from the English. In particular, their agriculture and pastoral lifestyle were seen as backward and uncivilized. Gerald argues that the Welsh were incapable of feeding themselves without imports and lived almost exclusively on oats, a common animal feed. ${ }^{23}$ Describing their dwellings as temporary Gerald explained how the Welsh lived differently from the English:

They do not live in towns, villages or castles, but lead a solitary existence, deep in the woods. It is not their habit to build great palaces, or vast and towering structures of stone and cement. Instead they content themselves with wattled huts on the edge of the forest, put up with little labour or expense, but strong enough to last a year or so. They do not have orchards or gardens, but if you give them fruit or garden produce they are only too pleased to eat it. Most of their land is used for pasture. They cultivate very little of it, growing a few flowers and sowing a plot here and there. ${ }^{24}$

Agriculture was the sign of civilization going back thousands of years, and here were a people who chose to take little part in this vital activity. As manorialism grew and spread throughout the British Isles, here Gerald describes a people remote and old-fashioned, who did not embrace "commerce, shipping or industry" 25 , those staples of a civilized world. Instead, he argues that they focused on their herds and on military training.

\footnotetext{
23 "The Journey through Wales and the Description of Wales." $233 \& 272$.

24 "The Journey through Wales and the Description of Wales." 251-252.

25 "The Journey through Wales and the Description of Wales." 233.
} 
Family rituals were pointed out as being another area of vast difference between the Welsh and their English neighbors. The Welsh practice of concubinage sent church men into fits and prompted many letters and pamphlets condemning the practice. ${ }^{26}$ Fostering and the acceptance of bastard children was seen to go hand in hand with partitive inheritance to promote a society of internecine violence and dynastic struggle. In his second edition of The Description of Wales Gerald maintained that the Welsh peoples were irrevocably corrupted, arguing that:

There are three things which are causing the ruin of the Welsh people and preventing them, generation after generation, from ever enjoying prosperity. First is that all their sons, both legitimate and illegitimate, insist upon taking equal shares of their patrimony. One result of this, as I have said already, is that they not infrequently kill each other. The second is that they entrust the upbringing of their sons to important people of good family in the neighbourhood. When the fathers die, each foster-parent does all in his power to ensure the succession of his protégé, which leads to murder, arson, and wholesale destruction. Thirdly, through their natural pride and obstinacy, they will not order themselves as other nations do so successfully, but refuse to accept the rule and dominion of a single king. ${ }^{27}$

${ }^{26}$ See Charles Trice Martin, ed. Registrum Epistolarum Fratris Johannis Peckham, Archiepiscopi Cantuariensis, 3 vols., vol. 2 (London: Longman, 1882-1885); Anon, "Untitled - a Fragment of a History Written Late in the Thirteenth Century and Possibly Drawn up by One of Archbishop Peckham's Clerks at the Time When He Was Occupied with the Welsh Negotiations." 273.

${ }^{27}$ Gerald of Wales, "The Journey through Wales and the Description of Wales." 
Here Gerald blames these social customs for the downfall of the Welsh people. It is interesting that he argues that their stubborn determination to remain free is their ultimate undoing. In Gerald's view, if the Welsh could just act like other nations, they would be powerful. If they acted like civilized peoples, they would prosper.

Gerald of Wales and other contemporary authors presented a generalized outsider opinion of what it meant to be Welsh, what it meant to label someone with the terms le waleys (of Wales) or walensis (Welsh). This is an identity placed upon the Welsh population by others; the Welsh were in a subaltern position in that they were not embracing this identity as the truth, but were forced to live with others believing it was who they were. Yet this constructed identity misaligns with the reality of the multicultural communities and mixed English-Welsh families that lived and thrived on Montgomery-Shropshire border. If there is one major element that could possibly create division in the community at the local level it was the idea of a collective Welsh legal identity, which Welshmen and Welshwomen often referenced when seeking legal judgements. Yet legal identity created less of a cultural divide than may be expected. Contact between the English and the Welsh populations meant that the cultural and legal norms of each group adapted to those of the other. Intermarriage between English and Welsh families in this region frequently served as a means to make these changes.

Intermarriage and living in multicultural communities played a part in shaping the identities of the English and Welsh peoples along the frontier of the Welsh March. What identity was this exactly? It was not purely English nor purely Welsh, yet elements of both collective identities remained. This identity can be seen through the ways in which the border inhabitants used concurrent English and Welsh legal systems throughout this 
period. Of particular interest to me is the use individuals made of these legal systems to their own advantage. A man might argue to have his case heard under Welsh law based on a Welsh ancestor or the ancestry of his wife, if it meant that the law would work to his benefit. That same man might then choose to have another case heard under English law for the same reasons. Members of these mixed families and communities were aware of having both an English and Welsh identity and used this knowledge to their own benefit when appealing to the legal system. This manipulation of the legal system and the fluidity of self-identification stands out in sharp contrast with the view of many historians that the English and Welsh populations lived in self-contained parallel communities according to vastly differing customs and habits.

In the following chapters I explain how the choices of individuals and families in the Central March to use their identities reflected the legal and cultural realities of living in a multicultural region, rather than the prescribed generalized identity placed upon the Welsh as a people. I present a nuanced picture of what legal and cultural identification as an Englishman or Englishwoman or as a Welshman or Welshwoman, or even as an English or Welsh family, actually meant in life on the border.

I begin in Chapter Two with a discussion of the work that has been done on the Welsh border and English and Welsh marriage, family, identity, and law. While historians have studied each of these topics in isolation, this study combines both the history of marriage and of law in order to further define identity and self-identification on the border.

The next two chapters address the background of the two elements that make up this study: marriage and law. The English and the Welsh had their own separate systems 
and traditions concerning marriage, inheritance, and legal rights. Chapter Three looks at the many marriages that were contracted between middling-level elites on both sides of the border. It asks what we can learn about English-Welsh interaction through these marriages and the mixed-heritage families that resulted from them. The differences and compromises in custom and practice of English and Welsh law are the topic of Chapter Four. I make an argument for the existence of a Welsh collective legal identity that shaped peoples' decisions in legal matters. Additionally, this discussion includes examples of individuals appearing in English courts to ask that their case be heard according to Welsh law.

Chapter Five, the first case study, is an extensive analysis of the Roll of the Shropshire Eyre of 1256. In it I ask the question of whether Shropshire had a Welsh population and, if so, how did the English and Welsh peoples of that county live and interact with each other. The Eyre provides a surprising amount of information about the demographics of Shropshire and the existence of a multicultural population is clear. Of the individuals included in criminal cases, as victims, perpetrators or attendant members of the community, Welsh people were involved in about ten percent of both the cases of misadventure (15 of 91) and murder (49 of 487). Since there is no evidence that the Welsh population was in any way singled out for a greater number of criminal accusations or deaths, it can be presumed that Welsh individuals made up at least ten percent of the general population.

In the second case study, Chapter Six, I make an in-depth study of several property suits recorded in The Welsh Assize Roll of 1277-1284. Escalating conflict between Edward I and Llywelyn, Prince of Wales in the 1270s and 1280s meant that 
many properties were occupied first by one army, then another. This often resulted in multiple legal claims for a single township or manor, with the original Welsh owners claiming hereditary right while supporters of Edward I made similar claims based on enfeoffment by the king. Questions of legal jurisdiction became increasingly complicated as parties appealed to law and legal custom in the hope of finding a loophole that would work to their benefit.

Finally, I discuss how these studies have added to the discussion of identity and self-identification in a border zone. I argue that legal documents and data on legal participation can be used as a valuable to too understand identity and interaction in multicultural communities and mixed-heritage families. 


\section{CHAPTER TWO \\ HISTORIOGRAPHY OF THE WELSH MARCHES}

This study places emphasis on marriages between Welshmen and Englishwomen and the connections between families that were forged by these unions as well as the influence of these women on the reoccurrence of intermarriage over generations. Building upon the work begun by Eleanor Searle, I discuss Anglo-Norman and Welsh intermarriage on the Central March as an active and strategic policy resulting in the creation of hybrid or mixed English and Welsh families. These families then developed their own practical form of self-identification.

Similarly, as Max Lieberman does, I look at the relationships and interactions between the English and Welsh populations along the Shropshire-Montgomery border. However, instead of discussing administrative practice I approach the region in a new way - through the lens of the marriages of the mid-ranking families of the English knightly class and their Welsh counterparts and then how mixed families self-identified as they participated in the legal system.

Brock Holden has written an analysis of elites on the border, including the most prominent elite family in Shropshire, the Mortimers, and I am moving beyond his work to look at the level of society below the elites. Ultimately, I argue that the Mid-Wales portion of the March (that is the borderland between Montgomery and Shropshire and northern Herefordshire) contained communities and individuals who were English, those who were Welsh, and those who were willing to self-identify as either when the need arose. As with many periods of history, most records that historians have access to today address the activities of the upper elite portion of society. I have found that, while the highest level of English society in this region avoided intermarriage with their Welsh 
neighbors, the middling elites did not. Members of the knightly class, those whose families served as the tenants-in-chief, sheriffs, and stewards to the great Marcher lords, often formed marriages within their own communities; communities made up of both English and Welsh peoples. Thus this study contributes to the growth of a broader understanding of portions of society which has often been left out of the historical narrative.

The field of frontier studies has developed much in the past forty years. Where it once was a study primarily of liminal borders such as the roman fort lines along the Danube and boundaries like Hadrian's Wall, frontier studies has become a field focused on political, economic, and cultural contact between peoples in a border zone. For an excellent and comprehensive historiography of frontiers please see Daniel Powers's The Norman Frontier in the Twelfth and Early Thirteenth Centuries. ${ }^{28}$

The definition of the Welsh March and analysis of its unique position between England and Wales has been refined throughout the twentieth century. Early discussions of the March defined it along geographical terms in the sense of a specific geographic space with a physical demarcation of separation. Many past historians and ethnographers have tended to refer to the March as a physical boundary which, when speaking of the Central March, was located along the Severn River, Offa's Dyke, or the line of AngloNorman castles that sprung up just to their east. ${ }^{29}$

${ }^{28}$ Daniel Power, The Norman Frontier in the Twelfth and Early Thirteenth Centuries, Cambridge Studies in Medieval Life and Thought (Cambridge ; New York: Cambridge University Press, 2004),

${ }^{29}$ W. Sinclair Jones, "Caus Castle's Historic Associations," Montgomeryshire Collections 38 (1917). 


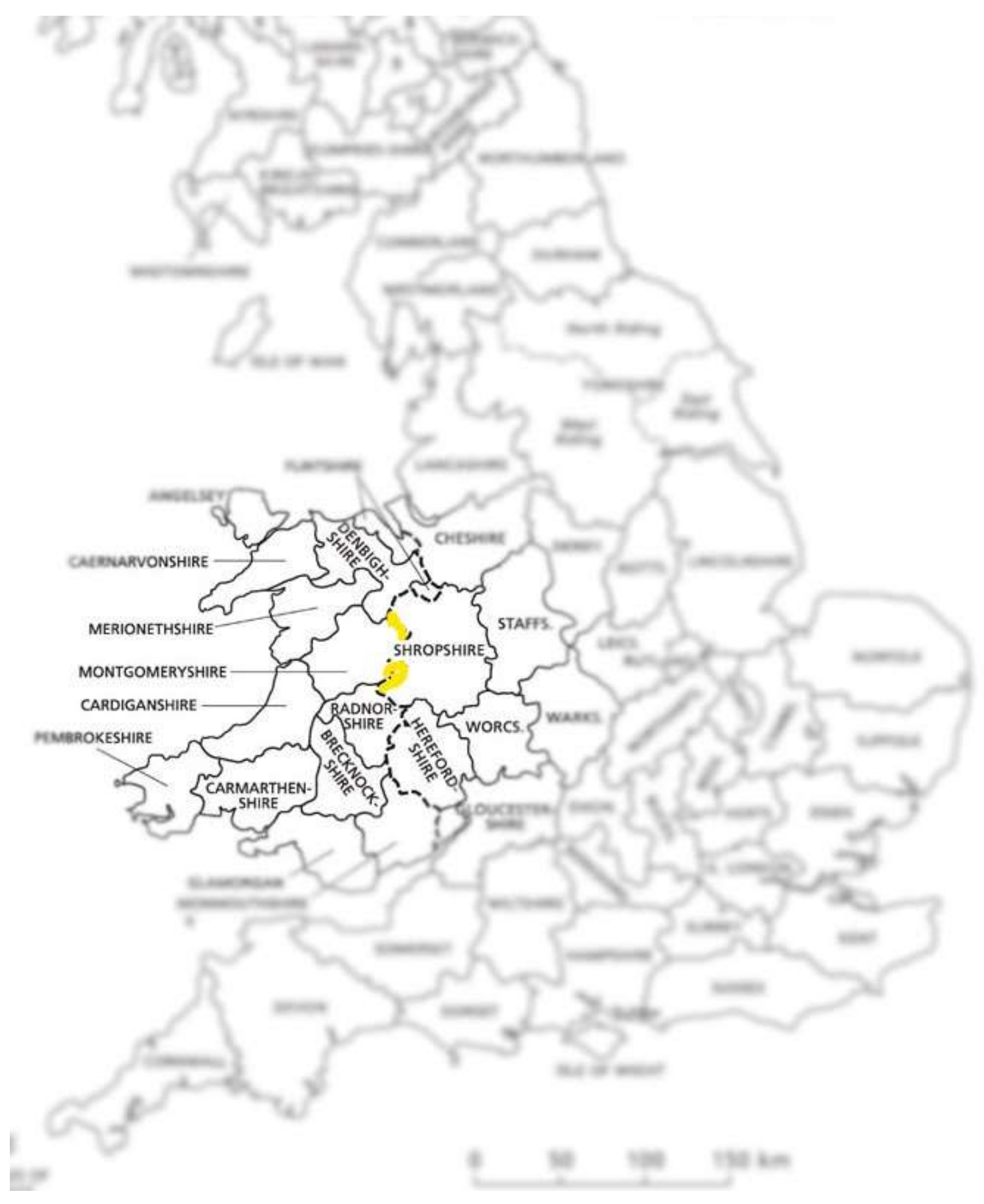

Figure 2.1

Location of liminal boundaries between England and Wales in the Central March 
The Anglo-Norman castle line, while formidable, did not actually function as a solid border. One of the densest collection of castles was in the Gorddwr, a mountainous area east of both the Severn and Offa's Dyke that, throughout the thirteenth century, was claimed by both the Corbet family of Shropshire and the Princes of Powys as part of their demesne. The Severn also became a particularly tempting place to draw the border because in 1288 the river was made the official dividing line between the dioceses of St. Asaph and Hereford. ${ }^{30}$ However, limiting the Central March to a strictly geographical definition falls short once it becomes clear that the English and Welsh populations of the region lived on both sides of the river and Offa's Dyke. I have chosen the title Fording the Severn for this work to draw attention to the reality that people often forded the river on a weekly or even daily basis; it was not a barrier to contact and interaction between members of Central March populations.

Recently the Welsh historical community has, for the most part, accepted the argument of R. R. Davies that the March was not only a physical boundary but also a zone of both English and Welsh identity and practice and, in some circumstances, a hybridized culture made up of both. ${ }^{31}$ Building on this definition Max Lieberman and

${ }^{30}$ Archdeacon Thomas, "The Gorther," Montgomeryshire Collections 38 (1917).

${ }^{31}$ R. R. Davies has made the most prolific and influential contributions to the study of Wales in the Middle Ages since the advent of Welsh History as a discipline at the end of the nineteenth century. Chief among these is R. R. Davies, Conquest, Coexistence, and Change: Wales, 1063-1415, The History of Wales, [V. 2] (Oxford; [Cardiff]: Clarendon Press ; University of Wales Press, 1987), See also Domination and Conquest : The Experience of Ireland, Scotland, and Wales, 1100-1300 (Cambridge; New York: Cambridge University Press, 1990),; The First English Empire: Power and Identities in the British Isles 1093-1343 (New York: Oxford University Press, 2000),; Glanmor Williams and R. R. Davies, Welsh Society and Nationhood: Historical Essays Presented to Glanmor Williams (Cardiff: University of Wales Press, 1984); R. R. Davies, Lordship \& Society in the March of Wales, 1282-1400 (Oxford: Oxford University Press, 1978),; "Colonial Wales," Past \& Present, no. 65 (1974).; "Race Relations in Post- 
Brock Holden both write specifically of the March as an area marked out by the changeable limits of border lordships. And while Lieberman points out that "it may be that the twelfth-century Marchia Walliae came to be thought of as a military buffer zone, initially on the Shropshire borders, later all along the Anglo-Welsh frontier" he also acknowledges that "the usage of the phrase Marchia Walliae between the late eleventh and the early fourteenth centuries suggests that the medieval concept of the Welsh March was a malleable one." ${ }^{, 32}$ Brian Golding has perhaps summed it up best when he points out that

The [Welsh] boundary with England was scarcely fixed: Offa's Dyke, though it made a demarcation of sorts, recognised as both a legal and psychological frontier, was crossed from both sides by expansionists, and the 'debatable lands' of the Marches were, throughout the Anglo-Norman period (and long beyond), and extraordinary racial, linguistic, and administrative mix. ${ }^{33}$

Conquest Wales: Confrontation and Compromise, Cecil-Williams Lecture 1973," Transactions of the Honorable Society of Cymmrodorion (1974/1975).; and "The Identity of 'Wales' in the Thirteenth Century," in From Medieval to Modern Wales: Historical Essays in Honour of Kenneth O. Morgan and Ralph A. Griffiths, ed. Davies \& Jenkins (Cardiff: University of Wales Press, 2004),

${ }^{32}$ Brock Holden, Lords of the Central Marches: English Aristocracy \& Frontier Society 1087-1265 (Oxford: Oxford University Press, 2008), 44. Max Lieberman, The Medieval March of Wales: The Creation and Perception of a Frontier, 1066-1283 (New York: Cambridge University Press, 2010), 5-10.

${ }^{33}$ Brian Golding, Conquest and Colonization: The Normans in Britain, 10661100 , ed. Jeremy Black, Rev. ed., British History in Perspective (Basingstoke: Palgrave, 2001), 49-50. 
The term marchia itself can be somewhat confusing - as Kevin Mann has addressed in his excellent article on the history of the term's use. ${ }^{34}$ From the perspective of twelfthand thirteenth-century writers the march could be anything from a borderland in concept to a specific geographical area. Mann argues, based on word usage of marchia compared to Marchia Walliae, used largely from the 1240 s onward, that while contemporary writers often referred to the area of the marchia as a border zone, that zone was dependent on the geography of lordship. Lands specifically in the Marchia Walliae were considered to be lands in Wales itself. In spite of these complications I have chosen to use the term March as historians broadly use it in order to limit confusion. ${ }^{35}$

In the context of this study I draw from these definitions to identify the Central March as a frontier made up of both the physical zone of inhabitation stretching from central Powys to the eastern boundaries of Shropshire and the cultural zone in which people embraced practices and values attributed to both English and Welsh society. Thus this definition embraces the boundaries of particular lordships and communities in both physical terms and in terms of the self-identification of the peoples who lived there. In this way the entirety of Shropshire can, at times, be part of this frontier.

It is important to note that there have been many generalizations about the characteristics of the Welsh March that present an inaccurate picture of how the English and Welsh populations interacted with each other. Specifically, the assumption that the particulars of the Southern March can be generalized to the rest of the border; the

${ }^{34}$ Kevin Mann, "'The March of Wales"," Welsh History Review 18, no. 1 (1996).

${ }^{35}$ The best discussion of the historiography of Medieval Frontiers that I have come across is that of Power, The Norman Frontier in the Twelfth and Early Thirteenth Centuries. Preface. 
continuation of the upland/lowland dichotomy; and the myth of baronial supremacy. Anglo-Norman conquest and settlement of South Wales and along the Southern March was quick and complete. Norman, English, and even Flemish families colonized the region and the separation of these communities from those of the Welsh was intentional and persistent. An Anglo-Norman presence resulted in manorial and city records, and so it is not surprising that historians have often turned to South Wales when searching for sources. The information from these sources has often been generalized to apply to the entire March. And yet the circumstances of the region are different from those of the Central March, where the English and Welsh populations lived in much more mixed communities, and of the Northern March, which was sparsely populated by either group until the mid-thirteenth century.

One example of this habit of generalization is Kenneth Murphy's discussion of the development of medieval Welsh towns. Murphy states that the "twin themes of economic exploitation and military service were to characterize towns in Wales for over two centuries" yet his analysis is based on the unique circumstances of English and Flemish colonial settlements in South Wales in which "migrants encouraged to settle in a hostile frontier zone not only created a workforce essential to exploit the land of new lordships, but also formed the basis of an army willing to side against the dispossessed Welsh." ${ }^{36}$ This analysis does not necessarily apply to Central March towns such as Montgomery, Welshpool, or Shrewsbury, which show clear signs of having diverse multicultural populations.

${ }^{36}$ Kenneth Murphy, "The Rise and Fall of the Medieval Town in Wales," in Towns in Decline, Ad 100-1600, ed. T. R. Slater (Burlington: Ashgate, 2000), 193. 
The assumption that the Southern March can equate to the March in general is also dangerous in that it encourages the continuation of the upland/lowland dichotomy. There is a persistent idea in the non-Welsh historiography of the medieval British Isles that the Welsh and English lived in separate and geographically distinct communities. In some ways this idea comes from analysis of intentionally separate English and Welsh communities in South Wales. In these communities the Welsh population was at times dispossessed, forcibly excluded from English towns, and forced to settle in upland pasturage. But this was not the case in other areas of English occupation, including along the Central March. To further confuse the issue, distinct upland Welsh and lowland English communities were recorded by seventeenth and eighteenth-century ethnographers and visitors to Wales, leading to the assumption by many scholars that this separation could be projected backwards into the Middle Ages. The result of these practices was to create an oversimplified belief that Welsh communities lived almost exclusively in the uplands according to an almost entirely pastoral lifestyle. Meanwhile, these supposedly insular communities were often compared with an ideal of the English, who lived in lowland towns and practices manorial-style agriculture. In 1923 E. Estyn Evans perpetuated this oversimplification by noting that "the origin of the political boundary between England and Wales lies ultimately between life on the plain and life on the hills." ${ }^{37}$ While it was true that Welsh communities were predominantly pastoral as opposed to manorial and the use of upland pasturage was a normal part of Welsh life, geography and colonization were stronger factors in determining the location of Welsh

\footnotetext{
${ }^{37}$ E. Estyn Evans, "An Essay on the Historical Geography of the ShropshireMontgomeryshire Borderland," Montgomeryshire Collections 40 (1923). 246.
} 
settlements than any sort of Welsh dedication to a pastoral lifestyle. This was particularly true in the Central March where both the English and the Welsh settled in the Severn Valley. ${ }^{38}$ The geography of the Central March, as detailed below, meant that the English and Welsh peoples lived side by side on many occasions. Note that this concept of upland-lowland differing modes of living is also tied to the judgement of lowland agricultural living as civilized as compared to the upland pastoral life.

A brief note on baronial supremacy; the idea that the Welsh March was a place where influential barons exercised near-monarchical powers appears in many histories of the British Isles. Many place the rise of these powers early in the twelfth century, citing the reference in the Magna Carta to a lex marchiae that ran side by side with Welsh and English laws. Yet there is very little evidence for the existence of a true law of the march until later and the idea that the "king's writ did not run" in the March is clearly not true in practice. Even when there is evidence of increasing baronial power in the thirteenth century, it cannot be generalized to the March as a whole. While the southern baronial families developed a degree of power, the process took time. As Golding pointed out, the great Anglo-Norman lords were "concerned to subdue Wales, not settle in it, and the colonizers here were lesser men, the castellans of royal and baronial castles, families like the de Barri, with few, if any, tenurial interests elsewhere. Indeed, the colonization of Wales owed most to ambitious younger sons with few prospects." ${ }^{39}$ This reality meant

${ }^{38}$ Lieberman, The Medieval March of Wales: The Creation and Perception of a Frontier, 1066-1283. 24-25. In addition, archaeological analysis of medieval upland dwellings has been inconclusive as to whether they were inhabited permanently, semipermanently, or seasonally.

${ }^{39}$ Golding, Conquest and Colonization: The Normans in Britain, 1066-1100. 81. 
that the concept of distinct Marcher liberties which allowed the Marcher lords to rule as they chose with little regard for English law or the power of the crown was one that took time to develop. Davies and Lieberman place the rise of these liberties in the thirteenth century $^{40}$ and the examples of truly powerful Marcher lordships was a phenomenon of the period from the reign of Edward III to the Wars of the Roses.

Recent historical studies on the Welsh March have focused on understanding the specific identifications and roles of individuals and families along the March. In Lords of the Central Marches: English Aristocracy \& Frontier Society 1087-1265, Holden has written an analysis of the elite and knightly class English families of Hereford and the southern March. Most of his work addresses the elite families who controlled this region for much of the period between the Norman Conquest and the fourteenth century: the Braoese, Clifford, Lacy, and Mortimer families. With the exception of the Mortimers, who held lands in Shropshire to the north and are thus given the least attention by Holden, these families maintained their control over the region through the formation of fluid administrative practices and advantageous English marriages. These elites and the knightly class who served as their retainers created blocks of administrative and tenurial control and appear to have had little contact with their Welsh counterparts. Holden's approach offers a useful analytical model to be applied to other areas of the March. He discusses each family individually while still acknowledging the interconnections within this small and powerful group. Most usefully to this work is the chapter he includes on

${ }^{40}$ Lieberman, The Medieval March of Wales: The Creation and Perception of a Frontier, 1066-1283. 20. 
the knightly class in Hereford, where he uses marriage and tenurial records to reconstruct the role of this group along an increasingly solidifying border.

Max Lieberman, with The Medieval March of Wales: The Creation and Perception of a Frontier, 1066-1283, has focused the discussion on Marcher identity to the area specifically along the Shropshire-Montgomery border. Arguing that this area was the most fluid portion of the border, and thus the last to solidify into a clear liminal and cultural boundary, Lieberman discusses the development of administrative and military systems in the region. Because of the mixed English and Welsh population, he argues that administrative practices had to take into account diverse forms of tenure and legal identification and it is through developing these practices that the March became a form of hybridized society. Like Holden, Lieberman accepts Davies' argument that the March was a place of fluid identity and practice in which administrators and military leaders had to react to circumstances, thus creating a hybridized administrative organization.

Other recent studies have looked at the role of elite women along the Welsh March. Like Holden and Lieberman, Emma Cavell analyzes the administration of a region of the March in her article "Aristocratic Widows and the Medieval Welsh Frontier: The Shropshire Evidence: The Rees Davies Prize Essay.". What sets her work apart is that instead of focusing on a geographic portion of the border she instead put forward an argument about the important role of elite Englishwomen as administrators and protectors of the March. Cavell does not address the questions of identity or interaction between the English and Welsh, but her work has brought the forward the important role played by women in the region. In her $\mathrm{PhD}$ thesis Noblewomen in Shropshire and the Adjacent 
March of Wales, 1150-1350 Cavell expands this argument to a discussion of the importance of these noblewomen in the "creation, maintenance, and decline of family power and landed estates" in Shropshire and the bordering Welsh lands. Following the life-cycle of the English noblewoman, she "looks at the wives, widows, daughters and heiresses of a wide group of closely interlinked county and border families, and considers their roles as vehicles for the promotion of family power and interest, and as agents in their own right on the frontier between England and Wales"41. Cavell discusses the agency of these land-holding women through the lens of gender and argues that they performed many important administrative functions and provided social and political connections in a frontier society dominated by military men. Thus a gap existed between contemporary ideas about gender roles and the actions taken by women such as Isabel de Mortimer, Maude Pantulf, and Hawise le Strange.

\section{Marriage}

Welshwomen have been the subject of relatively few historical studies of the Welsh medieval period, for a number of reasons, one of the most visible being the lack of manorial and monastic documents that include women. The study of medieval women began primarily with the analysis of charters issued by queens and countesses. Cavell's work on elite border women and Susan John's Gender, Nation and Conquest in the High Middle Ages: Nest of Deheubarth fit with this historiographic approach, and there have been a number of very recent studies on elite women including Linda Mitchell's Joan de

\footnotetext{
${ }^{41}$ Emma Cavell, "Noblewomen in Shropshire and the Adjacent March of Wales, 1150-1350," (Unpublished Dissertation: Balliol College Oxford, 2006). Long Abstract
} 
Valence: The Life and Influence of a Thirteenth-Century Noblewoman. ${ }^{42}$ Welshwomen have been included in the legal and kinship studies of Robin Chapman Stacey and T. M. Charles Edwards, but as a category of society rather than as individuals. ${ }^{43}$ In the same way Jane Cartwright has addressed the limited historical sources about Welsh nuns, there were only three women's monastic houses in medieval Wales, and come to the conclusion that "women may have been too important within the social, political and economic concerns and interests of the secular community to have been actively encouraged to retreat to the more isolated and rarified religious environments." ${ }^{44}$ Under these circumstances it is no wonder that most historical discussions of Welsh woman have focused on their role in marriages, both English and Welsh.

By using the categories of intermarriage and female agency, we can gain access to further historical information on the lives of Welshwomen. Intermarriage is often a category used to study areas of cultural and territorial conversion and expansion. As Eleanor Searle argued in her seminal work Predatory Kinship and the Creation of

${ }^{42}$ Susan M. Johns, Gender, Nation and Conquest in the High Middle Ages : Nest of Deheubarth, Gender in History (New York: Palgrave Macmillan, 2013); Linda Elizabeth Mitchell, Joan De Valence: The Life and Influence of a Thirteenth-Century Noblewoman, The New Middle Ages, See also Portraits of Medieval Women : Family, Marriage, and Politics in England, 1255-1350, 1st ed., New Middle Ages (New York: Palgrave Macmillan, 2003),

${ }^{43}$ Robin Chapman-Stacey, "Divorce, Medieval Welsh Style," Speculum Oct (2002); T. M. Charles-Edwards, Early Irish and Welsh Kinship (New York: Clarendon, 1993),

${ }^{44}$ Jane Cartwright, Feminine Sanctity and Spirituality in Medieval Wales (Cardiff: University of Wales Press, 2008), 20. See also "The Desire to Corrupt: Convent \& Community in Medieval Wales," in Medieval Women in Their Communities, ed. Watt (Toronto: University of Toronto Press, 1997), 
Norman Power, 840-1066, intermarriage was a fundamental way in which the Scandinavian Normans achieved and sustained their power over the inhabitants of Normandy. She brought strategic marriages to the forefront of the discussion of Norman development, writing that:

This is a landscape of warrior nobles. But that does not mean that men alone figure in the landscape. Far from it. The Normans built their 'state' out of property and women, as well as out of men and swords. We will see their politics more dearly by putting their women, as they did, into the landscape. And we shall not assume, as is done so often, that the women were subservient prey and plunder. There is no reason to suppose that they did not share the predatory values of their society, and, as we shall see, there is evidence that they did. ${ }^{45}$

Searle's insistence that women had agency within these frontier marriages is borne out not only by her own research, but also by analysis of Anglo-Norman and Welsh marriages.

Welsh historians have noted that Anglo-Welsh marriages "served to cement the new order and to legitimize political change" 46 and "helped to break down racial barriers" ${ }^{\prime 7}$ in particular through the creation of bilingual families, yet Cavell is not wrong when she states that "The historiographical March is a world in which women, if they feature at all, are curiously skimmed over as adjuncts to the border lords who occupy

${ }^{45}$ Eleanor Searle, Predatory Kinship and the Creation of Norman Power, 8401066 (Berkeley: University of California Press, 1988), 11.

${ }^{46}$ Golding, Conquest and Colonization: The Normans in Britain, 1066-1100. 81.

${ }^{47}$ Davies, "Race Relations in Post-Conquest Wales: Confrontation and Compromise, Cecil-Williams Lecture 1973." 52. 
center stage, or as passive conduits for the transfer of land and alliance between men."48 The active role that English and Welsh women played in their frontier marriages is often overlooked. These women often remained connected to their natal families, as Welsh women traditionally were, and these relationships may have played a part in the development of future marriages between their sons and grandsons and women from their natal families or communities.

\section{Identity}

Community identity and self-identification can be difficult to parse in the Middle Ages. The lack of first-person primary sources such as journals or letters in which individuals can describe how they interpret their own identity means that medieval historians are often left with little information from which to determine how people identified themselves. Historiographic discussions of identity have, in the last fifty years, been dominated by Benedict Anderson's concept of the imagined community. He suggests that a community can be imagined "because the members of even the smallest [community] will never know most of their fellow-members, meet them, or even hear of them, yet in the minds of each lives the image of their communion." ${ }^{49}$ The imagined community is intrinsically tied to the discussion of nationalism, a concept that Anderson argues did not exist in the pre-modern world before the advent of print culture. Anderson

${ }^{48}$ Emma Cavell, "Aristocratic Widows and the Medieval Welsh Frontier: The Shropshire Evidence: The Rees Davies Prize Essay," Transactions of the Royal Historical Society 17, no. ArticleType: research-article / Full publication date: 2007 / Copyright (C) 2007 Royal Historical Society (2007). 58.

${ }^{49}$ Benedict Anderson, Imagined Communities: Reflections on the Origin and Spread of Nationalism, Revised ed. (New York: Verso, 1991), 6. 
restricts his use of imagined communities to the modern world, something that makes direct application of the concept to the Middle Ages problematic.

Medieval historians have struggled to decide if and how they should apply the idea of imagined communities to the study of the Middle Ages. The result has been a discussion of what makes up a community and how such communities can overlap to create an identity shared across the group. In Medieval Women in Their Communities Diane Watt noted that "identities are sites of complex and sometimes conflicting differences; and consequently they are constructed not through a single static community but through the overlap and interaction of networks of communities." These identities could be ideological, socio-economic, or geographical, and they were shared by many people regardless of their extent beyond the traditional idea of a community as "a group of people living in a given locality, often, but not necessarily, tied by bonds of kinship." 50 Similarly Nicholas Howe mirrors Anderson's imagined communities by writing that community "identifies a group of people having a common purpose or identity as well as some shared knowledge of each other." In this context "the larger the group becomes, the more likely it is that the source of its 'communion' will become imagined or tenuous or abstract." ${ }^{, 51}$ It is this concept of community and identity that I mean when I speak of the development of a medieval Welsh shared legal identity.

This shared legal identity was strong among Welsh individuals and calls for its application appear in chronicles and court cases throughout the eleventh, twelfth, and

${ }^{50}$ Diane Watt, ed. Medieval Women in Their Communities (Cardiff: University of Wales Press, 1997). 2, 4.

${ }^{51}$ Nicholas Howe, "Introduction," in Visions of Community in the Pre-Modern World, ed. Nicholas Howe (Notre Dame: University of Notre Dame Press, 2002), 1. 
thirteenth centuries. Yet this identity did not always dictate a person's actions. Below I will argue that Welsh legal identity could and was used tactically to achieve legal outcomes in an individual's best interest. Individuals could choose which of their multiple identities to use depending on the context. This active choice is key to understanding how Welsh legal identity was used and how Welsh, and sometimes English, individuals understood its utility.

\section{A note on Welsh legal historiography}

To this point most legal historians of Wales have focused on either the exploration of the law texts themselves or on the practice of law in Welsh courts. I have used this research to further my own discussion on how Welsh individuals used the concepts of Welsh law to then interact with English courts. Throughout my research I have relied gratefully on the work of Dafydd Jenkins, Sara Elin Roberts, Robin Chapman

Stacey, T. M. Charles-Edwards, J. Beverley Smith and Llinos Beverley Smith. ${ }^{52}$ The

${ }^{52}$ Dafydd Jenkins and Morfydd E. Owen, The Welsh Law of Women : Studies Presented to Professor Daniel A. Binchy on His Eightieth Birthday, 3 June 1980 (Cardiff: University of Wales Press, 1980); Dafydd Jenkins, "The Administration of Law in Medieval Wales: The Role of the Ynad Cwmwd (Judex Patrie)," in Lawyers and Laymen, ed. B. Walters (Cardiff: University of Wales Press, 1986); The Law of Hywel Dda: Law Texts from Medieval Wales, Translated and Edited, The Welsh Classics (Gomer Press, 1986); Sara Elin Roberts, "More Plaints in Medieval Welsh Law," Studia Celtica 48 (2014); Sara Elin \& Jones Roberts, Bryn, "Cyfraith Hywel," in http://cyfraithhywel.cymru.ac.uk/en/index.php (Research funded by the University of Wales, Website by Coleg Cymraeg Cenedlaethol, 2010-2011); Chapman-Stacey, "Divorce, Medieval Welsh Style."; "Learning to Plead in Medieval Welsh Law," Studia Celtica 38 (2004); Charles-Edwards, Early Irish and Welsh Kinship; J. Beverley Smith, "Judgement under the Law of Wales," Studia Celtica 39 (2005); Llinos Beverley Smith, "The Statute of Wales, 1284," Welsh History Review 10, no. 2 (1980); "A Contribution to the History of Galanas in Late-Medieval Wales," Studia Celtica 43 (2009). 
Cyfraith Hywel digital project has also been an invaluable research aid. ${ }^{53}$ The distinction elements of English and Welsh law will be addressed in Chapter Four.

${ }^{53}$ Roberts, "Cyfraith Hywel." 


\section{CHAPTER THREE \\ ENGLISH-WELSH MARRIAGES ON THE CENTRAL MARCH}

The argument that a concept of a collective Welsh legal identity existed, and therefore was a factor in self-identification by inhabitants of the Central March, is dependent upon the fact that such mixed families existed. There is ample evidence that, beginning with the Norman Conquest, the Anglo-Norman and Welsh populations along the Montgomery-Shropshire border engaged energetically in the practice of intermarriage. These marriages created families and communities that had claims to Norman, English, and Welsh heritage. I will discuss this heritage and the ways in which the members of these families manipulated their identity to serve in their best legal interest in later chapters. But first I must begin with a discussion of how and why such mixed marriages came about and how the creation of families that had both English and Welsh roots changed society along the Central March. In particular, the marriages and interactions of the Anglo-Norman Corbet, Wynston, and William of Elbeth families and of the extended families of the Gwaithfoed, Gwenwys, Gwyn ap Gruffudd (Gwyn), and Bleddyn ap Cynfyn kin groups, show the development of the region as a place of mixed heritage and allow for the possibility for personal choice in self-identification. ${ }^{54}$

In the years immediately after the Norman Conquest, Norman magnates who were assigned to control the region of the Welsh March made, for the most part, Norman or English marriages and this trend continued for several generations. This circumstance has made it tempting to look simply at the upper elite level of society and, noting this trend

54 This study would not have been possible without the work of Peter C. Bartrum, Welsh Genealogies: Ad 300-1400, 8 vols. (Cardiff: University of Wales Press, Board of Celtic Studies, 1974), and "The Bartrum Project," in www.cadair.aber.uk (University of Wales-Aberystwyth). 
toward Norman or English marriages, argue that intermarriage with the local Welsh population was minimal. Analysis of the Braose, Lacy, Monmouth, Mortimer, and Clifford families, the five most powerful Anglo-Norman families in the March, bears this out. The Mortimers, as the family who would come to control the MontgomeryShropshire area, followed this marriage strategy and expanded their holdings across the rest of England. Conversely, it was the lower elite families who intermarried with their Welsh neighbors. These were knightly families (using Brock Holden's definition of the knightly class as a "larger body of men [than simply those who "carried the appellation of 'knight'”], holding land by military service of the magnates"). ${ }^{55}$ The families who supplied Sheriffs and castellans for the Earls of Shrewsbury and whose property and prospects were firmly entrenched in the Central March. Marriage was just as much of a tool for success and family survival as were military services and diplomacy in turn.

This is a different conclusion than that determined by Brock Holden in his study of the knightly class in Hereford and South Wales. He argues that the knightly families of Hereford married almost exclusively with each other in order to preserve landholdings within the family and this practice served to isolate them from both their elite English and elite and mid-ranking Welsh neighbors. This is not the case with the middling-elite families in Shropshire. Holden's argument depends upon his assumption that there was a distinct division between the English and Welsh populations in the March that created a "separateness of Marcher Society" and that this separateness was both a cause and effect of endogamy within the knightly class. He accepts this division as fact, noting that "In

${ }^{55}$ Holden, Lords of the Central Marches: English Aristocracy \& Frontier Society 1087-1265. 88-89. 
this division between tightly governed, manorialized lowlands and tribute-paying uplands lay the origins of the Englishries and Welshries ${ }^{56}$ which would mare the later social landscape of the March.” As I have previously argued, the Montgomery-Shropshire region does not support this conclusion and provides little or no evidence of intentionally separate communities nor of insular marriage strategies.

Instead, there is evidence that the Norman knights who followed the great lords to England and were then given lands and small frontier castles to hold in their names were eager and willing to contract marriages with their new Welsh neighbors. It is tempting to look at these marriages as a somewhat standard form of what has been termed "Norman Marriage Strategies" - the canny way the Normans strengthened and legitimized their conquest by forming marriages with the wives or daughters of their conquered neighbors. Such marriages appear to have been part of their standard frontier policy in Normandy and post-Conquest England to gain access to new land holdings along the border, these acquisitions legitimized by marriage and laws of inheritance. ${ }^{57}$ The story of strategic marriage between the Normans and the Welsh is more complicated. There were major difference in inheritance law that had to be taken into account - Welsh legal tradition allowed for only temporary alienation of land, and even then women could not inherit land, only moveable property. Additionally, Welsh dynastic instability meant that many prominent Welsh families were themselves interested in Norman, or Anglo-Norman, marriages to stabilize and, in many ways, legitimize their own positions. Thus, the

${ }^{56}$ Lords of the Central Marches: English Aristocracy \& Frontier Society 10871265. 43, 112-135, 214.

${ }^{57}$ Searle, Predatory Kinship and the Creation of Norman Power, 840-1066. 
marriages formed between the Normans and the Welsh in the 150 years after the Conquest were not necessarily a part of a "Norman marriage strategy" but instead demonstrate the ways in which people on both sides of the border took advantage of opportunities to advance not only the holdings, but also the local power and prestige of their families.

I begin with the story of two Normans of the knightly class who, through choice and action, became Welsh. Through settlement and intermarriage the Normans William of Elsbeth (Elbeuf in Normandy) and Andryw of Valence so fully integrated themselves into Welsh society in Hereford and Montgomery that William of Elsbeth became the eponymous head of a Welsh kin group that existed into the fifteenth century. His descendants came to hold lands along the Severn directly on the Welsh side of the twelfth-century English castle-line that came to define a liminal border between Montgomery and Shropshire. Andryw of Valence was the great-grandfather of Sir Gilbert Wynston of Tre-wyn, the head of the Wynston kin group living in Radnor and northern Hereford. Andryw's son married into the family of Gwaithfoed of Gwent and over the next five generations developed marriage connections with Welsh families in Brecon, Monmouth, and Radnor.

The root of the transformation of these Norman knights into Welsh clan leaders can best be explained in the context of the marriages they and their sons and grandsons made with women of prominent Welsh Marcher families, both English and Welsh. The Wynston family contracted mostly Welsh marriages with the exception of the branch of the family stemming from Sir Gilbert's great grandson John Wynston who married Joan, 
the daughter of one Reginald Cecil. Many of their male descendants married the daughters of Englishmen who lived along the Radnor-Hereford border.

Additionally, intermarriage between prominent Welsh border families and the Corbets, LeStranges, and, later, the Scudamores, tied the English and Welsh communities together so tightly that it is difficult at times to determine how they would legally and culturally identify themselves. The Corbet family in particular contracted many Welsh marriages for both their sons and daughters throughout the twelfth and thirteenth centuries. In many ways these marriages appear to have been matters of practicality since the Corbets held several castles in the English castle defense line along the Severn and thus held lands directly adjacent to those held by Welsh kin groups such as the Bleddyn ap Cynfyn family. While their overlords had other concerns beyond the March, these knightly families were active members of their communities on both sides of the liminal border. They may represent the closest to a hybridized identity formed along the MidWales March.

By the early twelfth century it is increasingly difficult to tease out the differences between a Norman family and an English one. The Corbet, William of Elbeth, and Wynston families have clear Norman antecedents and did not retain lands on both sides of the channel. With their focus entirely on developing a position in England they can most accurately be described as being Anglo-Norman. These families often contracted marriages with their Welsh neighbors along the Central March. ${ }^{58}$

${ }^{58}$ All of these families settled in or acquired land through marriage in Shropshire and Montgomery/Powys with exception of the Wynston family, which held lands to the south in Brecon and Hereford. 
One of the most prominent middling-elite families in Shropshire was that of the Corbets. Roger de Corbet came to England as a part of the Conquest with his father and brother. Though originally from the Pay de Caux, Roger Corbet served under Lord Roger de Montgomery and was given by him lands to hold along the central border of west Shropshire. As his seat Roger de Corbet built a castle which he named Caus. The castle near Forden, in the area known as the Gorddwr, was built at about the same time, from similar materials, and in an identical style and this castle too was held by the Corbets and was sometimes known as Westbury or Nantcribba. ${ }^{59}$ The Gorddwr comprised the area between Northern Shropshire and Montgomeryshire along both sides of the Severn River and west of Offa's Dyke. Based on Domesday C. J. Spurgeon identifies the Corbet holdings of Leighton, Edderton, Forden, Thornbury, Wolston Mynd, and Wropton as making up the Gorddwr. ${ }^{60}$ Subsequent generations of his heirs would serve as the Barons of Caus until the male line died out in the fourteenth century. Caus was the main family seat and the dominant branch of the family was most often identified as being a 'Corbet of Caus'. Two centuries later a dispute over the episcopal control of the Gorddwr that was brought before the pope in 1297 also identified the following parishes as among those paying tithes in the Gorddwr: Braginton, Guilsfield, Ystrad Marchell, Bausley, Winnington, Trefnant, and Middleton. Thus, the Corbets maintained a fairly stable section of land along the Central March.

${ }^{59}$ P. G. Barton, "Gruffudd Ap Gwenwynwyn's Trefnant Market 1279-1282," Montgomeryshire Collections 90 (2002).

${ }^{60}$ Spurgeon, "Gwyddgrug Castle (Forden) and the Gorddwr Dispute in the Thirteenth Century," Montgomeryshire Collections 57, no. 2 (1962). 
The first Welsh marriage that is recorded for the Corbet family was that of Roger de Corbet's great-granddaughter Margaret, who married Gwynwynwyn ap Owain

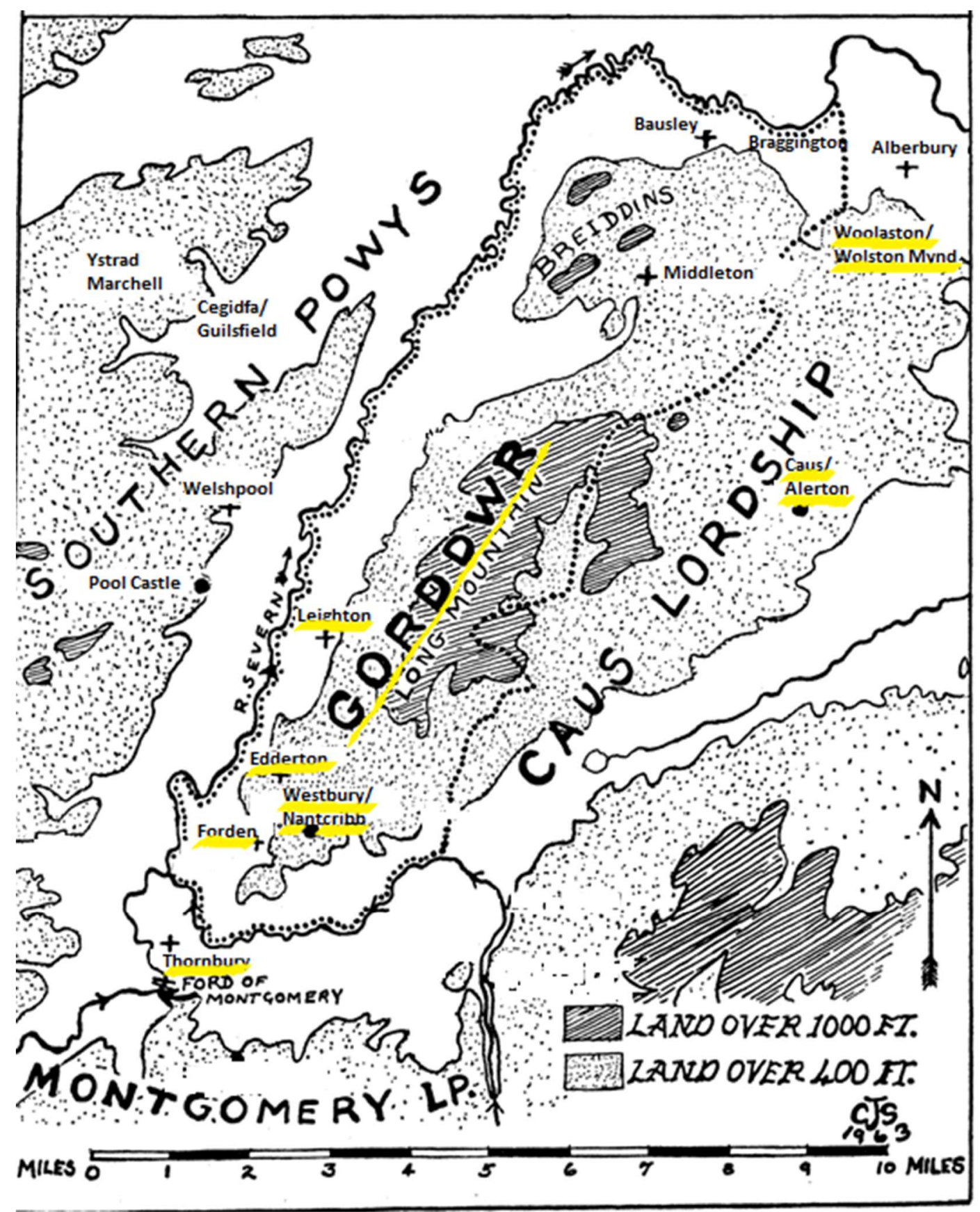

Fig. 3.1 Corbet landholdings c. 1086 Domesday 


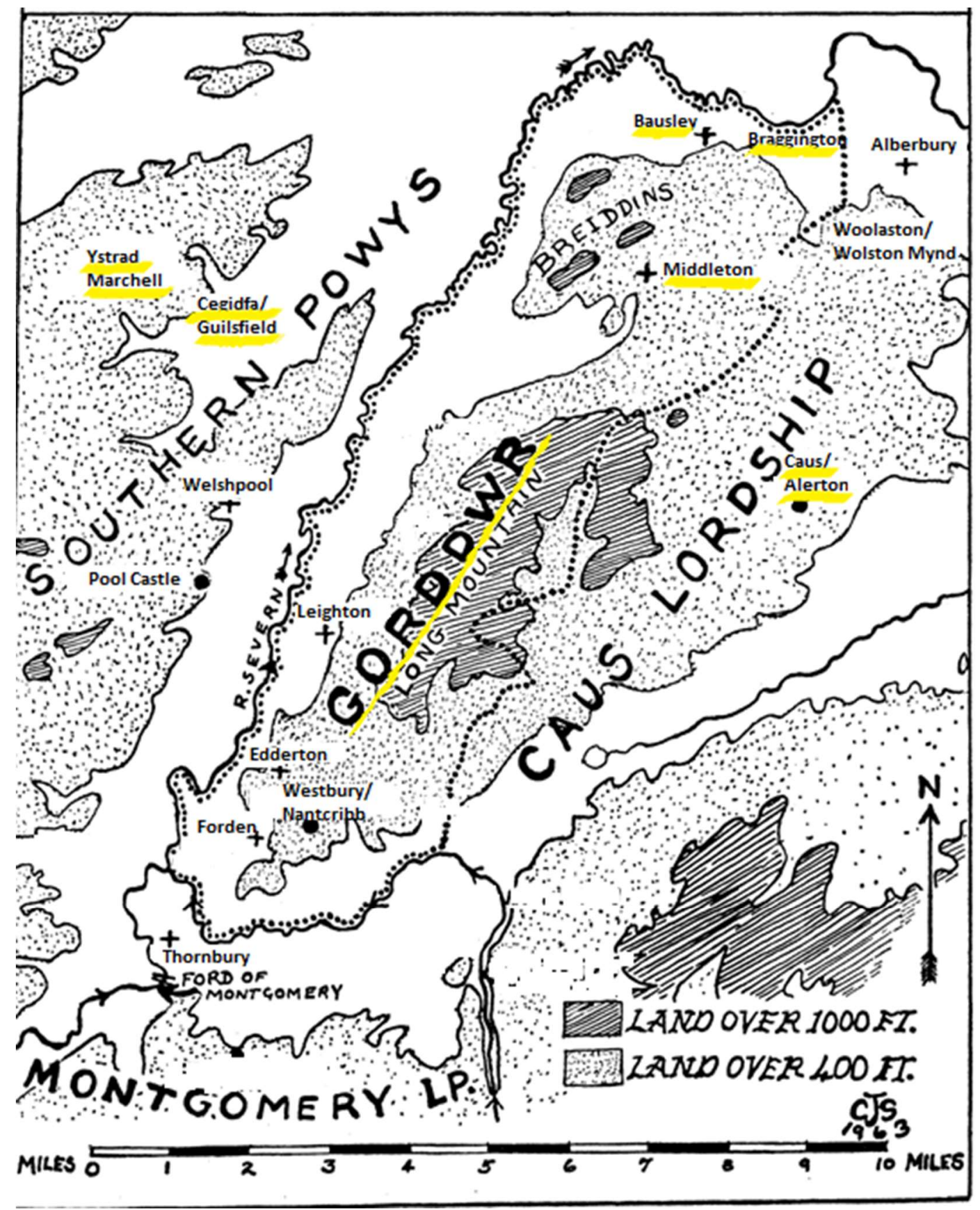

Fig. 3.2 Corbet landholdings c. 1297 
Cyfeiliog, the Prince of Upper Powys and a member of the powerful Bleddyn ap Cynfyn kin group. ${ }^{61}$ The marriage of Margaret Corbet to Gwynwynwyn ap Cyfeiliog most likely took place between 1210 and Gwynwynwyn's death in 1216 - it was his second marriage and only one child is known to have been born of the union. The benefits of this marriage for the Corbet family are clear - Margaret's marriage meant that her brother, Thomas Corbet, Baron of Caus, gained influence and prestige by allying himself with a branch of the ruling family in Powys. Gwynwynwyn held right over the land all along the Montgomery-Shropshire border, land which abutted the Corbet holdings, and Thomas Corbet was interested in advancing his own position - he is known for a lifetime full of land litigation with his English and Welsh neighbors. ${ }^{62}$ It is difficult to determine the extent of influence that Margaret's marriage had on the marriages of future female Corbets to Welshmen, but given the prestige of the marriage it is quite possible that Margaret's marriage was a factor in not only promoting future Corbet marriages but also in making these marriages more attractive to the other Welsh families of the region. ${ }^{63}$

Gwynwynwyn, for his part, gained lands in Shropshire as a part of Margaret's dowry - his son Gruffudd would spend much of the 1250s-60s fighting over who held

${ }^{61}$ It has been suggested that Margaret may have had a paternal aunt who also made a Welsh marriage to a Llywelyn ap Iowerth, but there is no known evidence of who this aunt might have been or which Welsh family her husband was a member of.

${ }^{62}$ For further discussion of the career of Thomas Corbet see Melissa Julian Jones, "Family Strategy or Personal Principles? The Corbets in the Reign of Henry lii" (paper presented at the Authority and Resistance in the Age of Magna Carta Conference, Aberystwyth and Lampeter, 2013, 2015).

${ }^{63}$ Genealogical data for the Bleddyn ap Cynfyn family comes from Bartrum, Welsh Genealogies: Ad 300-1400. "Bleddyn ap Cynfyn" Tables 1, 3-5, 7, 8, 11, 14, 17, $18,20,21,24,26,27,29-31,37,38,45-48, \& 53$ from Vol 1-4, 28-81. 
legal right to these lands in the Gorddwr, Gruffudd through his mother or Margaret's brother Thomas Corbet. Gwynwynwyn too may have been wishing for an ally to strengthen his power in the region. Powys had been divided into Upper and Lower Powys after the death of Maredudd ap Bleddyn ap Cynfyn in 1133. His sons Madoc and Gruffudd divided the territory and the rule of Upper Powys eventually fell to Gruffudd's grandson Gwynwynwyn. With the rise of Gwynedd's fortunes under the rule of Llywelyn the Great in the late twelfth and early thirteenth centuries, the already-divided rulers of Powys needed support from their Anglo-Norman neighbors.

The trend of Anglo-Norman marriages with the Princes of Upper Powys continued in subsequent generations - Margaret and Gwynwynwyn's son Gruffudd married Hawise the daughter of John LeStrange. The LeStrange family had built a strong powerbase in central Shropshire and John LeStrange served as the Sheriff of the county for many years. The LeStranges and Thomas Corbet did not always get along and Gruffudd, who also frequently argued with his uncle, quite possibly sought to for a relationship that would serve as a counterbalance against him. That said, the two often worked together; in the 1250s Gruffudd and his uncle Thomas held a 'love day' at Alberbury ${ }^{64}$ This was a day for both Englishmen and Welshmen to come together to socialize and interact as one community. Thomas and Gruffudd organized the event together - they were not just neighbors but also as close relatives. The connection Margaret Corbet forged between her natal family and the Welsh Princes of Powys may well have been a factor behind their joint effort.

${ }^{64}$ Alan Harding, ed. The Roll of the Shropshire Eyre of 1256 (London: Selden Society, 1981). 149. 


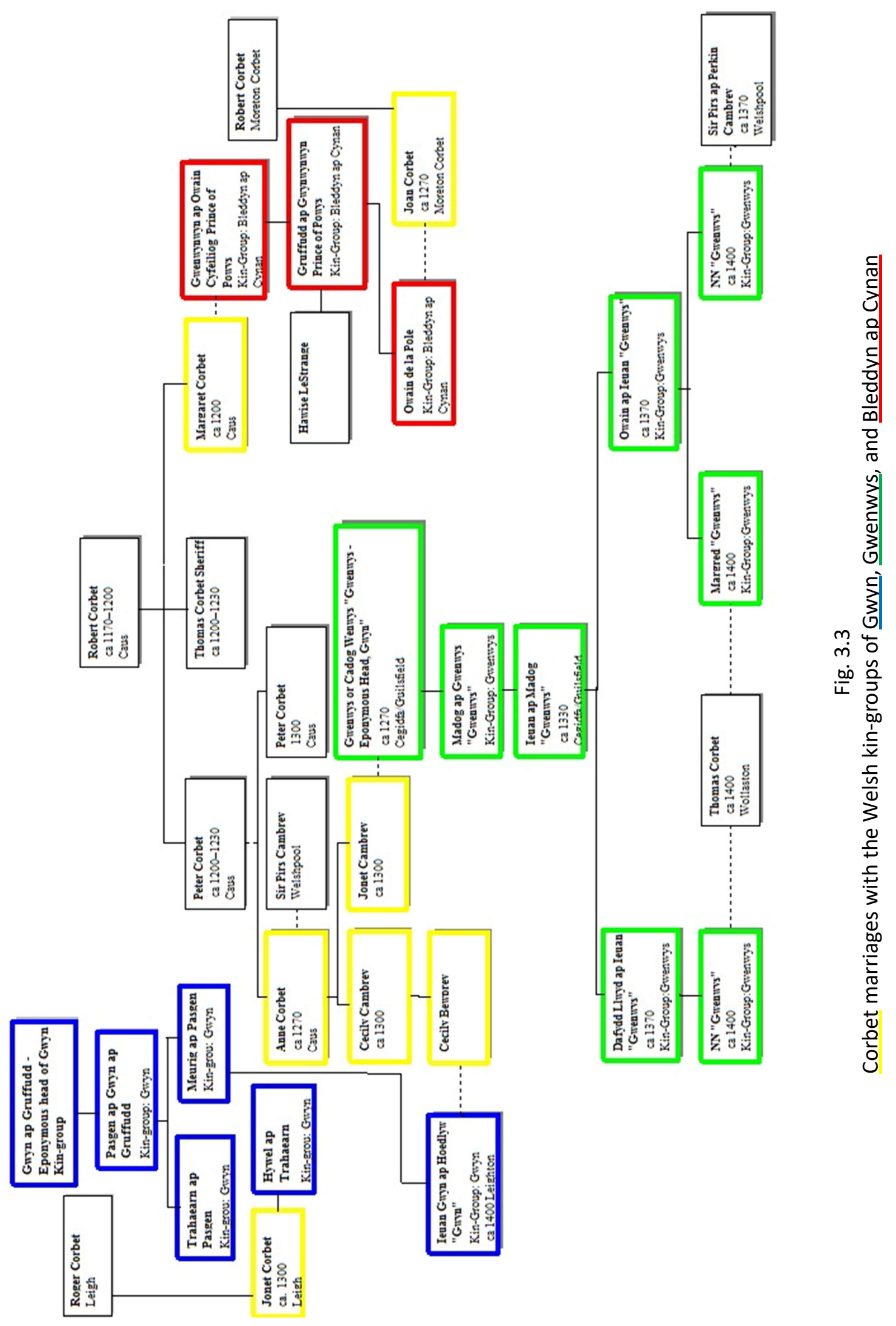


Gruffudd would be the last Prince of Powys, but because he ultimately chose to ally himself with Edward I in the final push to conquer Gwynedd, his sons retained and divided his lands as their inheritance. The eldest, Owain ap Gruffudd, known as de la Pole because of his control of Welshpool, also married an Anglo-Norman wife. Joan Corbet was a member of the Moreton Corbets, a younger branch of the family that had settled in central Shropshire. The Moreton Corbets were tied much more closely to the area around Shrewsbury than to the March. Robert Corbet of Moreton served as a Sheriff for Shropshire from midsummer of 1288 until November of 1289 and may also have been the Robert Corbet who served as Justice of Gaol Delivery for Shropshire from 1273 to $1292 .{ }^{65}$ By this marriage Joan's family would gain access, and eventual control over, lands along the border. It should be noted that Joan's father Robert also fought frequently with Thomas Corbet and by allying both families were able to exert influence on lands within the Corbets of Caus' sphere of influence. As for why Owain chose this particular marriage partner, it is possible that Owain was influenced by his Corbet grandmother to maintain the connection her natal family.

The geographical location of the lands of the Corbets of Caus brought them into direct contract with both the Gwenwys and Gwyn ap Gruffudd (Gwyn) kin groups. ${ }^{66}$ Most of these marriages are came through the descendants of Anne Corbet, daughter of

\footnotetext{
${ }^{65}$ R. W. Eyton, Antiquities of Shropshire, 8 vols. (Shiffnal: John Russell Smith 1854-1860),

${ }^{66}$ Genealogical data for the Gwenwys family comes from Bartrum, Welsh Genealogies: Ad 300-1400. "Gwenwys" Tables 1, 2 \& 4. Vol 1-4, 479-482.

Genealogical data for the Gwyn ap Gruffudd (Gwyn) family comes from Welsh Genealogies: Ad 300-1400. "Gwyn ap Gruffudd" Tables 3-5. Vol 1-4, 488-495.
} 
Peter Corbet of Caus. Anne Corbet was born around the 1270s and married one Sir Pirs Cambrey of Welshpool. The couple had two daughters, Cecily and Jonet. It was through Jonet's marriage to Gwenwys or Cadog Wenwys of Cegidfa, the eponymous head of the Gwenwys kin group, that the two families forged a connection. Two of Jonet's greatgranddaughters would both later go on to marry Thomas Corbet of Wollaston in the early fifteenth century.

The Gwenwys family held most of its land in the area the Welsh called Cegidfa, also known as Guilsfield - the area located directly across the Severn from Castle Forden and much of the Gorddwr. They also held lands in the parishes of Leighton, Wollaston, and Ystrad Marchell and in Forden, Nantcriba, and the Gorddwr in general. There were important marriages made between the Corbet family of Caus and the Gwenwys family.

Marriage connections with the Gwyn kin group also came, in part, from the descendants of Anne Corbet. Anne's granddaughter Cecily married Ieuan Gwyn ap Hoedlyw. One of Ieuan's cousins married another Corbet, Jonet Corbet daughter of Roger Corbet of Leigh at the beginning of the fourteenth century. The Gwyn family also held many neighboring lands with the Corbets, including in the parishes of Bausley, Leighton and Leigh, Trefnant, and Ystrad Marchell. They also held lands in Forden, Nantcriba, Westbury, and the Gorddwr as well as in Cegidfa/Guilsfield. Given the close physical proximity of these families' land-holdings it is highly probable that the fact that these families were neighbors was a strong factor in the formation of these marriages.

The Gwyn and Gwenwys families themselves had marital ties to each other and to the prominent Bleddyn ap Cynfyn kin group. As the following chart shows, the connections between these families and their English neighbors, particularly the Corbets, 
were a tangled skein. It is tempting to ask if the formation of a mixed marriage, by the thirteenth century mostly between Welsh brides and English husbands, made it more likely that future generations would contract similar marriages, even to the point of choosing members of the same extended family. Such a conclusion is strongly suggested by the available genealogical evidence, but ultimately cannot be determined.

Another Corbet marriage that sheds light on a different strategy to gain a place in this border zone than that usually used by the Corbet family is that of Joyce Corbet. A contemporary of Thomas and Margaret Corbet, Joyce Corbet, daughter of one Peter Corbet of Caus, married a man named Robert of Brampton. This marriage mostly likely took place before 1210 because their son Owain was of age by 1225 . On the surface this appears to be a marriage between two non-Welsh Shropshire families. However, the ancestry of Robert of Brampton is a more complicated story than it first appears. The family began in the region with the arrival of William of Elbeth or Elbeuf of Normandy in the late eleventh century. ${ }^{67}$ Not much is known about William, but it is possible that he married a Welshwoman. His son was known as William Darchog Da, or William the good-rider in Welsh, and the family gained land along the border. There are no marriage records for the William of Elbeth family before those of Robert and his children, but William's descendants have Welsh names. It is a reasonable conclusion that William made the choice to integrate himself into the Welsh border community to as he carved out a place for himself outside of Normandy. Robert de Brampton was thus the son of

\footnotetext{
${ }^{67}$ Genealogical data for the William of Elbeth family comes from Welsh Genealogies: Ad 300-1400. "William of Elbeth" Tables 1-4. Vol 1-4, 929-932.
} 
Madog ap Einion Godris, son of William Darchog Da and grandson of William of Elbeth. Subsequent generations married into both Anglo-Norman families through the line of Joyce and Robert's son Hywel and many prominent Welsh families in Montgomery through the line of their son Meurig.

To return again to the Bleddyn ap Cynfyn family, the most prominent landholding family in Powys, including in Montgomery along the border. Bleddyn ap Cynfyn was succeeded by his son Maredudd and, as discussed above, the rule of Powys was divided between two of Maredudd's sons upon his death in 1133. A third son, Iorwerth Goch ap Maredudd, sometimes known as Gervase Goch in court records, was given land in Upper Powys to hold under his brother Gruffudd, but he lost it to regional unrest in 1166. In his seminal twelve volume work on the history of Shropshire Eyton suggests that Iorworth Goch formed ties with the Peverel family in Shropshire in order to expand his holdings. Eyton was never able to explain exactly what the connection between these two families was, but it is true that after the death of several Peverel heirs in the 1130s and 40s Iorworth Goch put forward an official claim to the family lands in Sutton, Shropshire. The inheritance had fallen to a distant relative who had subsequently died on Crusade and left everything to his four sisters. Iorworth himself had married as his second wife Maud, the daughter of Roger de Manley of Cheshire, and there is a remote possibility that his claim came through her. Even though his connection to the Peverel lands is not fully explained, we do know that Iorwerth Goch was recognized as tenant-inchief during the reign of Henry II. ${ }^{68}$

${ }^{68}$ Welsh Genealogies: Ad 300-1400. "Bleddyn ap Cynfyn" Table 37. Vol 1-4, 64. Bartrum cites Eyton, Antiquities of Shropshire. Vol 2, 111. Vol 3, 141-142. 
Now in control of three properties in Shropshire, Iorworth continued his expansion into English territory by marrying his son Gruffudd to Matilda LeStrange, daughter of Guy LeStrange of Alveley and co-heir with her brother Ralph and cousin John LeStrange of Knockin (the father of Hawise LeStrange, wife of the last prince of Powys) The LeStranges were a prominent central Shropshire family and marriage to a coheir of the LeStrange estate meant that Gruffudd held the properties of Dovaston and Kynaston in the right of his wife as well as that of Sutton, which he had inherited from his own father. Both of Gruffudd's sons, from his marriage to Matilda and an earlier Welsh marriage, married Anglo-Norman wives. Through strategic marriage Iorwerth Goch ap Maredudd, the disinherited son of a price, was able to carve out a place for himself and his descendants not in the contested lands of Upper Powys but in the relative safety of Shropshire.

The Bleddyn ap Cynfyn family was large and at different times throughout the twelfth and thirteenth centuries various other members also made Anglo-Norman marriages. A distant cousin of Gruffudd ap Iorwerth Goch married yet another LeStrange - Elizabeth, the daughter or granddaughter of Matilda LeStrange's cousin John of Knockin - in the early thirteenth century. Elizabeth's grandson was none other than Owain Glyn Dwr who led the famous rebellion against English rule in 1402. Another Bleddyn ap Cynfyn cousin married Emma Audley around the same time and settled to the south in Radnor. One of Bleddyn ap Cynfyn's own sons even married the daughter of Picot de Sai as his fourth of five wives. It appears that even in the early years after the conquest the Bleddyn ap Cynfyn family saw value in building family connections with the newly arrived Normans. 
One further example of marriages that could work to the benefit of both families comes from the Welsh descendants of Gwaithfoed of Gwent, who settled in many places along the south and central border of Wales ${ }^{69}$ Gwaithfoed lived in the early twelfth century and appears to have left his home in either Gwent or Cereidigion to acquire new land. New kin groups were often formed this way and Gwaithfoed the eponymous head of this new group. It is through two of his three sons that we can see connections formed between Welsh and Anglo-Norman families. Aeddon of Grosmont began a southern branch of the family when he married the daughter of Sir John Russel of Kentchurch. Another of Gwaithfoed's sons, Gwyn Anwyl, settled in Whitecastle and Wynston, Herefordshire. Gwyn's son was known as Sir John Gwyn of Tre-Wyn, or Wynston. ${ }^{70}$ In the early 1200s John married his daughter Emlyn to a relative newcomer to the neighborhood, the Anglo-Norman Sir Tryw. Sir Tryw's father Sir Andrew of Valence was the first of the family to settle along the Welsh border. Emlyn's dowry appears to have included lands in Wynston, which were then passed on to her son, Sir. Gilbert Wynston of Tre-Wyn. Through this marriage the family of Andrew of Valence was able to gain a place in the community. This is one of the early examples of how Welsh property law customs had been adapted to make Welsh marriages attractive to their nonWelsh neighbors. The connection with Valence was also kept alive by Gilbert's eventual marriage to Isabel, the daughter of William de Valence, Earl of Pembroke.

${ }^{69}$ Genealogical data for the Gwaithfoed family comes from Bartrum, Welsh Genealogies: Ad 300-1400. "Gwaithfoed” Table 1. Vol 1-4, 469.

${ }^{70}$ Genealogical data for the Bleddyn ap Cynfyn family comes from Welsh Genealogies: Ad 300-1400. "Wynston" Tables 1 \& 2. Vol 1-4, 933-934. 
These examples represent just a fraction of the marriages taking place along the Welsh March in the eleventh, twelfth, and thirteenth centuries. With the exception of the Wynston family, I have limited them to families located along the MontgomeryShropshire border. It is clear that the middle and upper elites of Powys and the middle elites or knightly families of Shropshire intermarried often and for a variety of reasons. Motivations for many these marriages stemmed from the fact that these families were often neighbors who shared common property boundaries. Others appear to have been contracted to extend the family's power and influence. Finally, the possibility that an Englishwoman or Welshwoman in a mixed marriage played some role in promoting mixed marriages for her children and grandchildren. The very existence of these mixed families created a hybridity of cultural heritage and the possibility for complex identity in the Central March. 


\section{CHAPTER FOUR \\ WELSH LAW: PROPERTY, INHERITANCE, AND KIN-GROUP RELATIONSHIPS IN THEORY AND PRACTICE}

During the twelfth and thirteenth centuries the Welsh people living along the border between the English county of Shropshire and the Welsh county of Montgomery were caught between the idea of a collective Welsh legal identity and the realities of living in mixed English-Welsh communities in which legal and social separateness was not practical. While the territory of Wales had been divided into multiple kingdoms with conflicting dynasties and political agendas for hundreds of years, the Welsh people had long believed in the idea of a Welsh legal system that transcended these divides. This legal system was called the Laws of Hywel Dda, so named for the tenth-century ruler who is credited with its compilation. Hywel Dda set out a number of legal procedures that were unique to Wales and unlike the laws of its neighbors (the Irish and the English first the Anglo-Saxons, and then the Anglo-Normans) specifically in the ways in which land was held and how inheritance was distributed. A clear understanding of these legal systems is a key factor in the discussion of identity along the Shropshire-Montgomery frontier. First, it is necessary to discuss what the idea of a collective Welsh legal identity meant to the Welsh population. Then, to explain the ways in which the legal procedures detailed in Hywel Dda describe living under Welsh law. In particular, analysis of the Welsh laws concerning land tenure, inheritance, and marriage, and how they are dependent upon an understanding of the Welsh legal concept of galanas. A comparison of these legal procedures to those of post-conquest Common Law shows the other side of that mixed community. This step provides background necessary to show, via the case studies in following chapters, that this region did not adhere strictly to Welsh law but 
instead adapted various possibilities to the realities of a mixed community. To understand the frontier there has to be a discussion of what strict adherence to Welsh law would look like, how that law differed from English common law, and how these legal systems were then used by individuals living on the Montgomery-Shropshire border.

\section{Evidence of a Welsh Legal Identity}

At the time of the Norman Conquest there was no unified Kingdom of Wales. Princes fought for territorial control against each other, rival branches of their extended families, and even against their own brothers. They made alliances with the Irish and the Anglo-Saxons and sought control over the remnants of earlier Welsh kingdoms. These political fractures and the frequent military conflicts they entailed meant that the definition of being Welsh during the twelfth and thirteenth centuries did not necessarily include adherence to a unified administrative system or government. Yet while Welshmen paid their taxes and swore their oaths to different princes and lords under different forms of administration, they perceived that all of Wales was united by a single system of laws.

The Laws of Hywel Dda date back to the tenth century and it would be a valid question to ask if these laws still applied to Welsh life in the twelfth and thirteenth centuries. In truth, the extant copies of the Welsh laws were compiled beginning in the late twelfth century and continuing on into the fifteenth. The eight manuscripts of the Iorworth $^{71}$ redaction make up some of the earliest Welsh legal texts, having been begun

${ }^{71}$ The primary manuscript cited for the Iorworth redaction is Peniarth 29 (MS. A), for the Cyfnerth redaction it is Harleian 4353 (MS. V), and for the Blegywryd it is BL 
sometime during the reign of Llewellyn ap Iorworth (r. 1194-1240). Iorworth is the most complete set of Welsh laws and is associated specifically with legal procedures in Gwynedd. Yet it is similar in content to the other major Welsh redactions, the Blegywryd and the Cyfnerth. The Blegywryd Redaction comes from south Wales but the similarity of its content with that of the Iorworth and the Cyfnerth makes it clear that they were part of a larger unified legal tradition. The other collection of Welsh law is the Latin Texts made up of five Latin manuscripts dating from the late twelfth and thirteenth centuries.

Peniarth 28 of the Latin Texts is the oldest extant manuscript of Welsh law, having been written c. 1175-1200. These Latin manuscripts also bear a striking resemblance to their Welsh-language counterparts. ${ }^{72}$ The legal tradition created in the tenth century and retained under the general title of the Laws of Hywel Dda, as seen in the extant manuscripts, appears to have been consistent in both theory and practice among the Welsh-speaking peoples.

The historical Laws of Hywel Dda came to be associated with what it meant to be Welsh. A Welshman was not simply one who lived in territory that had historically been a part of the geographic boundaries called Wales but also a man whose life was governed by the responsibilities and protections afforded by Hywel Dda. The universal nature of Hywel Dda can be seen in references in the central and southern Welsh chronicle the Brut y Tywysogion. The Brut records that in the year 928

Cotton Titus D IX (MS. L). The Latin Texts most commonly cited are Peniarth 28 (Lat A) and Cotton Vespasian E XI 1 (Lat B).

${ }^{72}$ Arthur Wade Wade-Evans, ed. Welsh Medieval Law: Being a Text of the Laws of Howel the Good, Namely the British Museum Harleian Ms. 4353 of the 13th Century, with Translation Introduction, Appendix, Glossary Index, and a Map (Oxford: Clarendon Press, 1909; reprint, University of Toronto Libraries). vii-xix. Roberts, "Cyfraith Hywel." 
Hywel the Good, son of Cadell, king of all Wales, went to Rome, and three bishops with him, - Martin, Bishop of Menevia; Mordaf, bishop of Bangor, and Marchlwys, bishop of Teilaw: and Blegywryd, son of Owain, chief of the court of Llandav, brother to Morgan, king of Glamorgan, accompanied them. The reason they went there was, to consult the wise in what manner to improve the laws of Wales, and to ascertain the laws of other countries and cities, and the laws in force in Britain during the sovereignty of the emperors of Rome. And after obtaining information of these things, and the counsel of the wise, they returned to Britain, where Hywel convoked all the heads of the tribes of the country and their assistants, and all the wise and learned, ecclesiastical and lay, in a combined session at the White House upon Tav in Dyved. And after searching what was procured from every country, the laws of Dyvnwal Moelmud were found to be the best; and by the learning and doctrinal skill of the Doctor Blegywryd they were arranged; and by the judgment of the whole assembly they were expounded, improved, and augmented; and after the laws had passed the judgment and verdict of the country in the assembly, they were authorized and made legal in all the country of Wales. And after that Hywel went a second time to Rome, and obtained the judgement of the wise there, and ascertained those laws to be in accordance with the law of God and the laws of countries and cities in the receipt of faith and baptism. He then returned to Wales, and submitted his laws to the judgement of the cantrevs, comots, and verdict of the country ${ }^{73}$; and thence they

73 "The cantrevs, comots. .." refers to the local and regional units of land measurement used in Wales. A cantref was roughly the equivalent of an English county and a commote was a division within that territory. 
became authorized in all of the lordships of Wales, and in every court of lord and tribe, until they became paramount; and no others were used in any court of country and lord in Wales; and from the goodness of his laws he was called Hywel the Good. [sic] $]^{74}$

Notice how much emphasis is placed on the collective nature of the formation of this legal code; it was adopted only after the wisest men of Wales, as well as those in Rome, had been consulted. The law was then applied to every part of Wales, regardless of ruler or government. The Brut tells the story of the creation of the Laws of Hywel Dda as a cooperative effort to make the law a part of what it meant to be Welsh.

The attribution of the creation of Welsh law to Hywel Dda also appears in the extant manuscripts of Welsh law. The two earliest, Peniarth 28 (c. 1175-1200) from the Latin Texts and Peniarth 29 (c. 1200) from the Iorworth redaction, begin with a preface that names Hywel the Good (Hywel Dda) as the original compiler of Welsh Law. Later manuscripts reflect this attribution. Peniarth 28 begins by explaining how the Law came about, recording that Hywel, known as the good, or Dda, "having convened before the virtuous men, in one place, a tribunal, by general consensus, and carefully examining and having moderately blended (traditions) drew up the British laws." ${ }^{.75}$ Once again the emphasis is placed on the inclusion of wise men who were familiar with local custom and

${ }^{74}$ Brut Y Tywysogion: The Gwentian Chronicle of Caradoc of Llancarvan, (London: J. R. Smith, 1862), http://www.archive.org/details/brutytywysogiong00cararich. Electronic Book, not in copywrite. 21-23.

75 "Brittannie leges rex Howel, qui gonominabatur Bonus, id est Da, regni sui. . . sapientium et in uno loco ante suum tribunal congregatorum uno consensus et diligenti examination mediocriter temperateque constituit. " Hywel David Emanuel, The Latin Texts of the Welsh Laws (Cardiff: Wales U.P., 1967), 109. 
the therefore universal nature of the laws. Additionally, Peniarth 29 and Harleian 4353, from the Cyfnerth redaction, both state that a curse was placed on anyone in Wales "who perverted the laws and kept them not." ${ }^{76}$ Clearly, the compilers of these manuscripts actively engaged with and perpetuated the idea that Welsh law was something that applied to the entire Welsh people, regardless of region.

The Brut also assumes a group legal identity that went back to Hywel Dda. In 962 Hywel's son Owain “came [to Caerleon upon Usk], and bound himself to pay to Edgar [king of the Saxons] the tribute imposed on the Prince of Dinevor yearly by the law of Hywel the Good." $" 77$ More than a century later it is recorded that, when in 1094 a Norman force led by Paine Turberville invaded and began to demolish a castle at Cardiff "the Welsh insisted upon the preservation of the ancient privileges and customs of their country, and the laws of Hywel the Good, and to hold their lands free." Turberville and his advisors chose to pacify the local Welsh population and "the Welsh [had] their privileges and customs as they ought, and as they existed before the time of the Frenchmen." ${ }^{78}$ The Brut makes yet another reference to Hywel Dda when, in 1110, the people of Glamorgan discovered that Robert of Gloucester was planning to introduce the laws of Henry I into his territory. The Welshmen rose up, took Robert and his wife captive in their castle, and "put them in prison until he restored to the Welsh their freedom, privileges, and laws, as they had been since the time of Hywel the Good" and

${ }^{76}$ Wade-Evans, Welsh Medieval Law: Being a Text of the Laws of Howel the Good, Namely the British Museum Harleian Ms. 4353 of the 13th Century, with Translation Introduction, Appendix, Glossary Index, and a Map. 1li \& 145-146.

${ }^{77}$ Brut Y Tywysogion: The Gwentian Chronicle of Caradoc of Llancarvan. 29.

${ }^{78}$ Brut Y Tywysogion: The Gwentian Chronicle of Caradoc of Llancarvan. 79. 
required that he give an oath that "no office, duty, or assistance, should be imposed upon any Welshman without such person being allowed his land free and his due privilege, as was lawful to the Welsh nation." ${ }^{.79}$ There was thus a unified concept of Welsh law and, in particular, a Welsh form of tenure and specific Welsh legal rights.

English courts also recognized that there was a concept of traditional Welsh law. Thirteenth-century court records in Shropshire frequently make reference to cases being heard "secundum leges et consuetudines Wallensicas" or according to the Welsh laws and customs. ${ }^{80}$ The final years of the war between Gwynedd and England led to the dispossession of many landholders on both sides of the Severn and thus The Welsh Assize Roll, 1277-1284 records mostly property disputes. Often cases included at least one Welshman or woman. In these situations, requests to have cases heard according to Welsh law and tradition are common. Some of these cases involved elites with large landholdings, such as when Adam de Montgomery made a claim for the land between the Severn and the Wye rivers against Gruffudd ap Gwynwynwyn. Gruffudd asserted his right to the land and offered "to prove [this right] according to Welsh laws and customs. ${ }^{" 81}$ His claim was recorded using the standard language of secundum leges et consuetudines Wallensicas and Adam de Montgomery subsequently withdrew his case. The same phrase was used when Walter de Pedwardin and his wife Angharad sought the wardship of Angharad's son by her previous marriage, Llewellyn ab Owain. It was

${ }^{79}$ Brut Y Tywysogion: The Gwentian Chronicle of Caradoc of Llancarvan. 93-95.

80 J. Conway Davies, ed. The Welsh Assize Roll, 1277-1284: Assize Roll No. 1147, History \& Law Series (Cardiff: Board of Celtic Studies University of Wales, 1940). Harding, The Roll of the Shropshire Eyre of 1256.

${ }^{81}$ Davies, The Welsh Assize Roll, 1277-1284: Assize Roll No. 1147. 235. 
argued that even though his step-father was English Llewellyn, as the child of two Welsh parents, ought to have his case heard under Welsh law. ${ }^{82}$

In another case Ralph le Boteler and his wife Matilda made a claim for a manor and advowson of the local church against the Welshman Owain ap Gruffudd. Owain asserted that he held the manor legally under the traditional rules of Welsh partitive inheritance secundum legem Wallensicam. Ralph and Matilda countered with the argument that Welsh law did not apply since the manor was not in Welsh territory. In this case Owain, identifying himself as a member of the hominibus Wallensibus, was making the argument that as a Welshman he was under the jurisdiction of Welsh law regardless of which side of the border his land was on, an interpretation that is in keeping with the idea of a collective Welsh legal identity. ${ }^{83}$ Unlike in English law or even Norman law, where law was differentiated by region or territory, Welsh law applied to Welsh people, regardless of their location.

A similar argument for the use of Welsh law outside of Wales had been made before Henry III in 1241. Senana, wife of Gruffudd ap Llewellyn and sister-in-law of the David ap Llewellyn, the then Prince of Gwynedd, argued for Henry to intervene in her husband's case. David had imprisoned Gruffudd and Senana petitioned that the English king judge "whether lawfully he ought to be detained in prison; and in order that the king by judgement of his court shall cause him to have [justice], according to Welsh law, concerning the portion, which ought to fall to him of the inheritance of his father

${ }^{82}$ The Welsh Assize Roll, 1277-1284: Assize Roll No. 1147. 246.

${ }^{83}$ The Welsh Assize Roll, 1277-1284: Assize Roll No. 1147. 252-256. 
Llewellyn, of which the said David now deprives him." ${ }^{84}$ Because Gruffudd was a Welshman, his right to a share of the family inheritance should be judged by Welsh law. The primacy of Welsh law for Welshmen was maintained even with the acceptance of English legal jurisdiction.

A legal distinction also appears in criminal cases, specifically with regards to whether English or Welsh law should be used to hear cases and which legal system held jurisdiction. According to the English perspective, Welsh jurisdiction could apply to crimes that took place in the Walechariam, the Welsh lands. The Roll of the Shropshire Eyre of 1256 records two cases in the Hundred of Pimhill in which Welsh legal jurisdiction is cited. John of Prescott appealed Henry, abbot of Shrewsbury, and two other clerks for robbing him of a horse and $4 \mathrm{p}$. The abbot first claimed that the court had no jurisdiction over cases involving religious. ${ }^{85}$ When this claim failed he "testified that this [robbery] had happened inside Welshry (Walecheriam), so nothing can be inquired." ${ }^{86}$ In the same court session John son of William son of Philip appealed Fulk Fitz Warin for the death of his brother William. Once again the question was whether the crime was committed in a place where English or Welsh legal jurisdiction applied. Fulk testified that "he ought not to answer here, because this happened within Welshry (Walecheriam)." A review of the coroners' rolls determined that "it happened beyond Oswestry within the

${ }^{84}$ Calendar of Charter Rolls Henry Iii Ad 1226-1257, vol. 1 (London: Public Records Office, 1903), 262.

${ }^{85}$ Abbot Henry's claim of immunity from trial in a secular court was most likely a stall tactic. The right of the secular court to try religious men and women had been put in place by the Constitutions of Clarendon in the 1170s and the statute was virtually unopposed after the death of Archbishop Thomas Becket.

${ }^{86}$ Harding, The Roll of the Shropshire Eyre of 1256. 289. 
land of Wales. So by agreement Fulk is quit." ${ }^{87}$ The phrase used for the land of Wales, intra terram Walliensis, also appears to be the standard legal terminology to refer to Welsh jurisdiction.

The Calendar of Charter Rolls Henry III-Edward I 1257-1300 reflects the sometimes unclear nature of jurisdiction when it noted in 1285 that "the land of Wales, which since no short time was subject by feudal law to the kings of England, is now united to the king's dominion not only by power but by way of justice." 88 Pre-Edwardian Conquest Wales had often been under English rule, but not until the destruction of the kingdom of Gwynedd in 1282 had Wales been under English legal jurisdiction. The extent of Welsh jurisdiction, whether it was based on the location of the property and the ancestry of the claimants, or both, varied from assize to assize and eyre to eyre, a problem I will address in much greater detail in the following case studies. But regardless of what each individual court ruled, it is clear that the idea of a distinct form of Welsh law existed and that individuals involved in disputes often requested that Welsh law be used in judging their case. The concept of a Welsh legal identity that encompassed all Welshmen and women remained strong throughout the twelfth and thirteenth centuries. Compilation of Welsh laws into texts that all claimed a common ancestor in The Laws of Hywel Dda reinforced this idea.

${ }^{87}$ The Roll of the Shropshire Eyre of 1256. 289.

${ }^{88}$ Calendar of Charter Rolls Henry Iii-Edward I Ad 1257-1300, vol. 2 (London: Public Records Office, 1906), 284. 


\section{The Laws of England and the Anglo-Normans}

Many thousands of pages have been written to describe the development and the particulars of English Common Law. Historians have made conflicting arguments that its roots were Anglo-Saxon and that it was defined by the Norman Conquest or the reign of Henry I or the Angevin period of legal centralization under Henry II. It is not my intention to enter into this discussion, one which has occupied English legal historians for over a century. ${ }^{89}$ Instead, I have sidestepped this debate over origins and instead chosen to discuss elements of Common Law concerning land tenure, inheritance, and property that were in general practice in England by the end of the twelfth century. This information is necessary to understand the subsequent arguments about their differences from Welsh law.

I begin with a brief introduction to the English court system. Itinerant royal courts called Eyre Courts began during the reign of Henry I. These courts consisted of two royal justices who made a circuit from county to county to hear both civil and criminal cases.

They were held somewhat sporadically until the Angevin period, when they became much more regular. Part of Henry II's campaign to centralize and normalize the English legal system included the implementation of a standardized system of writs ${ }^{90}$ and

89 John Hudson, The Formation of the English Common Law : Law and Society in England from the Norman Conquest to Magna Carta, Medieval World (London ; New York: Longman, 1996), 19-23.

${ }^{90}$ Writs were originally royal decrees sent to ensure that a certain legal procedure was followed. As the use of writs increased under Henry II they became generalized concerning the type of procedure and were available to the general public. Sir Frederick Pollock and Frederic William Maitland noted that by the end of Henry II's reign several types of writs were available and "between these the would-be litigant must make his choice; he must choose an appropriate writ and with it an appropriate form of action." Writs could be purchased so that the court would ask the defendant a particular question. One of the most frequently used writs was that of novel disseisin, which directed that the 
traveling Eyre Courts. Intended to ensure that great lords could not hold unlimited power within their territory, the legal changes implemented under Henry II also ensured that the people of England had access to royal courts. Additionally, a court could be called to deal with a particular question, such as the Welsh Assizes ${ }^{91}$ of 1277-1284 that dealt specifically with property cases concerning lands in formerly Welsh territory.

It was important, then, for itinerant royal justices to have access to local knowledge. This brings us to the jury. The thirteenth century jury was comprised of twelve, or occasionally twenty-four, men of good-standing in the local community who could give evidence based on collective community memory. Jurors could be called upon to recall, for example, if a man had been in possession of a piece of property when he died, in order to determine if it rightly belonged to his heirs. They also testified in cases where one heir was fighting another and could explain why one should be favored over the other - the Shropshire Eyre of 1256 includes several cases where an heir's suit was dismissed because he or she was known to be illegitimate. In one example the jury was sufficiently aware of the workings of the community to know that, while the plaintiff was the oldest male child in his family, his parents had not married until after he was born, thus excluding him from inheritance. In the case of who should inherit the lands of Adam

court ask and answer the question "Did $B$ unjustly and without a judgement disseise $A$ of his free tenement. .." To disseise meant to deprive one of property rightly held. Because they were used in royal courts, writs allowed a tenant who had been deprived of his land to bring his case against the one who took it from him, even if it was his own lord. Sir Frederick Pollock and Frederic William Maitland, The History of English Law before the Time of Edward I, 2nd Edition, Liberty Press Reprint ed., vol. 1 (Cambridge: Cambridge University Press, 1898), 159-60.

${ }^{91}$ Additionally, while a writ is an order for the court to ask a particular legal question, an assize is the question itself. Thus one could purchase a writ of novel disseisin in order to instigate the procedure of the assize of novel disseisin. 
Hunter in Gravenhunger the jury determined that, while Adam had been seised at the time of his death and therefore his next heir should inherit, that heir could not be his daughter Agnes "because she was born long before Adam married her mother, and so is a bastard." 92

Juries also gave evidence about local traditions of land usage. Walter Haket of Wheathill brought a case against his neighbor John of Bromden in which he claimed that John had intentionally obstructed the path that Walter used to take his cattle to pasture by building a ditch. A key element of Walter's case was that the path in question had long been in use and thus should be maintained. He lost his case because, even though he did have the memory of the community on his side regarding the existence of the path, the men on the jury also remembered that John, when initially building the ditch, had secured Walter's consent and even paid him 5 shillings for the inconvenience. ${ }^{93}$ Sometimes jurymembers were actually sent out to make surveys and confirm the physical conditions of property under dispute, and if they failed to fulfill this task they could be fined. In a dispute over ownership of a certain wood between Richard son of Robert of Clifton and Richard of Harley both parties agreed that there should be a perambulation of the wood in order to settle the case. The Shropshire Eyre of 1256 records

The sheriff therefore has orders to go in person to Belswardyn wood, taking with him 12 lawful knights of the neighbourhood of Harley and Clifton, and by their oath make a perambulation, using clear boundary-marks and dividing-lines, between Richard of Clifton's wood in Clifton and Richard of Harley's wood in

\footnotetext{
${ }^{92}$ Harding, The Roll of the Shropshire Eyre of 1256. 31-32.

${ }^{93}$ The Roll of the Shropshire Eyre of 1256. 16.
} 
Harley. The sheriff shall make the perambulation known here on the Saturday after the Purification [sic] by the mouths of four knights. Afterwards, upon that day, come four knights who were at the perambulation, Eudes of Hodnet, Stephen of Bitterley, Peter of Minton and William of Leighton, who say that the perambulation began on the south from the Prior of Wenlock's land and proceeded along an old hedge between the wood and the field until it came to a great alder-tree. From the alder Richard may make a fence through that part of the wood if he so wishes, as far as a green oak, and thence through marsh and wood to a white oak an so on to another white oak standing in the fields. ${ }^{94}$

Because of their itinerant nature the Eyre Courts relied upon these twelve jurors from Harley and Clifton to know the intimate details of both the people in their community and the traditional boundaries of land ownership.

Property in post-Norman Conquest England was held under a system of tenure based on some form of agreement between the landlord and the tenant. Usually that agreement consisted of an oath taken by the tenant to the landlord that included the promise of fee or service. The landlord, for his part, would acknowledge that the tenant was seised, or in legal possession, of the land. Service requirements could be a certain number of days of work on the landlord's manor or of military service. While some form of service remained common, particularly knight's service in contested areas such as the Welsh border, by the mid-twelfth century many tenants held their land in fee. This meant that they paid an annual fee in coin or kind in exchange for their land. The oath, sometimes in the form of homage, remained an important element of the tenurial

${ }^{94}$ The Roll of the Shropshire Eyre of 1256. 56-57. 
agreement. John Hudson points out that when land stayed within a particular family over a several generations the ceremonies of 'seising' or actually transferring land from the landlord to the tenant became less important. Elsewhere Hudson notes that by the thirteenth century the ceremony of seisin was a physical process in which "the transfer was fulfilled by a real quitting of possession by the grantor, for example the removal of chattels, and the concomitant acquiring of seisin by the grantee." ${ }^{95}$ However, in areas where there were frequent changes in property ownership, such as when land was transferred through an heiress, the particulars of the agreement were emphasized. ${ }^{96}$ Court records on the Welsh border appear to bear this out and the majority of inheritance cases dealt with the question of whether the deceased had been in seisin of the property upon his or her death. The standard format in the records was to ask "Was mother/father of seised in demesne of in on the day he/she died?" ${ }^{97}$ Once again, use or occupation did not necessarily mean seisin. In the case asking if Robert Pickard was seised of two acres in Smethcote on the day he died, it was determined that Robert had held the land under a lease and therefore was not in seisin. Thus, he was not able to pass the land on to his son and heir. ${ }^{98}$

${ }^{95}$ John Hudson, Land, Law, and Lordship in Anglo-Norman England (Oxford: Oxford University Press, 1997), 160 n. 18.

${ }^{96}$ The Formation of the English Common Law : Law and Society in England from the Norman Conquest to Magna Carta. 88-89 \& 95. Land, Law, and Lordship in AngloNorman England. 16-22.

${ }^{97}$ Ass. ven. rec. si.__ frater/mater___ fuit seistus in dominico/dominica suo etc. Harding, The Roll of the Shropshire Eyre of 1256.

${ }^{98}$ The Roll of the Shropshire Eyre of 1256. 80. 
When land remained within a family for a long period of time the ceremonial aspects of seisin was often overlooked. Some claimants for land cited the history of seisin in their family as proof of their right to the property in question. When Isabel daughter of Richard of Fennemere claimed a virgate of land in Fennemere she argued that "A certain Edwin, her ancestor, was seised of the land in demesne and as of fee, taking the profits therefrom, in the time of Henry grandfather of the present king; and from Edwin the right descended to a certain Edwin as son and heir, and from that Edwin to a certain Richard as son and heir, and from Richard to this Isabel who now claims as daughter and heir."99

The writ of novel disseisin was commonly used to instigate cases to determine if someone had been unjustly deprived of his or her land. One example of this is the case Ralph of The Lowe brought against William of St. George claiming that William had disseised him of his common pasturage in Neen in southeastern Shropshire. Ralph argued that William had ejected him from using thirty acres of heathland to pasture his animals. William countered that Ralph had never been seised of the land, but instead had used it as common land. The jurors agreed with William that, while he had used the land, Ralph had never been seised of it and therefore had no claim. ${ }^{100}$

English tenure allowed the tenant to alienate land if he desired, as long as the increasingly-compensatory elements of the agreement with upheld. Land could be granted by one tenant to another in a process of subinfeudation or quit by the original tenant so that the land was returned to his landlord. Subinfeudation was common and even small landholders could choose to alienate a portion of that holding to a tenant.

99 The Roll of the Shropshire Eyre of 1256. 64.

${ }^{100}$ The Roll of the Shropshire Eyre of 1256.14-15. 
There was no legal system of entailment, but many individuals chose not to alienate property that had been inherited but rather property that they themselves had acquired. Property that was geographically distant from the individual's main holdings was also more likely to be alienated. ${ }^{101}$

The most common way in which property was transferred was through inheritance. In Anglo-Norman England the genealogically closest heir was most likely to inherit. If there were multiple sons the eldest received the entire inheritance and by the 1130s families without sons divided property equally between daughters. Inheritance by heiress or heiresses was a frequent occurrence on the English side of the Welsh border. This system of direct inheritance by the heir was not foolproof, however, and at times a lord could step in and accept the claim of an alternative heir. Heirs were occasionally displaced because of perceived lack of ability, illness, or simply local politics. At the lower levels of society a lord could chose to place a new tenant on a piece of land when the previous one died and he did not always chose someone from within the former tenant's family. Lords could use the death of a tenant as a way to gain increased fees by not allowing the tenant's heirs to inherit the tenurial agreement but instead bring in new tenants who would pay more. One of the systemic changes in property law made by Henry II was to create the writ of mort d'ancestor which allowed close relatives to challenge a lord who cancelled their tenancy upon the death of the principal tenant. Mort d'ancestor allowed the son, daughter, brother, sister, nephew, or niece of the deceased

${ }^{101}$ Hudson, The Formation of the English Common Law : Law and Society in England from the Norman Conquest to Magna Carta. 100-103. 
tenant to make a claim to the land based on a history of occupation and tenurial agreement. This led to the lands being, in general practice, fully heritable by $1200 .^{102}$ The use of writs such as novel disseisin and mort d'ancestor as well as the writ of dower could be tricky. It was important that a writ include all relevant landholders and all relevant heirs. When Robert de Meysy and his wife Eve made a claim of disseisin against Philip Marmiun and his wife Joan, along with John of Newton and Roger of Westley, they failed to take into account that Philip and Joan did not hold the land on their own: the land was jointly held by Joan and her sister Isabel as the co-heirs of their father. Because Isabel and her husband William Walerand were not listed on the writ the writ was declared invalid and the case dismissed. Robert and Eve were fined and the court recorded "Let them sue by another writ if they wish." ${ }^{103}$ Similar verdicts could be found if the land on the writ was written as being in the wrong parish, if current occupants had not held the land when the writ was issued, or if writs of novel disseisin were purchased after the statute of limitations on disseisin of a year and a day since the actual displacement.

Both the English and Welsh populations along the border made legal claims based on custom. The definition and particulars of custom changed based on legal system and region, but the role of custom as precedent remained constant. Welsh custom, as discussed above, centered around the right of tenants to claim Welsh tenure and practices

${ }^{102}$ Land, Law, and Lordship in Anglo-Norman England. 66-67. The Formation of the English Common Law : Law and Society in England from the Norman Conquest to Magna Carta. 97-100 \& 126. Maitland, The History of English Law before the Time of Edward I.1. 157, 2. 59-60.

${ }^{103}$ Harding, The Roll of the Shropshire Eyre of 1256. 126-127. 
even when their landlords were replaced by Englishmen. References to English custom often referred to new laws enforced by the Anglo-Norman overlords on the English population in Shropshire. Many disputes over custom had to do with new Anglo-Norman forest laws. When John Wyard made a plea against Walter de Clifford that he should have "the right to make an eyre on a nag and with a groom, to make forest attachments, and to do all those other things which pertain to forest jurisdiction" he argued that "all his ancestors, in the reigns of the kings of England from a time whereof the memory of man runneth not to the contrary" had the rights to such use of the forest. ${ }^{104}$ As the thirteenth century progressed, the claim to custom became more difficult. This case, brought before the Shropshire Eyre in 1256, was ultimately decided against John Wyard because he did not have a charter to substantiate his claim.

\section{Living According to Welsh Law}

In order to analyze whether the twelfth- and thirteenth-century Welsh population along the Shropshire-Montgomery border lived in a different way than their English counterparts we must first determine what life according to Welsh law actually meant. The Welsh legal texts' definitions of kinship and the procedures for inheritance and the holding of property are different from those practiced under English Common Law or even Norman property law.

Kinship was at the heart of the Welsh legal system. Relationships were calculated to the fourth generation through both the paternal and maternal lines. These calculations were necessary to figure out both legal responsibility and the ways in which inheritance could be divided. The basic reason for being able to calculate kinship was to determine

${ }^{104}$ The Roll of the Shropshire Eyre of 1256. 78-80. 
which family members should pay or receive galanas and sarhaed. Once these categories of kin were established they were applied to all other questions regarding kin relationships.

Galanas was at the same time the payment to be made in the case of an individual's death and the compensation to be given to the victim's family. Sarhaed was an equivalent used in cases of insult or injury. Together galanas and sarhaed were similar to the Anglo-Saxon concept of wergeld. However, unlike many Anglo-Saxon legal codes, Welsh law books spend little time determining the particular value of individuals at different levels within the community hierarchy. Instead, they described the percentage of galanas responsibility held by different parts of the family. The perpetrator and different degrees of his or her kin were held responsible for contributing specific percentages of these payments. The same percentages applied to determine which members of the victim's family received compensation and what portion of the whole that compensation was. The key to understanding how to calculate galanas was to identify four generations of kin. The same calculation was used to determine who paid galanas and who received it. If one man killed another the slayer was responsible for one-third of the required galanas and his family for the remaining two-thirds. When calculating the receipt of galanas the widow of the victim received half of his third and his brothers received the other half. The family of the slayer's father was then responsible for two-thirds of the family payment and his mother's family for one-third. The amount to be paid by the family was then divided into four paying groups: ${ }^{105}$

${ }^{105}$ Charles-Edwards, Early Irish and Welsh Kinship. 182-189. 
- Slayer's father and brothers plus father's male kin (father, brothers, and nephews) $=$ one-third of family payment

- Slayer's father's mother's male kin (brothers and nephews) = one-third of family payment

- Slayer's mother's male kin (father, brothers, and nephews) = two-ninths of family payment

- Slayer's mother's mother's male kin (grandfather, brothers, and nephews) $=$ one-ninth of family payment

This system was generally referred to as 'thirding' and the family members it identified were considered close kin or the 'four kindreds'. ${ }^{106}$ The family that qualified for galanas was thus based on lateral relationships in which the mother's male kin played an important role. By the twelfth century galanas was no longer collected in most parts of Wales, but the 'four kindreds' provided a legal structure that was used to settle property and inheritance disputes. Some legal cases also required oaths or pledges from kin and the number of men serving as 'oath-helpers' be decided using the base galanas calculation of two-thirds of the men being from the paternal kindred and one-third from the maternal kindred. ${ }^{107}$ Inheritance of property could then also be determined based on this definition of family.

${ }^{106}$ Early Irish and Welsh Kinship.194.

107 T. Pierce Jones, "Social \& Historical Aspects of the Welsh Laws," Welsh History Review (1963). 39-40. 
Because Welsh law had a lateral rather than paternal-lineal view of kinship, the people who represent close kin in a family often went back no further than an individual's grandfathers or great-uncles. Welsh law encourages the involvement of uncles, cousins, and nephews from both the father's and the mother's side of the family in cases involving homicide or, much more frequently, division of inheritance. Family within the degree of the 'four kindreds' generally lived in the same geographical area. The system of dividing inheritance into thirds, ninths, and possibly sixteenths, meant that one farmstead could very likely belong to several family members. At the same time, a member of that family could inherit a third of a farmstead from his brother and a sixteenth of another from his maternal great-uncle. These lands were often not coterminous and thus some form of group administration was necessary. Co-inheritance fit exactly with the Welsh legal view of land tenure. According to the law codes, Welsh land tenure was communal in that land was held at large by a kin-group and, at least theoretically, was to be periodically redistributed based on the needs of the families within the group, thus making land neither alienable nor heritable.

Welsh law was further differentiated from that of the English because family movable possessions were distributed through partible inheritance, not only among sons but also frequently among daughters, rather than through any form of primogeniture. Also, the idea that land in Wales was not heritable is somewhat misleading; in practice Welsh families divided their land between male heirs in accordance to the galanas system, which meant that not only sons but also uncles often made claims for a portion of the inheritance. While land was in this way inherited, it was still considered to be part of the larger kin-group holding. When a man passed on his land to his heirs what mattered 
was actually possession and usage of the land, rather than a modern concept of ownership. This form of usage or tenure was known as priodolder and will be discussed in greater detail below.

Illegitimate children were also able to inherit under Welsh law. As we saw in the case of Senana wife of Gruffudd ap Llewellyn appealing to Henry III for a review of her husband's inheritance claim in accordance with Welsh law. This case demonstrates some of the complexities involved in appealing to Welsh law when it best served the petitioner's interest. Gruffudd, the son of Llewellyn the Great and a Welsh concubine, was the illegitimate son of two Welsh parents. In 1241 he and his wife petitioned the English king for the restoration of Gruffudd's portion of the Gwyneddian inheritance due him under Welsh law. His brother David, who had inherited the rule of Gwynedd, was the son of Llewellyn the Great by his English wife Joanna (herself illegitimate, the natural daughter of King John I of England). David made the claim to his right to the entirety of the inheritance according to the English law of primogeniture, which excluded illegitimate heirs. ${ }^{108}$ But Welsh law allowed for equal inheritance by sons regardless of legitimacy, a practice that proved to baffle, and sometimes, outrage Englishmen. For example, the Welsh practice of concubinage and the acceptance of illegitimate children was a continuous source of annoyance to Archbishop of Canterbury John Peckham in the 1270 s and 80 s.

Welsh law did not allow for women to inherit land under any circumstances, although they were able to inherit movable property in equal measure with their brothers. And, in keeping with the degrees of kinship established by galanas, male kin related

${ }^{108}$ Calendar of Charter Rolls Henry Iii Ad 1226-1257.1. 262-63. 
through the female line could inherit. Thus, the ties created by marriage were important to matters of inheritance. Even after marriage Welsh women retained strong legal connections to their natal families. The galanas of a Welsh woman was calculated based on a woman's natal kin in the same way as a Welsh man's. Conversely, the responsibility to pay or receive sarhaed on her behalf belonged to her husband and his family. T. M. Charles-Edwards noted that the Welsh woman "stands between two kindreds, belonging for galanas to one, for sarhaed to the other, and not fully a member of either, but yet knitting them together in alliance." ${ }^{109}$ These alliances remained a strong source of power in kin groups and it is in the area of female inheritance that the first adaptations between English and Welsh law would be made. I will discuss this development further in the forthcoming case studies.

One of the most visible differences between English and Welsh law was the difference in land tenure. The Welsh process of tenure, centered on kin group holdings, did not function in the same way as the manorial system emerging in England. English tenure meant an assessment based on the land itself and involved an oath of fealty in exchange for the use of the land. According to Welsh law, any dues were paid based on the family group itself and not on the size of land held. In Wales the clan element was retained in that the kin group paid the land fees as a group and not as individual land holders. Kin-groups paid as a unit, even if they had spread branches of the family throughout the region. For example, freeman's dues paid to Gwynedd in the years leading up to the Edwardian Conquest were paid at Deunant for the whole of the Hedd Molwynog clan, even though the clan itself had spread to seven different settlements

${ }^{109}$ Charles-Edwards, Early Irish and Welsh Kinship. 186. 
throughout Rhufoniog in northeastern Wales. ${ }^{110}$ Because so much of the land was held communally, the practice of the personal oath in exchange for land was uncommon. Another difference was that free kin-groups often owned mills attached to specific gwelyau, or the landholding of the kin-group as a whole. The English manorial practice of requiring everyone in an area to use the local lord's mill did not become common in many parts of Wales until after the Edwardian Conquest. ${ }^{111}$

A key point in any English property case was to demonstrate that a man or woman had been seised, or have seisin, in the land in question at the time of his or her death. Sir Frederick Pollock and Frederic William Maitland dedicated almost all of the second volume of their seminal work on medieval English law to the discussion of property, tenure, and inheritance, and their definition of seisin is extensive. At the most basic level, seisin meant to be in actionable possession of property - that is, the legally recognized possessor of the land. The question then becomes how then can a person be determined to be seised? Pollock and Maitland suggest that "before we attribute possession to a man, we must apparently know something about the intentions that he has in regard to the thing, or rather about the intentions that he must be supposed to have when the manner in which he came by the thing has been taken into consideration. .. to say at once that we require to know how he came by the thing."112 Either communal

${ }^{110}$ D. Huw Owen, "Tenurial and Economic Developments in North Wales in the Twelfth and Thirteenth Centuries," Welsh History Review 6 (1972). 120

111 James Given, "The Economic Consequences of the English Conquest of Gwynedd," Speculum 64, no. 1 (1989). 27.

${ }^{112}$ Sir Frederick Pollock and Frederic William Maitland, The History of English Law before the Time of Edward I, 2nd Edition, Liberty Fund Reprint ed., vol. 2 (Cambridge: Cambridge University Press, 1898), 36. 
knowledge or documentary evidence was needed to show how a man came to obtain possession, specifically whether he had engaged in an oath that formalized his possession. English court records are filled with discussions of when an individual had been confirmed to have seisin of a piece of land, and this was the factor that mattered in determining who had right to that land. This process was applied equally in cases when a man or woman had been disseised or deprived of their property and when the rightful heir or heirs to an inheritance were in question.

The Welsh legal process to determine possession and legal right to land was different than the English system. Rather than being dependent upon the oath, Welsh law determined right by evidence of a historical physical possession. This type of tenure was known as priodolder and was based on a claim that the land in question had been continuously occupied by a family member within the degree of the 'four kindreds' over a period of at least four generations. This process of possession over time, which D. Huw Owen termed "perpetual mortgage" 113 , meant that an individual's claim to land changed from one of physical possession at a particular moment to one of legal right to that possession. Non-priodolder forms of tenure, such as the purchase of land or as a gift from the king, could, over time, be transformed into hereditary land through this process. ${ }^{114}$ Evidence of the continued use of priodolder to determine legal right can be seen in

113 Owen, "Tenurial and Economic Developments in North Wales in the Twelfth and Thirteenth Centuries." 130.

114 "Tenurial and Economic Developments in North Wales in the Twelfth and Thirteenth Centuries."; "The Middle Ages," in Settlement and Society in Wales, ed. D. Huw Owen (Cardiff: University of Wales Press, 1989), 
English court records where men and women of Welsh descent based their claim on the continuous occupation of their ancestors over several generations.

\section{Legal Adaptations in practice:}

In the subsequent chapters I will discuss how the choices of the individuals and families on the border in the way they pursued marital and community connections and used the available legal systems reflects a distinct concept of Welsh legal identity that was, nevertheless, fluid in its use and interpretation. I begin by demonstrating that intermarriage and multicultural communities were common in Shropshire and along the English-Welsh border.

In the following case studies, I draw out specific cases from the Roll of the Shropshire Eyre of 1256 and the Welsh Assize Roll of 1277-1284 that demonstrate how mixed English-Welsh families used an adapted form of Welsh law in the English court system to pursue property cases on both sides of the border. The Shropshire Eyre includes many examples of mixed English and Welsh couples as well as cases between English and Welsh neighbors and both English and Welshmen serving in the court. Examples include the appointment of one William Welsh (Willelmum le Waleys) as an attorney for William Walerand and his wife Iseult in a case concerning land in Pulverbatch and the use of the Common Law writ of novel disseisin against Robert son of Robert Welsh (Roberti de Wales) over a tenement. ${ }^{115}$

${ }^{115}$ Harding, The Roll of the Shropshire Eyre of 1256. 5 \& 70-71. 
The Welsh Assize Roll ${ }^{116}$ is primarily made up of cases in which men and women sought to reclaim lands lost during the final conflict between Gwynedd and England in the 1270 s to 1282 . Many of these cases concern couples who held property by inheritance in both England and Wales and in most cases a couple sought to reclaim lost lands in the right of the Welsh wife. While there are a number of cases that can serve as relevant examples of how Welsh law had been adapted to allow for women to inherit property when they married outside the kin group system, one case in particular stands out. In 1278 Angharad f. Owain and her husband Sir Walter de Pedwardin attended the Assizes and filed suit to regain land lost in Edward I's recent conquest of Gwynedd. Angharad, a Welshwoman, claimed lands in Cedywain, Powys, as her right as heir to Owain ap Maredudd, lands which were currently held by Roger Mortimer by grant from the king. Her right to this land was strongly contested and, over the next several years, Angharad and Sir Walter applied to the English courts again and again. Their argument relied on using elements of both English and Welsh law to substantiate their claim, while their opponents also used legal loopholes, both English and Welsh, to delay or end the case. The history of this case takes us through a tangled skein of Welsh kinship laws, English and Welsh concepts land of tenure and possession, and a dizzying progression of legal technicalities and evasions that provide a glimpse of how individuals on the Central March used their heritage and identity to manipulation the legal system to their own benefit. These case studies demonstrate the adaptations made to Welsh law and the ways in which Welsh peoples used their legal identity to their own advantage.

${ }^{116}$ Davies, The Welsh Assize Roll, 1277-1284: Assize Roll No. 1147. 


\section{CHAPTER FIVE \\ THIS IS MY COMMUNITY, IS IT MY COURT? A CASE STUDY OF MULTICULTURAL COMMUNITIES AND LEGAL PARTICIPATION IN THE ROLL OF THE SHROPSHIRE EYRE OF 1256}

It can be asked what a collection of court cases, combined into a lone legal document from 1256, can tell about multicultural interactions in the county of Shropshire. After all, legal documents are often sparse in detail and narrow in scope. That being said, throughout the following case study I argue that the information contained in the Roll of the Shropshire Eyre of 1256 provides ample evidence to support the designation of Shropshire as the location of many multicultural communities made up of both English and Welsh peoples. This first point can clearly be seen in the cases that record English and Welsh men and women suing and supporting each other and serving as pledges and attorneys for one another. Accounts of disputes between neighbors, questions of rights of access, and even the reports of misadventure and murder support the argument that the Welsh lived far and wide throughout the English county and that they interacted as members of their villages and towns, rather than members of communities segregated by ethnicity and cultural difference. This can be seen further through the record that a total of twenty Welshmen were chosen as jurors, a role specifically restricted to long-standing, prominent, and trustworthy members of a community.

The data supplied by the Roll of the Shropshire Eyre also supports the idea that Welsh individuals often voluntarily used the English legal system for their own purposes and to their advantage. While the Welsh Assizes, 1277-1283, the subject of the next case study, features many references to individuals asking that their case be heard according to Welsh law, the petitions of the Eyre remained, for the most part, within the English legal system. Thus, Welshmen and women would have needed at least some working 
knowledge of how English Common Law worked. The truth of this can be seen in instances in which defendants argued to dismiss cases based on an incomplete or erroneous application of English Law.

Finally, this case study provides an example of how legal sources can be used to answer questions of community interaction and identity. These sources, so often overlooked by cultural historians, contain slivers of insight into English-Welsh cooperation, instances of mixed-heritage families, and at least a few of the realities of multicultural interaction in the Middle Ages.

\section{The Eyre Court of 1256:}

In the early days of January 1256 , a retinue of judges and their accompanying clerks and attendants arrived in Shrewsbury, the legal and economic center of Shropshire, to hold a Court in Eyre. Thirteenth-century Eyre courts consisted of groups royal justices who traveled from county to county to hear local cases. Shropshire had previously been visited by Justices in Eyre in 1221, 1227, 1240, and 1248. Because there was a gap of several years between courts, when the justices arrived in Shropshire in 1256 they had a full docket of civil and criminal cases to hear. The Eyre court began on Friday, the $14^{\text {th }}$ of January in 1256 and continued for about one month. This particular Eyre court had four justices: Simon of Walton (soon to be elected Bishop of Norwich), the Abbot of Peterborough John of Caux, and Robert of Shottenden and Nicholas of Hadlow, both from Kent. The court documents recorded that cases were heard before S. of Walton and his fellow justices and it appears that Simon of Walton was the head justice. ${ }^{117}$

${ }^{117}$ Harding, The Roll of the Shropshire Eyre of 1256. xi-xv. 
These men met in Shrewsbury and began by hearing civil cases in order of appearance. Criminal cases were then reviewed be geographical region of hundred, liberty, manor, or borough. Because of this approach it is much easier to trace the locations of the criminal cases than those of civil ones, especially when there were multiple possibilities for a location. For example, in the plea of Mort d'Ancestor by Dafydd s. Yagan against Nicholas Meverel concerning land in Rowton, Rowton could have been located on the western side of Shropshire in Alberbury parish in the Hundred of Ford or in the eastern portion of the county in High Ercall parish in the Hundred of Bradford. It can be tempting to assume that a case involving Dafydd s. Yagan ${ }^{118}$, a Welshman, would concern property in Alberbury since the parish directly abuts the border with Wales. ${ }^{119}$ However, as I will argue throughout this study, Welsh men and women lived in communities across the county, not just along the border.

\section{What makes him a Welshman?}

The process of tracing a Welsh presence in Shropshire is heavily dependent on name evidence. That being said, using personal names as evidence of ethnicity and identity can be problematic. As Stephanie Mooers Christelow has pointed out, A person's identity can be guessed by place of birth and status, by appearance or race, by her or his name(s), and by religious practice, gastronomic styles, and costume, but is established primarily through the language and dialect that she or

\footnotetext{
${ }^{118}$ Yagan is mostly likely a form of the Welsh cognomen Fychan ('Small'), along with the the similar Fagan, Vaugan, and Vaughn.

${ }^{119}$ Harding, The Roll of the Shropshire Eyre of 1256. No. 142.
} 
he speaks, and her/his accent. Ethnicity is demonstrated through one's considered emphasis on origin, kin, and nomenclature. ${ }^{120}$

Because factors such as language or dialect are extremely difficult for modern historians to determine, assigning ethnicity for historical purposes can be very difficult. That said, name evidence can supply a probability or likelihood of identity.

Names are given by family members and can reflect the heritage of one or both parents or grandparents, popular naming trends within a community, or a connection with a non-relative of that name. Because of the subjectivity of naming, they can tell us about both personal- and socially-constructed forms of identity. As John Reuben Davies has argued,

Personal names can reveal aspects of medieval society that might otherwise be unknown; for a person's name is far more than just a label for identification; it is a public statement and it carries a message. A name may evoke history, embody prophetic expectations, or signify a destiny. A name therefore carries with it a certain weight, a meaning given to it by the society from which it comes. In short, a person's name brings with it identity and culture: it represents a cultural choice. $^{121}$

\footnotetext{
${ }^{120}$ Stephanie Mooers Christelow, "Name and Ethnicity in Anglo-Norman England," in Studies on the Personal Name in Later Medival England and Wales, ed. Dave Postles \& Joel T. Rosenthal (Kalamazoo: Medieval Institute Publications, 2006), 342.

${ }^{121}$ John Reuben Davies, "Old Testament Personal Names among the Britons: Their Occurrence and Significance before the Twelfth Century" (paper presented at the 18th Annual Conference of the Society for Name Studies in Britain and Ireland, Falmouth, 2009). 1.
} 
Welsh Name

\begin{tabular}{|c|c|c|c|}
\hline $\begin{array}{l}\text { Kenewrek Welsh } \\
\text { (Edgemond Parish) }\end{array}$ & Walliens' & $\begin{array}{l}\text { Brother Nicholas } \\
\text { Welsh of Buildwas } \\
\text { Abbey }\end{array}$ & Le Waleys \\
\hline $\begin{array}{l}\text { Llewelyn s. } \\
\text { Wrennok s. Meurin } \\
\text { s. Meurith and other } \\
\text { Welshmen of Rinan }\end{array}$ & Socii sui Walenses & $\begin{array}{l}\text { Henry Wele of } \\
\text { Loton } \\
\text { John Welsh of } \\
\text { Hales }\end{array}$ & $\begin{array}{l}\text { Wele } \\
\text { Le Waleys }\end{array}$ \\
\hline $\begin{array}{l}\text { Tuthegy, a } \\
\text { Welshwoman } \\
\text { (Chirbury Parish) }\end{array}$ & Quedam Walensis & $\begin{array}{l}\text { Philip Welsh } \\
\text { (Clunbury Parish) }\end{array}$ & Le Waleys \\
\hline $\begin{array}{l}\text { Wrennon, a } \\
\text { Welshman } \\
\text { (Bromfield Parish) }\end{array}$ & Quidam Walensis & $\begin{array}{l}\text { Robert s. Robert } \\
\text { Welsh of Ragdon }\end{array}$ & De Wales \\
\hline $\begin{array}{l}\text { Yareford Welsh of } \\
\text { Bitterley }\end{array}$ & Walens' & Robert Welsh & Waleis \\
\hline $\begin{array}{l}\text { A certain poor } \\
\text { Welshman in } \\
\text { Wydicote }\end{array}$ & $\begin{array}{l}\text { Quidam Walensis } \\
\text { pauper }\end{array}$ & $\begin{array}{l}\text { Robert Welsh of } \\
\text { Adderley }\end{array}$ & Le Waleys \\
\hline \multirow{2}{*}{\multicolumn{2}{|c|}{$\begin{array}{l}\text { Indeterminate Name } \\
\text { (By the mid-twelfth century Adam was a } \\
\text { popular name in both England and Wales) }\end{array}$}} & $\begin{array}{l}\text { Roger Welsh of } \\
\text { Burlton }\end{array}$ & Le Waleys \\
\hline & & $\begin{array}{l}\text { Simon Wele of } \\
\text { Myndtown }\end{array}$ & Wele \\
\hline $\begin{array}{l}\text { Adam, a Welshman } \\
\text { of Lee/Priorslee }\end{array}$ & Quidam Walensis & $\begin{array}{l}\text { Stephen Welsh of } \\
\text { Sheet }\end{array}$ & Le Walsse \\
\hline \multirow[t]{3}{*}{$\begin{array}{l}\text { Adam Wele of } \\
\text { Overs }\end{array}$} & Wele & $\begin{array}{l}\text { William Welsh } \\
\text { (High Ercall Parish) }\end{array}$ & Le Waleys \\
\hline & & $\begin{array}{l}\text { William Welsh } \\
\text { (Church } \\
\text { Pulverbatch Parish) }\end{array}$ & Le Waleys \\
\hline & Individu & $\begin{array}{l}\text { ble } 5.1 \\
\text { identified as being W } \\
\text { ire Eyre of } 1256\end{array}$ & ish in \\
\hline
\end{tabular}

\section{English Name}

. 
In the Eyre of 1256 there are two ways to identify an individual as Welsh - by the use of a Welsh name or by the specification that an individual is Welsh. As can be seen in Table 5.1, of the more than two-thousand recorded names in the Eyre record, only twenty were identified as being Welsh (usually as le Waleys) or of Wales (Walensis). Neither of these identifiers were chosen by the individual him/herself, but they can provide information into how the community and family saw that individual's identity. An individual's parents, and possibly extended family members, chose his or her name. As Dave Postles points out,

Names are, and were, of course, conferred by others onto us. Identity, as it occurs through naming, is thus not a realization of John Locke's punctual person but rather a social act exercised by others on the self. The naming process is thus constitutive of individualization and identification, and also identity, the latter less as selfhood as within the social sphere. The identity involved in the naming process is thus not selfhood, that is, personal identity, but social and cultural identity, and it is precisely in this context that it has something to offer to historians of social organizations and cultures. ${ }^{122}$

Thus, the names chosen by parents in twelfth and thirteenth-century Shropshire can convey all sorts of cultural information, such as the way a person's parents selfidentified, how a community saw a person's identity, and which members of society a person's parents valued and sought to emulate and/or commemorate. Names have trends,

122 Dave Postles, "Identity and Identification: Some Recent Research into the English Medieval "Forename"," in Studies on the Personal Name in Later Medieval England and Wales, ed. Dave Postles \& Joel T. Rosenthal (Kalamazoo: Medieval Institute Publication, 2006), 30-31 
and the names of elites were quite popular. For example, Robert Bartlett has identified the trend of naming children after lords and princes as "simple cultural emulation of a powerful neighbor." "23 The Paradox of Medieval Scotland Project has come to similar conclusions based on the growth in popularity of names such as William, Robert, John, Richard, and Henry in Scotland in the twelfth and thirteenth centuries. In fact, they found that these five names made up twenty-seven percent of all names recorded in documents extant from that period. ${ }^{124}$ This trend appears in the Roll of the Shropshire Eyre as well, where the most popular male names were William (350), Richard (207), John (157), Roger (136) and Robert (131), all names of Anglo-Norman kings and magnates. The most popular names for women included Alice (29), Matilda (21) and Margaret or Margery (21), which were also often the names of queens and princesses. ${ }^{125}$

Elites were not the only ones who influenced naming trends. Saints names were also popular, especially when using the name of a local saint, as we will see below with the frequent Welsh use of the name Dafydd. Iris Shagrir has identified what she calls 'universal religious names' in the Central Middle Ages, in particular the names Peter, John, James, Philip, Thomas, and Nicholas. ${ }^{126}$ Note that all but one of these are New

${ }^{123}$ Robert Bartlett, The Making of Europe: Conquest, Colonization and Cultural Change 950-1350 (Princeton: Princeton University Press, 1993), 277.

${ }^{124}$ The Paradox of Medieval Scotland Project is administered by King's College London. These findings refer to the $20101^{\text {st }}$ edition of the database, which includes all documents between 1093-1286 known to exist concerning Scotland. Matthew Hammond, "Introduction: The Paradox of Medieval Scotland, 1093-1286," in New Perspectives on Medieval Scotland, ed. Matthew Hammond (Woodbridge: The Boydell Press, 2013),

${ }^{125}$ See Appendix Four.

${ }^{126}$ Matthew Hammond, ed. New Perspectives on Medieval Scotland, 1093-1286 (Woodbridge: The Boydell Press, 2013). 37. 
Testament names. Philip, Thomas, and Nicholas were also popular names in the Roll of the Shropshire Eyre, with more than one hundred Thomases and roughly fifty Nicholases and Philips. It is more difficult to find usage patterns of female saints' names in the Eyre; Margaret can be identified with the popular St. Margaret of Antioch, but could also be connected to St. Margaret of Scotland and thus to both a saint and an elite.

If we thus recognize that names convey a particular social and cultural affiliation or commemorate individuals on which a society places high value, then the use of a name that can be identified as Welsh must inherently contain some connection to Welsh peoples. That is not to say that every person with a Welsh name thought of him or herself as being ethnically or culturally Welsh, spoke the Welsh language, or had at least one family member who was Welsh; it is also possible that a child was given a Welsh name to commemorate an important non-familial relationship with a holder of that name. It is therefore not irrefutable, but still highly likely, that a man such as Madog of Picklescot can be considered to have some connection to Welsh culture and therefore is counted as being Welsh for the purpose of this study.

Many names are recognized as being of Welsh origin or as the Cymrucized version of a non-Welsh name. In her study of twenty-three extant texts from Northern, Southwestern, and Southeastern Wales from 1256-1315 Heather Jones found that, in these records that primarily recorded the affairs of individuals and communities identified as being Welsh, the most common names across all of the documents were John, Dafydd, 


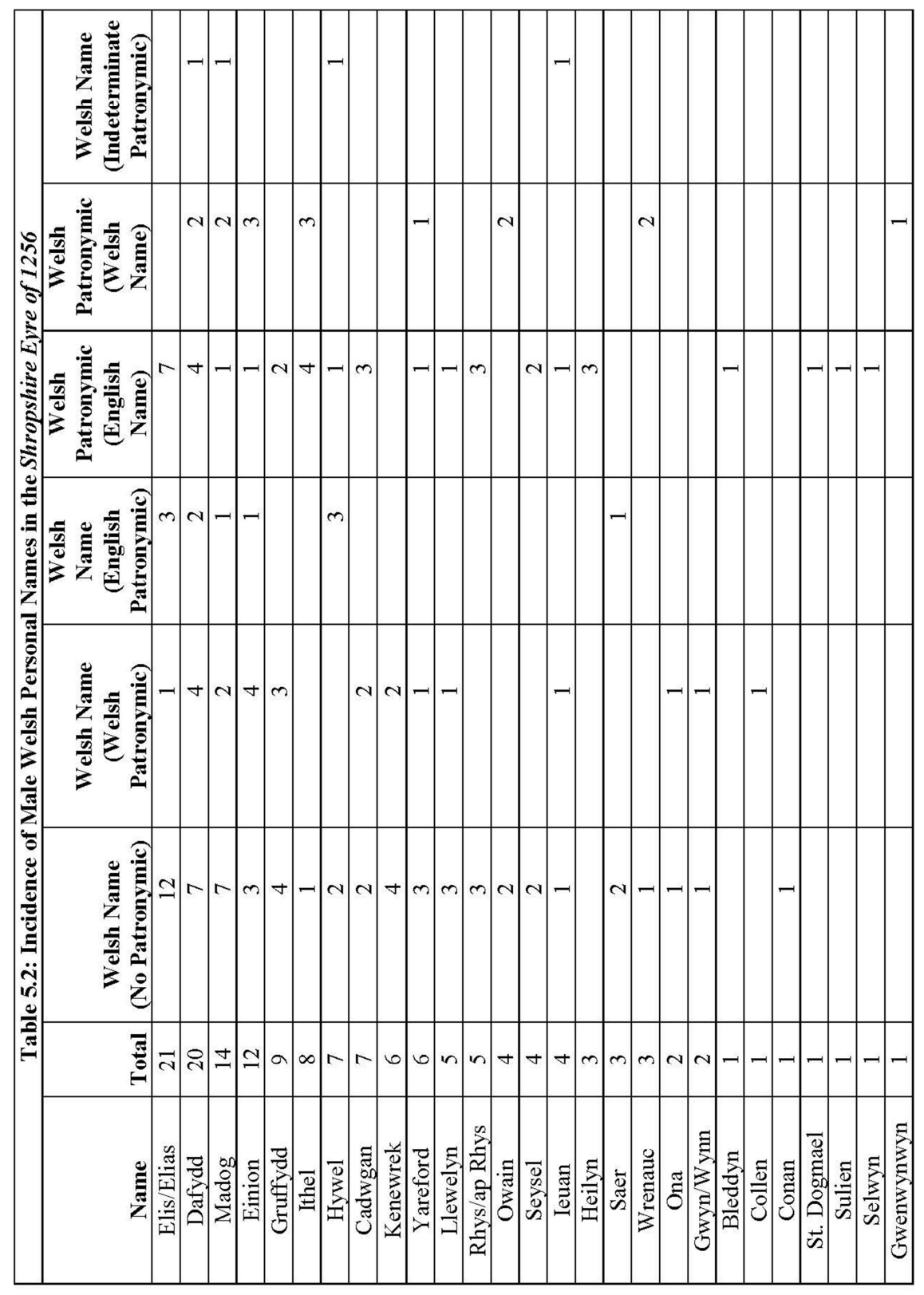


Madog, Iorwerth, and Einion. ${ }^{127}$ Madog, Iorwerth, and Einion are clearly Welsh and were also popular in Shropshire, as can be seen in Table 5.2. Additionally, of the 150 individuals in the Roll of the Shropshire Eyre I have identified as having Welsh names Madog (14), Dafydd (12), and Einion (12) were among the most popular.

Two of the most frequently-occurring Welsh-associated names in the Roll of the Shropshire Eyre are Elias and Dafydd and it may initially be unclear why I have classified these names as Welsh. Of these two names it is easiest to trace the Welsh connections to the use of the name Dafydd. St. Dafydd of Wales (d. 601) was, and remains, the patron saint of Wales, and his is the most commonly used name of all Welsh regional saints. ${ }^{128}$ Public exposure to the cult of St. Dafydd was high in the eleventh and twelfth centuries. The Vita of St Dafydd was written by Rhygyfarch ap Sulien of Llanbadarn Fawr at the end of the eleventh century and Bishop Bernard of St. Dafydds Cathedral furthered the promotion of his cult when he sought, and received, papal recognition for the church as a pilgrimage destination for those who could not go to Rome. $^{129}$

127 John was often interchangeable with the Cymrucized Ieuan. Heather Jones, "Comparing Historic Name Communities in Wales: Some Approaches and Considerations," in Studies on the Personal Name in Later Medieval England and Wales, ed. Dave Postles \& Joel T. Rosenthal (Kalamazoo: Medieval Institute Publications, 2006), 271.

${ }^{128}$ St. Dafydd also lent his name to one of the four diocese in Wales and its cathedral church. H. D. Farmer, "David (Dewi) of Wales," in The Oxford Dictionary of Saints (2011).

${ }^{129}$ John Reuben Davies, "The Cult of Saints in the Early Welsh March: Aspects of Cultural Transmission in a Time of Political Conflict," in The English Isles: Cultural Transmission and Political Conflict in Britain and Ireland, 1100-1500, ed. S. Duffy and S. Foran (Dublin: Four Courts Press, 2013), 47. 
In addition to the popularity of Dafydd as a saint's name, it was also the name of an Old Testament hero. As John Reuben Davies has shown in his work on naming traditions among speakers of Brittonic languages, Old Testament names were unusually popular in Wales, Brittany, and Cornwall. In comparison, Old Testament names were much less common among other Celtic peoples such as the Irish and Scots. And, he notes, "among the English we find that Old Testament names were very rarely to be found after the conversion." ${ }^{130}$ Not only were names such as Samuel, Dafydd, Daniel, Joseph, and Jacob common in documents such as the Book of Llandaf, Elias was also popular. ${ }^{131}$ Harding, in his critical edition of the Roll of the Shropshire Eyre, has generalized references to Elie, Eli, Elyas, Elias, and Eliam to the Anglicized Ellis. These names are most likely versions of the Welsh Elias or Elis, derived from the Old Testament prophet Elias/Elijah. As Figure 5.2 shows Elias was the most popular Welsh name in the Roll of the Shropshire Eyre and the inclusion of individuals named Elias adds greatly to the discussion of where and why Welsh individuals engaged in the legal processes of the Eyre Court.

For the purpose of this study I have chosen to identify all individuals in the Roll of the Shropshire Eyre named Elias and Dafydd as Welsh, barring any explicit reference or cognomen that would suggest otherwise. Keeping in mind that because Dafydd was also a popular name in Scotland, it is not impossible that a Dafydd mentioned in the Eyre was

130 "Old Testament Personal Names among the Britons: Their Occurrence and Significance before the Twelfth Century." 3-5. For an in-depth discussion of the Welsh use of Old Testament names that have Dafyddic associations see the entire article.

131 "Old Testament Personal Names among the Britons: Their Occurrence and Significance before the Twelfth Century." 16-18. 
not Welsh. I have found that twelve of the twenty usages of the name Dafydd are unambiguously Welsh based on the criteria of:

- Occurrence of [name] with a Welsh-named child, parent, or grandparent as in Dafydd s. Einion ${ }^{132}$ or Ona s. Dafydd Wych ${ }^{133}$

- Identification by location as in Dafydd of Montgomery ${ }^{134}$

- Occurrence of [name] as the patronymic with an English first name as in William s. Dafydd ${ }^{135}$

The remaining eight are indeterminate and I have chosen to include them for simplicity. Hopefully with further study more information will become available concerning these men: David Blake of Diddlebury, David Blake of Whixall, David Bollyn, David s. Henry of Woodhouse, David Crakewein, David of Marchamley, David s. Alexander of Bradeshull, and David of Stockton. ${ }^{136}$

I have not chosen to do the same with individuals named Adam. While Adam too is an Old Testament name, there are so many references to Adam in the Eyre that it seems problematic to assume a Welsh connection for each one. Unlike with occurrences of Elias or Dafydd, where the possibility of error was small, there are sixty-six individuals either

132 Throughout this study instances of "son of" or "daughter of" will be designated by the use of [name] s. [name] and [name] d. [name]. Harding, The Roll of the Shropshire Eyre of 1256 . No. 818 .

${ }^{133}$ The Roll of the Shropshire Eyre of 1256. No. 736.

${ }^{134}$ The Roll of the Shropshire Eyre of 1256. Nos. 61, 298, and 924.

${ }^{135}$ The Roll of the Shropshire Eyre of 1256. No. 45.

${ }^{136}$ For more detailed information please see Appendix 4. Although David of Stockton served as a juror in Chirbury along the Welsh border, I have found no further sign of him being more or less Welsh than the other seven listed. 
named Adam or identified as the son or daughter of Adam. Of these, based on similar criteria to that used with Dafydd, only six appear to have clear Welsh ties. Adam Wele ${ }^{137}$ and Adam, a Welshman, ${ }^{138}$ are explicitly identified as being Welsh (see Figure 5.1), while Adam of Arwystli ${ }^{139}$ is identified by location. Adam s. Dafydd, ${ }^{140}$ Hywel s. Adam, ${ }^{141}$ and Adam Cyrecok/Ceiriog ${ }^{142}$ have clear Welsh associations.

There are relatively few references to Welsh women's names in the Roll of the Shropshire Eyre. As can be seen in Table 5.3 Iseult is the most common and this may be tied to its use in popular Arthurian literature. Many other women from the Eyre can be identified as Welsh because of their relatives' names, as in the instances of Alice d. Isabel d. Elias of Leighton, ${ }^{143}$ Gillian niece of Robert s. Owen, ${ }^{144}$ and Matilda d. Elias of Roden. ${ }^{145}$

Still others can be identified as part of a Welsh household because of their marriage to a Welshman or a man with Welsh relatives. This is true for Douce of

${ }^{137}$ Harding, The Roll of the Shropshire Eyre of 1256. Nos. 258 and 910.

${ }^{138}$ The Roll of the Shropshire Eyre of 1256. No. 797.

${ }^{139}$ The Roll of the Shropshire Eyre of 1256. No. 784.

${ }^{140}$ The Roll of the Shropshire Eyre of 1256. No 99.

${ }^{141}$ The Roll of the Shropshire Eyre of 1256. No. 822.

${ }^{142}$ The Roll of the Shropshire Eyre of 1256. No. 522.

${ }^{143}$ The Roll of the Shropshire Eyre of 1256. No. 246.

${ }^{144}$ The Roll of the Shropshire Eyre of 1256. No. 306.

${ }^{145}$ The Roll of the Shropshire Eyre of 1256. No. 697. 
Kempton who, upon her suicide, was noted to be the wife of one Llewelyn. ${ }^{146}$ Additionally, Agnes wife of Rhys of Overton was mentioned in a case of entry concerning property in Loton, ${ }^{147}$ Emeline wife of Einion s. Owain participated in a compromise, ${ }^{148}$ and Sybil wife of William s. Hugh Heilyn of Bromlow was a defendant in a case of dower in Bromlow. ${ }^{149}$

\begin{tabular}{|c|c|c|c|c|c|c|c|}
\hline Female & Total & $\begin{array}{c}\text { Welsh Name (No } \\
\text { Patronymic) }\end{array}$ & $\begin{array}{c}\text { Welsh Name } \\
\text { (Welsh } \\
\text { Patronymic) }\end{array}$ & \begin{tabular}{|c|} 
Welsh \\
Name \\
(English \\
Patronymic)
\end{tabular} & $\begin{array}{c}\text { Welsh } \\
\text { Matronymic } \\
\text { (English } \\
\text { Name) } \\
\end{array}$ & $\begin{array}{c}\text { Welsh } \\
\text { Matronymic } \\
\text { (Welsh } \\
\text { Name) }\end{array}$ & $\begin{array}{l}\text { Welsh Name } \\
\text { (Indeterminate } \\
\text { Patronymic) }\end{array}$ \\
\hline Iseult & 7 & 5 & & & 2 & & \\
\hline Angharad/Angret & 2 & 2 & & & & & \\
\hline Gwladys & 2 & 1 & & & 1 & & \\
\hline Gwyneth & 1 & & & 1 & & & \\
\hline
\end{tabular}

\section{What does this tell us?}

Now that it has been established what makes a person Welsh in the context of this study, we move on to a discussion of the presence of a Welsh population in Shropshire. Judging by the records of Welsh people in the Roll of the Shropshire Eyre it is clear that these individuals were not restricted to areas along the English-Welsh border but instead were spread around the county living in dozens of parishes. This data is presented visually in Figure 5.1 and, as you can see, Welsh men and women lived throughout

${ }^{146}$ The Roll of the Shropshire Eyre of 1256. No. 487.

${ }^{147}$ The Roll of the Shropshire Eyre of 1256. No. 41.

148 The Roll of the Shropshire Eyre of 1256. No. 54.

${ }^{149}$ The Roll of the Shropshire Eyre of 1256. No. 149. 
Figure 5.1

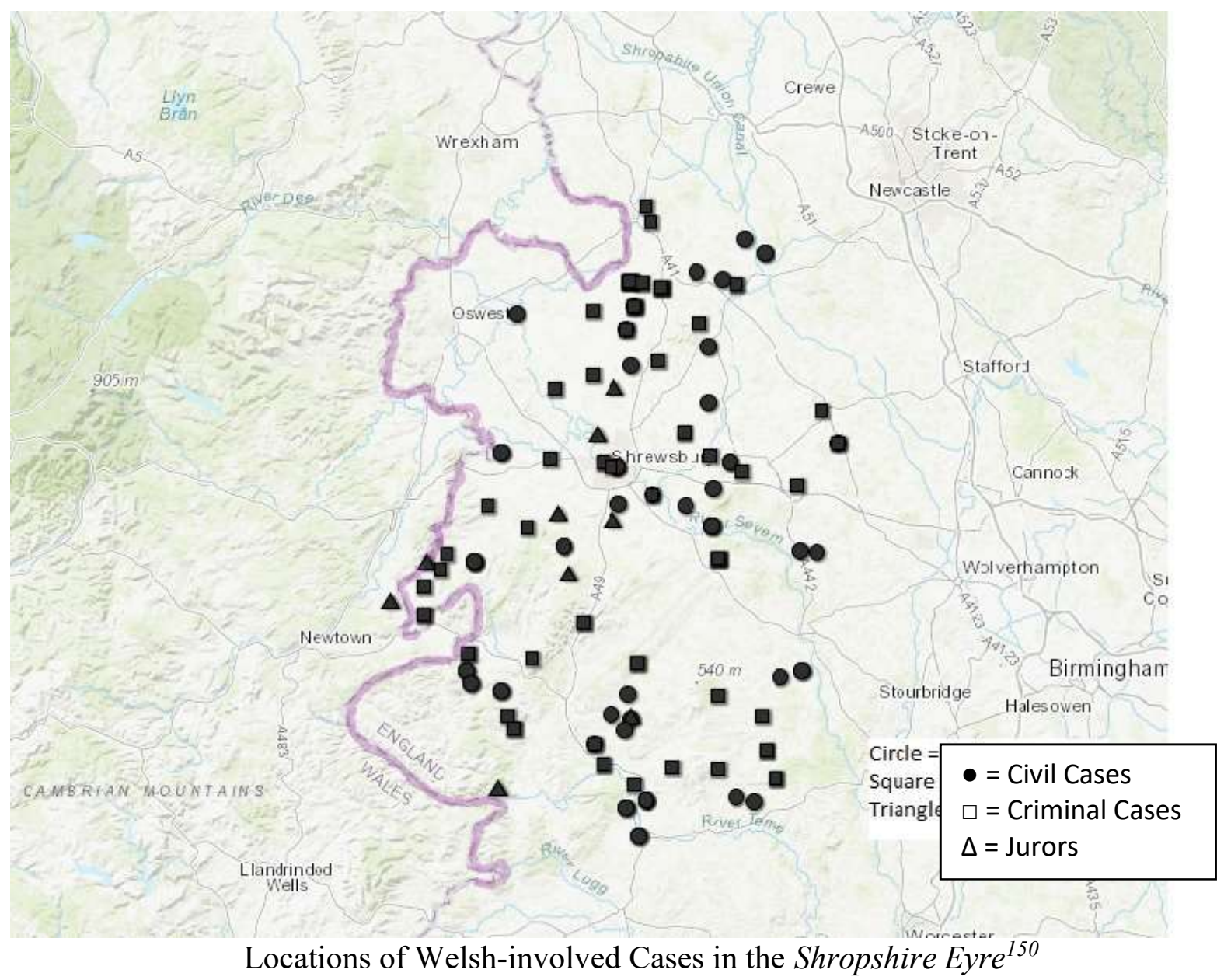

${ }^{150}$ Map created in 2017 using a template provided by Gis Visualizer www.gpsvisualizer.com/map_input. 
Shropshire. ${ }^{151}$ The criminal and civil cases included in the Roll of the Shropshire Eyre show that Welsh individuals lived in mixed communities and in a variety of landscapes. Unlike in much of English-controlled southern Wales, the English and the Welsh did not live in separate villages identified as Englishries or Welshries. Also unlike southern Wales, there is no evidence that Welsh people in Shropshire favored upland pasturage over lowland farming settlements. This may be largely due to the difference in topography since much of Shropshire is made up of lowland river valleys. Figures 5.2 and 5.3 have been included at the end of this chapter to provide a general geographical context for the cases discussed below. Figure 5.2 is a map of the Hundreds in Shropshire, a political and judicial subdivision of the county, while Figure 5.3 is a map of the county parishes, which were used to draw both political and ecclesiastical boundaries.

One of the many elements of Welsh life in Shropshire that can be gleaned from the Roll of the Shropshire Eyre is whether or not Welsh men and women voluntarily used the court system. Choosing to participate in the legal system implies a familiarity with English rights and laws and how they compared to Welsh law and custom. When Welsh plaintiffs wanted to bring a case, they had to know enough about the English legal system to understand which writ they needed to purchase and how that writ should be applied.

\section{Criminal cases involving Welsh persons:}

At first it came as a surprise that there were more Welsh participants in criminal cases than in civil ones; yet after thoroughly reading through the cases the reason for this became quite clear - an individual often had no control over whether he or she was

151 This map does not include those Welsh persons who did not have a specific location listed or instances when the place cannot be located on modern maps. For these individuals please see Appendix Five. 
mentioned in the records of a criminal case. Involuntary involvement could be because the individual was a victim of a crime, a witness to a crime, a first finder, or the one accused of perpetrating the crime. Therefore, involvement in criminal cases was not necessarily based upon choice. However, there are a few examples of Welsh individuals choosing to take part in a criminal case either as pledges for others involved or by bringing the case to court themselves.

Both criminal and civil cases required community participation in the form of pledges. Pledges were roughly the equivalent of bail in today's legal system. As mentioned above, often a considerable amount of time could pass between court sessions and some civil cases spanned years. In such situations the plaintiff(s) and defendant(s) were required to promise that they would return to continue the case at the next available opportunity. The security for these promises came in the form of one or several neighbors agreeing to guarantee their fulfillment of the promise, or suffer fines. Pledges could be made by family members, as was often the case in Wales, or neighbors as they were willing. In one case a woman named Clemence sought an investigation into the death of her husband William of Whitechurch. To ensure that she would appear in court she named both Cadwgan ap Einion of Hinton and John s. Richard Hake as her pledges. ${ }^{152}$ This is just one example of Welshmen and Englishmen serving together as pledges. Pledges could also be called upon to ensure that the first finder or any witnesses to a crime also appeared in court. As you will see in the following two cases, first finders were not always able, or willing, to attend when called upon. The first case involves the accidental death of a boy in Rhiston in Chirbury Parish. The unnamed boy was found

${ }^{152}$ Harding, The Roll of the Shropshire Eyre of 1256. No. 742. 
drowned in the village, although it is not recorded if he drowned in a pond or the nearby Lack Brook. The first finder, also unnamed, discovered the body and reported it to the community. The people of Rhiston should have called in one of the county coroners to confirm cause of death, but instead they simply buried the body. Two Welsh members of the Rhiston community, Einion Bawthan and Maurice s. Ithel, pledged to be financially responsible for ensuring the appearance of the first finder at any future court enquiries. When the Shropshire Eyre court was called the death was duly examined by Simon of Walton and his fellow justices. In order to get a complete picture of the events the first finder was called to give testimony at the court. However, in this instance, he or she was unable or unwilling to attend the court and his or her pledges had to pay the required fine for not ensuring the first finder's presence. ${ }^{153}$

Sometimes individuals who could not attend court were able to have themselves excused because of illness. Also, because a considerable time could pass between court sessions, at times a witness or first finder actually died before they could appear in court. It is tempting to assume that there must have been something preventing the first finder in the next case from testifying, but I can find no record of a request for an excuse due to illness or incapacity in his name. In the list of criminal cases for the Bradford Hundred it is recorded that one Madog s. Ithel killed Daniel s. Ieuan in the village of Whixall. Both men were from that village and as soon as the crime was committed Madog fled. It happens that it was Ieuan of Whixhall who discovered his own son Daniel's body, and so he was recorded as the first finder. To ensure that he would appear at any future enquiry two men from the nearby village of Bronington agreed to be Ieuan's pledges. Bronington,

${ }^{153}$ The Roll of the Shropshire Eyre of 1256. No. 815. 
while only a few miles away from Whixall, was technically in the Welsh county of Maelor, but clearly interaction in the area was not restricted by an idea of a firm border between England and Wales. Perhaps the men he chose as pledges, Kenewrek Seys and Madog s. Yareford were relatives or friends. Regardless, they were Welshmen willing to include themselves in future legal action by accepting the role of pledges. When Ieuan did not appear before the court these men were held financially responsible. ${ }^{154}$

Individuals could also ask that a case be heard because they felt that the community and local court has not properly addressed the issue. Accusers could be both men and women, as is seen in the first case discussed below. These cases clearly show Welsh individuals choosing to participate in the English legal system.

One of the cases was from the Manor of Worthen on the west side of Shropshire, bordering Wales. In this case Isabel d. Iseult had accused Henry of Gydesay in the shire court of the rape of her virginity. Summoned to present the case before the justices in Eyre, Henry failed to appear and an order went out for his arrest. This case helps to demonstrate that women, be they English, Welsh, or of mixed heritage, had recourse to the courts and could bring such cases on their own. ${ }^{155}$

Further examples of Welsh individuals using the court system include bringing charges of assault, false imprisonment, and even murder against members of their communities. From the Hundred of Munslow a Welshman named William Bleddyn accused Reginald s. Andrew of Holdgate of coming upon him in the woods and assaulting, wounding, and maltreating him for no reason, since William had been

${ }^{154}$ The Roll of the Shropshire Eyre of 1256. No. 720.

${ }^{155}$ The Roll of the Shropshire Eyre of 1256. No. 542. 
lawfully in the king's peace at the time. ${ }^{156}$ William had made a technical error on his application of writ, but the court decided to hear his case anyway, arguing that "for the sake of the observance of the peace, let the truth be enquired of the country. The jurors say that Reginald is guilty of this trespass so is to be imprisoned." ${ }^{157}$ In this way William received justice, even though he had to pay a fine of half a mark because of the error. William of Bleddyn has been identified as a Welshman because of his name, Bleddyn means 'little wolf' in Welsh. ${ }^{158}$ Yet he clearly understood enough about the English legal system to know which writ to purchase in order to bring his case to court. The technical error was in incorrectly recording the year of the attack, a mistake that anyone, English or Welsh, could make.

Sometimes cases could be tricky if the persons involved held positions of power such as the offices of sheriff or bailiff. A former bailiff in Bradford Hundred named William Cadwgan brought a case before the Eyre court accusing Thomas Corbet of Caus of capturing and falsely imprisoning him for some time in his castle. He argued that Thomas subsequently only released him once William had acquired a writ of the king addressed to the current sheriff of Shropshire directing that he be released. William Cadwgan's case was questioned because he had not followed the correct procedures of making an appeal to the shire court previous to submitting it to the Eyre and he was initially imprisoned for a false appeal because of this misstep. However, Thomas Corbet

${ }^{156}$ Being in the King's Peace (in pace domini regis) usually meant that there were no current warrants or accusations against the person at that time.

${ }^{157}$ Harding, The Roll of the Shropshire Eyre of 1256. No. 613.

158 "Welsh Names (Traditional)," http://www.namenerds.com/welsh/trad2.html. 
eventually came before the Eyre court and acknowledged that he had imprisoned William, but that it had been on the orders of the then sheriff of the county. It turned out that William had served as a bailiff under Thomas Corbet's command when Thomas had been sheriff. When Thomas Corbet handed over the office to his successor he found that William Cadwgan was more than 40 shillings in debt to the county. The new sheriff, Robert of Grendon, had directed Thomas to deal with collecting the arrears. Therefore, Thomas argued, he had simply been following these instructions when he imprisoned William. ${ }^{159}$ This case tells us two things; one is that William Cadwgan was willing to bring a case against a prominent English family, the Corbets. He had also previously served as a bailiff. There are a few additional references within the Roll of the Shropshire Eyre in which Welshmen served in such positions. The possibility of personal ties to Wales and community identification as Welsh does not seem to have hindered them in their involvement in local government.

The last case I wish to discuss of voluntary judicial participate by Welsh persons in criminal cases is that of the murder of Daniel s. Madog Was, also in the Hundred of Bradford. Daniel's brother Ieuan s. Madog had brought an appeal to the shire court accusing Madog and Osbert, sons of Ithel of Coton, and Kenewerk and Osbert, the sons of Wyard Little, of killing Daniel. The case was directed on to the Eyre but Iouan s. Madog Was never appeared at that court and the case was left unresolved. Multiple Welsh families were involved in this case, including the voluntary participation of Ieuan's pledge Kenewrek Seys of nearby Whixall. The presence of these families in

${ }^{159}$ The Roll of the Shropshire Eyre of 1256. No. 738. 
Bradford, located in the northeastern part of Shropshire, once again demonstrates that the Welsh population of Shropshire was wide ranging.

Unlike the specific cases just discussed, most Welsh involvement in criminal cases was involuntary. Every unattended or unexpected death had to be investigated by the coroner and then later reported to the courts. Welshmen and women appear in the category of misadventure, that is, accidental death, as victims. In murder investigations they appeared as accused perpetrators, victims, witnesses, and those who first came upon the body, known as first finders. The following Table 5.4 shows a breakdown of data from these cases by hundred, manor, and borough. Clearly there were Welsh people located throughout the county. Of the 616 cases concerning death recorded in the Roll of the Shropshire Eyre sixty-six (roughly nine percent) involved people that can be identified as Welsh. Of that sixty-six, fifteen cases involved misadventure (sixteen percent of the total ninety-one cases of misadventure) and Welsh-involved murder cases were just about ten percent of the total of 487 murders investigated, with forty-nine cases. Finally, there were two Welsh-involved executions and one suicide. ${ }^{160}$ This data provides a glimpse of who lived in the villages and towns of Shropshire and how these individuals were identified in record as having some connection to Welsh culture, most usually by name but also by distinct identification such as le Waleys or Walensis.

Misadventure was a frequent cause of death in the Middle Ages and I have chosen a smattering of such cases to discuss here, all from different locations throughout the county, all involving Welsh victims. Accidental deaths very rarely involved strangers, so there is little chance that the Welsh victims described here were not permanent residents

${ }^{160}$ For raw data see Appendix 4 


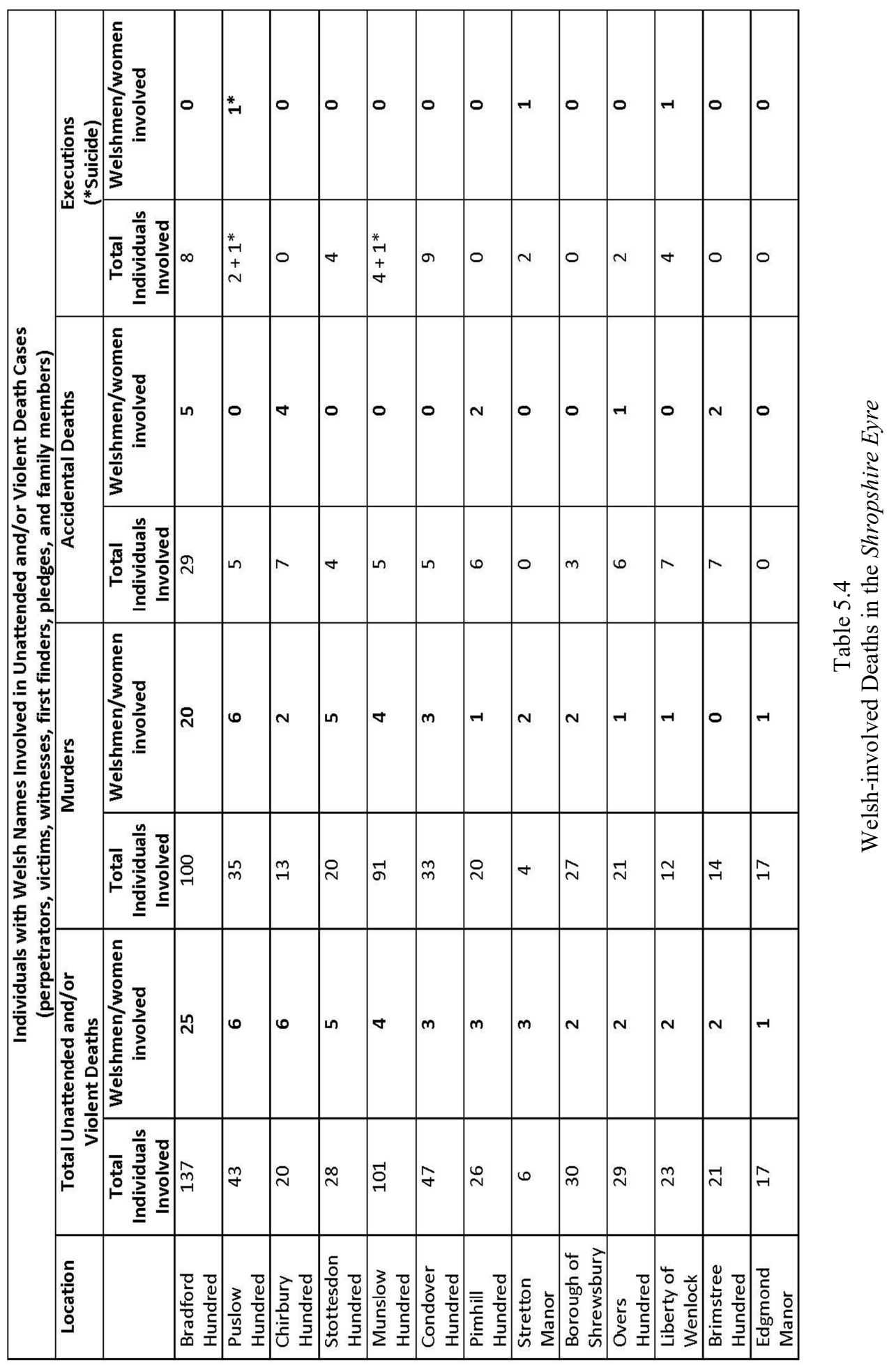




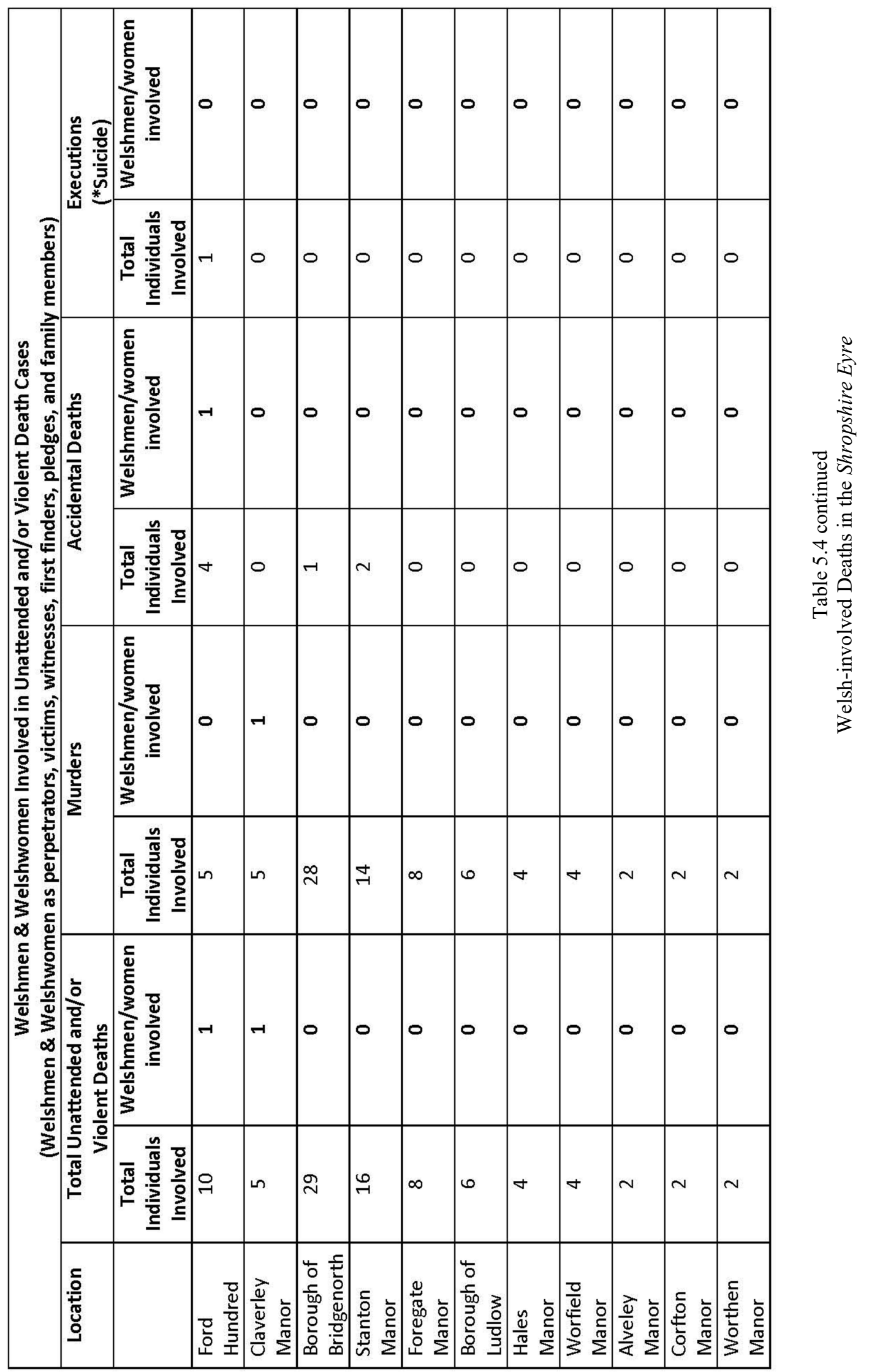


The daughter of a woman with the Welsh name of Gwladys had an epileptic fit and was found in a field outside the town of Wem. Similarly, in two other cases where a victim was found already dead, the individuals were identified specifically as being Welsh. William Welsh (le Waleys) was found crushed to death in a marl pit in Bradford Hundred, ${ }^{161}$ and Tuthegy, a Welshwoman (Quedam Walensis) was found dead in Martin's Field in Chirbury. ${ }^{162}$ These cases once again provide evidence of a Welsh population living in many communities throughout Shropshire.

The other form of non-voluntary involvement in criminal cases can be seen in the records of murders investigated. The forty-nine murder cases involving Welsh individuals present a variety of situations. The cases I discuss here were chosen for their diverse locations and content variety. As mentioned previously, Ieuan of Whixall was the first to find the body of his murdered son Daniel. ${ }^{163}$ The murder, also a Welshman named Madog s. Ithel of Whixall, immediately fled, an action generally considered to be an admission of guilt. Whixall was in the Hundred of Bradford, a large region that had the highest murder rate in the county. ${ }^{164}$ The incidence of a Welsh victim, much less a Welsh perpetrator, does not seem to have been an uncommon occurrence as no special emphasis was placed on the case and it was presented as simply one of the one-hundred murder

${ }^{161}$ Harding, The Roll of the Shropshire Eyre of 1256. No. 705.

${ }^{162}$ The Roll of the Shropshire Eyre of 1256. No. 819.

${ }^{163}$ The Roll of the Shropshire Eyre of 1256. No. 720.

${ }^{164}$ Bradford covered a very large area, roughly the entire northeastern quadrant of the county, until it was divided into North Bradford and South Bradford. The Roll of the Shropshire Eyre was created before this division was made. 
cases from the region. The same was true for a similar case, also in Bradford, in which Kenewrek s. Dafyyd Wych and his brother Ona killed one Wynn s. Madog in the town of Prees. Kenewrek quickly fled to the church of Prees for sanctuary and later admitted his crime and abjured the realm. No mention is made of a flight by his brother Ona, although it is recorded that Ona had no chattels that could be disposed of by the court. In this situation it is possible that Ona s. Dafydd Wych was killed during the commission of the crime. $^{165}$

The next two cases involve Welsh victims but not Welsh perpetrators. In central Shropshire in the fields outside the village of Millichope Roger of Middlehope and Isabel d. Ellis of Sutton were killed by a band of three men. Ellis of Sutton was most likely an anglicization of Elias of Sutton, and he was probably a Welshman originating from the area around the parish of Sutton, later Sutton Maddock, where the descendants of one of the younger princes of Powys built a community through intermarriage and settlement in the early years of the twelfth century. It is unfortunately unclear whether he had moved to the area of Millichope or, if not, why his daughter Isabel was then several parishes away from her home. ${ }^{166}$ The three killers were soon identified as Roger Tosti, Richard Tosti, and Philip s. Ellis. It is not mentioned why these men attacked the couple; one of the difficulties of court records is that they can leave out the more intimate details of relationships even while they provide evidence of community interaction. It is possible that Philip s. Ellis was also a son of Ellis of Sutton, and thus Isabel's brother, but there is

${ }^{165}$ Harding, The Roll of the Shropshire Eyre of 1256. No. 736.

166 The identification of Isabel by her father rather than by a husband implies that she was unmarried at the time of her death. 
really no way of knowing. Roger, Richard, and Philip were subsequently caught and hanged for their crime. ${ }^{167}$ Likewise, in Shrewsbury, the center of commerce and legal activity in the county, a Welshman named Wynn Croucher was murdered by one Hugh Huslegrey. The case was discussed as any other case in the borough of Shrewsbury and no special emphasis was placed on the victim's identity. ${ }^{168}$

Finally, I would like to briefly mention an additional way, besides victim, perpetrator, or first finder, that Welsh individuals appear in criminal cases. Welsh people could also witness a crime and be called upon to testify as to what they saw. A woman named Muriel from the Hundred of Munslow in south central Shropshire accused Richard Lubbe and his brother William of shooting her husband Henry of Pantel with an arrow so that he died. After the case against Richard and William was settled, as well as an accusation of accessory against Richard Spark, he was found not guilty, it was testified that there had been a number of witnesses to the event. These witnesses, including Colin s. Dafydd and one Roger, a baker "who lives in Montgomery,"169 were charged with being present and yet not arresting Richard Lubbe after the crime was committed and fined. Colin s. Dafydd can be considered to be a Welshman according to the parameters set out at the beginning of this study, but the identity of Roger the baker is less clear. Montgomery was an English town and fortress located inside Wales itself so it is equally possible that Roger was an Englishman living in Wales or a Welshman. Regardless, when he witnessed this crime he was several municipal districts away from Montgomery.

\footnotetext{
${ }^{167}$ Harding, The Roll of the Shropshire Eyre of 1256. No. 656.

168 The Roll of the Shropshire Eyre of 1256. No. 884.

${ }^{169}$ The Roll of the Shropshire Eyre of 1256. No. 576.
} 
Because of the involuntary nature of almost all Welsh participation in criminal cases brought before the Eyre court, the data presented in these records provides useful demographic information about the Welsh population of Shropshire from 1248, the date of the last eyre court, and the court recorded here in 1256. Civil cases provide similar but less complete data. Many Welshmen and women were involuntarily drawn into judicial engagement as the plaintiffs in civil cases, while others chose to participate.

\section{Civil Cases involving Welsh persons:}

The most common civil cases heard before the Eyre court in 1256 were those concerning the holding or inheritance of property. Petitioners had to navigate the complicated English legal rules about when and how a person could have possession of a piece of property, laws that included discussions of the difference between habitation and possession and whether a person would have to be physically present to attain seisin. ${ }^{170}$ The Roll of the Shropshire Eyre provides several examples of Welsh individuals choosing to engage in the legal process by bringing writs and claims against other members of their communities. For example, both Kardigan s. Lewis Wechan ${ }^{171}$ and William Rhys ${ }^{172}$ brought writs of novel disseisin against those who they claimed had illegally deprived, or

${ }^{170}$ For more on the complex process of defining seisin and a more in-depth definition of the writ of novel disseisin and the writ of mort d'ancestor please revisit Chapter 4.

${ }^{171}$ Wechan was a version of the more common Fychan. Harding, The Roll of the Shropshire Eyre of 1256. No. 81.

172 The Roll of the Shropshire Eyre of 1256. No. 96. 
disseised, them of their lands. Similarly, William s. Dafydd ${ }^{173}$ and Richard s. Einion ${ }^{174}$ purchased writs of mort d'ancestor arguing that they had legal hereditary rights to lands held by the Abbot of Wigmore and in the Hundred of Pimhill respectively.

Another example of a Welshman voluntarily participating in the legal process was the appeal by Elias s. Richard Cadwgan that Robert de Say keep an agreement previously made between Elias and Robert's father Hugh de Say concerning land that Elias had held in Moreton in the parish of Hodnet. The agreement had been for ten years but when Hugh de Say died three years into the lease his son Robert ejected Elias. Elias asked for 100s. in damages and the return of his land for the remaining seven years of the lease, but Robert argued that there was no written evidence of such an agreement. Interestingly Robert demanded a judgement by the court as to "whether Ellis [sic] can put him [Robert] to law or an inquiry of the country concerning his father's act when he produces no support except his bare word." ${ }^{175}$ This demand by Robert de Say is actually a departure from the regular process of determining rights of possession and use according to both English and Welsh laws. This is because it calls into question information that could be obtained by an "inquiry of the country" such as the questioning of a jury of twelve men of good standing who were cognizant of the particulars of land holding in Moreton and the surrounding area. Unfortunately, we have no further information about this case, but it does demonstrate the increasing use of written rather than oral evidence in

${ }^{173}$ The Roll of the Shropshire Eyre of 1256. No. 45.

${ }^{174}$ The Roll of the Shropshire Eyre of 1256. No. 97.

${ }^{175}$ The Roll of the Shropshire Eyre of 1256. No. 119. 
England and changes that would soon be coming to both English and Welsh legal practice.

Welsh men also voluntarily participated in the Eyre court by serving as pledges, attorneys, and jurors. Pledges have already been discussed above, but some additional examples include: Madog s. Ivor of Edstaston serving as a pledge for a widow named Matilda in a case over her dower rights; ${ }^{176}$ Adam Wele (the Welshman) of Overs serving as a joint pledge with Hamo Fesaunt in a case of disseisin; ${ }^{177}$ Einion of Tenbury serving with Alan Corbet of Haston as pledges for Hugh of Wotherton in his suit against the Prior of Chirbury; ${ }^{178}$ and David of Montgomery of the Monks of Foregate serving as a pledge for William Buscer in a case of novel disseisin. ${ }^{179}$

Additionally, a Welsh man would occasionally serve as an attorney for a neighbor, friend, relative, or overlord. Attorneys served as the representative and voice of one or more members of a court case, usually when said person(s) were not going to be able to attend required court appearances. This situation often applied to elites who would be traveling to London or Normandy at the time of the trial or were simply too busy to deal with the details of ongoing court dates. Only two people with Welsh names appointed attorneys in the Roll of the Shropshire Eyre, both women; in a combined case of several individuals in a plea of land against Saer Mauveysyn, Edwin and his wife

${ }^{176}$ The Roll of the Shropshire Eyre of 1256. No. 147.

${ }^{177}$ The Roll of the Shropshire Eyre of 1256. No. 258.

${ }^{178}$ The Roll of the Shropshire Eyre of 1256. No. 470.

${ }^{179}$ The Roll of the Shropshire Eyre of 1256. No. 61. 
Iseult ${ }^{180}$ joined their fellow litigants in appointing two men to serve as attorneys for the entire group, and in a case of dower concerning Iseult Walerand, discussed below. There were also two instances in which a Welshman was appointed the attorney for his elite overlord. Brother Nicholas Welsh served as attorney for the Abbot of Buildwas ${ }^{181}$ and William Welsh was the attorney for William and Iseult Walerand in the above-mentioned case of dower. ${ }^{182}$

The most prominent Welsh participant of the court was Madog of Sutton, for whom the parish of Sutton Maddock would later be named. A descendant of a younger branch of the family that ruled Powys throughout the eleventh and twelfth centuries, Madog was arguably the most influential Welshman in Shropshire. His name appears as a witness on many of the charters issued by Shropshire elites and he was also a frequent visitor to the court whenever the king was nearby. He was prominent enough to have been called to serve on at least three juries throughout the county. While there are nineteen other Welshmen who also served as jurors, these men were only called once and for local cases. Madog was considered to be a prominent member of the community of the entirety of Shropshire and thus his jury appearances were widespread, from Wem in

${ }^{180}$ The Roll of the Shropshire Eyre of 1256. No. 197.

${ }^{181}$ The Roll of the Shropshire Eyre of 1256. No. 69

182 The Roll of the Shropshire Eyre of 1256. No. 11. 
the Bradford Hundred in the northeast, ${ }^{183}$ to The Heath, ${ }^{184}$ most likely in the Parish of Worthen along the Welsh border, and Wooferton in Muslow to the south. ${ }^{185}$

While the Roll of the Shropshire Eyre contains evidence of this voluntary use of English courts by Welsh individuals, a larger percentage civil cases including Welsh peoples are instances of involuntary participation. Most often these cases concerned seisin of dower or inherited property, but a few dealt with other local disputes. These cases could be termed claims of nuisance and the claim that Hugh of Harrington brought against Madog of Sutton is typical of such cases. ${ }^{186}$ Hugh put before the court that Madog had obstructed the path from his lands to the church in the village of Harrington by building a ditch and a hedge. The court ruled in favor of Madog in a decision that questioned the existence of said ditch and hedge. This is an example of a typical claim of nuisance actions by a neighbor brought to the court. The record of this case provides us with not only information about who held land in the village of Harrington but also which people were neighbors with adjoining property. While scarce, these details help to fill in a better picture of English and Welsh life and interaction in Shropshire communities.

Even involuntary property cases could show how a Welsh individual used the court system to his or her advantage. When the Abbot of Shrewsbury brought a claim for half a virgate of land in Ridgewardine against William Cadwgan, William responded by pointing out that the writ was faulty, since it did not include his brother Thomas

${ }^{183}$ The Roll of the Shropshire Eyre of 1256. No. 48.

184 The Roll of the Shropshire Eyre of 1256. No. 114.

185 The Roll of the Shropshire Eyre of 1256. No. 332.

${ }^{186}$ The Roll of the Shropshire Eyre of 1256. No. 293. 
Cadwgan, who held half of the said land. ${ }^{187}$ The court agreed with William and ordered that the Abbot must acquire another writ that includes both brothers if he wanted to bring his case. Similarly, Einion and Thomas, sons of Dewynt, argued for the correct process of law when they faced a claim by William s. Richard Pygot for eleven-and-a-half acres in Bromlow. ${ }^{188}$ William argued that the brothers held the land through the entry of their father Dewynt who had been granted the land by William's father Richard Pygot. He claimed that the term of the grant had expired and that the land should be returned to his possession. Einion responded by providing to the court a charter of feoffment, thus proving that the land had never been held by term but by fee, which had been paid. Einion s. Dewynt's actions once again confirmed the theory that individuals used the available legal systems in whichever way was advantageous. Einion could have argued for the application of Welsh law to the situation, but he did not need to.

Finally, the Roll of the Shropshire Eyre includes a number of instances in which the participants of a civil case followed English legal procedure and paid a fine for a compromise. This is just one example of how Welsh individuals and families used the English court system and navigated the complexities of Common Law, at times melding it with their own Welsh Law of Hywel Dda. The case between Margery d. William Arnold and Roger s. Hywel demonstrates how complicated this process could be. ${ }^{189}$ The original case was brought by Margery and heard by a grand assize of twelve jurors to determine if Margery had been illegally denied property she should have held by right

${ }^{187}$ The Roll of the Shropshire Eyre of 1256. No. 283.

${ }^{188}$ The Roll of the Shropshire Eyre of 1256. No. 250.

${ }^{189}$ The Roll of the Shropshire Eyre of 1256. No. 16. 
through the actions of Roger s. Hywel. Roger was the tenant of a virgate and a half of land in Weston, in the parish of Burford in Overs. His tenancy had begun under Margery's uncle Richard and, upon his death, the land had passed to Richard's sister Alice, from whom Roger continued his tenancy.

It was the death of Alice that prompted the conflict between Margery and Roger s. Hywel. Roger argued, based on his knowledge of the inner workings of the community in Weston, that Margery could not be the next heir to the property because she was illegitimate, her father William never having married Alice. This was an entirely English argument - under Welsh law it would not have mattered that Margery was illegitimate. Thus Roger, son of a Welshman, if possibly not a man who considered himself to be Welsh, used English laws to his own advantage. However, in a clear demonstration that the application of any law, English or Welsh, could differ greatly from the letter of the law, Margery could make the argument that she was her mother Alice's heir, legitimate or not, because she was the child of Alice's body. ${ }^{190}$ Thus it is not terribly surprising that Margery and Roger eventually procured a chirograph detailing a compromise to the situation.

The cases detailed in this study, both civil and criminal, voluntary and involuntary, support the arguments that the Welsh population of Shropshire extend beyond the border region into the whole of the county, and that these Welshmen and women were judged to be regular members of their communities. Exceptions can possibly exist for those referred to specifically as from Wales (Walensis) or as being

${ }^{190}$ Note that even as the court considered Margery's position based on her illegitimacy, they still identified her for the record as Margery d. William Arnold. 
Welsh (le Waleys), but these ethnic attributions are present in the Roll of the Shropshire Eyre without bias and it is therefore impossible to determine if being identified as Welsh set these people apart or simply served as handy identifiers in a world full of Thomases and Williams. These cases also provide evidence of the use of the English court system by the Welsh population. In fact, many of the Welsh individuals called to court were able to use their personal comprehension of the specifics of English law in order to argue to their advantage. Lastly, and most importantly, the data from the Roll of the Shropshire Eyre has provided details of how English and Welsh members of a community interacted with each other and worked with and against their multicultural neighbors. 


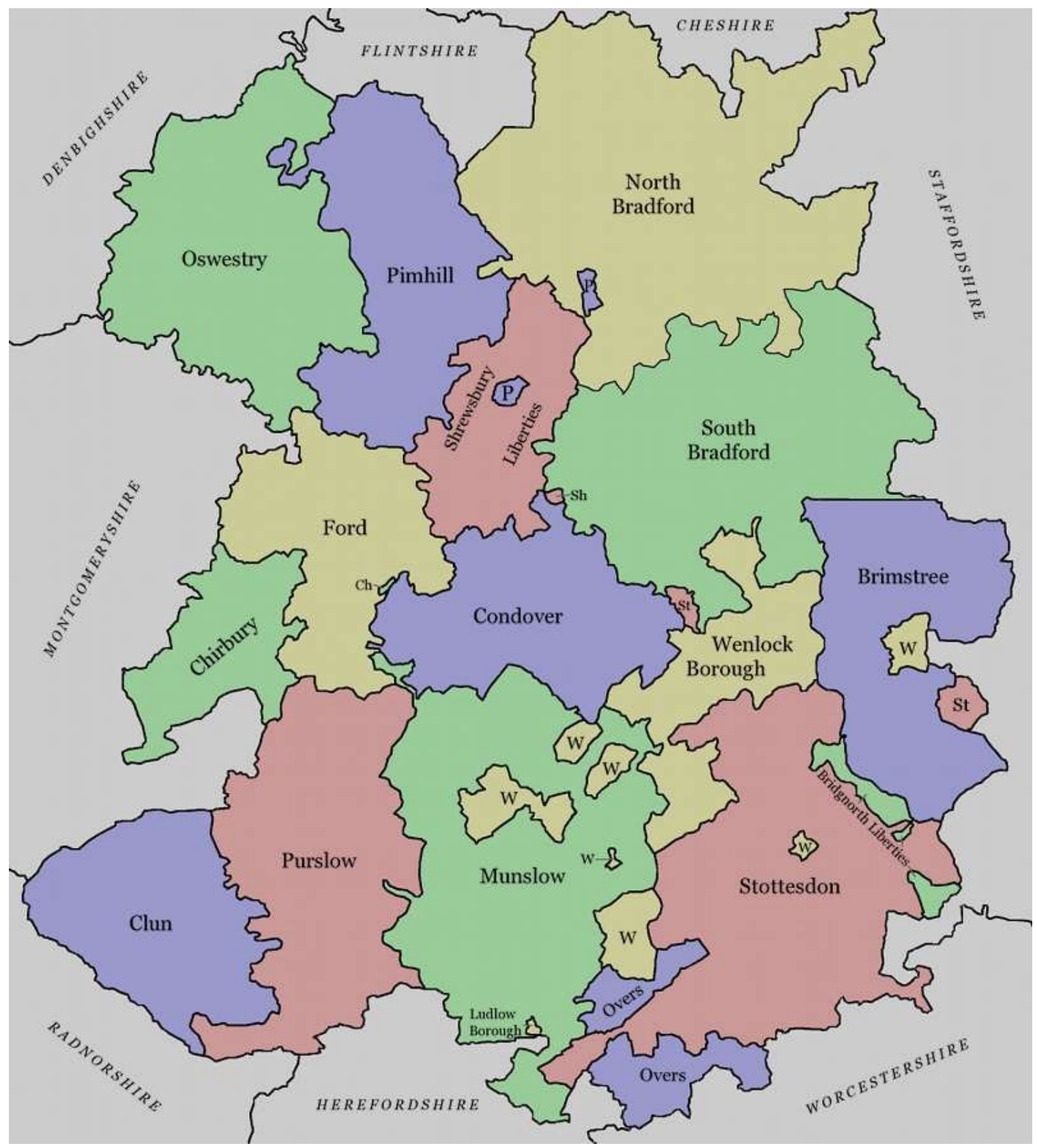

Figure 5.2

The Hundreds of Shropshire 


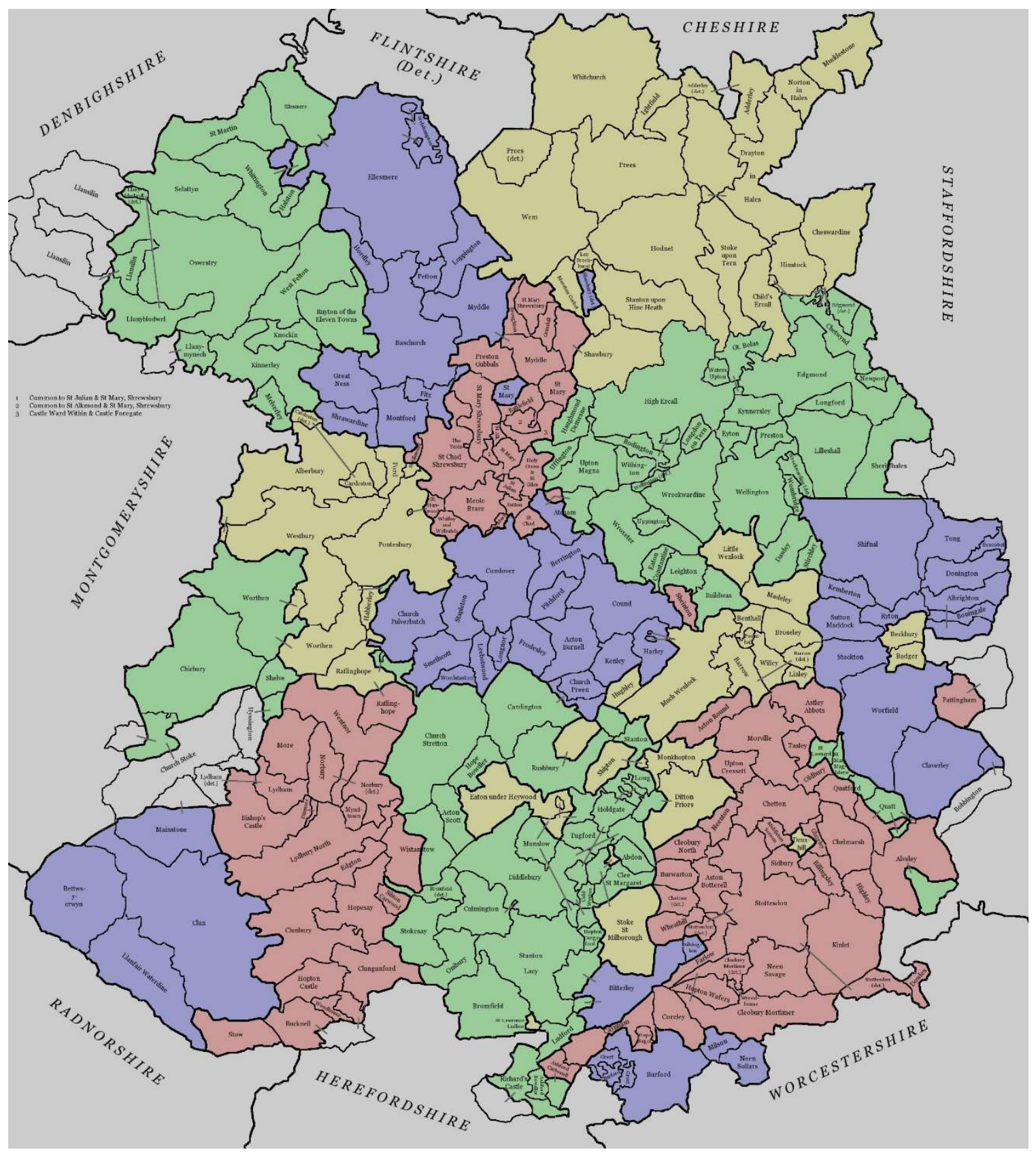

Figure 5.3

The Parishes of Shropshire 


\section{CHAPTER SIX \\ THIS LAND IS MY LAND: A CASE STUDY OF MIXED-ETHNICITY COUPLES AND LEGAL PARTICIPATION IN THE WELSH ASSIZE ROLL 1277-1284}

Many of the cases discussed in this study concern lands that were located in the familiar border zone where Shropshire met the Welsh counties of Montgomery and Denbighshire. These cases demonstrate how English and Welsh individuals and members of multicultural families chose to approach the pursuit or defense of their property in this region of fluid contact and multicultural communities. I have also chosen some cases that extend beyond this region, in particular the suit brought by John and Matilda Giffard again Rhys Vychan and his counter-suit against them. While the property in question was in Carmarthen in southern Wales, the case provides examples of both how long a case could continue without result and how Rhys Vychan, a Welshman, understood property law in Wales to be different from that in England. Many of the key arguments in this case concern legal jurisdiction and what English and Welsh law meant in the later years of Edward I's defeat and subsummation of Wales.

The legal suits that make up this case study come from Welsh Assize Roll, 12771284. This roll is a compilation of the records for a usually triannual series of courts held specifically to address property disputes in Marcher and formerly Welsh territory. The 1270s saw a resurgence of Gwyneddian power under Llewelyn ap Gruffudd, Prince of Wales, and the subsequent conflict with England meant that the inhabitants of this region faced almost certain loss of land, buildings, and livestock. As Gwynedd made its last push for survival many individuals, both English and Welsh, were unlawfully disseised of their property by military occupation. Lands transferred back and forth between English and Welsh control depending on the success or failure of military maneuvers at the local 
level. Some found that their land had been taken by Llywelyn, Prince of Wales, only to be retaken by adherents of King Edward I, who then bestowed the property on yet another supporter.

The assizes were called to provide legal recourse in these disputes. The court was usually led by two or three royal justices, sometimes more. In the beginning cases were decided under the direction of Ralph de Fremingham, but he moved on and was replaced by 1278 with Walter de Hopton. De Hopton usually had other justices with him, but for the most part they are not named. It should be noted that at least one justice was the Welshman Hywel ap Meurig, who was named as such at the 1278 court in Builth.

The courts were held mostly at Oswestry on the northern border between Denbighshire, Shropshire, and Chester, Montgomery in the Central March, and the Church of St. Michael in Elfael located along the southern border between Hereford and Brecon. Occasionally cases were heard in locations determined by the property in question, for example in the suit between John and Matilda Giffard and Rhys ap Vychan a special court session was held just for them at the bridge over the Dulas river near the township of Hay, this being a central location between the Carmarthen holdings and the border towns generally used for the assizes. ${ }^{191}$ The following table is a chronological list of court locations.

It should be noted that both the justices and those involved in the cases at the assizes had to travel frequently and, at times, long distances. In 1281 and early 1282 the court moved continuously between Montgomery and the Church of St. Michael in Elfael, a distance of thirty-five miles. Often the justices would hear cases in one of the townships

${ }^{191}$ Davies, The Welsh Assize Roll, 1277-1284: Assize Roll No. 1147. 316-317. 


\begin{tabular}{|c|c|c|c|}
\hline Nov 28, 1277 & Oswestry & $\operatorname{Dec} 4,1280$ & Montgomery \\
\hline Feb 9, 1278 & Oswestry & Jan 14,1281 & Montgomery \\
\hline April 8, 1278 & Builth & Feb 16,1281 & Montgomery \\
\hline July 22,1278 & Oswestry & April 21, 1281 & Dulas near Hay \\
\hline Sept 11,1278 & Rhuddlan & April 25, 1281 & Montgomery \\
\hline Jan 14, 1279 & Oswestry & June 15,1281 & Montgomery \\
\hline Feb 5, 1279 & Outside Hay & June 22,1281 & $\begin{array}{l}\text { Church of St. } \\
\text { Michael in Elfael }\end{array}$ \\
\hline May 10, 1279 & Montgomery & July 26, 1281 & Montgomery \\
\hline July 1,1279 & Montgomery & July 31,1281 & $\begin{array}{l}\text { Church of St. } \\
\text { Michael in Elfael }\end{array}$ \\
\hline Sept 24, 1279 & $\begin{array}{l}\text { Church of St. } \\
\text { Michael in Crucorney }\end{array}$ & Sept 30,1281 & $\begin{array}{l}\text { Church of St. } \\
\text { Michael in Elfael }\end{array}$ \\
\hline Oct 6,1279 & Montgomery & Oct 6,1281 & Montgomery \\
\hline Dec 2, 1279 & Montgomery & Dec 1,1281 & $\begin{array}{l}\text { Church of St. } \\
\text { Michael in Elfael }\end{array}$ \\
\hline Dec 9, 1279 & Montgomery & Dec 8, 1281 & Montgomery \\
\hline Jan 14,1280 & Abergavenny & $\operatorname{Jan} 20,1282$ & $\begin{array}{l}\text { Church of St. } \\
\text { Michael in Elfael }\end{array}$ \\
\hline April 29, 1280 & Montgomery & $\operatorname{Jan} 27,1282$ & Montgomery \\
\hline June 25,1280 & Montgomery & April 6, 1282 & $\begin{array}{l}\text { Church of St. } \\
\text { Michael in Elfael }\end{array}$ \\
\hline July 8,1280 & Builth & April 12, 1282 & Montgomery \\
\hline Sept 1,1280 & Diddlebury & May 31, 1282 & Montgomery \\
\hline Sept 11,1280 & Boughrood & Nov 12,1282 & Montgomery \\
\hline Oct 6,1280 & Montgomery & $\begin{array}{c}\text { April } 26,1283 \\
\text { June } 5,1284\end{array}$ & $\begin{array}{l}\text { Montgomery } \\
\text { Oswestry }\end{array}$ \\
\hline
\end{tabular}

Table. 6.1

Dates and Locations of the Welsh Assizes ${ }^{192}$

and the other five to seven days later. The court also moved to more distant locations. On the $24^{\text {th }}$ of September, 1279 , the assize was in session in Crucorney in southern Wales, and twelve days later it was fifty-seven miles away in Montgomery. Similarly, the assize met in Oswestry on January 14, 1279 and then again in Hay on the $5^{\text {th }}$ of February. The justices had traveled nearly seventy miles in the middle of winter.

192 The Welsh Assize Roll, 1277-1284: Assize Roll No. 1147. 122-123. Davies has only translated the dates of the court appearances at the Assize itself. Other dates, such as when Angharad f. Owain and Walter de Pedwardine, her husband, were summoned to appear before the King at Westminster a month from Easter in 1278, I have translated myself. A month from Easter in 1278 was the $17^{\text {th }}$ of May. 


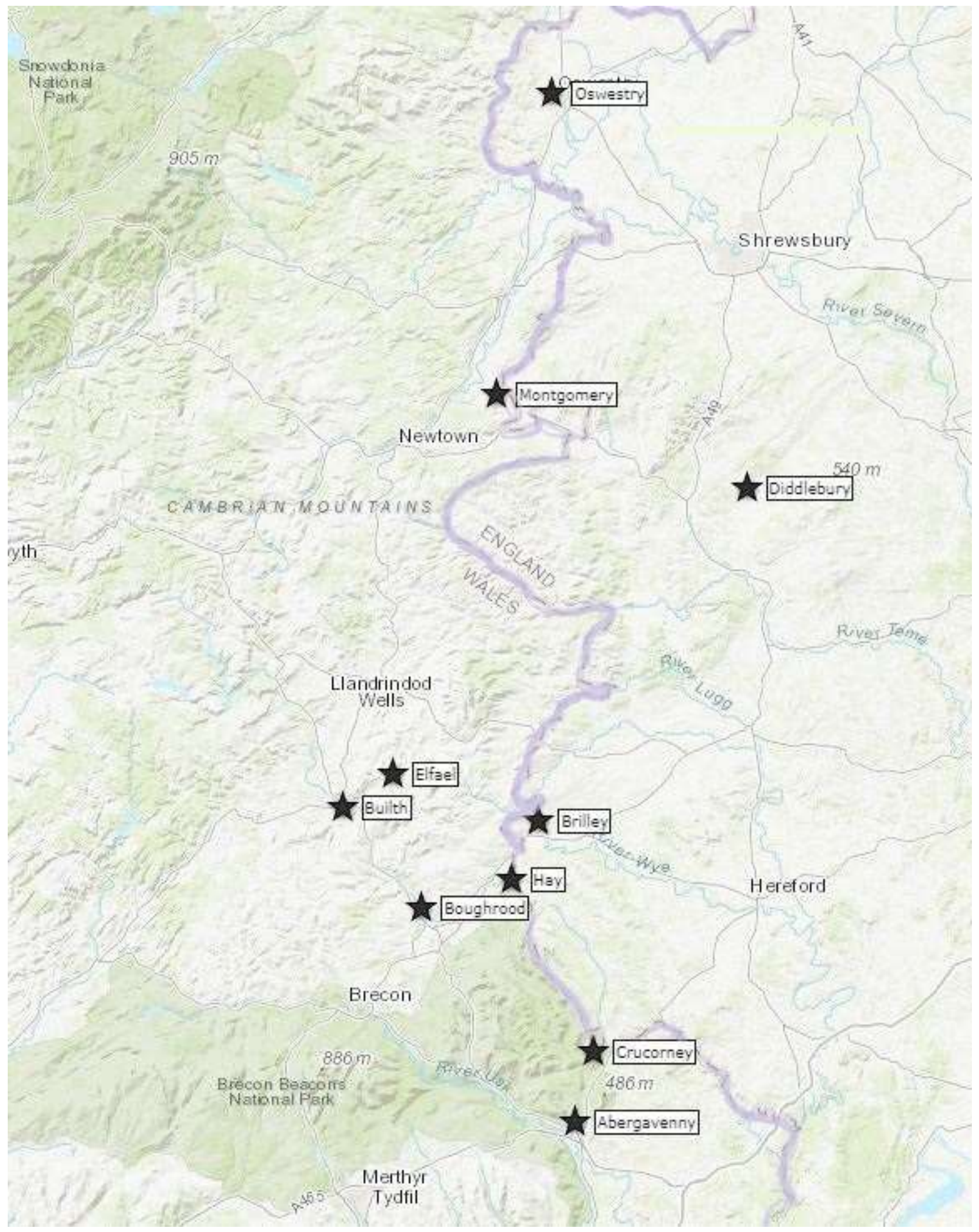

Fig. 6.1

Locations of the Welsh Assizes ${ }^{193}$

${ }^{193}$ Map created in 2018 using the template provided by Gis Visualizer 
Claimants, complainants, and defenders also had to travel. The most extreme trip any one plaintiff had to make was when Angharad f. Owain, her husband Walter de Pedwardine, and her son Owain ap Madog were summoned to appear before the King's court in Westminster. They learned of the summons at the court held in Oswestry in February of 1278 and were ordered to appear on the $17^{\text {th }}$ of May of that same year. That left three months for them to arrange to travel over 160 miles to London. After their day at the royal court they returned quickly enough to attend the court at Oswestry on July 22. Others made dozens of appearances, as will be seen in the case of John and Matilda Giffard versus Rhys Vychan below.

\section{Conflicting Custom - Bastardy and Inheritance through the Female Line:}

The role and run of Welsh custom had come up before in English courts. The English generally agreed that Welsh customs could be applied to a lawsuit if it took place in Wales. Thus, they often viewed English courts as being under the jurisdiction of English Common Law. The Welsh living in Shropshire, as discussed previously in Chapters four and five, saw jurisdiction as something that was dependent on the identity of the individuals involved in the case. This would change throughout the $1280 \mathrm{~s}$ because, while the king had promised that Welsh law and custom would run in the territory considered Welsh, the realities of the incorporation of post-conquest Wales into the English kingdom meant that English law became more and more dominant.

The Welsh customs concerning bastard children had long been a thorn in the side of English administration. Many Archbishops of Canterbury argued against it and the custom that allowed bastard children to inherit alongside legitimate siblings, the result of the common practice of concubinage, was seen by critics as one of the roots of Welsh 
societal disorder. ${ }^{194}$ Bastard children and their heirs could gain and hold lands as a rightful part of their inheritance. The rights these children had could even effect dynasties; the last two Princes of Wales were the sons of Gruffydd ap Llywelyn, the son of Llywelyn Fawr by his concubine or secular wife Tangwystl Goch. ${ }^{195}$ The two following cases present examples of how the Welsh customary treatment of bastard children was disputed in The Welsh Assize Roll.

At Montgomery on the morrow of the Close of Easter, May 29, in 1280 Gruffydd ap Maredudd, his brother Cynan, and their nephew Llywelyn came before the court to claim the two commotes of Geneu'r Glyn and Creuddlyn. They argued that their father Maredudd had been seised of Creuddlyn until he was ejected by Llywelyn, the Prince of Wales. Similarly, Cynan had been seised of Geneu'r Glyn until he too was ejected by force and power. The use of the phrase "force and power" in their claim signified that the land had been taken by extra-legal means. When the armies of King Edward I took the region back from the Prince control of the commotes fell to Rhys ap Maelgwn, who did homage to the king for them. When Rhys later defected to the Prince the royal court disinherited Rhys and, thereby, his son Rhys Vychan ap Rhys.

Rhys Vychan came and defended his claim to the commotes by arguing that neither Gruffydd nor his brother or nephew tried to claim the land when it was in question, specifically when Rhys ap Maelgwn did homage to the king and then when 265.

${ }^{194}$ Gerald of Wales, "The Journey through Wales and the Description of Wales."

195 The nature of their relationship is still debated today. If Tangwystl was truly his wife then Llywelyn Fawr became a bigamist upon his marriage to Johanna, herself the bastard daughter of King John I. 
Rhys Vychan reclaimed his inheritance. Claims were meant to be made quickly and English courts followed a clear statute of limitations, being a year and a day from when the right to the property was in question. At this point the case turned nasty as Gruffydd and his party announced that Rhys Vychan was the bastard son of Rhys ap Maelgwn "by a harlot", rather than a true-born son. ${ }^{196}$ According to Welsh law this distinction should not have made any difference, yet here were Welshmen seeking to use the English aversion to partitive inheritance and bastardy to their own advantage. Bogo de Knovill, the King's bailiff in Montgomery hotly denied that Rhys, who held his lands of the king and was thus in his favor, was a bastard nor his mother a harlot. The case was referred to the king's court the $21^{\text {st }}$ of May, 1280 however no assize court is recorded as having met that day. Because of this it is impossible to determine whether the brothers' argument about Rhys Vychan's parentage was ever settled. The next bastardy case is more complete.

At the first formal meeting of the assizes on the $2^{\text {nd }}$ of February, 2018, a man named Gruffydd ab Einion and his five brothers, Maredudd, Einion, Owain, Hywel, and Dafydd, arrived in Oswestry to present a claim for their inheritance. The case they presented was simple: their father Einion ap Gruffydd had died seised of his lands in Langollen Fechan, Ystwennant, Llwythdr, Hafodwen, Dolwen, Nancennin, Tregeriog and

${ }^{196}$ Davies, The Welsh Assize Roll, 1277-1284: Assize Roll No. 1147. 278-279. 


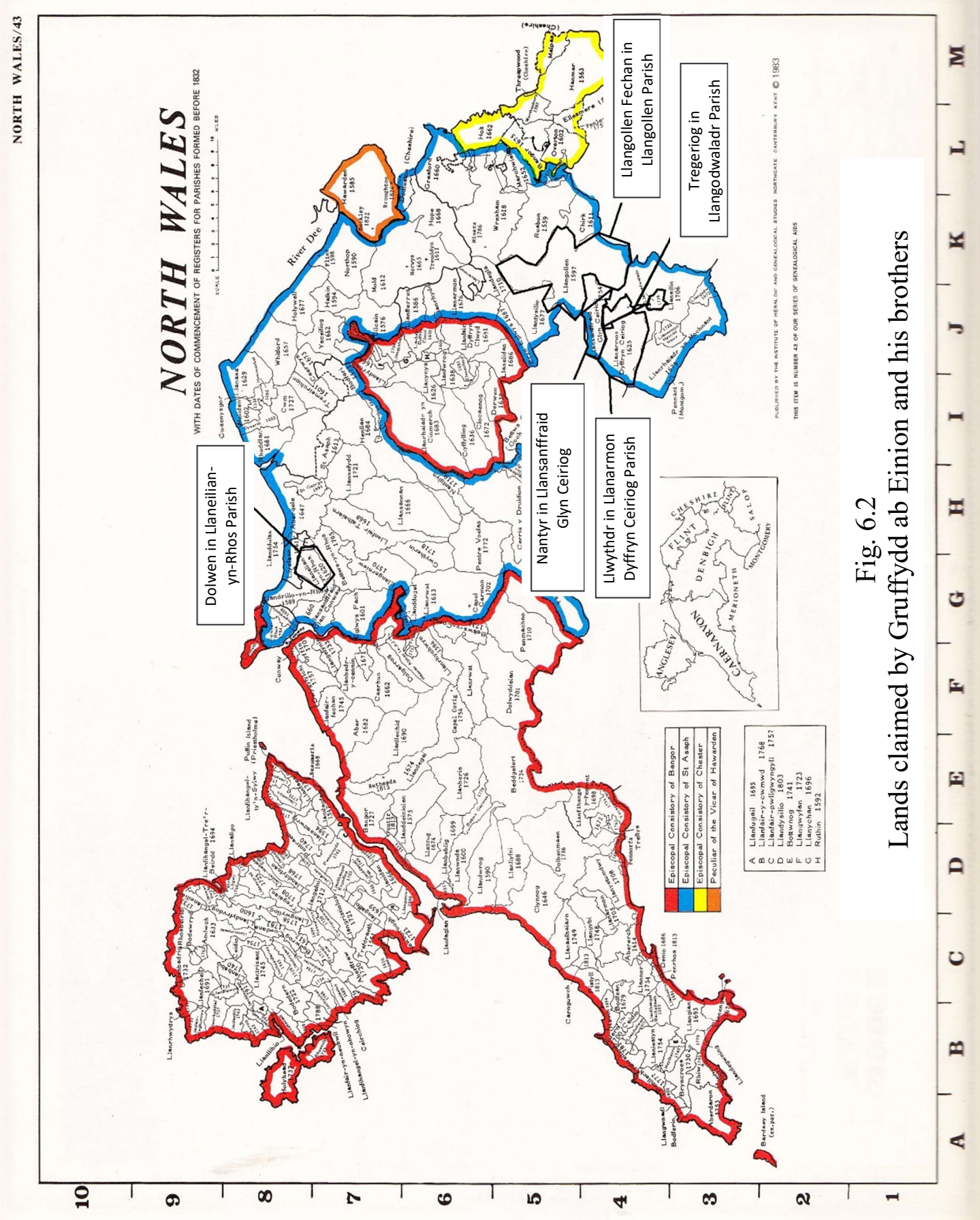


Nantyr. ${ }^{198}$ Most of these holdings were located in the border zone between Shropshire and Denbishire, although Dolwen, in the parish of Llaneilian-yn-Rhos, was located so far west it was almost in Gwynedd. They maintained that Owain ap Gruffydd ap Madog, who then occupied Nancennin, Tregeriog in Llangadwaladr Parish, and Nantyr in Llansanffraid Glyn Ceiriog Parish, did so unjustly. The same argument also applied to Llywelyn Vychan (ap Maredud ap Madog), Owain's brother, who likewise occupied the rest of the lands they claimed. It seemed to be a simple case of determining whether Einion ap Gruffydd died seised.

The response made by defendants Owain ap Gruffydd and Llywelyn Vychan was anything but simple. They claimed that Einion was born a bastard and, in addition to that barrier to inheritance, was also a Cistercian monk. ${ }^{199}$ Because of these factors, they argued, Gruffydd and his brothers had no legal claim to the properties in question. Owain and Llywelyn Vychan claimed to make this argument in accordance with Welsh law, arguing that the laws of Wales did not allow a bastard to inherit, and requested the case be heard under the Welsh Law of Cyfraith Hywel. ${ }^{200}$

197 "\#43 North Wales, with Dates of Commencement of Registers for Parishes Formed before 1832," (Canterbury: The Institute of Heraldic \& Genealogical Studies, 1983). Used with permission.

${ }^{198}$ The locations of Ystwennant, Hafodwen, and Nancennin are unknown.

${ }^{199}$ Einion religionem intravit in ordinem Cisterciensem et ibidem professionem fecit. Davies, The Welsh Assize Roll, 1277-1284: Assize Roll No. 1147. 257.

${ }^{200}$ A bastard secundum legem Walensicam aliquam hereditatem per descensium patris non debent optinere. Additionally, the Welsh Law of Hywel Dda was often referred to as "the law called Cyfraith" (secundum quod lex Walensica que vocatur keuereyth desiderat). The Welsh Assize Roll, 1277-1284: Assize Roll No. 1147. 257. 
These circumstances seem like an insurmountable barrier to Gruffydd and his brothers regaining their inheritance. But Gruffydd took it in stride; he pointed out that Einion had indeed married their mother and that, even though he was bastard, his sons were not. Gruffydd also argued that Einion's bastardy and the time he served as a Cistercian had no bearing on the case because, regardless of his past, he had been seised at his death. If Owain ap Maredudd and Llywelyn Vychan were correct in their interpretation of Welsh law then, Gruffydd noted, the case need not be heard under Welsh law. ${ }^{201}$ He himself was Welsh, the son and heir of a Welshman, and the lands he and his brothers claimed were also in Wales. And yet, he had no difficulty in suggesting that the legal procedures that would best support his case be used.

Gruffydd, his brothers, and Owain ap Maredudd appeared in court again in October of 1280 to hear the judgement of jurors summoned from nearby parishes. They found that Einion ap Gruffydd had died seised of his lands in Nancennin and the bailiff was ordered to put Gruffydd and his brothers in seisin as soon as possible. The bailiff later came and complained that he was unable to do so because of the power of Llywelyn Vychan, brother of Owain, and his men. Llywelyn was willing to defy the court's ruling to maintain the lands in question in the hands of his family members. ${ }^{202}$

There is no further mention of Einion's bastardy or experience in religious orders in The Welsh Assize Roll. The very fact that the jury ruled on the question of seisin at death concerning Nancennin indicates that his unique circumstances had no bearing on

${ }^{201}$ Gruffydd argued non est illa lex Walensica que vocatur Keuereyth in isto cusa observando. The Welsh Assize Roll, 1277-1284: Assize Roll No. 1147. 257.

202 The Welsh Assize Roll, 1277-1284: Assize Roll No. 1147. 305. 
the outcome of the case. The brothers' suit against Llywelyn Vychan for the townships of Llangollen Fechan, Ystwennant, Llwythdr, Hafodwen, Dolwen, Tregeriog, and Nantyr remained undecided. Llywelyn avoided a judgement by failing to show up to defend his own position when the decision about Nancennin was delivered at Montgomery. Six months later he appeared at the court at Dulas near Hay and presented a writ to have his case heard in person by the king. Subsequently the case was moved from the assizes to King Edward I's court at Westminster a month from Easter in 1281. Further references to a land dispute between Lywelyn and the sons of Einion ap Gruffydd give few details beyond the extension of the case into the fall of that year. ${ }^{203}$

Both of these cases involved Welsh individuals putting forward certain meanings and interpretations of Welsh law when it served their purposes. Neither case correctly followed procedures secundum legem Walensicam, and the parties involved showed a limited familiarity with Welsh Law. This is contrast to the records of The Roll of the Shropshire Eyre of 1256. It may be that in the later years of the thirteenth century English courts had become so dominant in the March of Wales that the value of knowledge of the Law of Hywel Dda was diminishing.

In addition to cases where bastardy was a factor, there were also cases where inheritance was claimed through the female line. While it was true that English landholders preferred to leave their lands to their sons and, by the 1200 s, their eldest son in particular, many Englishmen died leaving only female heirs. The early years of the thirteenth century saw many wealthy heiresses begin new dynasties built upon their

${ }^{203}$ The Welsh Assize Roll, 1277-1284: Assize Roll No. 1147. 305, 318, 325, and 330. 
fathers' property. It is surprising, then, that when both Adam de Montgomery and Maredudd ap Iorwerth put forward claims based upon the rights of their mothers they were answered by the legal question of whether property could pass through the female line.

In May of 1279 Adam de Montgomery claimed against Owain ap Gruffydd ap Gwenwynwyn the whole of the commote of Arwystli as his by right of inheritance. Gruffydd ap Gwenwynwyn, sometimes called the 'Last Prince of Powys', was a powerful presence in northern Montgomeryshire and throughout the border zone between that county and Shropshire. Owain was his eldest son and stood to inherit his lands and influence. But Adam was not without his own resources. He often served the king in Montgomery and claimed ancestral control over Arwystli going back three generations. He argued that his great-grandfather Hywel ab Ieuaf had been seised of the commote during the reign of King John. From Hywel the land had passed to his daughter Amice and from Amice to her own son Philip. Philip, in turn, was Adam's father and thus there was a clear line of inheritance.

Owain ap Gruffydd ap Gwenwynwyn replied that Amice had had brothers, men who now had living male heirs and whom, as such, were "nearer in blood than the issue of a woman." 204 This was a claim much more in keeping with English customs and laws than those of the Welsh. It has been questioned how 'Welsh' the children of Gruffydd ap Gwenwynwyn actually were. Their mother was an Englishwoman, a le Strange from the family of the sheriff of Chester, and Owain's own wife was a Corbet from central Shropshire. And Gruffydd himself was known for his political waffling between

${ }^{204}$ The Welsh Assize Roll, 1277-1284: Assize Roll No. 1147. 275. 
Gwynedd and England until, after a failed coup attempt, he was solidified as a supporter of King Edward I. It is most likely that, regardless of his self-identification as English or Welsh, Owain had chosen this argument in the hope that it would work in his favor. In any case it did not work. Adam reminded the court that "according to Welsh law women are not silenced for the sake of male heirs" and Owain quickly abandoned this approach. The case soon became a series of court appearances and claims and counterclaims concerning the seisin of Hywel ab Ieuaf that extended into 1280.

Maredudd ap Iorwerth also faced questions about the legitimacy of inheritance through the female line when he also brought suit against Owain ap Gruffydd ap Gwenwynwyn, in this case concerning the manor of Talgarth. As in the previous case, Maredudd was a descendant of Hywel ab Ieuaf and claimed his inheritance through one of Hywel's daughters, this time his daughter Gwenllian. From there the manor passed from Maredudd, her son, and on to another Gwenllian, this time her granddaughter. Finally, it passed from this Gwenllian to Maredud ap Iorwerth. ${ }^{205}$

Owain once again made the argument that a claim should not be made through Gwenllian f. Hywe ab Ieuaf because she had brothers who, in turn, had their own male heirs. Additionally, he argued that Gwenllian had been a bastard daughter of Hywel. Maredudd and Owain met again in Montgomery on the morrow of St. John the Baptist, July 25,1280 . There it was decided that Maredudd's claim was false and he was to be amerced in addition to losing any right to Talgarth.

The difference between this case and the case of Adam de Montgomery appears to be that Maredudd's claim was through a bastard daughter and that claim could not

${ }^{205}$ The Welsh Assize Roll, 1277-1284: Assize Roll No. 1147. 278. 
compete with those of the heirs of Hywel's legitimate sons. Appeals to recourse according to either English or Welsh custom and law, in cases of bastardy and inheritance through the female line, appear to have been made without reference to the actual laws of Wales. Rather, these appeals were made to aid the individual in his quest to prove his right at the expense of his opponent.

\section{Recovering Dower and Inheritance - The case of Angharad f. Owain ap Maredudd:206}

In December of 1279 Angharad f. Owain ap Maredudd and her second husband, Sir Walter de Pedwardin, appeared before the Welsh Assize, then meeting in Montgomery, and asked that their civil case finally be resolved since for the last three years they had "by supplication to the king, made from Parliament to Parliament, prosecuted their right." ${ }^{207}$ Angharad and Sir Walter's case presents a good example of the struggles many mixed English-Welsh couples faced as they navigated the changing legal structures of the Welsh March in the final years of the Edwardian Conquest of Wales. The greatest of these struggles was the necessity of working with an amalgamation of English and Welsh inheritance and property laws while at the same time avoiding the legal loopholes and bureaucratic obstructions used by their opponents. Time was also a difficulty; as the Welsh Assize records show, complicated cases like Angharad and Sir Walter's were often bumped up to higher courts where they lay dormant for months or even years.

${ }^{206} \mathrm{f}$. X serves to signify daughter of X, in much the same way that ap or ab X signify son of $\mathrm{X}$.

${ }^{207}$ Davies, The Welsh Assize Roll, 1277-1284: Assize Roll No. 1147. 286-287. 


\section{CENTRAL WALES}

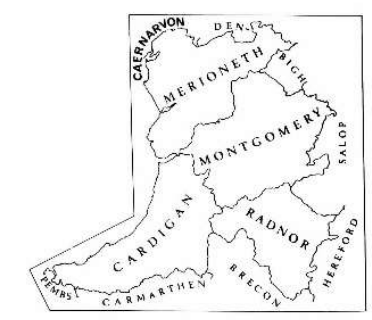

WITH DATES OF COMMENCEMENT OF REGISTERS FOR PARISHES FORMED BEFORE 1832

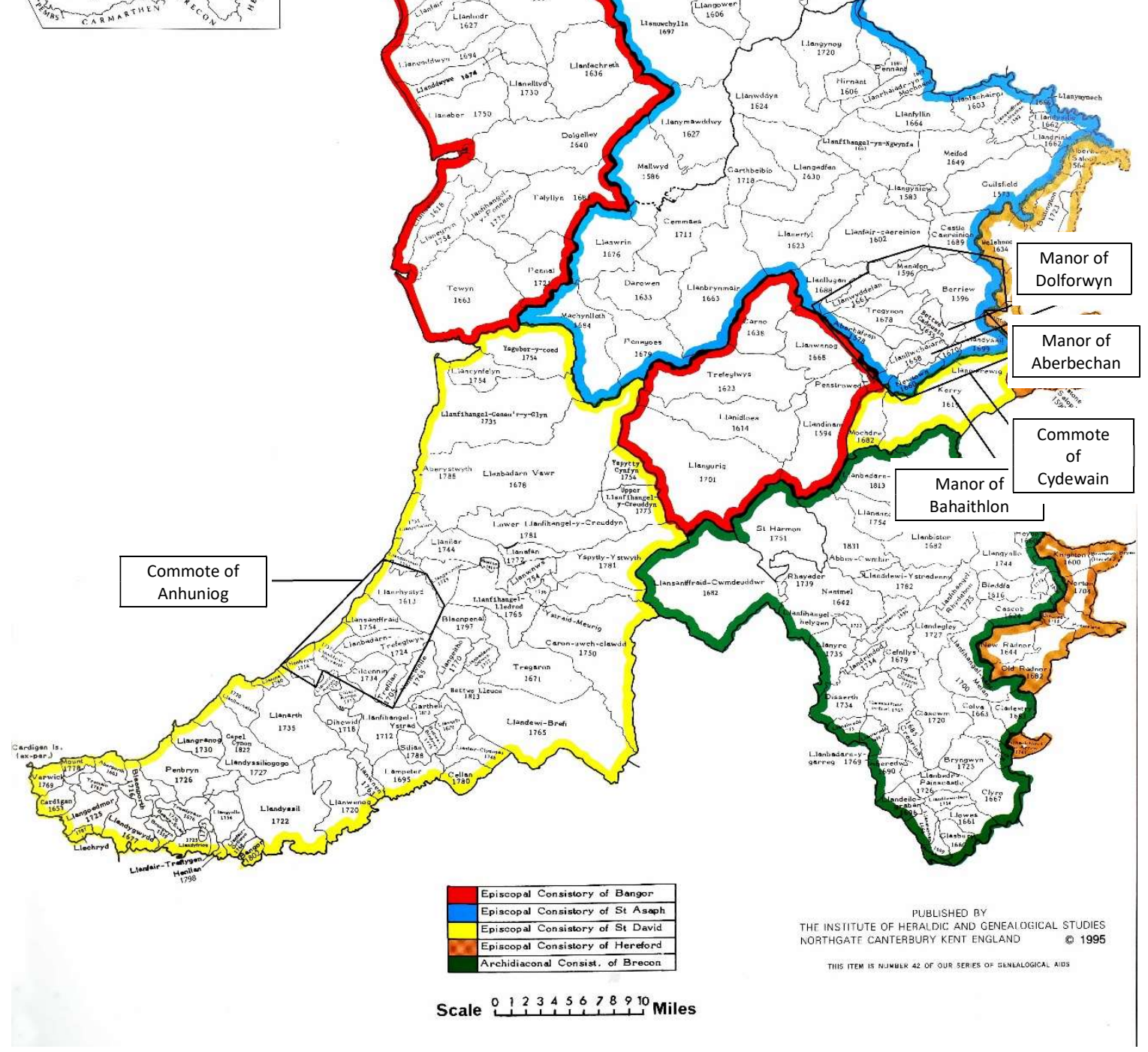

Fig. 6.3 Lands claimed by Angharad f. Owain ${ }^{208}$

208 "\#42 Central Wales, with Dates of Commencement of Registers for Parishes Formed before 1832," (Canterbury: The Institute of Heraldic \& Genealogical Studies, 1995). Used with permission. 
This was true for the property suits brought by Angharad. During the conflict she was ejected from the dower lands of her first marriage by the men of Edward I. The king, in turn, had bestowed them, roughly comprising the commote of Anhuniog, on two of his lieutenants - Sir Payn de Chaworth and Lewis ap Gruffudd. Angharad's inheritance from her father was in the commote of Cedewain. Because of its strategic position along the border with Shropshire and its close proximity to English strongholds at Montgomery and Welshpool the land was keenly sought by both King Edward I and Llewelyn ap Gruffudd. In 1272-73 Angharad's vills of Dolforwyn and Aberbechan and the manor of Bahaithlon were occupied by Llewelyn's troops and he soon built a castle at Dolforwyn. Over the next few years the castle changed hands several times and when Angharad and Sir Walter initiated their claim for the return of these lands Dolforwyn Castle was firmly in the hands of the English.

As a Welshwoman, Angharad's dower and inheritance of these lands were, technically, legal contradictions. According to the Law of Hywel Dda women could not inherit property. This Welsh legal tradition, which dates back to the late tenth century, instead stipulated that a daughter's portion of the partible inheritance should be in movable goods alone. Land inheritance was divided among sons and other maternal and paternal male relatives to the fourth degree. While land was inherited in this way, it was still considered to be part of a larger kin-group holding. When a man passed on his land to his heirs what mattered was actually possession and usage of the land, rather than a modern concept of ownership. In this way, under Welsh law men could inherit land but not own it, and thus could not legally give lands to their wives as dower. A man's wife did, however, receive one-third of the compensation if her husband was killed, so once 
again it is movable property that changes, rather than land. Under these circumstances it may seem that Angharad's situation was highly unusual, but that was not the case.

Throughout the twelfth and thirteenth centuries the Anglo-Norman and Welsh populations in the region energetically embraced the practice of intermarriage. For the Anglo-Normans, the most common way in which property was transferred was through inheritance. In Anglo-Norman England the genealogically closest heir was most likely to inherit. If there were multiple sons the eldest received the entire inheritance and by the 1130s families without sons divided property equally between daughters. Inheritance by heiress or heiresses was a frequent occurrence on the Welsh border. Therefore, when an Anglo-Norman man married Welshwoman he expected that she would eventually gain some land through inheritance, particularly if she was an only child or had no brothers. Acquisition of land through intermarriage was a tried and true tactic of the Normans and after 1066 they used it to great effect on both sides of the Welsh March.

Yet the system could not work if Welshwomen were prohibited from inheriting land. The result was that some adaptation of the Welsh legal system was necessary. While the twelfth century saw the first written redactions of the Welsh legal code, some elements of Hywel Dda were ignored in areas with highly mixed populations. It is difficult to pinpoint at exactly which point the Welsh brides of Anglo-Normans began to receive land inheritance, but by the mid-thirteenth century petitions regarding Welshwomen's inheritance often appear in Shropshire court records. Other elements of Welsh property law were also being adapted to fit with English Common Law. Some Welshmen dowered their wives with land, a process that could, if a woman were to become a widow and remarry, cause that land to be alienated and lost to the kin-group 
forever. Land inheritance by Welsh sons was also becoming more permanent - while Hywel Dda stipulated that the land was ultimately owned by the kin-group and that reapportionment should be done when necessary to meet the needs of every family in the community, this practice was most common in the parts of Wales remote from English contact, where mixed marriages were not an issue.

By outlining these important adaptations of inheritance law I do not want to give the impression that the Welsh population along the border simply abandoned their Welsh legal traditions in favor of Common Law. Welsh law was cited frequently in English courts as secundum leges et consuetudines Wallensicas (according to Welsh law and tradition) and Welsh men and women often asked that their cases be judged in this way regardless of whether or not their opponents were Welsh and/or the lands in questions were actually in Wales. To the Welsh the law and custom of Wales could be applied to any person of Welsh heritage. This created some confusion because the English were much more likely to base legal jurisdiction on the physical location of the property in question. And, as will be seen below in the cases of Ralph and Matilda Boteler and John and Matilda Giffard, individuals chose to accept the form of jurisdiction most useful to their case.

Welsh law was most often used in relation to questions of tenure or seisin of land. Property in post-Norman Conquest England was held under a system of tenure based on some form of agreement between the landlord and the tenant. Usually that agreement consisted of an oath taken by the tenant to the landlord that included the promise of fee or service. The landlord, for his part, would acknowledge that the tenant was seised, or in legal possession, of the land. Often this acknowledgement was in the form of physically 
removing his own property and himself from that land. In a land dispute an heir or heiress would have to prove that his or her father had been properly recognized as being seized upon his death. A majority of inheritance cases dealt with the question of whether the deceased had been in seisin of the property upon his or her death. Possession in Welsh law was based not on recognition of an oath but on by having occupied the land for at least four generations. Inheritance cases being judged under Welsh law often included references to the land having been held by the claimant's grandfather and greatgrandfather.

Differing ideas about inheritance, jurisdiction, and the possession of land meant that mixed English-Welsh couples like Angharad and Sir Walter had to be familiar with the workings of both Welsh law and Common Law, or risk having their case dismissed because of a technicality. Angharad, as the widow of one Welshman and the daughter of another, could easily have had her case heard under Welsh law. Instead, she petitioned for the return of both her dower lands and her inheritance according to English law.

In February of 1277 Angharad brought a suit in the assize court at Oswestry to reclaim her dower lands in the commote of Anhuniog that were currently under the control of two of Edward I's lieutenants, Sir Payn de Chaworth and Lewis ap Gruffud (Lewis de la Pole, son of Gruffudd ap Gwynwynwyn, last Prince of Powys and ally of the king). Before the king's justices at Oswestry she argued that she should have right to her dower lands because her first husband had been seised in them at the time of his death. Thus she used the English legal concept of seisin to prove that her late Welsh husband had legal right to gift her with these lands. She had held them properly as her dower until 
her ejection by Edward I's forces during the war. The case was accepted and a date was set for it to be heard. Angharad also had her husband Sir Walter de Pedwardin added as an advocate for her if necessary. This began a process that covered several years. From the beginning of 1278 to the end of 1289, Angharad and Walter would pursue justice from court to court.

On the Friday before Palm Sunday, April 8 in 1278, the case was heard at Builth by the king's justices Sir Walter de Hopton and Hywel ab Meurig. Angharad and Sir Walter petitioned again for the return of her dower but also that they regain the wardship of Angharad's son from her first marriage, Llewelyn ab Owain. Once again the argument for her dower rights was based upon her husband having been seised at the time of his death. She also argued for wardship, and thus control over her minor son's property, "as the law and custom of the country require." ${ }^{209}$ The king, as the defendant, was represented by William, the clerk of Sir Roger de Molis, who was the king's steward at Cardigan. William argued that the lands could not be returned because the king held them as pure demesne, Angharad's son Llewelyn having submitted them to him. Angharad and Sir Walter responded that it was impossible for Llewelyn to have legally submitted his lands to the king because he was still a minor. The court determined that the cased must be heard before the king and rescheduled it for a month from Easter, May 17, 1278. ${ }^{210}$

This is the last record we have of Angharad's battle to regain her dower and the wardship of her son. While there is evidence that she and Sir Walter continued to seek the

${ }^{209}$ The Welsh Assize Roll, 1277-1284: Assize Roll No. 1147. 243.

${ }^{210}$ The Welsh Assize Roll, 1277-1284: Assize Roll No. 1147. 241-242. 


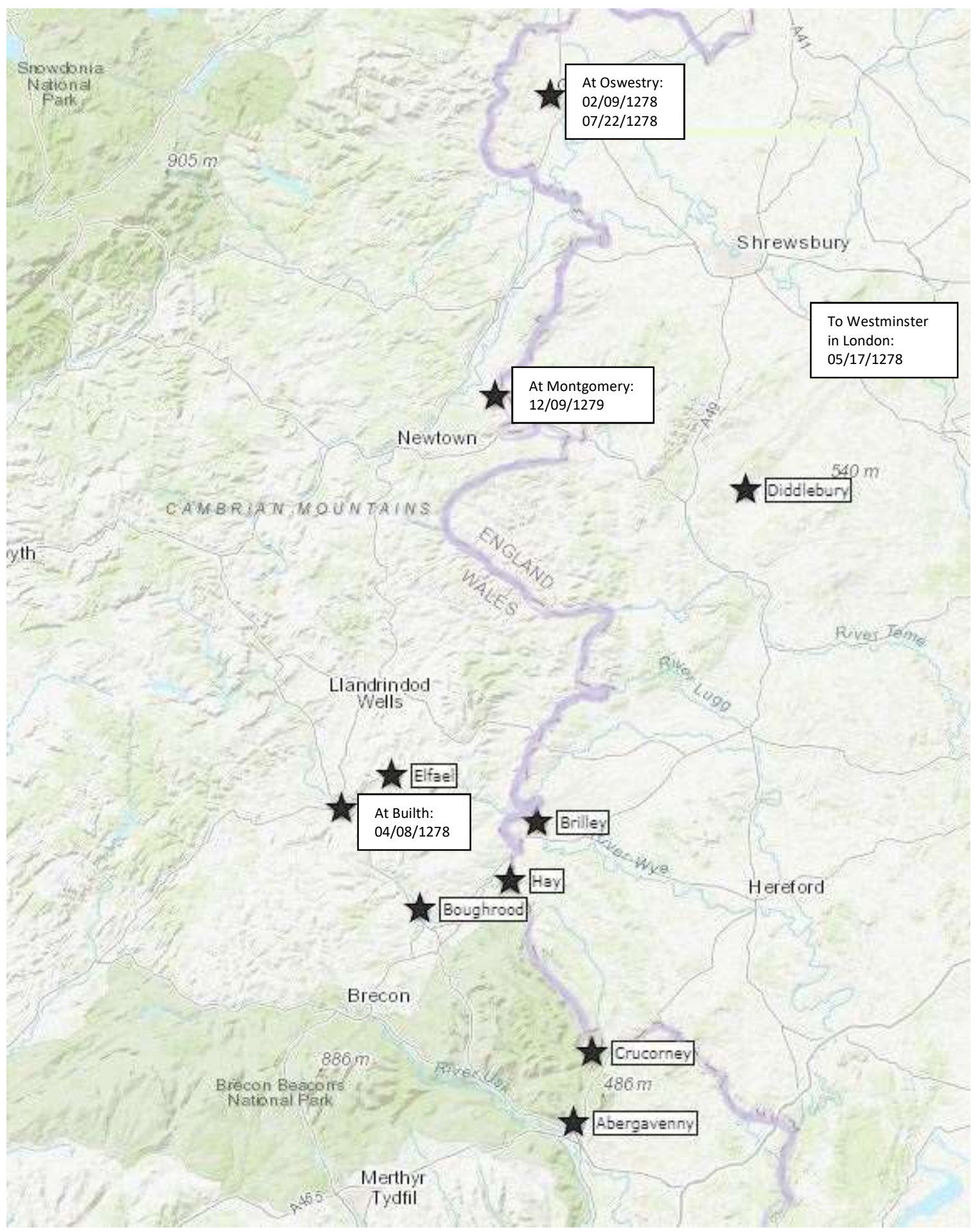

Figure 6.4 Court Appearances of Angharad f. Owain, wife of Walter de Pedwardine by location and date 211

${ }^{211}$ Map created in 2018 using a template provided by Gis Visualizer 
land she had inherited from her father, there is no way of knowing if she regained the lands given to her by her first husband. Given the location of Anhuniog and its distance from Angharad and Sir Walter's other properties and the vigor with which they pursued her inheritance in Cydewain I am inclined to think that she never regained her dower lands.

At the May 1278 court session in Westminster, where her case for Anhuniog had been referred, there is no mention of a verdict on her dower. She did, however, bring a suit to have the king return to her the lands she had inherited in Cydewain. While she claimed the entire cantref as her right the case focused specifically on three vills in Ucheldre, the vills of Dolforwyn and Aberbechan, and the manor of Bahaithlon. She argued that her father Owain ap Maredudd had been seised at the time of his death and that she was his direct heir. The court accepted the case and set a date for it to be heard.

On July $22^{\text {nd }}, 1278$ Angharad presented her case before the king's justices at Oswestry. She stated that she had been seised of the vils of Dolforwyn and Aberbechan when she was ejected by the soldiers of Llewelyn ap Gruffudd, Prince of Wales. Therefore, these lands should be returned to her. Angharad's claim to the manor of Bahaithlon demonstrates how much her family had embraced the Common Law rules for inheritance and subinfeudation. She detailed how Bahaithlon had been given to her maternal grandmother Julia as dower by her husband Maredudd. Julia had, in turn, enfeoffed her son Owain with the manor. Some time before his death Owain then enfeoffed his daughter Angharad. Thus, when it was taken by the soldiers of Gwynedd Bahaithlon had been under Angharad's control as tenant. Additionally, with Owain dead 
the outright claim to the property passed, upon Julia's death, to Angharad as heir. In her claim for the manor of Bahaithlon then Angharad asserted that she had right to the property by both seisin and a history of occupation. Her argument for the rights to Dolforwyn and Aberbechan was much more straight forward as she had been both seised and in physical possession at the time of her ejection.

In response, the king had sent Bogo de Knovill to represent him with the following argument: that while her father had died seised of the property Angharad had never been siesed herself. He argued that she had never taken possession of these vills because they were so quickly occupied by Llywelyn ap Gruffudd, Prince of Wales. Thus, Angharad had no grounds for bringing suit against the king. The court decided to set a later date for the final decision in the case, but that date wasn't recorded. The case had reached a murky stage - judging by similar cases from the Welsh Assize it should have been enough for the defense to admit that Angharad's father had died while seised and that she was his heir to verify her claim. Perhaps it was because the defendant was, after all, the king, that Bogo de Knovill tried to make an argument about the need for a formal recognition of seisin. As John Hudson has pointed out, when a family had been in possession of a particular piece of land for a long time a ceremony or physical transfer of possession was less important. ${ }^{212}$

It was a year and a half before Angharad's case again appeared in the Welsh Assizes. On a Saturday in early December, 1279, Angharad and Sir Walter once again

${ }^{212}$ Hudson, The Formation of the English Common Law : Law and Society in England from the Norman Conquest to Magna Carta. 88-89 \& 95. Land, Law, and Lordship in Anglo-Norman England, Oxford Historical Monographs (New York: Oxford University Press, 1994), 16-22. 
came before the king's justices in Montgomery. They repeated the details of her claim, this time emphasizing her right to the rest of Cydewain specifically excluding Dolforwyn, Aberbechan, and Bahaithlon manor. While this implies that the fates of these properties had been decided, it is unclear if they had been retained by the king or returned to Angharad. J. C. Davies noted in his critical edition of the Welsh Assizes that after the July 1278 hearing "the record of the case is almost indecipherable" and I have found no further mention of these properties beyond their exclusion in 1279 .

Once again the king sent Bogo de Knovill as his representative, although this time he was joined by Sir Roger Mortimer. The defense once again denied Angharad's claim, this time arguing that according to Welsh law as heir she had to make her case to these lands within a year and a day of her original suit. This was a confusing argument because the time restriction of a year and a day was a requirement not of Welsh courts but of English ones. And as they were in an English court and Angharad had made no request that the case be heard under Welsh law, this appears as a somewhat desperate attempt by Bogo de Knovill and Sir Roger to find a legal loophole that would allow them to yet again postpone the case, or even have it dismissed for good. Angharad and Sir Walter responded by pointing out that they had attempted to settle the case but it had been delayed on one occasion by the representatives for the defense not showing up to court. Additionally, they had pursued the case at Oswestry and "by supplication to the king made from parliament to parliament, prosecuted their right."213

Having spent the last few years pursuing a judgement against the king in vain, Angharad and Sir Walter then entered a new petition in which they transferred their claim

${ }^{213}$ Davies, The Welsh Assize Roll, 1277-1284: Assize Roll No. 1147. 286-87. 
against the king to one against Sir Roger Mortimer. The king had granted Cydewain to Sir Roger and he was now in actual possession of the land. Angharad maintained that she had been in full seisin of Cydewain for three weeks after her father's death, thus negating a possible repeat of earlier arguments that she had never actually been seised, and then had been forcibly ejected from that land by Sir Roger. In this way Sir Roger had disseised her and thus he held Cydewain illegally. She also argued that by this action Sir Roger had deprived her of leirwite to the value of 30s. a year, leirwite being a fine for premarital sex in the cantref. ${ }^{214}$ Angharad argued that she was used to a fermor levying the returns of his ferm to her for her own use. In response Sir Roger denied having used force against Angharad and stated that since he had received the land by charter from the king, no case could be brought against him because he had not been the injuring party. Once again, the court postponed any judgement, rescheduling the case for three weeks from the following Easter, May 12, 1280.

And that is how the story ends - Angharad and Sir Walter do not appear again in the court records for the Welsh Assizes and the next extant documentation of the king's justices' activity in the region is from the 1330s. There is no way to tell what became of Angharad's inheritance, but what we can know is the challenges she faced as a Welshwoman seeking her inheritance, as a widow fighting for her dower, and as a resident of the Central March at the end of the last war between England and Wales. She was willing to repeatedly use the legal system available to her, even though her

${ }^{214}$ Lierwite differed from the fines for marriage collected in England (Merchet) and Wales (Amobry). Luke Owen Pike, "Chronicles \& Memorials of Great Britain and Ireland During the Middle Ages," Google Books Edition ed., Dear Books of the Reign of King Edward III Year XV (London: HM Stationary Office, 1891). 285-286. 
opponents were the king of England and his powerful supporters. Angharad's attempts to regain her lands provide us with a glimpse of the frustrations and challenges she faced as she navigated the legal complexities of the Central March.

\section{Does Welsh law and Welsh tenure always apply to land in Wales? The cases of Ralph and Matilda le Boteler and John and Matilda Giffard:}

As we saw in Chapter Five, in The Roll of the Shropshire Eyre of 1256 Welsh individuals could, and at times did, request legal disputes to be heard under Welsh law. Some English residents of Shropshire also referred to Welsh law when asking that the case against them be dismissed for being outside the jurisdiction of the English courts. These English and Welsh uses and working definitions of legal practice became increasingly complicated as the war between King Edward I and Gwynedd continued and ultimately shifted in England's favor. In particular, the question of the primacy of English or Welsh tenure in Wales was hotly debated. I have chosen the claim of Ralph and Matilda de Boteler against Owain ap Gruffydd ap Madog and the separate suits and countersuits between John and Matilda Giffard and Rhys ap Vychan and Morgan ap Maredudd to demonstrate this debate.

When the assize met on July 22, 1278 Ralph and Matilda de Boteler appeared and claimed the manor of Bangor and the advowson of its church as Matilda's right by inheritance. Matilda put forward that her grandfather, Hugh de Pauton, had been seised of the manor during the reign of King Henry III. From Hugh the land had passed to his son and heir William, and from William to Matilda as his nearest heir and daughter. She maintained that her father William had been seised of the land when he was ejected "by force and power of the Welsh" under the command of Owain's grandfather Madog and 


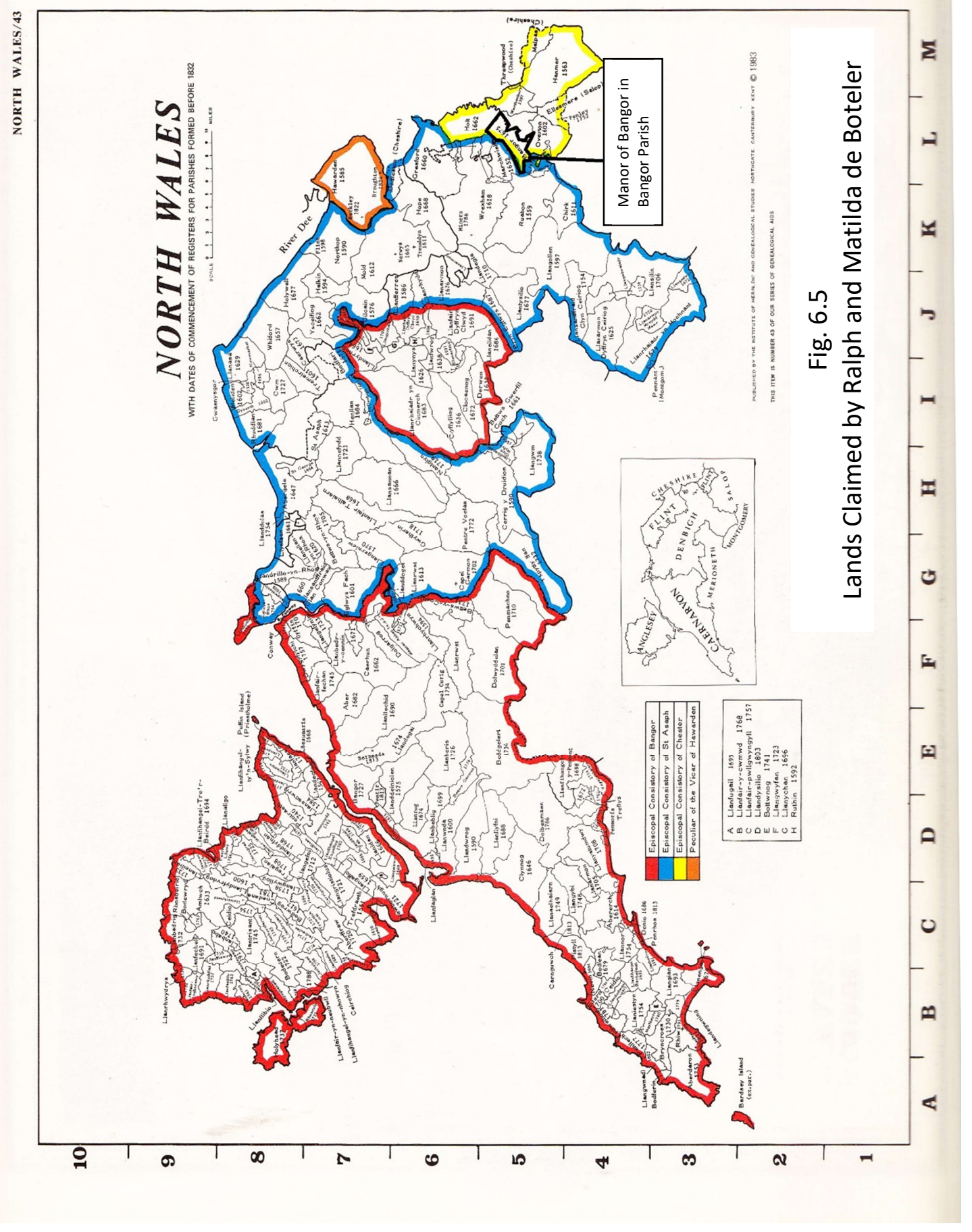

215 "\#43 North Wales, with Dates of Commencement of Registers for Parishes Formed before 1832." Used with permission. 
that he had held this land "as Englishry" or according to English tenure. ${ }^{216}$ This meant that he held it by fee as a sargeantry of the landholder-in-chief, in this case the Bishop of Chester.

Owain responded with an appeal to both English and Welsh legal procedure. He maintained that, since the manor of Bangor was located in the land of Wales the case should be heard according to Welsh law and custom. ${ }^{217}$ Additionally, since he held only a portion of the manor, the rest being held in part by his brothers, nephews, and other parceners, he asked whether the case could continue without these people in attendance, in keeping with Welsh law. ${ }^{218}$ This was also a rule in English law and all writs were required to include all involved parties or specifically exclude them by, for example, only claiming against Owain the exact portion of the manor he held himself. The court agreed with this argument and rescheduled the case for the morrow of Michaelmas, September 30, 1278 .

When the court resumed the case in September it was again deferred, this time until January of 1279. Ralph, Matilda, and Owain all came to reiterate their claims, but Owain's parceners, even thought they had been summoned, did not show. Once again Ralph and Matilda explained how the land should be Matilda's by right of inheritance

${ }^{216}$ Davies, The Welsh Assize Roll, 1277-1284: Assize Roll No. 1147. 253-254.

${ }^{217}$ Secundum legem et consuetudines Walensica et paratus erit Ius suum defendere et et eidem inde respondere per legem Walensiam que vocatur Keuereyth. The Welsh Assize Roll, 1277-1284: Assize Roll No. 1147. 253.

${ }^{218}$ Quia si contingeret ipsum aliquot modo dictum tenementum admittere per Iudicium iidem participes sui predicti secundum legem Wallensicam in dampno secum conicarent. Et quia testum est quod lex Wallensica talis est. The Welsh Assize Roll, 12771284: Assize Roll No. 1147. 253. 
from her father William. In response, and instead of citing legal technicalities, Owain countered that he held the land as barony from the king, as had his ancestors. This barony, he maintained, was held as Welshry, or in accordance with Welsh legal procedure, even though it was held of Edward I. His argument may seem contradictory but was in keeping with earlier cases in the Welsh Assize Roll in which Welsh individuals pointed out that the king had agreed to allow the law of Wales to continue to run in formerly Welsh territory, a promise that was maintained in the Statute of Rhuddlan Edward issued in 1284.

Legally, both Matilda de Boteler and Owain ap Gruffydd ap Madog had valid claims to Bangor. The question then was to determine which legal right, being from different legal systems, had primacy. Owain continued to insist that the case be heard under Welsh law and requested an inquiry by Welshmen into whether the manor was held in Englishry or Welshry. He made several appeals for verification per homines Wallenses in order that these men, being Welsh themselves and familiar with Welsh law, could testify before the court in favor of his right under the laws of Cyfraith Hywel. At the same time Matilda and Ralph continued to make their case according to the basic rules of English property law. Because of these complications the case was sent to be heard before the king in person, but Edward I was on the continent on the scheduled court date in May, and so the hearing was rescheduled for October of $1279 .{ }^{219}$

219 Owain was prepared to prove his claim per homines Wallenses eiusdem tenement propinquiores prout lex Wallensica desiderat secundum quod curia consideraverit. Additionally, Owain per iusticiarios requisites si velit quod ista verifiacio procedat habita medietate iuratorum de hominibus Wallensibus et medietate de englescheria vel quod eadem verificacio fiat per homines iuratos de marchia in medio existentes inter Englisheriam et Walescheriam. Qui dicit quod nullo modo set secundum 


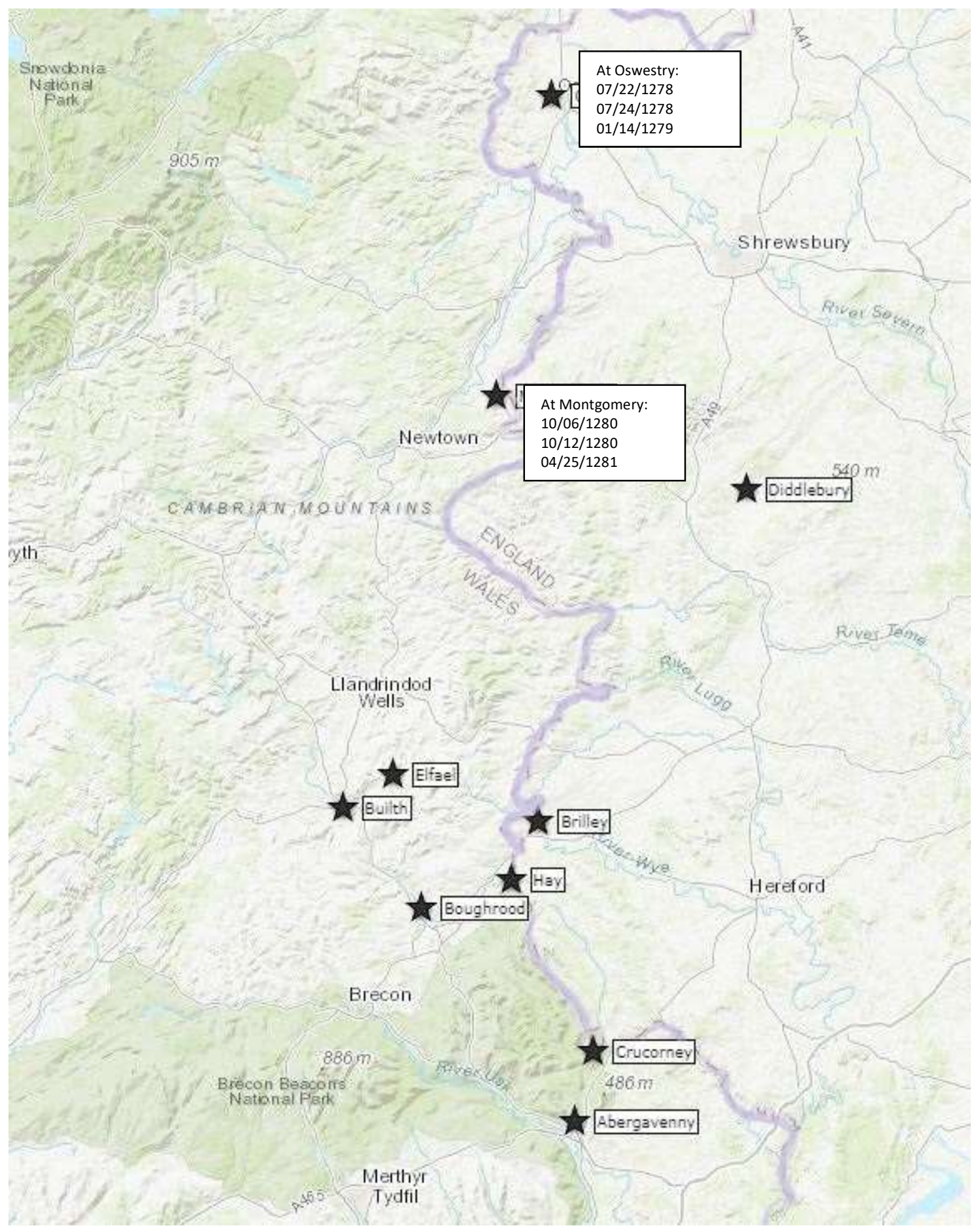

Fig. 6.6

Court Appearances by Ralph and Matilda de Boteler by location and date 220

legem Wallensicam per homines Wallenses verificacioni procedat. The Welsh Assize Roll, 1277-1284: Assize Roll No. 1147. 254.

${ }^{220}$ Map created in 2018 using a template provided by Gis Visualizer 
The debate over seisin of the manor of Bangor continued into 1281with little progress. Matilda and Ralph appointed attorneys to represent them while Owain was unable to attend several scheduled court sessions. While he was fined for not appearing at Oswestry in July of 1278 , he sent representatives to request and pay the required fine to be excused from later sessions in October of 1280 and February and April of $1281 .{ }^{221}$ The last mention of the case in the Welsh Assize Roll was made on the $25^{\text {th }}$ of April in 1281, when Ralph and Matilda were given yet another day to have their case heard before the court. There is no record that the case was heard on that appointed day, a week from Trinity, June $9^{\text {th }}, 1281$ and no verdict is listed. Once again we are left with a debate over jurisdiction that was never resolved.

The final two suits in this study involved John Giffard and his wife Matilda concerning lands they claimed were their right in the county of Carmarthen in southwestern Wales. The first was a claim made by Morgan ap Maredudd and/or Rhys ap Maredudd for two parts of the commote of Hirfryn, with appurtenances, which he argued the Giffards held illegally. At Montgomery in July of 1279 Morgan ap Maredudd came and argued that he had a hereditary right to these two portions of Hirfryn because his father, Maradudd, had been seised of them at his death. John and Matilda, who themselves claimed it by Matilda's right from her father, Walter de Clifford,

${ }^{221}$ An excuse, called an Essoin, could be requested if the individual had a legitimate reason for missing his or her court date and had not defaulted multiple times in the past. An Essoin required a fee or a pledge.

See Appendix Six under the cases of Owain ap Gruffydd ap Madog or Appendix Seven for the courts at Montgomery on 10/06/1280, 02/16/1281, and 04/25/1281. The Welsh Assize Roll, 1277-1284: Assize Roll No. 1147. 304, 307, 318, and 320-21. 


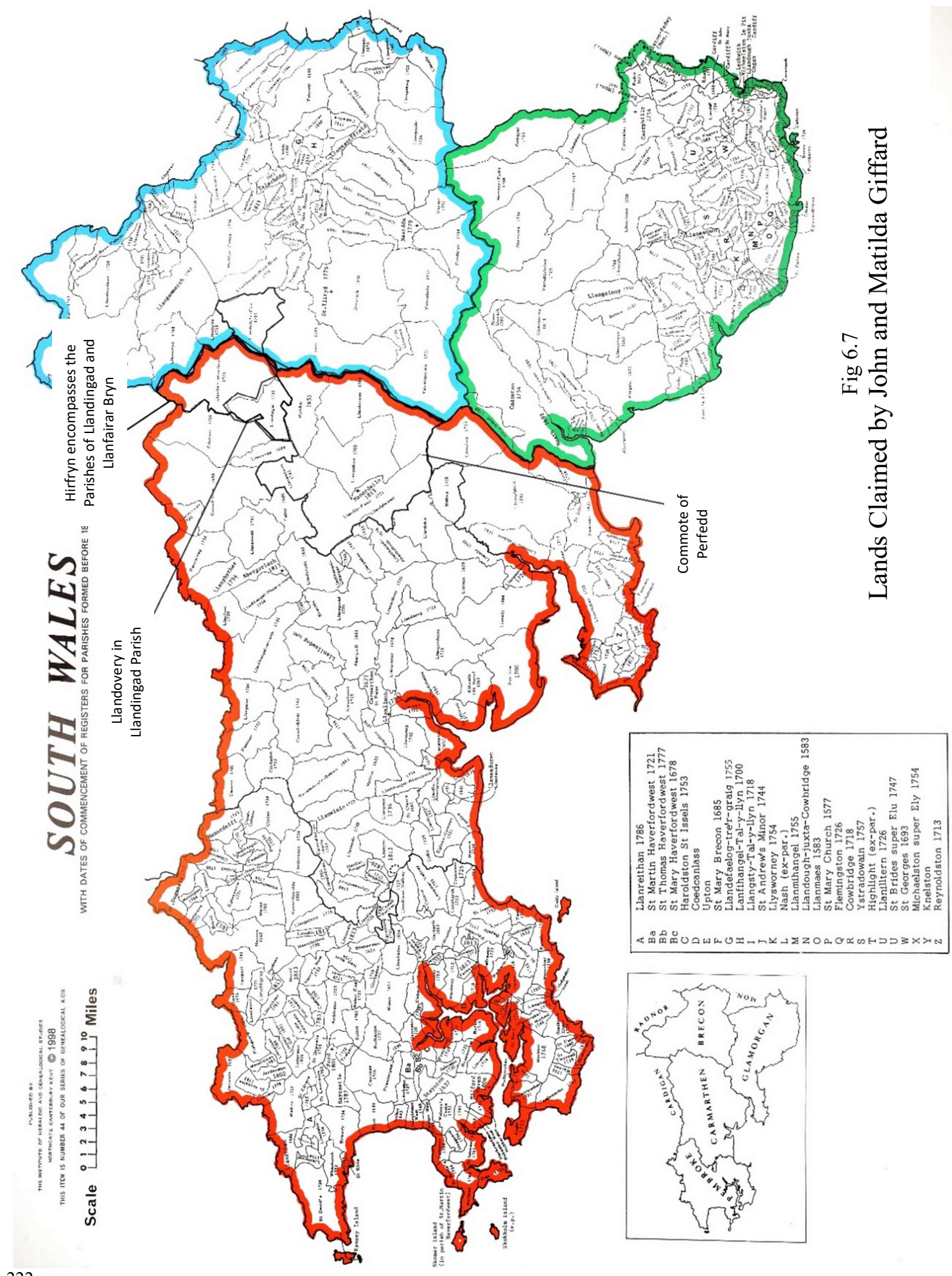

222 "\#44 South Wales, with Dates of Commencement of Registers for Parishes Formed before 1832," (Canterbury: The Institute of Heraldic \& Genealogical Studies, 1998). Used with permission. 
countered that since they held these lands not only as inheritance but also as a Barony directly from the king they ought not to answer without a writ in accordance with proper English legal procedure. Morgan, in turn, said he could prove that this portion of Hirfryn was held according to Welsh law. Once again, the question of which legal procedure and jurisdiction carried more weight. ${ }^{223}$

Both parties were directed to appear before the court again three weeks from Michaelmas in 1279. Thus began an ongoing process of appointing attorneys and arranging court dates until they arrived in Builth on July $10^{\text {th }}, 1280$. They had come to hear jurors give testimony, only to learn that the case was being postponed yet again, this time for a lack of jurors. Orders were issued to the bailiffs of the surrounding region to summon men again, this time to give testimony on July $29^{\text {th }}$. It is probable that Morgan ap Maredudd and John and Matilda remained in Builth for the interim two weeks. ${ }^{224}$

Something else happened at that July $10^{\text {th }}$ court; the Welsh Assize Roll records the exact same circumstances and outcome for the case between John and Matilda and Morgan ap Maredudd, a Rhys ap Maredudd, and a Rhys Vychan. Rhys Vychan, discussed below, was also in the process of suing the Giffards for two parts of the commote of Hirfryn and later half of a third part of Hirfryn. ${ }^{225}$ To make things even more

${ }^{223}$ Secundum legem Walensicam clamat tenere et quod per legem Walensicam debeat teneri et non per Baroniam. The Welsh Assize Roll, 1277-1284: Assize Roll No. 1147. 295.

${ }^{224}$ The Welsh Assize Roll, 1277-1284: Assize Roll No. 1147. 298.

${ }^{225}$ See Appendices Six and Seven for Rhys Vychan and February $2^{\text {nd }}, 1279$, the date of the first record of Rhys' claim. The Welsh Assize Roll, 1277-1284: Assize Roll No. 1147. 
complicated, this was the first record of a dispute between them and a Rhys ap Maredudd. Later court records would indicate that the Giffards were in the process of suing this Rhys for lands in Llandovery, Hirfryn, and Perfedd and, more specifically, for half of a third part of Hirfryn. It seems likely that the recorder has made some sort of error and conflated Morgan ap Maredudd with either or both Rhys ap Maredudd and Rhys Vychan.

My first thought was that Rhys Vychan's father could have been named Maredudd and that the court could be recording him in two different ways. However, it is stated on two different occasions that Rhys Vychan was the son of one Rhys Gryg ap Rhys Vychan. ${ }^{226}$ Additionally, when he was called to answer to a countersuit by the Giffards in April of 1281 Rhys Vychan claimed Rhys ap Maredudd as a parcener and argued that no decision about Hirfryn could be made without Rhys ap Maredudd's presence at court. ${ }^{227}$ If Rhys Vychan and Rhys ap Maredudd were indeed two different people, then it becomes more probable that Morgan ap Maredudd and Rhys ap Maredudd were the same. With the continuous entries about Rhys Vychan and the Giffards, it is not impossible that Morgan was transposed to Rhys in the text. Finally, the record from July $10^{\text {th }}$ was the last time any dispute between Morgan ap Mardudd and John and Matilda Giffard was mentioned; all future references to the case involved Rhys rather than Morgan.

If we accept that Morgan was Rhys ap Maredudd, the case follows a much clearer path. A hearing was scheduled for January, February, and then April of 128. Rhys ap

${ }^{226}$ The Welsh Assize Roll, 1277-1284: Assize Roll No. 1147. 268 \& 290.

${ }^{227}$ The Welsh Assize Roll, 1277-1284: Assize Roll No. 1147. 321. 
Maredudd missed all three of these court dates, ${ }^{228}$ prompting the court, when he also did not appear in June, to rule that because of his defaults seisin would be recovered by John and Matilda. Rhys, in addition to losing any claim to Hirfryn, was also amerced a fine to the court. Interestingly, this was the second time a case in the Welsh Assize Roll was decided against a party because of default and not by any application of law, English or Welsh. No verdict was given on the question of jurisdiction in Hirfryn. ${ }^{229}$ Because of this legal jurisdiction and the primacy of English or Welsh tenure was left to be settled, at least partially, in the case between John and Matilda and Rhys Vychan.

At the court in Oswestry on the morrow of St. Hilary ${ }^{230}$ in 1279 the Giffards put forward a claim against Rhys Vychan for the Castle of Llandovery, its vill and

${ }^{228}$ Rhys ap Maredudd did apply for an excuse from the April court, 04/25/1281, with an Essoin by Richard Chypham. However, in later sessions it is noted that he defaulted by not attending that day. The Welsh Assize Roll, 1277-1284: Assize Roll No. 1147. 323.

229 See Appendix Six for Isabella Mortimer v. Anian, Bishop of St. Asaph, 10/06/1279. The Welsh Assize Roll, 1277-1284: Assize Roll No. 1147. 296 \& 328-29.

While this was the end of the court case between the Giffards and Rhys ap Maredudd, it was noted by the justices at the September $30^{\text {th }}, 1281$ court held at the Church of St. Michael near Elfael that seisin had not yet been returned to John and Matilda. Seisin had been hindered by a group of Rhys' men, including his steward Llywelyn ap Madog, and Gronw Goch, the constable of Dryswyln. The Welsh Assize Roll, 1277-1284: Assize Roll No. 1147. 332.

${ }^{230}$ The 14 th of January 


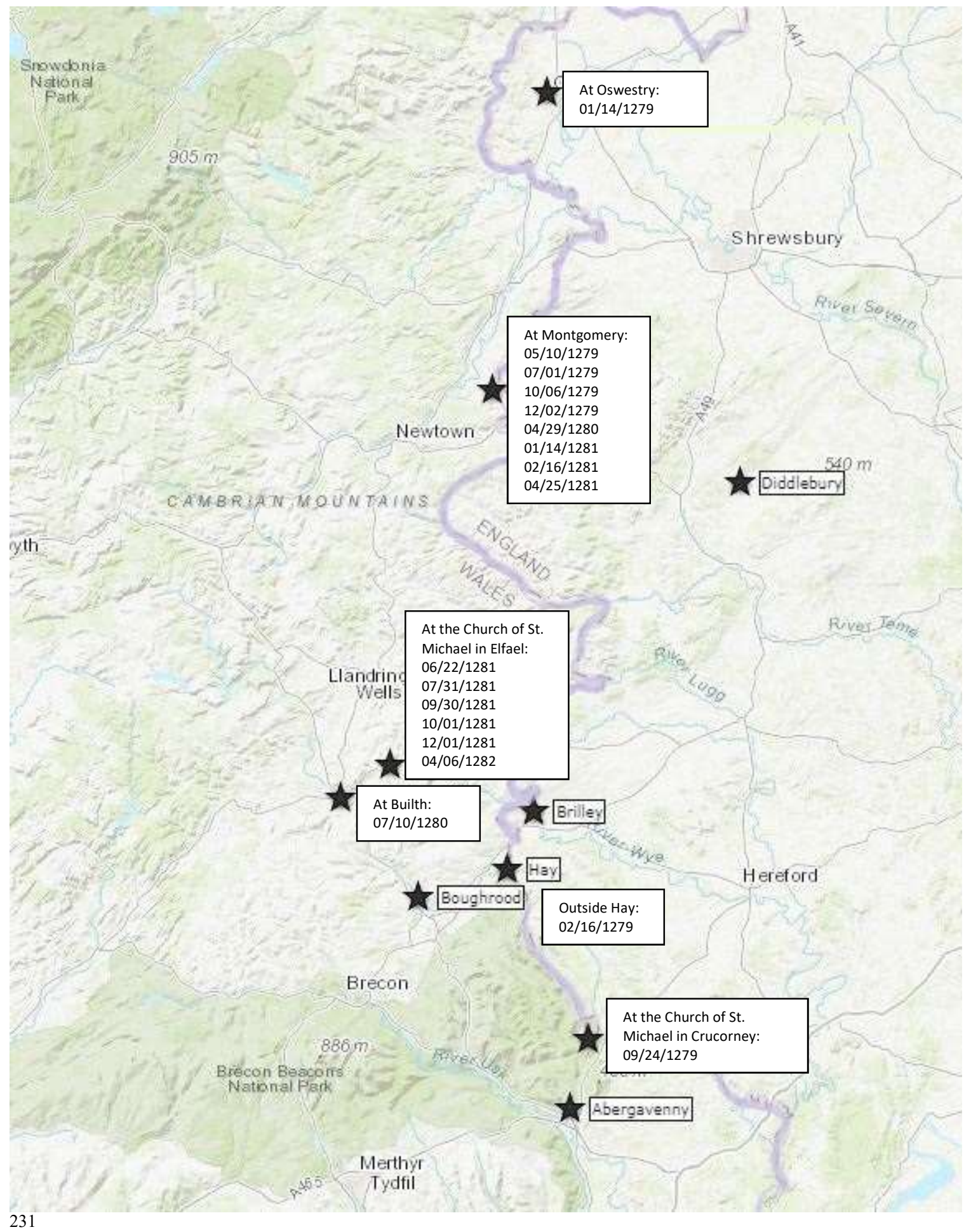

Fig 6.7

Court Appearances by John and Matilda Giffard in cases involving Morgan ap Maredudd, Rhys ap Maredudd, and Rhys Vychan, by location and date

${ }^{231}$ Map created in 2018 using a template provided by Gis Visualizer 
appurtenances, and the commote of Perfedd. They argued that the land was Matilda's by right because it had descended to her as inheritance from her father. Directed to come again before the court on the $5^{\text {th }}$ of February, the Giffards appeared and made a revised petition that dropped their claim to Llandovery Castle while still maintaining their claim to its vill. A second, and separate, claim was made for of Perfedd. Additionally, John and Matilda detailed their right to the whole of Hirfryn, which they currently held. The inclusion of Hirfryn was undoubtedly in response to a suit brought against them that same day by Rhys Vychan.

The Giffards' arguments for Matilda's right to Llandovery and Perfedd were based on the same claim: that Matilda's ancestor Walter de Clifford had been seised of these lands long ago, Llandovery since the reign of Henry III and Perfedd since Richard I had ruled. Through inheritance these lands had eventually passed into the right of Matilda as daughter and nearest heir. The circumstances of why Matilda was not in possession of Llandovery and Perfedd reflect the legal questions common to the tumultuous time of the Edwardian Conquest of Wales. They claimed that at some point during the reign of Henry III Walter de Clifford had bestowed custody of Llandovery on his bailiff, one Rhys Vychan, grandfather to the defendant. In subsequent years the bailiff has turned against the king's peace and supported Gwynedd during the war. Because of this he had kept control of Llandovery by force until he died. Llandovery then passed to his son Rhys Gryg and from him to the current Rhys Vychan. The Giffards also argued that many years past Walter de Clifford had been forcibly deprived of the commote of Perfedd by Rhys' ancestor, Hywel ap Maredudd. From Hywel the land had descended to Rhys 
Vychan by hereditary right, perhaps through his mother's family unless Hywel had been an ancestor of the Rhys' grandfather, Rhys Vychan. ${ }^{232}$

Rhys Vychan responded to these claims with arguments based on legal jurisdiction and form of tenure. He began by putting forward that he held Perfedd by right, according to Welsh law (secundum legem Wallensicam). Further, Edward I and Llywelyn, Prince of Wales, had made a compact that the law and custom of Wales would continue to run in lands that were considered to be, geographically, in Wales. ${ }^{233}$ This was the same argument he made in his suit initiated that same day against John and Matilda for the right to two parts of Hirfryn. The question of deciding these cases by English or Welsh law continued through the next three years as John and Matilda argued for Perfedd and Rhys Vychan sought Hirfryn. ${ }^{234}$

Rhys' initial response to the claim for Llandovery was that he did not hold the tenements in question. This was quickly countered by John and Matilda who argued that since Rhys held them in seisin of the king he was the tenant and thus could answer their suit. Abandoning that approach in December of 1279, Rhys continued to make arguments based on legal questions and technicalities. First, he maintained that if he had to answer the suit it should be under Welsh law and in a Welsh court because the lands in question

${ }^{232}$ Davies, The Welsh Assize Roll, 1277-1284: Assize Roll No. 1147. 268-270.

${ }^{233}$ Rhys said quod est condicionis Wallenscise unde cum dominus Rex sibi et aliis hominibus eiusdem condicionis concessit leges suas et consuetudines Wallenscicas per formam composicionis inter ipsum dominum regem Lewelinum principem Wallie firmatam petit quod secundum eandem legem possit ius suum defendere. The Welsh Assize Roll, 1277-1284: Assize Roll No. 1147. 269.

${ }^{234}$ Rhys continued his claim for "two parts of Hirfryn" into 1282 while Matilda and John shifted their claim for Hirfryin from "two parts" to "half the third part" in early 1281. The Welsh Assize Roll, 1277-1284: Assize Roll No. 1147. 321, 331 \& 338. 
were in Carmarthen on the western coastline of Wales. John and Matilda countered with the opposite; that they held the land as a Marcher Barony of the King in-chief and thus the case must be heard in the king's court under English common law (secundum legem commune Anglie). ${ }^{235}$ When the court ruled in July of 1280 that the case should indeed, as a Marcher Barony, be heard by the English legal system, he changed tactics one again. This time he noted that English law required that the case be brought by a king's writ, which the Giffards had not purchased. Here Rhys, having been thwarted in his pursuit of his claim under Welsh law, used an English legal technicality to continue to delay judgement. Because the same decision on jurisdiction had been made in the case for Perfedd a few months earlier, he used the same technicality in that case as well. ${ }^{236}$ Rhys later further delayed the cases for Llandovery and Hirfryn by making similar arguments, asking for a viewing of Llandovery by the men of Carmarthen and requesting that the court meet closer to that region so that locals could testify on his behalf. ${ }^{237}$

The debate over the primacy of Welsh legal jurisdiction or the rights of a Marcher Barony had been settled. Despite the compact of Edward I and Llywelyn, Prince of Wales and in contradiction to the 1284 Statute of Rhuddlan, Welsh law was superseded in Wales, at least for those who held their lands as a Barony of the king. These men and women were middling- to high-elites who held large tracts of land comprised of multiple parishes and dozens of hamlets, townships, and farms. John and Matilda Giffard held whole commotes and some, such as Gilbert de Clare the Earl of Gloucester, claimed

\footnotetext{
${ }^{235}$ See Appendix Seven for 12/02/1279.

${ }^{236}$ Davies, The Welsh Assize Roll, 1277-1284: Assize Roll No. 1147. 289-291.

${ }^{237}$ The Welsh Assize Roll, 1277-1284: Assize Roll No. 1147. 327-28.
} 
whole regions of Welsh territory. Their opponents in many cases were also elites, the former local and regional lords and kin-group leaders of Wales.

And yet, the cases heard by the Welsh assizes had bearing on the entirety of Wales. Landholders, and the particulars of how they held their lands, could have a large impact on the lives and livelihoods of their tenants and retainers. Some claims to Welsh law and custom were upheld, as in the decision that bastardy had no bearing on the claims of Gruffydd ab Einion and his brothers. Others used whatever bits of both legal systems they could to promote their rights, even if it meant a Welshman claiming that Welsh law did not apply to his case while his English opponents said it did. ${ }^{238}$ The suits detailed in the Welsh Assize Roll have provided, once again, evidence of intermarriage between the peoples of England and Wales and support for the argument that the Welsh understood the laws of Hywel Dda, often sought to have them applied in the same ways they had been used in their grandparents lifetime, and were willing to manipulate their suit or defense based on which legal procedures where most likely to support their side of the story.

${ }^{238}$ The Welsh Assize Roll, 1277-1284: Assize Roll No. 1147. 285-86. 


\section{CONCLUSION}

The stated purpose of this study was to explain how the choices of individuals and families in the Central March to choose whether to claim a English or Welsh identities reflected the legal and cultural realities of living in a multicultural region, rather than the prescribed generalized identity placed upon the Welsh as a people. Research of genealogical records has proven that many individuals living along the border zone married their sons and daughters to the sons and daughters of their neighbors, regardless of cultural heritage and identity. Legal proceedings also provide evidence that mixed English and Welsh marriages took place frequently throughout the thirteenth century. Finally, the legal records preserved in The Roll of the Shropshire Eyre of 1256 and the Welsh Assize Roll clearly demonstrate that many individuals considered themselves or their neighbors to be Welsh based on their names, their background, their presence in Wales, or their claims to Welsh legal jurisdiction.

Welsh identity, as detailed in religious and governmental correspondence and popular literature, such as the writings of Gerald of Wales, was that of a people who were wild and brash, craven and irresponsible. A people to be admired for their savage authenticity and despised for their lack of civilization. The descriptions Gerald gives of the Welsh match the prevailing humoral understanding of difference in the medieval world. The Welsh, in keeping with their mythological roots, were this way because of their hot Trojan blood. They were also a product of their home, a ragged land of mountain ridges and extreme valleys. It is not surprising that this land was the place the Pearl poet chose as the home of the Green Knight and the site of his final confrontation with Sir Gawain. ${ }^{239}$

${ }^{239}$ Sir Gawain sought his challenger in the Wirral, an area of northern Wales between Chester and Gwynedd. Marie Borroff, ed. Sir Gawain and the Green Knight, Patience, and Pearl: Verse Translation (New York: W. W. Norton \& Company, 2001). 
And yet, this idea of "wild Welshness" was in no way reflected by the ways in which Central Marcher communities and individuals interacted with each other. The intermarried, they opposed and supported each other in court, they went through the same natural tragedies and the same wars. Montgomery, an English outpost in the Welsh part of the March, was burned several times in the twelfth and thirteenth centuries, a tragedy endured by its entire population, both English and Welsh. Both populations shared the same lived experience.

So what, then, did it mean to be Welsh? As I have argued above, many Welsh individuals in the Central March appear to have embraced their heritage by naming their children Welsh names, even when they lived in Shropshire. But this cannot be taken as an absolute of solidarity with Wales itself - names could be chosen to signify many things, including friendship, and a fair number of individuals with English names had at least one parent with a Welsh name. The same was true of Welsh legal identity. The historically universal application of the law of Hywel Dda in Wales combined with the frequent requests for the application of Welsh law and custom in English courts provide ample evidence for the existence of a collective Welsh legal identity, one that could be claimed by all Welsh individuals no matter where they were. And still this legal identity was not monolithic; many people sought recourse to Welsh law when they believed it would be to their benefit. The suggestion by the representatives of Edward I that Welsh law be used in his court battle with Gruffydd ap Gwenwynwyn, last Prince of Powys, makes this clear. If Welsh law could help the King, he would use it. Gruffydd's response that Welsh law did not apply in this case was made for the same reasons. ${ }^{240}$

The result of frequent multicultural marriages was that by the thirteenth century many individuals could make valid claims to either legal system and traditional customs. Historical identity blurred to the point that, for some families, it was nearly indeterminate. Selfidentification as English or Welsh became a choice, not a cultural mandate. Some chose to fully

${ }^{240}$ Davies, The Welsh Assize Roll, 1277-1284: Assize Roll No. 1147. 285-286. 
embrace one history or the other, as if often seen in the United States today when second or third generation Americans begin to strongly self-identify with the culture and history of their grandparents in the "home country". One only has to look at the self-defined Irish American communities in places such as Boston to seen that this is true.

As England and Wales moved on into the fourteenth century, Wales now officially incollectived into the English nation, identities continued to form and diverge. Some families chose to identify with the status quo and embrace a new English identity that included the peoples of Wales. Others chose to emphasize the Welsh aspects of their heritage, sparking the formation of a sense of Welsh nationalism. It is no wonder a resurgence of Welsh vernacular literature took place at the same time.

In the wake of the Owain Glyn Dŵr Rebellion that began in 1400, the final push for Welsh independence until the nineteenth century, the English became concerned about a full Welsh revolt. In a panic Parliament, which had no Welsh members, passed extreme measures to suppress action by the people they termed to be Welsh. Their definition of a Welshman, as described in the Statutes of Wales, was a man who had "wholly been born in Wales and whose mother and father had been born there as well." ${ }^{241}$ Considering how many English and Welsh mixed marriages had been made in the last two centuries, this geographical definition of "Welshness" did not encompass the breadth of Welsh identity. Under this definition, these men could no-longer serve as officials and could not purchase land in England or in "English" towns in Wales. In a decision that had the potential for drastic consequences for the governance and economy of Welsh towns, no Welshman could be a burgess or "have franchise with the English burgesses." ${ }^{242}$ They could not hold castles, man town walls, or carry weapons outside their homes. Even travelling poets and troubadours were banned for purportedly spreading Glyn Dŵr

\footnotetext{
${ }^{241}$ Ivor Bowen, ed. The Statutes of Wales (London: T. Fisher Unwin, 1908). 34. ${ }^{242}$ The Statutes of Wales. 33-34.
} 
propaganda. ${ }^{243}$ And finally, Parliament announced that no dispute involving an English individual could be heard under any law but English Common law.

Welshmen were not the only ones facing restrictions. Parliament also issued limitations on Englishmen who had, or might in the future, marry Welshwomen. According to a statute issued in 1402, no Englishman with a Welsh wife could hold office or serve as a burgess if she had any connections to any individuals involved with the rebellion, or any Welsh wife married after the beginning of the rebellion, nor any Welsh wife in the future. These Welshwomen were considered to have too much potential influence over their husbands for them to be trustworthy. ${ }^{244}$

To my knowledge there has not been an extensive study on the impact of these legal changes on Welsh concepts of identity and personal choices of self-identification. In the future I plan to expand my own work by looking into the available fourteenth- and fifteenth-century records and once again asking the questions: "Who is a Welshperson" and "How did s/he interpret and act upon self-identification."

${ }^{243}$ As Griffiths points out, this ban was never effectively put in place. Ralph Alan Griffiths, "Owain Glyndwr and the Seige of Coity Castle, 1404-1405," Morgannwg: Transactions of the Glamorgan Local History Society 45 (2001). 10.

${ }^{244}$ Bowen, The Statutes of Wales. 34-36. 


\section{APPENDIX ONE \\ FAMILY/KIN-GROUP/LOCATION DATABASE FROM WELSH GENEALOGIES: AD $300-1400^{233}$}

Appendix One is a collection of data gleaned from Peter Bartrum's Welsh Genealogies:

$A D$ 300-1400. This collection fills 8 volumes and its entirety is not included here.

Instead, I have chosen to limit my discussion and analysis to the families and kin-groups that were located in either Montgomeryshire or Shropshire. Below Welsh individuals are identified by name, family or kin-group, and location by both parish and cantref. The following data has proven to be a useful reference when determining family connections, as can be seen in Chapter Three.

A brief note on generation notations - Bartrum has chosen to group individuals by generation, especially when specific dates for birth and death are unknown. The listed generations, as (1), roughly correspond to the following dates:

\begin{tabular}{|c|c|}
\hline$(0)=1000$ & $(8)=1270$ \\
\hline$(1)=1030$ & $(9)=1300$ \\
\hline$(2)=1070$ & $(10)=1330$ \\
\hline$(3)=1100$ & $(11)=1370$ \\
\hline$(4)=1130$ & $(12)=1400$ \\
\hline$(5)=1170$ & $(13)=1430$ \\
\hline$(6)=1200$ & $(14)=1470$ \\
\hline$(7)=1230$ & $(15)=1500$ \\
\hline
\end{tabular}

${ }^{233}$ Bartrum, Welsh Genealogies: Ad 300-1400. 


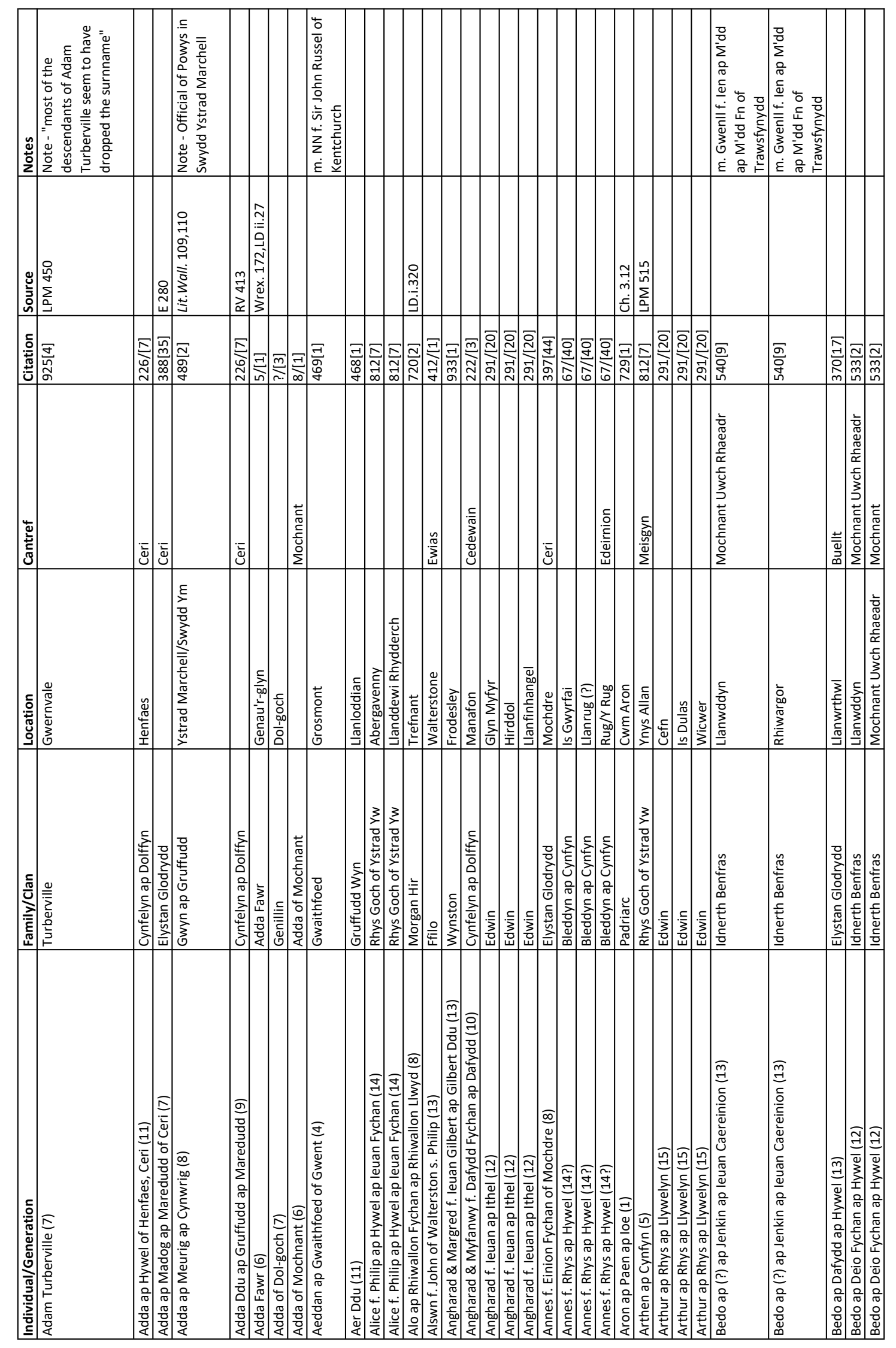



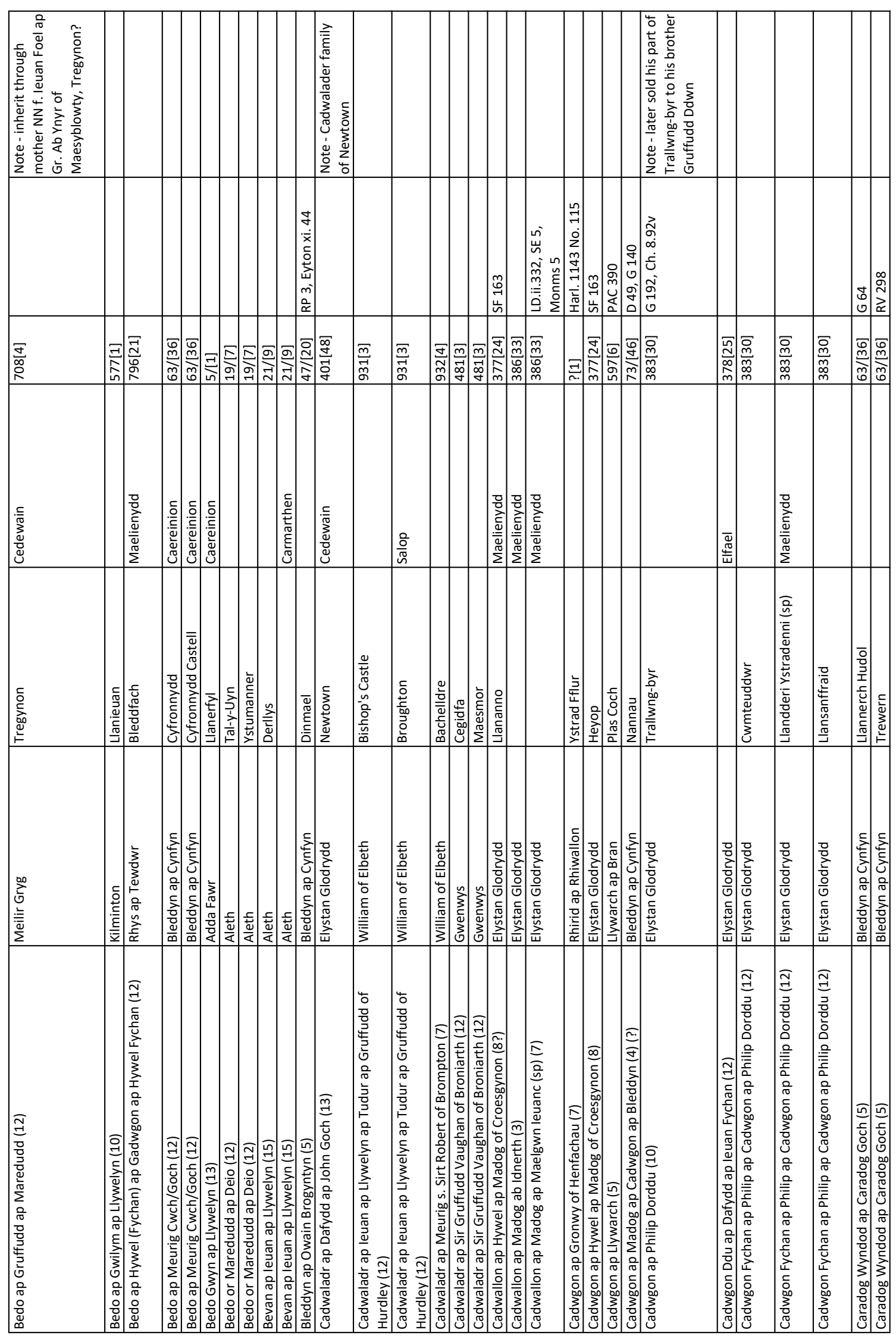


\begin{tabular}{|c|c|c|c|c|c|c|c|c|c|c|c|c|c|c|c|c|}
\hline 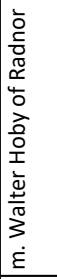 & 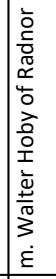 & & 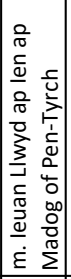 & & & & 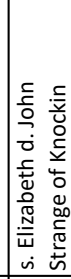 & & & & & & & & & \\
\hline & & & & 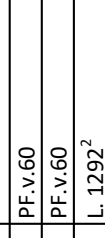 & 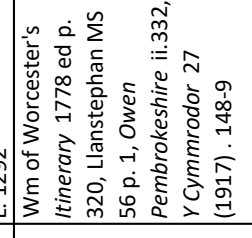 & 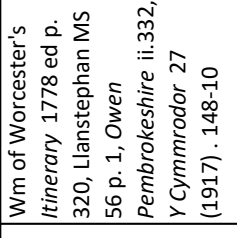 & 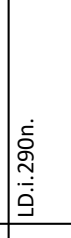 & $\mid \begin{array}{l}\overrightarrow{0} \\
\vec{a} \\
\vec{a}\end{array}$ & & 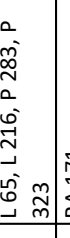 & 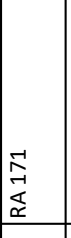 & 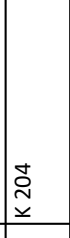 & & & & \\
\hline 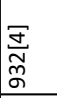 & 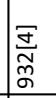 & & 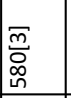 & 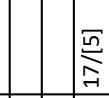 & 层 & Е & 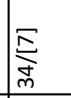 & 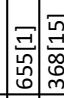 & 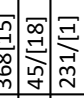 & $\underset{\vec{D}}{E}$ & 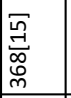 & 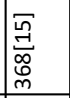 & 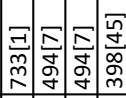 & 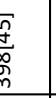 & $\mid \begin{array}{c}\Xi \\
0 \\
0 \\
o \\
j\end{array}$ & 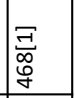 \\
\hline & & 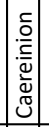 & & | & 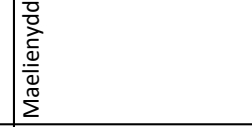 & 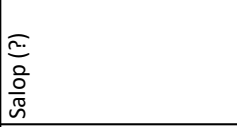 & 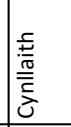 & & & 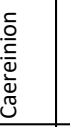 & & & & & 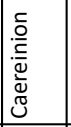 & \\
\hline 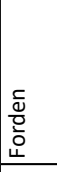 & \begin{tabular}{|l}
$\frac{1}{3}$ \\
$\frac{3}{0}$ \\
$\frac{0}{0}$ \\
\end{tabular} & & 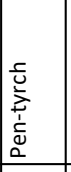 & 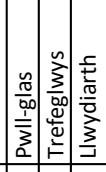 & 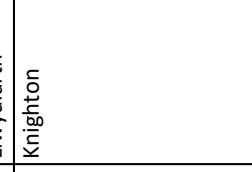 & 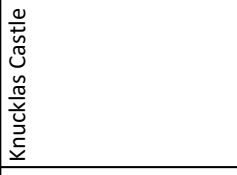 & 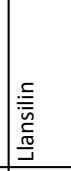 & 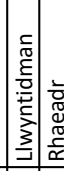 & 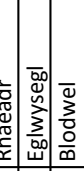 & & 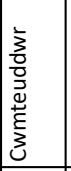 & 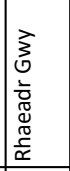 & 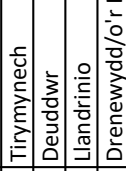 & 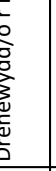 & 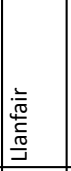 & 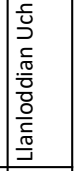 \\
\hline 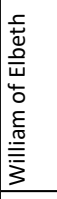 & 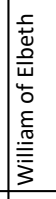 & & 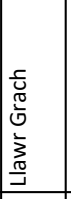 & 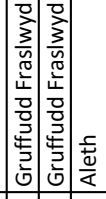 & 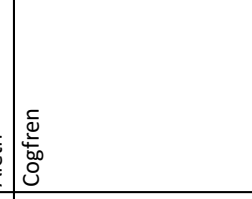 & 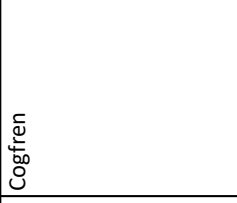 & 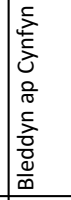 & 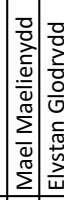 & 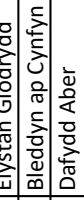 & 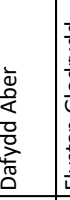 & 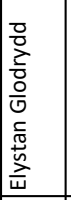 & 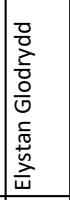 & 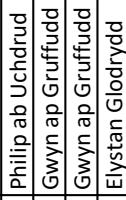 & 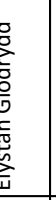 & 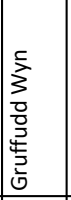 & 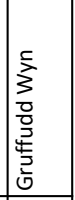 \\
\hline 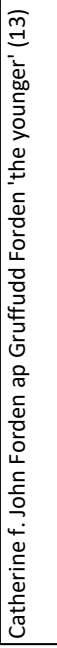 & 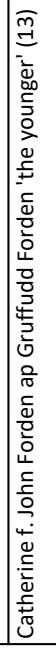 & 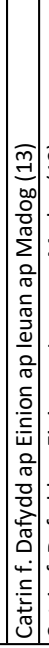 & 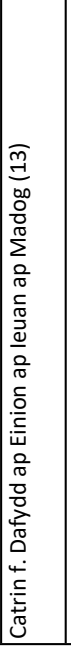 & 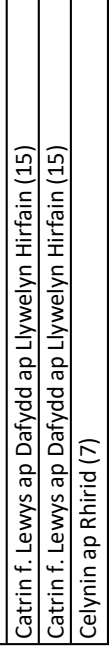 & 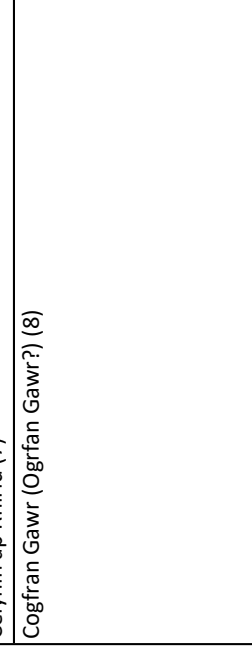 & 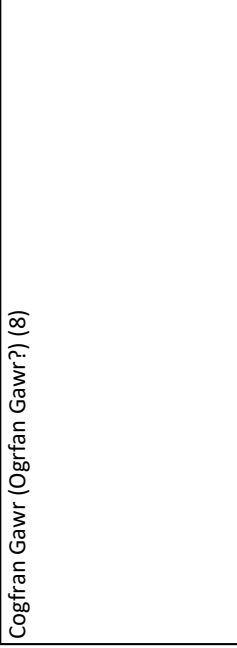 & 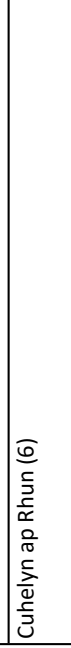 & 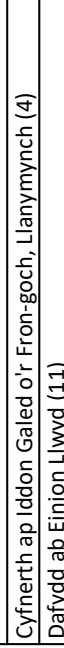 & 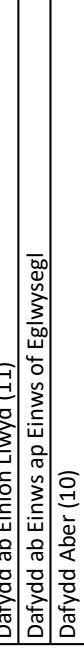 & 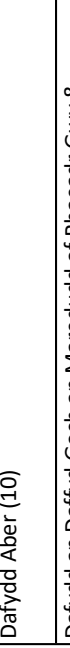 & 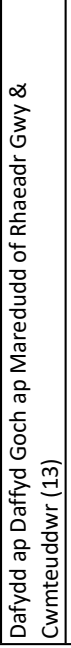 & 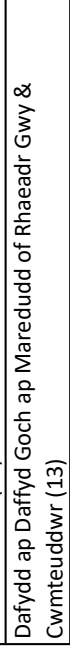 & 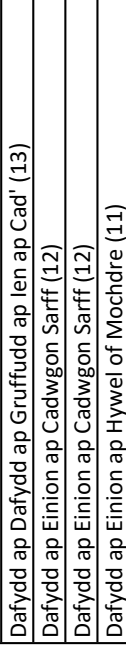 & 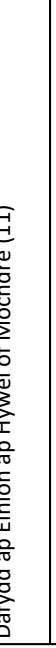 & 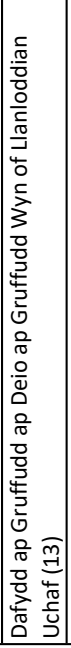 & 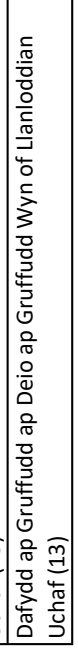 \\
\hline
\end{tabular}




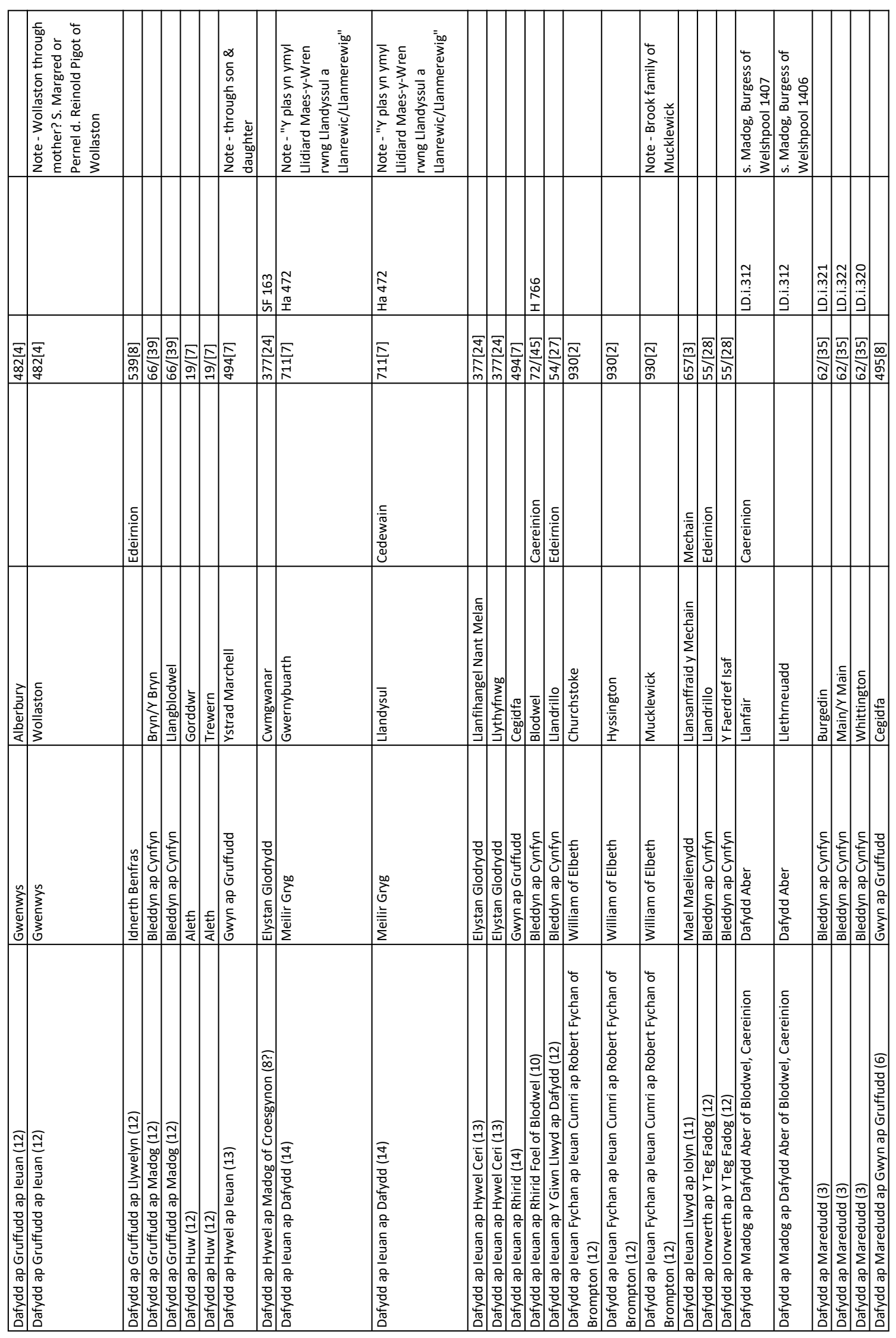




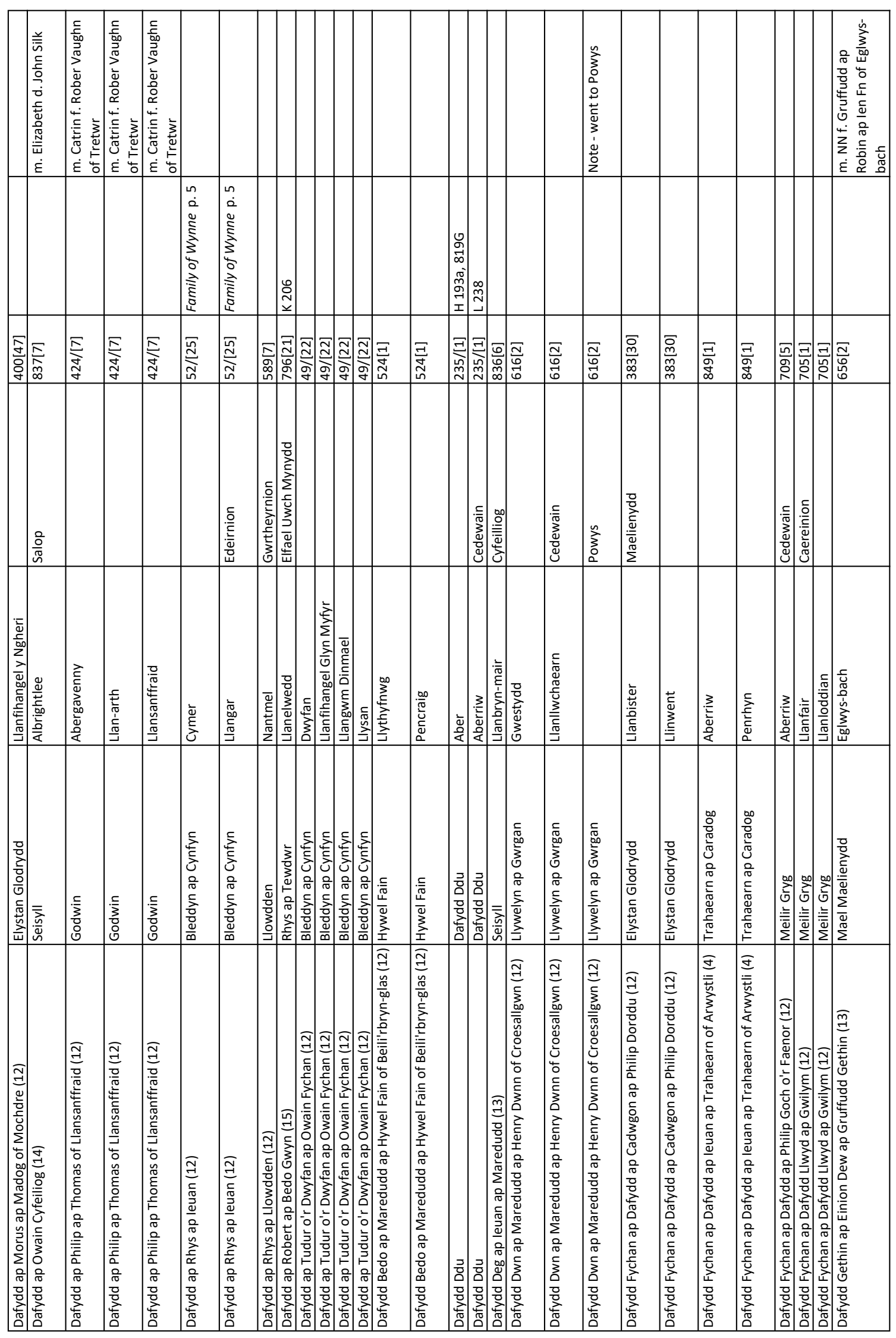




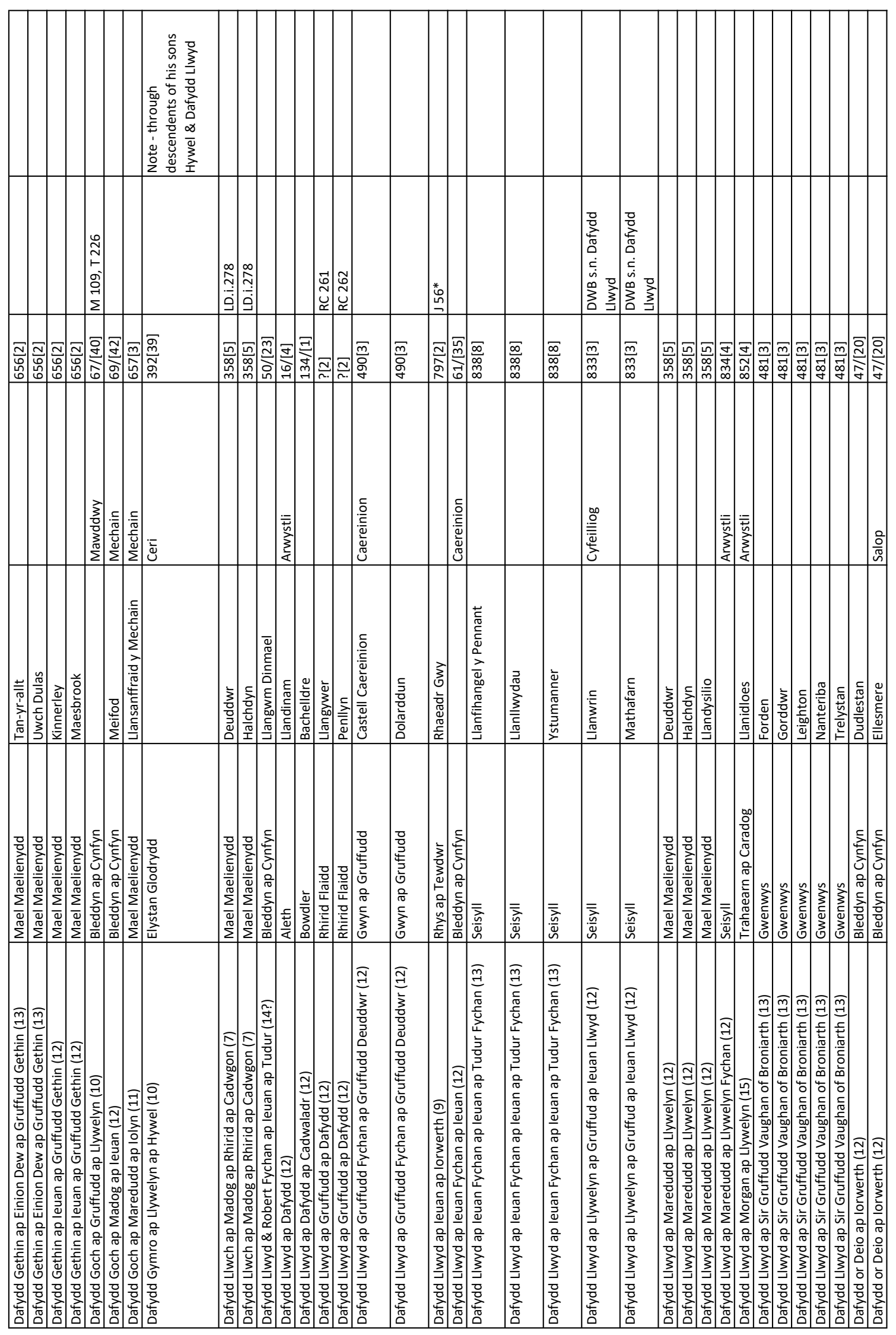




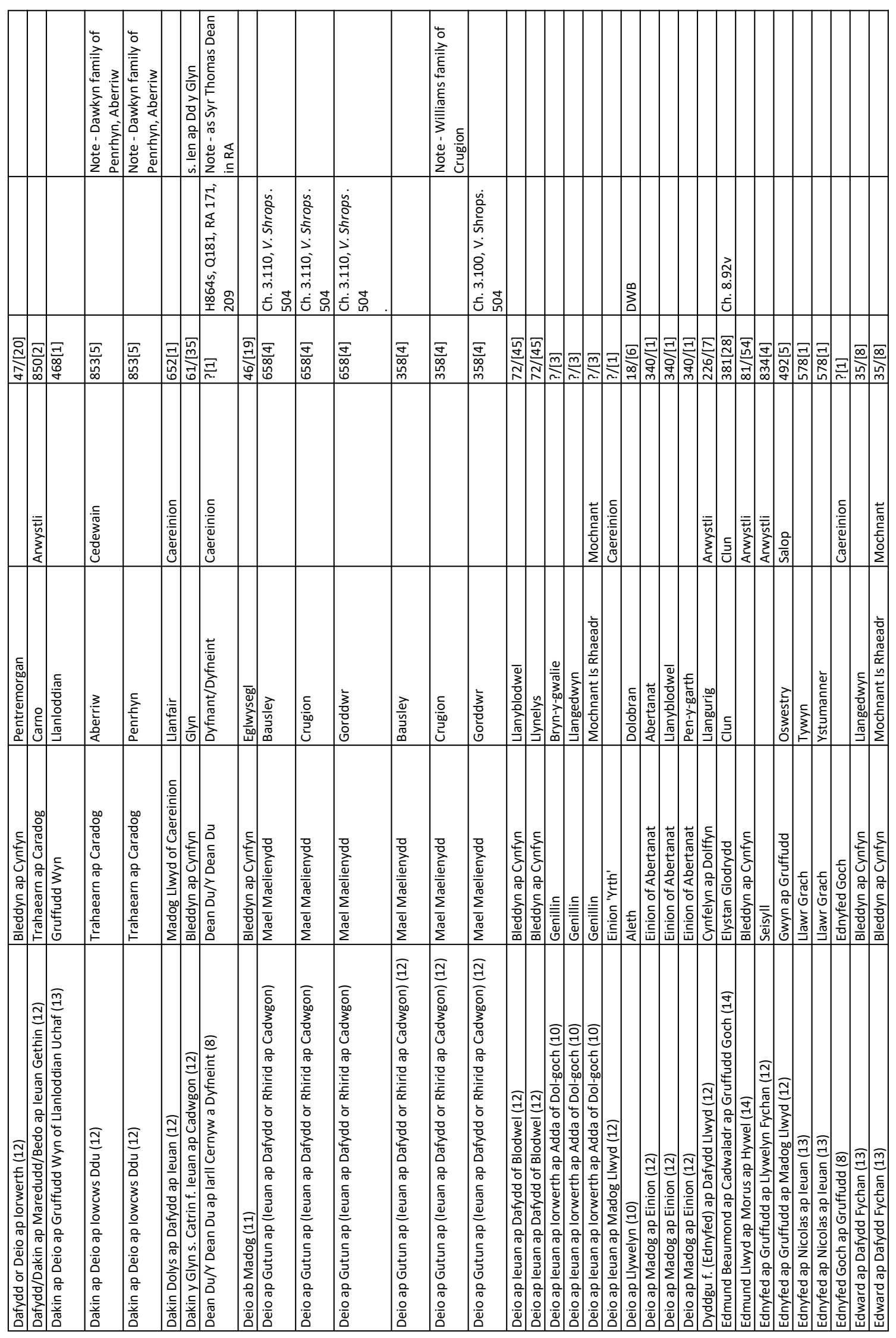




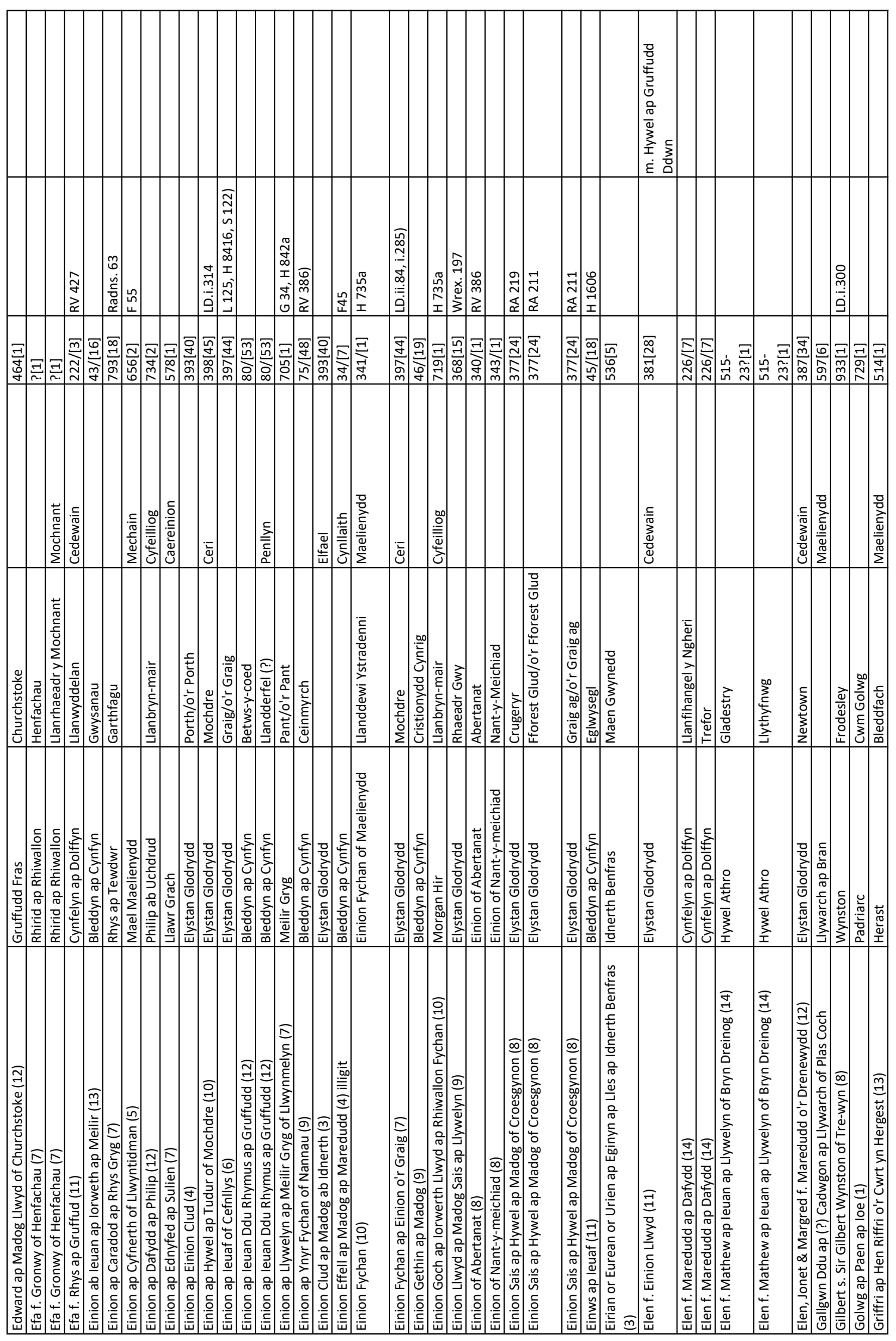




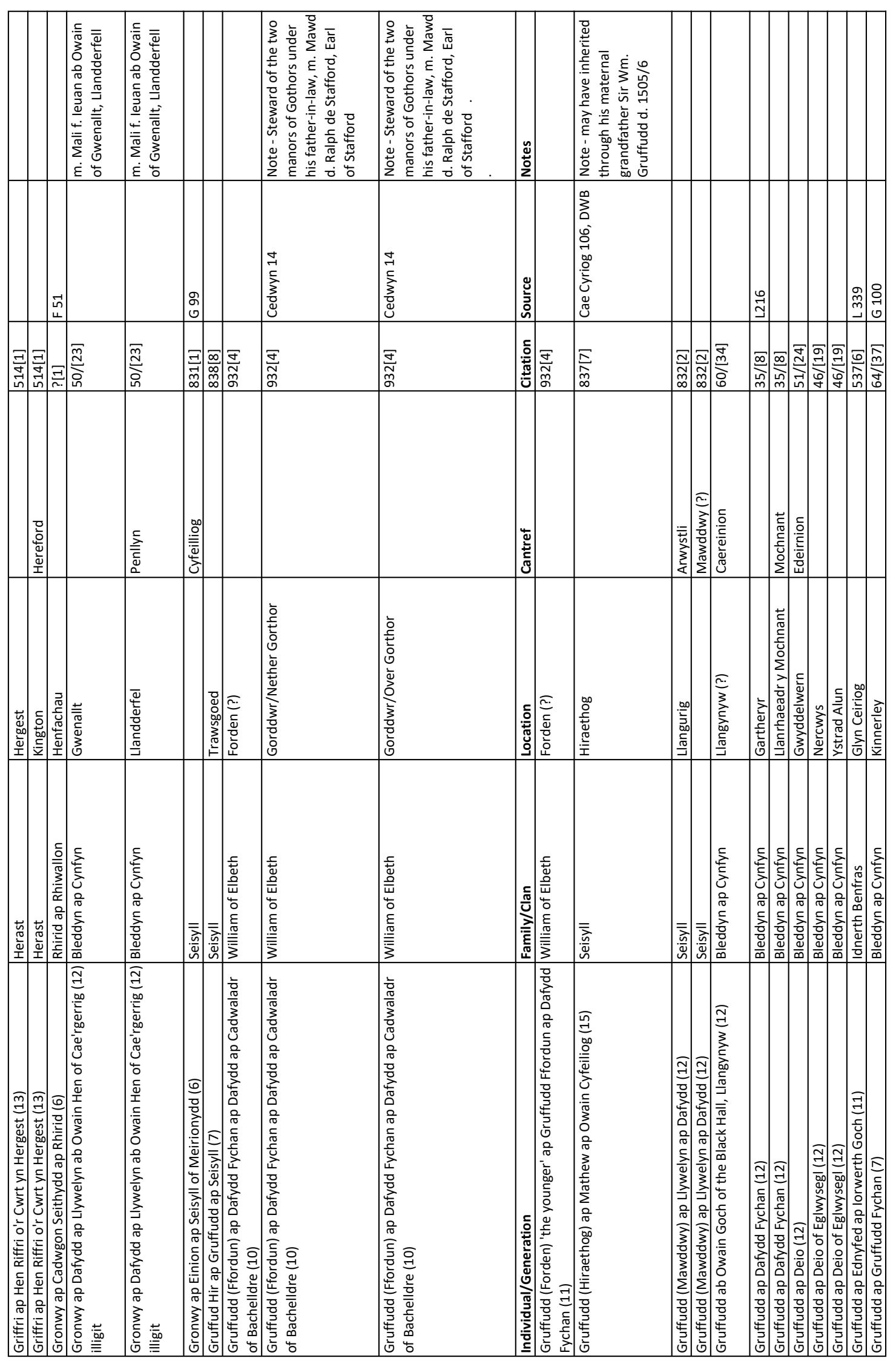




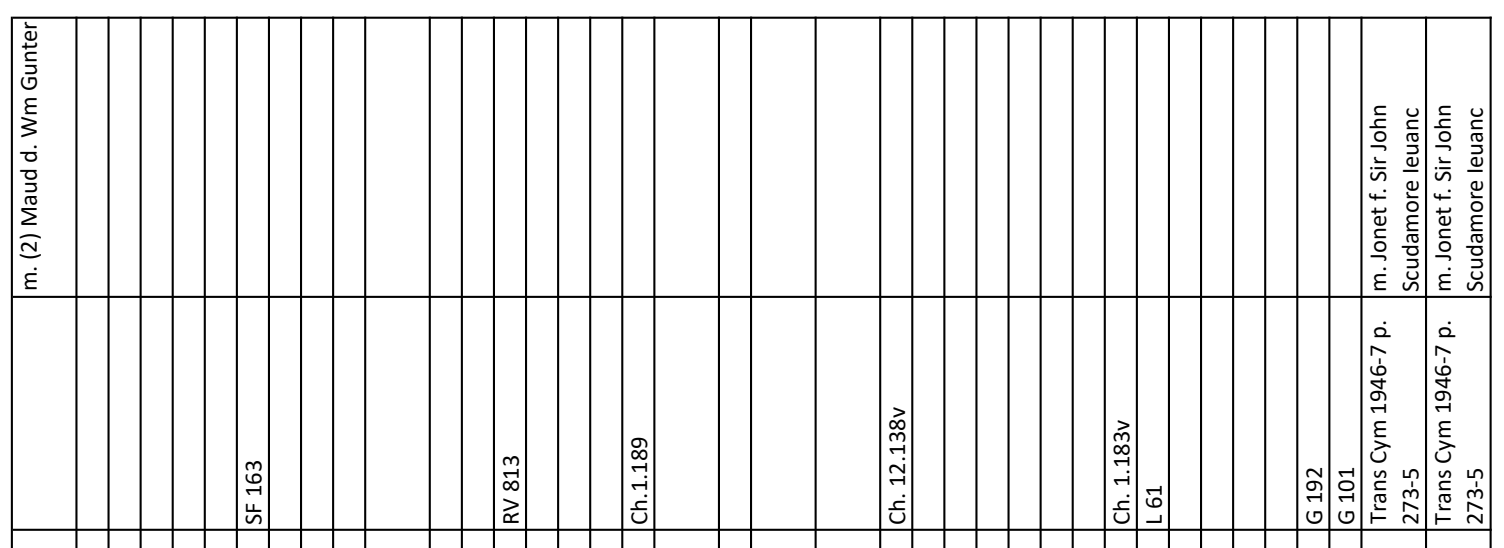

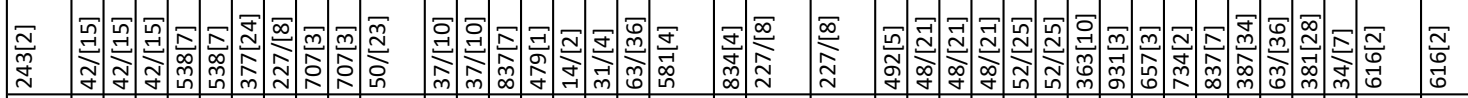

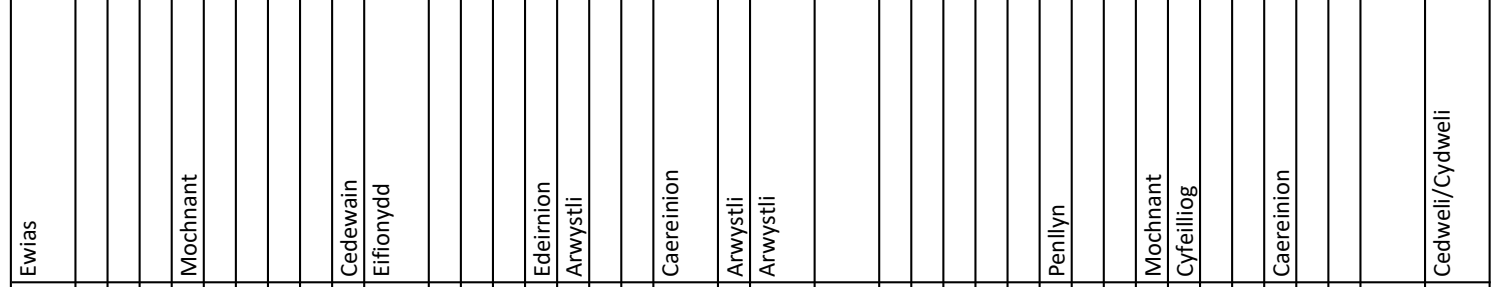

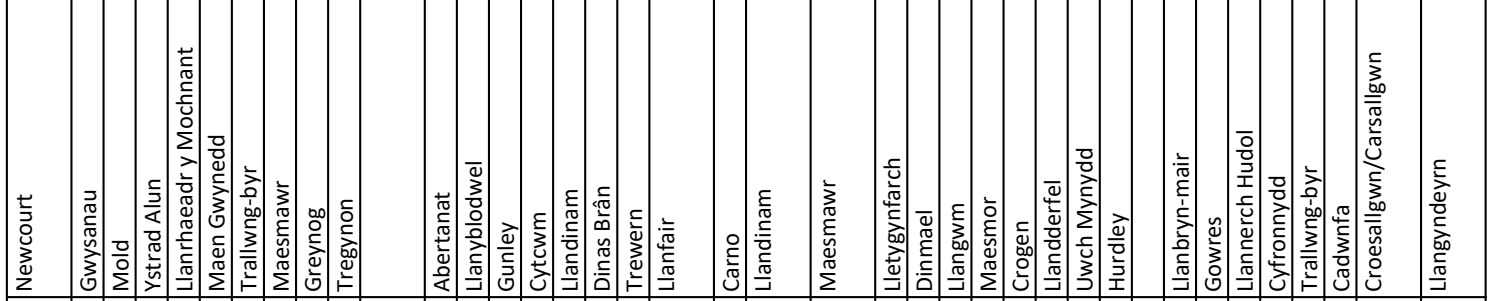

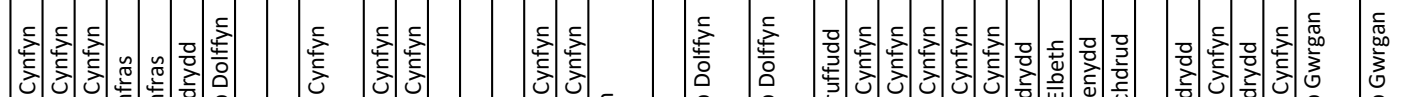

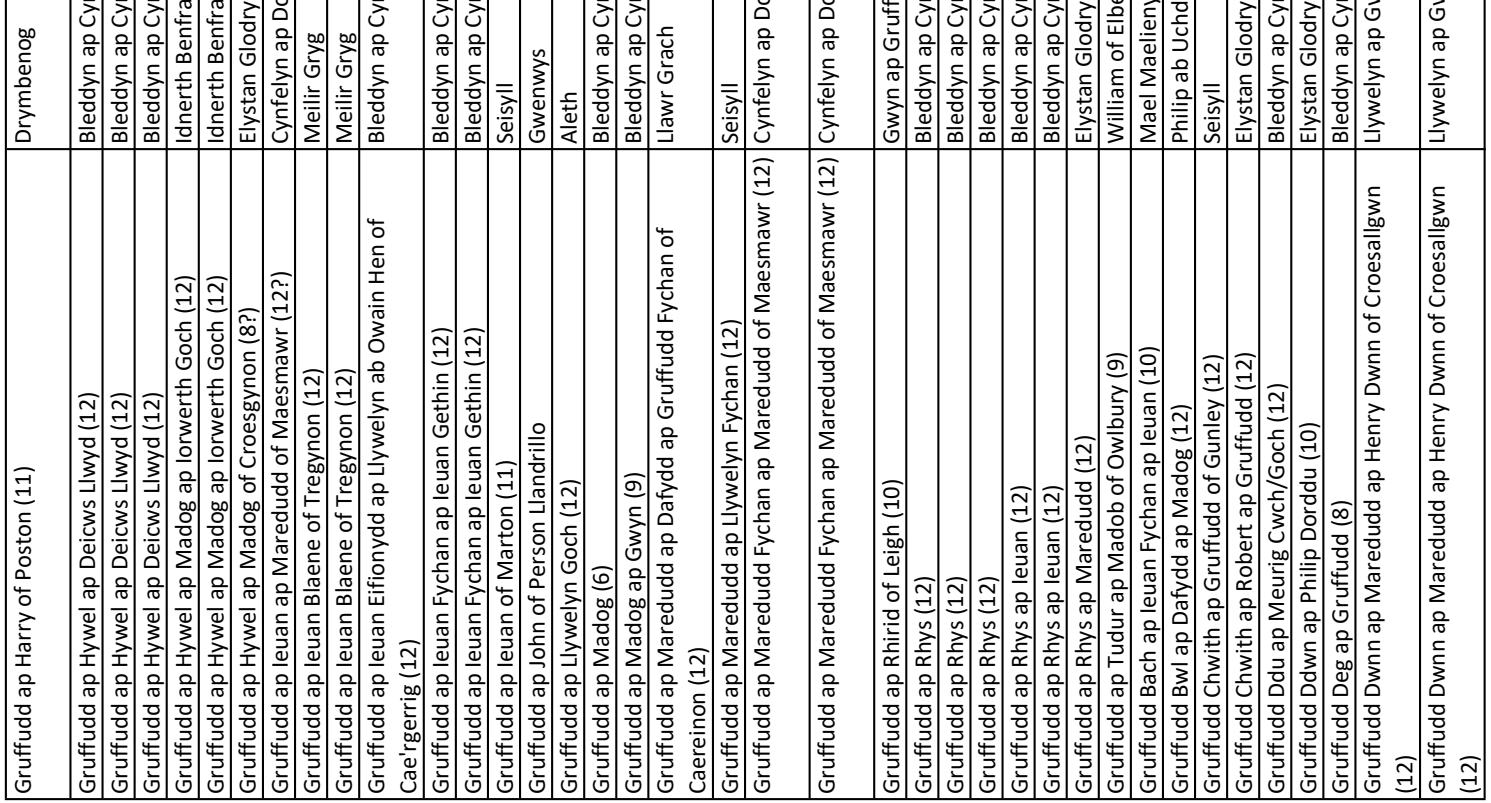




\begin{tabular}{|c|c|c|c|c|c|c|c|c|c|c|c|c|c|}
\hline & 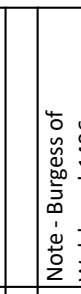 & & 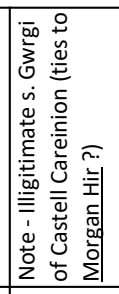 & 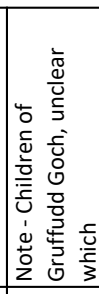 & 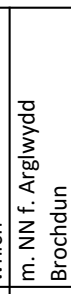 & 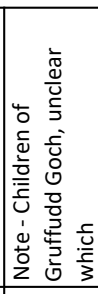 & & 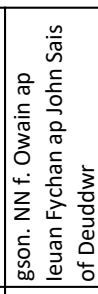 & 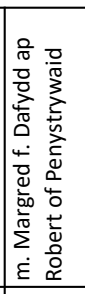 & & 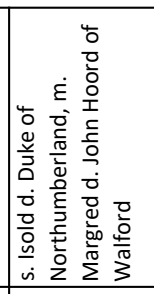 & 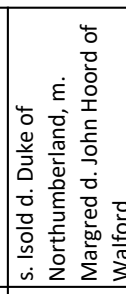 & \\
\hline 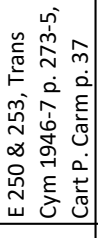 & 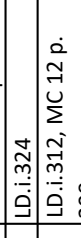 & 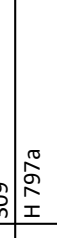 & 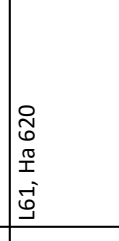 & & 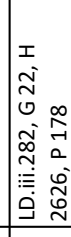 & & & & & & 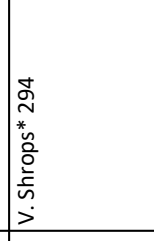 & 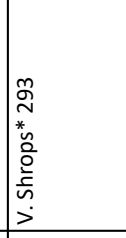 & \\
\hline \begin{tabular}{|l}
$\bar{\lambda}$ \\
$\substack{0 \\
0 \\
0}$ \\
\end{tabular} & 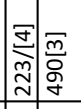 & 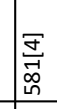 & 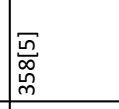 & 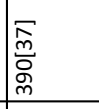 & 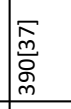 & 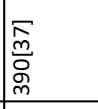 & 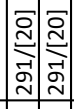 & 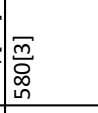 & 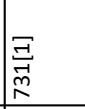 & 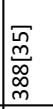 & 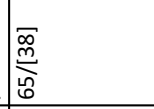 & 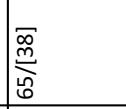 & 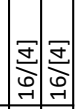 \\
\hline & 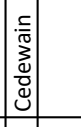 & 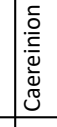 & & & נَّ & & & 嵩 & 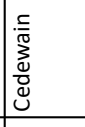 & $\begin{array}{l}\frac{0}{0} \\
\frac{0}{n} \\
\end{array}$ & 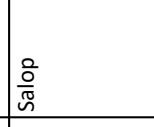 & & \begin{tabular}{|c|} 
\\
\\
$\bar{n}$ \\
\end{tabular} \\
\hline 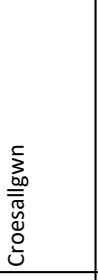 & 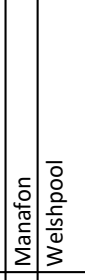 & & \begin{tabular}{|l|}
$\frac{3}{3}$ \\
$\frac{0}{0}$ \\
$\bar{z}$ \\
0 \\
\end{tabular} & 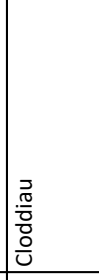 & 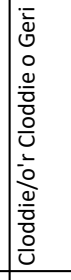 & 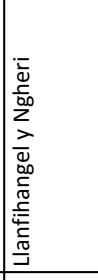 & 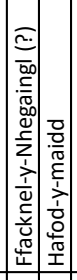 & 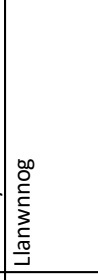 & 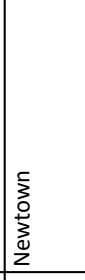 & 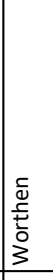 & 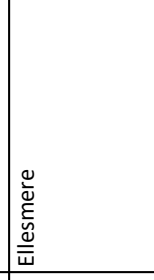 & 总 & 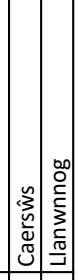 \\
\hline 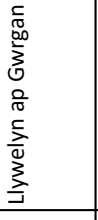 & 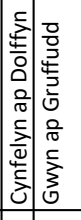 & 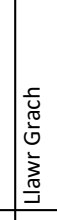 & 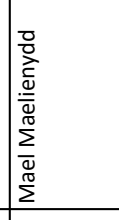 & 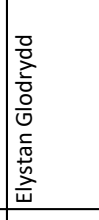 & 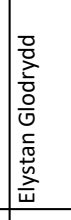 & 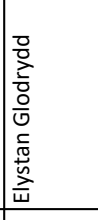 & 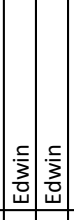 & 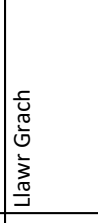 & 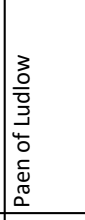 & 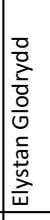 & 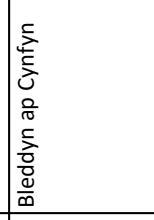 & 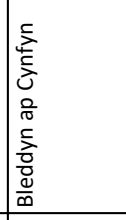 & 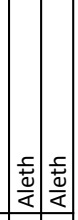 \\
\hline 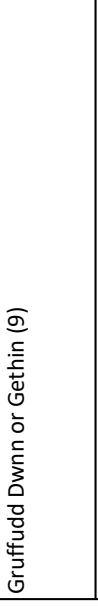 & 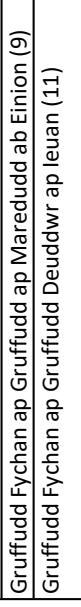 & 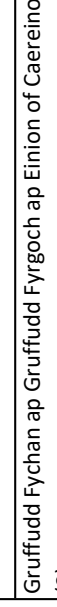 & 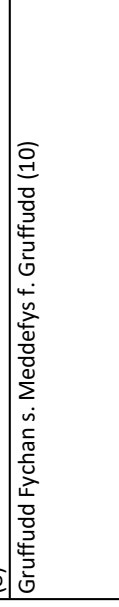 & 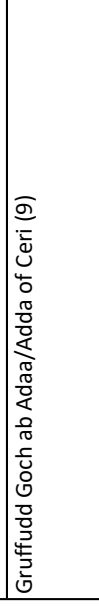 & 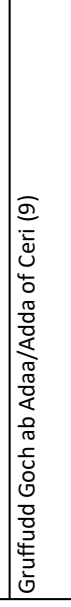 & 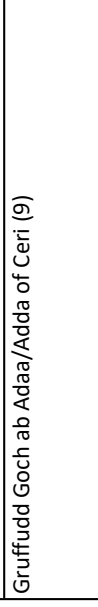 & 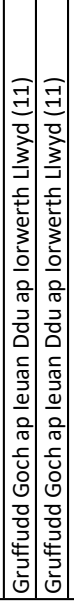 & 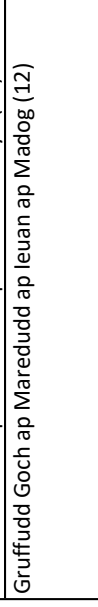 & 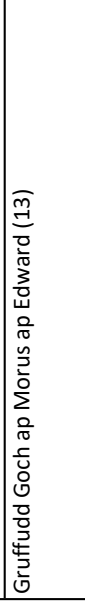 & 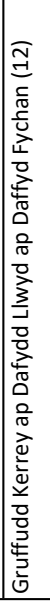 & 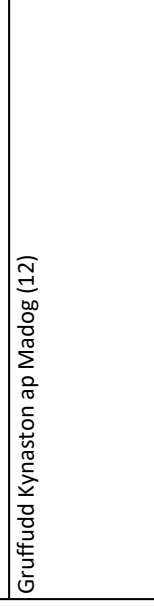 & 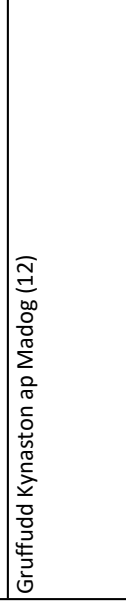 & 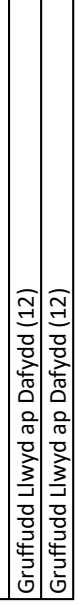 \\
\hline
\end{tabular}









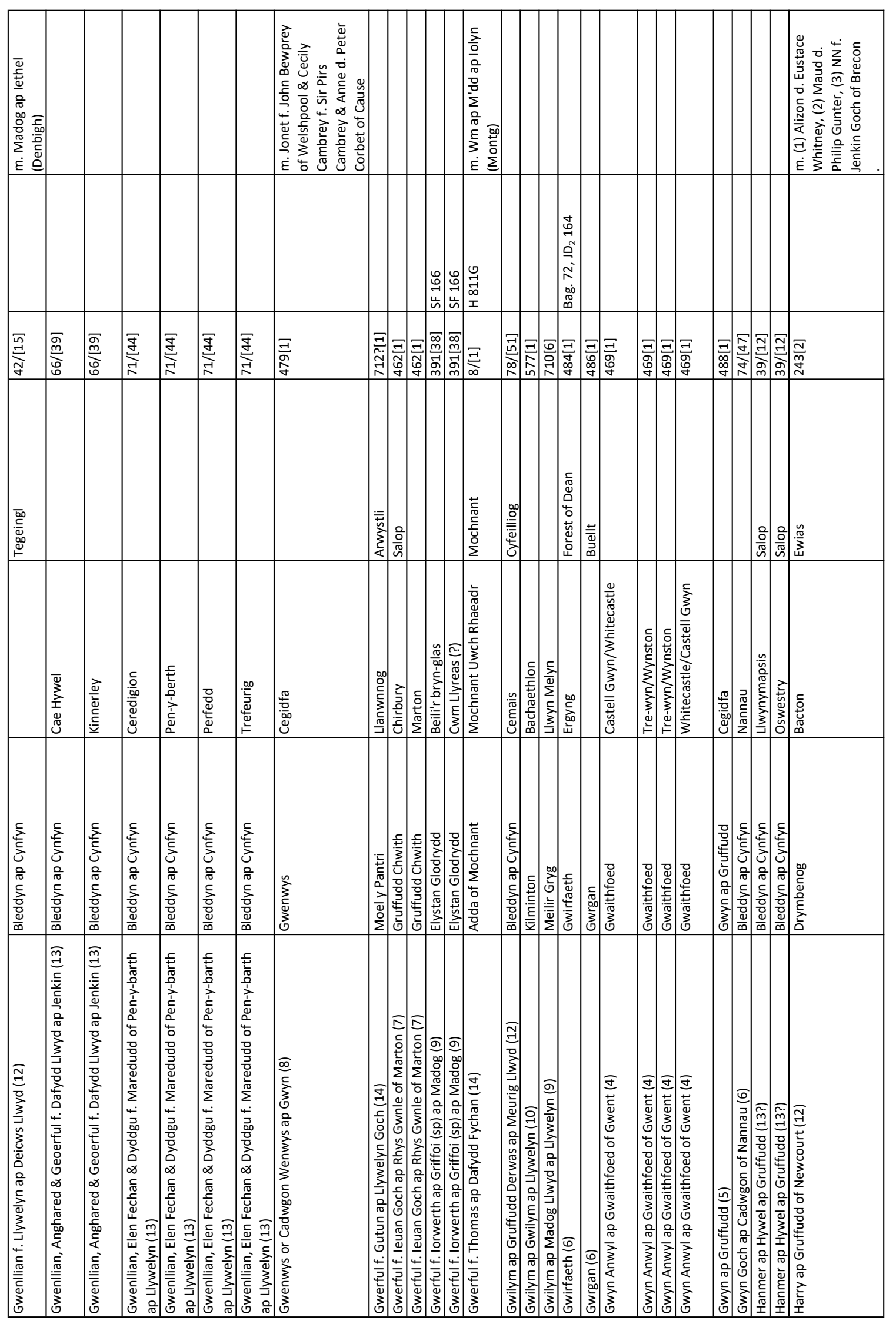




\begin{tabular}{|c|c|c|c|c|c|c|c|c|c|c|c|}
\hline 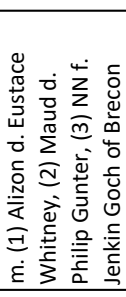 & 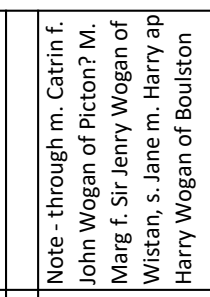 & & & & 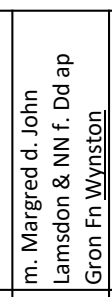 & 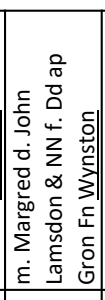 & 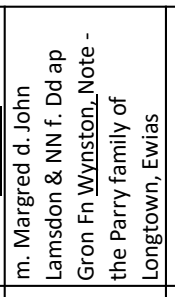 & & 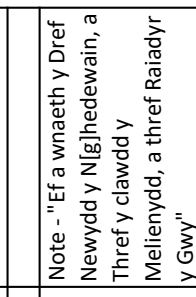 & 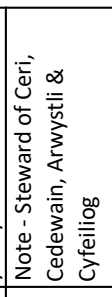 & 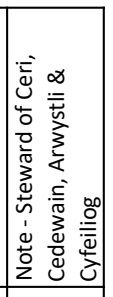 \\
\hline & 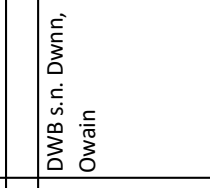 & & & $\mid \begin{array}{l}\vec{a} \\
\vec{f}\end{array}$ & & & 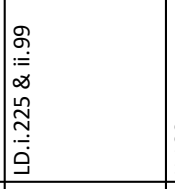 & $\begin{array}{l}\tilde{y} \\
\vec{a} \\
\underline{\underline{n}}\end{array}$ & 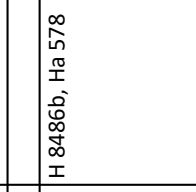 & $\begin{array}{l}\infty \\
m \\
\\
\bar{\Xi} \\
\end{array}$ & 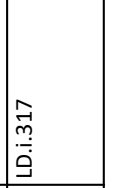 \\
\hline$\underset{\substack{\mathbb{N} \\
\stackrel{d}{d}}}{ }$ & 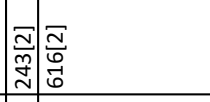 & \begin{tabular}{|l} 
\\
\\
$\vdots$ \\
$\vdots$ \\
\end{tabular} & 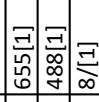 & 今 & 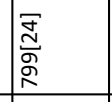 & 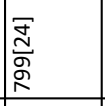 & 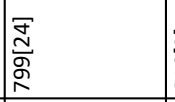 & \begin{tabular}{|l}
$\bar{T}$ \\
$\underline{0}$ \\
0 \\
0 \\
\end{tabular} & $\underset{\infty}{\mathrm{I}} \underset{\mathrm{N}}{\mathrm{F}}$ & 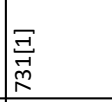 & 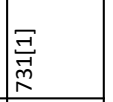 \\
\hline 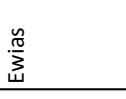 & 紊 & 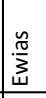 & & & 耪 & & 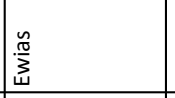 & & \begin{tabular}{|c|}
$\frac{0}{0}$ \\
\\
\end{tabular} & 离 & 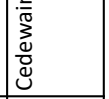 \\
\hline 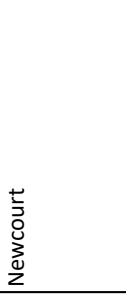 & 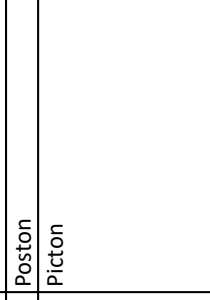 & 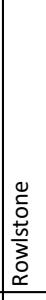 & 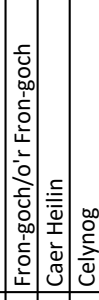 & 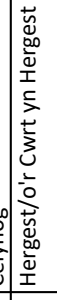 & \begin{tabular}{|l}
$\frac{.}{0}$ \\
$\frac{\partial}{U}$ \\
\end{tabular} & 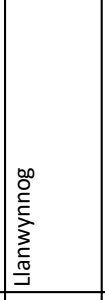 & 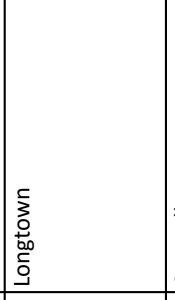 & 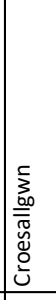 & 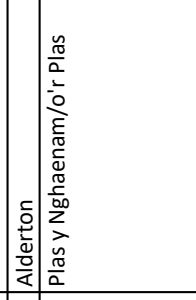 & & \\
\hline 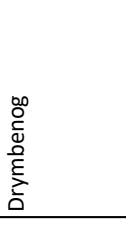 & 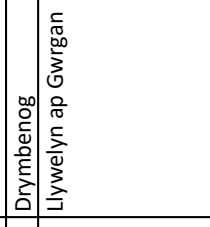 & 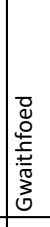 & 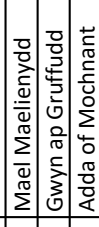 & 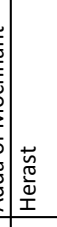 & 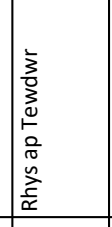 & 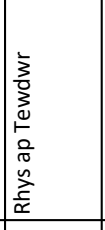 & 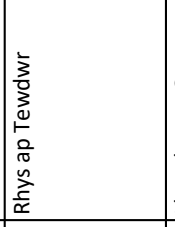 & 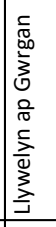 & 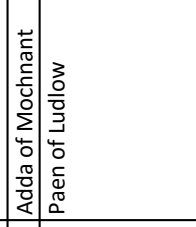 & 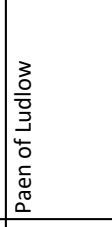 & 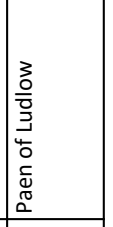 \\
\hline 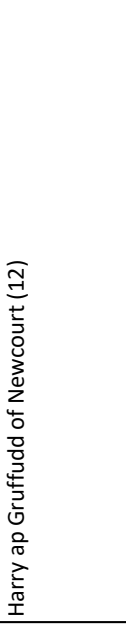 & 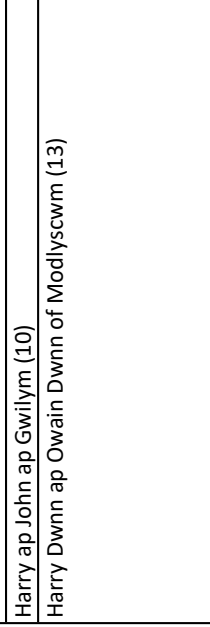 & 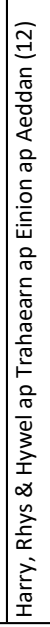 & 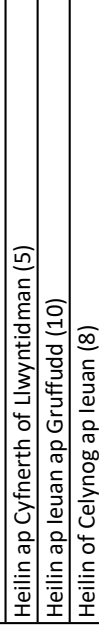 & 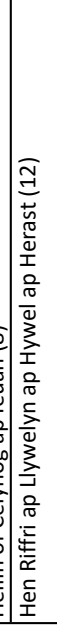 & 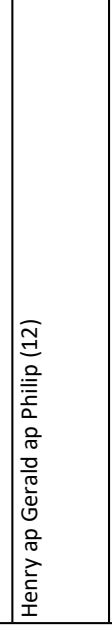 & 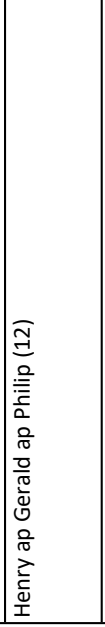 & 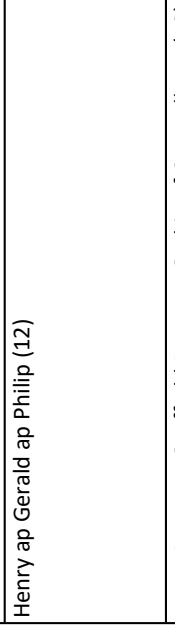 & 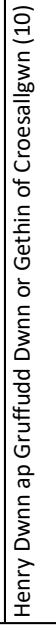 & 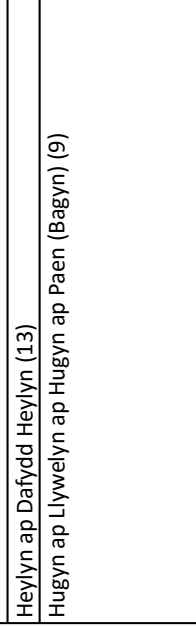 & 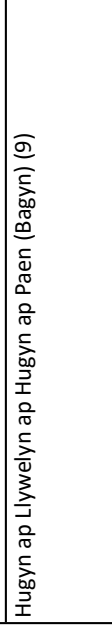 & 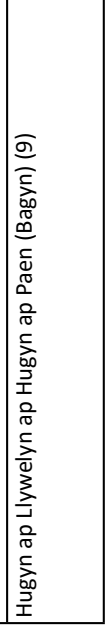 \\
\hline
\end{tabular}




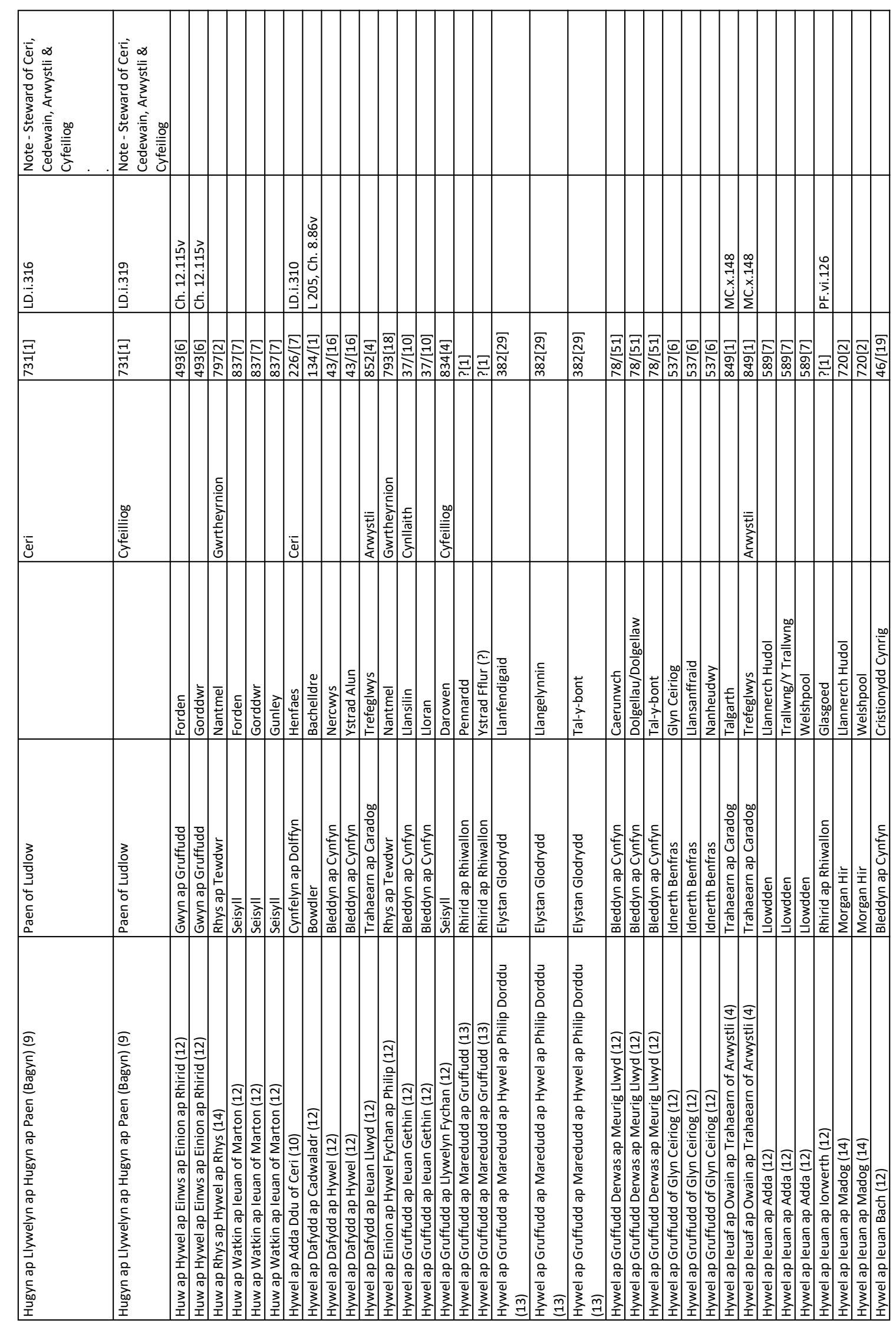




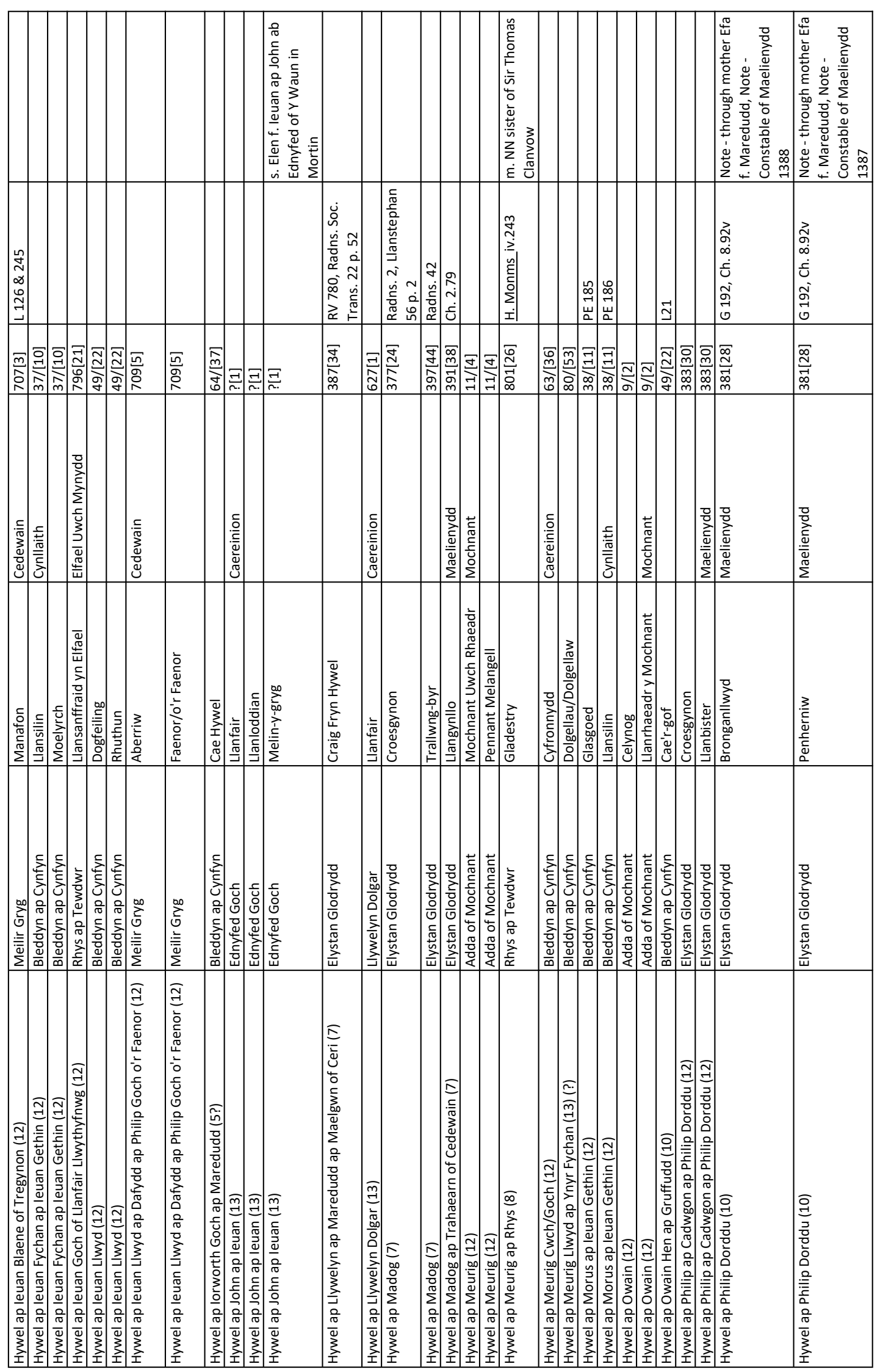




\begin{tabular}{|c|c|c|c|c|c|c|c|c|c|c|c|c|c|c|}
\hline & 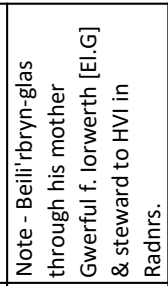 & 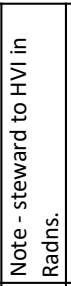 & 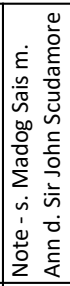 & & & 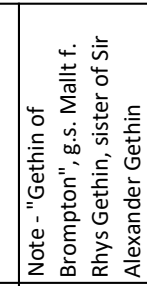 & & 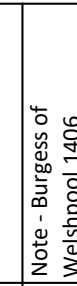 & & 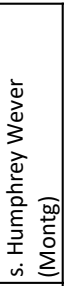 & 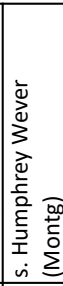 & 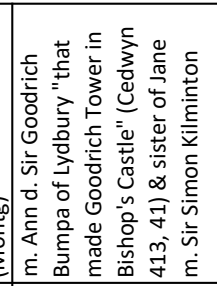 & 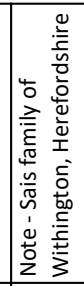 & \\
\hline 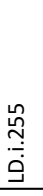 & 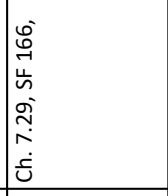 & 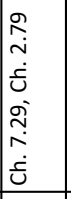 & 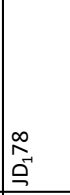 & & & & & 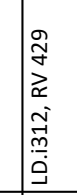 & 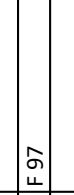 & & & 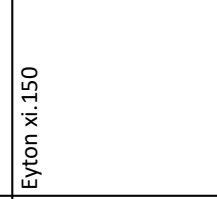 & & 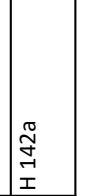 \\
\hline 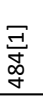 & 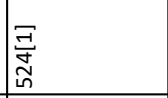 & \begin{tabular}{|l} 
E \\
离 \\
In
\end{tabular} & 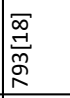 & 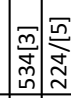 & 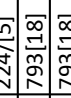 & 象 & 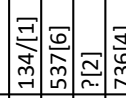 & 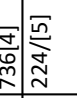 & 矛 & $\underset{\partial}{\partial}$ & $\underset{\partial}{5}$ & F & 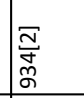 & 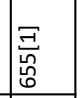 \\
\hline 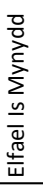 & & 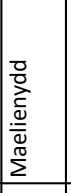 & & 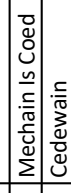 & & & 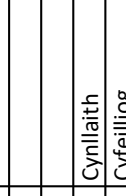 & 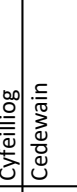 & 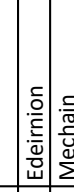 & 竞 & & & 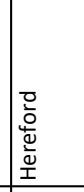 & \\
\hline 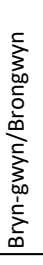 & 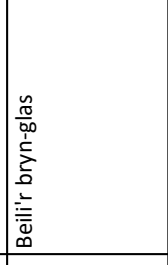 & 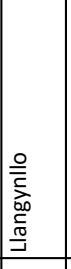 & 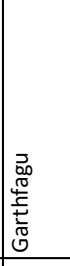 & 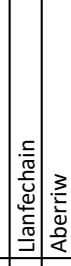 & 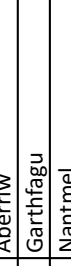 & 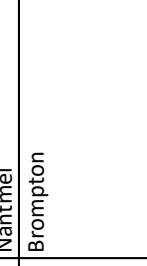 & 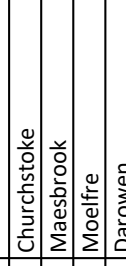 & 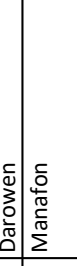 & 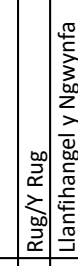 & 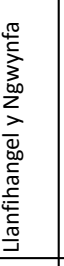 & 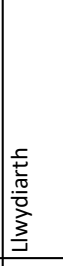 & 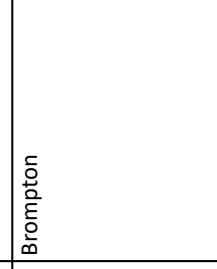 & 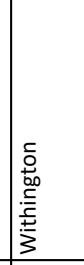 & 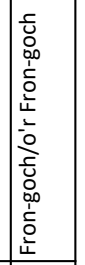 \\
\hline 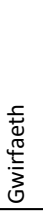 & 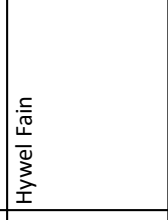 & 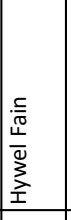 & 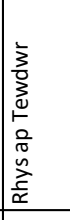 & 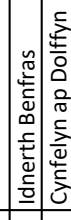 & 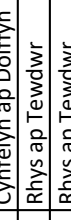 & 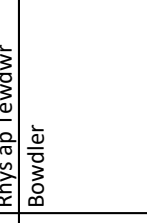 & 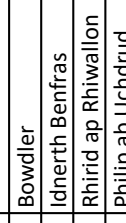 & 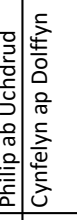 & 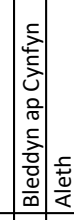 & 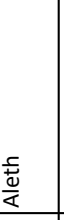 & $\frac{\bar{E}}{\frac{\mathrm{E}}{\alpha}}$ & 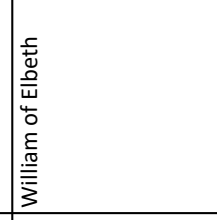 & 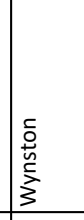 & 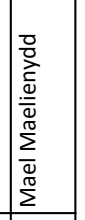 \\
\hline 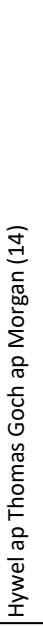 & 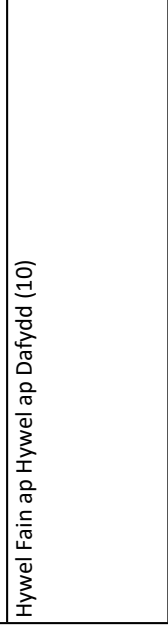 & 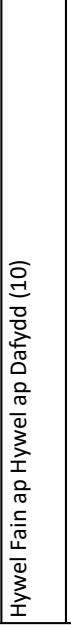 & 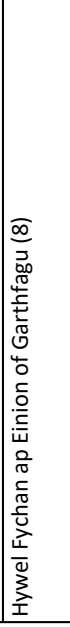 & 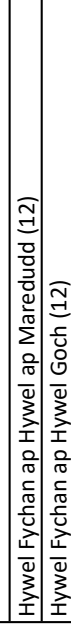 & 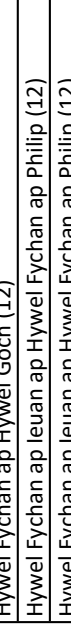 & 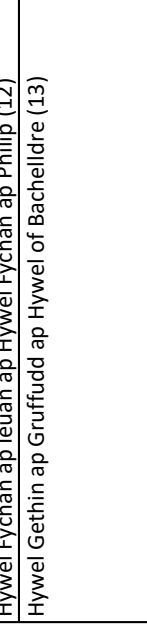 & 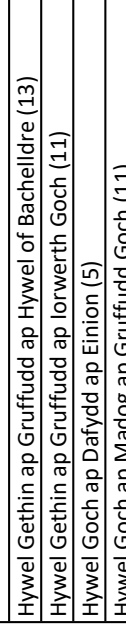 & 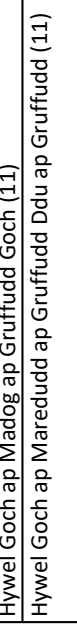 & 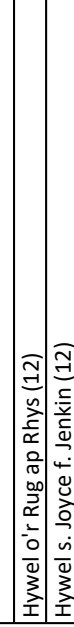 & 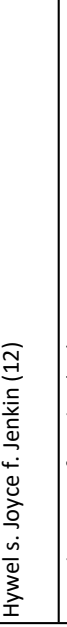 & 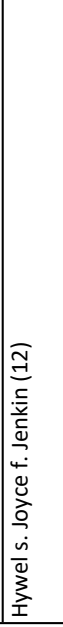 & 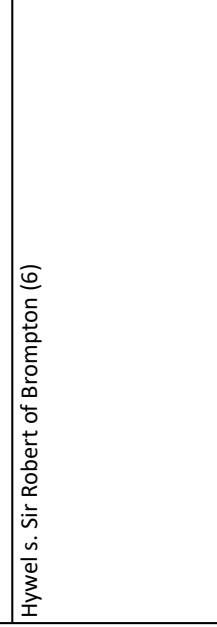 & 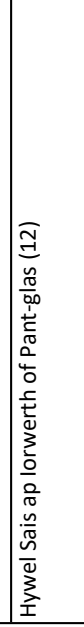 & 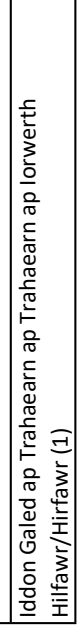 \\
\hline
\end{tabular}




\begin{tabular}{|c|c|c|c|c|c|c|c|c|c|c|c|c|c|c|c|c|c|c|c|c|}
\hline & 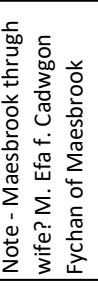 & & & & & & & & & & & & & 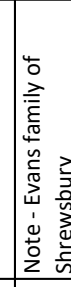 & 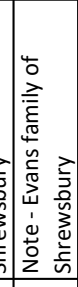 & 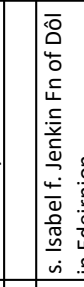 & 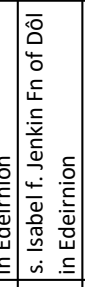 & 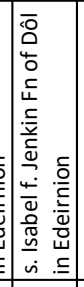 & 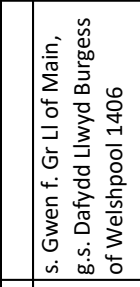 & 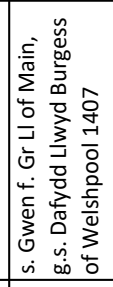 \\
\hline 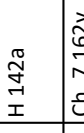 & 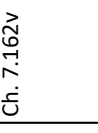 & $\stackrel{m}{m}$ & 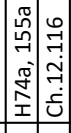 & & & & & & & & & & & & & 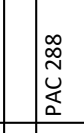 & 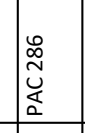 & 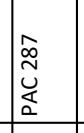 & 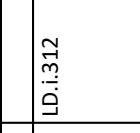 & 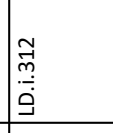 \\
\hline 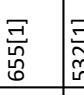 & $\underset{\bar{N}}{\bar{N}}$ & 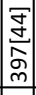 & $\omega_{\substack{\infty \\
\infty}}^{\infty}$ & $\stackrel{3}{2}$ & & 玆 & 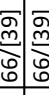 & 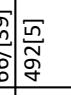 & $\stackrel{m}{\frac{m}{n}} \frac{\bar{m}}{\stackrel{m}{m}}$ & 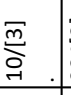 & 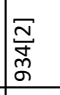 & 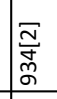 & 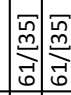 & 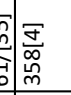 & 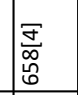 & 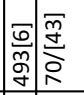 & $\frac{\bar{g}}{\stackrel{y}{g}}$ & 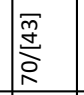 & 量 & \\
\hline & & 웅 & & 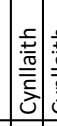 & & & & 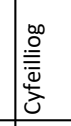 & 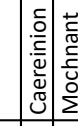 & 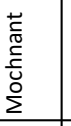 & & & & $\begin{array}{c}\frac{2}{2} \\
\end{array}$ & 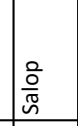 & & & & $\mid$ & \\
\hline 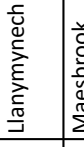 & 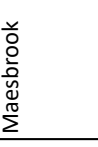 & & 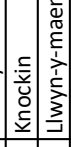 & 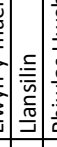 & 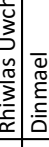 & 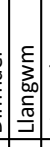 & 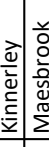 & 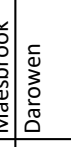 & 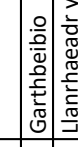 & 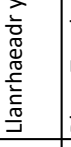 & 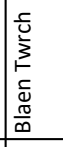 & 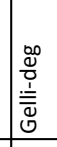 & 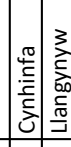 & 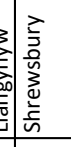 & 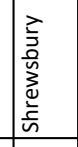 & \begin{tabular}{|l|} 
\\
$\frac{3}{3}$ \\
$\frac{3}{0}$ \\
$\frac{0}{4}$ \\
\end{tabular} & 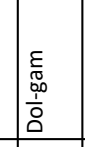 & 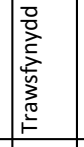 & 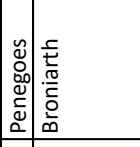 & \begin{tabular}{|l}
$\frac{\pi}{5}$ \\
$\frac{5}{00}$ \\
o. \\
\end{tabular} \\
\hline 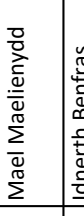 & 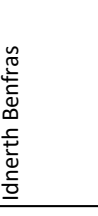 & & 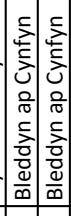 & 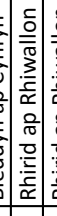 & & & 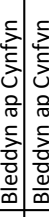 & 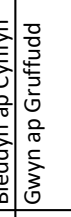 & 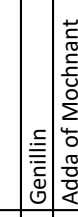 & 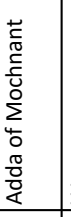 & 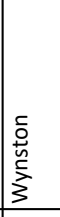 & 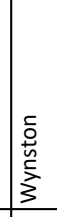 & 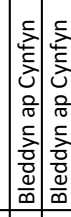 & 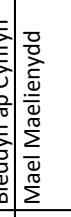 & 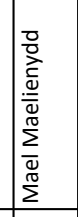 & 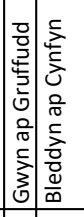 & 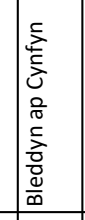 & 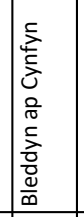 & 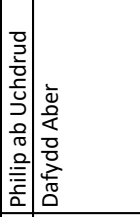 & 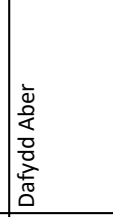 \\
\hline 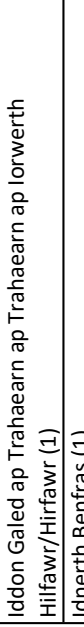 & 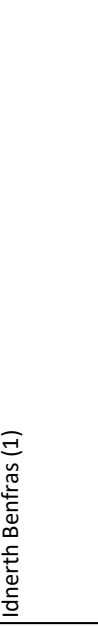 & & 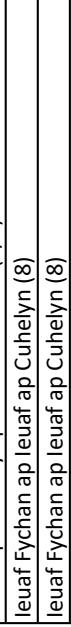 & 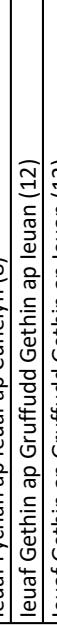 & 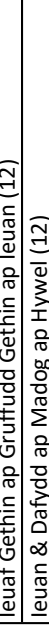 & 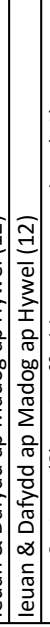 & 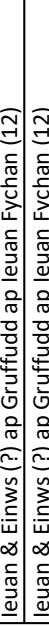 & 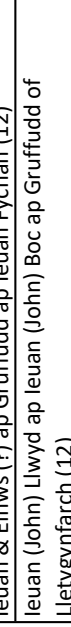 & 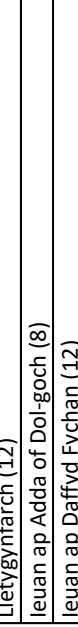 & 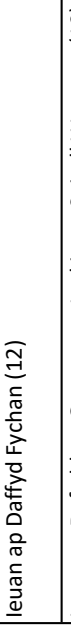 & 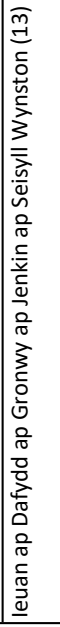 & 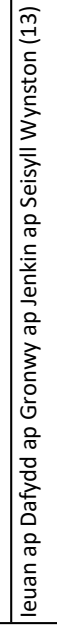 & 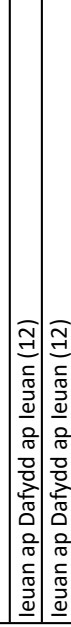 & 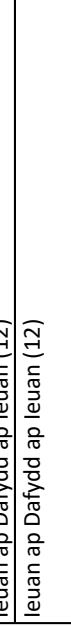 & 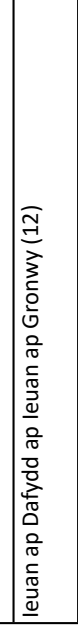 & 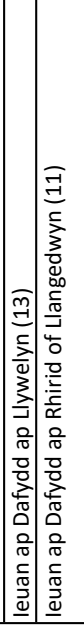 & 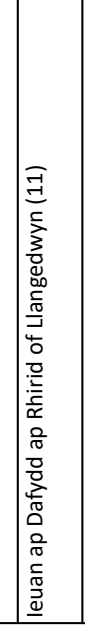 & 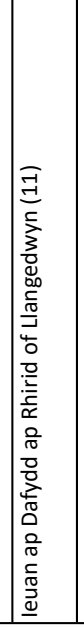 & 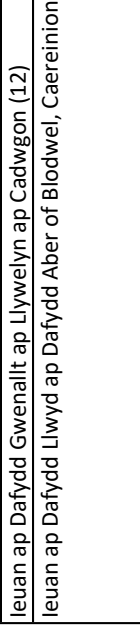 & 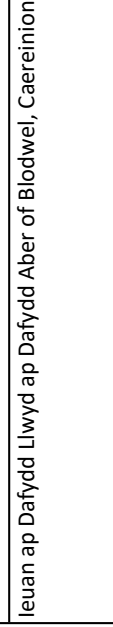 \\
\hline
\end{tabular}




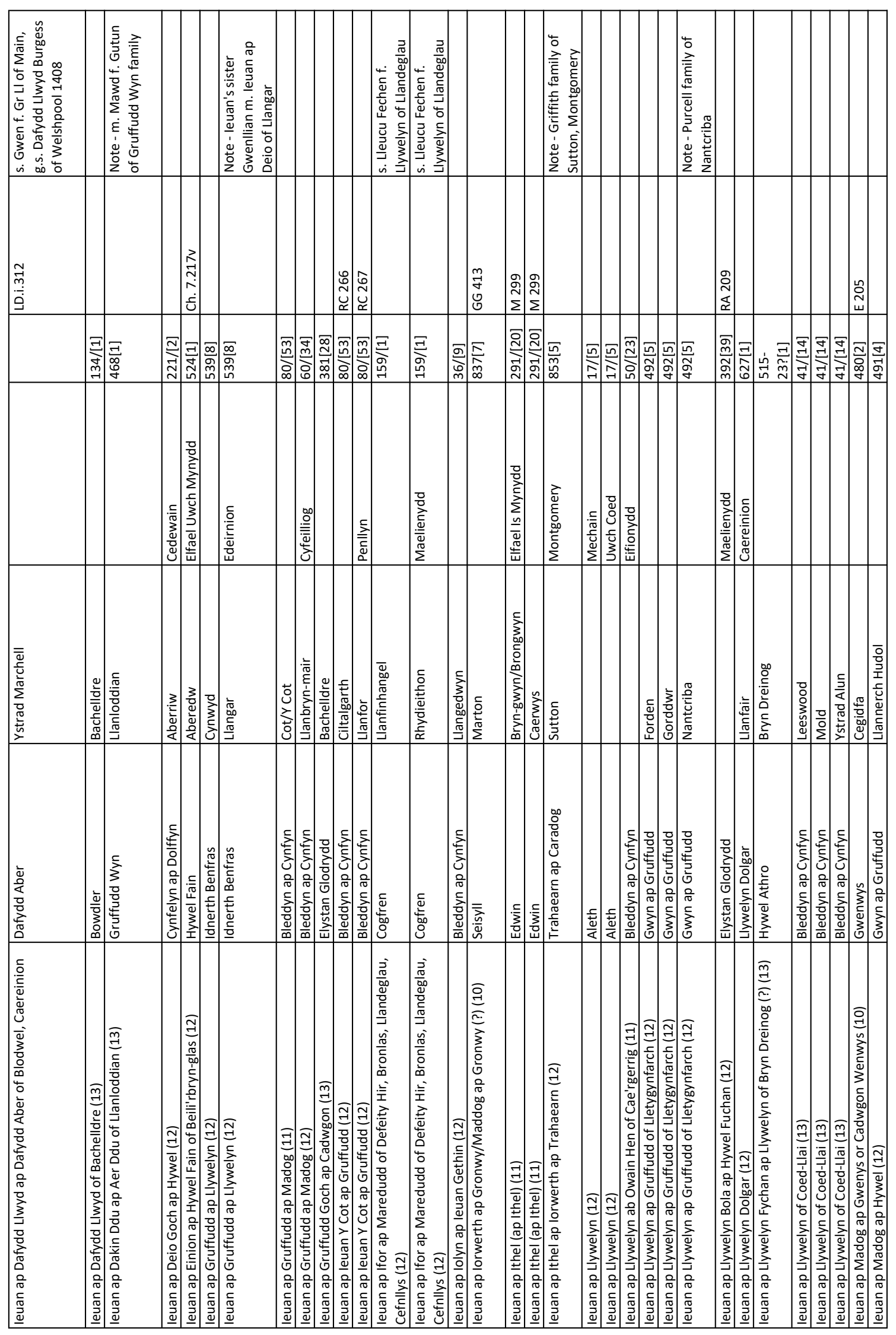




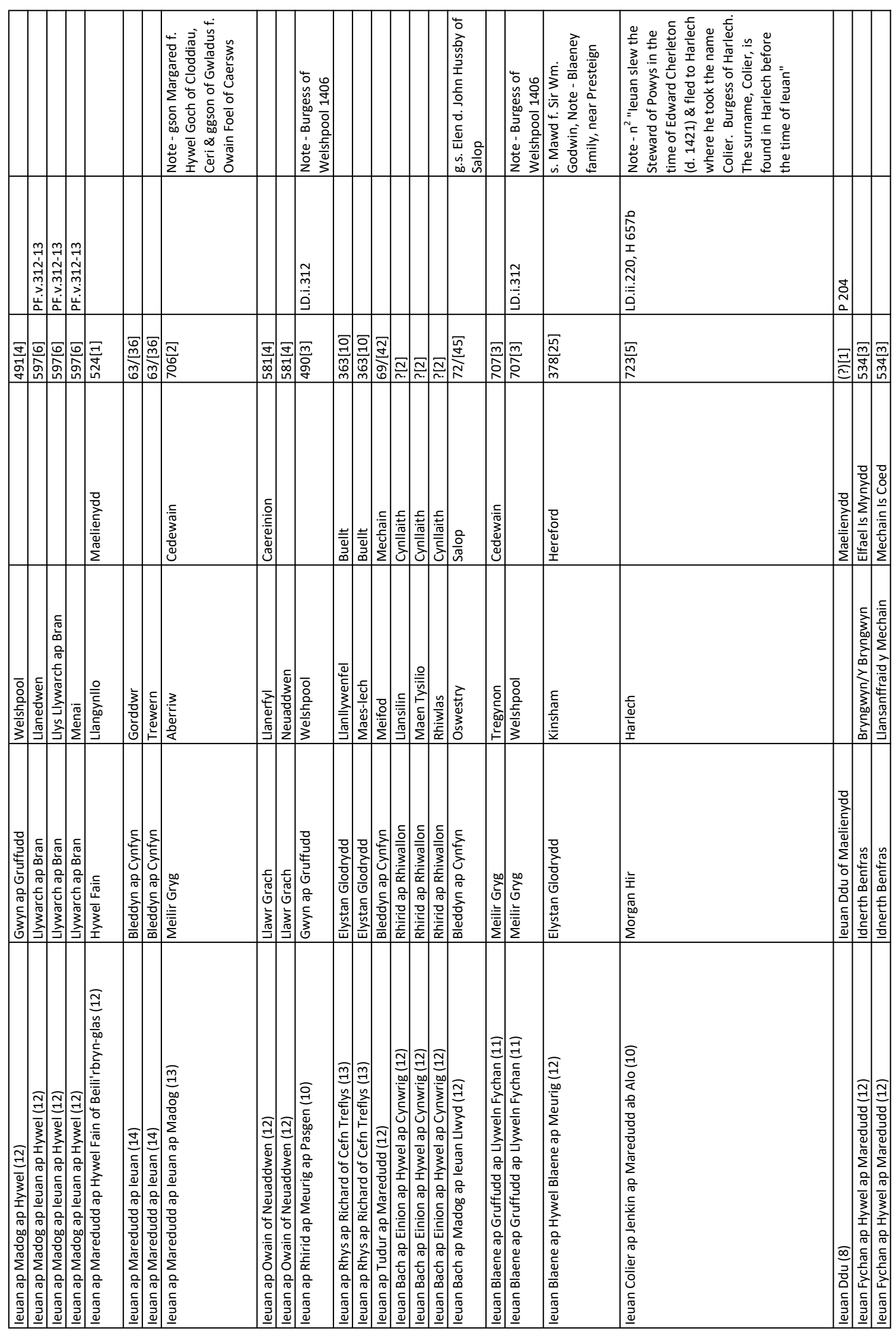




\begin{tabular}{|c|c|c|c|c|c|c|c|c|c|c|c|c|c|c|c|c|c|c|c|c|c|c|}
\hline & & & & & & & & & & & & & & 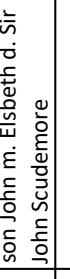 & & & & & 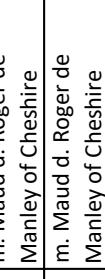 & & & \\
\hline & 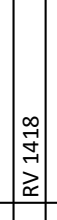 & & 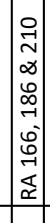 & & & & & & & 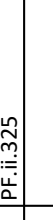 & & & & $\begin{array}{l}\text { f } \\
\text { x. } \\
\text { o } \\
\end{array}$ & 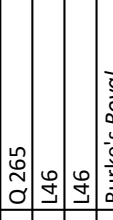 & 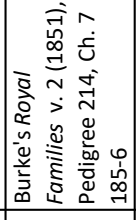 & 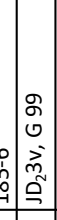 & 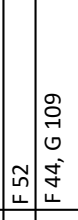 & 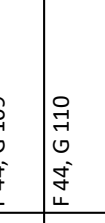 & 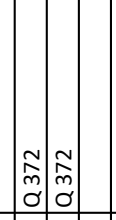 & & 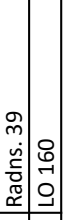 \\
\hline 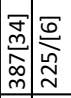 & 永 & & 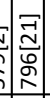 & 矛部 & $\sum_{\substack{\Delta \\
N}}^{\infty}$ & & 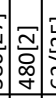 & 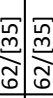 & & $\frac{\sqrt{3}}{2}$ & & 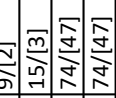 & 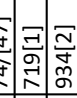 & 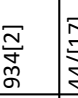 & 馬商商 & F & 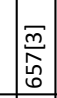 & 畄 & 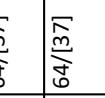 & 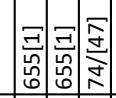 & & 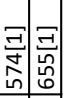 \\
\hline 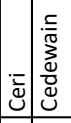 & & & & & 豙 & 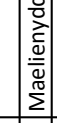 & & & & $\bar{\Xi}$ & & & 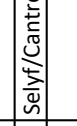 & & 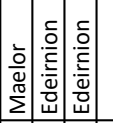 & & 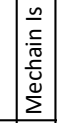 & 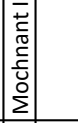 & 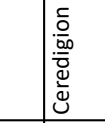 & & & \\
\hline 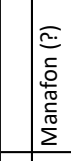 & 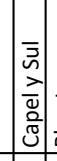 & & & | & 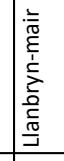 & 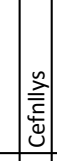 & $\frac{5}{0}$ & 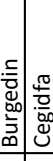 & 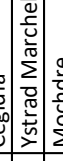 & 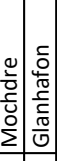 & 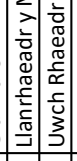 & 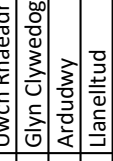 & & 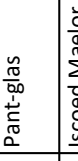 & 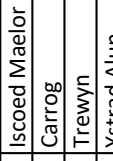 & \begin{tabular}{|l}
$\frac{5}{3}$ \\
$\frac{5}{4}$ \\
$\frac{0}{0}$ \\
$\frac{0}{5}$ \\
\end{tabular} & 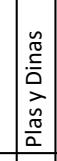 & 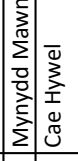 & 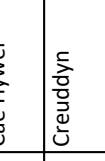 & 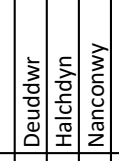 & $=$ & 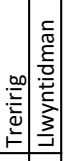 \\
\hline 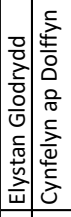 & 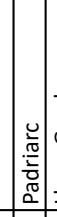 & & 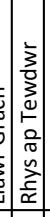 & & : & 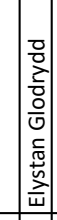 & 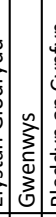 & 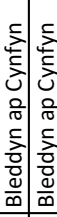 & 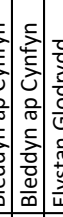 & 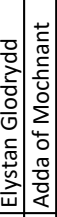 & 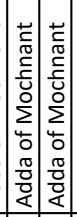 & 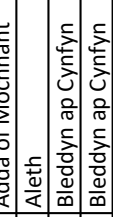 & 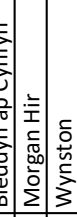 & 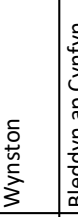 & 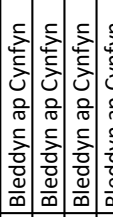 & 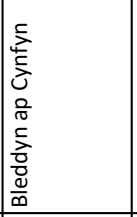 & 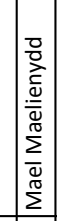 & 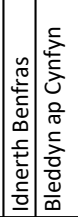 & 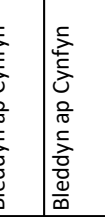 & 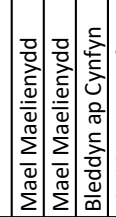 & 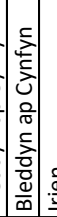 & 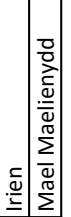 \\
\hline 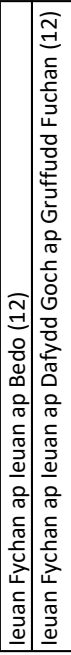 & 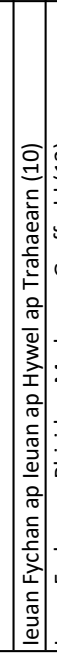 & 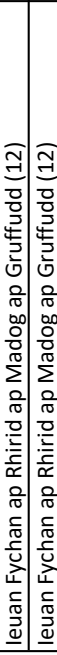 & & 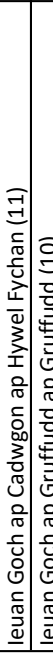 & 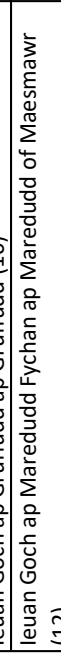 & 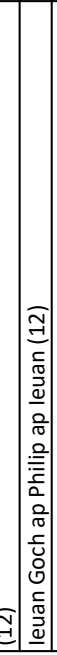 & 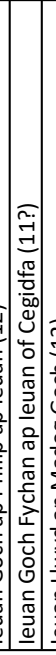 & 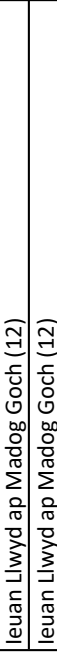 & 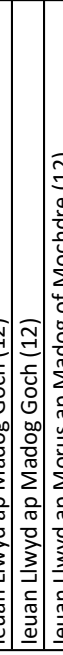 & 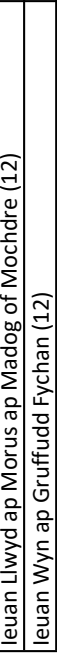 & 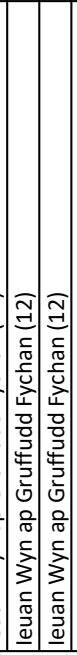 & 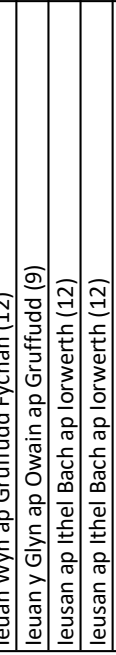 & 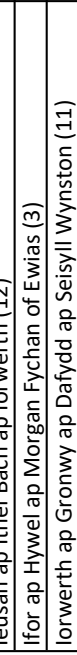 & 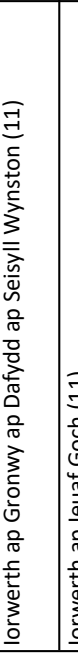 & 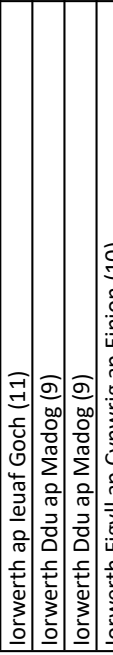 & 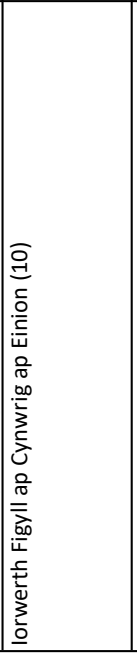 & 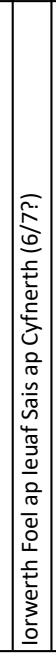 & 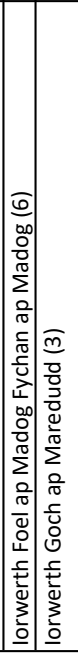 & 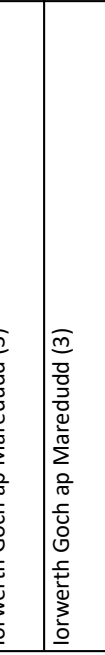 & 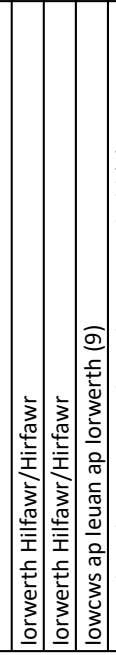 & 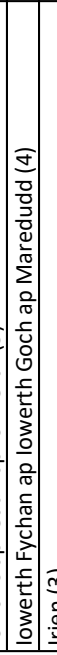 & 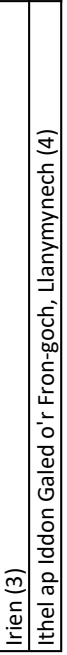 \\
\hline
\end{tabular}




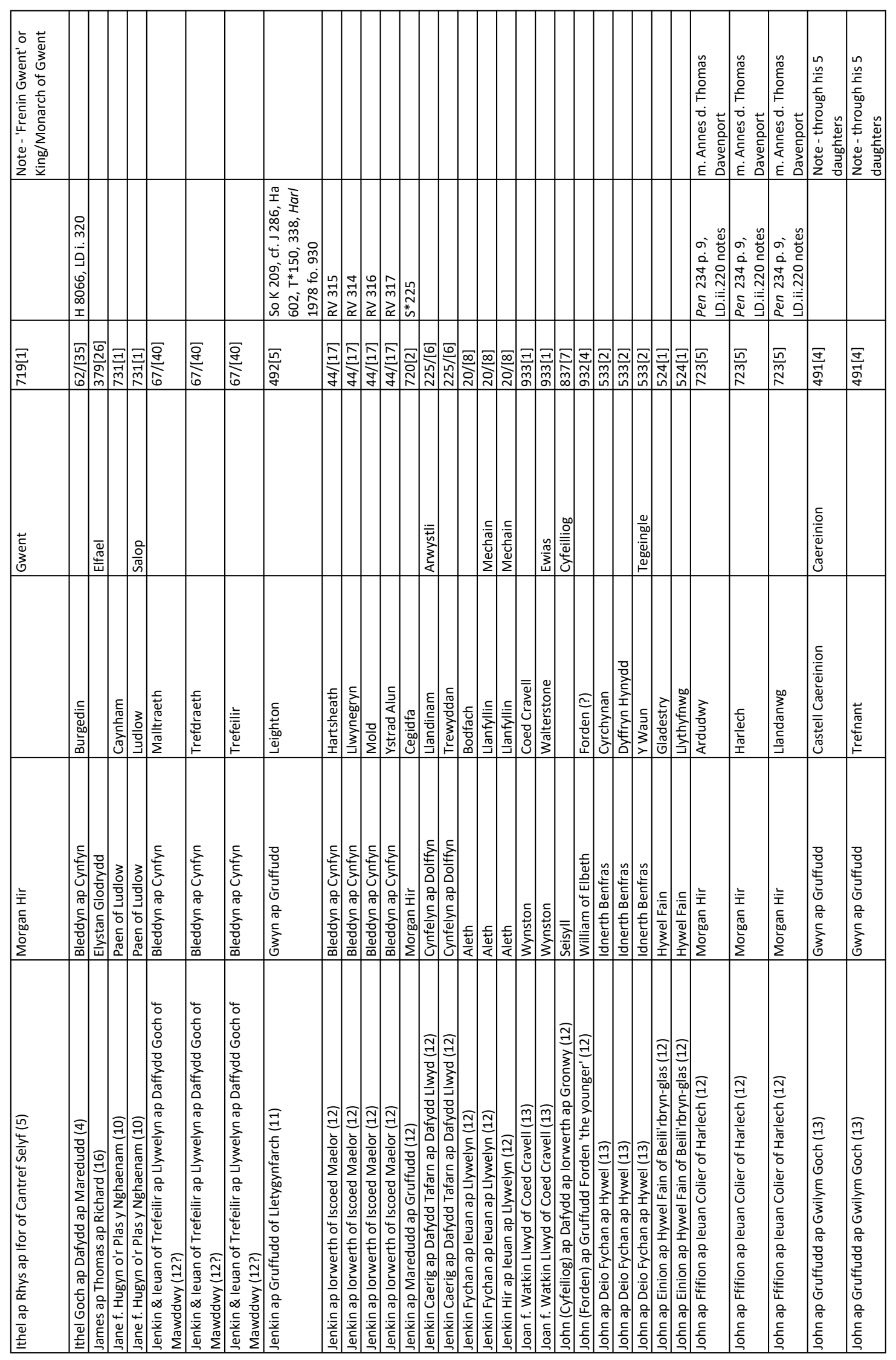




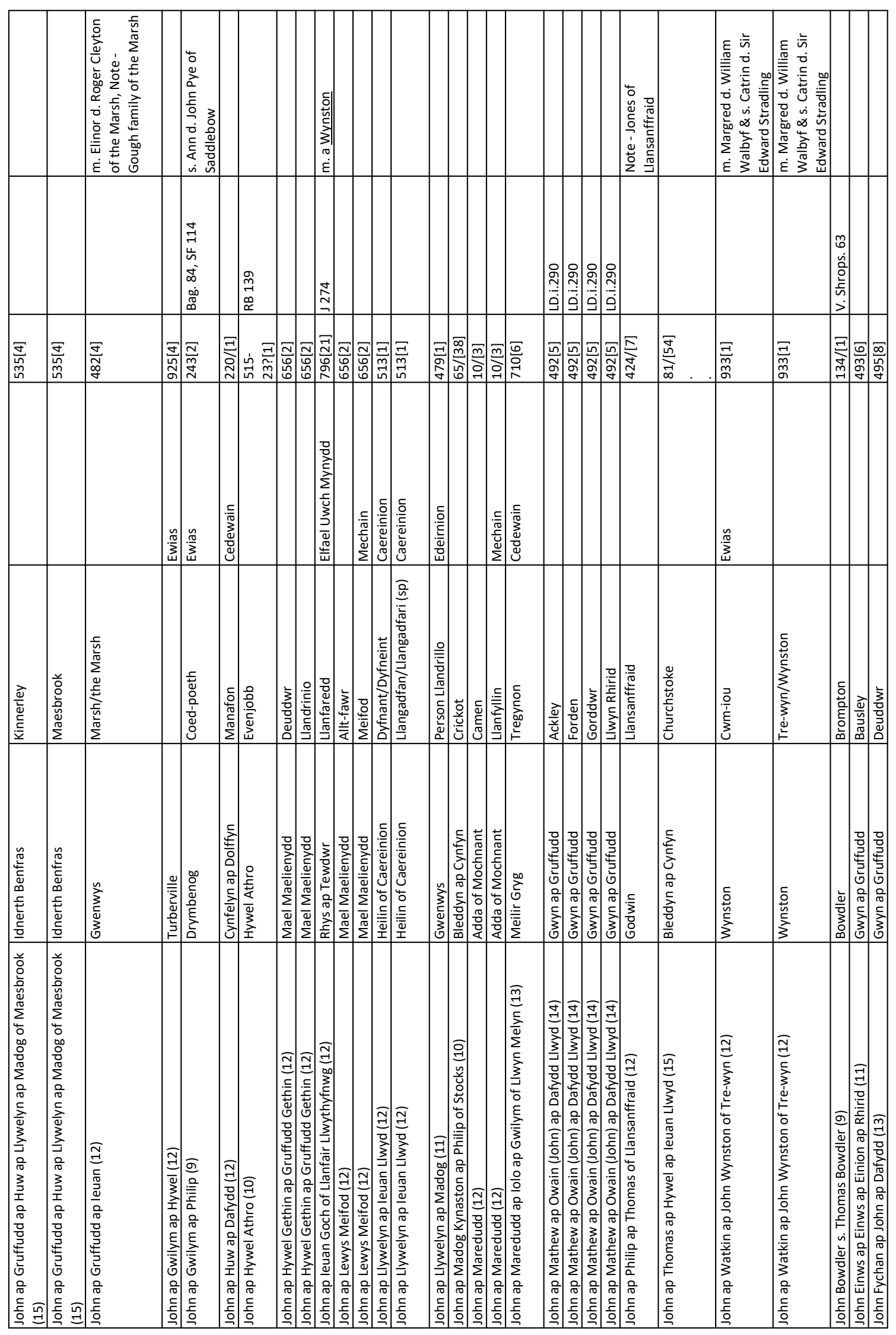




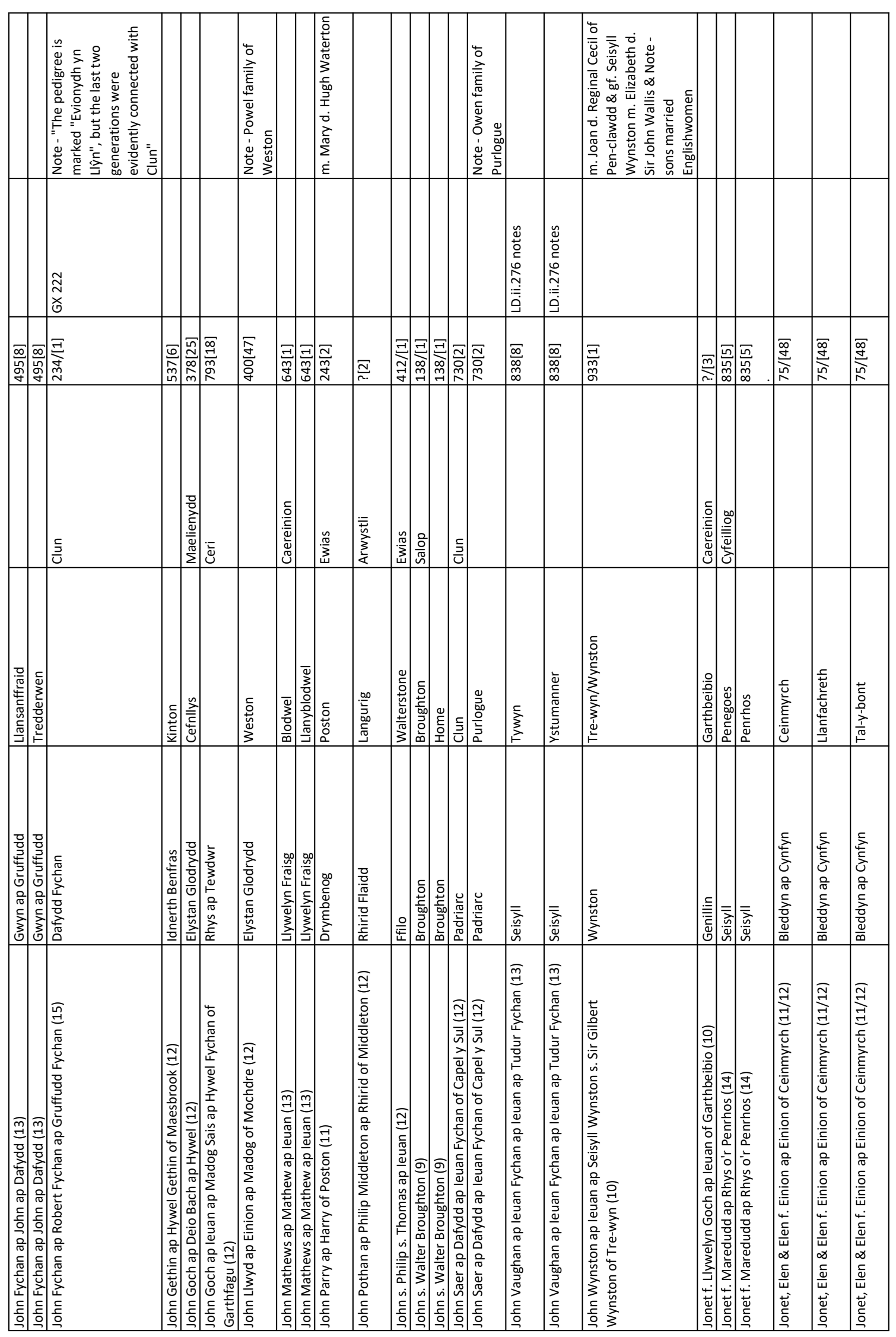



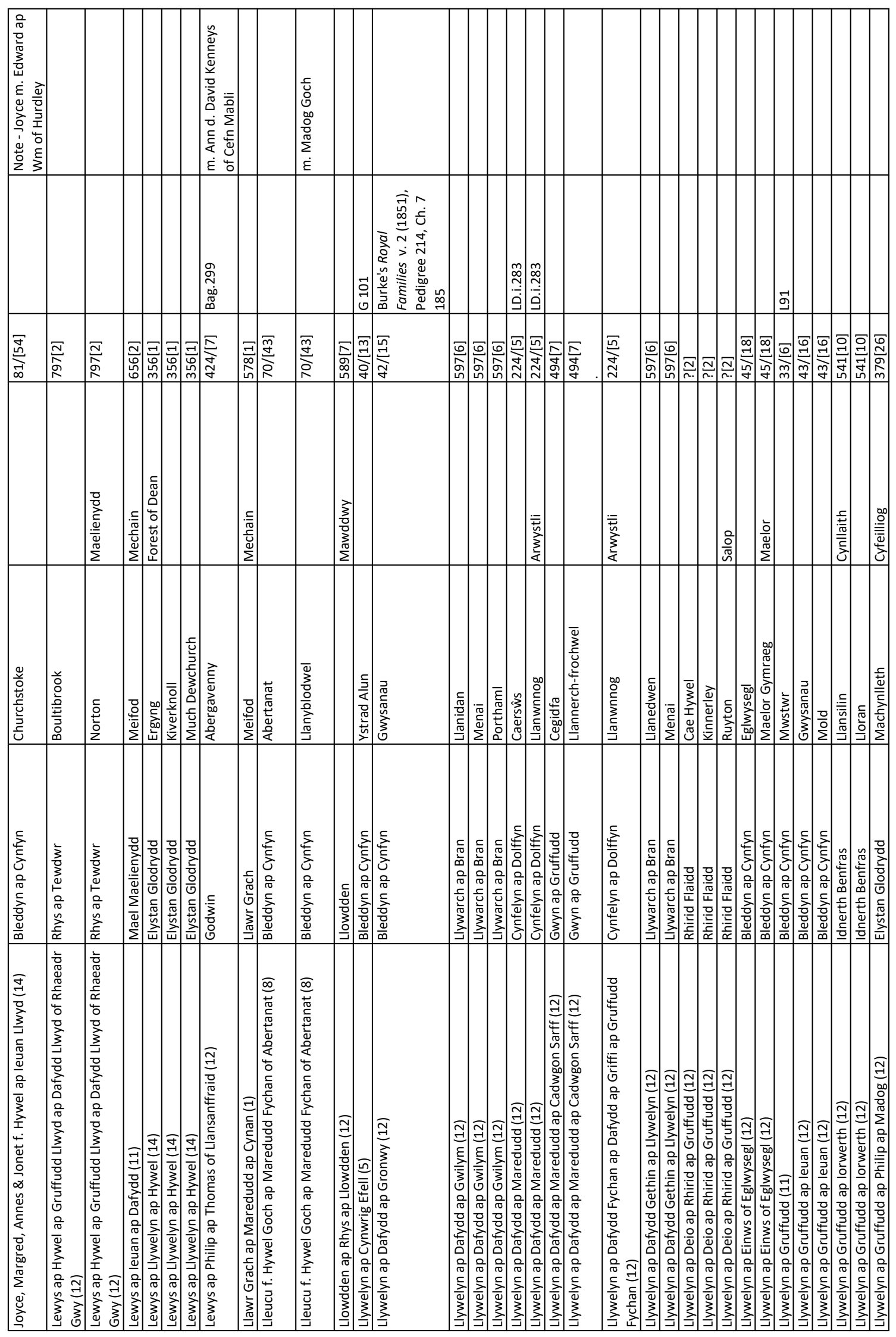


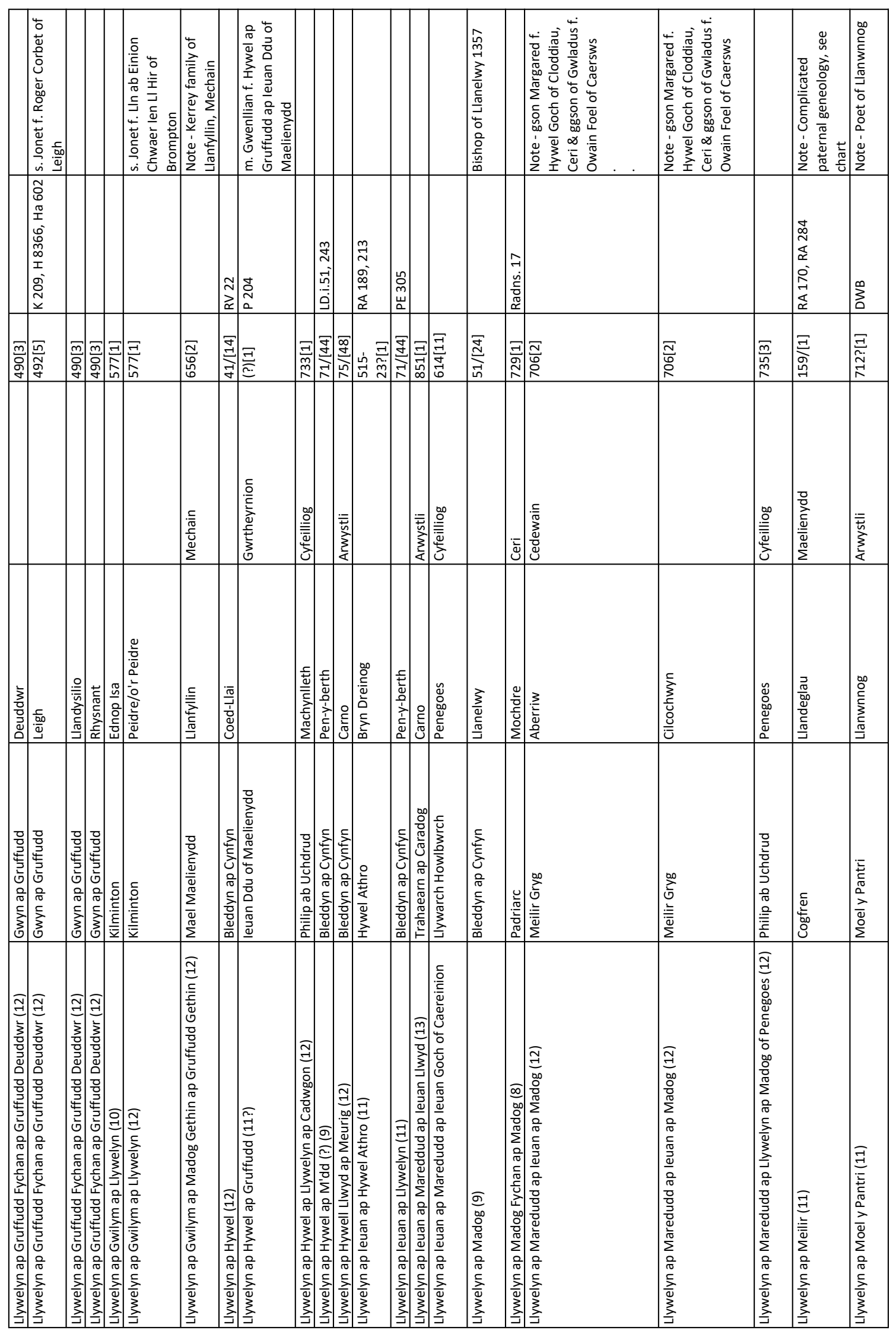









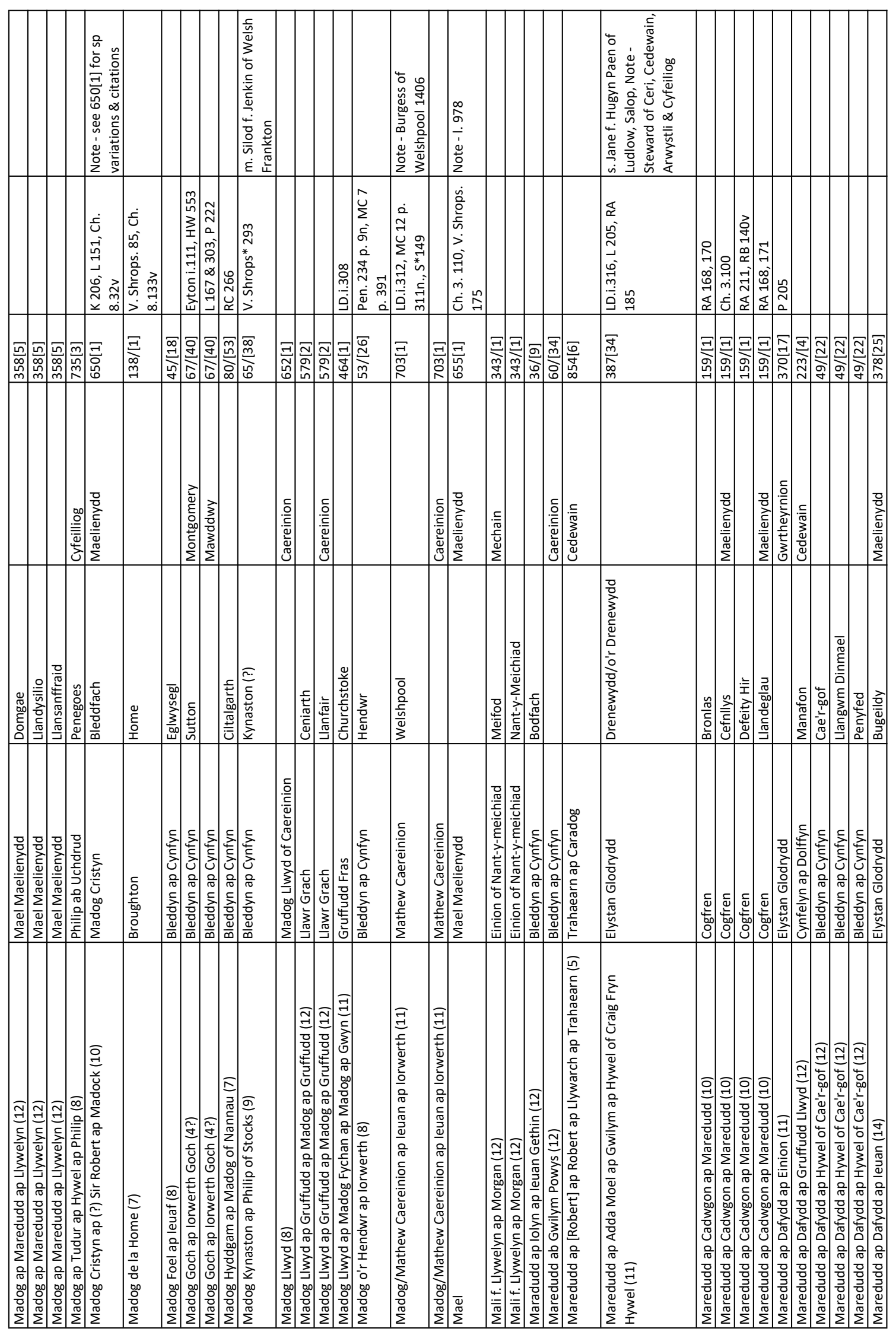




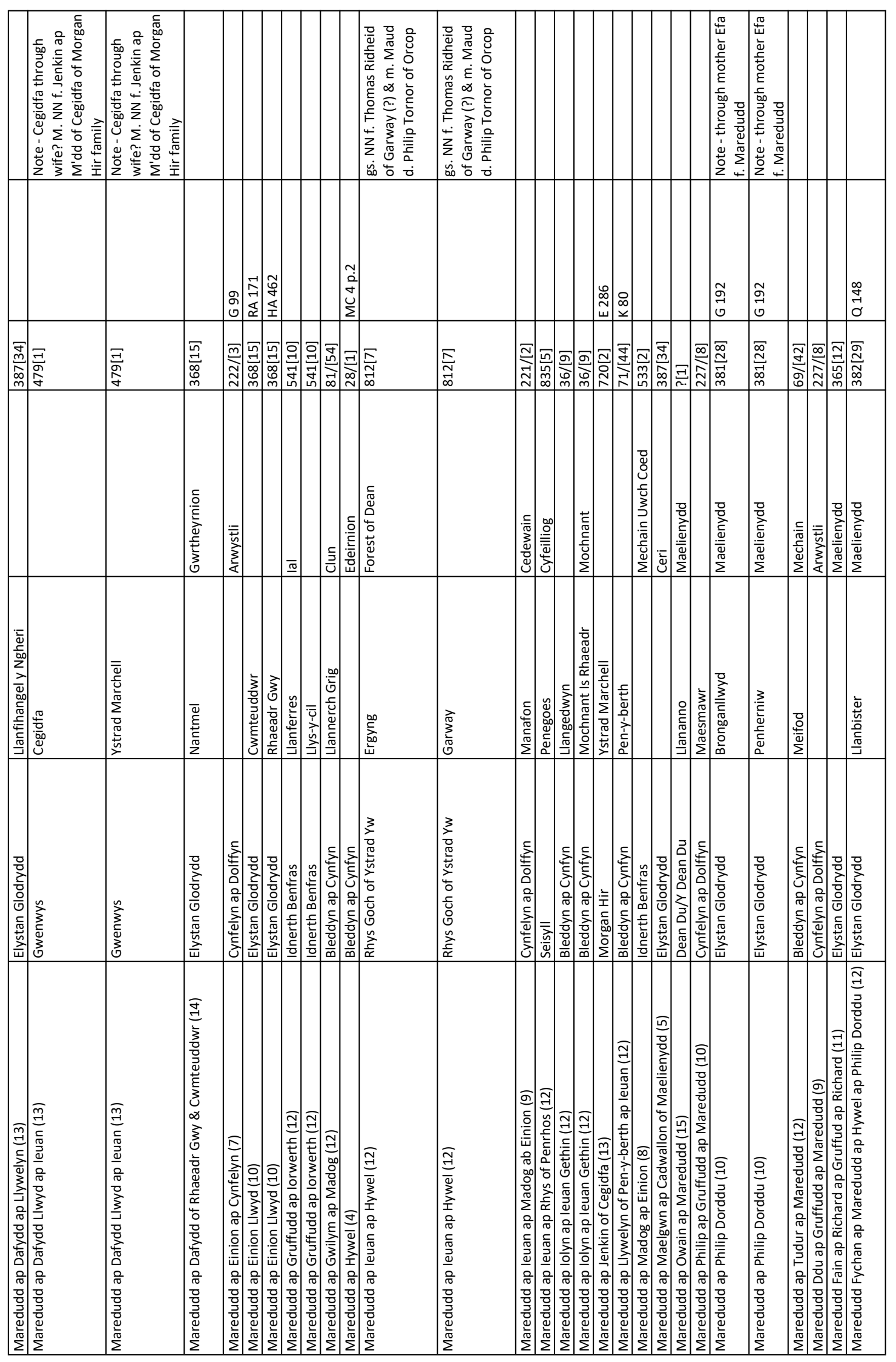




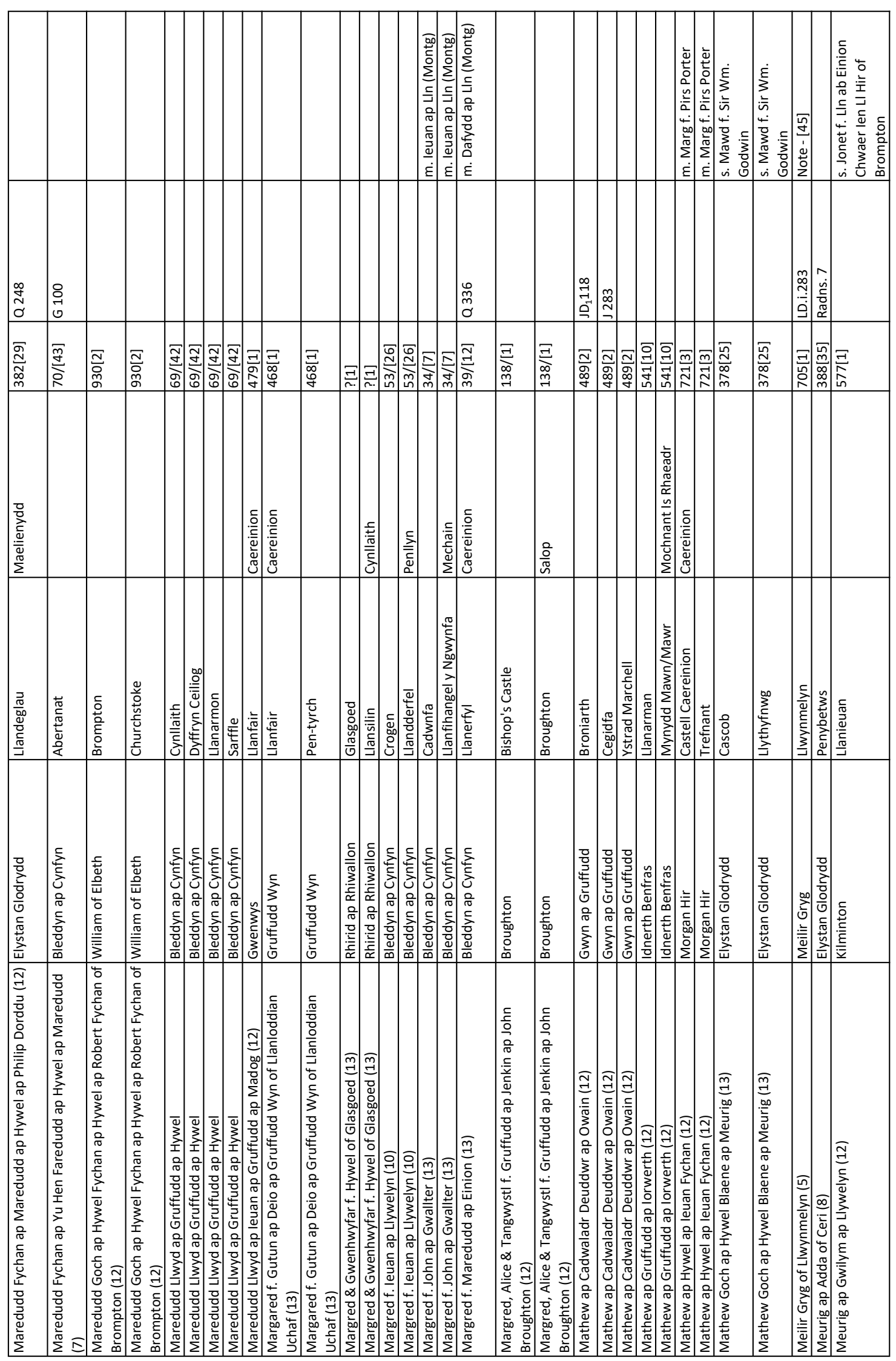




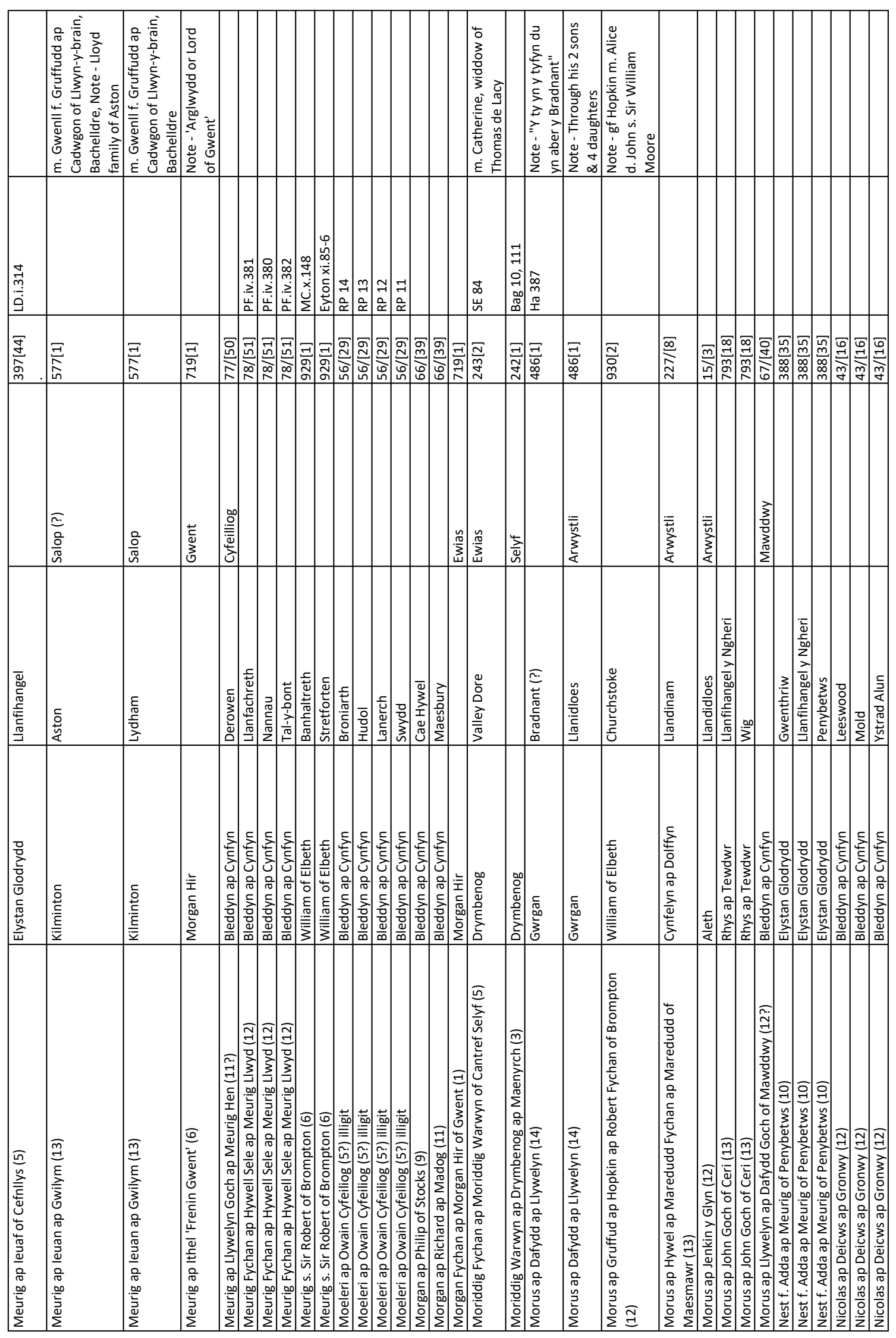




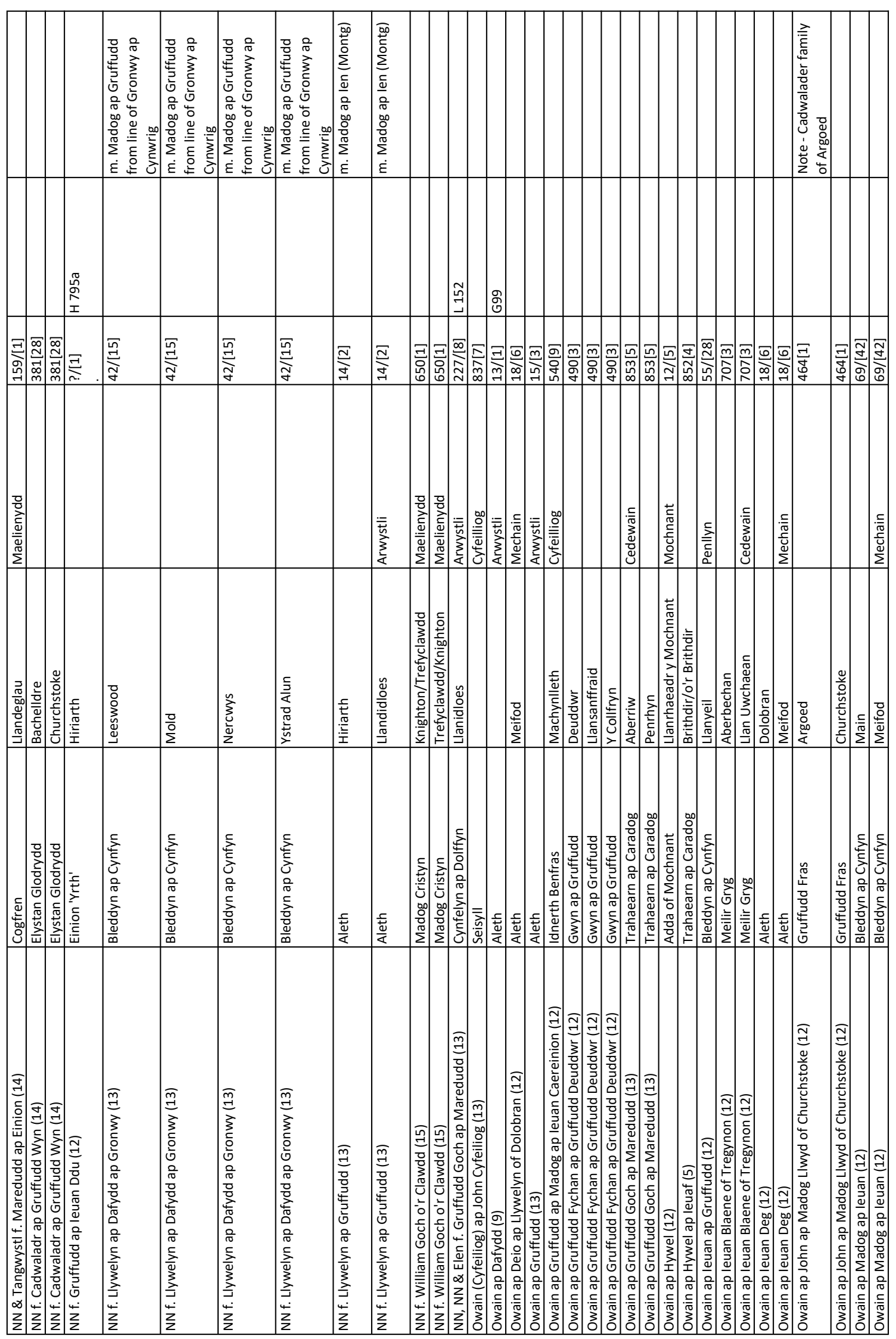




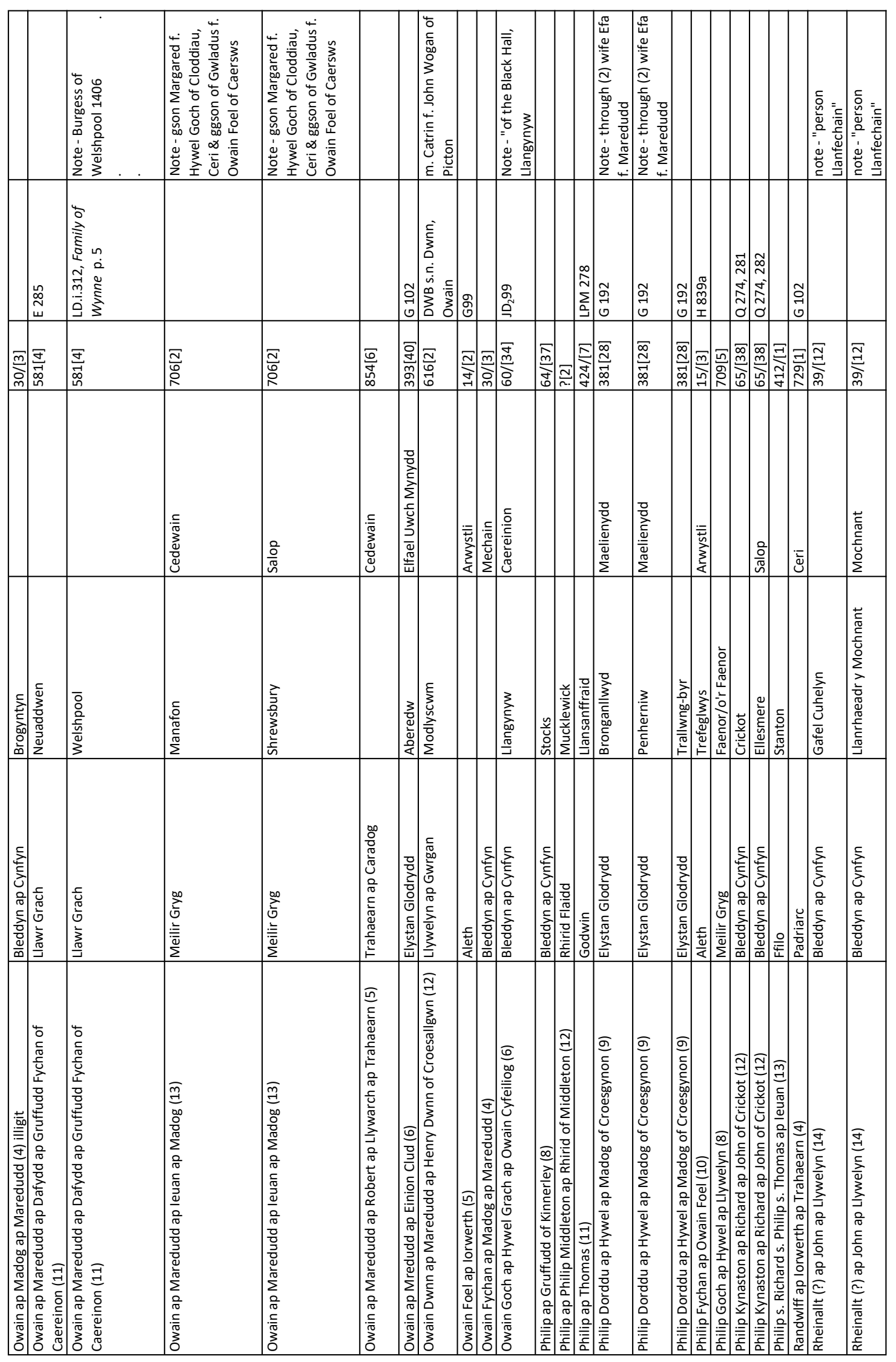




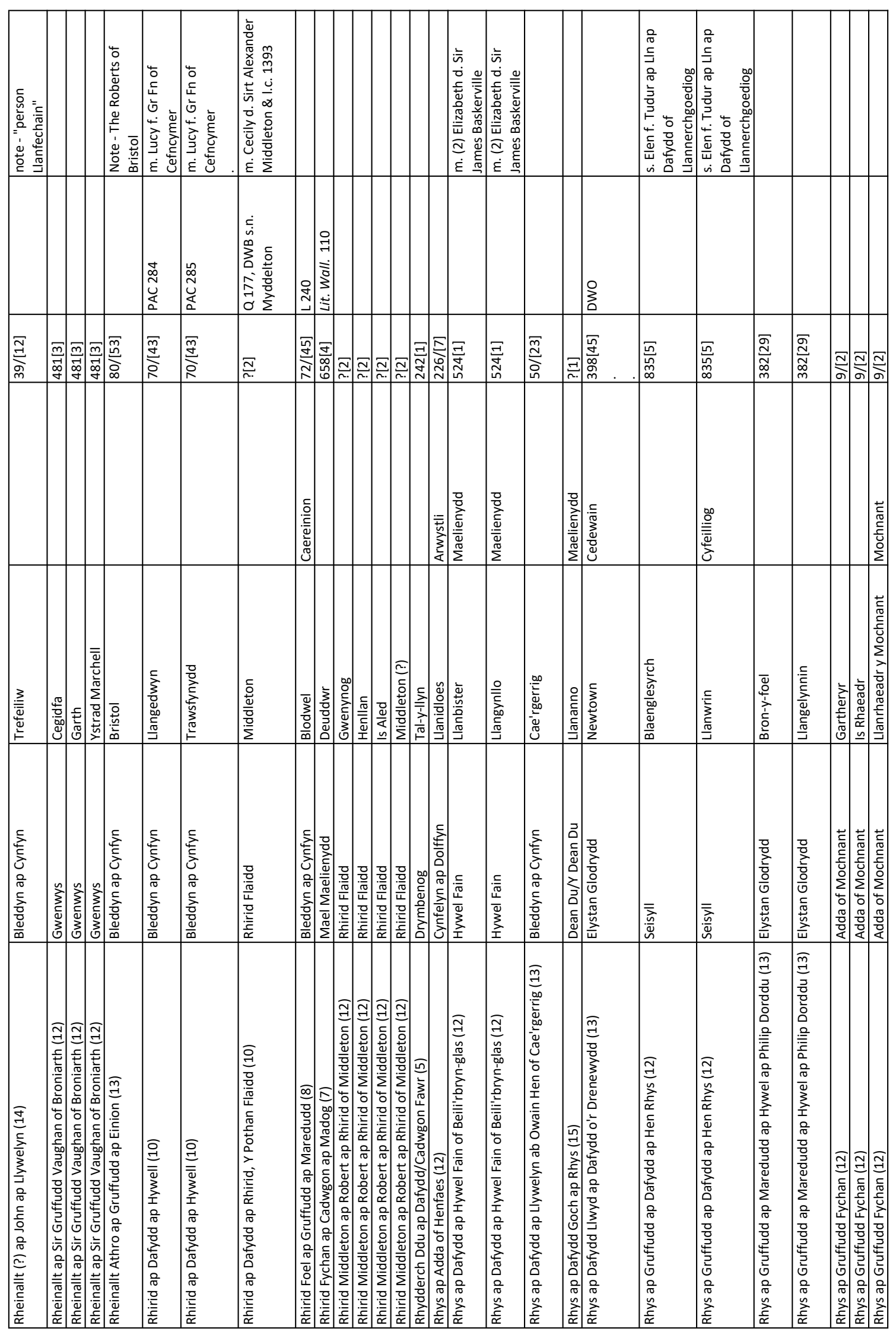




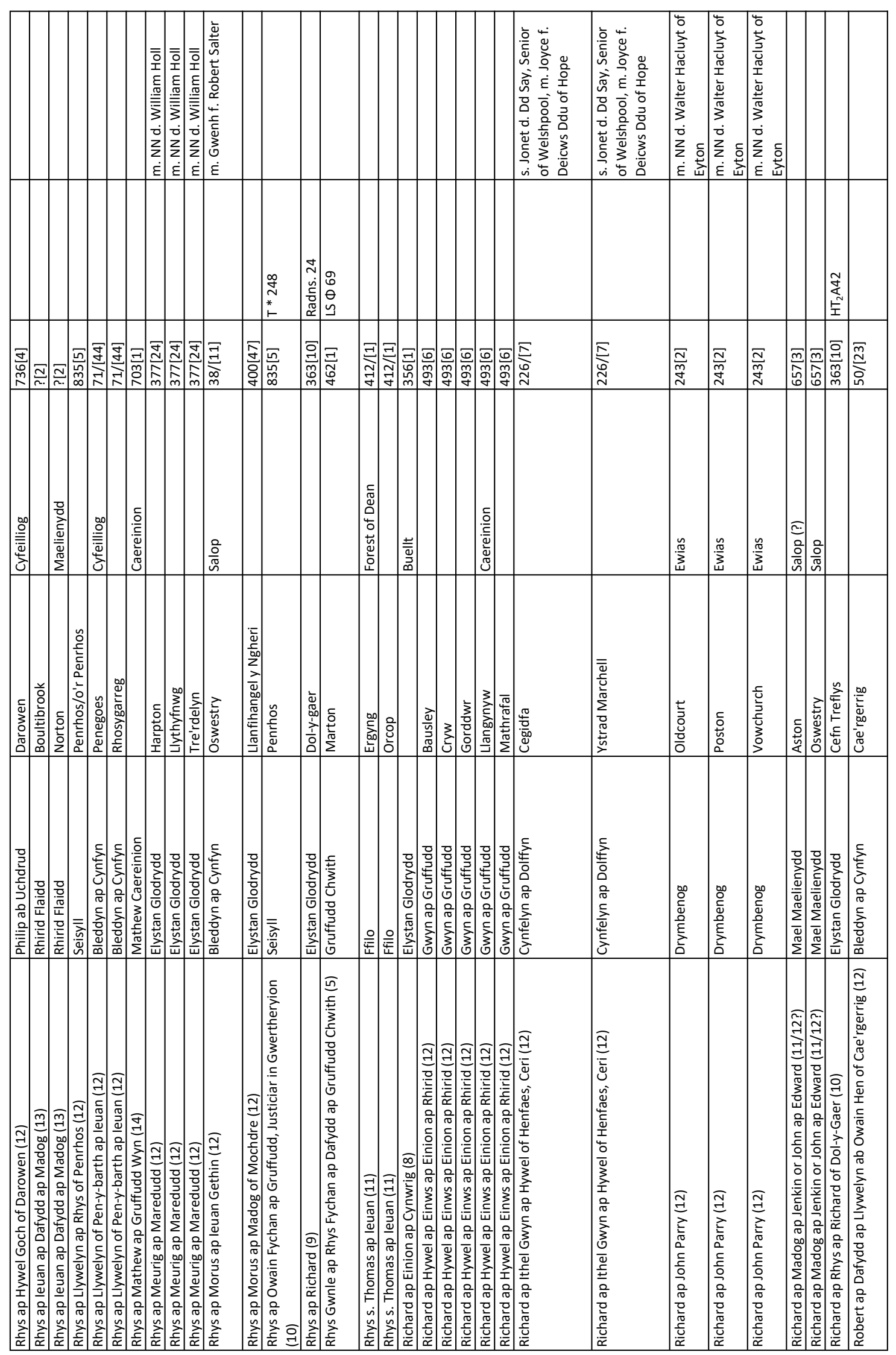




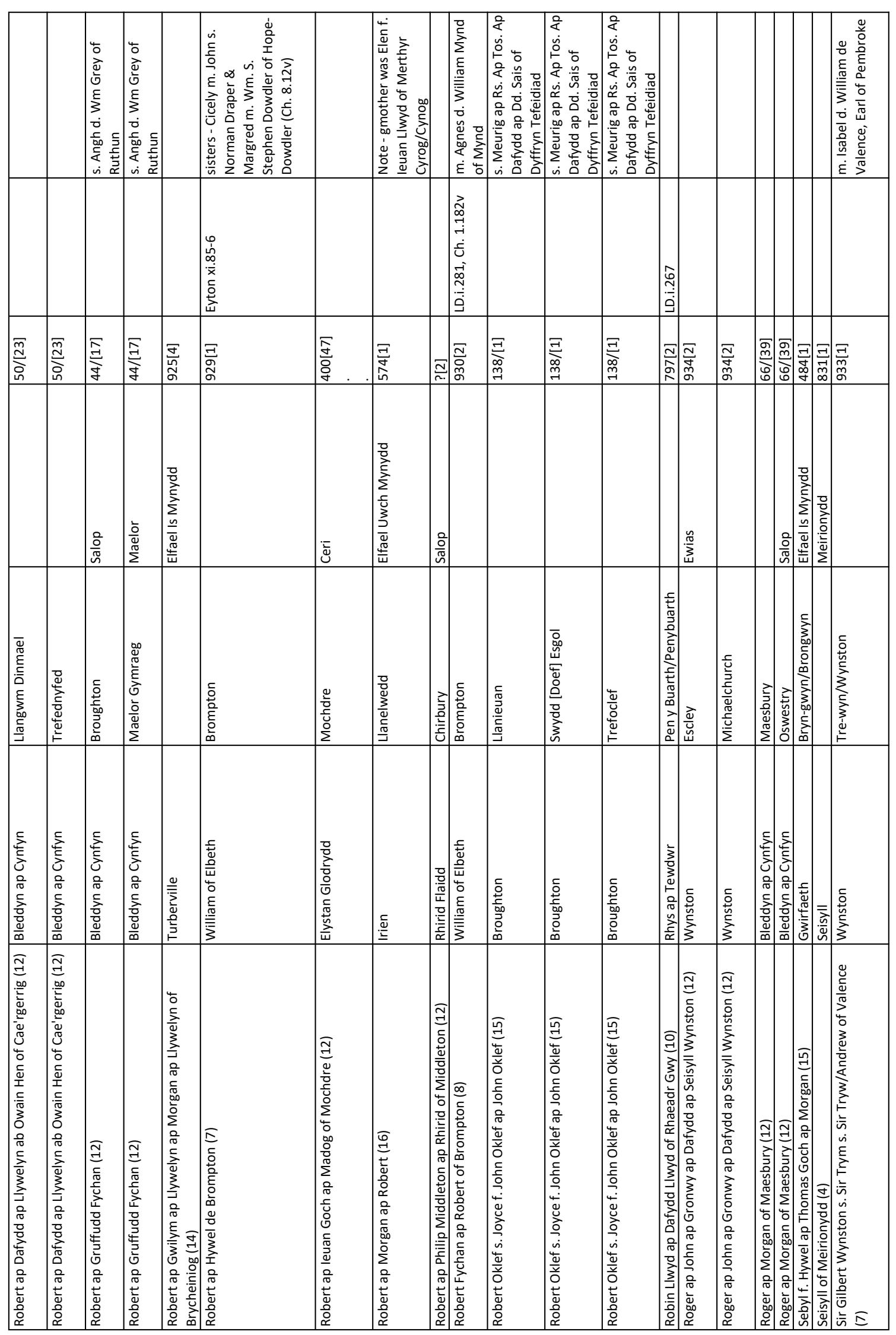




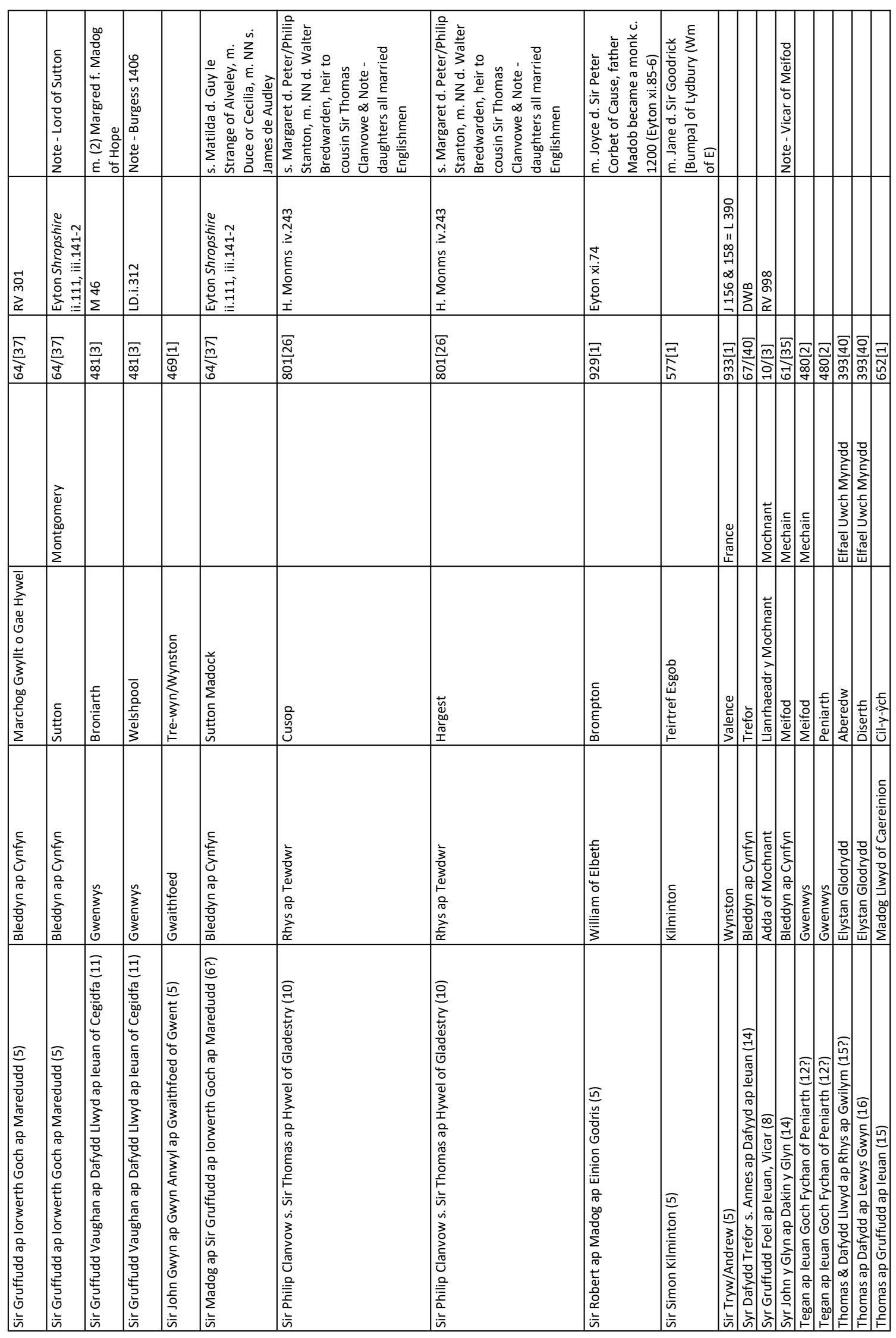




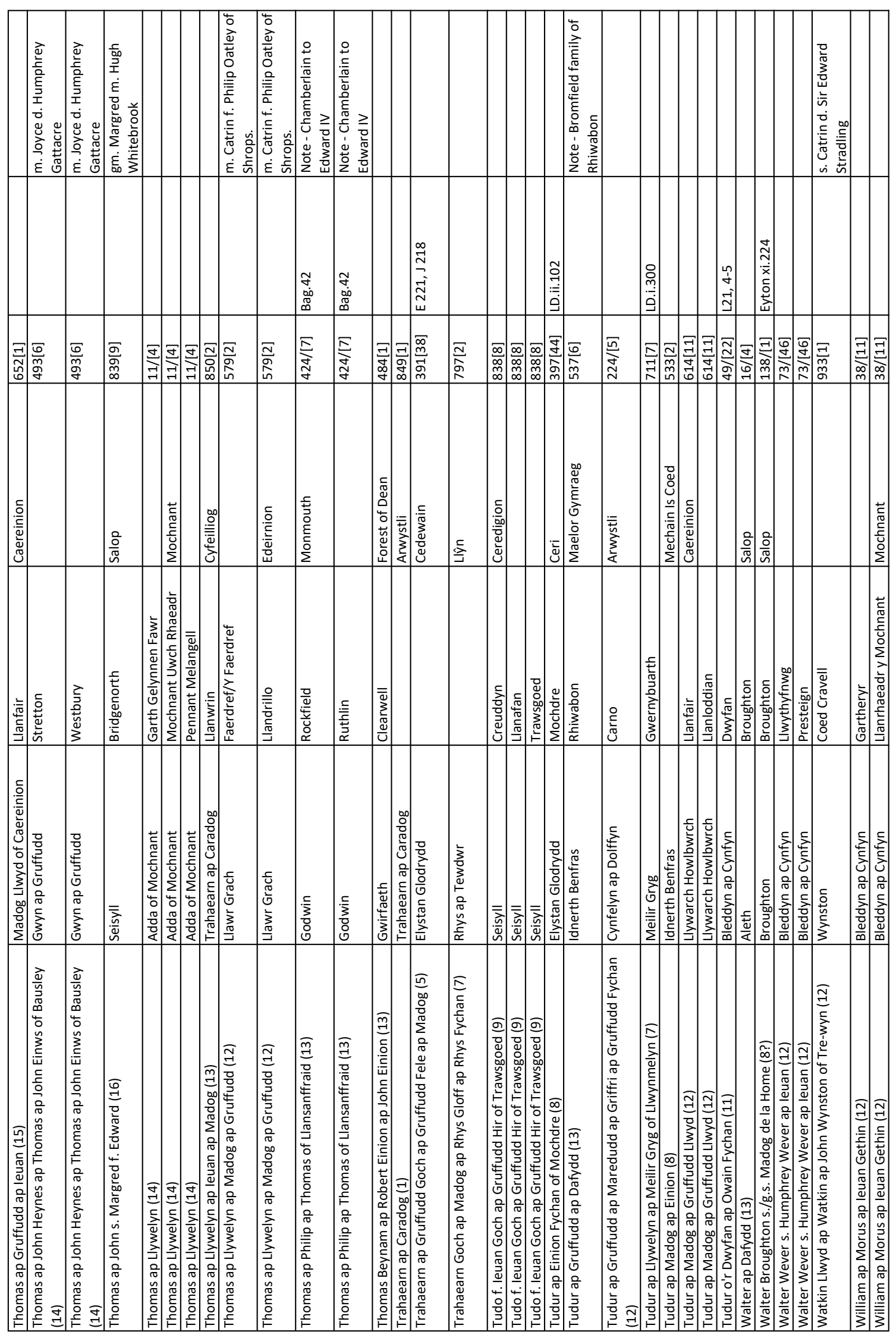




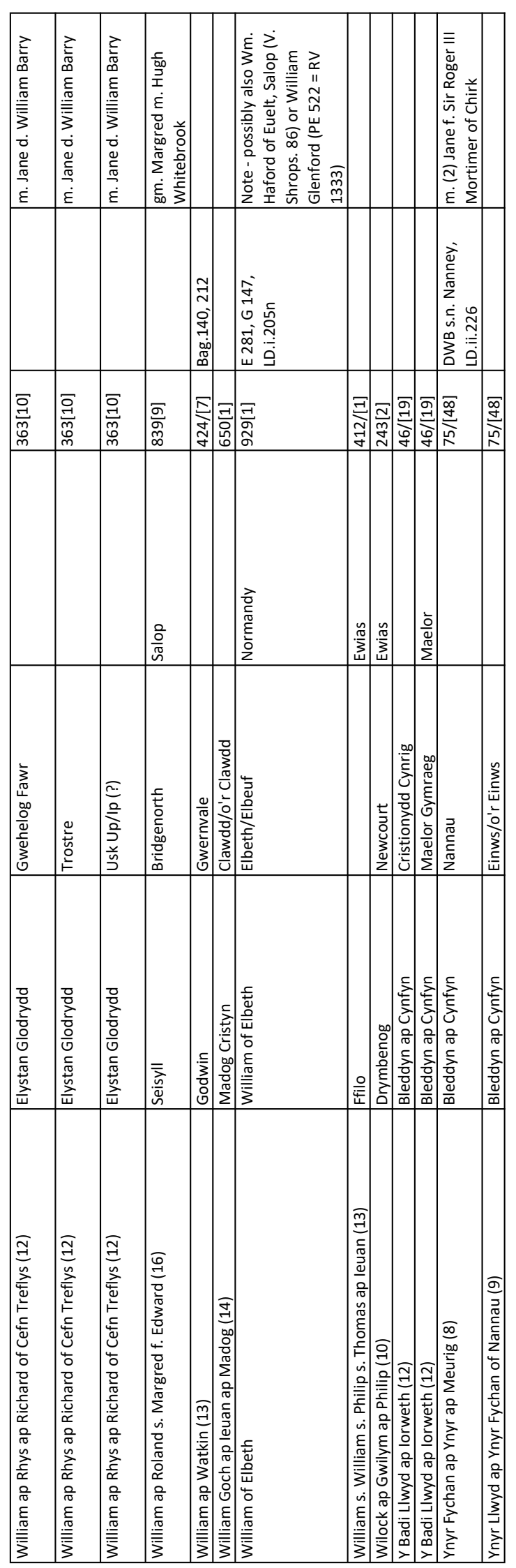




\section{APPENDIX TWO \\ TOWNSHIP/COUNTY/HUNDRED DATABASE FROM THE SHROPSHIRE GAZETTEER: WITH AN APPENDIX INCLUDING A SURVEY OF THE COUNTY, AND VALUABLE MISCELLANIOUS INFORMATION WITH PLATES ${ }^{234}$}

Appendix Two is a list of all of the townships in Shropshire sorted by Parish and Hundred. It can often be difficult to locate a particular town or hamlet, especially those that have disappeared from today's maps. The author of The Shropshire Gazetteer used data from before the 1823 parish reorganization to create a list of the townships in each parish. I have chosen here to sort the data alphabetically by township as the most useful method to pinpoint difficult-to-find pre-modern locations.

234 The Shropshire Gazetteer: With an Appendix Including a Survey of the County, and Valuable Miscellaneous Information, with Plates, (Wem: T. Gregory, 1824). 


\begin{tabular}{|c|c|c|c|c|}
\hline Township & Parish & Hundred & Hundred Subdivision & County \\
\hline Abbey Forgate (east end) & Holy Cross \& St. Giles & Liberties of Shrewsbury & Stone Ward Constablewick & Shropshire \\
\hline Abbey Forgate (west end) & Holy Cross \& St. Giles & Liberties of Shrewsbury & Stone Ward Constablewick & Shropshire \\
\hline Abcott & Clungunford & Purslow & Stow & Shropshire \\
\hline Abdon & Abdon & Munslow & Lower Munslow & Shropshire \\
\hline Abertannat & Llanyblodwell & Oswestry & Upper Oswestry & Shropshire \\
\hline Ackleton & Worfield & Brimstree & Bridgenorth & Shropshire \\
\hline Acton \& Down & Lydbury & Purslow & Bishop's Castle & Shropshire \\
\hline Acton Burnel & Acton Burnel & Condover & Cound & Shropshire \\
\hline Acton Pigott & Acton Burnel & Condover & Cound & Shropshire \\
\hline Acton Reynolds & Shawbury & Liberties of Shrewsbury & Whitechurch* & Shropshire \\
\hline Acton Round & Acton Round & Stottesdon & Chelmarsh & Shropshire \\
\hline Acton Scott & Acton Scott & Munslow & Upper Munslow & Shropshire \\
\hline Adcot \& Milford & Great Ness & Pimhill & Baschurch & Shropshire \\
\hline Adderley & Adderley & North Bradford & Drayton & Shropshire \\
\hline Admaston & Wrockwardine & South Bradford & Wellington & Shropshire \\
\hline Adney & Edgmond & South Bradford & Newport & Shropshire \\
\hline Adstone & Wentnor & Purslow & Bishop's Castle & Shropshire \\
\hline Alam Bridge/Allom Bridge & Alveley & Liberties of Bridgenorth & & Shropshire \\
\hline Alberbury & Alberbury & Ford & Ford & Shropshire \\
\hline Albright Hussey/All Hussey & Battlefield & Liberties of Shrewsbury & Castle Ward Constablewick & Shropshire \\
\hline Albright Lee & St. Alkmond & Liberties of Shrewsbury & Castle Ward Constablewick & Shropshire \\
\hline Albrighton & Albrighton & Brimstree & Shiffnal & Shropshire \\
\hline Albrighton & St. Mary (Shrewsbury) & Pimhill & Baschurch & Shropshire \\
\hline Albrighton (Chapelry) & St. Mary (Shrewsbury) & Pimhill & Baschurch & Shropshire \\
\hline Alcaston & Acton Scott & Munslow & Upper Munslow & Shropshire \\
\hline Aldenham & & Stottesdon & Bridgenorth* & Shropshire \\
\hline Alderton & Middle/Myddle & Liberties of Shrewsbury & Ellesmere* & Shropshire \\
\hline Alderton & Great Ness & Pimhill & Baschurch & Shropshire \\
\hline Aldon & Stoke Say & Munslow & Lower Munslow & Shropshire \\
\hline Alkington & Whitechurch & North Bradford & Whitechurch & Shropshire \\
\hline All Stretton & Church Stretton & Munslow & Upper Munslow & Shropshire \\
\hline Allscote & Worfield & Brimstree & Bridgenorth & Shropshire \\
\hline Allscott & Wrockwardine & South Bradford & Wellington & Shropshire \\
\hline Almington & Drayton & & & Stafford \\
\hline Alveley & Billingsley & Stottesdon & Chelmarsh & Shropshire \\
\hline Amaston & Alberbury & Ford & Ford & Shropshire \\
\hline Apley & & Brimstree & Bridgenorth & Shropshire \\
\hline Ascott/Arscott & Pontesbury & Ford & Pontesbury & Shropshire \\
\hline Ash Magna & Whitechurch & North Bradford & Whitechurch & Shropshire \\
\hline Ash Parva & Whitechurch & North Bradford & Whitechurch & Shropshire \\
\hline Ashfield & Ditton Priors & Wenlock & 1st/Main & Shropshire \\
\hline Ashford Bowdler & Ashford Bowdler & Munslow & Lower Munslow & Shropshire \\
\hline Ashford Carbonel & Ashford Carbonel & Munslow & Lower Munslow & Shropshire \\
\hline Ashford Carbonel & Ashford Carbonel & Stottesdon & Cleobury & Shropshire \\
\hline Asterley & Pontesbury & Ford & Pontesbury & Shropshire \\
\hline Asterton & Norbury & Purslow & Bishop's Castle & Shropshire \\
\hline Astley (Chapelry) & St. Mary (Shrewsbury) & Liberties of Shrewsbury & Castle Ward Constablewick & Shropshire \\
\hline Astley Abbots & Astley Abbotts & Stottesdon & Chelmarsh & Shropshire \\
\hline Aston & Claverley & Brimstree & Bridgenorth & Shropshire \\
\hline Aston & Shiffnal & Brimstree & Shiffnal & Shropshire \\
\hline Aston & Munslow & Munslow & Lower Munslow & Shropshire \\
\hline Aston & Wem & North Bradford & Whitechurch & Shropshire \\
\hline Aston & Oswestry & Oswestry & Upper Oswestry & Shropshire \\
\hline Aston & Wellington & South Bradford & Wellington & Shropshire \\
\hline Aston Air/Aston Eyre/Aston Ayres & Morvield/Morvill & Stottesdon & Chelmarsh & Shropshire \\
\hline Aston Boterel & Aston Boterel & Stottesdon & Cleobury & Shropshire \\
\hline Aston in Hopesay & Hopesay & Purslow & Stow & Shropshire \\
\hline Aston Pigott & Worthen, Worthen Quarter & Chirbury & Lower Chirbury & Shropshire \\
\hline Aston Rogers & Worthen, Worthen Quarter & Chirbury & Lower Chirbury & Shropshire \\
\hline Atcham/Attingham & Atcham & South Bradford & Wellington & Shropshire \\
\hline Atterley & Much Wenlock/Wenlock Magna & Wenlock & 1st/Main & Shropshire \\
\hline Auston & Pontesbury & Ford & Pontesbury & Shropshire \\
\hline Badger & Badger & Wenlock & 2nd/Northeast & Shropshire \\
\hline Bagley & Hordley & Pimhill & Ellesmere & Shropshire \\
\hline Balderton & Middle/Myddle & Pimhill & Ellesmere & Shropshire \\
\hline Barnesley & Worfield & Brimstree & Bridgenorth & Shropshire \\
\hline Barrow & Barrow & Wenlock & 1st/Main & Shropshire \\
\hline Baschurch, Boreatton \& Birch & Baschurch & Pimhill & Baschurch & Shropshire \\
\hline Batch \& Norton & Culmington & Munslow & Upper Munslow & Shropshire \\
\hline Battlefield & Battlefield & Liberties of Shrewsbury & Castle Ward Constablewick & Shropshire \\
\hline Bausley Lower & Alberbury & Deyther \& Caurse & & Montgomery \\
\hline Bausley Upper & Alberbury & Deyther \& Caurse & & Montgomery \\
\hline Bayston & Condover & Condover & Condover & Shropshire \\
\hline Beachfield/Beachford & Worthen, Byn Weston Quarter & Chirbury & Lower Chirbury & Shropshire \\
\hline Bearstone & Muckleston/Muccleston & North Bradford & Drayton & Shropshire \\
\hline Beckbury & Beckbury & Wenlock & 2nd/Northeast & Shropshire \\
\hline Beckjay & Clungunford & Purslow & Stow & Shropshire \\
\hline Bedstone \& Say & Bedstone & Purslow & Stow & Shropshire \\
\hline Belswardine/Belserdine & Leighton & Condover & Condover & Shropshire \\
\hline Bennet's End & Cainham & Stottesdon & Cleobury & Shropshire \\
\hline Benthall & Alberbury & Ford & Ford & Shropshire \\
\hline Benthall & Benthall & Wenlock & 1st/Main & Shropshire \\
\hline Berghill & Whittington & Oswestry & Upper Oswestry & Shropshire \\
\hline
\end{tabular}




\begin{tabular}{|c|c|c|c|c|}
\hline Berrington & Berrington & Condover & Cound & Shropshire \\
\hline Berwich/Berwick/Little Berwick & St. Mary (Shrewsbury) & Liberties of Shrewsbury & Castle Ward Constablewick & Shropshire \\
\hline Berwick Maviston & Atcham & South Bradford & Wellington & Shropshire \\
\hline Besbridge & Claverley & Brimstree & Bridgenorth & Shropshire \\
\hline Besford & Moreton Corbet & Pimhill & Baschurch & Shropshire \\
\hline Betchcott & Smethcott & Condover & Condover & Shropshire \\
\hline Betton & Drayton & North Bradford & Drayton & Shropshire \\
\hline Betton & Atcham & Condover & Cound & Shropshire \\
\hline Betton \& Alkmere & St. Chad & Liberties of Shrewsbury & Stone Ward Constablewick & Shropshire \\
\hline Bettws/Bettus & Bettus & Clun & Mainstone & Shropshire \\
\hline Bickton & Clun & Clun & Clun & Shropshire \\
\hline Bicton \& Calcot & St. Chad & Liberties of Shrewsbury & Welsh Ward Constablewick & Shropshire \\
\hline Billingsley & Billingsley & Stottesdon & Chelmarsh & Shropshire \\
\hline Birch \& Lyth & Ellesmere & Pimhill & Ellesmere & Shropshire \\
\hline Bishop's Castle & Bishop's Castle & Purslow & Bishop's Castle & Shropshire \\
\hline Bitterley & Bitterley & Overs & Overs & Shropshire \\
\hline Black Park & Whitechurch & North Bradford & Whitechurch & Shropshire \\
\hline Blakeway Farm & Harley & Condover & Cound & Shropshire \\
\hline Bletchley & Hodnet & North Bradford & Drayton & Shropshire \\
\hline Blodwell & Llanyblodwell & Oswestry & Upper Oswestry & Shropshire \\
\hline Bloor & Drayton & & & Stafford \\
\hline Bold \& Charlcott & Cleobury North & Stottesdon & Chelmarsh & Shropshire \\
\hline Boningale/Boninghal & Boningale/Boninghall & Brimstree & Shiffnal & Shropshire \\
\hline Booley & Stanton upon Hine Heath & North Bradford & Whitechurch & Shropshire \\
\hline Boreton & Condover & Condover & Condover & Shropshire \\
\hline Boscobel & (Extra-Parochial) & Brimstree & Shiffnal & Shropshire \\
\hline Botevyle & Church Stretton & Munslow & Upper Munslow & Shropshire \\
\hline Bouldon/Boulden & Holdgate & Munslow & Lower Munslow & Shropshire \\
\hline Boycott & Pontesbury & Ford & Pontesbury & Shropshire \\
\hline Bradney & Worfield & Brimstree & Bridgenorth & Shropshire \\
\hline Braggington & Alberbury & Ford & Ford & Shropshire \\
\hline Bratton & Wrockwardine & South Bradford & Wellington & Shropshire \\
\hline Broadstone & Munslow & Munslow & Lower Munslow & Shropshire \\
\hline Broadward & Clungunford & Purslow & Stow & Shropshire \\
\hline Brockton & Sutton Maddock & Brimstree & Shiffnal & Shropshire \\
\hline Brockton & Worthen, Worthen Quarter & Chirbury & Lower Chirbury & Shropshire \\
\hline Brockton & Long Stanton/Stanton Long & Munslow & Lower Munslow & Shropshire \\
\hline Brockton & Lydbury & Purslow & Bishop's Castle & Shropshire \\
\hline Bromfield & Bromfield & Munslow & Lower Munslow & Shropshire \\
\hline Bromley Burcot & Worfield & Brimstree & Bridgenorth & Shropshire \\
\hline Bromlow & Worthen, Bromlow Quarter & Chirbury & Lower Chirbury & Shropshire \\
\hline Brompton & Church Stoke & Chirbury & Upper Chirbury & Shropshire \\
\hline Brompton & Berrington & Condover & Cound & Shropshire \\
\hline Bronnygarth & St. Martin & Oswestry & Upper Oswestry & Shropshire \\
\hline Brookhampton & Holdgate & Munslow & Lower Munslow & Shropshire \\
\hline Broom & Cardington & Condover & Cound & Shropshire \\
\hline Broom \& Rowton & Hopesay & Purslow & Stow & Shropshire \\
\hline Broseley & Broesley & Wenlock & 1st/Main & Shropshire \\
\hline Broughall & Whitechurch & North Bradford & Whitechurch & Shropshire \\
\hline Broughton & Claverley & Brimstree & Bridgenorth & Shropshire \\
\hline Broughton & Broughton & Liberties of Shrewsbury & Castle Ward Constablewick & Shropshire \\
\hline Broughton & Bishop's Castle & Purslow & Bishop's Castle & Shropshire \\
\hline Brunslow/Brownslow & Edgton & Purslow & Stow & Shropshire \\
\hline Brynn & Llanyblodwell & Oswestry & Upper Oswestry & Shropshire \\
\hline Buckton & Bucknell & Purslow & Stow & Shropshire \\
\hline Buildwas & Buildwas & South Bradford & Wellington & Shropshire \\
\hline Bulthey & Alberbury & Ford & Ford & Shropshire \\
\hline Buraston & Burford & Overs & Overs & Shropshire \\
\hline Burcot & Wrockwardine & South Bradford & Wellington & Shropshire \\
\hline Burfield & $\overline{\text { (Extra-Parochial) }}$ & Clun & & Shropshire \\
\hline Burford & Burford & Overs & Overs & Shropshire \\
\hline Burlton & Loppington & Pimhill & Ellesmere & Shropshire \\
\hline Burton & Much Wenlock/Wenlock Magna & Wenlock & 1st/Main & Shropshire \\
\hline Burton/Borton & Berrington & Condover & Cound & Shropshire \\
\hline Burwarton & Burwarton & Stottesdon & Cleobury & Shropshire \\
\hline Burway & Munslow & Munslow & Lower Munslow & Shropshire \\
\hline Byn Weston & Worthen, Byn Weston Quarter & Chirbury & Lower Chirbury & Shropshire \\
\hline Cainham & Cainham & Stottesdon & Cleobury & Shropshire \\
\hline Cakemore & Hales Owen & Brimstree & Hales Owen & Shropshire \\
\hline Callaughton & Much Wenlock/Wenlock Magna & Wenlock & 1st/Main & Shropshire \\
\hline Cantlop & Berrington & Condover & Cound & Shropshire \\
\hline Cardeston & Cardeston & Ford & Ford & Shropshire \\
\hline Cardington & Cardington & Munslow & Upper Munslow & Shropshire \\
\hline Carreghorn & Llanymynech & Oswestry & Upper Oswestry & Shropshire \\
\hline Castle Forgate & St. Alkmond & Liberties of Shrewsbury & Castle Ward Constablewick & Shropshire \\
\hline Castle Forgate & St. Julian & Liberties of Shrewsbury & Castle Ward Constablewick & Shropshire \\
\hline Castle Forgate & St. Mary (Shrewsbury) & Liberties of Shrewsbury & Castle Ward Constablewick & Shropshire \\
\hline Castle Pulverbatch & Church Pulverbatch/Churton & Condover & Condover & Shropshire \\
\hline Castle Ward & St. Alkmond & Liberties of Shrewsbury & Castle Ward Constablewick & Shropshire \\
\hline Castle Ward & St. Mary (Shrewsbury) & Liberties of Shrewsbury & Castle Ward Constablewick & Shropshire \\
\hline Castle Wright & Mainstone & Clun & Mainstone & Shropshire \\
\hline Catstree & Worfield & Brimstree & Bridgenorth & Shropshire \\
\hline Caughley & Barrow & Wenlock & 1st/Main & Shropshire \\
\hline Cause & Westbury & Ford & Ford & Shropshire \\
\hline
\end{tabular}




\begin{tabular}{|c|c|c|c|c|}
\hline Caynton & Edgmond & South Bradford & Newport & Shropshire \\
\hline Charlton/Chorlton & Wrockwardine & South Bradford & Wellington & Shropshire \\
\hline Chatwell & Cardington & Munslow & Upper Munslow & Shropshire \\
\hline Chelmick & Hope Bowdler & Munslow & Upper Munslow & Shropshire \\
\hline Cheney Lougville/China Longville & Wistanstow & Purslow & Stow & Shropshire \\
\hline Cherrington & Edgmond & South Bradford & Newport & Shropshire \\
\hline Cherrington & Great Bolas & South Bradford & Newport & Shropshire \\
\hline Chesterton & Worfield & Brimstree & Bridgenorth & Shropshire \\
\hline Cheswardine & Cheswardine & North Bradford & Drayton & Shropshire \\
\hline Chetton & Chetton & Stottesdon & Chelmarsh & Shropshire \\
\hline Chetwynd & Chetwynd & South Bradford & Newport & Shropshire \\
\hline Chetwynd Aston & Edgmond & South Bradford & Newport & Shropshire \\
\hline Chicknell & Claverley & Brimstree & Bridgenorth & Shropshire \\
\hline Child's Ercall & Ercall Parva/Child's Ercall & North Bradford & Drayton & Shropshire \\
\hline Chilton & Atcham & Condover & Cound & Shropshire \\
\hline Chippenhall & Cheswardine & North Bradford & Drayton & Shropshire \\
\hline Chirbury & Chirbury & Chirbury & Upper Chirbury & Shropshire \\
\hline Church Aston (Chapelry) & Edgmond & South Bradford & Newport & Shropshire \\
\hline Church Pulverbatch & Church Pulverbatch/Churton & Condover & Condover & Shropshire \\
\hline Church Stretton & Church Stretton & Munslow & Upper Munslow & Shropshire \\
\hline Claverball/Cloverley/Corverall & Prees & North Bradford & Whitechurch & Shropshire \\
\hline Claverley & Claverley & Brimstree & Bridgenorth & Shropshire \\
\hline Clay, Felton \& Witbach & Bromfield & Munslow & Lower Munslow & Shropshire \\
\hline Clee St Margaret & Clee St. Margaret & Munslow & Lower Munslow & Shropshire \\
\hline Clee Stanton, Clee Downton \& the Moor & Stoke St. Milborough & Wenlock & 7th/South & Shropshire \\
\hline Cleobury Foreign & Cleobury Mortimer & Stottesdon & Cleobury & Shropshire \\
\hline Cleobury Mortimer & Cleobury Mortimer & Stottesdon & Cleobury & Shropshire \\
\hline Cleobury North & Cleobury North & Stottesdon & Chelmarsh & Shropshire \\
\hline Clewilsey & Llanvair/Llanfair Waterdine & Clun & Mainstone & Shropshire \\
\hline Clive (Chapelry) & St. Mary (Shrewsbury) & Liberties of Shrewsbury & Castle Ward Constablewick & Shropshire \\
\hline Clotley & Wrockwardine & South Bradford & Wellington & Shropshire \\
\hline Clun & Clun & Clun & Clun & Shropshire \\
\hline Clunbury \& Little Brompton & Clunbury & Purslow & Stow & Shropshire \\
\hline Clungunford & Clungunford & Purslow & Stow & Shropshire \\
\hline Clunton & Clunbury & Purslow & Stow & Shropshire \\
\hline Cockshut \& Crosemere & Ellesmere & Pimhill & Ellesmere & Shropshire \\
\hline Cold Hatton & Ercal Magna/High Ercall & South Bradford & Wellington & Shropshire \\
\hline Cold Weston & Cold Weston & Munslow & Lower Munslow & Shropshire \\
\hline Colebatch & Bishop's Castle & Purslow & Bishop's Castle & Shropshire \\
\hline Coleham & Holy Cross \& St. Giles & Liberties of Shrewsbury & Stone Ward Constablewick & Shropshire \\
\hline Coleham & St. Julian & Liberties of Shrewsbury & Stone Ward Constablewick & Shropshire \\
\hline Colemere/Coolmere & Ellesmere & Pimhill & Ellesmere & Shropshire \\
\hline Comley & Cardington & Munslow & Upper Munslow & Shropshire \\
\hline Condover & Condover & Condover & Condover & Shropshire \\
\hline Condover Hamlets & Condover & Condover & Condover & Shropshire \\
\hline Coppice Green & Shiffnal & Brimstree & Shiffnal & Shropshire \\
\hline Copthorn & Bickton & Liberties of Shrewsbury & & Shropshire \\
\hline Corfton & Diddlebury & Munslow & Lower Munslow & Shropshire \\
\hline Corley/Coreley & Corley/Coreley & Stottesdon & Cleobury & Shropshire \\
\hline Cornley & & Munslow & & Shropshire \\
\hline Coston \& Shelderton & Clungunford & Purslow & Stow & Shropshire \\
\hline Coston in Coston \& Shelderton & Clunbury & Purslow & Stow & Shropshire \\
\hline Cothercott & Church Pulverbatch/Churton & Condover & Condover & Shropshire \\
\hline Cotton & Wem & North Bradford & Whitechurch & Shropshire \\
\hline Cotton & Alveley & Liberties of Bridgenorth & & Shropshire \\
\hline Cotton Hill & St. Alkmond & Liberties of Shrewsbury & Castle Ward Constablewick & Shropshire \\
\hline Cotton Hill & St. Julian & Liberties of Shrewsbury & Castle Ward Constablewick & Shropshire \\
\hline Cotton Hill & St. Mary (Shrewsbury) & Liberties of Shrewsbury & Castle Ward Constablewick & Shropshire \\
\hline Cotton, Shottaton \& Shelvocke & Ruyton/Ruyton of 11 Towns & Oswestry & Lower Oswestry & Shropshire \\
\hline Cotwall \& Moor Town & Ercal Magna/High Ercall & South Bradford & Wellington & Shropshire \\
\hline Cound Lower & Cound & Condover & Cound & Shropshire \\
\hline Cound Upper & Cound & Condover & Cound & Shropshire \\
\hline Cradley & Hales Owen & & & Worcester \\
\hline Cressage (Chapelry) & Cound & Condover & Condover & Shropshire \\
\hline Cricket & Ellesmere & Pimhill & Ellesmere & Shropshire \\
\hline Crickheath & Oswestry & Oswestry & Upper Oswestry & Shropshire \\
\hline Criggeon & Alberbury & Deyther \& Caurse & & Montgomery \\
\hline Cronkhill & Atcham & Condover & Cound & Shropshire \\
\hline Cruckmeole \& Arscott & Pontesbury & Ford & Pontesbury & Shropshire \\
\hline Cruckton, Newnham \& Sascott & Pontesbury & Ford & Pontesbury & Shropshire \\
\hline Crudgington & Ercal Magna/High Ercall & South Bradford & Wellington & Shropshire \\
\hline Culmington & Culmington & Munslow & Upper Munslow & Shropshire \\
\hline Cynnynion & Oswestry & Oswestry & Upper Oswestry & Shropshire \\
\hline Dallicote & Claverley & Brimstree & Bridgenorth & Shropshire \\
\hline Darlaston & Prees & North Bradford & Whitechurch & Shropshire \\
\hline Dawley Magna/Great Dawley & Great Dawley & South Bradford & Wellington & Shropshire \\
\hline Dawley Parva/Little Dawley & Great Dawley & South Bradford & Wellington & Shropshire \\
\hline Daywell & Whittington & Oswestry & Upper Oswestry & Shropshire \\
\hline Detton & Neen Savage & Stottesdon & Cleobury & Shropshire \\
\hline Deuxhill & Deuxhill & Wenlock & 6th/East & Shropshire \\
\hline Diddlebury & Diddlebury & Munslow & Lower Munslow & Shropshire \\
\hline Dinchope & Bromfield & Munslow & Lower Munslow & Shropshire \\
\hline Dinmore (adjoins Clungunford) & (Extra-Parochial) & Purslow & Stow & Shropshire \\
\hline Dinthill & St. Alkmond & Liberties of Shrewsbury & Welsh Ward Constablewick & Shropshire \\
\hline
\end{tabular}




\begin{tabular}{|c|c|c|c|c|}
\hline Ditton Priors & Ditton Priors & Wenlock & 1st/Main & Shropshire \\
\hline Doddington & Cleobury Mortimer & Stottesdon & Cleobury & Shropshire \\
\hline Dodington & Whitechurch & North Bradford & Whitechurch & Shropshire \\
\hline Donnington & Donnington & Brimstree & Shiffnal & Shropshire \\
\hline Donnington & Wroxeter & South Bradford & Wellington & Shropshire \\
\hline Dorrington & Condover & Condover & Condover & Shropshire \\
\hline Dorrington & Muckleston/Muccleston & North Bradford & Drayton & Shropshire \\
\hline Dovaston & Kinnerley & Oswestry & Lower Oswestry & Shropshire \\
\hline Dowles & Dowles & Stottesdon & Cleobury & Shropshire \\
\hline Down Rossal & St. Chad & Liberties of Shrewsbury & Welsh Ward Constablewick & Shropshire \\
\hline Downton & Staunton Lacy & Munslow & Lower Munslow & Shropshire \\
\hline Downton & Upton Magna & South Bradford & Wellington & Shropshire \\
\hline Drayton & Shiffnal & Brimstree & Shiffnal & Shropshire \\
\hline Drayton & Drayton & North Bradford & Drayton & Shropshire \\
\hline Duddleston (Lower) & Ellesmere & Oswestry & Upper Oswestry & Shropshire \\
\hline Duddleston (Upper) & Ellesmere & Oswestry & Upper Oswestry & Shropshire \\
\hline Dudlick/Didlick & Stottesdon & Stottesdon & Cleobury & Shropshire \\
\hline Dudmaston & Quat & Stottesdon & Chelmarsh & Shropshire \\
\hline Dudston & Chirbury & Chirbury & Upper Chirbury & Shropshire \\
\hline Eamstry/Emstry & Atcham & Condover & Cound & Shropshire \\
\hline Eardington & Quatford & Stottesdon & Chelmarsh & Shropshire \\
\hline Eardiston \& Yarson & Ruyton/Ruyton of 11 Towns & Oswestry & Lower Oswestry & Shropshire \\
\hline Earnwood & Kinlett & Stottesdon & Cleobury & Shropshire \\
\hline East Hamlets & Staunton Lacy & Munslow & Lower Munslow & Shropshire \\
\hline Easthope & Easthope & Munslow & Lower Munslow & Shropshire \\
\hline Eastwall & Rushbury & Munslow & Upper Munslow & Shropshire \\
\hline Eastwick & Ellesmere & Pimhill & Ellesmere & Shropshire \\
\hline Eaton & Stokes upon Tern & North Bradford & Drayton & Shropshire \\
\hline Eaton & Eaton under Haywood & Wenlock & 5th/West & Shropshire \\
\hline Eaton \& Choulton & Lydbury & Purslow & Bishop's Castle & Shropshire \\
\hline Eaton Constantine & Eaton Constantine & South Bradford & Wellington & Shropshire \\
\hline Eaton Mascott & Berrington & Condover & Cound & Shropshire \\
\hline Ebnall & Whittington & Oswestry & Upper Oswestry & Shropshire \\
\hline Eddicliff & Clun & Clun & Clun & Shropshire \\
\hline Edenhope & Mainstone & Clun & Mainstone & Shropshire \\
\hline Edgboulton & Shawbury & North Bradford & Whitechurch & Shropshire \\
\hline Edge, Lea \& Polmere & Pontesbury & Ford & Pontesbury & Shropshire \\
\hline Edgeley & Whitechurch & North Bradford & Whitechurch & Shropshire \\
\hline Edgerley & Kinnerley & Oswestry & Lower Oswestry & Shropshire \\
\hline Edgeton & Edgton & Purslow & Stow & Shropshire \\
\hline Edgmond & Edgmond & South Bradford & Newport & Shropshire \\
\hline Edstaston (Chapelry) & Wem & North Bradford & Whitechurch & Shropshire \\
\hline Ellerdine & Ercal Magna/High Ercall & South Bradford & Wellington & Shropshire \\
\hline Ellerton & Cheswardine & North Bradford & Drayton & Shropshire \\
\hline Ellesmere & Ellesmere & Pimhill & Ellesmere & Shropshire \\
\hline Elson \& Greenhill & Ellesmere & Pimhill & Ellesmere & Shropshire \\
\hline Enchmarsh & Cardington & Munslow & Upper Munslow & Shropshire \\
\hline English Frankton & Ellesmere & Pimhill & Ellesmere & Shropshire \\
\hline Ensdon & Montford & Pimhill & Baschurch & Shropshire \\
\hline Eudon Burnell & Chetton & Stottesdon & Chelmarsh & Shropshire \\
\hline Eudon George & Chetton & Stottesdon & Chelmarsh & Shropshire \\
\hline Ewdness & Worfield & Brimstree & Bridgenorth & Shropshire \\
\hline Eyten & Baschurch & Pimhill & Baschurch & Shropshire \\
\hline Eyton & Alberbury & Ford & Ford & Shropshire \\
\hline Eyton & Eyton upon the Wildmoors & South Bradford & Wellington & Shropshire \\
\hline Eyton \& Plowden & Lydbury & Purslow & Bishop's Castle & Shropshire \\
\hline Eyton/Dryton/Eyton upon Severn & Wroxeter & South Bradford & Wellington & Shropshire \\
\hline Fareley & Pontesbury & Ford & Pontesbury & Shropshire \\
\hline Farlow (Chapelry) & Stottesdon & & & Hereford \\
\hline Farmcote & Claverley & Brimstree & Bridgenorth & Shropshire \\
\hline Fauls Green & Prees & North Bradford & Whitechurch & Shropshire \\
\hline Felhampton & Wistanstow & Munslow & Upper Munslow & Shropshire \\
\hline Felton Butler & Great Ness & Pimhill & Baschurch & Shropshire \\
\hline Fenemere & Baschurch & Pimhill & Baschurch & Shropshire \\
\hline Fernhill & Whittington & Oswestry & Upper Oswestry & Shropshire \\
\hline Fitchell & Baschurch & Pimhill & Baschurch & Shropshire \\
\hline Fitz, Grafton \& Mytton & Fitz & Pimhill & Baschurch & Shropshire \\
\hline Ford & Ford & Ford & Ford & Shropshire \\
\hline Forest of Hayes & Westbury & Ford & Ford & Shropshire \\
\hline Forton & Whittington & Oswestry & Upper Oswestry & Shropshire \\
\hline Forton & Montford & Pimhill & Baschurch & Shropshire \\
\hline Frankwell & St. Chad & Liberties of Shrewsbury & Welsh Ward Constablewick & Shropshire \\
\hline Frantiler & & Oswestry & & Shropshire \\
\hline Frodesley & Frodesley & Condover & Condover & Shropshire \\
\hline Funnonvair & Llanvair/Llanfair Waterdine & Clun & Mainstone & Shropshire \\
\hline Garmston & Leighton & South Bradford & Wellington & Shropshire \\
\hline Gatacre & Claverley & Brimstree & Bridgenorth & Shropshire \\
\hline Gatten & Ratlinghope & Ford & Ratlinghope* & Shropshire \\
\hline Glazeley & Glazeley & Stottesdon & Chelmarsh & Shropshire \\
\hline Golding & Cound & Condover & Cound & Shropshire \\
\hline Goldstone & Cheswardine & North Bradford & Drayton & Shropshire \\
\hline Gravenhanger & Muckleston/Muccleston & North Bradford & Drayton & Shropshire \\
\hline Great \& Little Berwick & St. Mary (Shrewsbury) & Liberties of Shrewsbury & Castle Ward Constablewick & Shropshire \\
\hline Great Bolas & Great Bolas & South Bradford & Newport & Shropshire \\
\hline
\end{tabular}




\begin{tabular}{|c|c|c|c|c|}
\hline Great Lyth & Condover & Condover & Condover & Shropshire \\
\hline Great Ness & Great Ness & Pimhill & Baschurch & Shropshire \\
\hline Great Ryton & Condover & Condover & Condover & Shropshire \\
\hline Great Sutton & Diddlebury & Munslow & Lower Munslow & Shropshire \\
\hline Greet & Greet & Overs & Overs & Shropshire \\
\hline Gretton & Cardington & Munslow & Upper Munslow & Shropshire \\
\hline Gretton & Rushbury & Munslow & Upper Munslow & Shropshire \\
\hline Grimmer & Worthen, Bromlow Quarter & Chirbury & Lower Chirbury & Shropshire \\
\hline Grindle & Ryton & Brimstree & Shiffnal Hatton Constablewick & Shropshire \\
\hline Grinshill & Grinshill & Liberties of Shrewsbury & Castle Ward Constablewick & Shropshire \\
\hline Guildendown & Clun & Chirbury & (Detatched) & Shropshire \\
\hline Habberley & Habberley & Ford & Pontesbury & Shropshire \\
\hline Habberley & Worthen, Heath Quarter & Ford & Chirbury* & Shropshire \\
\hline Hadley & Wellington & South Bradford & Wellington & Shropshire \\
\hline Hadnal & Middle/Myddle & Liberties of Shrewsbury & Ellesmere* & Shropshire \\
\hline Hales & Drayton & & & Stafford \\
\hline Hales Owen & Hales Owen & Brimstree & Hales Owen & Shropshire \\
\hline Halford/Hatford & Bromfield & Munslow & Lower Munslow & Shropshire \\
\hline Hall Mill & Alberbury & Ford & Ford & Shropshire \\
\hline Hallon & Worfield & Brimstree & Bridgenorth & Shropshire \\
\hline Halstone & (Extra-Parochial) & Oswestry & & Shropshire \\
\hline Hanwood & Hanwood/Great Hanwood & Liberties of Shrewsbury & Welsh Ward Constablewick & Shropshire \\
\hline Harcourt & Stanton upon Hine Heath & North Bradford & Whitechurch & Shropshire \\
\hline Harcourt & Stottesdon & Stottesdon & Cleobury & Shropshire \\
\hline Hardwick & Ellesmere & Pimhill & Ellesmere & Shropshire \\
\hline Hardwick \& Shotton & Middle/Myddle & Liberties of Shrewsbury & Ellesmere* & Shropshire \\
\hline Harley & Harley & Condover & Cound & Shropshire \\
\hline Harlscot & St. Alkmond & Liberties of Shrewsbury & Castle Ward Constablewick & Shropshire \\
\hline Harnage & Cound & Condover & Cound & Shropshire \\
\hline Harrington & Sutton Maddock & Brimstree & Shiffnal Sutton Maddock Constablewick & Shropshire \\
\hline Hasbury & Hales Owen & Brimstree & Hales Owen & Shropshire \\
\hline Haston & Middle/Myddle & Liberties of Shrewsbury & Ellesmere* & Shropshire \\
\hline Hatton & Shiffnal & Brimstree & Shiffnal Hatton Constablewick & Shropshire \\
\hline Hatton & Eaton under Haywood & Wenlock & 5th/West & Shropshire \\
\hline Haughmond \& Haughton & (Extra-Parochial) & South Bradford & Wellington & Shropshire \\
\hline Haughton & Shiffnal & Brimstree & Shiffnal & Shropshire \\
\hline Haughton & West Felton & Oswestry & Lower Oswestry & Shropshire \\
\hline Haughton & Ercal Magna/High Ercall & South Bradford & Wellington & Shropshire \\
\hline Haughton & Upton Magna & South Bradford & Wellington & Shropshire \\
\hline Haughton, Croft \& etc. & Morvield/Morvill & Stottesdon & Chelmarsh & Shropshire \\
\hline Hawkstone & Hodnet & North Bradford & Drayton & Shropshire \\
\hline Hawn & Hales Owen & Brimstree & Hales Owen & Shropshire \\
\hline Hayes & Cardington & Munslow & Upper Munslow & Shropshire \\
\hline Heath (Chapelry) & Stoke St. Milborough & Munslow & Lower Munslow & Shropshire \\
\hline Heath Nether & Worthen, Heath Quarter & Ford & Chirbury* & Shropshire \\
\hline Heath Upper & Worthen, Heath Quarter & Ford & Chirbury* & Shropshire \\
\hline Heathton & Claverley & Brimstree & Bridgenorth & Shropshire \\
\hline Hem/The Hem/Hem Hills & Shiffnal & Brimstree & Shiffnal Hatton Constablewick & Shropshire \\
\hline Hencot & St. Alkmond & Liberties of Shrewsbury & Castle Ward Constablewick & Shropshire \\
\hline Henley & Staunton Lacy & Munslow & Lower Munslow & Shropshire \\
\hline Henlle & Whittington & Oswestry & Upper Oswestry & Shropshire \\
\hline High Ercall & Ercal Magna/High Ercall & South Bradford & Wellington & Shropshire \\
\hline High Hatton & Stanton upon Hine Heath & North Bradford & Whitechurch & Shropshire \\
\hline Higley & Higley & Stottesdon & Chelmarsh & Shropshire \\
\hline Hill Division & Hales Owen & Brimstree & Hales Owen & Shropshire \\
\hline Hilton & Worfield & Brimstree & Bridgenorth & Shropshire \\
\hline Hindford & Whittington & Oswestry & Upper Oswestry & Shropshire \\
\hline Hinstock & Hinstock & North Bradford & Drayton & Shropshire \\
\hline Hinton & Whitechurch & North Bradford & Whitechurch & Shropshire \\
\hline Hinton, Auston \& Farley & Pontesbury & Ford & Pontesbury & Shropshire \\
\hline Hisland & Oswestry & Oswestry & Upper Oswestry & Shropshire \\
\hline Hissington & Hissington & & & Montgomery \\
\hline Hobbaris \& Menutton & Clun & Clun & Clun & Shropshire \\
\hline Hobendrid & Clun & Clun & Clun & Shropshire \\
\hline Hockham/Hoccom & Worfield & Brimstree & Bridgenorth & Shropshire \\
\hline Hockleton & Chirbury & Chirbury & Upper Chirbury & Shropshire \\
\hline Hodnet & Hodnet & North Bradford & Drayton & Shropshire \\
\hline Holdgate & Holdgate & Munslow & Lower Munslow & Shropshire \\
\hline Hollyhurst \& Chinnel & Whitechurch & North Bradford & Whitechurch & Shropshire \\
\hline Holt Preen & Cardington & Condover & Cound & Shropshire \\
\hline Home & Wentnor & Purslow & Bishop's Castle & Shropshire \\
\hline Hope & Worthen, Bromlow Quarter & Chirbury & Lower Chirbury & Shropshire \\
\hline Hope Baggot & Hope Baggot/Baggotshope & Stottesdon & Cleobury & Shropshire \\
\hline Hope Bowdler & Hope Bowdler & Munslow & Upper Munslow & Shropshire \\
\hline Hopesay, Barlow \& Carwood & Hopesay & Purslow & Stow & Shropshire \\
\hline Hopstone & Claverley & Brimstree & Bridgenorth & Shropshire \\
\hline Hopton & Hopton & Munslow & Lower Munslow & Shropshire \\
\hline Hopton & Great Ness & Pimhill & Baschurch & Shropshire \\
\hline Hopton \& Espley & Hodnet & North Bradford & Drayton & Shropshire \\
\hline Hopton \& Hagley & Hopton Castle & Purslow & Stow & Shropshire \\
\hline Hopton Wafers & Hopton Wafers & Stottesdon & Cleobury & Shropshire \\
\hline Horderley (adjoins Edgton) & $\overline{\text { (Extra-Parochial) }}$ & Purslow & Stow & Shropshire \\
\hline Hordley & Hordley & Pimhill & Ellesmere & Shropshire \\
\hline Horton & Wem & North Bradford & Whitechurch & Shropshire \\
\hline
\end{tabular}




\begin{tabular}{|c|c|c|c|c|}
\hline Horton & Eyton upon the Wildmoors & South Bradford & Wellington & Shropshire \\
\hline Howle & Chetwynd & North Bradford & Drayton & Shropshire \\
\hline Howle Gale & & Munslow & & Shropshire \\
\hline Hughley & Hughley & Wenlock & 1st/Main & Shropshire \\
\hline Hungerford \& Millichope & Eaton under Haywood & Wenlock & 5th/West & Shropshire \\
\hline Hunnington & Hales Owen & Brimstree & Hales Owen & Shropshire \\
\hline Hunnington \& Evelith & Shiffnal & Brimstree & Shiffnal Hatton Constablewick & Shropshire \\
\hline Idsall/Shiffnal & Shiffnal & Brimstree & Shiffnal & Shropshire \\
\hline Ightfield & Ightfield & North Bradford & Whitechurch & Shropshire \\
\hline Illey & Hales Owen & Brimstree & Hales Owen & Shropshire \\
\hline Innage & Shiffnal & Brimstree & Shiffnal & Shropshire \\
\hline Isombridge & Ercal Magna/High Ercall & South Bradford & Wellington & Shropshire \\
\hline Iston Rhynn (Lower) & St. Martin & Oswestry & Upper Oswestry & Shropshire \\
\hline Iston Rhynn (Upper) & St. Martin & Oswestry & Upper Oswestry & Shropshire \\
\hline Kemberton & Kemberton & Brimstree & Shiffnal & Shropshire \\
\hline Kempton & Clunbury & Purslow & Stow & Shropshire \\
\hline Kenley & Kenley & Condover & Cound & Shropshire \\
\hline Kenston & Hodnet & North Bradford & Drayton & Shropshire \\
\hline Kenwick Park & Ellesmere & Pimhill & Ellesmere & Shropshire \\
\hline Kenwick Wood & Ellesmere & Pimhill & Ellesmere & Shropshire \\
\hline Kenwick, Stocket \& Whettal & Ellesmere & Pimhill & Ellesmere & Shropshire \\
\hline Ketley & Wellington & South Bradford & Wellington & Shropshire \\
\hline Kevencallonegg & Bettus & Clun & Mainstone & Shropshire \\
\hline Kingslow & Worfield & Brimstree & Bridgenorth & Shropshire \\
\hline Kinlett & Kinlett & Stottesdon & Cleobury & Shropshire \\
\hline Kinnerley \& Argoed & Kinnerley & Oswestry & Lower Oswestry & Shropshire \\
\hline Kinnersley & Kinnersley & South Bradford & Newport & Shropshire \\
\hline Kinnerton & Wentnor & Purslow & Bishop's Castle & Shropshire \\
\hline Kinsley & & Stottesdon & & Shropshire \\
\hline Kinton & Great Ness & Pimhill & Baschurch & Shropshire \\
\hline Knockin & Knockin & Oswestry & Lower Oswestry & Shropshire \\
\hline Kynaston/Kinaston & Kinnerley & Oswestry & Lower Oswestry & Shropshire \\
\hline Lacon & Wem & North Bradford & Whitechurch & Shropshire \\
\hline Lady Halton \& Hill Halton & Bromfield & Munslow & Lower Munslow & Shropshire \\
\hline Langley & Hales Owen & Brimstree & Hales Owen & Shropshire \\
\hline Lapal & Hales Owen & Brimstree & Hales Owen & Shropshire \\
\hline Lawley & Wellington & South Bradford & Wellington & Shropshire \\
\hline Lawton \& Little Sutton & Diddlebury & Munslow & Lower Munslow & Shropshire \\
\hline Lea & Pontesbury & Ford & Pontesbury & Shropshire \\
\hline Lea \& Oakley & Bishop's Castle & Purslow & Bishop's Castle & Shropshire \\
\hline Leake & Westbury & Ford & Ford & Shropshire \\
\hline Leaton & St. Mary (Shrewsbury) & Liberties of Shrewsbury & Castle Ward Constablewick & Shropshire \\
\hline Leaton & Wrockwardine & South Bradford & Wellington & Shropshire \\
\hline Lee & Ellesmere & Pimhill & Ellesmere & Shropshire \\
\hline Lee Brockhurst & Lee Brockhurst & North Bradford & Whitechurch & Shropshire \\
\hline Lee Gromery & Wellington & South Bradford & Wellington & Shropshire \\
\hline Leebotwood & Leebotwood & Condover & Condover & Shropshire \\
\hline Leg Street & Oswestry & Oswestry & Upper Oswestry & Shropshire \\
\hline Leigh & Worthen, Bromlow Quarter & Chirbury & Lower Chirbury & Shropshire \\
\hline Leighton & Leighton & South Bradford & Wellington & Shropshire \\
\hline Leighton & Wolston/Weston, Worthen Quarter & & & Montgomery \\
\hline Lenwardine & & Munslow & & Shropshire \\
\hline Liberty of Rounsley & Alveley & Liberties of Bridgenorth & & Shropshire \\
\hline Lilleshall & Lilleshall & South Bradford & Newport & Shropshire \\
\hline Linches & Westbury & Ford & Ford & Shropshire \\
\hline Lineal & Ellesmere & Pimhill & Ellesmere & Shropshire \\
\hline Linley & More & Purslow & Bishop's Castle & Shropshire \\
\hline Linley & Linley & Wenlock & 1st/Main & Shropshire \\
\hline Little Bolas & Hodnet & North Bradford & Drayton & Shropshire \\
\hline Little Brompton in Clunbury & Hopesay & Purslow & Stow & Shropshire \\
\hline Little Drayton & Drayton & North Bradford & Drayton & Shropshire \\
\hline Little Hanwood & Pontesbury & Liberties of Shrewsbury & Stone Ward Constablewick & Shropshire \\
\hline Little Lyth \& Westley & Condover & Condover & Condover & Shropshire \\
\hline Little Ness & Little Ness & Pimhill & Baschurch & Shropshire \\
\hline Little Ness (Chapelry) & Baschurch & Pimhill & Baschurch & Shropshire \\
\hline Little Stretton & Church Stretton & Munslow & Upper Munslow & Shropshire \\
\hline Llanforda & Oswestry & Oswestry & Upper Oswestry & Shropshire \\
\hline Llanhowell & & Clun & & Shropshire \\
\hline Llanvair/Lanfair & Llanvair/Llanfair Waterdine & Clun & Mainstone & Shropshire \\
\hline Llanyblodwell & Llanyblodwell & Oswestry & Upper Oswestry & Shropshire \\
\hline Llanymynech & Llanymynech & Oswestry & Upper Oswestry & Shropshire \\
\hline Llynkliss/Llunk-Llyss & Llanyblodwell & Oswestry & Upper Oswestry & Shropshire \\
\hline Llyntidmon/Lwyntidmon & Llanymynech & Oswestry & Upper Oswestry & Shropshire \\
\hline Llyntlanan/Lwyntlanan & Llanymynech & Oswestry & Upper Oswestry & Shropshire \\
\hline Llynymon/Lloynymain/Llwynymaen & Oswestry & Oswestry & Upper Oswestry & Shropshire \\
\hline Long/Longdon & Long/Longdon upon Tern & South Bradford & Wellington & Shropshire \\
\hline Longdon Lower & Pontesbury & Ford & Pontesbury & Shropshire \\
\hline Longdon Upper & Pontesbury & Ford & Pontesbury & Shropshire \\
\hline Longford & Hodnet & North Bradford & Drayton & Shropshire \\
\hline Longford & Longford & South Bradford & Newport & Shropshire \\
\hline Longnor & Longnor & Condover & Condover & Shropshire \\
\hline Longslow & Drayton & North Bradford & Drayton & Shropshire \\
\hline Longville, Lushcott \& Eastwall & Eaton under Haywood & Wenlock & 3rd/West & Shropshire \\
\hline Loppington & Loppington & Pimhill & Ellesmere & Shropshire \\
\hline
\end{tabular}




\begin{tabular}{|c|c|c|c|c|}
\hline Loughton (Chapelry) & Chetton & Stottesdon & Chelmarsh & Shropshire \\
\hline Lowe $\&$ Ditches & Wem & North Bradford & Whitechurch & Shropshire \\
\hline Lower Hayton & Staunton Lacy & Munslow & Lower Munslow & Shropshire \\
\hline Lower Ledwitch & Bitterley & Munslow & Lower Munslow & Shropshire \\
\hline Lower Parks & Diddlebury & Munslow & Lower Munslow & Shropshire \\
\hline Ludford & Ludford & & & Hereford \\
\hline Ludlow & St. Lawrence & Ludlow Borough & Broad Street \& Castle Street Ward & Shropshire \\
\hline Ludlow & St. Lawrence & Ludlow Borough & Corve Street Ward & Shropshire \\
\hline Ludlow & St. Lawrence & Ludlow Borough & Old Street Ward & Shropshire \\
\hline Ludstone & Claverley & Brimstree & Bridgenorth & Shropshire \\
\hline Lurkenhope & Stow & Clun & Clun & Shropshire \\
\hline Lutley & Hales Owen & & & Worcester \\
\hline Lutwyche & Rushbury & Munslow & Upper Munslow & Shropshire \\
\hline Lydbury North & Lydbury & Purslow & Bishop's Castle & Shropshire \\
\hline Lydham & Lydham & Purslow & Bishop's Castle & Shropshire \\
\hline Lydleys & Cardington & Munslow & Upper Munslow & Shropshire \\
\hline Lythwood & Condover & Condover & Condover & Shropshire \\
\hline Madeley & Madeley & Wenlock & 1st/Main & Shropshire \\
\hline Maesbrook (Issa) & Kinnerley & Oswestry & Lower Oswestry & Shropshire \\
\hline Maesbrook (Ucha) & Kinnerley & Oswestry & Lower Oswestry & Shropshire \\
\hline Maesbury & Oswestry & Oswestry & Upper Oswestry & Shropshire \\
\hline Mainstone & Mainstone & Clun & Mainstone & Shropshire \\
\hline Malin's Lee & Great Dawley & South Bradford & Wellington & Shropshire \\
\hline Marchamley/Marchomley & Hodnet & North Bradford & Drayton & Shropshire \\
\hline Marrington & Chirbury & Chirbury & Upper Chirbury & Shropshire \\
\hline Marsh \& Wigmore & Westbury & Ford & Ford & Shropshire \\
\hline Marton & Chirbury & Chirbury & Upper Chirbury & Shropshire \\
\hline Marton & Middle/Myddle & Pimhill & Ellesmere & Shropshire \\
\hline Mawley Hall & & Stottesdon & & Shropshire \\
\hline Meadow Town & Worthen, Bromlow Quarter & Chirbury & Lower Chirbury & Shropshire \\
\hline Meadowly & & Stottesdon & & Shropshire \\
\hline Medlicott & Wentnor & Purslow & Bishop's Castle & Shropshire \\
\hline Meeson & Great Bolas & South Bradford & Newport & Shropshire \\
\hline Melverley (Lower) & Melverley/Morfellee & Oswestry & Lower Oswestry & Shropshire \\
\hline Melverley (Upper) & Melverley/Morfellee & Oswestry & Lower Oswestry & Shropshire \\
\hline Menethesney & Llanvair/Llanfair Waterdine & Clun & Mainstone & Shropshire \\
\hline Meole Brace & Meole Brace & Liberties of Shrewsbury & Stone Ward Constablewick & Shropshire \\
\hline Merrington & Preston Gubbals/Gobalds & Liberties of Shrewsbury & Castle Ward Constablewick & Shropshire \\
\hline Mickle Wood & Leebotwood & Condover & Condover & Shropshire \\
\hline Mickley & Prees & North Bradford & Whitechurch & Shropshire \\
\hline Middle/Myddle & Middle/Myddle & Pimhill & Ellesmere & Shropshire \\
\hline Middlehope & Diddlebury & Munslow & Lower Munslow & Shropshire \\
\hline Middleton & Chirbury & Chirbury & Upper Chirbury & Shropshire \\
\hline Middleton & Alberbury & Deyther \& Caurse & & Montgomery \\
\hline Middleton & Oswestry & Oswestry & Upper Oswestry & Shropshire \\
\hline Middleton & Bitterley & Munslow & Lower Munslow & Shropshire \\
\hline Middleton Priors & Ditton Priors & Wenlock & 1st/Main & Shropshire \\
\hline Middleton Scriven & Middleton Scriven & Stottesdon & Chelmarsh & Shropshire \\
\hline Milford & Little Ness & Pimhill & Baschurch & Shropshire \\
\hline Millen Heath & Prees & North Bradford & Whitechurch & Shropshire \\
\hline Milson & Milson & Overs & Overs & Shropshire \\
\hline Mindtown & Mindtown & Purslow & Bishop's Castle & Shropshire \\
\hline Minsterley & Westbury & Ford & Ford & Shropshire \\
\hline Minton & Church Stretton & Munslow & Upper Munslow & Shropshire \\
\hline Minutton & & Clun & & Shropshire \\
\hline Mirebank & Baschurch & Pimhill & Baschurch & Shropshire \\
\hline Monk Hopton & Monk Hopton & Wenlock & 1st/Main & Shropshire \\
\hline Monk Meole \& Gooshill & St. Chad & Liberties of Shrewsbury & Welsh Ward Constablewick & Shropshire \\
\hline Montford & Montford & Pimhill & Baschurch & Shropshire \\
\hline Moor with Batchcot & Richard's Castle & Munslow & Lower Munslow & Shropshire \\
\hline More \& Moreswood & More & Purslow & Bishop's Castle & Shropshire \\
\hline Moreton Corbet & Moreton Corbet & North Bradford & Whitechurch & Shropshire \\
\hline Moreton Say/Sea (Chapelry) & Hodnet & North Bradford & Drayton & Shropshire \\
\hline Morfe & & Liberties of Bridgenorth & & Shropshire \\
\hline Morton \& Moreton (Chapelry) & Oswestry & Oswestry & Lower Oswestry & Shropshire \\
\hline Morvill & Morvield/Morvill & Stottesdon & Chelmarsh & Shropshire \\
\hline Mose & Quat & Stottesdon & Chelmarsh & Shropshire \\
\hline Moston & Stanton upon Hine Heath & North Bradford & Whitechurch & Shropshire \\
\hline Muckleton & Shawbury & North Bradford & Whitechurch & Shropshire \\
\hline Mucklewick & Hissington & Chirbury & Lower Chirbury & Shropshire \\
\hline Munslow & Munslow & Munslow & Lower Munslow & Shropshire \\
\hline Muxton \& Donnington & Lilleshall & South Bradford & Newport & Shropshire \\
\hline Nash & Burford & Overs & Overs & Shropshire \\
\hline Neen Savage & Neen Savage & Stottesdon & Cleobury & Shropshire \\
\hline Neen Solars/Neen Sollers & Neen Solars & Overs & Overs & Shropshire \\
\hline Neenton & Neenton & Stottesdon & Chelmarsh & Shropshire \\
\hline Nesscliff & Great Ness & Pimhill & Baschurch & Shropshire \\
\hline Netley & Stapleton & Condover & Condover & Shropshire \\
\hline New Minton/New Marton & Ellesmere & Pimhill & Ellesmere & Shropshire \\
\hline Newcastle & Clun & Clun & Clun & Shropshire \\
\hline Newnes & Ellesmere & Pimhill & Ellesmere & Shropshire \\
\hline Newport & Newport & South Bradford & Newport & Shropshire \\
\hline Newton & Worfield & Brimstree & Bridgenorth & Shropshire \\
\hline Newton & St. Mary (Shrewsbury) & Liberties of Shrewsbury & Castle Ward Constablewick & Shropshire \\
\hline
\end{tabular}




\begin{tabular}{|c|c|c|c|c|}
\hline Newton \& Edgebold & Meole Brace & Liberties of Shrewsbury & Stone Ward Constablewick & Shropshire \\
\hline Newton \& Merehouse & Baschurch & Pimhill & Baschurch & Shropshire \\
\hline Newton (Chapelry) & Wem & North Bradford & Whitechurch & Shropshire \\
\hline Newton on the Hill & Middle/Myddle & Pimhill & Ellesmere & Shropshire \\
\hline Nobold & Meole Brace & Liberties of Shrewsbury & Stone Ward Constablewick & Shropshire \\
\hline Nonnely & Loppington & Pimhill & Ellesmere & Shropshire \\
\hline Norbury & Norbury & Purslow & Bishop's Castle & Shropshire \\
\hline Nordley Regis & Billingsley & Stottesdon & Chelmarsh & Shropshire \\
\hline Northwood & Wem & North Bradford & Whitechurch & Shropshire \\
\hline Northwood & Ellesmere & Pimhill & Ellesmere & Shropshire \\
\hline Norton & Stockton & Brimstree & Shiffnal & Shropshire \\
\hline Norton & Norton in Hales & North Bradford & Drayton & Shropshire \\
\hline Norton & Wroxeter & South Bradford & Wellington & Shropshire \\
\hline Nox & Pontesbury & Ford & Pontesbury & Shropshire \\
\hline Oaken Gates/Oaken Yates & Shiffnal & Brimstree & Shiffnal & Shropshire \\
\hline Oakes & Pontesbury & Condover & Condover & Shropshire \\
\hline Oatley/Astley, Newton \& Spoonhill & Ellesmere & Pimhill & Ellesmere & Shropshire \\
\hline Obaston & Kinnerley & Oswestry & Lower Oswestry & Shropshire \\
\hline Obley & Clunbury & Clun & Clun & Shropshire \\
\hline Obley & Clunbury & Purslow & Stow & Shropshire \\
\hline Old Marton & Whittington & Oswestry & Upper Oswestry & Shropshire \\
\hline Oldbury & Hales Owen & Brimstree & Hales Owen & Shropshire \\
\hline Oldbury & Oldbury & Stottesdon & Chelmarsh & Shropshire \\
\hline Oldington & Worfield & Brimstree & Bridgenorth & Shropshire \\
\hline Ollerton & Stokes upon Tern & North Bradford & Drayton & Shropshire \\
\hline Onibury & Onibury & Munslow & Lower Munslow & Shropshire \\
\hline Onslow & St. Chad & Liberties of Shrewsbury & Welsh Ward Constablewick & Shropshire \\
\hline Osbaston & Ercal Magna/High Ercall & South Bradford & Wellington & Shropshire \\
\hline Oswestry & Oswestry & Oswestry & Upper Oswestry & Shropshire \\
\hline Overton & Richard's Castle & Munslow & Lower Munslow & Shropshire \\
\hline Overton & Stottesdon & Stottesdon & Cleobury & Shropshire \\
\hline Park's Lane & Claverley & Brimstree & Bridgenorth & Shropshire \\
\hline Parlogue & Clun & Clun & Clun & Shropshire \\
\hline Payne's Lane & Shiffnal & Brimstree & Shiffnal & Shropshire \\
\hline Peeton/Peaton & Diddlebury & Munslow & Lower Munslow & Shropshire \\
\hline Penley & Ellesmere & & & Flint \\
\hline Pentregaer & Oswestry & Oswestry & Upper Oswestry & Shropshire \\
\hline Pentryhodry & Clun & Clun & Clun & Shropshire \\
\hline Peplow & Hodnet & North Bradford & Drayton & Shropshire \\
\hline Petton & Petton & Pimhill & Baschurch & Shropshire \\
\hline Picklescott & Smethcott & Condover & Condover & Shropshire \\
\hline Pickstock & Edgmond & North Bradford & Drayton & Shropshire \\
\hline Pilson & Chetwynd & North Bradford & Drayton & Shropshire \\
\hline Pimley & St. Mary (Shrewsbury) & Liberties of Shrewsbury & Castle Ward Constablewick & Shropshire \\
\hline Pitchford & Pitchford & Condover & Cound & Shropshire \\
\hline Plomere & Pontesbury & Ford & Pontesbury & Shropshire \\
\hline Plox Green & Westbury & Ford & Ford & Shropshire \\
\hline Plush & Cardington & Munslow & Upper Munslow & Shropshire \\
\hline Pontesbury & Pontesbury & Ford & Pontesbury & Shropshire \\
\hline Pontesford, Plealey \& Sibberscott & Pontesbury & Ford & Pontesbury & Shropshire \\
\hline Porkington (Lower) & Sellatyn & Oswestry & Upper Oswestry & Shropshire \\
\hline Porkington (Upper) & Sellatyn & Oswestry & Upper Oswestry & Shropshire \\
\hline Posenhall & (Extra-Parochial) & Wenlock & 1st/Main & Shropshire \\
\hline Poston & Diddlebury & Munslow & Lower Munslow & Shropshire \\
\hline Poston & Munslow & Munslow & Lower Munslow & Shropshire \\
\hline Poynton & Ercal Magna/High Ercall & South Bradford & Wellington & Shropshire \\
\hline Preen/Church Preen & Preen/Church Preen & Condover & Cound & Shropshire \\
\hline Prees & Prees & North Bradford & Whitechurch & Shropshire \\
\hline Prescot & Baschurch & Pimhill & Baschurch & Shropshire \\
\hline Presthope & Much Wenlock/Wenlock Magna & Wenlock & 1st/Main & Shropshire \\
\hline Preston & Preston upon the Wild Moors & South Bradford & Newport & Shropshire \\
\hline Preston Boats & Upton Magna & South Bradford & Wellington & Shropshire \\
\hline Preston Brockhurst & Moreton Corbet & North Bradford & Whitechurch & Shropshire \\
\hline Preston Brockhurst & Shawbury & North Bradford & Whitechurch & Shropshire \\
\hline Preston Brockhurst & Moreton Corbet & Pimhill & Baschurch & Shropshire \\
\hline Preston Gubbles/Gobalds & Preston Gubbals/Gobalds & Liberties of Shrewsbury & Castle Ward Constablewick & Shropshire \\
\hline Preston Montford & St. Alkmond & Liberties of Shrewsbury & Welsh Ward Constablewick & Shropshire \\
\hline Priest Weston & Chirbury & Chirbury & Upper Chirbury & Shropshire \\
\hline Priors Halton & Bromfield & Munslow & Lower Munslow & Shropshire \\
\hline Priors Lee (Chapelry) & Shiffnal & Brimstree & Shiffnal & Shropshire \\
\hline Puleston & Edgmond & North Bradford & Drayton & Shropshire \\
\hline Pulley & Meole Brace & Liberties of Shrewsbury & Stone Ward Constablewick & Shropshire \\
\hline Pulley & St. Julian & Liberties of Shrewsbury & Stone Ward Constablewick & Shropshire \\
\hline Quat & Quat & Stottesdon & Chelmarsh & Shropshire \\
\hline Quat Jarvis & Quat & Liberties of Bridgenorth & & Shropshire \\
\hline Quat Jarvis & Quat & Stottesdon & Chelmarsh & Shropshire \\
\hline Quat Malvern & Quat & Stottesdon & Chelmarsh & Shropshire \\
\hline Ragdon & Hope Bowdler & Munslow & Upper Munslow & Shropshire \\
\hline Ratlinghope & Ratlinghope & Purslow & Bishop's Castle & Shropshire \\
\hline Rednall & West Felton & Oswestry & Lower Oswestry & Shropshire \\
\hline Reilth & Mainstone & Clun & Mainstone & Shropshire \\
\hline Rewins Farm & Worthn & Chirbury & Lower Chirbury & Shropshire \\
\hline Rhiston & Church Stoke & Chirbury & Upper Chirbury & Shropshire \\
\hline Rhitton & Shelve & Chirbury & Lower Chirbury & Shropshire \\
\hline
\end{tabular}




\begin{tabular}{|c|c|c|c|c|}
\hline Rhos Goch & Wolston/Weston, Worthen Quarter & & & Montgomery \\
\hline Ridgacre & Hales Owen & Brimstree & Hales Owen & Shropshire \\
\hline Ridge, Upper \& Lower & Ellesmere & Pimhill & Ellesmere & Shropshire \\
\hline Rindleford & Worfield & Brimstree & Bridgenorth & Shropshire \\
\hline Rocke & Staunton Lacy & Munslow & Lower Munslow & Shropshire \\
\hline Roden & Ercal Magna/High Ercall & South Bradford & Wellington & Shropshire \\
\hline Rodington & Rodington & South Bradford & Wellington & Shropshire \\
\hline Romsley & Hales Owen & Brimstree & Hales Owen & Shropshire \\
\hline Rorrington & Chirbury & Chirbury & Upper Chirbury & Shropshire \\
\hline Roughton & Worfield & Brimstree & Bridgenorth & Shropshire \\
\hline Rowley & Worfield & Brimstree & Bridgenorth & Shropshire \\
\hline Rowton & Alberbury & Ford & Ford & Shropshire \\
\hline Rowton & Ercal Magna/High Ercall & South Bradford & Wellington & Shropshire \\
\hline Ruckley \& Langley (Chapelry) & Acton Burnel & Condover & Cound & Shropshire \\
\hline Rudge & Pattingham & Stottesdon & Chelmarsh & Shropshire \\
\hline Rugantin & Bettus & Clun & Mainstone & Shropshire \\
\hline Rushbury & Rushbury & Munslow & Upper Munslow & Shropshire \\
\hline Rushton & Wroxeter & South Bradford & Wellington & Shropshire \\
\hline Ruthall \& Ashfield & Priors Ditton & Munslow & Lower Munslow & Shropshire \\
\hline Ruyton & Ruyton/Ruyton of 11 Towns & Oswestry & Lower Oswestry & Shropshire \\
\hline Rye, Felton \& Burway & Bromfield & Munslow & Lower Munslow & Shropshire \\
\hline Ryton & Ryton & Brimstree & Shiffnal & Shropshire \\
\hline Sambrook & Cheswardine & North Bradford & Drayton & Shropshire \\
\hline Sandford & Prees & North Bradford & Whitechurch & Shropshire \\
\hline Sandford & West Felton & Oswestry & Upper Oswestry & Shropshire \\
\hline Sansaw & St. Mary (Shrewsbury) & Liberties of Shrewsbury & Castle Ward Constablewick & Shropshire \\
\hline Scute Church & Ratlinghope & Purslow & Bishop's Castle & Shropshire \\
\hline Sellatyn & Sellatyn & Oswestry & Upper Oswestry & Shropshire \\
\hline Selley & Llanvair/Llanfair Waterdine & Clun & Mainstone & Shropshire \\
\hline Shadwell & Clun & Clun & Clun & Shropshire \\
\hline Sharwardine & Sharwardine & Pimhill & Baschurch & Shropshire \\
\hline Shavington & Adderley & North Bradford & Drayton & Shropshire \\
\hline Shaw & Shiffnal & Brimstree & Shiffnal & Shropshire \\
\hline Shawbury & Shawbury & North Bradford & Whitechurch & Shropshire \\
\hline Sheet & Ludford & Stottesdon & Cleobury & Shropshire \\
\hline Shelderton & Clungunford & Munslow & Lower Munslow & Shropshire \\
\hline Shelton \& Oxon & St. Chad & Liberties of Shrewsbury & Welsh Ward Constablewick & Shropshire \\
\hline Shelton \& Oxon & St. Julian & Liberties of Shrewsbury & Welsh Ward Constablewick & Shropshire \\
\hline Shelve & Shelve & Chirbury & Lower Chirbury & Shropshire \\
\hline Shinton & Shineton & Stottesdon & Chelmarsh & Shropshire \\
\hline Shipley & Claverley & Brimstree & Bridgenorth & Shropshire \\
\hline Shipley \& Rudge & Claverley & Brimstree & Bridgenorth & Shropshire \\
\hline Shipton & Shipton & Wenlock & 4th/West & Shropshire \\
\hline Sibdon & Sibdon Castle & Purslow & Stow & Shropshire \\
\hline Sidbury & Sidbury & Stottesdon & Chelmarsh & Shropshire \\
\hline Siefton & Culmington & Munslow & Upper Munslow & Shropshire \\
\hline Silvington \& Cleeton & Silvington & Overs & Overs & Shropshire \\
\hline Skyborrah & Llanvair/Llanfair Waterdine & Clun & Mainstone & Shropshire \\
\hline Sleap & Wem & North Bradford & Whitechurch & Shropshire \\
\hline Sleap & Middle/Myddle & Pimhill & Ellesmere & Shropshire \\
\hline Sleap & Ercal Magna/High Ercall & South Bradford & Wellington & Shropshire \\
\hline Smethcot & Middle/Myddle & Liberties of Shrewsbury & Ellesmere* & Shropshire \\
\hline Smethcott & Smethcott & Condover & Condover & Shropshire \\
\hline Snitton & Bitterley & Stottesdon & Cleobury & Shropshire \\
\hline Sonde & Worfield & Brimstree & Bridgenorth & Shropshire \\
\hline Soudley & Cheswardine & North Bradford & Drayton & Shropshire \\
\hline Soughton & Llansilin & Oswestry & Upper Oswestry & Shropshire \\
\hline Soulton & Wem & North Bradford & Whitechurch & Shropshire \\
\hline Sparchford & Diddlebury & Munslow & Lower Munslow & Shropshire \\
\hline Spoad & Clun & Clun & Clun & Shropshire \\
\hline Spoonley & Adderley & North Bradford & Drayton & Shropshire \\
\hline St. John's & Ellesmere & Pimhill & Ellesmere & Shropshire \\
\hline St. Kenelen Chapel & Hales Owen & Brimstree & Hales Owen & Shropshire \\
\hline St. Martin & St. Martin & Oswestry & Upper Oswestry & Shropshire \\
\hline Stableford & Worfield & Brimstree & Bridgenorth & Shropshire \\
\hline Stanford & Edgmond & South Bradford & Newport & Shropshire \\
\hline Stanlow & Worfield & Brimstree & Bridgenorth & Shropshire \\
\hline Stanton & Stanton upon Hine Heath & North Bradford & Whitechurch & Shropshire \\
\hline Stanton Long & Long Stanton/Stanton Long & Munslow & Lower Munslow & Shropshire \\
\hline Stanton/Stoneton & Shiffnal & Brimstree & Shiffnal & Shropshire \\
\hline Stanwardine in the Fields & Baschurch & Pimhill & Baschurch & Shropshire \\
\hline Stanwardine in the Wood & Baschurch & Pimhill & Baschurch & Shropshire \\
\hline Stanway \& Wilderhope & Rushbury & Munslow & Upper Munslow & Shropshire \\
\hline Stapleton \& the Hamlets & Stapleton & Condover & Condover & Shropshire \\
\hline Staunton Lacy & Staunton Lacy & Munslow & Lower Munslow & Shropshire \\
\hline Steel & Prees & North Bradford & Whitechurch & Shropshire \\
\hline Steventon \& Holdgate's Fee & Ludford & Stottesdon & Cleobury & Shropshire \\
\hline Stirchley & Stirchley & South Bradford & Wellington & Shropshire \\
\hline Stitt & Ratlinghope & Purslow & Bishop's Castle & Shropshire \\
\hline Stocks \& Coptiviney & Ellesmere & Pimhill & Ellesmere & Shropshire \\
\hline Stockton & Stockton & Brimstree & Shiffnal & Shropshire \\
\hline Stockton & Chirbury & Chirbury & Upper Chirbury & Shropshire \\
\hline Stockton & Longford & South Bradford & Newport & Shropshire \\
\hline Stoke & Stokes upon Tern & North Bradford & Drayton & Shropshire \\
\hline
\end{tabular}




\begin{tabular}{|c|c|c|c|c|}
\hline Stoke & Burford & Overs & Overs & Shropshire \\
\hline Stoke Say \& Newton & Stoke Say & Munslow & Lower Munslow & Shropshire \\
\hline Stoke St. Milborough & Stoke St. Milborough & Wenlock & 7th/South & Shropshire \\
\hline Stone Acton & Rushbury & Munslow & Upper Munslow & Shropshire \\
\hline Stone Burley & Culmington & Munslow & Upper Munslow & Shropshire \\
\hline Stone Ward & St. Alkmond & Liberties of Shrewsbury & Stone Ward Constablewick & Shropshire \\
\hline Stone Ward & St. Chad & Liberties of Shrewsbury & Stone Ward Constablewick & Shropshire \\
\hline Stone Ward & St. Julian & Liberties of Shrewsbury & Stone Ward Constablewick & Shropshire \\
\hline Stottesdon & Stottesdon & Stottesdon & Cleobury & Shropshire \\
\hline Stow \& Weston & Stow & Purslow & Stow & Shropshire \\
\hline Strefford & Wistanstow & Munslow & Upper Munslow & Shropshire \\
\hline Stretton & Westbury & Ford & Ford & Shropshire \\
\hline Styche \& Woodlands & Hodnet & North Bradford & Drayton & Shropshire \\
\hline Sugdon & Rodington & South Bradford & Wellington & Shropshire \\
\hline Sundorn & (Extra-Parochial) & South Bradford & Wellington & Shropshire \\
\hline Sutton & Sutton & Liberties of Shrewsbury & Stone Ward Constablewick & Shropshire \\
\hline Sutton & Drayton & North Bradford & Drayton & Shropshire \\
\hline Sutton & West Felton & Oswestry & Lower Oswestry & Shropshire \\
\hline Sutton & Claverley & Brimstree & Bridgenorth & Shropshire \\
\hline Sutton Maddock & Sutton Maddock & Brimstree & Shiffnal Sutton Maddock Constablewick & Shropshire \\
\hline Swancote & Worfield & Brimstree & Bridgenorth & Shropshire \\
\hline Sweeney & Oswestry & Oswestry & Upper Oswestry & Shropshire \\
\hline Tasley & Tasley & Stottesdon & Chelmarsh & Shropshire \\
\hline Teddesmere/Tedsmere & West Felton & Oswestry & Lower Oswestry & Shropshire \\
\hline Tern & Ercal Magna/High Ercall & South Bradford & Wellington & Shropshire \\
\hline Tetchill & Ellesmere & Pimhill & Ellesmere & Shropshire \\
\hline Thonglands & Munslow & Munslow & Lower Munslow & Shropshire \\
\hline Tibberton (Chapelry) & Edgmond & South Bradford & Newport & Shropshire \\
\hline Ticklerton & Eaton under Haywood & Wenlock & 5th/West & Shropshire \\
\hline Tilley & Wem & North Bradford & Whitechurch & Shropshire \\
\hline Tilsop & Burford & Overs & Overs & Shropshire \\
\hline Tilstock & Whitechurch & North Bradford & Whitechurch & Shropshire \\
\hline Timbirth & Chirbury & Chirbury & Upper Chirbury & Shropshire \\
\hline Tir y Coed & Kinnerley & Oswestry & Lower Oswestry & Shropshire \\
\hline Tong & Tong & Brimstree & Shiffnal & Shropshire \\
\hline Totterton & Lydbury & Purslow & Bishop's Castle & Shropshire \\
\hline Treberth & Llanvair/Llanfair Waterdine & Clun & Mainstone & Shropshire \\
\hline Trebrodier & Bettus & Clun & Mainstone & Shropshire \\
\hline Trefarclawdd & Oswestry & Oswestry & Upper Oswestry & Shropshire \\
\hline Treflach & Oswestry & Oswestry & Upper Oswestry & Shropshire \\
\hline Trefnant & Alberbury & Ford & Ford & Shropshire \\
\hline Trefonnen & Oswestry & Oswestry & Upper Oswestry & Shropshire \\
\hline Trelystan & Wolston/Weston, Worthen Quarter & & & Montgomery \\
\hline Trench & Ellesmere & Pimhill & Ellesmere & Shropshire \\
\hline Treprennal & Llanymynech & Oswestry & Lower Oswestry & Shropshire \\
\hline Treverward & Clun & Clun & Clun & Shropshire \\
\hline Twyford & West Felton & Oswestry & Upper Oswestry & Shropshire \\
\hline Uckington & Atcham & South Bradford & Wellington & Shropshire \\
\hline Uffington & Uffington & South Bradford & Wellington & Shropshire \\
\hline Up Rossal/The Isle & St. Chad & Liberties of Shrewsbury & Welsh Ward Constablewick & Shropshire \\
\hline Upper Hayton & Staunton Lacy & Munslow & Lower Munslow & Shropshire \\
\hline Upper Parks & Diddlebury & Munslow & Lower Munslow & Shropshire \\
\hline Uppington & Alberbury & Deyther \& Caurse & & Montgomery \\
\hline Uppington & Uppington & South Bradford & Wellington & Shropshire \\
\hline Upton & Shiffnal & Brimstree & Shiffnal & Shropshire \\
\hline Upton Cresset & Upton Cresset & Stottesdon & Chelmarsh & Shropshire \\
\hline Upton Magna & Upton Magna & South Bradford & Wellington & Shropshire \\
\hline Vennington & Westbury & Ford & Ford & Shropshire \\
\hline Walcot & Chirbury & Chirbury & Upper Chirbury & Shropshire \\
\hline Walcot & Wellington & South Bradford & Wellington & Shropshire \\
\hline Walford & Baschurch & Pimhill & Baschurch & Shropshire \\
\hline Wall under Haywood & Rushbury & Munslow & Upper Munslow & Shropshire \\
\hline Wallop & Westbury & Ford & Ford & Shropshire \\
\hline Walton & Worthen, Byn Weston Quarter & Chirbury & Lower Chirbury & Shropshire \\
\hline Walton & Onibury & Munslow & Lower Munslow & Shropshire \\
\hline Walton & Ercal Magna/High Ercall & South Bradford & Wellington & Shropshire \\
\hline Walton & Stottesdon & Stottesdon & Cleobury & Shropshire \\
\hline Walton & Much Wenlock/Wenlock Magna & Wenlock & 1st/Main & Shropshire \\
\hline Warley & Hales Owen & Brimstree & Hales Owen & Shropshire \\
\hline Warley Wigorn & Hales Owen & & & Worcester \\
\hline Waters Upton & Waters Upton & South Bradford & Wellington & Shropshire \\
\hline Wattlesborough & Alberbury & Ford & Ford & Shropshire \\
\hline Wattlesborough & Cardeston & Ford & Ford & Shropshire \\
\hline Wellington & Wellington & South Bradford & Wellington & Shropshire \\
\hline Welsh Frankton & Whittington & Oswestry & Upper Oswestry & Shropshire \\
\hline Welsh Ward & St. Chad & Liberties of Shrewsbury & Welsh Ward Constablewick & Shropshire \\
\hline Welshhampton & Welshhampton & Pimhill & Ellesmere & Shropshire \\
\hline Welshhampton Wood & Ellesmere & Pimhill & Ellesmere & Shropshire \\
\hline Wem & Wem & North Bradford & Whitechurch & Shropshire \\
\hline Wenlock & Much Wenlock/Wenlock Magna & Wenlock & 1st/Main & Shropshire \\
\hline Wenlock Parva/Little Wenlock & Wenlock Parva/Little Wenlock & Wenlock & 1st/Main & Shropshire \\
\hline Wentnor & Wentnor & Purslow & Bishop's Castle & Shropshire \\
\hline West Felton & West Felton & Oswestry & Lower Oswestry & Shropshire \\
\hline West Hamlets & Staunton Lacy & Munslow & Lower Munslow & Shropshire \\
\hline
\end{tabular}




\begin{tabular}{|c|c|c|c|c|}
\hline Westbury & Westbury & Ford & Ford & Shropshire \\
\hline Westhope (Chapelry) & Diddlebury & Munslow & Lower Munslow & Shropshire \\
\hline Westley/Winsley & Westbury & Ford & Ford & Shropshire \\
\hline Weston & Burford & Overs & Overs & Shropshire \\
\hline Weston \& Oxenbold & Monk Hopton & Wenlock & 1st/Main & Shropshire \\
\hline Weston \& Wixhill under Red Castle (Chapelry) & Hodnet & North Bradford & Drayton & Shropshire \\
\hline Weston Cotton & Oswestry & Oswestry & Upper Oswestry & Shropshire \\
\hline Weston Lullingfield & Baschurch & Pimhill & Baschurch & Shropshire \\
\hline Weston Rhynn (Lower) & St. Martin & Oswestry & Upper Oswestry & Shropshire \\
\hline Weston Rhynn (Upper) & St. Martin & Oswestry & Upper Oswestry & Shropshire \\
\hline Wetherton/Wotherton & Chirbury & Chirbury & Upper Chirbury & Shropshire \\
\hline Whethill/Wheathill & Whethill/Wheathill & Stottesdon & Cleobury & Shropshire \\
\hline Whetmore & Burford & Overs & Overs & Shropshire \\
\hline Whettleton & Stoke Say & Munslow & Lower Munslow & Shropshire \\
\hline Whitcott \& Hardwick & Norbury & Purslow & Bishop's Castle & Shropshire \\
\hline Whitcott Evan & Clun & Clun & Clun & Shropshire \\
\hline Whitcott Keyset & Clun & Clun & Clun & Shropshire \\
\hline Whitechurch & Whitechurch & North Bradford & Whitechurch & Shropshire \\
\hline Whitley \& Welbach & St. Chad & Liberties of Shrewsbury & Stone Ward Constablewick & Shropshire \\
\hline Whittemore & Bobbington & Brimstree & Bridgenorth & Shropshire \\
\hline Whittingslow & Wistanstow & Munslow & Upper Munslow & Shropshire \\
\hline Whittington & Whittington & Oswestry & Upper Oswestry & Shropshire \\
\hline Whitton & Westbury & Ford & Ford & Shropshire \\
\hline Whitton (Chapelry) & Burford & Overs & Overs & Shropshire \\
\hline Whixall & Prees & North Bradford & Whitechurch & Shropshire \\
\hline Wigwig, Homer \& Harley & Much Wenlock/Wenlock Magna & Wenlock & 1st/Main & Shropshire \\
\hline Wikey & Ruyton/Ruyton of 11 Towns & Oswestry & Lower Oswestry & Shropshire \\
\hline Wilcot & Great Ness & Pimhill & Baschurch & Shropshire \\
\hline Wilderley & Church Pulverbatch/Churton & Condover & Condover & Shropshire \\
\hline Willaston & Prees & North Bradford & Whitechurch & Shropshire \\
\hline Willey & Willey & Wenlock & 1st/Main & Shropshire \\
\hline Wilmington & Chirbury & Chirbury & Upper Chirbury & Shropshire \\
\hline Wilston & Cardington & Munslow & Upper Munslow & Shropshire \\
\hline Winnington & Alberbury & Ford & Ford & Shropshire \\
\hline Winsbury & Chirbury & Chirbury & Upper Chirbury & Shropshire \\
\hline Winscote & Worfield & Brimstree & Bridgenorth & Shropshire \\
\hline Wirswall & Whitechurch & & & Cheshire \\
\hline Wistanstow & Wistanstow & Munslow & Upper Munslow & Shropshire \\
\hline Wistanstow \& Woolston & Wistanstow & Purslow & Stow & Shropshire \\
\hline Wistanswick & Stokes upon Tern & North Bradford & Drayton & Shropshire \\
\hline Withington & Withington & South Bradford & Wellington & Shropshire \\
\hline Wollascot & St. Mary (Shrewsbury) & Liberties of Shrewsbury & Castle Ward Constablewick & Shropshire \\
\hline Wollaston & Alberbury & Ford & Ford & Shropshire \\
\hline Wolstaston & Wolstaston & Condover & Condover & Shropshire \\
\hline Wolverley & Wem & North Bradford & Whitechurch & Shropshire \\
\hline Wombridge & Wombridge & South Bradford & Wellington & Shropshire \\
\hline Woodbatch & Bishop's Castle & Purslow & Bishop's Castle & Shropshire \\
\hline Woodcot & Sheriff Hales & South Bradford & Newport & Shropshire \\
\hline Woodcote \& Horton & St. Chad & Liberties of Shrewsbury & Welsh Ward Constablewick & Shropshire \\
\hline Woodhouse & Shiffnal & Brimstree & Shiffnal & Shropshire \\
\hline Woodhouses (New) & Whitechurch & North Bradford & Whitechurch & Shropshire \\
\hline Woodhouses (Old) & Whitechurch & North Bradford & Whitechurch & Shropshire \\
\hline Woodseaves & Drayton & North Bradford & Drayton & Shropshire \\
\hline Woodside \& Lizard & Shiffnal & Brimstree & Shiffnal & Shropshire \\
\hline Woollerton & Hodnet & North Bradford & Drayton & Shropshire \\
\hline Woolston & West Felton & Oswestry & Upper Oswestry & Shropshire \\
\hline Woolverton/Wooferton & Richard's Castle & Munslow & Lower Munslow & Shropshire \\
\hline Woore (Chapelry) & Muckleston/Muccleston & North Bradford & Drayton & Shropshire \\
\hline Wooton & Oswestry & Oswestry & Upper Oswestry & Shropshire \\
\hline Wootton & Staunton Lacy & Munslow & Lower Munslow & Shropshire \\
\hline Worfield & Worfield & Brimstree & Bridgenorth & Shropshire \\
\hline Worthen & Worthen, Worthen Quarter & Chirbury & Lower Chirbury & Shropshire \\
\hline Woundwall/Wondwall & Claverley & Brimstree & Bridgenorth & Shropshire \\
\hline Wrentnall & Church Pulverbatch/Churton & Condover & Condover & Shropshire \\
\hline Wrickton \& Walkersrow & Stottesdon & Stottesdon & Cleobury & Shropshire \\
\hline Wrockwardine & Wrockwardine & South Bradford & Wellington & Shropshire \\
\hline Wrockwardine Wood & Wrockwardine & South Bradford & Wellington & Shropshire \\
\hline Wroxeter & Wroxeter & South Bradford & Wellington & Shropshire \\
\hline Wyke & Shiffnal & Brimstree & Shiffnal Hatton Constablewick & Shropshire \\
\hline Wyke \& Bradley & Much Wenlock/Wenlock Magna & Wenlock & 1st/Main & Shropshire \\
\hline Wyken & Worfield & Brimstree & Bridgenorth & Shropshire \\
\hline Wytheford (Great) & Shawbury & North Bradford & Whitechurch & Shropshire \\
\hline Wytheford (Little) & Shawbury & North Bradford & Whitechurch & Shropshire \\
\hline Yeaton & Baschurch & Pimhill & Baschurch & Shropshire \\
\hline Yockleton & Westbury & Ford & Ford & Shropshire \\
\hline \multirow[t]{9}{*}{ Yorton } & Broughton & Liberties of Shrewsbury & Castle Ward Constablewick & Shropshire \\
\hline & Quatford & Liberties of Bridgenorth & & Shropshire \\
\hline & St. Leonard & Liberties of Bridgenorth & & Shropshire \\
\hline & St. Mary Magdalen & Liberties of Bridgenorth & & Shropshire \\
\hline & Bucknell & & & Hereford \\
\hline & Llansilin & & & Denbigh \\
\hline & Llanymynech & & & Denbigh \\
\hline & Lydham & & & Montgomery \\
\hline & Mainstone & & & Montgomery \\
\hline
\end{tabular}




\begin{tabular}{|l|c|l|l|l|}
\hline & Muckleston/Muccleston & & & Stafford \\
\hline & Pattingham & & Stafford \\
\hline & Richard's Castle & & Hereford \\
\hline & Sheriff Hales & & & Staford \\
\hline
\end{tabular}




\section{APPENDIX THREE \\ WELSH LEGAL MANUSCRIPTS}

\section{Iorwerth}

A - Peniarth 29

B - BL Cotton Titus D II

C - BL Cotton Caligula A III

D - Peniarth 32

E - BL Additional 14931

G - Peniarth 35

K - Peniarth 40

Lew - Peniarth 39

\section{Blegywryd}

I - Peniarth 38

J - Jesus College, Oxford, MS LVII

L - BL Cotton Titus D IX

$\mathrm{M}$ - Peniarth 33

$\mathrm{N}$ - Peniarth 36B

O - Peniarth 36A

$\mathrm{P}$ - Peniarth 259A

Q - Wynnstay 36

$\mathrm{R}$ - Peniarth 31

$\mathrm{S}-\mathrm{BL}$ Additional 22356

$\mathrm{T}$ - Harleian 958

Tim - Llanstephan 116

$\mathrm{Tr}$ - Trinity College Cambridge 1329

Llan - Llanstephan 29

Bost - LlGC 24029A

Ep - Peniarth 258

\section{Cyfnerth}

Mk - Bodorgan Manuscript

U - Peniarth 37

V - Harleian 4353

W - Cotton Cleopatra A XIV

X - Cotton Cleopatra B V

Y - NLW 20143A

Z - Peniarth 259B

\section{Lladin}

Lat A - Peniarth 28

Lat B - Cotton Vespasian E XI 1

Lat C - Harleian 1796

Lat D - Rawlinson C 821

Lat E - Corpus Christi College, Cambridge 454

\section{Arall}

Colan - Peniarth 30

F - Peniarth 34

$\mathrm{H}$ - Peniarth 164

As - Peniarth 175

Mor - Peniarth 36C 


\section{APPENDIX FOUR \\ THE ROLL OF THE SHROPSHIRE EYRE OF 1256 DEMOGRAPHIC DATABASE ${ }^{235}$}

Appendix Four contains the record of every individual and court case listed in The Roll of the Shropshire Eyre of 1256, a collection of more than 2700 entries. These are sorted by name and then by location and are identified as either civil or criminal cases. Each entry includes the role of the individual, be it that of plaintiff, defendant, perpetrator, or witness. Some individuals are listed multiple times because of their involvement in multiple cases and inquiries. This data from the Shropshire Eyre has enabled me estimate the percentage of Welsh individuals in Shropshire in 1256 and to demonstrate that many Shropshire communities were home to both English and Welsh peoples. Welsh individuals are marked in gray.

${ }^{235}$ Harding, The Roll of the Shropshire Eyre of 1256. 


\begin{tabular}{|c|c|c|c|c|c|}
\hline Name & Role & Conc. Location & Type of Case & Entry No & Parish \\
\hline A certain poor Welshman & Victim & Wydicote & Misadventure & No. 799 & Brimstree \\
\hline Abbot of Buildwas & Defendant & Bridgenorth & Entry & No. 215 & \\
\hline \begin{tabular}{|l} 
Abbot of Buildwas \\
\end{tabular} & Defendant & Cressage & Novel Disseisin & No. 91 & \\
\hline \begin{tabular}{|l} 
Abbot of Buildwas \\
\end{tabular} & Plaintiff & Kinnerton & Judgement & No. 508 & Purslow \\
\hline Abbot of Buildwas & Pledge & & Executed & No. 788 & Condover \\
\hline \begin{tabular}{|l} 
Abbot of Buildwas \\
\end{tabular} & Pledge & & Fine & No. 871 & Bridgenorth \\
\hline Abbot of Buildwas & & & Appoint Attorney & No. 69 & \\
\hline Abbot of Combermere & Defendant & Drayton & Novel Disseisin & No. 27 & \\
\hline Abbot of Croxden & & & Appoint Attorney & No. 173 & \\
\hline Abbot of Croxden & & & Compromise & No. 118 & \\
\hline Abbot of Croxdon & & & Custom \& Services & No. 434 & \\
\hline Abbot of Hales & Accused & & Custom \& Services & No. 646 & Hales \\
\hline Abbot of Hales & Accused & & Imprisonment & No. 648 & Hales \\
\hline Abbot of Hales & Accused & & Extortion & No. 647 & Hales \\
\hline Abbot of Haughmond & (mention) & Clive \& Haughton & Nuisance & No. 95 & \\
\hline Abbot of Haughmond & Defendant & Leebotwood & Dower & No. 85 & \\
\hline Abbot of Haughmond & Defendant & Shrewsbury & Entry & No. 290 & \\
\hline Abbot of Haughmond & Plaintiff & Fitz & Custom \& Services & No. 339 & \\
\hline Abbot of Lilleshall & Defendant & Atcham in Berwick & Novel Disseisin & No. 327 & \\
\hline Abbot of Lilleshall & Defendant & Wrockwardine & Novel Disseisin & No. 156 & \\
\hline Abbot of Lilleshall & Defendant & Tern/Sleap \& Turn & Nuisance & No. 277 & \\
\hline Abbot of Lilleshall & Defendant & Smethcote & Seisin @ Death & No. 209 & \\
\hline Abbot of Lilleshall & Plaintiff & Tong Wood \& Grange @ Lizard & Nuisance & No. 111 & \\
\hline \begin{tabular}{|l|} 
Abbot of Lilleshall \\
\end{tabular} & & & Compromise & No. 165 & \\
\hline Abbot of Lilleshall & & & Compromise & No. 76 & \\
\hline Abbot of Lilleshall & & Uckington & Perambulation & No. 352 & \\
\hline Abbot of Shrewsbury & (mention) & Loton & Seisin @ Death & No. 14 & \\
\hline Abbot of Shrewsbury & (mention) & Shrewsbury & Seisin @ Death & No. 309 & \\
\hline Abbot of Shrewsbury & Accused & Shrewsbury & Custom \& Services & No. 864 & Bridgenorth \\
\hline Abbot of Shrewsbury & Defendant & & Custom \& Services & No. 296 & \\
\hline Abbot of Shrewsbury & Defendant & Tunstall & Dower & No. 312 & \\
\hline Abbot of Shrewsbury & Defendant & Foregate & Mort d'Ancestor & No. 274 & \\
\hline Abbot of Shrewsbury & Defendant & Ridgwardine & Novel Disseisin & No. 318 & \\
\hline Abbot of Shrewsbury & Defendant & Shrewsbury & Seisin @ Death & No. 101 & \\
\hline Abbot of Shrewsbury & Plaintiff & & Custom \& Services & No. 319 & \\
\hline Abbot of Shrewsbury & Plaintiff & Ridgwardine & Entry & No. 283 & \\
\hline Abbot of Shrewsbury & Plaintiff & Ruckley & Novel Disseisin & No. 226 & \\
\hline Abbot of Shrewsbury & Plaintiff & Tern/Sleap \& Turn & Nuisance & No. 277 & \\
\hline Abbot of Welshpool & Accused & & Default & No. 834 & Ford \\
\hline \begin{tabular}{|l|} 
Abbot of Wigmore \\
\end{tabular} & (mention) & Ellastone & Seisin @ Death & No. 77 & \\
\hline \begin{tabular}{|l|} 
Abbot of Wigmore \\
\end{tabular} & Defendant & Walford & Entry & No. 90 & \\
\hline \begin{tabular}{|l|} 
Abbot of Wigmore \\
\end{tabular} & Plaintiff & Walford \& Wigmore & Nuisance & No. 270 & \\
\hline \begin{tabular}{|l|} 
Abbot of Wigmore \\
\end{tabular} & & & Compromise & No. 45 & \\
\hline Absolon of Upham & Attorney & & Novel Disseisin & No. 267 & \\
\hline Adam Aldrebald & Accused & Chetwynd & Murder & No. 715 & Bradford \\
\hline Adam Berde & Defendant & Woofferton & Seisin @ Death & No. 33 & \\
\hline Adam Bishop & Accused & & Theft/Absconded & No. 723 & Bradford \\
\hline Adam Black of Longford & Pledge & & Assault & No. 743 & Bradford \\
\hline Adam Blake & Accused & & Default & No. 518 & Purslow \\
\hline Adam Brenhend & Defendant & Charlton & Novel Disseisin & No. 121 & \\
\hline \begin{tabular}{|l|} 
Adam Chirin \\
\end{tabular} & Defendant & Chetwynd & Novel Disseisin & No. 110 & \\
\hline Adam Cory & Accused & & Theft & No. 552 & Stottesdon \\
\hline Adam Cyrecok [Ceiriog] & Accused & & Execution/Murder & No. 552 & Stottesdon \\
\hline Adam Diveri of Prees & Pledge & Prees & Theft & No. 786 & Condover \\
\hline \begin{tabular}{|l|} 
Adam Edrich \\
\end{tabular} & Defendant & Chetwynd & Novel Disseisin & No. 110 & \\
\hline \begin{tabular}{|l|} 
Adam Fat of Lee in Wombridge \\
\end{tabular} & Accused & Dawley & Murder & No. 735 & Bradford \\
\hline Adam Huberd & Accused & & Absconded & No. 540 & Overs \\
\hline Adam Hubert & Accused & & Absconded & No. 796 & Condover \\
\hline Adam Mestling & Accused & & Absconded & No. 812 & Brimstree \\
\hline Adam of Acton & Defendant & Down & Novel Disseisin & No. 56 & \\
\hline Adam of Arundel & Victim & Clunbury & Misadventure & No. 490 & Purslow \\
\hline Adam of Buerton & Victim & Gravenhunger & Murder & No. 675 & Bradford \\
\hline Adam of Eudon & Warrenty & Walford & Entry & No. 90 & \\
\hline Adam of Faintree & Juror & Lawton & Novel Disseisin & No. 473 & \\
\hline \begin{tabular}{|l|} 
Adam of Haughton \\
\end{tabular} & Pledge & Bridgenorth & Entry & No. 215 & \\
\hline Adam of Kent & Accused & & Murder & No. 892 & Shrewsbury \\
\hline Adam of Kingswood & Accused & & Execution & No. 564 & Stottesdon \\
\hline Adam of Norton & Victim & Norton & Murder & No. 716 & Bradford \\
\hline Adam of Preston & Defendant & Preston & Novel Disseisin & No. 107 & \\
\hline Adam of Soudley & Accused & & Theft & No. 750 & Bradford \\
\hline Adam of Stanway & Accused & & Theft & No. 601 & Munslow \\
\hline \begin{tabular}{|l} 
Adam of Stokesay \\
\end{tabular} & Defendant & Sheet \& Wettleton \& Stokesay & Seisin @ Death & No. 99 & \\
\hline Adam of Walton s. Gilbert Charcoalburner & Accused & Wootton & Murder & No. 654 & Stanton \\
\hline Adam of Whitelaw & Bailiff & Bradford & Theft & No. 756 & Bradford \\
\hline Adam Paynel & Attorney & & Plea of Covenant & No. 233 & \\
\hline Adam Peacock & Defendant & Diddlebury & Novel Disseisin & No. 152 & \\
\hline Adam Plamer & Defendant & Chetwynd & Novel Disseisin & No. 110 & \\
\hline Adam Poitevin & Accused & Kenley & Execution/Murder & No. 777 & Condover \\
\hline Adam Pollard of Lee & Court Official & Donnington & Nuisance & No. 331 & \\
\hline Adam Pride of Shrewsbury & Pledge & Preston & Novel Disseisin & No. 107 & \\
\hline Adam Provost of Edgmond & Defendant & Chetwynd & Novel Disseisin & No. 110 & \\
\hline Adam s. Brown of Norton & Payer & & Fine & No. 878 & Bridgenorth \\
\hline Adam s. David & Defendant & Sheet \& Wettleton \& Stokesay & Seisin @ Death & No. 99 & \\
\hline Adam s. Emma & Attorney & & Plea of Land & No. 206 & \\
\hline Adam s. Isabel d. Robert of Pembroke & Defendant & Bayston & Novel Disseisin & No. 208 & \\
\hline Adam s. John & Plaintiff & Tyrley & Novel Disseisin & No. 280 & \\
\hline \begin{tabular}{|l|} 
Adam s. John of Stretton \\
\end{tabular} & Accused & Stretton & Murder/Absconded & No. 598 & Munslow \\
\hline Adam s. Margaret & Accused & & Murder & No. 740 & Bradford \\
\hline Adam s. Nicholas & Victim & Chelmick, Hope Bowdler, West Wall \& Acton & Murder/Assault & No. 606 & Munslow \\
\hline Adam s. Peter of Calverhall & Plaintiff & Calverhall & Novel Disseisin & No. 74 & \\
\hline
\end{tabular}




\begin{tabular}{|c|c|c|c|c|c|}
\hline Adam s. Peter of Calverhall & Plaintiff & Claverhall & Novel Disseisin & No. 157 & \\
\hline Adam s. Philip of Charlton & Accused & Charlton, Walcot \& Uckington & Murder & No. 688 & Bradford \\
\hline \begin{tabular}{|l|} 
Adam s. Robert Beadle of Preen \\
\end{tabular} & Accused & & Assault & No. 794 & Condover \\
\hline Adam s. Roger of Ness & Accused & Ness & Murder & No. 845 & Pimhill \\
\hline Adam s. Roger of Sheinton & Pledge & & Assault & No. 791 & Condover \\
\hline Adam s. Thomas & Plaintiff & Shrewsbury & Entry & No. 237 & \\
\hline \begin{tabular}{|l|} 
Adam s. Thomas of Idsall \\
\end{tabular} & Accused & & Theft & No. 810 & Brimstree \\
\hline Adam s. William & & & Compromise & No. 143 & \\
\hline \begin{tabular}{|l|} 
Adam s. William of Hope \\
\end{tabular} & Pledge & Wigwig & Murder & No. 784 & Condover \\
\hline \begin{tabular}{|l|} 
Adam s. William of Leighton \\
\end{tabular} & Plaintiff & Leighton & Mort d'Ancestor & No. 4 & \\
\hline Adam s. Wolurich of Whixall & Pledge & & Murder & No. 753 & Bradford \\
\hline Adam Serjeant & Defendant & Atcham in Berwick & Novel Disseisin & No. 327 & \\
\hline Adam Smathelin of Newport & Accused & & Absconded & No. 812 & Brimstree \\
\hline \begin{tabular}{|l|} 
Adam Stonecutter \\
\end{tabular} & Accused & Longslow, Drayton \& Longford & Theft/Execution & No. 722 & Bradford \\
\hline Adam Toke & Accused & Newport & Murder & No. 759 & Edgmond \\
\hline \begin{tabular}{|l} 
Adam Turner \\
\end{tabular} & Accused/Pledge & Newport \& the Weald & Rape & No. 739 & Bradford \\
\hline Adam Wade & Defendant & Rodenhurst & Nuisance & No. 22 & \\
\hline Adam Wele of Overs & Pledge & Milson & Novel Disseisin & No. 258 & \\
\hline \begin{tabular}{|l|} 
Adam Wrekessame \\
\end{tabular} & Accused & & Murder & No. 742 & Bradford \\
\hline Adam, a Welshman & Victim & Lee & Misadventure & No. 797 & Brimstree \\
\hline \begin{tabular}{|l|} 
Adam, Priest of Norton \\
\end{tabular} & Accused & & Theft & No. 749 & Bradford \\
\hline Adan Wele & Juror & & & No. 910 & Overs \\
\hline Adeline & (mention) & Gravenhunger & Seisin @ Death & No. 82 & \\
\hline Adeline wd. Benedict Baker & Plaintiff & Shrewsbury & Entry & No. 349 & \\
\hline Adeline wd. Benedict Baker & & & Custom \& Services & No. 480 & \\
\hline \begin{tabular}{|l|} 
Agatha d. Isabel \& Luke Beadle \\
\end{tabular} & (mention) & Foregate & Dower & No. 298 & \\
\hline Agnes d. Adam Hunter & Plaintiff & Gravenhunger & Seisin @ Death & No. 82 & \\
\hline Agnes d. Adam Mason of Wrockwardine & Accuser & Newport \& the Weald & Rape & No. 739 & Bradford \\
\hline Agnes d. Joceus Frend \& w. Walter of The Marsh & Plaintiff & Chelmick & Seisin@ Death & No. 52 & \\
\hline Agnes d. John de Bracy & Plaintiff & Abdon & Novel Disseisin & No. 73 & \\
\hline Agnes d. Margery, a widow of Berrington & Accuser & & Rape & No. 792 & Condover \\
\hline Agnes d. Richard of Overton $+d$. Gillian & Defendant & Overton & Entry & No. 41 & \\
\hline Agnes d. Walter of Steventon & Plaintiff & Ludlow & Entry & No. 108 & \\
\hline \begin{tabular}{|l} 
Agnes de Bracy d. John de Bracy \\
\end{tabular} & Plaintiff & Abdon & Right & No. 288 & \\
\hline Agnes Kylewyne & Accused & & Theft & No. 671 & Wenlock \\
\hline Agnes of Ledwich & Plaintiff & & Novel Disseisin & No. 10 & \\
\hline Agnes of Pulley & Victim & Lyth wood & Murder & No. 893 & Shrewsbury \\
\hline Agnes w. Henry of Wyrley & Plaintiff & Calverhall & Novel Disseisin & No. 74 & \\
\hline \begin{tabular}{|l|} 
Agnes W. John of Preston \\
\end{tabular} & Plaintiff & Preston & Novel Disseisin & No. 107 & \\
\hline Agnes w. Martin Kempe & & & Compromise & No. 294 & \\
\hline Agnes w. Martin Kempe & & & Compromise & No. 324 & \\
\hline Agnes w. Peter de Sascy & & & Compromise & No. 238 & \\
\hline Agnes w. Peter de Sascy & & & Plea of Debt & No 205 & \\
\hline \begin{tabular}{|l} 
Agnes w. Rees of Overton [Rhys] \\
\end{tabular} & (mention) & Overton & Entry & No. 41 & \\
\hline Agnes w. Richard Hooper & & & Compromise & No. 243 & \\
\hline Agnes w. Robert Welsh & & & Compromise & No. 165 & \\
\hline Agnes wd. Geoffrey of Ledwich & Plaintiff & Moreton & Novel Disseisin & No. 216 & \\
\hline \begin{tabular}{|l|} 
Agnes wd. Thomas s. Richard \\
\end{tabular} & Plaintiff & Gravenhunger & Dower & No. 117 & \\
\hline Agnes wd. Warin of Tedstill & Accuser & Tedstill & Unlawful Entry & No. 566 & Stottesdon \\
\hline Alan Conerur & Defendant & Ellastone & Seisin @ Death & No. 77 & \\
\hline Alan Corbet of Haston & Pledge & Espley & Novel Disseisin & No. 470 & \\
\hline Alan de Castello b. Alice wd. Reginald de Gaugy & Accused & & Theft/Harbor & No. 863 & Bridgenorth \\
\hline \begin{tabular}{|l|} 
Alan Fox of Isombridge \\
\end{tabular} & Accused & & Murder & No. 731 & Bradford \\
\hline Alan Harper & Defendant & Upton & Novel Disseisin & No. 29 & \\
\hline Alan of Amaston & Pledge & Amaston & Novel Disseisin & No. 272 & \\
\hline \begin{tabular}{|l|} 
Alan of Bluntesbur \\
\end{tabular} & Accused & & Theft & No. 810 & Brimstree \\
\hline Alan of Buildwas & Defendant & Posenhall & Novel Disseisin & No. 223 & \\
\hline Alan of Buildwas & & & & No. 265 & \\
\hline Alan of Eudon & Pledge & Neen Savage & Novel Disseisin & No. 2 & \\
\hline \begin{tabular}{|l|} 
Alan of Tibberton \\
\end{tabular} & Victim & & Murder & No. 764 & Edgmond \\
\hline Alan of Wrickton & Victim & Wrickton & Murder & No. 555 & Stottesdon \\
\hline Alan s. Alan & Plaintiff & Foregate & Mort d'Ancestor & No. 274 & \\
\hline \begin{tabular}{|l|} 
Alan s. Robert \\
\end{tabular} & & & Compromise & No. 143 & \\
\hline Alan s. Stephen & Defendant & Shrewsbury & Entry & No. 329 & \\
\hline Alan s. William of Bridgenorth & Accused & Bridgenorth & Murder & No. 936 & Bridgenorth \\
\hline Alan s. William of Pattingham & Accused & Ruckley grange & Murder & No. 807 & Brimstree \\
\hline Alan s. Wydo & & & Compromise & No. 133 & \\
\hline Aldith of Bridgenorth, boy of 2yrs & Victim & Bridgenorth & Misadventure & No. 868 & Bridgenorth \\
\hline Aldith s. Stephen s. Osbert Harper \& Alice w. Roger Wain & Plaintiff & Corfton & Seisin @ Death & No. 137 & \\
\hline \begin{tabular}{|l|} 
Aldith wd. William Miller \\
\end{tabular} & Accuser & & Murder & No. 824 & Chirbury \\
\hline Alexander Bosse & Plaintiff & Drayton & Novel Disseisin & No. 27 & \\
\hline Alexander Cantrich & Victim & Dawley & Murder & No. 735 & Bradford \\
\hline Alexander of The Heath & Defendant & The Heath & Novel Disseisin & No. 230 & \\
\hline Alfred de Boys & Accuser & & Corruption & No. 649 & Hales \\
\hline Alfred Lubbe & Witness & Ludlow & Murder & No. 576 & Munslow \\
\hline Alice Blunde & Defendant & Lydbury & Dower & No. 44 & \\
\hline Alice Chaumpeneys & (mention) & & Theft & No. 793 & Condover \\
\hline Alice Chaumpeneys & Witness & Shrewsbury & Imprisonment & No. 738 & Bradford \\
\hline Alice d. Felice of Burton & Victim & Burton & Misadventure & No. 783 & Condover \\
\hline Alice d. Isabel d. Ellis s. Hervey \& n. Avice w. Robert Bykedune & (mention) & Leighton & Entry & No. 246 & \\
\hline Alice d. Robert of Longville & Victim & Wilderhope, Lake, East Wall \& Stanway & Misadventure & No. 605 & Munslow \\
\hline Alice d. Simon & Plaintiff & Corfton & Novel Disseisin & No. 105 & \\
\hline Alice d. Warin + Alice d. Pain & Plaintiff & Wenlock & Seisin @ Death & No. 36 & \\
\hline Alice d. William & Plaintiff & Shrewsbury & Novel Disseisin & No. 330 & \\
\hline Alice d. William \& s. Ida & Plaintiff & Shrewsbury & Right & No. 278 & \\
\hline Alice d. William \& s. Ida & & & AppointAttorney & No. 281 & \\
\hline Alice Meyle & Defendant & Sheet \& Wettleton \& Stokesay & Seisin @ Death & No. 99 & \\
\hline Alice of Allscote & Accused & Ludlow \& Worfield & Murder & No. 935 & Bridgenorth \\
\hline \begin{tabular}{|l|} 
Alice of Preen \\
\end{tabular} & & & Compromise & No. 325 & \\
\hline Alice of Tibberton & Accused & & Murder & No. 763 & Edgmond \\
\hline Alice s. Richard \& m. Margery (d. Willaim Arnold) & (mention) & Weston & Entry & No. 16 & \\
\hline
\end{tabular}




\begin{tabular}{|c|c|c|c|c|c|}
\hline Alice s. Susan Attelegh & Plaintiff & Legh & Entry & No. 333 & \\
\hline Alice w. Adam s. William & & & Compromise & No. 143 & \\
\hline Alice w. John Bracy & & & AppointAttorney & No. 203 & \\
\hline Alice w. John Croucher & Plaintiff & Pole & Entry & No. 305 & \\
\hline Alice w. Richard of Lake & Witness & Welbach, Asterley, Westley \& Minsterley & Murder & No. 774 & Condover \\
\hline Alice w. Richard Yongebonde & Plaintiff & Donnington & Entry & No. 17 & \\
\hline Alice w. Roger Wain \& s. Stephen s. Osbert Harper \& Aldith & Plaintiff & Corfton & Seisin @ Death & No. 137 & \\
\hline Alice w. Thomas of Beckbury \& wd. John of Beckbury & Plaintiff & Nobold, Beckbury \& Golding & Dower & No. 162 & \\
\hline Alice w. Thomas of Sambrook & & & AppointAttorney & No. 70 & \\
\hline Alice w. Thomas of Sambrook & & & Compromise & No. 69 & \\
\hline Alice w. William of Roden & Plaintiff & Pulley & Novel Disseisin & No. 148 & \\
\hline Alice w. William the Smith & Victim & fields of Woodcote & Misadventure & No. 724 & Bradford \\
\hline Alice wd. Edward Atechire & Plaintiff & Shear & Dower & No. 104 & \\
\hline Alice wd. Reginald de Gaugy & Accused & & Murder & No. 933 & Bridgenorth \\
\hline Alice wd. Reginald de Gaugy & Accused & & Theft/Harbor & No. 863 & Bridgenorth \\
\hline Alice wd. Reginald of Oaks & Plaintiff & Prescott & Dower & No. 124 & \\
\hline \begin{tabular}{|l|} 
Alice wd. Warin Child \\
\end{tabular} & Plaintiff & Shrewsbury & Entry & No. 290 & \\
\hline Alice/Cecily w. Richard Smith & Plaintiff & Calverhall & Novel Disseisin & No. 74 & \\
\hline Almaric Dyer & Pledge & Bridgenorth & Murder & No. 936 & Bridgenorth \\
\hline Amaric the dyer of Bridgenorth & Accused & & Theft & No. 865 & Bridgenorth \\
\hline Amice d. Richard Bullig & Victim & river Roden & Misadventure & No. 699 & Bradford \\
\hline Amice w. Robert de Lacy & & & AppointAttorney & No. 205 & \\
\hline Amice w. Robert de Lacy & & & Compromise & No. 238 & \\
\hline Amice w. William Page & Defendant & Aston & Dower & No. 149 & \\
\hline Amice w. William Page & & & AppointAttorney & No. 183 & \\
\hline Amilan of Broseley & Pledge & Wenlock & Mort d'Ancestor & No. 89 & \\
\hline Andrew s. Nicholas of Willey & (mention) & Cressage & Wardship & No. 130 & \\
\hline Angret w. Attast Hochepot [Angharad] & Defendant & Colebatch & Seisin @ Death & No. 23 & \\
\hline Anora of Ercall, s. Cecilia of Ercall & & & Compromise & No. 59 & \\
\hline Arnold Atestope & (mention) & Habberley \& Nethercote & Entry & No. 247 & \\
\hline Arnold of Berkeley & (mention) & Diddlebury & Novel Disseisin & No. 152 & \\
\hline \begin{tabular}{|l|} 
Arnold of Berkeley \\
\end{tabular} & Accused & & Default & No. 535 & Overs \\
\hline \begin{tabular}{|l|} 
Arnold of Berkeley \\
\end{tabular} & Defendant & Whatmore & Novel Disseisin & No. 317 & \\
\hline Arnold of Berkeley & & & Novel Disseisin & No. 196 & \\
\hline Arnold of Brookhampton & Accused & Castle Holdgate & Theft & No. 592 & Munslow \\
\hline Attast Hochepot & Defendant & Colebatch & Seisin @ Death & No. 23 & \\
\hline Aumger s. Clement & Defendant & Eudon & Entry & No. 154 & \\
\hline Aurice w. John le Poer & Plaintiff & Amaston & Novel Disseisin & No. 272 & \\
\hline Aurice w. John le Poer & & & AppointAttorney & No. 200 & \\
\hline Aveline wd. Roger s. Alewy & Defendant & Bagley & Seisin @ Death & No. 86 & \\
\hline Avice w. Hugh s. James & & & Compromise & No. 301 & \\
\hline Avice w. John le Poer & Defendant & Yockleton \& Amaston & Praecipe in Capite & No. 128 & \\
\hline Avice w. Robert Bykedune \& d. Ellis s. Hervey \& s. Isabel & Plaintiff & Leighton & Entry & No. 246 & \\
\hline Avice w. Robert de Lacy & Warrenty & Spoonhill, Manor of & Seisin @ Death & No. 126 & \\
\hline Avice w. Robert of Bicton & Plaintiff & Leighton & Entry & No. 302 & \\
\hline Avice wd. William Goldsmith & Plaintiff & Wheathill & Dower & No. 257 & \\
\hline Baldwin of Montgomery & Warrenty & Chelmick & Seisin @ Death & No. 52 & \\
\hline Baldwin of Westbury & Pledge & & Rape & No. 542 & Worthen \\
\hline Benedict Bond of Ledwich & Pledge & Moreton & Novel Disseisin & No. 217 & \\
\hline Benedict Locksmith & Accused & & Murder & No. 894 & Shrewsbury \\
\hline Benedict of Dudhill & Defendant & Loughton & Novel Disseisin & No. 251 & \\
\hline Bertram & Victim & Hinton, Lilleshall, Brockton \& Little Hales & Murder & No. 686 & Bradford \\
\hline Bertram de Burgh & Defendant & Lee & Custom \& Services & No. 161 & \\
\hline Bertram de Burgh & Defendant & Lee & Mort d'Ancestor & No. 219 & \\
\hline Bertram de Burgh & Pledge & & Fine & No. 661 & Wenlock \\
\hline Bishop of Coventry & (mention) & St. Mary's & Assault & No. 901 & Shrewsbury \\
\hline Bishop of Coventry & (mention) & & Murder & No. 934 & Bridgenorth \\
\hline Bishop of Coventry & (mention) & & Murder/Harbor & No. 861 & Bridgenorth \\
\hline Bishop of Coventry & (mention) & [inside Welshry] & Theft & No. 857 & Pimhill \\
\hline Bishop of Coventry \& Lichfield & (mention) & Legh & Entry & No. 333 & \\
\hline Bishop of Hereford & (mention) & Lydbury & Dower & No. 44 & \\
\hline Bishop of Hereford & Accused & & Default & No. 514 & Purslow \\
\hline Bishop of Worcester & (mention) & Marton & Seisin @ Death & No. 256 & \\
\hline Brian of Brampton & Court Official & & At Mercy & No. 43 & \\
\hline Brian of Brampton & Court Official & & Perambulation & No. 351 & \\
\hline Brian of Brampton & Payer & & Execution & No. 564 & Stottesdon \\
\hline Brice of Cleobury [ap Rhys] & Defendant & The Bold & Dower & No. 211 & \\
\hline Brice of Cleobury [ap Rhys] & Juror & Lawton & Novel Disseisin & No. 473 & \\
\hline Brother Cadigan [Cadwgan] & Victim & Severn & Misadventure & No. 826 & Ford \\
\hline Brown of Norton & Accused & & Theft & No. 750 & Bradford \\
\hline Brown s. Adam s. Brown of Norton & Pledge & & Fine & No. 878 & Bridgenorth \\
\hline Burga of Willey & Defendant & & Wardship & No. 130 & \\
\hline Burga of Willey & & & AppointAttorney & No. 202 & \\
\hline Cadigan of Mucklewick [Cadwgan] & Victim & Broughton & Murder & No. 502 & Purslow \\
\hline Cadigan s. Eynon of Hinton [Cadwgan] [Einion] & Pledge & & Trespass/Force & No. 742 & Bradford \\
\hline Cecilia d. Joceus Frend \& w. Philip s. Bernard Crofton & Plaintiff & Chelmick & Seisin @ Death & No. 52 & \\
\hline Cecilia of Ercall, s. Anora of Ercall & & & Compromise & No. 59 & \\
\hline Cecily d. Richard s. Osbert \& s. Margery of Halton & Plaintiff & Woofferton & Right & No. 332 & \\
\hline Cecily English & & & AppointAttorney & No. 184 & \\
\hline Cecily English & & & Compromise & No. 83 & \\
\hline Cecily w. Richard of Pimley & Defendant & Pimley, Manor of & Novel Disseisin & No. 145 & \\
\hline Cecily w. Simon Miller of Broadward & First Finder & Clungenford, Broadward, Jay \& Beckjay & Murder & No. 488 & Purslow \\
\hline Christine d. Richard s. Osbert \& s. Margery of Halton & Plaintiff & Woofferton & Right & No. 332 & \\
\hline Christine w. Nicholas of Haselour & Plaintiff & Sheet & Novel Disseisin & No. 328 & \\
\hline Christine w. Robert of Hardwick & First Finder & Uppington & Misadventure & No. 681 & Bradford \\
\hline Christine w. Roger Croucher & Victim & Bletchley & Murder & No. 714 & Bradford \\
\hline Christine w. Roger French & Attorney & & Plea of Land & No. 180 & \\
\hline Clemence wd. William of Whitechurch & Accuser & Whitechurch & Murder/Force/Incitement & No. 742 & Bradford \\
\hline Clement of Nantwich & Accused & & Trespass/Force & No. 742 & Bradford \\
\hline Coleman le Blund of Ludlow $n$. Coleman of Ludlow & Plaintiff & Sheet \& Wettleton \& Stokesay & Seisin @ Death & No. 99 & \\
\hline Coleman le Blund of Ludlow $n$. Coleman of Ludlow & & & Appoint Attorney & No. 182 & \\
\hline
\end{tabular}




\begin{tabular}{|c|c|c|c|c|c|}
\hline Coleman of Ludlow & Accused & Ludlow & Theft & No. 579 & Munslow \\
\hline Coleman of Ludlow & Defendant & Sheet & Novel Disseisin & No. 328 & \\
\hline Coleman the White & Defendant & Whettleton, Stokesay \& Steventon & Custom \& Services & No. 347 & \\
\hline Coleman White of Ludlow & Payer & & Fine & No. 503 & Purslow \\
\hline \begin{tabular}{|l|} 
Colin s. David [Collen] [Dafydd] \\
\end{tabular} & Witness & Ludlow & Murder & No. 576 & Munslow \\
\hline Constantine of Diddlebury & Accused & & Default & No. 635 & Corfton \\
\hline Conyn of Hope [Conan] & Accused & Cornewood & Murder & No. 531 & Overs \\
\hline Daniel s. Madoc Was [Madog] & Victim & & Murder & No. 753 & Bradford \\
\hline Daniel s. Yewan [leuan] & Victim & Whixall & Murder & No. 720 & Bradford \\
\hline David Blake & Defendant & Diddlebury & Novel Disseisin & No. 152 & \\
\hline David Blake & Victim & Whixall & Execution/Murder & No. 719 & Bradford \\
\hline David Bollyn & Defendant & Amaston & Novel Disseisin & No. 272 & \\
\hline \begin{tabular}{|l|} 
David Bollyn \\
\end{tabular} & & & Novel Disseisin & No. 200 & \\
\hline David Crakewein & Witness & Wigwig & Murder & No. 784 & Condover \\
\hline David of Marchamley & Pledge & Marchamley & Theft & No. 786 & Condover \\
\hline David of Montgomery & Juror & & & No. 924 & Foregate \\
\hline David of Montgomery [Dafydd] & Defendant & Foregate & Dower & No. 298 & \\
\hline David of Montgomery of the Monks' Forgate [Dafydd] & Pledge & Monks' Forgate & Novel Disseisin & No. 61 & \\
\hline David of Stockton [Dafydd] & Juror & & & No. 912 & Chirbury \\
\hline David s. Alexander of Bradeshull [Dafydd] & Pledge & Tedstill & Unlawful Entry & No. 566 & Stottesdon \\
\hline \begin{tabular}{|l|} 
David s. Eynon [Dafydd] [Einion] \\
\end{tabular} & Accused & Chirbury & Murder & No. 818 & Chirbury \\
\hline David s. Henry & Plaintiff & Woodhouse & Novel Disseisin & No. 159 & \\
\hline David s. Ralph s. Adam of Arwystli & Pledge & Wigwig & Murder & No. 784 & Condover \\
\hline David s. Yagan [Dafydd] [Fychan] & Plaintiff & Rowton & Mort d'Ancestor & No. 142 & \\
\hline Dean \& Chapter of St. Mary's Shrewsbury & Defendant & Fitz & Custom \& Services & No. 339 & \\
\hline Dean \& Chapter of St. Mary's Shrewsbury & Defendant & Sutton & Entry & No. 64 & \\
\hline Dean \& Chapter of St. Mary's Shrewsbury & Defendant & Clive & Utrum & No. 300 & \\
\hline Dean \& Chapter of St. Mary's Shrewsbury & & & Plea of Land & No. 189 & \\
\hline Dean of the Bishop of Chester & (mention) & & Theft & No. 749 & Bradford \\
\hline Denise & (mention) & Preen & Seisin @ Death & No. 240 & \\
\hline Douce w. Llewelyn & Victim & Kempton & Suicide & No. 487 & Purslow \\
\hline Edith d. Adam of Cheswell & Victim & Cheswell \& Adeney & Misadventure & No. 704 & Bradford \\
\hline Edith w. Henry Dobyn & Defendant & Nethercote & Entry & No. 248 & \\
\hline Edith w. Richard of Camberley & Plaintiff & & Compromise & No. 7 & \\
\hline Edith w. Robert Pride & (mention) & Shrewsbury & Entry & No. 349 & \\
\hline Edith wd. William Turner & Plaintiff & Oldbury & Dower & No. 167 & \\
\hline Edith, widow & Victim & Monk Hall & Murder & No. 568 & Munslow \\
\hline Edward of Brockton & Accused & Brockton, Lydbury, Colebatch \& Totterton & Murder & No. 501 & Purslow \\
\hline Edwin & & & Appoint Attorney & No. 197 & \\
\hline Ellis [Elis/Elias] & Victim & & Murder & No. 578 & Munslow \\
\hline Ellis of Atcham [Elis/Elias] & (mention) & & Executed & No. 788 & Condover \\
\hline Ellis of Berkeford [Elis/Elias] & Attorney & & Custom \& Services & No. 244 & \\
\hline Ellis of Condover [Elis/Elias] & Juror & & & No. 925 & Condover \\
\hline Ellis of Darliston [Elis/Elias] & Victim & Fields of Prees Heath & Misadventure & No. 679 & Bradford \\
\hline Ellis of Hardwick [Elis/Elias] & Juror & & & No. 916 & Nordley \& Astle \\
\hline Ellis of Stoke [Elis/Elias] & Juror & & & No. 906 & Bradford \\
\hline Ellis of Sutton [Elis/Elias] & Defendant & Sutton & Seisin @ Death & No. 292 & \\
\hline Ellis of Sutton [Elis/Elias] & Juror & & & No. 918 & Stanton \\
\hline Ellis of Sutton [Elis/Elias] & Pledge & & Fine & No. 577 & Munslow \\
\hline Ellis of The Hale [Elis/Elias] & Defendant & Chelmarsh & Novel Disseisin & No. 47 & \\
\hline Ellis of Walton [Elis/Elias] & Pledge & & Theft & No. 786 & Condover \\
\hline Ellis s. Hugh of Noneley [Elis/Elias] & Pledge & [inside Welshry] & Theft & No. 857 & Pimhill \\
\hline Ellis s. Richard [Elis/Elias] & Accused & & Theft & No. 750 & Bradford \\
\hline Ellis s. Richard Cadigan [Elis/Elias] [Cadwgan] & Plaintiff & Moreton & Novel Disseisin & No. 119 & \\
\hline Ellis Turner [Elis/Elias] & Accused & Whixall & Execution/Murder & No. 719 & Bradford \\
\hline Emeline w. Eynoun s. Owayn [Einion] [Owain] & & & Compromise & No. 54 & \\
\hline Emily w. Nicholas of Hastings & Defendant & Leighton & Mort d'Ancestor & No. 4 & \\
\hline Emily w. Nicholas of Hastings & & & Plea of Land & No. 266 & \\
\hline Emma Cole & Accused & Callaughton & Theft & No. 669 & Wenlock \\
\hline Emma d. Ellis of Roden [Elis/Elias] & First Finder & river Roden & Misadventure & No. 697 & Bradford \\
\hline Emma d. Osbert Butcher & Victim & & Murder & No. 895 & Shrewsbury \\
\hline Emma d. Richard s. Osbert \& s. Margery of Halton & Plaintiff & Woofferton & Right & No. 332 & \\
\hline Emma de Coudray d. Edith de Coudray d. Peter de Coudray & Plaintiff & Habberley \& Nethercote & Entry & No. 247 & \\
\hline Emma de Coudray d. Edith de Coudray d. Peter de Coudray & Plaintiff & Nethercote & Entry & No. 248 & \\
\hline Emma w. Geoffrey s. Henry of Ryton & & & AppointAttorney & No. 190 & \\
\hline Emma w. Geoffrey s. Henry of Ryton & & Stapleton & Compromise & No. 170 & \\
\hline Emma w. Henry Wele & Defendant & Loton & Seisin @ Death & No. 14 & \\
\hline Emma w. Herbert Bond & Defendant & Abdon & Right & No. 288 & \\
\hline Emma w. Simon of Colemore & Plaintiff & Astley & Dower & No. 472 & \\
\hline Emma w. William s. Cecily & Defendant & Woodhouse & Right & No. 344 & \\
\hline Erl of Rowton & Accused & & Default & No. 514 & Purslow \\
\hline Eudes Brown of Edstaston & Pledge & Edstaston & Murder & No. 683 & Bradford \\
\hline Eudes of Hodnet & (mention) & Broughton & Seisin @ Death & No. 26 & \\
\hline Eudes of Hodnet & Court Official & Eyton & Entry & No. 13 & \\
\hline Eudes of Hodnet & Court Official & Oxenbold & Entry & No. 30 & \\
\hline Eudes of Hodnet & Court Official & Wem & Novel Disseisin & No. 48 & \\
\hline Eudes of Hodnet & Court Official & Belswardyne Wood & Tort \& Force & No. 138 & \\
\hline Eudes of Hodnet & Defendant & & Custom \& Services & No. 289 & \\
\hline Eudes of Hodnet & Defendant & $\mathrm{H}$. & Novel Disseisin & No. 62 & \\
\hline Eudes of Hodnet & Defendant & Hope Bowdler & Novel Disseisin & No. 46 & \\
\hline Eudes of Hodnet & Defendant & Moreton & Novel Disseisin & No. 216 & \\
\hline Eudes of Hodnet & Defendant & Espley & Nuisance & No. 224 & \\
\hline Eudes of Hodnet & Defendant & Hopton & Nuisance & No. 225 & \\
\hline Eudes of Hodnet & Defendant & Marton & Seisin @ Death & No. 256 & \\
\hline Eudes of Hodnet & Juror & Woofferton & Right & No. 332 & \\
\hline Eudes of Hodnet & Plaintiff & & Custom \& Services & No. 287 & \\
\hline Eudes of Hodnet & Pledge & Brockton & Theft & No. 811 & Brimstree \\
\hline Eudes of Hodnet & Pledge & Sandford & Theft/Assaul & No. 747 & Bradford \\
\hline Eudes of Hodnet & Pledge & & Trespass & No. 743 & Bradford \\
\hline Eudes of Hodnet & Warrenty & Chelmick & Seisin @ Death & No. 52 & \\
\hline Eudes of Hodnet & & & Compromise & No. 253 & \\
\hline
\end{tabular}




\begin{tabular}{|c|c|c|c|c|c|}
\hline Eudes of Picthorne & Accused & Claverley & Murder & No. 628 & Claverley \\
\hline Eudes of Sutton & Victim & Wistanswick, Sutton, Colehurst \& Goldstone & Misadventure & No. 707 & Bradford \\
\hline Eva wd. Warin of Posenhall & Plaintiff & Posenhall & Dower & No. 146 & \\
\hline Eve w. Robert de Meysy & Plaintiff & Stapleton & Novel Disseisin & No. 313 & \\
\hline Eve w. Robert de Meysy & & & AppointAttorney & No. 267 & \\
\hline Eve wd. Adam s. Walter & Plaintiff & Lydbury & Dower & No. 44 & \\
\hline Eynon Bawthan of Rhiston [Einion] & Pledge & Rhiston & Misadventure & No. 815 & Chirbury \\
\hline Eynon of Harley [Einion] & Victim & Wigwig & Murder & No. 784 & Condover \\
\hline Eynon of Tenbury [Einion] & Pledge & Espley & Novel Disseisin & No. 470 & \\
\hline Eynon s. Alexander of Bradeshull [Einion] & Pledge & Tedstill & Unlawful Entry & No. 566 & Stottesdon \\
\hline Eynon s. Dewynt [Einion] & Defendant & Bromlow & Entry & No. 250 & \\
\hline Eynoun s. Owayn [Einion] [Owain] & & & Compromise & No. 54 & \\
\hline Eynun Hay [Einion] & Accused & Mawley, Presleye, Kyneredewell \& Cleobury & Murder & No. 545 & Stottesdon \\
\hline Florence de Gaugy & Plaintiff & Bridgenorth & Novel Disseisin & No. 12 & \\
\hline Floria d. Reginald & Defendant & Astley & Dower & No. 472 & \\
\hline Fluri of Whettleton & & & AppointAttorney & No. 186 & \\
\hline Fulk FitzWarin & Accused & [inside Welshry] & Murder & No. 858 & Pimhill \\
\hline Fulk FitzWarin & Defendant & & Custom \& Services & No. 287 & \\
\hline Fulk FitzWarin the Younger & Plaintiff & Alberbury & Novel Disseisin & No. 335 & \\
\hline Fulk of Fitzwarin & Pledge & Oxenbold & Entry & No. 30 & \\
\hline Gamel of Longford & Accused & Longford & Theft & No. 729 & Bradford \\
\hline Gemma wd. Ralph of Draycott & Plaintiff & Draycott & Dower & No. 337 & \\
\hline Geoffrey Andrew of Ludlow & Pledge & Ludlow & Theft & No. 579 & Munslow \\
\hline Geoffrey Bavel & Court Official & Foregate & Dower & No. 298 & \\
\hline Geoffrey Champion of Middleton & Pledge & Middleton & Theft & No. 786 & Condover \\
\hline Geoffrey Chandler & Defendant & Donnington & Entry & No. 17 & \\
\hline Geoffrey Chandler & & Donnington & Compromise & No. 19 & \\
\hline Geoffrey de Genevill & Pledge & Stanton Lacy & Seisin @ Death & No. 164 & \\
\hline Geoffrey de la Mare & & & Appoint Attorney & No. 245 & \\
\hline Geoffrey Genevill & (mention) & Cressage & Novel Disseisin & No. 91 & \\
\hline Geoffrey le Poer & Juror & The Heath & Entry & No. 114 & \\
\hline Geoffrey le Poer & Juror & Wem & Novel Disseisin & No. 48 & \\
\hline Geoffrey le Poer & Juror & Woofferton & Right & No. 332 & \\
\hline Geoffrey Luvet & Victim & Nash & Murder & No. 526 & Overs \\
\hline Geoffrey Mope & Victim & Bridgenorth & Murder & No. 866 & Bridgenorth \\
\hline Geoffrey of Cure & Bailiff & Longslow, Drayton \& Longford & Theft/Execution & No. 722 & Bradford \\
\hline Geoffrey of Kinnersley & (mention) & & Theft/Murder & No. 556 & \begin{tabular}{|l|} 
Stottesdon \\
\end{tabular} \\
\hline Geoffrey of Ledwich & Defendant & Moreton & Novel Disseisin & No. 217 & \\
\hline Geoffrey of Ledwich & Defendant & & Novel Disseisin & No. 10 & \\
\hline Geoffrey of Ledwich & & & Compromise & No. 123 & \\
\hline Geoffrey of Ledwich & & & Plea of Warranty & No. 203 & \\
\hline Geoffrey of Ledwych & & & Custom \& Services & No. 615 & Munslow \\
\hline Geoffrey of Overton & Defendant & Neen Savage & Novel Disseisin & No. 2 & \\
\hline Geoffrey of Overton & Warrenty & Walford & Entry & No. 90 & \\
\hline Geoffrey of Overton & & & Appoint Attorney & No.179 & \\
\hline Geoffrey of Pimley & Defendant & Pimley, Manor of & Novel Disseisin & No. 145 & \\
\hline Geoffrey of Stretton s. Isabel of Ledwich & Plaintiff & Cleeton & Seisin @ Death & No. 168 & \\
\hline Geoffrey of Thorpe & (mention) & & Perambulation & No. 351 & \\
\hline Geoffrey of Thorpe & Attorney & & Custom \& Services & No. 434 & \\
\hline Geoffrey of Thorpe & Pledge & & Trespass & No. 743 & Bradford \\
\hline Geoffrey of Toppesfield & Attorney & & Custom \& Services & No. 244 & \\
\hline Geoffrey Ovyet s. William Ovyet & Plaintiff & Norton & Seisin @ Death & No. 106 & \\
\hline Geoffrey Pynok & Defendant & Moreton & Novel Disseisin & No. 217 & \\
\hline Geoffrey s. Andrew of Ludlow & Court Official & Moreton & Novel Disseisin & No. 217 & \\
\hline Geoffrey s. Edith of Newton & Defendant & Bomere & Novel Disseisin & No. 98. & \\
\hline Geoffrey s. Geoffrey of Ledwich & Defendant & Abdon & Novel Disseisin & No. 73 & \\
\hline Geoffrey s. Henry of Ryton & & & Appoint Attorney & No. 190 & \\
\hline Geoffrey s. Henry of Ryton & & Stapleton & Compromise & No. 170 & \\
\hline Geoffrey s. Thomas of Pitchford & Accused & Pitchford & Murder & No. 768 & Condover \\
\hline Gervase of Ludlow & Juror & & Judgement & No. 617 & Munslow \\
\hline Gilbert Bucknell & Coroner & & Judgement & No. 506 & Purslow \\
\hline Gilbert Bucknell & Coroner & & & No. 484 & Shropshire \\
\hline Gilbert Hayward & Accused & & Theft & No. 620 & Munslow \\
\hline Gilbert of Bucknell & Court Official & Wem & Novel Disseisin & No. 48 & \\
\hline Gilbert of Bucknell & Juror & Eyton & Entry & No. 13 & \\
\hline Gilbert of Bucknell & Juror & Oxenbold & Entry & No. 30 & \\
\hline Gilbert of Bucknell & Juror & The Heath & Entry & No. 114 & \\
\hline Gilbert of Bucknell & Juror & Weston & Entry & No. 16 & \\
\hline Gilbert of Bucknell & Juror & Wem & Novel Disseisin & No. 48 & \\
\hline Gilbert of Bucknell & Juror & Woofferton & Right & No. 332 & \\
\hline Gilbert of Frome & & & Plea of Land & No. 180 & \\
\hline \begin{tabular}{|l|} 
Gilbert of Middleton, Chaplain \\
\end{tabular} & Plaintiff & Stottesdon & Novel Disseisin & No. 261 & \\
\hline Gilbert of Stretton, Reave & Victim & & Execution/Murder & No. 625 & Stretton \\
\hline Gilbert of Weston & Accused & & Theft & No. 860 & Pimhill \\
\hline Gilbert s. Gilbert of Foregate & Victim & & Murder & No. 883 & Foregate \\
\hline Gilbert s. of Richard Clerk & Defendant & Monks' Forgate & Novel Disseisin & No. 61 & \\
\hline Gilbert s. Walter & Attorney & & Novel Disseisin & No. 200 & \\
\hline Gilbert, Forester to Roger Sprengehose & Victim & Netley \& Frodesley & Execution/Murder & No. 781 & Condover \\
\hline Giles of Burford & Accused & Worfield & Murder & No. 673 & Worfield \\
\hline Giles of Erdington & Plaintiff & Moreton \& Preston in Besford & Novel Disseisin & No. 102 & \\
\hline Giles of Norfolk, Parson of Burford & Accused & & Murder & No. 934 & Bridgenorth \\
\hline Gillian d. Ellis of Woodcote [Elis/Elias] & Plaintiff & Woodcote & Mort d'Ancestor & No. 271 & \\
\hline Gillian d. Reginald & Defendant & Astley & Dower & No. 472 & \\
\hline Gillian d. Reginald of Orleton & Plaintiff & Orleton & Seisin @ Death & No. 334 & \\
\hline Gillian d. Warin \& $n$. Robert of Deuxhill & Plaintiff & Deuxhill & Seisin @ Death & No. 42 & \\
\hline Gillian d. Warin \& n. Robert s. Owen [Owain] & Plaintiff & Deuxhill & Seisin @ Death & No. 306 & \\
\hline Gillian d. Warner & Defendant & Kenley & Seisin @ Death & No. 55 & \\
\hline Gillian de Gaugy & Plaintiff & Bridgenorth & Novel Disseisin & No. 12 & \\
\hline Gillian $n$. William Porter & Plaintiff & Shrewsbury & Seisin @ Death & No. 101 & \\
\hline Gillian n. William Porter & Plaintiff & Shrewsbury & Seisin @ Death & No. 309 & \\
\hline Gillian of Kenley & Plaintiff & & Mort d'Ancestor & No. 8 & \\
\hline
\end{tabular}




\begin{tabular}{|c|c|c|c|c|c|}
\hline Gillian of Sheet & Plaintiff & Sheet & Novel Disseisin & No. 328 & \\
\hline Gillian of Tunstall & Plaintiff & & Dower & No. 171 & \\
\hline \begin{tabular}{|l} 
Gillian s. Helewise de Baskerville \\
\end{tabular} & Plaintiff & Northwood & Mort d'Ancestor & No. 5 & \\
\hline Gillian w. Richard de Molis & & & Compromise & No. 236 & \\
\hline Gillian wd. Coleman of Ludlow & Defendant & Sheet \& Wettleton \& Stokesay & Seisin @ Death & No. 99 & \\
\hline Gillian wd. Hugh de Say & Plaintiff & Cheney Hill & Dower & No. 155 & \\
\hline Gillian wd. Hugh de Say & & & AppointAttorney & No. 195 & \\
\hline Gillian wd. Richard of Tunstall & Plaintiff & Tunstall & Dower & No. 312 & \\
\hline \begin{tabular}{|l} 
Gilvert of Bucknell \\
\end{tabular} & Court Official & Eyton & Entry & No. 13 & \\
\hline \begin{tabular}{|l|} 
Gilvert of Bucknell \\
\end{tabular} & Court Official & Oxenbold & Entry & No. 30 & \\
\hline \begin{tabular}{|l} 
Gladys [Gwladys] \\
\end{tabular} & Defendant & Willaston & Seisin @ Death & No. 213 & \\
\hline Gode of Peaton & Victim & Cleobury North & Murder & No. 558 & Stottesdon \\
\hline Godfrey of Cardeston & Victim & Montford bridge & Murder & No. 829 & Ford \\
\hline Goodith w. Reginald Okeman & (mention) & Criddon & Dower & No. 307 & \\
\hline Gregory & Victim & & Misadventure & No. 658 & Wenlock \\
\hline Gregory of Beachfield & Pledge & Wellington & Theft & No. 761 & Edgmond \\
\hline Griffin [Gruffydd] & Accused & & Imprisonment & No. 790 & Condover \\
\hline Griffin of Aqualate [Gruffydd] & Pledge & Donnington & Entry & No. 17 & \\
\hline \begin{tabular}{|l} 
Griffin of Overs [Gruffydd] \\
\end{tabular} & Pledge & Lydbury & Novel Disseisin & No. 81 & \\
\hline Griffin of Ultak [Gruffydd] & Accused & & Execution/Murder & No. 524 & Stretton \\
\hline \begin{tabular}{|l} 
Griffin s. Eynon [Grufydd] [Einion] \\
\end{tabular} & Accused & & Default & No. 834 & Ford \\
\hline Griffin s. Wraunoc [Gruffydd] & Defendant & Chelmarsh & Novel Disseisin & No. 47 & \\
\hline Gruffydd ap Gwenwynwyn & Accused & & Default & No. 822 & Chirbury \\
\hline \begin{tabular}{|l|} 
Gunnild wd. Richard of Halford \\
\end{tabular} & Plaintiff & Hales & Dower & No. 315 & \\
\hline \begin{tabular}{|l|} 
Gunnild wd. Richard of Halford \\
\end{tabular} & & & AppointAttorney & No. 175 & \\
\hline Guy of Croswen & Accused & Baschurch & Murder & No. 856 & Pimhill \\
\hline \begin{tabular}{|l} 
Gyun Lowar \\
\end{tabular} & Accused & & Murder & No. 742 & Bradford \\
\hline Hamo Fesaunt & Pledge & Milson & Novel Disseisin & No. 258 & \\
\hline Hamon Butler & Court Official & & At Mercy & No. 43 & \\
\hline Hamon de Curzon & Plaintiff & & Custom \& Services & No. 116 & \\
\hline \begin{tabular}{|l|} 
Hamon de Curzun \\
\end{tabular} & Accused & Whitton \& Ashford Carbonell & Murder & No. 538 & Overs \\
\hline Hamon of Middleton & Juror & Lawton & Novel Disseisin & No. 473 & \\
\hline Hamon of Presthope & Victim & Wenlock & Murder/Assault & No. 668 & Wenlock \\
\hline Hamon of Uppington & Pledge & Uppington & Misadventure & No. 681 & Bradford \\
\hline Hamon Plamer & Defendant & Bridgenorth & Novel Disseisin & No. 24 & \\
\hline \begin{tabular}{|l|} 
Hamon Strange s. John Strange \\
\end{tabular} & Plaintiff & Wrockwardine & Novel Disseisin & No. 156 & \\
\hline Hamund of Birches & Victim & Bridgenorth & Imprisonment & No. 548 & Stottesdon \\
\hline \begin{tabular}{|l|} 
Hamund s. Richard of Ellesmere \\
\end{tabular} & Pledge & Tedstill & Unlawful Entry & No. 566 & Stottesdon \\
\hline Hamund/Hamon Palmer & Payer & & Fine & No. 862 & Bridgenorth \\
\hline Hawise of Shyrington & & & Compromise & No. 163 & \\
\hline \begin{tabular}{|l|} 
Helewise de Baskerville \\
\end{tabular} & Plaintiff & Northwood & Mort d'Ancestor & No. 5 & \\
\hline Henry Bacun c. Joan Bacun & Plaintiff & \begin{tabular}{|l} 
Bridgenorth \\
\end{tabular} & Seisin@ Death & No. 222 & \\
\hline \begin{tabular}{|l|} 
Henry Baret \\
\end{tabular} & Accused & & Execution & No. 769 & Condover \\
\hline Henry Bright & Accused & & Theft & No. 618 & Munslow \\
\hline Henry Bruntespore & Accused & & Theft & No. 810 & Brimstree \\
\hline \begin{tabular}{|l|} 
Henry Capel \\
\end{tabular} & Accuser & & Assault & No. 743 & Bradford \\
\hline Henry Cointerel & Accused & & Custom \& Services & No. 872 & Bridgenorth \\
\hline \begin{tabular}{|l|} 
Henry Coudrey \\
\end{tabular} & Accused & Wellington & Absconded & No. 755 & Bradford \\
\hline Henry Cuggel & Victim & Criddon & Murder/Assault & No. 563 & Stottesdon \\
\hline Henry de Boys & (mention) & & Fine & No. 610 & Munslow \\
\hline Henry de Boys & Accused & Ludlow Market & Murder & No. 612 & Munslow \\
\hline Henry de Girros & Defendant & & Dower & No. 147 & \\
\hline Henry de Say & Victim & & Murder & No. 506 & Purslow \\
\hline Henry Dobyn & Defendant & Nethercote & Entry & No. 248 & \\
\hline Henry Forst of Kenley & Pledge & & Rape & No. 672 & Wenlock \\
\hline Henry French & Victim & Bromfield & Murder & No. 574 & Munslow \\
\hline Henry Hod & Accused & & Execution/Murder & No. 522 & Overs \\
\hline Henry Hubaud & Plaintiff & Overton & Entry & No. 41 & \\
\hline \begin{tabular}{|l} 
Henry Liere \\
\end{tabular} & Accused & & Theft & No. 513 & Purslow \\
\hline Henry Marshall & & & Compromise & No. 158 & \\
\hline \begin{tabular}{|l|} 
Henry Mauveysyn \\
\end{tabular} & & & Novel Disseisin & No. 176 & \\
\hline \begin{tabular}{|l|} 
Henry Melde \\
\end{tabular} & Defendant & Sheet \& Wettleton \& Stokesay & Seisin @ Death & No. 99 & \\
\hline \begin{tabular}{|l|} 
Henry Miller \\
\end{tabular} & Defendant & Hordley & Novel Disseisin & No. 221 & \\
\hline Henry Miller of Diddlebury & Pledge & Great Sutton & Novel Disseisin & No. 66 & \\
\hline Henry Moyses & Accused & Down & Murder & No. 486 & Shropshire \\
\hline \begin{tabular}{|l} 
Henry Niter \\
\end{tabular} & Victim & & Execution/Murder & No. 552 & Stottesdon \\
\hline Henry of Alveley & Accused & Alveley & Default & No. 544 & Alveley \\
\hline Henry of Bearston, Carpenter & Victim & Hatton & Murder & No. 691 & Bradford \\
\hline Henry of Chester & Witness & Newport & Murder & No. 759 & Edgmond \\
\hline Henry of Grinshill & Defendant & Clive \& Haughton & Nuisance & No. 95 & \\
\hline Henry of Gydesay & Accused & & Rape & No. 542 & Worthen \\
\hline Henry of Hope Bowdler & Plaintiff & Ragdon & Novel Disseisin & No. 166 & \\
\hline Henry of Kenley & Defendant & & Mort d'Ancestor & No. 8 & \\
\hline Henry of Leigh & Attorney & & Entry & No. 9 & \\
\hline Henry of Leigh & Defendant & Preston & Entry & No. 235 & \\
\hline Henry of Leigh & & & Compromise & No. 140 & \\
\hline Henry of Montford & Attorney & & & No. 67 & \\
\hline Henry of Morfe & (mention) & Alveley & Novel Disseisin & No. 3 & \\
\hline Henry of Onibury & Victim & River Onny in Onibury, Whettleton \& Aldon & Suicide & No. 580 & Munslow \\
\hline Henry of Pantel & Victim & Ludlow & Murder & No. 576 & Munslow \\
\hline Henry of Perry & (mention) & Alveley & Novel Disseisin & No. 3 & \\
\hline Henry of Shavington & Defendant & Sandford & Novel Disseisin & No. 279 & \\
\hline Henry of Shavington & Defendant & Shavington & \begin{tabular}{|l|} 
Novel Disseisin \\
\end{tabular} & No. 122 & \\
\hline Henry of Shavington & Pledge & & Assault & No. 748 & Bradford \\
\hline Henry of Shavington & Pledge & Sandford & Theft/Assaul & No. 747 & Bradford \\
\hline Henry of Sidbury & Accused & Sidbury & Default & No. 565 & Stottesdon \\
\hline Henry of Sidbury & Defendant & Charlcotte & Dower & No. 211 & \\
\hline Henry of Sidbury & Defendant & Neen & \begin{tabular}{|l|} 
Novel Disseisin \\
\end{tabular} & No. 1 & \\
\hline Henry of Whettleton & Attorney & & Plea of Land & No. 186 & \\
\hline Henry of Winsbury & Victim & Winsbury & Misadventure & No. 817 & Chirbury \\
\hline Henry Parker of Hadley & Accused & & Theft & No. 750 & Bradford \\
\hline
\end{tabular}




\begin{tabular}{|c|c|c|c|c|c|}
\hline \begin{tabular}{|l|} 
Henry Partriche \\
\end{tabular} & Accused & & Custom \& Services & No. 905 & Shrewsbury \\
\hline Henry Potter & Victim & Newport & Murder & No. 757 & Edgmond \\
\hline Henry Prat & Accused & & Absconded & No. 876 & Bridgenorth \\
\hline Henry Prende of Westley & Pledge & & Imprisonment & No. 790 & Condover \\
\hline Henry Red & Accused & & Theft & No. 810 & Brimstree \\
\hline \begin{tabular}{|l} 
Henry Russell \\
\end{tabular} & & & Plea of Villeinage & No. 188 & \\
\hline \begin{tabular}{|l} 
Henry Russell of Marton \\
\end{tabular} & Pledge & Marton & Novel Disseisin & No. 134 & \\
\hline Henry s. Amice of Bridgenorth & Accused & & Theft & No. 865 & Bridgenorth \\
\hline Henry s. Ellis [Elis/Elias] & Victim & Bulwardine & Murder & No. 630 & Claverley \\
\hline \begin{tabular}{|l} 
Henry s. Geoffrey \\
\end{tabular} & Victim & Duddlewick & Misadventure & No. 561 & Stottesdon \\
\hline \begin{tabular}{|l} 
Henry s. Gilbert of Wollerton \\
\end{tabular} & Pledge & Wollerton & Theft & No. 786 & Condover \\
\hline \begin{tabular}{|l|} 
Henry s. Henry Rowse \\
\end{tabular} & Defendant & Leighton & Entry & No. 246 & \\
\hline \begin{tabular}{|l|} 
Henry s. Ives Braz \\
\end{tabular} & Victim & Doddington & Execution/Murder & No. 734 & Bradford \\
\hline Henry s. John & Defendant & Petton & Seisin @ Death & No. 260 & \\
\hline Henry s. John of Stretton & Accused & Stretton & Murder/Absconded & No. 598 & Munslow \\
\hline Henry s. Nicholas & Pledge & & Theft & No. 786 & Condover \\
\hline Henry s. Nicholas of Frankwell & Accused & Frankwell & Murder & No. 891 & Shrewsbury \\
\hline Henry s. Owel of Longford [Hywel] & Pledge & Longford & Theft & No. 786 & Condover \\
\hline Henry s. Richard of Tunstall & Pledge & Tunstall & Dower & No. 312 & \\
\hline Henry s. Richard of Tunstall & Pledge & & Novel Disseisin & No. 79 & \\
\hline Henry s. Richard of Wollerton & Pledge & Wollerton & Theft & No. 786 & Condover \\
\hline Henry s. Roger Hore & Plaintiff & Kenley & Seisin @ Death & No. 55 & \\
\hline Henry s. the priest of The Bold in Burwarton & Pledge & Northwood & Mort d'Ancestor & No. 5 & \\
\hline Henry s. Thomas s. Hamon & Plaintiff & Preen & Seisin @ Death & No. 239 & \\
\hline Henry s. William of Alveley & (mention) & Alveley & Novel Disseisin & No. 3 & \\
\hline Henry s. William of Batchcott & Pledge & Wigwig & Murder & No. 784 & Condover \\
\hline Henry s. William of Colemore & Defendant & Colemore & Novel Disseisin & No. 60 & \\
\hline Henry s. William Warin of Clee St. Margaret & Accused & Clee St. Margaret \& Weston & Murder & No. 589 & Munslow \\
\hline Henry Shoemaker & Pledge & Drayton & Novel Disseisin & No. 27 & \\
\hline Henry Smith & Victim & & Murder & No. 881 & Foregate \\
\hline Henry the Carpenter of Preen & Pledge & & Assault & No. 794 & Condover \\
\hline Henry the smith of Shrewsbury & Accused & & Murder & No. 895 & Shrewsbury \\
\hline Henry Ulvyng & Defendant & Moreton & Novel Disseisin & No. 217 & \\
\hline Henry Wade & Defendant & Ludlow & Entry & No. 108 & \\
\hline Henry Wele & Defendant & Loton & Seisin @ Death & No. 14 & \\
\hline Henry Wolf & Victim & Camlad & Murder & No. 813 & Chirbury \\
\hline Henry, a forester & Victim & Donnington & Murder & No. 803 & Brimstree \\
\hline Henry, Abbot of Shrewsbury & Accused & [inside Welshry] & Theft & No. 857 & Pimhill \\
\hline Henry, Abbot Shrewsbury & Defendant & Shrewsbury & Novel Disseisin & No. 125 & \\
\hline Henry, Abbot Shrewsbury & Defendant & & Novel Disseisin & No. 79 & \\
\hline Henry, Fisher & Victim & Cressage & Murder & No. 765 & Condover \\
\hline Herbert Bond & Defendant & Abdon & Right & No. 288 & \\
\hline Herbert Bretun & Plaintiff & & & & \\
\hline \begin{tabular}{|l} 
Herbert Cosin \\
\end{tabular} & Defendant & Moreton & Novel Disseisin & No. 217 & \\
\hline Herbert Cosin & Pledge & Moreton & Novel Disseisin & No. 217 & \\
\hline Herbert of Abdon & (mention) & Abdon & Novel Disseisin & No. 73 & \\
\hline Herbert of Abdon & Pledge & Moreton & Novel Disseisin & No. 217 & \\
\hline Herbert of Coreley & Pledge & Walford \& Wigmore & Nuisance & No. 270 & \\
\hline \begin{tabular}{|l|} 
Herbert of Corfton \\
\end{tabular} & Accuser & & Imprisonment/Theft & No. 577 & Munslow \\
\hline Herbert of Ledwich & Defendant & Sheet \& Wettleton \& Stokesay & Seisin @ Death & No. 99 & \\
\hline Herbert of Ledwich & Juror & & Judgement & No. 617 & Munslow \\
\hline Herbert of Ledwich & & & Mort d'Ancestor & No. 182 & \\
\hline Herbert of Lutwyche, outlaw & Accused & Cardington, Gretton, Willstone \& Acton & Execution/Murder & No. 603 & Munslow \\
\hline Herbert s. John s. John Strange & Accused & & Murder & No. 823 & Chirbury \\
\hline Hobbe Shorth & Accused & Mawley, Kinlet \& Detton & Murder & No. 547 & Stottesdon \\
\hline Hoel of Stockton [Hywel] & Juror & & & No. 912 & Chirbury \\
\hline Hoel s. William [Hywel] & Defendant & Woodbatch & Seisin @ Death & No. 299 & \\
\hline Howel of Amaston [Hywel] & Pledge & Amaston & Novel Disseisin & No. 272 & \\
\hline Howel s. Adam [Hywel] & Accused & & Default & No. 822 & Chirbury \\
\hline Hugh b. Prior of Chirbury & Accused & & Default & No. 822 & Chirbury \\
\hline Hugh b. Richard Dun & Accused & & Murder & No. 706 & Bradford \\
\hline Hugh Bond of Leebotwood & Accused & Longnor & Murder & No. 779 & Condover \\
\hline Hugh Brook & Pledge & Neen & Nuisance & No. 113 & \\
\hline Hugh Champeneys & Accused & & Theft & No. 793 & Condover \\
\hline Hugh Criket of the Monks' Forgate & Pledge & Monks' Forgate & Novel Disseisin & No. 61 & \\
\hline Hugh Cute & Accused & Hope & Murder & No. 527 & Overs \\
\hline \begin{tabular}{|l} 
Hugh de Baskerville \\
\end{tabular} & Juror & Lawton & Novel Disseisin & No. 473 & \\
\hline Hugh de Baskerville & Plaintiff & Sidbury & Novel Disseisin & No. 40 & \\
\hline Hugh de Cheyney & Coroner & Bitterley & Misadventure & No. 519 & Overs \\
\hline Hugh de Cheyney & Coroner & Whitton & Misadventure & No. 525 & Overs \\
\hline \begin{tabular}{|l} 
Hugh de Cheyney \\
\end{tabular} & Coroner & Lawton, Little Sutton \& Bitterley & Murder & No. 652 & Stanton \\
\hline Hugh de Cheyney & Coroner & & & No. 484 & Shropshire \\
\hline Hugh de Cheyney & Juror & & Judgement & No. 617 & Munslow \\
\hline Hugh de Cheyney & Payer & & Fine & No. 610 & Munslow \\
\hline Hugh de Cheyney & Pledge & The Heath & Imprisonment/Theft & No. 621 & Munslow \\
\hline Hugh de Graham & Accused & & Trespass/Force & No. 742 & Bradford \\
\hline Hugh de Say & & & Plea of Land & No. 186 & \\
\hline Hugh de Say & & & Plea of Land & No. 191 & \\
\hline Hugh de Troia & Accused & & Murder & No. 824 & Chirbury \\
\hline Hugh de Wynvill & Pledge & & Compromise & No. 7 & \\
\hline Hugh Huslegrey & Accused & Frankwell & Murder & No. 884 & Shrewsbury \\
\hline Hugh Marculf & Accused & & Theft & No. 786 & Condover \\
\hline Hugh Mason & Pledge & & Fine & No. 534 & Overs \\
\hline Hugh Mason s. Hugh Mason & Payer & & Fine & No. 534 & Overs \\
\hline Hugh Miller & Accused & Coston, Burton' \& Beckbury & Murder & No. 491 & Purslow \\
\hline Hugh Miller & Victim & R. Teme in Woofferton, Ashford Bowdler \& Overton & Misadventure & No. 569 & Munslow \\
\hline Hugh Mortimer & Defendant & Chelmarsh & Novel Disseisin & No. 47 & \\
\hline Hugh of Alston & Victim & & Custom \& Services & No. 830 & Ford \\
\hline Hugh of Beckbury & Accused & & Murder & No. 795 & Condover \\
\hline Hugh of Beckbury & Pledge & & Theft & No. 793 & Condover \\
\hline Hugh of Beckbury & Warrenty & Oldbury & Dower & No. 167 & \\
\hline
\end{tabular}




\begin{tabular}{|c|c|c|c|c|c|}
\hline Hugh of Berrington & Plaintiff & Acton & Novel Disseisin & No. 51 & \\
\hline Hugh of Berrington & Plaintiff & Acton & Nuisance & No. 218 & \\
\hline \begin{tabular}{|l|} 
Hugh of Boningale \\
\end{tabular} & Accused & & Murder & No. 795 & Condover \\
\hline Hugh of Dudmaston & Plaintiff & & Plea of Debt & No. 346 & \\
\hline Hugh of Dudmaston & & Legh & Compromise & No. 63 & \\
\hline Hugh of Grinshill & Defendant & Clive \& Haughton & Nuisance & No. 95 & \\
\hline Hugh of Hampton & Defendant & Thakimor & Novel Disseisin & No. 75 & \\
\hline Hugh of Harrington & Defendant & Harrington in Sutton & Novel Disseisin & No. 311 & \\
\hline Hugh of Harrington & Plaintiff & Harrington in Sutton & Nuisance/Novel Disseisin & No. 293 & \\
\hline \begin{tabular}{|l|} 
Hugh of Hollycott \\
\end{tabular} & Juror & Lawton & Novel Disseisin & No. 473 & \\
\hline Hugh of Kingsham of Gloucester & Accused & & Custom \& Services & No. 905 & Shrewsbury \\
\hline Hugh of Kingslow & Payer & & Fine & No. 661 & Wenlock \\
\hline Hugh of Leebotwood & Court Official & & Perambulation & No. 352 & \\
\hline Hugh of Leebotwood & Pledge & & Fine & No. 627 & Stretton \\
\hline Hugh of Longslow & Attorney & & Dower & No. 171 & \\
\hline \begin{tabular}{|l} 
Hugh of Longslow \\
\end{tabular} & Attorney & & Mort d'Ancestor & No. 8 & \\
\hline Hugh of Longslow & Pledge & & Fine & No. 882 & Foregate \\
\hline Hugh of Longslow & Pledge & Lee & Mort d'Ancestor & No. 219 & \\
\hline Hugh of Ludlow, Mason & Accused & & Theft & No. 641 & Ludlow \\
\hline Hugh of Nantwich & Accused & & Trespass/Force & No. 742 & Bradford \\
\hline \begin{tabular}{|l} 
Hugh of Okeover \\
\end{tabular} & Sheriff & & & No. 483 & Shropshire \\
\hline Hugh of Orelton & Victim & Batchcott, Wooferton, Ashford Bowdler \& Overton & Murder & No. 570 & Munslow \\
\hline Hugh of Peplow & Pledge & Peplow & Theft & No. 786 & Condover \\
\hline Hugh of Posenhall & Plaintiff & Posenhall & Novel Disseisin & No. 223 & \\
\hline Hugh of Preensthorp & Accused & & Theft & No. 620 & Munslow \\
\hline Hugh of Preston & Payer & & Fine & No. 627 & Stretton \\
\hline Hugh of Ridgwardine & Pledge & & Trespass/Assault & No. 741 & Bradford \\
\hline Hugh of Sheinton & Accused & & Default & No. 787 & Condover \\
\hline Hugh of Sheinton & Accuser & & Assault & No. 791 & Condover \\
\hline Hugh of Sheinton & Court Official & & At Mercy & No. 43 & \\
\hline Hugh of Sheinton & Plaintiff & Donnington & Nuisance & No. 331 & \\
\hline Hugh of Stretton & Payer & & Fine & No. 599 & Munslow \\
\hline Hugh of Sullinghal & Court Official & Donnington & Nuisance & No. 331 & \\
\hline Hugh of Sutton & Plaintiff & Chelmarsh & Novel Disseisin & No. 47 & \\
\hline Hugh of The Marsh & Accused & Bridgenorth & Murder & No. 557 & Stottesdon \\
\hline Hugh of Wotherton & Plaintiff & Espley & Novel Disseisin & No. 470 & \\
\hline Hugh of Wotherton & Plaintiff & Milson & Novel Disseisin & No. 258 & \\
\hline \begin{tabular}{|l|} 
Hugh Peche \\
\end{tabular} & Defendant & Northwood & Mort d'Ancestor & No. 5 & \\
\hline Hugh s. Albert of Ludlow & Accuser & & Murder & No. 538 & Overs \\
\hline Hugh s. Alice & Defendant & Bomere & Novel Disseisin & No. 98. & \\
\hline Hugh s. Edward & Defendant & Shear & Dower & No. 104 & \\
\hline \begin{tabular}{|l|} 
Hugh s. Godfrey of Yorton \\
\end{tabular} & Defendant & Bomere & Novel Disseisin & No. 98. & \\
\hline Hugh s. Hugh & Defendant & Ridgwardine & Entry & No. 283 & \\
\hline Hugh s. Hugh of Hinstock & Accused & Pickstock & Murder & No. 737 & Bradford \\
\hline Hugh s. Hugh of Rigwardine & Plaintiff & Ridgwardine & Novel Disseisin & No. 318 & \\
\hline Hugh s. James & & & Compromise & No. 301 & \\
\hline \begin{tabular}{|l|} 
Hugh s. John of Stretton \\
\end{tabular} & Accused & Stretton & Murder/Absconded & No. 598 & Munslow \\
\hline Hugh s. Lewyn [Llywelyn] & Defendant & Foregate & Dower & No. 298 & \\
\hline Hugh s. Margery & Defendant & Foregate & Seisin @ Death & No. 273 & \\
\hline Hugh s. Norman & Payer & & Trespass & No. 743 & Bradford \\
\hline \begin{tabular}{|l|} 
Hugh s. Philip of Rowton \\
\end{tabular} & Accused & & Theft/Absconded & No. 833 & Ford \\
\hline \begin{tabular}{|l|} 
Hugh s. Robert Beadle of Preen \\
\end{tabular} & Accused & & Assault & No. 794 & Condover \\
\hline Hugh s. Roger of Felton & Victim & Pitchford & Murder & No. 768 & Condover \\
\hline Hugh s. William of Moor & Victim & Oxenbold & Misadventure & No. 659 & Wenlock \\
\hline \begin{tabular}{|l|} 
Hugh s. William the Goldsmith \\
\end{tabular} & & & Compromise & No. 158 & \\
\hline \begin{tabular}{|l|} 
Hugh Toly of Rowton \\
\end{tabular} & Pledge & Amaston & Novel Disseisin & No. 272 & \\
\hline Hugh Wagge & Accused & & Assault & No. 890 & Shrewsbury \\
\hline Hugh, Chaplain of Morville & (mention) & & Misadventure & No. 553 & Stottesdon \\
\hline Hugh, Potter of Habberley & Pledge & & Rape & No. 542 & Worthen \\
\hline Hugo de Baskerville & Plaintiff & Northwood & Nuisance & No. 87 & \\
\hline Hugo Dun & Accused & Burcote & Murder & No. 674 & Worfield \\
\hline \begin{tabular}{|l|} 
Id' s. Roger \\
\end{tabular} & Defendant & Bomere & Novel Disseisin & No. 98. & \\
\hline \begin{tabular}{|l|} 
Ida d. Emma \\
\end{tabular} & Plaintiff & Woodhouse & Right & No. 344 & \\
\hline Ida d. William \& s. Alice & Attorney & & Plea of Land & No. 281 & \\
\hline Ida d. William \& s. Alice & Plaintiff & Shrewsbury & Right & No. 278 & \\
\hline Ingelard of Woodhouse & Victim & Woodhouse & Murder & No. 778 & Condover \\
\hline \begin{tabular}{|l|} 
Ingreth Spiche \\
\end{tabular} & Defendant & Sutton & Seisin @ Death & No. 292 & \\
\hline \begin{tabular}{|l} 
Ingreth Spigh' \\
\end{tabular} & Defendant & Corfton & Seisin@ Death & No. 137 & \\
\hline Ingrith d. Adam & Plaintiff & Charlton & Novel Disseisin & No. 121 & \\
\hline Iorward/Jorward of Cotes [lorwerth] & Defendant & Aston & Dower & No. 149 & \\
\hline Isabel d. Ellis of Sutton [Elis/Elias] & Victim & Field of Millichope & \begin{tabular}{|l|} 
Execution/Murder \\
\end{tabular} & No. 656 & Wenlock \\
\hline Isabel d. Iseult & Accuser & & Rape & No. 542 & Worthen \\
\hline \begin{tabular}{|l|} 
Isabel d. Reginald \\
\end{tabular} & Defendant & Astley & Dower & No. 472 & \\
\hline Isabel d. Richard & & & AppointAttorney & No. 199 & \\
\hline Isabel d. Richard of Coleham \& wd. Luke s. Hugh & Plaintiff & Shrewsbury & Entry & No. 6 & \\
\hline \begin{tabular}{|l|} 
Isabel d. Richard of Fennemere \\
\end{tabular} & Plaintiff & Fennemere & Entry & No. 151 & \\
\hline \begin{tabular}{|l|} 
Isabel d. Richard of Fennemere \\
\end{tabular} & & & AppointAttorney & No. 477 & \\
\hline Isabel d. Robert of Pembroke & Defendant & Bayton & Novel Disseisin & No. 208 & \\
\hline Isabel de Gaugy & Plaintiff & Bridgenorth & Novel Disseisin & No. 12 & \\
\hline Isabel w. Roger of Birch & Defendant & Birch & Mort d'Ancestor & No. 97 & \\
\hline Isabel w. Roger s. William & Defendant & Eyton & Entry & No. 13 & \\
\hline Isabel w. William Turner & & & AppointAttorney & No. 266 & \\
\hline Isabel w. William Walerand & Defendant & & & No. 150 & \\
\hline Isabel w. William Walerand \& d. Hugh of Kilpec & (mention) & Stapleton & Novel Disseisin & No. 313 & \\
\hline \begin{tabular}{|l|} 
Isabel wd. Henry of More \\
\end{tabular} & & & AppointAttorney & No. 269 & \\
\hline Isabel wd. Luke Beadle & Plaintiff & Foregate & Dower & No. 298 & \\
\hline Isabel wd. Philip Miller \& w. Richard Miller & Defendant & Shrewsbury & Seisin @ Death & No. 340 & \\
\hline Isabel wd. Philip of Aston & Accuser & & Murder & No. 823 & Chirbury \\
\hline \begin{tabular}{|l|l} 
Isabel wd. Walter of Hadnall \\
\end{tabular} & & & AppointAttorney & No. 482 & \\
\hline Iseult Nune & Defendant & Sheet \& Wettleton \& Stokesay & Seisin @ Death & No. 99 & \\
\hline Iseult of Cleobury & (mention) & Neen Savage, Neen \& Hopton Wafers & Murder & No. 546 & Stottesdon \\
\hline
\end{tabular}




\begin{tabular}{|c|c|c|c|c|c|}
\hline Iseult Punch & Defendant & Woofferton & Right & No. 332 & \\
\hline Iseult w. Edwin & & & AppointAttorney & No. 197 & \\
\hline Iseult w. William Walerand & Plaintiff & Pulverbatch & Entry & No. 11 & \\
\hline Iseult w. William Walerand & Plaintiff & Pulverbatch & Right & No. 475 & \\
\hline Iseult w. William Walerand & Plaintiff & Pulverbatch & & No. 264 & \\
\hline Ismay w. Philip Gascon & Plaintiff & Shrewsbury & Entry & No. 329 & \\
\hline \begin{tabular}{|l|} 
Ithel Velin of Siefton [Ithel] \\
\end{tabular} & Accused & & Default & No. 635 & Corfton \\
\hline Ives of Brockton & Accused & Brockton & Theft & No. 811 & Brimstree \\
\hline Ives of Longford & Pledge & Longford & Theft & No. 786 & Condover \\
\hline \begin{tabular}{|l|} 
Ives of Soulton \\
\end{tabular} & Plaintiff & Hawode in Soulton & Novel Disseisin & No. 220 & \\
\hline \begin{tabular}{|l|l|} 
Ives s. Parnel \\
\end{tabular} & Defendant & Birch & Mort d'Ancestor & No. 97 & \\
\hline Ivor of Diddlebury & Accused & & Theft/Absconded & No. 633 & Corfton \\
\hline \begin{tabular}{|l|} 
Ivor of Rowton \\
\end{tabular} & Pledge & & Fine & No. 610 & Munslow \\
\hline James de Audley & (mention) & & Assault & No. 794 & Condover \\
\hline James de Audley & Defendant & Chetwynd & Novel Disseisin & No. 110 & \\
\hline James de Audley & Warrenty & Gravenhunger & Seisin @ Death & No. 82 & \\
\hline James de Audley & & & Appoint Attorney & No. 434 & \\
\hline James de Audley & & & Compromise & No. 118 & \\
\hline James de Audley & & & Compromise & No. 343 & \\
\hline James de Audley & & Aston & Perambulation & No. 351 & \\
\hline James de Audley & & & Plea of Debt & No. 245 & \\
\hline James de Audley & & Chetwynd & Return & No. 321 & \\
\hline \begin{tabular}{|l} 
James of Hell' \\
\end{tabular} & & & Compromise & No. 301 & \\
\hline \begin{tabular}{|l} 
James of Ledwich \\
\end{tabular} & Defendant & Moreton & Novel Disseisin & No. 217 & \\
\hline \begin{tabular}{|l|} 
James the Chaplain of Shrewsbury \\
\end{tabular} & Accused & & Murder & No. 883 & Foregate \\
\hline James the Parson of Donnington & (mention) & Donnington & Nuisance & No. 331 & \\
\hline James, the Cook & Witness & Castle Holdgate & Murder & No. 591 & Munslow \\
\hline Jeukin of Marchamley & Accused & & Murder & No. 740 & Bradford \\
\hline Joan d. Alexander \& s. Lucy & Defendant & Sutton & Seisin @ Death & No. 292 & \\
\hline \begin{tabular}{|l} 
Joan d. Reginald \\
\end{tabular} & Defendant & Astley & Dower & No. 472 & \\
\hline \begin{tabular}{|l} 
Joan de Arras w. Ralph de Arras \\
\end{tabular} & & & AppointAttorney & No. 354 & \\
\hline \begin{tabular}{|l}
$J o a n$ de Gaugy \\
\end{tabular} & Plaintiff & Bridgenorth & Novel Disseisin & No. 12 & \\
\hline Joan of Corfton & Defendant & Corfton & Seisin @ Death & No. 137 & \\
\hline \begin{tabular}{|l|}
$J o a n$ \\
\end{tabular} & Defendant & Sutton & Seisin @ Death & No. 292 & \\
\hline \begin{tabular}{|l|} 
Joan of Lee d. Leonard of Lee \\
\end{tabular} & Plaintiff & Weston & Seisin @ Death & No. 160 & \\
\hline Joan w. John of Beoley & & & Custom \& Services & No. 173 & \\
\hline Joan w. Luke s. Alexander & Defendant & Little Sutton & Entry & No. 285 & \\
\hline \begin{tabular}{|l|} 
Joan w. Philip Marmiun \\
\end{tabular} & Defendant & Pulverbatch & Entry & No. 11 & \\
\hline Joan w. Philip Marmiun & Defendant & Pulverbatch & Right & No. 475 & \\
\hline Joan w. Philip Marmiun & Defendant & Pulverbatch & & No. 264 & \\
\hline Joan w. Philip Marmiun & & & AppointAttorney & No. 150 & \\
\hline Joan w. Philip Marmiun & & & Novel Disseisin & No. 267 & \\
\hline \begin{tabular}{|l} 
Joan w. Philip Marmiun \& d. Hugh of Kilpec \\
\end{tabular} & (mention) & Steplewood in Condover & Novel Disseisin & No. 314 & \\
\hline \begin{tabular}{|l} 
Joan w. Philip Marmiun \& d. Hugh of Kilpec \\
\end{tabular} & Defendant & Stapleton & Novel Disseisin & No. 313 & \\
\hline Joan w. Ralph de Arras & Defendant & & Custom \& Services & No. 319 & \\
\hline Joan w. Ralph de Arras & Plaintiff & & Custom \& Services & No. 476 & \\
\hline \begin{tabular}{|l|} 
Joan w. Richard of Eaton \\
\end{tabular} & Defendant & & & & \\
\hline Joan wd. Walter de Biaumes & Plaintiff & Donington & Dower & No. 295 & \\
\hline Joan wd. Walter de Biaumes & Plaintiff & Donington & Dower & No. 341 & \\
\hline \begin{tabular}{|l|} 
Joan wd. Walter de Biaumes \\
\end{tabular} & Plaintiff & Donington & Plea of Land & No. 342 & \\
\hline John Abbloc & Defendant & Shrewsbury & Seisin @ Death & No. 309 & \\
\hline John b. Nicholas Glover & Accused & & Assault & No. 890 & Shrewsbury \\
\hline John b. Robert of Tywe & Accused & Garmston & Murder & No. 711 & Bradford \\
\hline John b. William Burgeys of Ellerton & Accused & Wellington & Absconded & No. 755 & Bradford \\
\hline John Bacun, Master & Defendant & Great Sutton & Novel Disseisin & No. 66 & \\
\hline John Baret & Defendant & Nash & Novel Disseisin & No. 93 & \\
\hline \begin{tabular}{|l} 
John Baret s. Osbert Baret \\
\end{tabular} & Attorney & & Novel Disseisin & No. 196 & \\
\hline John Baril & Accused & & Assault & No. 890 & Shrewsbury \\
\hline \begin{tabular}{|l|}
$J o h n$ Berry of Shresbury \\
\end{tabular} & Pledge & Foregate & Mort d'Ancestor & No. 274 & \\
\hline John Blodenoch & Defendant & Diddlebury & Novel Disseisin & No. 109 & \\
\hline \begin{tabular}{|l|} 
John Bodin \\
\end{tabular} & Victim & Claverley & Murder & No. 628 & Claverley \\
\hline John Bond & Victim & & Misadventure & No. 664 & Wenlock \\
\hline \begin{tabular}{|l|}
$J o h n$ Borrey \\
\end{tabular} & Defendant & Shrewsbury & Novel Disseisin & No. 125 & \\
\hline John Bracy & Attorney & & Plea of Warranty & No. 203 & \\
\hline John Bret & Accused & & Default & No. 808 & Brimstree \\
\hline John Brid & Defendant & Shrewsbury & Seisin @ Death & No. 309 & \\
\hline \begin{tabular}{|l|} 
John Carter \\
\end{tabular} & Accused & Longslow, Drayton \& Longford & Theft/Execution & No. 722 & Bradford \\
\hline John Chaplain of Shrewsbury & Victim & St. Chad's & Murder & No. 897 & Shrewsbury \\
\hline \begin{tabular}{|l|} 
John Chatheloke \\
\end{tabular} & Accused & & Theft & No. 904 & Shrewsbury \\
\hline \begin{tabular}{|l|}
$J o h n$ Choyn \\
\end{tabular} & Defendant & Shrewsbury & Novel Disseisin & No. 125 & \\
\hline John Croucher & Plaintiff & Pole & Entry & No. 305 & \\
\hline 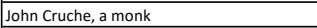 & Accused & [inside Welshry] & Theft & No. 857 & Pimhill \\
\hline \begin{tabular}{|l|} 
John Cunseyl \\
\end{tabular} & & & Plea of Land & No. 268 & \\
\hline John de Bracy & (mention) & Abdon & Right & No. 288 & \\
\hline \begin{tabular}{|l} 
John de Bracy \\
\end{tabular} & Court Official & Eyton & Novel Disseisin & No. 229 & \\
\hline John de Bracy & Defendant & Pulley & Novel Disseisin & No. 148 & \\
\hline John de Castello & Accused & & Murder & No. 934 & Bridgenorth \\
\hline 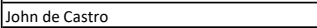 & Pledge & & Theft/Harbor & No. 863 & Bridgenorth \\
\hline \begin{tabular}{|l|} 
John de la Pole \\
\end{tabular} & Accuser & & Corruption & No. 649 & Hales \\
\hline John de Meaus & Attorney & & Plea of Land & No. 184 & \\
\hline John de Meaus & Defendant & Stretton & Dower & No. 92 & \\
\hline \begin{tabular}{|l|} 
John de Say \\
\end{tabular} & Pledge & Lydbury & Novel Disseisin & No. 81 & \\
\hline \begin{tabular}{|l|} 
John de Verdun \\
\end{tabular} & Accused & & Default & No. 614 & Munslow \\
\hline \begin{tabular}{|l} 
John del Heye of Lilleshall \\
\end{tabular} & Accused & Lilleshall & Murder & No. 732 & Bradford \\
\hline \begin{tabular}{|l} 
John du Plessis, Earl of Warwick \\
\end{tabular} & Defendant & Stottesdon & Novel Disseisin & No. 261 & \\
\hline \begin{tabular}{|l} 
John du Plessis, Earl of Warwick \\
\end{tabular} & Plaintiff & & Fugitive & No. 37 & \\
\hline John Dyer & Payer & & Fine & No. 869 & Bridgenorth \\
\hline John Field of Westhope & Accused & Westhope, Corfton \& Dinchope & Murder & No. 595 & Munslow \\
\hline \begin{tabular}{|l|} 
John Fitzalan \\
\end{tabular} & Warrenty & Cressage & Wardship & No. 130 & \\
\hline \begin{tabular}{|l|} 
John Fodeman of Corfton \\
\end{tabular} & Pledge & Corfton & Novel Disseisin & No. 105 & \\
\hline John French & & & At Mercy & No. 316 & \\
\hline
\end{tabular}




\begin{tabular}{|c|c|c|c|c|c|}
\hline John Gam & Accused & Harley & Murder & No. 785 & Condover \\
\hline \begin{tabular}{|l|} 
John Glidde \\
\end{tabular} & Accuser & & Theft/Harbor & No. 877 & Bridgenorth \\
\hline \begin{tabular}{|l} 
John le Poer \\
\end{tabular} & Defendant & Yockleton \& Amaston & Pracipe in Capite & No. 128 & \\
\hline \begin{tabular}{|l|} 
John le Poer \\
\end{tabular} & Plaintiff & Amaston & Novel Disseisin & No. 272 & \\
\hline John le Poer & & & Novel Disseisin & No. 200 & \\
\hline \begin{tabular}{|l|} 
John Makeprud of Aston \\
\end{tabular} & Pledge & & Fine & No. 599 & Munslow \\
\hline \begin{tabular}{|l|} 
John Medicus of Peaton \\
\end{tabular} & Accused & & Default & No. 635 & Corfton \\
\hline John Mortimer & Defendant & Bridgenorth & Seisin @ Death & No. 222 & \\
\hline \begin{tabular}{|l|} 
John of Arundel \\
\end{tabular} & Court Official & Woofferton & Right & No. 332 & \\
\hline \begin{tabular}{|l|l} 
John of Arundel \\
\end{tabular} & Defendant & Aston & Dower & No. 149 & \\
\hline \begin{tabular}{|l|} 
John of Arundel \\
\end{tabular} & Defendant & \begin{tabular}{|l|} 
Woodhouse \\
\end{tabular} & Right & No. 344 & \\
\hline John of Arundel & Juror & Eyton & Entry & No. 13 & \\
\hline John of Arundel & Juror & Oxenbold & Entry & No. 30 & \\
\hline \begin{tabular}{|l|l} 
John of Arundel \\
\end{tabular} & Juror & The Heath & Entry & No. 114 & \\
\hline John of Arundel & Juror & Weston & Entry & No. 16 & \\
\hline 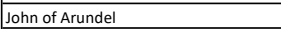 & Juror & Wem & Novel Disseisin & No. 48 & \\
\hline \begin{tabular}{|l|l|} 
John of Arundel \\
\end{tabular} & Juror & Woofferton & Right & No. 332 & \\
\hline \begin{tabular}{|l|} 
John of Arundel \\
\end{tabular} & & & Plea of Land & No. 206 & \\
\hline John of Ashford & Pledge & & Fine & No. 577 & Munslow \\
\hline \begin{tabular}{|l|} 
John of Beoley \\
\end{tabular} & & & Custom \& Services & No. 173 & \\
\hline John of Bratford & Accused & & Trespass/Force & No. 741 & Bradford \\
\hline John of Bromden & Defendant & Wheathill & Dower & No. 257 & \\
\hline John of Bromden & Defendant & Wheathill & Novel Disseisin & No. 38 & \\
\hline \begin{tabular}{|l|} 
John of Bromden \\
\end{tabular} & Juror & Wooton & Custom \& Services & No. 249 & \\
\hline \begin{tabular}{|l|} 
John of Bromden \\
\end{tabular} & Plaintiff & Egarton in Bromden & Novel Disseisin & No. 255 & \\
\hline \begin{tabular}{|l|} 
John of Bromden \\
\end{tabular} & Pledge & The Heath & Novel Disseisin & No. 263 & \\
\hline 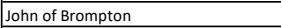 & Defendant & & Plea of Land & No. 353 & \\
\hline \begin{tabular}{|l|} 
John of Cainham \\
\end{tabular} & Pledge & The Heath & Novel Disseisin & No. 263 & \\
\hline 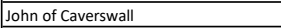 & & & Compromise & No. 101 & \\
\hline 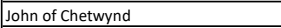 & Plaintiff & Chetwynd & Novel Disseisin & No. 110 & \\
\hline John of Chetwynd & Pledge & & Fine & No. 882 & Foregate \\
\hline \begin{tabular}{|l|} 
John of Chetwynd \\
\end{tabular} & Warrenty & Cressage & Wardship & No. 130 & \\
\hline John of Chetwynd & & & Compromise & No. 343 & \\
\hline \begin{tabular}{|l|} 
John of Chetwynd \\
\end{tabular} & & Stockton & Perambulation & No. 351 & \\
\hline \begin{tabular}{|l|} 
John of Chetwynd \\
\end{tabular} & & Chetwynd & Return & No. 321 & \\
\hline \begin{tabular}{|l} 
John of Colebatch s. John of Colebatch \\
\end{tabular} & Plaintiff & Colebatch & Seisin @ Death & No. 23 & \\
\hline John of Cotton & (mention) & Pole & Entry & No. 305 & \\
\hline 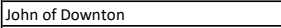 & Plaintiff & Mocktree & Entry & No. 94 & \\
\hline \begin{tabular}{|l|} 
John of Downton \\
\end{tabular} & & & Appoint Attorney & No. 204 & \\
\hline John of Drayton & Defendant & Charlcotte & Dower & No. 211 & \\
\hline John of Eastwick & Court Official & Donnington & Nuisance & No. 331 & \\
\hline 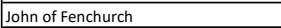 & Accuser & & Theft & No. 537 & Overs \\
\hline John of Gatacre & Pledge & Ragdon & Novel Disseisin & No. 166 & \\
\hline John of Greenhill & Pledge & Nobold, Beckbury \& Golding & Dower & No. 162 & \\
\hline John of Greet & Accused & Oldbury & Murder & No. 643 & Hales \\
\hline John of Hales & Defendant & Hales & Dower & No. 315 & \\
\hline John of Hales & & & Dower & No. 175 & \\
\hline John of Hawkstone & Defendant & Clive \& Haughton & Nuisance & No. 95 & \\
\hline John of Hunt & Accuser & & Corruption & No. 649 & Hales \\
\hline John of Husinton & Accused & Alcaston & Murder & No. 584 & Munslow \\
\hline \begin{tabular}{|l} 
John of Jay \\
\end{tabular} & Accused & & Default & No. 523 & Purslow \\
\hline John of Leinthall & & & Plea of Land & No. 205 & \\
\hline \begin{tabular}{|l|} 
John of Leintwardine \\
\end{tabular} & Attorney & & Plea of Land & No. 199 & \\
\hline 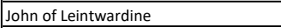 & Attorney & & Plea of Land & No. 477 & \\
\hline \begin{tabular}{|l|}
$J o h n$ of Lindsey \\
\end{tabular} & Accused & St. Chad's & Murder & No. 897 & Shrewsbury \\
\hline \begin{tabular}{|l|} 
John of Longslow \\
\end{tabular} & Accused & fields of Chetwynd & Execution/Murder & No. 685 & Bradford \\
\hline John of Newton & Defendant & Stapleton & Novel Disseisin & No. 313 & \\
\hline John of Norton in Hales & Victim & Hales & Murder & No. 645 & Hales \\
\hline \begin{tabular}{|l} 
John of Pedwardine \\
\end{tabular} & Plaintiff & Adforton & Novel Disseisin & No. 18 & \\
\hline John of Pitchford & (mention) & Lee & Custom \& Services & No. 161 & \\
\hline \begin{tabular}{|l|} 
John of Pole \\
\end{tabular} & Defendant & Pole & Entry & No. 305 & \\
\hline \begin{tabular}{|l} 
John of Prescott \\
\end{tabular} & Accuser & [inside Welshry] & Theft & No. 857 & Pimhill \\
\hline \begin{tabular}{|l} 
John of Prescott \\
\end{tabular} & Defendant & Shrewsbury & Entry & No. 6 & \\
\hline \begin{tabular}{|l|} 
John of Preston \\
\end{tabular} & Defendant & Foregate & Dower & No. 298 & \\
\hline \begin{tabular}{|l|} 
John of Preston \\
\end{tabular} & Plaintiff & Preston & Novel Disseisin & No. 107 & \\
\hline \begin{tabular}{|l} 
John of Rotherford \\
\end{tabular} & Pledge & & Fine & No. 600 & Munslow \\
\hline \begin{tabular}{|l|} 
John of Rowton \\
\end{tabular} & Plaintiff & Rowton \& Obaston & Nuisance & No. 58 & \\
\hline John of Rowton & Pledge & & Trespass/Assault & No. 741 & Bradford \\
\hline John of Ruthall & Court Official & Moreton & Novel Disseisin & No. 217 & \\
\hline John of Syrenok & Juror & Hopton & \begin{tabular}{|l|} 
Novel Disseisin \\
\end{tabular} & No. 57 & \\
\hline \begin{tabular}{|l} 
John of The Lowe \\
\end{tabular} & Attorney & & Custom \& Services & No. 478 & \\
\hline \begin{tabular}{|l|} 
John of Tong \\
\end{tabular} & (mention) & Smethcote & Seisin @ Death & No. 209 & \\
\hline John of Whittingslow & Pledge & & Assault & No. 791 & Condover \\
\hline \begin{tabular}{|l|} 
John of Winsley \\
\end{tabular} & Victim & Winsley fields & Misadventure & No. 825 & Ford \\
\hline \begin{tabular}{|l|} 
John of Wolverhampton \\
\end{tabular} & Accused & Wolverhampton & Executed & No. 887 & Shrewsbury \\
\hline \begin{tabular}{|l} 
John of Wolverley \\
\end{tabular} & Accused & & Theft/Assault & No. 741 & Bradford \\
\hline \begin{tabular}{|l|} 
John of Woofferton \\
\end{tabular} & Defendant & Woofferton & Entry & No. 320 & \\
\hline John Palmer of Shrewsbury & Victim & & Imprisonment & No. 899 & Shrewsbury \\
\hline \begin{tabular}{|l|} 
John Pyrun \\
\end{tabular} & (mention) & Pole & Entry & No. 305 & \\
\hline \begin{tabular}{|l|} 
John s. Agatha of Coreley \\
\end{tabular} & Accused & Coreley & Murder & No. 528 & Overs \\
\hline John s. Alan & & & Custom \& Services & No. 509 & Purslow \\
\hline \begin{tabular}{|l|} 
John s. Alan \\
\end{tabular} & & Wroxeter & Perambulation & No. 352 & \\
\hline 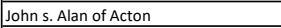 & & Spoonhill, Bourton \& Callaughton & Perambulation & No. 336 & \\
\hline \begin{tabular}{|l} 
John s. Alexander of Diddlebury \\
\end{tabular} & Plaintiff & Great Sutton & Novel Disseisin & No. 66 & \\
\hline John s. Berner \& b. Thomas & & & Compromise & No. 294 & \\
\hline \begin{tabular}{|l|} 
John s. Eylmer \\
\end{tabular} & Defendant & Hordley & Novel Disseisin & No. 221 & \\
\hline \begin{tabular}{|l|} 
John s. Gillian of Ledwich \\
\end{tabular} & Pledge & Moreton & Novel Disseisin & No. 217 & \\
\hline \begin{tabular}{|l|} 
John s. Hamon Beadle \\
\end{tabular} & Accused & & Murder & No. 760 & Edgmond \\
\hline John s. Herbert of Corfton & Accuser & & Imprisonment/Theft & No. 577 & Munslow \\
\hline John s. Hugh & Plaintiff & Lee & Mort d'Ancestor & No. 219 & \\
\hline John s. Hugh & Pledge & Moreton & Novel Disseisin & No. 217 & \\
\hline
\end{tabular}




\begin{tabular}{|c|c|c|c|c|c|}
\hline John s. Hugh & Defendant & Moreton & Novel Disseisin & No. 217 & \\
\hline John s. Hugh Lohne & Plaintiff & Shrewsbury & Novel Disseisin & No. 330 & \\
\hline John s. Hugh of Bolas & Plaintiff & Lee & Custom \& Services & No. 161 & \\
\hline John s. John & Defendant & Bomere & Novel Disseisin & \begin{tabular}{|l|} 
No. 98. \\
\end{tabular} & \\
\hline John s. John of Churchill & Plaintiff & & Custom \& Services & No. 244 & \\
\hline John s. John of Montgomery & Accused & Corfton & Murder & No. 632 & Corfton \\
\hline John s. John Strange & Accused & & Murder & No. 823 & Chirbury \\
\hline John s. John Tece & Plaintiff & Wenlock & Mort d'Ancestor & No. 89 & \\
\hline John s. John Tece & Plaintiff & Cressage & Seisin @ Death & No. 129 & \\
\hline John s. Lucy of Diddlebury & Accused & & Theft/Absconded & No. 633 & Corfton \\
\hline John s. Magg & Accused & & Theft & No. 786 & Condover \\
\hline John s. Nicholas & Accused & & Default & No. 822 & Chirbury \\
\hline John s. of Henry of Longford & Pledge & Longford & Theft & No. 786 & Condover \\
\hline John s. of Hugh of Peplow & Victim & Tern near Ercal \& Little Peplow & Misadventure & No. 684 & Bradford \\
\hline John s. of Richare de la Mare & Pledge & & Theft & No. 786 & Condover \\
\hline John s. Peter & Victim & Edgton \& Broome & Murder & No. 500 & Purslow \\
\hline John s. Peter n. Roger of Aston & Warrenty & & Dower & No. 149 & \\
\hline John s. Philip & Court Official & Wem & Novel Disseisin & No. 48 & \\
\hline John s. Philip & Juror & Eyton & Entry & No. 13 & \\
\hline John s. Philip & Juror & Oxenbold & Entry & No. 30 & \\
\hline John s. Philip & Juror & The Heath & Entry & No. 114 & \\
\hline John s. Philip & Juror & Weston & Entry & No. 16 & \\
\hline John s. Philip & Juror & Woofferton & Right & No. 332 & \\
\hline John s. Philip & Accused & Bulwardine & Default & No. 631 & Claverley \\
\hline John s. Philip of Acton & Victim & Cardington, Gretton, Willstone \& Acton & Execution/Murder & No. 603 & Munslow \\
\hline John s. Philip of Horton & Victim & Shrewsbury & Murder & No. 853 & Pimhill \\
\hline John s. Ralph of Huntington & Plaintiff & Woofferton & Entry & No. 320 & \\
\hline John s. Ralph of Mose & Accused & & Custom \& Services & No. 875 & Bridgenorth \\
\hline John s. Ralph the Chaplain of Aston & Accused & Newport & Murder & No. 762 & Edgmond \\
\hline John s. Richard Hake & Pledge & & Trespass/Force & No. 742 & Bradford \\
\hline John s. Robert & Payer & & Fine & No. 511 & Purslow \\
\hline John s. Robert of Home & Pledge & Wentnor, Ratlinghope, Medlicott \& Home & Murder & No. 492 & Purslow \\
\hline John s. Roger of Bagley & Plaintiff & Bagley & Seisin @ Death & No. 326 & \\
\hline John s. Roger of Eyton & Plaintiff & Eyton & Entry & No. 13 & \\
\hline John s. Roger Palmer & & & Compromise & No. 236 & \\
\hline John s. Roger Palmer & & & Compromise & No. 243 & \\
\hline John s. Roger s. Alewy & Plaintiff & Bagley & Seisin @ Death & No. 86 & \\
\hline John s. Seysel & Victim & Mawley, Kinlet \& Detton & Murder & No. 547 & Stottesdon \\
\hline John s. Stephen & Juror & Wem & Novel Disseisin & No. 48 & \\
\hline John s. Stephen of Harley & Victim & Harley & Murder & No. 785 & Condover \\
\hline John s. Stephen of Leighton & Witness & Garmston & Murder & No. 687 & Bradford \\
\hline John s. the Chaplain & Victim & The Corve in Lawton \& Little Sutton & Misadventure & No. 651 & Stanton \\
\hline John s. Thomas Long of More & Accused & More & Absconded & No. 512 & Purslow \\
\hline John s. Thomas of Norbury & Victim & Longville & Murder & No. 496 & Purslow \\
\hline John s. William & Victim & Petton wood & Misadventure & No. 840 & Pimhill \\
\hline John s. William Goldsmith \& Alice & (mention) & Bridgenorth & Entry & No. 308 & \\
\hline John s. William of Calverhall & Defendant & Calverhall & Novel Disseisin & No. 74 & \\
\hline John s. William of Ercall & Attorney & & Novel Disseisin & No. 176 & \\
\hline John s. William Reysent & Accused & Sandford & Theft/Assaul & No. 747 & Bradford \\
\hline John s. William s. Philip & Accuser & [inside Welshry] & Murder & No. 858 & Pimhill \\
\hline John s. William Turner & Defendant & Shrewsbury & Novel Disseisin & No. 125 & \\
\hline John Schyre & Victim & Coreley & Murder & No. 528 & Overs \\
\hline John Sely & Plaintiff & Bridgenorth & Entry & No. 215 & \\
\hline John Small & Defendant & The Bold & Dower & No. 211 & \\
\hline John Smith of Burford & Accused & & Theft & No. 539 & Overs \\
\hline John Stabler of Peaton & Accused & & Theft/Absconded & No. 637 & Corfton \\
\hline John Stedman & Victim & Corfton & Murder & No. 597 & Munslow \\
\hline John Strange & (mention) & Bomere & Novel Disseisin & No. 98. & \\
\hline John Strange & Defendant & & Custom \& Services & No. 476 & \\
\hline John Sturmy & Defendant & & Custom \& Services & No. 244 & \\
\hline John Tece & Attorney & & Wardship & No. 202 & \\
\hline John Tece & Plaintiff & Cressage & Entry & No. 322 & \\
\hline John Trulle & Defendant & Moreton & Novel Disseisin & No. 217 & \\
\hline John Turner of Foregate & Accused & & Murder & No. 880 & Foregate \\
\hline John Welsh & Juror & & & No. 930 & Hales \\
\hline John Wyard & (mention) & Loughton & Novel Disseisin & No. 251 & \\
\hline John Wyard & Plaintiff & Cleobury North & Custom \& Services & No. 207 & \\
\hline John Wyard & & & Plea of Liberty & No. 201 & \\
\hline John, Brother (of Croxden) & Attorney & & Custom \& Services & No. 173 & \\
\hline John, lay brother & Attorney & & Custom \& Services & No. 173 & \\
\hline John, servant of Roger Corbet & Victim & river Severn near Wroxeter, Norton \& Beslow & Misadventure & No. 726 & Bradford \\
\hline Jordan of Longford & Pledge & Longford & Theft & No. 786 & Condover \\
\hline \begin{tabular}{|l|} 
Jordan of Puleston \\
\end{tabular} & & & Compromise & No. 253 & \\
\hline Joukyn Pride & Accused & & Custom \& Services & No. 905 & Shrewsbury \\
\hline Jukyn Bleyz & Witness & & Murder & No. 507 & Purslow \\
\hline Jukyn Hemm & (mention) & Doddington & Execution/Murder & No. 734 & Bradford \\
\hline Kardigan s. Lewis Wechan [Cadwgan] [Fychan] & Plaintiff & Lydbury & Novel Disseisin & No. 81 & \\
\hline Katherine wd. Roger of Charlcotte & Plaintiff & The Bold \& Charlcotte & Dower & No. 211 & \\
\hline Kenewrek s. David Wych [Dafydd] [Fychan?] & Accused & Prees & Murder & No. 736 & Bradford \\
\hline Kenewrek s. Wyard Little & Accused & & Murder & No. 753 & Bradford \\
\hline Kenewrek Seys of Whixall & Pledge & & Murder & No. 753 & Bradford \\
\hline Kenewrek Spitfat & Accused & Whitechurch & Murder & No. 742 & Bradford \\
\hline Kenewrek Welsh & Accused & Newport & Murder & No. 758 & Edgmond \\
\hline Kenwrek Seys of Bronington [Kenewrek] & Pledge & Whixall & Murder & No. 720 & Bradford \\
\hline Laurence of Munslow & Accused/Victim & & Murder & No. 599 & Munslow \\
\hline Lauretta w. William Hunter & Defendant & Marton & Novel Disseisin & No. 112 & \\
\hline Lauretta w. William Hunter & Defendant & Marton & Novel Disseisin & No. 134 & \\
\hline Laurina w. William Forewyn & Victim & Kenley & Murder & No. 776 & Condover \\
\hline Lenot d. Gladys [Gwladys] & Victim & Wem & Misadventure & No. 689 & Bradford \\
\hline Llewelyn of Obley & Victim & Brampton & Murder & No. 488 & Purslow \\
\hline Llewelyn s. Wrennok s. Meurin [Llywelyn] (Welshman) & Accused & Edstaston & Murder & No. 683 & Bradford \\
\hline
\end{tabular}




\begin{tabular}{|c|c|c|c|c|c|}
\hline Llywelyn of Colbatch & Defendant & Colebatch & Seisin @ Death & No. 23 & \\
\hline Lucy d. Adam Essebern & Victim & Ledwyche Brook in Stoke \& Whitton & Misadventure & No. 521 & Purslow \\
\hline Lucy d. Alexander \& s. Joan & Defendant & Sutton & Seisin @ Death & No. 292 & \\
\hline \begin{tabular}{|l|} 
Lucy w. Nicholas Meverel \\
\end{tabular} & Defendant & Yockleton \& Amaston & Praecipe in Capite & No. 128 & \\
\hline Lucy w. Nicholas Meverel & Plaintiff & Amaston & Novel Disseisin & No. 272 & \\
\hline Lucy w. Nicholas Meverel & & & AppointAttorney & No. 200 & \\
\hline \begin{tabular}{|l|} 
Luke s. Alexander \\
\end{tabular} & Defendant & Little Sutton & Entry & No. 285 & \\
\hline Luke s. John & Accused & & Theft & No. 904 & Shrewsbury \\
\hline Mabel of Harley & Victim & & Rape & No. 672 & Wenlock \\
\hline Mabel w. Hamon of Presthope & Victim & Wenlock & Murder/Assault & No. 668 & Wenlock \\
\hline Madoc of Besford & Victim & Besford & Misadventure & No. 846 & Pimhill \\
\hline Madoc of Bucknell [Madog] & Juror & & & No. 911 & Purslow \\
\hline Madoc of Croswen & Accused & Baschurch & Murder & No. 856 & Pimhill \\
\hline \begin{tabular}{|l|} 
Madoc of Picklescote [Madog] \\
\end{tabular} & Juror & & & No. 913 & Condover \\
\hline Madoc of Picklescott [Madog] & Pledge & Wellington & Theft & No. 761 & Edgmond \\
\hline \begin{tabular}{|l} 
Madoc of Plealey [Madog] \\
\end{tabular} & Juror & & & No. 923 & Ford \\
\hline Madoc of Sutton [Madog] & Defendant & Harrington in Sutton & Nuisance/Novel Disseisin & No. 293 & \\
\hline Madoc of Sutton [Madog] & Juror & The Heath & Entry & No. 114 & \\
\hline Madoc of Sutton [Madog] & Juror & Wem & Novel Disseisin & No. 48 & \\
\hline Madoc of Sutton [Madog] & Juror & Woofferton & Right & No. 332 & \\
\hline \begin{tabular}{|l} 
Madoc of Sutton [Madog] \\
\end{tabular} & Plaintiff & Harrington in Sutton & Novel Disseisin & No. 311 & \\
\hline Madoc of Sutton [Madog] & & & Plea of Land & No. 269 & \\
\hline Madoc of Swanedon & Victim & Myddle \& Balderton & Misadventure & No. 854 & Pimhill \\
\hline Madoc s. Ivor of Easthampton/Estanton [Madog] & Pledge & & Dower & No. 147 & \\
\hline Madoc s. Yareford of Bronington [Madog] & Pledge & Whixall & Murder & No. 720 & Bradford \\
\hline Madoc s. Ythel of Coton [Madog] [Ithel] & Accused & & Murder & No. 753 & Bradford \\
\hline Madoc s. Ythel of Whixall [Madog] [lthel] & Accused & Whixall & Murder & No. 720 & Bradford \\
\hline Margaret Brian & & & AppointAttorney & No. 188 & \\
\hline Margaret w. William of Deuxhill & (mention) & Deuxhill & Seisin@ Death & No. 42 & \\
\hline Margaret wd. Roger of Aston & Plaintiff & Aston, Bromlow, Whitsborn \& Luckley & Dower & No. 149 & \\
\hline Margaret wd. Roger of Aston & & & Dower & No. 183 & \\
\hline Margery d. Robert of Hatton & Plaintiff & Hatton & Novel Disseisin & No. 35 & \\
\hline Margery d. William Arnold & Plaintiff & Weston & Entry & No. 16 & \\
\hline \begin{tabular}{|l|} 
Margery d. William Kede \\
\end{tabular} & Plaintiff & Broughton & Seisin @ Death & No. 26 & \\
\hline Margery d. William of Bicton & Victim & Bicton heath & Misadventure & No. 851 & Pimhill \\
\hline Margery de Lacy & Plaintiff & & Wardship & No. 130 & \\
\hline Margery $\mathrm{m}$. Walter Haket & (mention) & Egarton in Bromden & Novel Disseisin & No. 255 & \\
\hline \begin{tabular}{|l|} 
Margery of Halton d. Richard s. Osbert \\
\end{tabular} & Plaintiff & Woofferton & Right & No. 332 & \\
\hline Margery of Tugford & Plaintiff & Lawton & Novel Disseisin & No. 473 & \\
\hline Margery of Tugford & Plaintiff & Lawton & Novel Disseisin & No. 474 & \\
\hline Margery w. Gilbert of Frome & & & Plea of Land & No. 180 & \\
\hline \begin{tabular}{|l|} 
Margery w. Martin Rufferd \\
\end{tabular} & Plaintiff & Ludlow & Entry & No. 108 & \\
\hline Margery w. Roger s. Walter \& n. William Porter & Plaintiff & Shrewsbury & Seisin@ Death & No. 101 & \\
\hline Margery w. Roger s. Walter \& n. William Porter & Plaintiff & Shrewsbury & Seisin@ Death & No. 309 & \\
\hline Margery w. William of Brompton & & & AppointAttorney & No. 197 & \\
\hline \begin{tabular}{|l|} 
Margery w. William of Lyfford/Lifford \\
\end{tabular} & & & AppointAttorney & No. 197 & \\
\hline Margery w. William s. Osbert & Plaintiff & & Compromise & No. 7 & \\
\hline \begin{tabular}{|l|} 
Margery w. William s. the Priest \\
\end{tabular} & Defendant & Deuxhill & Seisin @ Death & No. 306 & \\
\hline Margery wd. Richard Landien & Plaintiff & Bitterley & Dower & No. 131 & \\
\hline Margery wd. Thomas Dun & Accuser & & Murder & No. 892 & Shrewsbury \\
\hline Margery wd. William Afcote. & & & & No. 194 & \\
\hline Martin Kempe & & & Compromise & No. 294 & \\
\hline Martin Kempe & & & Compromise & No. 324 & \\
\hline Martin of Broughton & Court Official & Eyton & Novel Disseisin & No. 229 & \\
\hline \begin{tabular}{|l|} 
Martin Rufferd \\
\end{tabular} & Plaintiff & Ludlow & Entry & No. 108 & \\
\hline Mascy of Ludlow & Juror & & Judgement & No. 617 & Munslow \\
\hline Master of Knights of the Temple in England & & & Compromise & No. 325 & \\
\hline Master of the Hospital of St. John, Ludlow & Defendant & Sheet \& Wettleton \& Stokesay & Seisin @ Death & No. 99 & \\
\hline \begin{tabular}{|l} 
Master of the Hospital of St. Oswald, Worcester \\
\end{tabular} & Plaintiff & Bealy Wood & Estover & No. 31 & \\
\hline Master Walter Palmer & Accused & & Murder/Harbor & No. 861 & Bridgenorth \\
\hline Master Walter Palmer & Payer & & Fine & No. 871 & Bridgenorth \\
\hline Matilda d. Ellis of Roden [Elis/Elias] & Victim & river Roden & Misadventure & No. 697 & Bradford \\
\hline Matilda d. Gillian & Plaintiff & Woodhouse & Right & No. 344 & \\
\hline Matilda d. Richard s. Stephen & Plaintiff & Loton & Seisin @ Death & No. 14 & \\
\hline Matilda de Cantilupe & (mention) & Marton & Seisin @ Death & No. 256 & \\
\hline Matilda de Coudray d. Peter de Coudray & Plaintiff & Habberley \& Nethercote & Entry & No. 247 & \\
\hline Matilda de Coudray d. Peter de Coudray & Plaintiff & Nethercote & Entry & No. 248 & \\
\hline Matilda Gnat & Accused/Victim & & Theft/Murder & No. 556 & Stottesdon \\
\hline Matilda s. Susan Attelegh & Plaintiff & Legh & Entry & No. 333 & \\
\hline \begin{tabular}{|l} 
Matilda w. Alexander Cantrich \\
\end{tabular} & First Finder & Dawley & Murder & No. 735 & Bradford \\
\hline Matilda w. Geoffrey Genevill \& d. Gilbert de Lacy & (mention) & Cressage & Novel Disseisin & No. 91 & \\
\hline Matilda w. Geoffrey Genevill \& d. Gilbert de Lacy & Pledge & Stanton Lacy & Seisin@ Death & No. 164 & \\
\hline Matilda w. Herbert of Corfton & Accuser & & Imprisonment/Theft & No. 577 & Munslow \\
\hline Matilda w. John of Hales & Defendant & Hales & Dower & No. 315 & \\
\hline \begin{tabular}{|l|} 
Matilda w. John of Hales \\
\end{tabular} & & & Dower & No. 175 & \\
\hline Matilda w. Peter Wycharde & Victim & Cocabite Street & Murder & No. 896 & Shrewsbury \\
\hline Matilda w. Ralph Butler & Defendant & Tyrley & Novel Disseisin & No. 291 & \\
\hline Matilda w. Ralph Butler & Plaintiff & Wem & Novel Disseisin & No. 48 & \\
\hline Matilda w. Robert Blundel \& d. Agnes \& Peter Clerk & Defendant & Chirbury & Novel Disseisin & No. 210 & \\
\hline Matilda w. Robert of Corfton & Witness & Bouldon, Poston \& Abdon & Murder & No. 590 & Munslow \\
\hline Matilda w. Walter of Pedwardine \& wd. William of Eyton & Plaintiff & Eyton on the Weald Moors & Dower & No. 144 & \\
\hline \begin{tabular}{|l|} 
Matilda wd. Andrew s. William \\
\end{tabular} & (mention) & Bridgenorth & Entry & No. 308 & \\
\hline \begin{tabular}{|l|} 
Matilda wd. Peter Packe \\
\end{tabular} & Plaintiff & & Dower & No. 147 & \\
\hline Matilda wd. William Beadle & Plaintiff & Diddlebury & Novel Disseisin & No. 152 & \\
\hline Matilda Wynd & Victim & Criddon & Murder/Assault & No. 563 & Stottesdon \\
\hline \begin{tabular}{|l|} 
Matilda, kinswoman/concubine (amice) of John of Gatacre \\
\end{tabular} & Victim & & Murder/Harbor & No. 861 & Bridgenorth \\
\hline Maurice s. Ithel of Rhiston & Pledge & Rhiston & Misadventure & No. 815 & Chirbury \\
\hline \begin{tabular}{|l} 
Michael of Moreton \\
\end{tabular} & Defendant & Norton & Novel Disseisin & No. 49 & \\
\hline Michael of Moreton & & & Compromise & No. 100 & \\
\hline Milisent s. William of Norton & Defendant & Norton & Entry & No. 310 & \\
\hline \begin{tabular}{|l|} 
Milisent w. Willaim Coleman \\
\end{tabular} & Victim & & Murder & No. 639 & Ludlow \\
\hline
\end{tabular}




\begin{tabular}{|c|c|c|c|c|c|}
\hline Monks of Combermere & Accused & & Trespass/Force & No. 742 & Bradford \\
\hline Muriel wd. Henry of Pantel & Accuser & Ludlow & Murder & No. 576 & Munslow \\
\hline \begin{tabular}{|l|} 
Nichola d. Leonard \\
\end{tabular} & & & Compromise & No. 140 & \\
\hline Nicholas Andrew & Juror & & Judgement & No. 617 & Munslow \\
\hline Nicholas Andrew of Ludlow & Defendant & Stokesay & Novel Disseisin & No. 15 & \\
\hline Nicholas Beadle & Defendant & Hordley & Novel Disseisin & No. 221 & \\
\hline Nicholas br. William of The Green & Defendant & Alveley & Novel Disseisin & No. 3 & \\
\hline Nicholas Colt & Defendant & Newport & Entry & No. 28 & \\
\hline Nicholas Crawe of Acton & Victim & Rowton & Murder & No. 494 & Purslow \\
\hline Nicholas Fulco & Accused & Cotes/Coton & Murder & No. 888 & Shrewsbury \\
\hline Nicholas Glover & Accused & & Assault & No. 890 & Shrewsbury \\
\hline Nicholas Mautravers & Victim & Severn near Cressage & Misadventure & No. 766 & Condover \\
\hline \begin{tabular}{|l} 
Nicholas Mercer of Ludlow \\
\end{tabular} & Victim & River Teme in Bromfield, Felton \& Burway & Misadventure & No. 573 & Munslow \\
\hline \begin{tabular}{|l|} 
Nicholas Meverel \\
\end{tabular} & Defendant & Rowton & Mort d'Ancestor & No. 142 & \\
\hline Nicholas Meverel & Defendant & Yockleton \& Amaston & Pracipe in Capite & No. 128 & \\
\hline \begin{tabular}{|l|} 
Nicholas Meverel \\
\end{tabular} & Plaintiff & Amaston & Novel Disseisin & No. 272 & \\
\hline \begin{tabular}{|l|} 
Nicholas Meverel \\
\end{tabular} & & & Novel Disseisin & No. 200 & \\
\hline Nicholas of Coton, a forester of Wombridge & Accused & Priors Lee \& Leonards Lee & Murder & No. 802 & Brimstree \\
\hline Nicholas of Deepdale & Victim & Bridgenorth & Murder & No. 557 & Stottesdon \\
\hline Nicholas of Easthampton & Pledge & Bitterley & Dower & No. 131 & \\
\hline \begin{tabular}{|l|} 
Nicholas of Edgton \\
\end{tabular} & Accused & & Default & No. 520 & Purslow \\
\hline Nicholas of Hampton & Court Official & Whatmore & Novel Disseisin & No. 317 & \\
\hline \begin{tabular}{|l|} 
Nicholas of Haselour \\
\end{tabular} & Attorney & & Mort d'Ancestor & No. 182 & \\
\hline \begin{tabular}{|l|} 
Nicholas of Haselour \\
\end{tabular} & Plaintiff & Whettleton, Stokesay \& Steventon & Custom \& Services & No. 347 & \\
\hline \begin{tabular}{|l} 
Nicholas of Haselour \\
\end{tabular} & Plaintiff & Sheet & Novel Disseisin & No. 328 & \\
\hline Nicholas of Haselour & Pledge & & Fine & No. 503 & Purslow \\
\hline \begin{tabular}{|l|} 
Nicholas of Hastings \\
\end{tabular} & Defendant & Leighton & Mort d'Ancestor & No. 4 & \\
\hline \begin{tabular}{|l|} 
Nicholas of Hastings \\
\end{tabular} & & & Plea of Land & No. 266 & \\
\hline \begin{tabular}{|l} 
Nicholas of Hinton \\
\end{tabular} & Victim & Stottesdon, Walton \& Harcourt & Murder & No. 549 & Stottesdon \\
\hline Nicholas of Hints & Court Official & Whatmore & Novel Disseisin & No. 317 & \\
\hline Nicholas of Hints & Defendant & Walford \& Wigmore & Nuisance & No. 270 & \\
\hline Nicholas of Hints & Warrenty & Walford & Entry & No. 90 & \\
\hline Nicholas of Hundeslawe of Hereford & Accused & & Custom \& Services & No. 905 & Shrewsbury \\
\hline Nicholas of Marham & Accused & Ludlow Market & Theft & No. 612 & Munslow \\
\hline Nicholas of Marlow & Accused/Victim & Ludlow & Murder & No. 638 & Ludlow \\
\hline Nicholas of Rowton & Juror & & Judgement & No. 617 & Munslow \\
\hline \begin{tabular}{|l|} 
Nicholas of Sallowe \\
\end{tabular} & Pledge & Bridgenorth & Murder & No. 936 & Bridgenorth \\
\hline Nicholas of Walford & Defendant & Walford \& Leintwardine & Nuisance & No. 139 & \\
\hline Nicholas of Walton, Clerk & Accused & Billingsley, Northwood \& Stottesdon & Murder & No. 562 & Stottesdon \\
\hline \begin{tabular}{|l|} 
Nicholas of Willey \\
\end{tabular} & Accused & & Misadventure & No. 658 & Wenlock \\
\hline Nicholas of Wychele & Coroner & & & No. 484 & Shropshire \\
\hline Nicholas Pissun & Accuser & & Assault & No. 890 & Shrewsbury \\
\hline Nicholas Porter & Pledge & Bridgenorth & Murder & No. 936 & Bridgenorth \\
\hline Nicholas Preke of Diddlebury, Miller & Accused & & Theft/Absconded & No. 633 & Corfton \\
\hline Nicholas Provost & Defendant & Neen & Novel Disseisin & No. 1 & \\
\hline Nicholas Provost & Defendant & Shrewsbury & Seisin @ Death & No. 309 & \\
\hline Nicholas Puleyn of Newport & Pledge & Newport & Trespass & No. 739 & Bradford \\
\hline \begin{tabular}{|l|} 
Nicholas Russell of Donnington \\
\end{tabular} & Accused & & Absconded & No. 812 & Brimstree \\
\hline \begin{tabular}{|l|} 
Nicholas s. Alexander of Newport \\
\end{tabular} & Pledge & Newport & Trespass & No. 739 & Bradford \\
\hline Nicholas s. Andrew & Plaintiff & The Heath & Novel Disseisin & No. 263 & \\
\hline \begin{tabular}{|l|} 
Nicholas s. Coleman \\
\end{tabular} & Witness & Ludlow & Murder & No. 576 & Munslow \\
\hline Nicholas s. Ellis of Eaton [Elis/Elias] & Juror & & & No. 923 & Ford \\
\hline \begin{tabular}{|l|} 
Nicholas s. Geoffrey of Overton \\
\end{tabular} & Defendant & Neen Savage & Novel Disseisin & No. 2 & \\
\hline Nicholas s. Gunnild wd. Richard of Haleford & Attorney & & Dower & No. 175 & \\
\hline Nicholas s. John of Castle Holdgate/The Heath & Victim & & Murder & No. 578 & Munslow \\
\hline Nicholas s. Margery de Lacy & Pledge & Stanton Lacy & Seisin @ Death & No. 164 & \\
\hline Nicholas s. Philip Miller \& Isabel & Defendant & Shrewsbury & Seisin @ Death & No. 340 & \\
\hline Nicholas s. Roger of Orleton & Pledge & & Assault & No. 744 & Bradford \\
\hline \begin{tabular}{|l|} 
Nicholas s. the Parson of Bitterley \\
\end{tabular} & Witness & Ludlow & Murder & No. 576 & Munslow \\
\hline \begin{tabular}{|l|} 
Nicholas s. Walter of Wormbridge \\
\end{tabular} & Victim & Lawton, Little Sutton \& Bitterley & Murder & No. 652 & Stanton \\
\hline Nicholas Smith & Defendant & Atcham in Berwick & Novel Disseisin & No. 327 & \\
\hline Nicholas Stury & Victim & & Murder & No. 894 & Shrewsbury \\
\hline \begin{tabular}{|l|} 
Nicholas the Baker \\
\end{tabular} & Juror & & Judgement & No. 617 & Munslow \\
\hline \begin{tabular}{|l} 
Nicholas the Clerk \\
\end{tabular} & Accused & Carwood in Sibdon & Execution/Murder & No. 497 & Purslow \\
\hline Nicholas Tubbe & Defendant & Norbury & Novel Disseisin & No. 50 & \\
\hline \begin{tabular}{|l} 
Nicholas Welsh, Brother \\
\end{tabular} & Attorney & & & No. 69 & \\
\hline \begin{tabular}{|l|} 
Nicholas, Parson of Hope Bowdler \\
\end{tabular} & Plaintiff & Eaton & Custom \& Services & No. 234 & \\
\hline \begin{tabular}{|l|} 
Nicola d. Leonard of Lee \\
\end{tabular} & Plaintiff & Weston & Seisin @ Death & No. 160 & \\
\hline \begin{tabular}{|l|} 
Olimpias of Whettleton \\
\end{tabular} & & & AppointAttorney & No. 191 & \\
\hline \begin{tabular}{|l|} 
Oliver b. Adam Hubert \\
\end{tabular} & Accused & & Absconded & No. 796 & Condover \\
\hline Ona Hyr & Accused & Doddington & Execution/Murder & No. 734 & Bradford \\
\hline Ona s. David Wych [Dafydd] [Fychan?] & Accused & Prees & Murder & No. 736 & Bradford \\
\hline Osbert Baret & Plaintiff & Whatmore & Novel Disseisin & No. 317 & \\
\hline \begin{tabular}{|l|} 
Osbert Baret \\
\end{tabular} & & & Appoint Attorney & No. 196 & \\
\hline Osbert de Girros & (mention) & Wooton & Custom \& Services & No. 249 & \\
\hline Osbert of Cornewood & Pledge & Cainham & Mort d'Ancestor & No. 254 & \\
\hline \begin{tabular}{|l} 
Osbert of Holloweay \\
\end{tabular} & Accused & Alveley \& Nordley & Murder & No. 543 & Alveley \\
\hline Osbert of Lee & Accuser & & Corruption & No. 649 & Hales \\
\hline Osbert of Rockhill & Pledge & Cainham & Mort d'Ancestor & No. 254 & \\
\hline Osbert of Wolebrowe & Victim & Broome & Misadventure & No. 782 & Condover \\
\hline \begin{tabular}{|l} 
Osbert s. Helyn [Heilyn] \\
\end{tabular} & & & Compromise & No. 127 & \\
\hline Osbert s. Wyard Little & Accused & & Murder & No. 753 & Bradford \\
\hline Osbert s. Ythel of Coton [Ithel] & Accused & & Murder & No. 753 & Bradford \\
\hline \begin{tabular}{|l} 
Osbert the Furber \\
\end{tabular} & Juror & & Judgement & No. 617 & Munslow \\
\hline Osbert, Parson of Diddlebury & (mention) & Diddlebury & Novel Disseisin & No. 109 & \\
\hline Ouger Collier & Defendant & Shrewsbury & Entry & No. 237 & \\
\hline \begin{tabular}{|l|} 
Pain of Brompton \\
\end{tabular} & Accused & & Trespass/Force & No. 742 & Bradford \\
\hline Parnel d. Lenot & Defendant & Hamton' & Entry & No. 132 & \\
\hline Parnel d. Richard & Plaintiff & Hamton' & Entry & No. 132 & \\
\hline Parnel of Westhope & Victim & Corfton & Murder & No. 632 & Corfton \\
\hline Parnel w. Henry Wade & Defendant & Ludlow & Entry & No. 108 & \\
\hline
\end{tabular}




\begin{tabular}{|c|c|c|c|c|c|}
\hline Parnel w. James of Hell' & & & Compromise & No. 301 & \\
\hline Parnel w. Ralph Goky & Defendant & Orleton & Seisin @ Death & No. 334 & \\
\hline Peter de Rivaux & Accused & Bulwardine & Default & No. 631 & Claverley \\
\hline Peter de Sascy & & & Compromise & No. 238 & \\
\hline \begin{tabular}{|l|} 
Peter de Sascy \\
\end{tabular} & & & Plea of Debt & No. 205 & \\
\hline Peter Diri [Deri] & Defendant & Chetwynd & Novel Disseisin & No. 110 & \\
\hline Peter Forester & Defendant & Chelmarsh & Novel Disseisin & No. 47 & \\
\hline Peter from the wood of Roger of Edgton & Accused & & Default & No. 521 & Purslow \\
\hline Peter Minton & Juror & Eyton & Entry & No. 13 & \\
\hline Peter Minton & Juror & Oxenbold & Entry & No. 30 & \\
\hline Peter Minton & Juror & Weston & Entry & No. 16 & \\
\hline \begin{tabular}{|l|} 
Peter of Hasewell \\
\end{tabular} & Accused & Bulwardine & Murder & No. 630 & Claverley \\
\hline Peter of Hasewell & Accused & Bridgenorth \& Chelmarsh & Theft & No. 551 & Stottesdon \\
\hline Peter of Minton & Court Official & Woofferton & Right & No. 332 & \\
\hline Peter of Minton & Court Official & Belswardyne Wood & Tort \& Force & No. 138 & \\
\hline Peter of Minton & Defendant & Whittingslow & Dower & No. 92 & \\
\hline Peter of Minton & Juror & The Heath & Entry & No. 114 & \\
\hline Peter of Minton & Juror & Wem & Novel Disseisin & No. 48 & \\
\hline Peter of Minton & Juror & Woofferton & Right & No. 332 & \\
\hline Peter of Pickstock & Defendant & Chetwynd & Novel Disseisin & No. 110 & \\
\hline Peter of Upton, Parson & Victim & Upton, Crudgington, Rowton \& Coldhatton & Misadventure & No. 676 & Bradford \\
\hline Peter Peverel & Defendant & Eyton on the the Weald Moors & Dower & No. 144 & \\
\hline Peter s. Avice & Defendant & Atcham in Berwick & Novel Disseisin & No. 327 & \\
\hline Peter s. John & First Finder & Cherrington & Misadventure & No. 693 & Bradford \\
\hline Peter s. Roger & Pledge & Wigwig & Murder & No. 784 & Condover \\
\hline Peter, Bishop of Hereford & Defendant & Lydbury & Novel Disseisin & No. 81 & \\
\hline Petronilla w. William Dod & Plaintiff & Wooton & Custom \& Services & No. 249 & \\
\hline Petronilla w. William Dod & & & AppointAttorney & No. 478 & \\
\hline Phiip Clerk & Defendant & & Appoint Attorney & No. 171 & \\
\hline Philip & Witness & Batchcott, Wooferton, Ashford Bowdler \& Overton & Murder & No. 571 & Munslow \\
\hline Philip Black, Baker & Witness & Ludlow & Murder & No. 576 & Munslow \\
\hline Philip Bret & Court Official & The Heath & Entry & No. 114 & \\
\hline Philip Bret & Juror & Eyton & Entry & No. 13 & \\
\hline Philip Bret & Juror & Oxenbold & Entry & No. 30 & \\
\hline Philip Bret & Juror & The Heath & Entry & No. 114 & \\
\hline Philip Bret & Juror & Weston & Entry & No. 16 & \\
\hline \begin{tabular}{|l|} 
Philip Buche \\
\end{tabular} & Accused & Myndtown & Murder & No. 498 & Purslow \\
\hline \begin{tabular}{|l} 
Philip Burel of Greet \\
\end{tabular} & Accused & & Absconded & No. 540 & Overs \\
\hline Philip Burrey & Plaintiff & & Custom \& Services & No. 296 & \\
\hline \begin{tabular}{|l|} 
Philip Caloch \\
\end{tabular} & Accused & Tedstill & Unlawful Entry & No. 566 & Stottesdon \\
\hline Philip Cleche of Shrewsbury & Accused & & Theft & No. 793 & Condover \\
\hline Philip de Clinton & Defendant & Stanton & Custom \& Services & No. 345 & \\
\hline \begin{tabular}{|l} 
Philip de Girros \\
\end{tabular} & Juror & Lawton & Novel Disseisin & No. 473 & \\
\hline Philip de Petra of Bridgenorth & Pledge & & Fine & No. 862 & Bridgenorth \\
\hline Philip Fuller & Defendant & Foregate & Seisin @ Death & No. 273 & \\
\hline Philip Gascon & Accused & Severn & Nuisance & No. 903 & Shrewsbury \\
\hline Philip Gascon & Plaintiff & Shrewsbury & Entry & No. 329 & \\
\hline Philip Hord & Accused & Tedstill & Unlawful Entry & No. 566 & Stottesdon \\
\hline \begin{tabular}{|l} 
Philip Hord \\
\end{tabular} & Payer & Tedstill & Unlawful Entry & No. 566 & Stottesdon \\
\hline \begin{tabular}{|l} 
Philip Marmiun \\
\end{tabular} & Accused & & Default & No. 787 & Condover \\
\hline \begin{tabular}{|l|} 
Philip Marmiun \\
\end{tabular} & Defendant & Pulverbatch & Entry & No. 11 & \\
\hline \begin{tabular}{|l} 
Philip Marmiun \\
\end{tabular} & Defendant & Stapleton & Novel Disseisin & No. 313 & \\
\hline \begin{tabular}{|l|} 
Philip Marmiun \\
\end{tabular} & Defendant & Steplewood in Condover & Novel Disseisin & No. 314 & \\
\hline \begin{tabular}{|l|} 
Philip Marmiun \\
\end{tabular} & Defendant & Pulverbatch & Right & No. 475 & \\
\hline Philip Marmiun & Defendant & Pulverbatch & & No. 264 & \\
\hline \begin{tabular}{|l|} 
Philip Marmiun \\
\end{tabular} & & & Novel Disseisin & No. 267 & \\
\hline \begin{tabular}{|l} 
Philip of Beckbury \\
\end{tabular} & Defendant & Nobold, Beckbury \& Golding & Dower & No. 162 & \\
\hline Philip of Benthall & Plaintiff & Benthall & Entry & No. 115 & \\
\hline Philip of Drayton, Vicar & Defendant & & Appoint Attorney & No. 171 & \\
\hline \begin{tabular}{|l|} 
Philip of Greet \\
\end{tabular} & Plaintiff & Hopton & Novel Disseisin & No. 57 & \\
\hline Philip of Hales & Accuser & & Corruption & No. 649 & Hales \\
\hline Philip of Kent & Accused & Doddington & Execution/Murder & No. 734 & Bradford \\
\hline Philip of Little Hereford & Victim & Whitton & Misadventure & No. 525 & Overs \\
\hline Philip of Prees & Recipient & & Fine & No. 511 & Purslow \\
\hline Philip of Ruthall & Pledge & Wellington & Theft & No. 761 & Edgmond \\
\hline Philip of Tilstock & Defendant & Shrewsbury & Seisin @ Death & No. 309 & \\
\hline Philip of Wichcott & (mention) & Loughton & Novel Disseisin & No. 251 & \\
\hline Philip of Woodhouse & Defendant & Hordley & Novel Disseisin & No. 221 & \\
\hline Philip Orkeney of Clunton & Pledge & & Murder & No. 505 & Purslow \\
\hline Philip s. Adam & Accused & & Execution & No. 495 & Purslow \\
\hline \begin{tabular}{|l|} 
Philip s. Adam \\
\end{tabular} & Victim & Chelmick, Hope Bowdler, West Wall \& Acton & Murder/Assault & No. 606 & Munslow \\
\hline Philip s. Bertram of Strefford & Victim & Wistanstow & Murder & No. 585 & Munslow \\
\hline Philip s. Ellis [Elis/Elias] & Accused & Field of Millichope & Execution/Murder & No. 656 & Wenlock \\
\hline Philip s. Gregory of Clunton & Pledge & & Murder & No. 508 & Purslow \\
\hline Philip s. Hugh of Aston & Pledge & Northwood & Mort d'Ancestor & No. 5 & \\
\hline Philip s. Iseult of Cleobury & Victim & Neen Savage, Neen \& Hopton Wafers & Murder & No. 546 & Stottesdon \\
\hline Philip s. John Goding & Accused & & Absconded & No. 512 & Purslow \\
\hline Philip s. Jordan of Rowton & Accused & Rowton & Murder & No. 494 & Purslow \\
\hline Philip s. Peter & Victim & Newport & Murder & No. 762 & Edgmond \\
\hline Philip s. Robert of Sutton & Accused & Castle Holdgate & Murder & No. 591 & Munslow \\
\hline Philip the Reeve of Downton & Accused & & Murder & No. 505 & Purslow \\
\hline \begin{tabular}{|l} 
Philip Tyler \\
\end{tabular} & Accused/Victim & & Murder & No. 600 & Munslow \\
\hline \begin{tabular}{|l|} 
Philip Welsh \\
\end{tabular} & Victim & Down & Murder & No. 486 & Purslow \\
\hline Philip Wolf of Stokesay & Accused & Ludlow Market & Murder & No. 582 & Munslow \\
\hline Philip Woodward of Suthop' & Pledge & Hayton & Novel Disseisin & No. 96 & \\
\hline Prior of Chirbury & Accused & & Default & No. 822 & Chirbury \\
\hline Prior of Chirbury & Defendant & Espley & Novel Disseisin & No. 470 & \\
\hline Prior of the Hospital of St. John of Jerusalem & & & Novel Disseisin & No. 205 & \\
\hline Prior of Wenlock & Defendant & Eaton & Custom \& Services & No. 234 & \\
\hline Prior of Wenlock & Defendant & Posenhall & Dower & No. 146 & \\
\hline Prior of Wenlock & Defendant & Benthall & Entry & No. 115 & \\
\hline
\end{tabular}




\begin{tabular}{|c|c|c|c|c|c|}
\hline Prior of Wenlock & Defendant & Oxenbold & Entry & No. 30 & \\
\hline Prior of Wenlock & Defendant & Eaton & Nuisance & No. 303 & \\
\hline Prior of Wenlock & Defendant & Preen & Seisin @ Death & No. 239 & \\
\hline Prior of Wenlock & Defendant & Preen & Seisin @ Death & No. 240 & \\
\hline Prior of Wenlock & Defendant & Preen & Seisin @ Death & No. 241 & \\
\hline Prior of Wenlock & Defendant & Preen & Seisin @ Death & No. 242 & \\
\hline Prior of Wenlock & Defendant & Wenlock & Seisin @ Death & No. 36 & \\
\hline Prior of Wenlock & Plaintiff & Middleton & Custom \& Services & No. 350 & \\
\hline Prior of Wenlock & Plaintiff & The Heath & Entry & No.114 & \\
\hline Prior of Wenlock & & Spoonhill, Bourton \& Callaughton & Perambulation & No. 336 & \\
\hline Prioress of Brewood & Defendant & Donington & Dower & No. 341 & \\
\hline Prioress of Brewood & Plaintiff & Donington & Custom \& Services & No. 323 & \\
\hline Prioress of Brewood & & & Novel Disseisin & No. 176 & \\
\hline Pylecok s. Robert Priest & Defendant & Diddlebury & Seisin @ Death & No. 214 & \\
\hline Quenith d. Roger of Ellastone \& s. Parnel d. Roger of Ellastone [ $\mathrm{Gw}$ ] & Plaintiff & Ellastone & Seisin @ Death & No. 77 & \\
\hline Rainulf s. Richard Russell & Defendant & Donington & Dower & No. 295 & \\
\hline Rainulf s. Richard Russell & Defendant & Donington & Plea of Land & No. 342 & \\
\hline Ralph & Defendant & Gravenhunger & Seisin @ Death & No. 82 & \\
\hline Ralph Buffard & Pledge & & Rape & No. 542 & Worthen \\
\hline Ralph Butler & Defendant & Tyrley & Novel Disseisin & No. 280 & \\
\hline Ralph Butler & Defendant & Tyrley & Novel Disseisin & No. 291 & \\
\hline Ralph Butler & Plaintiff & Wem & Novel Disseisin & No. 48 & \\
\hline Ralph Butler & Pledge & & Murder & No. 795 & Condover \\
\hline Ralph de Arras & Attorney & & Novel Disseisin & No. 10 & \\
\hline Ralph de Arras & Coroner & Wydicote & Misadventure & No. 799 & Brimstree \\
\hline Ralph de Arras & Coroner & & & No. 484 & Shropshire \\
\hline Ralph de Arras & Court Official & & At Mercy & No. 43 & \\
\hline Ralph de Arras & Court Official & Eyton & Entry & No. 13 & \\
\hline Ralph de Arras & Court Official & Oxenbold & Entry & No. 30 & \\
\hline Ralph de Arras & Court Official & The Heath & Entry & No. 114 & \\
\hline Ralph de Arras & Court Official & Wem & Novel Disseisin & No. 48 & \\
\hline Ralph de Arras & Court Official & & Perambulation & No. 351 & \\
\hline Ralph de Arras & Court Official & Woofferton & Right & No. 332 & \\
\hline Ralph de Arras & Defendant & & Custom \& Services & No. 319 & \\
\hline Ralph de Arras & Defendant & Neen & Novel Disseisin & No. 1 & \\
\hline Ralph de Arras & Defendant & Sidbury & Novel Disseisin & No. 40 & \\
\hline Ralph de Arras & \begin{tabular}{|l|} 
Defendant \\
\end{tabular} & Northwood & Nuisance & No. 87 & \\
\hline Ralph de Arras & Juror & Eyton & Entry & No. 13 & \\
\hline Ralph de Arras & Juror & Oxenbold & Entry & No. 30 & \\
\hline Ralph de Arras & Juror & The Heath & Entry & No. 114 & \\
\hline Ralph de Arras & Juror & Weston & Entry & \begin{tabular}{|l|} 
No. 16 \\
\end{tabular} & \\
\hline Ralph de Arras & Juror & Wem & Novel Disseisin & No. 48 & \\
\hline Ralph de Arras & Juror & Woofferton & Right & No. 332 & \\
\hline Ralph de Arras & Plaintiff & & Custom \& Services & No. 476 & \\
\hline Ralph de Arras & & & Compromise & \begin{tabular}{|l|} 
No. 133 \\
\end{tabular} & \\
\hline Ralph de Beyvill & Accused & & Murder & No. 824 & Chirbury \\
\hline Ralph Dire & Defendant & Chetwynd & Novel Disseisin & No. 110 & \\
\hline Ralph Falleden & Attorney & & & No. 150 & \\
\hline Ralph Forester & Court Official & Whatmore & Novel Disseisin & No. 317 & \\
\hline Ralph Goky & Defendant & Orleton & Seisin @ Death & No. 334 & \\
\hline Ralph Goky of Orleton & Accuser & & Assault & No. 744 & Bradford \\
\hline Ralph Grim & Accused & Middleton, Ledwich, Hopton \& The Moor & Murder & No. 587 & Munslow \\
\hline Ralph Mucke of Coreley & Pledge & Walford \& Wigmore & Nuisance & No. 270 & \\
\hline Ralph of Kent & Defendant & Eyton on the the Weald Moors & Dower & No. 144 & \\
\hline Ralph of Lostford & Accused & & Theft & No. 750 & Bradford \\
\hline Ralph of Moreton & Accused & Moreton & Absconded & No. 755 & Bradford \\
\hline Ralph of Mose & Accused & & Custom \& Services & No. 875 & Bridgenorth \\
\hline Ralph of Roughton & Accused & Tedstill & Unlawful Entry & No. 566 & Stottesdon \\
\hline Ralph of Roughton & Payer & Tedstill & Unlawful Entry & No. 566 & Stottesdon \\
\hline Ralph of Rouhull & Accuser & & Theft & No. 567 & Stottesdon \\
\hline Ralph of Ruthall & Pledge & Woodcote & Mort d'Ancestor & No. 271 & \\
\hline Ralph of Sandford & Plaintiff & Sandford & Novel Disseisin & No. 279 & \\
\hline Ralph of The Lowe & Defendant & Neen & Nuisance & No. 113 & \\
\hline Ralph of The Lowe & Plaintiff & Neen & Novel Disseisin & No. 34 & \\
\hline Ralph s. Adam of Arwystli & Witness & Wigwig & Murder & No. 784 & Condover \\
\hline Ralph s. Edith & Defendant & Bomere & Novel Disseisin & No.98. & \\
\hline Ralph s. Hawise of Shyrington & & & Compromise & No. 163 & \\
\hline Ralph s. John of Bitterley & Accused & Middleton, Ledwich \& Court of Hill & Murder & No. 520 & Overs \\
\hline Ralph s. Nicholas & Accused & & Default & No. 787 & Condover \\
\hline Ralph s. Richard of Longford & Pledge & Longford & Theft & No.786 & Condover \\
\hline Ralph s. Richard of Sandford & (mention) & Broughton & Seisin @ Death & No. 26 & \\
\hline Ralph s. Robert & Defendant & Lawton & Novel Disseisin & No. 474 & \\
\hline Ralph s. Robert of Hill & Defendant & Loughton & Novel Disseisin & No. 251 & \\
\hline Ralph Serjant & Defendant & Chetwynd & Novel Disseisin & No. 110 & \\
\hline Ralph Taylor & Defendant & Gravenhunger & Dower & No. 117 & \\
\hline Ralph the Parson of Lindridge & Defendant & Lawton & Novel Disseisin & No. 473 & \\
\hline Ralph the Parson of Lindridge & Defendant & Lawton & Novel Disseisin & No. 474 & \\
\hline Ralph, a goldsmith & (mention) & Woofferton & Seisin @ Death & No. 33 & \\
\hline Ralph, Parson of Lindridge & Defendant & Loughton & Novel Disseisin & No. 251 & \\
\hline Ranulf Forester & Defendant & Donnington & Nuisance & No. 331 & \\
\hline Ranulf of Wellington & Accused & & Theft & No. 750 & Bradford \\
\hline Ranulf Payn, Parson of Ruckley & Pledge & & Executed & No. 788 & Condover \\
\hline Ranulf s. Walter of Harpcote & Warrenty & Diddlebury & Novel Disseisin & No. 109 & \\
\hline Rees of Overton [Rhys] & (mention) & Overton & Entry & No. 41 & \\
\hline Reginald Cambun & Defendant & Chetwynd & Novel Disseisin & No. 110 & \\
\hline Reginald Colet & Accused & & Theft & No. 810 & Brimstree \\
\hline Reginald Costard & Defendant & Bomere & Novel Disseisin & No.98. & \\
\hline Reginald Cote & Victim & Wrickton & Murder & No. 554 & Stottesdon \\
\hline Reginald de Boterell & Accused & & Default & No. 834 & Ford \\
\hline Reginald de Boterell & Accused & & Default & No. 515 & Purslow \\
\hline Reginald de Gaugy & Victim & Bridgenorth & Murder & No.936 & Bridgenorth \\
\hline
\end{tabular}




\begin{tabular}{|c|c|c|c|c|c|}
\hline Reginald de Gaugy & Victim & Worfield & Murder & No. 673 & Worfield \\
\hline \begin{tabular}{|l|} 
Reginald de Girros \\
\end{tabular} & Accused & Wellington & Theft & No. 761 & Edgmond \\
\hline Reginald Furet & Accused & & Executed & No. 832 & Ford \\
\hline Reginald Godfrey & Accused & & Custom \& Services & No. 875 & Bridgenorth \\
\hline Reginald Knybbe of Marton & Pledge & Marton & Novel Disseisin & No. 134 & \\
\hline Reginald of Affcott & Bailiff/Serjeant & Castle Holdgate & Theft & No. 592 & Munslow \\
\hline Reginald of Aldon & Victim & Wootton & Murder & No. 654 & Stanton \\
\hline Reginald of Aston & & & Compromise & No. 212 & \\
\hline Reginald of Burley, Chaplain & Accused & & Default & No. 635 & Corfton \\
\hline Reginald of Cutput & Defendant & Chelmarsh & Novel Disseisin & No. 47 & \\
\hline Reginald of Eyton & Defendant & Acton Burnel & Novel Disseisin & No. 231 & \\
\hline Reginald of Eyton & Plaintiff & Eyton & Novel Disseisin & No. 229 & \\
\hline Reginald of Hanwood & Accused & Wallop & Custom \& Services & No. 864 & Bridgenorth \\
\hline Reginald of Shavington & Pledge & & Novel Disseisin & No. 79 & \\
\hline Reginald of Sleap & Plaintiff & Bomere & Novel Disseisin & No. 98. & \\
\hline \begin{tabular}{|l} 
Reginald Okeman \\
\end{tabular} & (mention) & Criddon & Dower & No. 307 & \\
\hline Reginald Porchet & At Mercy & & & No. 65 & \\
\hline Reginald s. Andrew of Holdgate & Accused & Bernestre Wood & Assault & No. 613 & Munslow \\
\hline Reginald s. Cecily & Victim & Manor of Ford & Misadventure & No. 837 & Ford \\
\hline Reginald s. Walter of Westley & Pledge & & Imprisonment & No. 790 & Condover \\
\hline Reginald s. William of Lacon & Pledge & river Roden & Misadventure & No. 697 & Bradford \\
\hline Reginald Scot & Bailiff & The Corve in Lawton \& Little Sutton & Misadventure & No. 651 & Stanton \\
\hline Reginald Scot & Bailiff & Batchcott, Wooferton, Ashford Bowdler \& Overton & Murder & No. 571 & Munslow \\
\hline Reginald Scot & Pledge & & Fine & No. 577 & Munslow \\
\hline Reginald Stone & Accused & & Default & No. 834 & Ford \\
\hline Reginald Woodcock & Plaintiff & Walford \& Leintwardine & Nuisance & No. 139 & \\
\hline \begin{tabular}{|l|} 
Remigius, clerk to Robert of Grendon \\
\end{tabular} & Accused & Ludlow Market & Theft & No. 612 & Munslow \\
\hline \begin{tabular}{|l|} 
Remigius, clerk to Robert of Grendon \\
\end{tabular} & Recipient & & Fine & No. 511 & Purslow \\
\hline Reyner of Dogpool & Defendant & Shrewsbury & Seisin@ Death & No. 309 & \\
\hline Reyner Rowse & Defendant & Pimley, Manor of & Novel Disseisin & No. 145 & \\
\hline Reyner Schyne & Defendant & Hordley & Novel Disseisin & No. 221 & \\
\hline \begin{tabular}{|l|} 
Richard Achilles \\
\end{tabular} & Victim & & Extortion & No. 636 & Corfton \\
\hline Richard Andrew & Plaintiff & Bridgenorth & Entry & No. 308 & \\
\hline Richard Athewey & Victim & Grinshill heath & Murder & No. 844 & Pimhill \\
\hline Richard Aubrey of Wenlock & Victim & Wenlock & Misadventure & No. 666 & Wenlock \\
\hline Richard b. Nicholas Glover & Accused & & Assault & No. 890 & Shrewsbury \\
\hline Richard b. the Smith & Accused & Tugford \& The Heath & Murder & No. 608 & Munslow \\
\hline Richard Bacon & Plaintiff & Shelderton & Custom \& Services & No. 276 & \\
\hline Richard Bacun of Bridgenorth & Pledge & Bridgenorth & Murder & No. 936 & Bridgenorth \\
\hline Richard Balle & Victim & Billingsley, Northwood \& Stottesdon & Murder & No. 562 & Stottesdon \\
\hline \begin{tabular}{|l|} 
Richard Bere \\
\end{tabular} & Defendant & Donnington & Entry & No. 17 & \\
\hline Richard Brewer & Victim & Chetwynd & Murder & No. 715 & Bradford \\
\hline \begin{tabular}{|l|} 
Richard Bridge of Wigwig \\
\end{tabular} & Accused & & Theft & No. 671 & Wenlock \\
\hline \begin{tabular}{|l|} 
Richard Brodeye of Rorrington \\
\end{tabular} & Accused & Wilmington & Murder & No. 820 & Chirbury \\
\hline Richard Bugge & Accused & & Theft/Harbor & No. 877 & Bridgenorth \\
\hline Richard Burnel & Accused & Brockton & Theft & No. 811 & Brimstree \\
\hline Richard Burnel of Enchmarsh & Victim & Enchmarsh & Murder & No. 604 & Munslow \\
\hline Richard Catchpole of Cause & Pledge & & Rape & No. 542 & Worthen \\
\hline Richard Champion of Abdon & Victim & Abdon, Clee St. Margaret, Bouldon \& The Heath & Misadventure & No. 588 & Munslow \\
\hline \begin{tabular}{|l|} 
Richard Clech \\
\end{tabular} & Plaintiff & Eaton & Nuisance & No. 303 & \\
\hline Richard Cobbe of Stafford & Victim & Grinshill heath & Murder & No. 844 & Pimhill \\
\hline \begin{tabular}{|l|} 
Richard Colfex \\
\end{tabular} & Accused & & Theft & No. 671 & Wenlock \\
\hline Richard Crowe & Victim & Cronkhill in Emstrey & Murder & No. 772 & Condover \\
\hline Richard Cunseil & Pledge & Clee St. Margaret & Novel Disseisin & No. 78 & \\
\hline Richard de Boys & Plaintiff & Neen & Entry & No. 259 & \\
\hline \begin{tabular}{|l} 
Richard de Furches \\
\end{tabular} & (mention) & Corfton & Murder & No. 597 & Munslow \\
\hline Richard de Molis & & & Compromise & No. 236 & \\
\hline Richard Dod & Accused & North Foregate & Murder & No. 900 & Shrewsbury \\
\hline \begin{tabular}{|l} 
Richard Doet \\
\end{tabular} & Defendant & Chetwynd & Novel Disseisin & No. 110 & \\
\hline \begin{tabular}{|l|} 
Richard Duggel of Chelmick \\
\end{tabular} & Defendant & Chelmick & Seisin @ Death & No. 52 & \\
\hline \begin{tabular}{|l|} 
Richard Duke \\
\end{tabular} & Accused & Bromfield & Murder & No. 574 & Munslow \\
\hline Richard Dun & Accused & & Murder & No. 706 & Bradford \\
\hline \begin{tabular}{|l|} 
Richard Dun \\
\end{tabular} & Accused & Cressage & Murder & No. 765 & Condover \\
\hline \begin{tabular}{|l} 
Richard Fieldhous \\
\end{tabular} & Pledge & The Heath & Novel Disseisin & No. 230 & \\
\hline Richard French & Attorney & Aston & Seisin @ Death & No. 284 & \\
\hline \begin{tabular}{|l|} 
Richard French \\
\end{tabular} & Defendant & Bitterley & Dower & No. 131 & \\
\hline Richard Fribald & Defendant & Hordley & Novel Disseisin & No. 221 & \\
\hline \begin{tabular}{|l|} 
Richard Garde \\
\end{tabular} & Defendant & Rodenhurst & Nuisance & No. 22 & \\
\hline Richard Godfrey of Hadnall & Accused & & Theft & No. 860 & Pimhill \\
\hline \begin{tabular}{|l|} 
Richard Gurdin \\
\end{tabular} & At Mercy & & & No. 25 & \\
\hline \begin{tabular}{|l|} 
Richard Gurdin \\
\end{tabular} & Court Official & Eyton & Novel Disseisin & No. 229 & \\
\hline Richard Hassard & Accused & Walton, Ercall, Wytheford \& Rowton & Execution/Murder & No. 678 & Bradford \\
\hline Richard Hooper & & & Compromise & No. 243 & \\
\hline Richard Irish & Defendant & Bromlow & Dower & No. 149 & \\
\hline \begin{tabular}{|l|} 
Richard Irish \\
\end{tabular} & & & Compromise & No. 101 & \\
\hline Richard King & Accused & Bourton, Presthope, Patton \& West Bradeley & Murder & No. 660 & Wenlock \\
\hline \begin{tabular}{|l|} 
Richard Knotte of the Moor \\
\end{tabular} & Accused & & Trespass/Force & No. 741 & Bradford \\
\hline \begin{tabular}{|l|} 
Richard Lethermon \\
\end{tabular} & Accused & Tugford \& The Heath & Murder & No. 608 & Munslow \\
\hline \begin{tabular}{|l|} 
Richard Lubbe \\
\end{tabular} & Accused & Ludlow & Murder & No. 576 & Munslow \\
\hline Richard Lubbe & & & Judgement & No. 642 & Ludlow \\
\hline Richard Marscot & & & Appoint Attorney & No. 197 & \\
\hline Richard Mese & Accused & Lawton, Little Sutton \& Bitterley & Murder & No. 652 & Stanton \\
\hline \begin{tabular}{|l|} 
Richard Miller \\
\end{tabular} & Defendant & Shrewsbury & Seisin @ Death & No. 340 & \\
\hline \begin{tabular}{|l|} 
Richard Nightingale \\
\end{tabular} & Attorney & Aston & Seisin @ Death & No. 284 & \\
\hline Richard Noble & Accused & Frankwell & Murder & No. 898 & Shrewsbury \\
\hline Richard of Acton & Pledge & & Assault & No. 794 & Condover \\
\hline Richard of Audmore & Accused & & Theft & No. 750 & Bradford \\
\hline Richard of Baddiley & Accuser & & Theft/Assault/Incitement & No. 741 & Bradford \\
\hline \begin{tabular}{|l} 
Richard of Bromfield s. Rose \& Matilda \\
\end{tabular} & Plaintiff & Woofferton & Seisin @ Death & No. 33 & \\
\hline Richard of Brugeshull & Accused & Tedstill & Unlawful Entry & No. 566 & Stottesdon \\
\hline Richard of Camberley & & & Compromise & No. 7 & \\
\hline
\end{tabular}




\begin{tabular}{|c|c|c|c|c|c|}
\hline Richard of Charlton & Defendant & Charlton & Novel Disseisin & No. 136 & \\
\hline Richard of Charlton (case repeat) & Defendant & Charlton & Novel Disseisin & No. 141 & \\
\hline Richard of Derrington & Accused & & Theft & No. 750 & Bradford \\
\hline Richard of East Wall & Victim & Pendeston Mill near Higford & Murder & No. 806 & Brimstree \\
\hline Richard of Eaton & Defendant & Chelmick & Seisin @ Death & No. 52 & \\
\hline Richard of Eaton & Pledge & Wellington & Theft & No. 761 & Edgmond \\
\hline Richard of Fennemere & Defendant & & Plea of Land & No. 477 & \\
\hline Richard of Flashbrook & Court Official & & Perambulation & No. 352 & \\
\hline Richard of Gannow & Defendant & Hordley & Novel Disseisin & No. 221 & \\
\hline Richard of Greet & Accused/Victim & & Murder & No. 599 & Munslow \\
\hline Richard of Grendon & Sheriff & & Imprisonment & No. 899 & \begin{tabular}{|l} 
Shrewsbury \\
\end{tabular} \\
\hline Richard of Grimley & Accused & & Murder & No. 881 & Foregate \\
\hline Richard of Harley & Court Official & & Perambulation & No. 352 & \\
\hline Richard of Harley & Defendant & Belswardyne Wood & Tort \& Force & No. 138 & \\
\hline Richard of Harley & Victim & & Murder & No. 670 & Wenlock \\
\hline Richard of Haughton & Accused & & Imprisonment & No. 859 & Pimhill \\
\hline Richard of Holloway & Defendant & Chetwynd & Novel Disseisin & No. 110 & \\
\hline Richard of Hothalles & Pledge & Wellington & Theft & No. 761 & Edgmond \\
\hline Richard of Ketley & Pledge & Ruckley & Novel Disseisin & No.226 & \\
\hline Richard of Keuere & Plaintiff & Stokesay & Novel Disseisin & No. 15 & \\
\hline Richard of Lake & Victim & Welbach, Asterley, Westley \& Minsterley & Murder & No. 774 & Condover \\
\hline Richard of Leominster & Witness & Ludlow & Murder & No. 576 & Munslow \\
\hline Richard of Little Wenlock, Chaplain & Accused & Little Wenlock & Murder & No. 665 & Wenlock \\
\hline Richard of Middlehope & Warrenty & Chelmick & Seisin @ Death & No. 52 & \\
\hline Richard of Norbury & Victim & Cause & Imprisonment & No. 515 & Purslow \\
\hline Richard of Onslow & Court Official & Eyton & Novel Disseisin & No. 229 & \\
\hline Richard of Petton & Court Official & Eyton & Novel Disseisin & No. 229 & \\
\hline Richard of Petton s. Richard of Petton & Plaintiff & Petton & Seisin @ Death & No. 260 & \\
\hline \begin{tabular}{|l|} 
Richard of Pimley \\
\end{tabular} & Defendant & Pimley, Manor of & Novel Disseisin & No. 145 & \\
\hline Richard of Plo... & Pledge & Sidbury & Novel Disseisin & No. 40 & \\
\hline Richard of Poston & Plaintiff & Cold Weston & Novel Disseisin & No. 135 & \\
\hline Richard of Preston & Accused & [inside Welshry] & Theft & No. 857 & Pimhill \\
\hline Richard of Preston & Defendant & Foregate & Dower & No. 298 & \\
\hline Richard of Preston & Pledge & Birch & Mort d'Ancestor & No. 97 & \\
\hline \begin{tabular}{|l|} 
Richard of Roden \\
\end{tabular} & Victim & Pimley & Misadventure & No. 710 & Bradford \\
\hline Richard of Scholde & Victim & Glazeley & Misadventure & No. 560 & Stottesdon \\
\hline Richard of Sleap & Accused & Drayton \& Soulton & Murder & No. 708 & Bradford \\
\hline Richard of Stapleton & Victim & Steplewood & Misadventure & No. 499 & Purslow \\
\hline Richard of Stocks in Sutton & Court Official & Eyton & Novel Disseisin & No. 229 & \\
\hline Richard of Stottesdon & Pledge & Northwood & Nuisance & No. 87 & \\
\hline Richard of Styche & Pledge & & Fine & No. 755 & Bradford \\
\hline Richard of The Lyth & Pledge & Tedstill & Unlawful Entry & No. 566 & Stottesdon \\
\hline Richard of The March & Victim & The Marsh & Murder & No. 583 & Munslow \\
\hline Richard of Tibberton & Defendant & Chetwynd & Novel Disseisin & No. 110 & \\
\hline Richard of Tunstall & Plaintiff & & Novel Disseisin & No.79 & \\
\hline Richard of Wall & Payer & & Fine & No. 600 & Munslow \\
\hline Richard of Willaston s. Robert of Willaston & Plaintiff & Willaston & Seisin @ Death & No. 120 & \\
\hline Richard of Winsley & Accused & & Absconded & No. 835 & Ford \\
\hline Richard of Wottenhull & Accused & Sandford & Theft/Assaul & No. 747 & Bradford \\
\hline Richard of Wottenhull & Defendant & Sandford & Novel Disseisin & No. 279 & \\
\hline Richard Oweyn of Stottesdon [Owain] & Accused & Stottesdon, Walton \& Harcourt & Murder & No. 549 & Stottesdon \\
\hline Richard Page & Victim & & Murder & No. 690 & Bradford \\
\hline Richard Palfreyman & Defendant & Diddlebury & Novel Disseisin & No. 152 & \\
\hline Richard Parker of Soudley & Pledge & Tyrley & Novel Disseisin & No. 280 & \\
\hline Richard Pas & Defendant & Aston & Dower & No. 149 & \\
\hline Richard Paunton & Accused & North Foregate & Murder & No. 900 & Shrewsbury \\
\hline Richard Pigun & Accused & & Absconded & No. 812 & Brimstree \\
\hline Richard Pyre & Accused & Tugford & Theft & No. 607 & Munslow \\
\hline Richard Rathbone & Defendant & Chetwynd & Novel Disseisin & No. 110 & \\
\hline Richard Rolin & Accused & & Theft & No. 786 & Condover \\
\hline Richard Rowse & Accused & & Execution & No. 616 & Munslow \\
\hline Richard Rowse & Accused/Victim & Ludlow & Murder & No. 638 & Ludlow \\
\hline Richard s. Alexander & Defendant & Willaston & Novel Disseisin & No. 80 & \\
\hline Richard s. Alice \& Warin Child & Attorney & Shrewsbury & Entry & No. 290 & \\
\hline Richard s. Aynun [Einion] & Plaintiff & Birch & Mort d'Ancestor & No. 97 & \\
\hline Richard s. Bernard of Cherrington & Pledge & Cherrington & Misadventure & No. 693 & Bradford \\
\hline Richard s. Gilbert of Aldon & Pledge & Stokesay & Novel Disseisin & No. 15 & \\
\hline Richard s. Griffith [Gruffydd] & Victim & & Murder & No. 740 & Bradford \\
\hline Richard s. Hamon Palmer of Bridgenorth & (mention) & & Theft/Harbor & No. 863 & Bridgenorth \\
\hline Richard s. Hawise of Shyrington & & & Compromise & No. 163 & \\
\hline Richard s. Henry & Plaintiff & Mocktree wood in Shelderton & Custom \& Services & No. 275 & \\
\hline Richard s. Henry of Bitterley & Pledge & & Dower & No. 147 & \\
\hline Richard s. Henry of Marchamley & Pledge & Marchamley & Theft & No. 786 & Condover \\
\hline Richard s. Hugh of Claverhall & Pledge & Shavington & Novel Disseisin & No. 122 & \\
\hline Richard s. Hugh of Muxton & Victim & Lilleshall & Murder & No. 732 & Bradford \\
\hline Richard s. Hugh of Sleap & Defendant & Bomere & Novel Disseisin & No. 98. & \\
\hline Richard s. Isabel of Ledwich & (mention) & Cleeton & Seisin @ Death & No. 168 & \\
\hline Richard s. Ithell s. Yowan of Crosemere [Ithel] [leuan] & Defendant & Hordley & Novel Disseisin & No. 221 & \\
\hline Richard s. John & Defendant & Clive \& Haughton & Nuisance & No. 95 & \\
\hline Richard s. John & Accused & & Default & No. 822 & Chirbury \\
\hline Richard s. John of Wollerton & Payer & Wollerton & Trespass & No. 745 & Bradford \\
\hline Richard s. Jordan & Victim & & Misadventure & No. 889 & Shrewsbury \\
\hline Richard s. Lucy & Victim & Castle Holdgate & Murder & No. 591 & Munslow \\
\hline Richard s. Matthew \& $n$. Adam of Norton & Plaintiff & Spoonhill, Manor of & Seisin @ Death & No. 126 & \\
\hline Richard s. Nicholas & Victim & Gilbert's Hill in Over Chilton & Murder & No. 773 & Condover \\
\hline Richard s. Osbert of Barlow & Accused & Edgton \& Broome & Murder & No. 500 & Purslow \\
\hline Richard s. Peter & Defendant & Ludlow & Entry & No. 108 & \\
\hline Richard s. Philip & Plaintiff & Tyrley & Novel Disseisin & No. 280 & \\
\hline Richard s. Ralph & Defendant & Chetwynd & Novel Disseisin & No. 110 & \\
\hline Richard s. Ralph & & & Compromise & No. 338 & \\
\hline Richard s. Ranulph of Eyton & Accused & Stanton & Murder & No. 653 & Stanton \\
\hline
\end{tabular}




\begin{tabular}{|c|c|c|c|c|c|}
\hline Richard s. Reginald of Upton, a madman & Victim & Upton & Misadventure & No. 798 & Brimstree \\
\hline Richard s. Richard & Defendant & Chetwynd & Novel Disseisin & No. 110 & \\
\hline Richard s. Richard Dod & Victim & Hanwood & Murder & No. 828 & Ford \\
\hline Richard s. Richard of Baschurch & Pledge & Acton Burnel & Novel Disseisin & No. 231 & \\
\hline Richard s. Richard of Bridgnorth \& n. Philip of Bridgenorth & Plaintiff & Astley & Seisin @ Death & No. 304 & \\
\hline Richard s. Richard of Chelmick & Accused & Chelmick, Hope Bowdler, West Wall \& Acton & Murder/Assault & No. 606 & Munslow \\
\hline Richard s. Richard of Loppington & Accused & & Theft & No. 860 & Pimhill \\
\hline Richard s. Richard of Rushton & Victim & Charlton, Walcot \& Uckington & Murder & No. 688 & Bradford \\
\hline Richard s. Richard of Shrewsbury & & & Compromise & No. 54 & \\
\hline Richard s. Richard of Tunstall & Pledge & Tunstall & Dower & No. 312 & \\
\hline \begin{tabular}{|l|} 
Richard s. Richard Ovyet \\
\end{tabular} & Defendant & Astley & Novel Disseisin & No. 286 & \\
\hline Richard s. Richard Pede of Down & Pledge & Down & Novel Disseisin & No. 56 & \\
\hline \begin{tabular}{|l|} 
Richard s. Richard Swart \\
\end{tabular} & Defendant & Chetwynd & Novel Disseisin & No. 110 & \\
\hline Richard s. Robert & Plaintiff & Steplewood in Condover & Novel Disseisin & No. 314 & \\
\hline Richard s. Robert & Plaintiff & Willaston & Seisin @ Death & No. 213 & \\
\hline Richard s. Robert & Accused & & Theft & No. 671 & Wenlock \\
\hline Richard s. Robert & Defendant & Prescott & Dower & No. 124 & \\
\hline Richard s. Robert of Aldenham & Payer & & Fine & No. 559 & Stottesdon \\
\hline Richard s. Robert of Clifton & Plaintiff & Belswardyne Wood & Tort \& Force & No. 138 & \\
\hline Richard s. Robert Syward & Plaintiff & Clee St. Margaret & Novel Disseisin & No. 78 & \\
\hline \begin{tabular}{|l|} 
Richard s. Robert Syward \\
\end{tabular} & Plaintiff & Willaston & Novel Disseisin & No. 80 & \\
\hline Richard s. Roger Child & Defendant & Adforton & Novel Disseisin & No. 18 & \\
\hline Richard s. Roger of Attingham & Victim & Condover & Murder & No. 709 & Bradford \\
\hline \begin{tabular}{|l|} 
Richard s. Roger of Norton, Clerk \\
\end{tabular} & Accused & Norton & Murder & No. 716 & Bradford \\
\hline Richard s. Seysot & Accused & Stretton & Murder & No. 623 & Stretton \\
\hline Richard s. Stephen & (mention) & Loton & Seisin @ Death & No. 14 & \\
\hline \begin{tabular}{|l|} 
Richard s. Stephen \\
\end{tabular} & Defendant & Fennemere & Entry & No. 151 & \\
\hline \begin{tabular}{|l|} 
Richard s. Stephen \\
\end{tabular} & Defendant & Fennemere & Novel Disseisin & No. 39 & \\
\hline \begin{tabular}{|l|} 
Richard s. Stephen \\
\end{tabular} & & & Plea of Land & No. 199 & \\
\hline Richard s. Syward of Wytheford & Pledge & Lee & Mort d'Ancestor & No. 219 & \\
\hline Richard s. Thomas Glover & Accused & & Assault & No. 890 & Shrewsbury \\
\hline \begin{tabular}{|l} 
Richard s. Walter \\
\end{tabular} & Defendant & West Wall & Seisin @ Death & No. 262 & \\
\hline Richard s. Walter Cosin & Victim & Abdon, Clee St. Margaret, Tugford \& The Heath & Murder & No. 609 & Munslow \\
\hline \begin{tabular}{|l|} 
Richard s. Walter of Broadstone \\
\end{tabular} & Victim & Tugford \& The Heath & Murder & No. 608 & Munslow \\
\hline \begin{tabular}{|l|} 
Richard s. Walter of Clive \\
\end{tabular} & Victim & & Murder & No. 706 & Bradford \\
\hline Richard s. Warin of Pulverbatch & Victim & Pulverbatch & Misadventure & No. 775 & Condover \\
\hline Richard s. William & Defendant & Chetwynd & Novel Disseisin & No. 110 & \\
\hline \begin{tabular}{|l|} 
Richard s. William \\
\end{tabular} & (mention) & Wentnor, Ratlinghope, Medlicott \& Home & Murder & No. 492 & Purslow \\
\hline Richard s. William & Victim & Acton & Murder & No. 849 & Pimhill \\
\hline Richard s. William of Hope & Accused & Chelmick, Hope Bowdler, West Wall \& Acton & Murder/Assault & No. 606 & Munslow \\
\hline \begin{tabular}{|l|} 
Richard s. William of The Green \\
\end{tabular} & Accused & Berwick & Murder & No. 855 & Pimhill \\
\hline Richard s. Wyllot & Accused & Longford & Murder & No. 728 & Bradford \\
\hline Richard Scrupe of Newport & Accused/Pledge & Newport & Trespass & No. 739 & Bradford \\
\hline Richard Smalheued & Victim & Frankwell & Murder & No. 898 & Shrewsbury \\
\hline Richard Smith & Plaintiff & Calverhall & Novel Disseisin & No. 74 & \\
\hline Richard Smith of Claverhall & Accused & & Theft & No. 750 & Bradford \\
\hline Richard Smith s. John Smith & Plaintiff & West Wall & Seisin @ Death & No. 262 & \\
\hline Richard Spark & Accused & Ludlow & Murder & No. 576 & Munslow \\
\hline Richard Sprengehose & Pledge & Tedstill & Unlawful Entry & No. 566 & Stottesdon \\
\hline \begin{tabular}{|l|} 
Richard Striche \\
\end{tabular} & Victim & Lea & Murder & No. 493 & Purslow \\
\hline Richard Swain & Pledge & & Custom \& Services & No. 116 & \\
\hline Richard Swart & Defendant & Chetwynd & Novel Disseisin & No. 110 & \\
\hline Richard Taylor & Accused & St. Mary's & Assault & No. 901 & Shrewsbury \\
\hline Richard the Clerk s. the Chaplain of Abdon & Accused & Abdon, Clee St. Margaret, Tugford \& The Heath & Murder & No. 609 & Munslow \\
\hline Richard the Long of Corfton & Accused & Corfton & Murder & No. 597 & Munslow \\
\hline \begin{tabular}{|l|} 
Richard the Mason of Stretton \\
\end{tabular} & Victim & Wentnor, Ratlinghope, Medlicott \& Home & Murder & No. 492 & Purslow \\
\hline Richard Tosti & Accused & Field of Millichope & Execution/Murder & No. 656 & Wenlock \\
\hline Richard Traynel of Audmore & Pledge & & Murder & No. 892 & Shrewsbury \\
\hline \begin{tabular}{|l|} 
Richard Turner s. Adam Turner \\
\end{tabular} & Plaintiff & Foregate & Seisin @ Death & No. 273 & \\
\hline Richard Tyrell & Coroner & Down & Murder & No. 486 & Purslow \\
\hline \begin{tabular}{|l|l} 
Richard Tyrell \\
\end{tabular} & Coroner & Rowton & Murder & No. 494 & Purslow \\
\hline \begin{tabular}{|l|} 
Richard Tyrell \\
\end{tabular} & Coroner & & & No. 484 & Shropshire \\
\hline \begin{tabular}{|l} 
Richard Tyrell \\
\end{tabular} & Court Official & & At Mercy & No. 43 & \\
\hline \begin{tabular}{|l} 
Richard Tyrell \\
\end{tabular} & Defendant & Cold Weston & Novel Disseisin & No. 135 & \\
\hline \begin{tabular}{|l|l} 
Richard Tyrell \\
\end{tabular} & Pledge & Bernestre Wood & Judgement & No. 613 & Munslow \\
\hline Richard u. Margery d. William Arnold \& b. Alice & (mention) & Weston & Entry & No. 16 & \\
\hline Richard Villein & Defendant & Hordley & Novel Disseisin & No. 221 & \\
\hline Richard Wade of Callaughton & Accused & Callaughton & Theft & No. 669 & Wenlock \\
\hline Richard Wertok & Victim & Longford, Moreton Say \& Longslow & Murder & No. 701 & Bradford \\
\hline Richard Witling of Cound Hill & Accused & & Rape & No. 792 & Condover \\
\hline Richard Wride & Victim & Bridgenorth & Imprisonment & No. 634 & Corfton \\
\hline Richard Wyfere & Accused & & Theft & No. 810 & Brimstree \\
\hline Richard Wynte & Defendant & Woodhouse & Right & No. 344 & \\
\hline Richard Yongebonde & Plaintiff & Donnington & Entry & No. 17 & \\
\hline Richard Yongebonde & & Donnington & Compromise & No. 19 & \\
\hline Richard, a parker & Accused & Shrewsbury & Murder & No. 853 & Pimhill \\
\hline \begin{tabular}{|l|} 
Richard, Carpenter \\
\end{tabular} & Accused & & Theft & No. 750 & Bradford \\
\hline Richard, Clerk of Abbot of Shrewsbury & Pledge & Wollerton & Trespass & No. 745 & Bradford \\
\hline Richard, Lord of Cherrington & Pledge & Cherrington & Misadventure & No. 693 & Bradford \\
\hline Richard, Parson of Rushbury & Payer & Bitterley & Murder & No. 518 & Overs \\
\hline Richard, servant of Thomas Berner & Accused & & Assault & No. 890 & Shrewsbury \\
\hline \begin{tabular}{|l|} 
Richelda w. John of Pole \\
\end{tabular} & Defendant & Pole & Entry & No. 305 & \\
\hline Rinan & Victim & Edstaston & Murder & No. 683 & Bradford \\
\hline Robert Aleyn & Defendant & Kenley & Seisin @ Death & No. 55 & \\
\hline Robert Archer of Aston & Pledge & Hayton & Novel Disseisin & No. 96 & \\
\hline Robert Ball & Accused & Lawton, Little Sutton \& Bitterley & Murder & No. 652 & Stanton \\
\hline Robert Blundel & Defendant & Chirbury & Novel Disseisin & No. 210 & \\
\hline \begin{tabular}{|l|} 
Robert Blundel \\
\end{tabular} & Pledge & & Murder & No. 795 & Condover \\
\hline Robert Brown & Victim & Alcaston & Murder & No. 584 & Munslow \\
\hline Robert Brown of Ash & Accused & & Execution & No. 754 & Bradford \\
\hline Robert Bule & Accused & Camlad & Murder & No. 813 & Chirbury \\
\hline
\end{tabular}




\begin{tabular}{|c|c|c|c|c|c|}
\hline Robert Bykedune & Plaintiff & Leighton & Entry & No. 246 & \\
\hline Robert Cat of Shire & Accused & & Absconded & No. 540 & Overs \\
\hline Robert Catchemare & Accused & & Theft & No. 510 & Purslow \\
\hline Robert Champion & Accused & Cocabite Street & Murder & No. 896 & Shrewsbury \\
\hline Robert Clerk & Attorney & & Plea of Land & No. 481 & \\
\hline Robert Clerk & Defendant & Acton & Novel Disseisin & No. 51 & \\
\hline Robert Cole, Hayward of Alcaston & Accused & The Marsh & Murder & No. 583 & Munslow \\
\hline Robert Coleman & Plaintiff & Marton & Novel Disseisin & No. 134 & \\
\hline Robert Cook & Attorney & & & No. 150 & \\
\hline Robert Corbet & Accused & & Custom \& Services & No. 752 & Bradford \\
\hline Robert Corbet & Defendant & Neen & Entry & No. 259 & \\
\hline Robert Corbet & Defendant & Moreton \& Preston in Besford & Novel Disseisin & No. 102 & \\
\hline Robert Corbet & Plaintiff & Clive & Utrum & No. 300 & \\
\hline Robert Corbet & Pledge & Tedstill & Unlawful Entry & No. 566 & Stottesdon \\
\hline Robert Corbet & & & Novel Disseisin & No. 200 & \\
\hline \begin{tabular}{|l|} 
Robert Corbet \\
\end{tabular} & & & Plea of Land & No. 179 & \\
\hline Robert Corbet of Cause b. Thomas Corbet & Pledge & & Murder & No. 795 & Condover \\
\hline Robert Cut & Plaintiff & Whitbrook & Novel Disseisin & No. 21 & \\
\hline \begin{tabular}{|l|} 
Robert de Furches \\
\end{tabular} & Defendant & Diddlebury & Novel Disseisin & No. 109 & \\
\hline \begin{tabular}{|l|} 
Robert de Furches \\
\end{tabular} & Defendant & Lawton & Novel Disseisin & No. 474 & \\
\hline \begin{tabular}{|l} 
Robert de Furches \\
\end{tabular} & Defendant & Loughton & Novel Disseisin & No. 251 & \\
\hline \begin{tabular}{|l|} 
Robert de Furches \\
\end{tabular} & Victim & & Extortion & No. 636 & Corfton \\
\hline \begin{tabular}{|l|} 
Robert de Lacy \\
\end{tabular} & Warrenty & Spoonhill, Manor of & Seisin @ Death & No. 126 & \\
\hline Robert de Lacy & & & Compromise & No. 238 & \\
\hline Robert de Meysy & Plaintiff & Stapleton & Novel Disseisin & No. 313 & \\
\hline Robert de Meysy & & & Appoint Attorney & No. 267 & \\
\hline Robert de Say & & & Plea of Covenant & No. 233 & \\
\hline Robert de Say of Audleybrow & Accused & & Default & No. 751 & Bradford \\
\hline Robert de Say s. Hugh de Say & Defendant & Lostford Mill & Custom \& Services & No. 297 & \\
\hline Robert de Say s. Hugh de Say & Defendant & Moreton & Novel Disseisin & No. 119 & \\
\hline Robert de Say/Robert of Grendon & Payer & & Fine & No. 755 & Bradford \\
\hline Robert Devenish & Defendant & Diddlebury & Novel Disseisin & No. 152 & \\
\hline Robert Dyer & Pledge & Bridgenorth & Murder & No. 936 & Bridgenorth \\
\hline Robert Fitzbeadle & Defendant & Chetwynd & Novel Disseisin & No. 110 & \\
\hline \begin{tabular}{|l|} 
Robert Ford \\
\end{tabular} & Plaintiff & Preston & Entry & No. 235 & \\
\hline Robert Gerebonde & Defendant & Amaston & Novel Disseisin & No. 272 & \\
\hline Robert Godknave & Victim & Stapleton \& Smethcott & Murder & No. 780 & Condover \\
\hline \begin{tabular}{|l|} 
Robert Hazelwood \\
\end{tabular} & Court Official & & Perambulation & No. 352 & \\
\hline Robert Hele, carter to the Prior of Chirbury & Victim & Chirbury & Misadventure & No. 814 & Chirbury \\
\hline Robert Herin of Hales & Victim & Drayton & Murder & No. 801 & Brimstree \\
\hline Robert Knode & Victim & Pickstock & Murder & No. 737 & Bradford \\
\hline Robert Knok of Castle Holdgate & Accused & & Theft & No. 601 & Munslow \\
\hline Robert le Poer s. Robert Pickard & Plaintiff & Smethcote & Seisin @ Death & No. 209 & \\
\hline Robert Lowys & Accused & Feniton & Custom \& Services & No. 864 & Bridgenorth \\
\hline \begin{tabular}{|l|} 
Robert Lune \\
\end{tabular} & Defendant & Habberley \& Nethercote & Entry & No. 247 & \\
\hline \begin{tabular}{|l|} 
Robert Lune \\
\end{tabular} & Juror & Neen & Novel Disseisin & No. 34 & \\
\hline Robert Lytherman & Defendant & Moreton & Novel Disseisin & No. 217 & \\
\hline \begin{tabular}{|l|} 
Robert Mason of Ticklerton \\
\end{tabular} & Victim & Stretton & Murder/Absconded & No. 598 & Munslow \\
\hline \begin{tabular}{|l} 
Robert Mauduit \\
\end{tabular} & Court Official & Moreton & Novel Disseisin & No. 217 & \\
\hline Robert Nater & Defendant & Chetwynd & Novel Disseisin & No. 110 & \\
\hline Robert of Acton & Defendant & Acton & Nuisance & No. 218 & \\
\hline Robert of Acton & Payer & & Theft & No. 793 & Condover \\
\hline Robert of Aldenham & Payer & & Fine & No. 559 & Stottesdon \\
\hline Robert of Aldermaston & Attorney & & & No. 238 & \\
\hline Robert of Attingham, Clerk & Victim & Attingham \& Berwick & Misadventure & No. 727 & Bradford \\
\hline Robert of Bicton & Plaintiff & Leighton & Entry & No. 302 & \\
\hline Robert of Bolas & Payer & & Trespass & No. 743 & Bradford \\
\hline Robert of Bouldon & & & Appoint Attorney & No. 268 & \\
\hline Robert of Campden & Accused & & Trespass/Force & No. 742 & Bradford \\
\hline \begin{tabular}{|l|} 
Robert of Charlton \\
\end{tabular} & Court Official & Acton Burnel & Novel Disseisin & No. 231 & \\
\hline Robert of Chelmarsh & Juror & Lawton & Novel Disseisin & No. 473 & \\
\hline Robert of Corfton & Victim & Bouldon, Poston \& Abdon & Murder & No. 590 & Munslow \\
\hline Robert of Cornewood & Court Official & Whatmore & Novel Disseisin & No. 317 & \\
\hline Robert of Derrington & Accused & & Theft & No. 750 & Bradford \\
\hline Robert of Dudley & Attorney & & & No. 70 & \\
\hline Robert of Espley & Plaintiff & Espley & Nuisance & No. 224 & \\
\hline Robert of Espley & Plaintiff & Hopton & Nuisance & No. 225 & \\
\hline Robert of Esthull & Court Official & Donnington & Nuisance & No. 331 & \\
\hline Robert of Exmouth & Defendant & Draycott & Dower & No. 337 & \\
\hline Robert of Eyton & Accused & & Trespass/Force & No. 742 & Bradford \\
\hline Robert of Fern & Victim & Cornewood & Murder & No. 531 & Overs \\
\hline Robert of Ford & Defendant & & Entry & No. 9 & \\
\hline Robert of Ford & & & Plea of Land & No. 481 & \\
\hline Robert of Girros & (mention) & Wooton & Custom \& Services & No. 249 & \\
\hline Robert of Grendon & Accused & Ludlow Market & Theft & No. 612 & Munslow \\
\hline Robert of Grendon & Sheriff & & Fine & No. 559 & Stottesdon \\
\hline \begin{tabular}{|l|} 
Robert of Grendon \\
\end{tabular} & Sheriff & Shrewsbury & Imprisonment & No. 738 & Bradford \\
\hline Robert of Grendon & Sheriff & Bridgenorth & Imprisonment & No. 634 & Corfton \\
\hline Robert of Grendon & Sheriff & Bridgenorth & Imprisonment & No. 548 & Stottesdon \\
\hline Robert of Grendon & Sheriff & Bridgenorth \& Chelmarsh & Theft & No. 551 & Stottesdon \\
\hline Robert of Grendon & Sheriff & Longslow, Drayton \& Longford & Theft/Execution & No. 722 & Bradford \\
\hline Robert of Grendon & Sheriff & & & No. 483 & Shropshire \\
\hline Robert of Halur' & Defendant & Chetwynd & Novel Disseisin & No. 110 & \\
\hline Robert of Hardwick & Victim & Uppington & Misadventure & No. 681 & Bradford \\
\hline Robert of Hatton & Defendant & Hatton & Novel Disseisin & No. 35 & \\
\hline Robert of Hawkstone & Defendant & Clive \& Haughton & Nuisance & No. 95 & \\
\hline Robert of Hinton & Victim & Hinton, Broughall, Whitechurch \& Ash & Murder & No. 677 & Bradford \\
\hline Robert of Hodnet & Payer & & Trespass & No. 743 & Bradford \\
\hline Robert of Hope & Defendant & Whitsborn \& Luckley & Dower & No. 149 & \\
\hline Robert of Hope & Plaintiff & Marton & Novel Disseisin & No. 112 & \\
\hline Robert of Hopton Wafers & Accused & Hopton Wafers & Default & No. 565 & Stottesdon \\
\hline
\end{tabular}




\begin{tabular}{|c|c|c|c|c|c|}
\hline Robert of Kilpeck & Accused & Ludlow & Murder & No. 638 & Ludlow \\
\hline Robert of Marchamley, Carpenter & Pledge & Marchamley & Theft & No. 786 & Condover \\
\hline Robert of Munslow & Attorney & & Plea of Land & No. 268 & \\
\hline Robert of Oakley & Defendant & Gravenhunger & Dower & No. 117 & \\
\hline Robert of Onibury, Collier & Accused & & Execution & No. 581 & Munslow \\
\hline Robert of Paterclyve & Court Official & Whatmore & Novel Disseisin & No. 317 & \\
\hline \begin{tabular}{|l|} 
Robert of Preen \\
\end{tabular} & Bailiff & The Heath & Imprisonment/Theft & No. 621 & Munslow \\
\hline Robert of Preen, Bailiff & Accused & & Extortion & No. 636 & Corfton \\
\hline Robert of Rollisowrd & Defendant & & Fugitive & No. 37 & \\
\hline Robert of Stockton & (mention) & & Perambulation & No. 351 & \\
\hline \begin{tabular}{|l|} 
Robert of The Bold \\
\end{tabular} & Juror & Lawton & Novel Disseisin & No. 473 & \\
\hline Robert of The Dean & Accused & & Theft & No. 671 & Wenlock \\
\hline Robert of Turleby & Attorney & & Plea of Debt & No. 245 & \\
\hline Robert of Tywe & Accused & Garmston & Murder & No. 711 & Bradford \\
\hline Robert of Weston & Victim & Severn & Misadventure & No. 886 & Shrewsbury \\
\hline \begin{tabular}{|l|} 
Robert of Whitton \\
\end{tabular} & Court Official & Eyton & Novel Disseisin & No. 229 & \\
\hline \begin{tabular}{|l|} 
Robert of Woodhouse \\
\end{tabular} & (mention) & Pontesbury & Fine & No. 831 & Ford \\
\hline \begin{tabular}{|l|} 
Robert of Wytetre \\
\end{tabular} & Accused & & Default & No. 822 & Chirbury \\
\hline Robert Pollard & Accused & & Absconded & No. 812 & Brimstree \\
\hline \begin{tabular}{|l|} 
Robert Pride \\
\end{tabular} & Defendant & Shrewsbury & Entry & No. 349 & \\
\hline \begin{tabular}{|l|} 
Robert Pride \\
\end{tabular} & & & Custom \& Services & No. 480 & \\
\hline Robert Prudhome & Accuser & Brockton & Theft & No. 811 & Brimstree \\
\hline Robert s. Adam & Defendant & Chetwynd & Novel Disseisin & No. 110 & \\
\hline Robert s. Adam & Defendant & Sandford & Novel Disseisin & No. 279 & \\
\hline \begin{tabular}{|l|} 
Robert s. Hawise of Shyrington \\
\end{tabular} & & & Compromise & No. 163 & \\
\hline \begin{tabular}{|l|} 
Robert s. Henry of Eaton \\
\end{tabular} & Accused & & Theft & No. 510 & Purslow \\
\hline Robert s. Hugh & & & Compromise & No. 153 & \\
\hline \begin{tabular}{|l|} 
Robert s. John of Ticklerton \\
\end{tabular} & Victim & Ticklerton & Misadventure & No. 663 & Wenlock \\
\hline Robert s. Parnel of Eyton & Pledge & Rowton & Mort d'Ancestor & No. 142 & \\
\hline Robert s. Reginald de Gaugy & Accused & & Murder & No. 933 & Bridgenorth \\
\hline Robert s. Reyner of Nobold & Victim & & Murder & No. 879 & Foregate \\
\hline \begin{tabular}{|l} 
Robert s. Richard \\
\end{tabular} & Defendant & Chetwynd & Novel Disseisin & No. 110 & \\
\hline \begin{tabular}{|l} 
Robert s. Richard of Gravenhunger \\
\end{tabular} & Accused & Gravenhunger & Murder & No. 675 & Bradford \\
\hline Robert s. Robert & Defendant & Stanton Lacy & Seisin @ Death & No. 164 & \\
\hline Robert s. Robert & Defendant & Eaton & Nuisance & No. 303 & \\
\hline Robert s. Robert & Defendant & Bomere & Novel Disseisin & No. 98. & \\
\hline Robert s. Robert Gysor & Accused & Stanton Long, Ashfield, Ruthall \& Brockton & Murder & No. 593 & Munslow \\
\hline Robert s. Robert of Clifton & Defendant & Whitbrook & Novel Disseisin & No. 21 & \\
\hline Robert s. Robert of Leebotwood & Plaintiff & Acton Burnel & Novel Disseisin & No. 231 & \\
\hline Robert s. Robert Welsh & Defendant & Ragdon & Novel Disseisin & No. 166 & \\
\hline Robert s. Roger of Newton & Defendant & Bomere & Novel Disseisin & No. 98. & \\
\hline Robert s. Sigge & Accused & & Theft & No. 750 & Bradford \\
\hline Robert s. Thomas Rabaz & Accused & & Assault & No. 743 & Bradford \\
\hline Robert s. Walter of Adforton & Pledge & Adforton & Novel Disseisin & No. 18 & \\
\hline Robert s. Walter of Pickstock & Defendant & Chetwynd & Novel Disseisin & No. 110 & \\
\hline Robert s. William of Claverhall & Pledge & Claverhall & Novel Disseisin & No. 157 & \\
\hline \begin{tabular}{|l|} 
Robert s. William of Hill Halton \\
\end{tabular} & Victim & R. Teme in Priors Halton, Hill Halton \& Robert's Halton & Misadventure & No. 572 & Munslow \\
\hline Robert Seys & Accused & & Murder & No. 742 & Bradford \\
\hline Robert Seys & Accused & & Murder & No. 823 & Chirbury \\
\hline Robert Slikeberd & Defendant & & Custom \& Services & No. 116 & \\
\hline Robert Slinge & Pledge & Leighton & Mort d'Ancestor & No. 4 & \\
\hline Robert Smith & Pledge & Bridgenorth & Murder & No. 936 & Bridgenorth \\
\hline Robert Smith of Bletchley & Pledge & Willaston & Novel Disseisin & No. 80 & \\
\hline Robert Swart & Defendant & Chetwynd & Novel Disseisin & No. 110 & \\
\hline Robert the carter of Richard Burnel & Accused & Brockton & Theft & No. 811 & Brimstree \\
\hline Robert the Physician & Accused & Hales & Murder & No. 644 & Hales \\
\hline Robert Veysin of Wrickton & Accused & Wrickton & Murder & No. 554 & Stottesdon \\
\hline Robert Walding & & & Plea of Land & No. 184 & \\
\hline Robert Weathercock & Victim & Eaton & Murder & No. 682 & Bradford \\
\hline Robert Welsh & & & Compromise & No. 165 & \\
\hline Robert Welsh of Adderley & Accused & & Default & No. 751 & Bradford \\
\hline Robert Whytebach & Witness & Ludlow & Murder & No. 576 & Munslow \\
\hline \begin{tabular}{|l|} 
Robert Woodward \\
\end{tabular} & Accused & & Murder & No. 740 & Bradford \\
\hline Robert, a deaf man of Kemberton & Victim & Kemberton & Misadventure & No. 800 & Brimstree \\
\hline Robert, Chaplain of Alcaston & Accused & Alcaston & Murder & No. 584 & Munslow \\
\hline Roger Arnold & Pledge & Pendeston Mill near Higford & Murder & No. 806 & Brimstree \\
\hline Roger b. Robert of Hawkstone & Defendant & Clive \& Haughton & Nuisance & No. 95 & \\
\hline Roger b. William of Middlehope & Attorney & & Plea of Utrum & No. 198 & \\
\hline \begin{tabular}{|l} 
Roger Bardolf \\
\end{tabular} & Court Official & The Heath & Entry & No. 114 & \\
\hline \begin{tabular}{|l|} 
Roger Bardolf \\
\end{tabular} & Juror & The Heath & Entry & No. 114 & \\
\hline Roger Bardolf & Juror & Wem & Novel Disseisin & No. 48 & \\
\hline \begin{tabular}{|l} 
Roger Bardolf \\
\end{tabular} & Juror & Woofferton & Right & No. 332 & \\
\hline Roger Bon Oste & Juror & Loughton & Novel Disseisin & No. 251 & \\
\hline Roger Burnel & Accused & Feniton & Custom \& Services & No. 864 & Bridgenorth \\
\hline Roger Burnel & Warrenty & Acton & Novel Disseisin & No. 51 & \\
\hline Roger Carpenter & Plaintiff & Bayston & Novel Disseisin & No. 208 & \\
\hline Roger Chaplin & Defendant & Corfton & Novel Disseisin & No. 105 & \\
\hline \begin{tabular}{|l|} 
Roger Constantine \\
\end{tabular} & Accused & & Default & No. 565 & Stottesdon \\
\hline \begin{tabular}{|l|} 
Roger Constantine \\
\end{tabular} & Plaintiff & & Plea of Land & No. 353 & \\
\hline \begin{tabular}{|l|} 
Roger Constantine \\
\end{tabular} & Warrenty & Wheathill & Dower & No. 257 & \\
\hline Roger Corbet & Accused & & Custom \& Services & No. 752 & Bradford \\
\hline Roger Croucher of Bletchley & Accused & Bletchley & Murder & No. 714 & Bradford \\
\hline Roger de Biaumes & Defendant & Donington & Custom \& Services & No. 323 & \\
\hline Roger de Biaumes & Warrenty & Donington & Dower & No. 295 & \\
\hline \begin{tabular}{|l|} 
Roger de Biaumes \\
\end{tabular} & Warrenty & Donington & Dower & No. 341 & \\
\hline Roger de Cadigan of Burton [Cadwgan & Accused & Brampton & Murder & No. 488 & Purslow \\
\hline Roger de Say & Attorney & & Dower/Land & No. 195 & \\
\hline Roger Dun & Victim & Bridgenorth & Imprisonment & No. 634 & Corfton \\
\hline Roger Fairchild & Pledge & Bridgenorth & Murder & No. 936 & Bridgenorth \\
\hline Roger Fat & Defendant & Moreton & Novel Disseisin & No. 217 & \\
\hline Roger Fat & Pledge & Moreton & Novel Disseisin & No. 217 & \\
\hline
\end{tabular}




\begin{tabular}{|c|c|c|c|c|c|}
\hline Roger Forester & Defendant & Bomere & Novel Disseisin & No. 98. & \\
\hline Roger French & & & Appoint Attorney & No. 180 & \\
\hline Roger Gaykith & Defendant & Hordley & Novel Disseisin & No. 221 & \\
\hline Roger Goky & Victim & Priors Lee \& Leonards Lee & Murder & No. 802 & Brimstree \\
\hline Roger Gray & Defendant & Chetwynd & Novel Disseisin & No. 110 & \\
\hline Roger Hastings & Plaintiff & Lostford Mill & Custom \& Services & No. 297 & \\
\hline Roger Hazelwood of Longford & Pledge & & Assault & No. 743 & Bradford \\
\hline Roger Hering of Wellington & Accused & & Assault & No. 744 & Bradford \\
\hline Roger Lamberd & Pledge & Bridgenorth & Murder & No. 936 & Bridgenorth \\
\hline Roger Makedaunce & Accused & & Murder & No. 760 & Edgmond \\
\hline Roger Miller & Witness & Castle Holdgate & Murder & No. 591 & Munslow \\
\hline Roger Miller of Cleobury & Defendant & Charlcotte & Custom \& Services & No. 348 & \\
\hline Roger Mortimer & Defendant & Bealy Wood & Estover & No. 31 & \\
\hline Roger Mortimer & & & Compromise & No. 123 & \\
\hline Roger Mortimer s. Ralph Mortimer & Defendant & Mocktree & Entry & No. 94 & \\
\hline Roger Nonel & Defendant & Ellastone & Seisin @ Death & No. 77 & \\
\hline Roger of Adcote & Victim & Adcote & Murder & No. 850 & Pimhill \\
\hline Roger of Birch & Defendant & Birch & Mort d'Ancestor & No. 97 & \\
\hline Roger of Boraston & Accused & & Execution & No. 533 & Overs \\
\hline Roger of Brecknock & Defendant & Woodcote & Mort d'Ancestor & No. 271 & \\
\hline Roger of Broom & Victim & & Murder & No. 602 & Munslow \\
\hline Roger of Cornewood & Pledge & & Compromise & No. 7 & \\
\hline Roger of Foxcote & Pledge & & Execution & No. 564 & Stottesdon \\
\hline Roger of Foxcote & Warrenty & Walford & Entry & No. 90 & \\
\hline Roger of Halesowen & Accused & & Default & No. 645 & Hales \\
\hline Roger of Hastings & & & Appoint Attorney & No. 233 & \\
\hline Roger of Haughton & Court Official & Donnington & Nuisance & No. 331 & \\
\hline Roger of Hopton & Accused & & Murder/Absconded & No. 655 & Stanton \\
\hline Roger of Horderley & Pledge & & Fine & No. 599 & Munslow \\
\hline Roger of Kenley, Cook & Pledge & & Fine & No. 627 & Stretton \\
\hline Roger of Kinver, an outlaw & Accused & & Murder/Harbor & No. 861 & Bridgenorth \\
\hline Roger of Leaton & Court Official & Eyton & Novel Disseisin & No. 229 & \\
\hline Roger of Ledwich & (mention) & Cleeton & Seisin @ Death & No. 168 & \\
\hline Roger of Ledwich & Pledge & Moreton & Novel Disseisin & No. 217 & \\
\hline Roger of Lee & Victim & Wombridge, Hadley, Ketley \& Horton & Misadventure & No. 698 & Bradford \\
\hline Roger of Leigh & Attorney & & Plea of Land & No. 481 & \\
\hline Roger of Longden & Court Official & Eyton & Novel Disseisin & No. 229 & \\
\hline Roger of Lostford & Accused & & Default & No. 751 & Bradford \\
\hline Roger of Lostford & Defendant & Gravenhunger & Dower & No. 117 & \\
\hline Roger of Luntley & Attorney & & Plea of Liberty/Market & No. 201 & \\
\hline Roger of Luntley & Attorney & & & No. 67 & \\
\hline Roger of Marsh & Defendant & Eyton & Novel Disseisin & No. 229 & \\
\hline Roger of Marsh & Plaintiff & Eyton & Entry & No. 252 & \\
\hline Roger of Middlehope & Victim & Field of Millichope & Execution/Murder & No. 656 & Wenlock \\
\hline Roger of Montgomery, Baker & Witness & Ludlow & Murder & No. 576 & Munslow \\
\hline Roger of Moor & Accused & Leighton & Default & No. 751 & Bradford \\
\hline Roger of More & Serjeant & More & Custom \& Services & No. 507 & Purslow \\
\hline Roger of Noneley & Accused & & Theft & No. 750 & Bradford \\
\hline Roger of Onslow & Defendant & Thakimor & Novel Disseisin & No. 75 & \\
\hline Roger of Pickstock & Accused & & Theft & No. 750 & Bradford \\
\hline Roger of Pilson & Pledge & & Rape & No. 672 & Wenlock \\
\hline Roger of Preste & Victim & North Foregate & Murder & No. 900 & Shrewsbury \\
\hline Roger of Puleston & Defendant & Donington & Dower & No. 341 & \\
\hline Roger of Puleston & Pledge & The Heath & Entry & No. 114 & \\
\hline Roger of Skimblescott & Plaintiff & Brockton & Novel Disseisin & No. 72 & \\
\hline Roger of Smethcote & Defendant & Clive \& Haughton & Nuisance & No. 95 & \\
\hline Roger of Stanton & Warrenty & Stanton Lacy & Seisin @ Death & No. 164 & \\
\hline Roger of Swin' & (mention) & & Perambulation & No. 351 & \\
\hline Roger of The Bold & Defendant & The Bold \& Charlcotte & Dower & No. 211 & \\
\hline Roger of The Bold & Juror & Wooton & Custom \& Services & No. 249 & \\
\hline Roger of The Down & Juror & Neen & Novel Disseisin & No. 34 & \\
\hline Roger of Wallop & Serjeant & Cause & Imprisonment & No. 515 & Purslow \\
\hline Roger of Westhope & Victim & Westhope, Corfton \& Dinchope & Murder & No. 595 & Munslow \\
\hline Roger of Westley & Defendant & Stapleton & Novel Disseisin & No. 313 & \\
\hline Roger of Wrockwardine & Accused & & Theft & No. 750 & Bradford \\
\hline Roger Page & Accused & & Theft & No. 721 & Bradford \\
\hline Roger Poping & Accused & Newport & Murder & No. 700 & Bradford \\
\hline Roger Porter of Wooton & Witness & Ludlow & Murder & No. 576 & Munslow \\
\hline Roger Punch & Defendant & Shrewsbury & Entry & No. 349 & \\
\hline Roger Puncke & Defendant & Shrewsbury & Novel Disseisin & No. 330 & \\
\hline Roger Pylle & Defendant & Wenlock & Mort d'Ancestor & No. 89 & \\
\hline Roger Pyrie & Accused & Stanton \& Westhope & Execution/Murder & No. 594 & Munslow \\
\hline Roger Rever & Defendant & Shrewsbury & Seisin @ Death & No. 309 & \\
\hline Roger Rowse of Uckington & Accused & & Theft & No. 750 & Bradford \\
\hline Roger s. Adam Hodinol & Victim & Stanton Long, Ashfield, Ruthall \& Brockton & Murder & No. 593 & Munslow \\
\hline Roger s. Adam of Langley & Accused & Langley & Theft/Absconded & No. 770 & Condover \\
\hline Roger s. Alan the Miller & Victim & Longford & Murder & No. 728 & Bradford \\
\hline Roger s. Alewy of Bagley & Pledge & [inside Welshry] & Theft & No. 857 & Pimhill \\
\hline Roger s. Alexander & Plaintiff & Newport & Entry & No. 28 & \\
\hline Roger s. Alice of Longnor & Accused & Netley \& Frodesley & Execution/Murder & No. 781 & Condover \\
\hline Roger s. Andrew & Witness & Castle Holdgate & Murder & No. 591 & Munslow \\
\hline Roger s. Celestria & Defendant & Norbury & Novel Disseisin & No. 50 & \\
\hline Roger s. David b. Adam s. David & Defendant & Sheet \& Wettleton \& Stokesay & Seisin @ Death & No. 99 & \\
\hline Roger s. Edwyn of Boraston & Victim & Corn Brook in Spurtree, Whatmore \& Milson & Misadventure & No. 529 & Overs \\
\hline Roger s. Ellis [Elis/Elias] & Juror & & & No. 912 & Chirbury \\
\hline Roger s. Eve & Defendant & Chelmarsh & Novel Disseisin & No. 47 & \\
\hline Roger s. Henry & Defendant & Bromlow & Dower & No. 149 & \\
\hline Roger s. Henry of Bridgenorth & Accused & & Theft & No. 865 & Bridgenorth \\
\hline Roger s. Hoel [Hywel] & Defendant & Weston & Entry & No. 16 & \\
\hline Roger s. John of Stretton & Accused & Stretton & Murder/Absconded & No. 598 & Munslow \\
\hline Roger s. John of Stretton & Payer & & Fine & No. 626 & Stretton \\
\hline
\end{tabular}




\begin{tabular}{|c|c|c|c|c|c|}
\hline Roger s. Martin of Yorton & Defendant & Bomere & Novel Disseisin & No. 98. & \\
\hline Roger s. Matthew of Eyton & Defendant & Eyton & Entry & No. 252 & \\
\hline Roger s. of Hugh of Longford & Pledge & Longford & Theft & No. 786 & Condover \\
\hline Roger s. of Roger of Ashford & Court Official & Moreton & Novel Disseisin & No. 217 & \\
\hline \begin{tabular}{|l|} 
Roger s. Philip \\
\end{tabular} & Defendant & Astley & Seisin @ Death & No. 304 & \\
\hline Roger s. Ralph & Defendant & Bomere & Novel Disseisin & No. 98. & \\
\hline \begin{tabular}{|l} 
Roger s. Richard \\
\end{tabular} & Defendant & Aston & Dower & No. 149 & \\
\hline Roger s. Richard & Victim & Berwick & Murder & No. 855 & Pimhill \\
\hline Roger s. Richard & Victim & & Murder/Absconded & No. 725 & Bradford \\
\hline \begin{tabular}{|l|} 
Roger s. Robert of Preen \\
\end{tabular} & Accused & & Murder & No. 602 & Munslow \\
\hline \begin{tabular}{|l|} 
Roger s. Roger of Weston \\
\end{tabular} & Plaintiff & Charlcotte & Custom \& Services & No. 348 & \\
\hline Roger s. Sybil & Victim & Garmston \& Soulton & Misadventure & No. 712 & Bradford \\
\hline Roger s. Thomas & Defendant & Eaton & Nuisance & No. 303 & \\
\hline Roger s. Thomas of Hopton & Pledge & Hopton & Theft & No. 786 & Condover \\
\hline Roger s. Walter & Defendant & Woodbatch & Seisin @ Death & No. 299 & \\
\hline Roger s. Warin of Onslow & Court Official & Eyton & Novel Disseisin & No. 229 & \\
\hline \begin{tabular}{|l|} 
Roger s. William \\
\end{tabular} & Defendant & Eyton & Entry & No. 13 & \\
\hline Roger s. William Berner & Plaintiff & Bridgenorth & Novel Disseisin & No. 24 & \\
\hline \begin{tabular}{|l|} 
Roger s. William of Eyton \\
\end{tabular} & Pledge & Rowton & Mort d'Ancestor & No. 142 & \\
\hline Roger s. William of Myddle & Defendant & Bomere & Novel Disseisin & No. 98. & \\
\hline \begin{tabular}{|l|} 
Roger s. William of Stanwardine \\
\end{tabular} & Court Official & Eyton & Novel Disseisin & No. 229 & \\
\hline Roger s. William of the Hill & Victim & Clee St. Margaret \& Weston & Murder & No. 589 & Munslow \\
\hline Roger Shepherd & Defendant & Chetwynd & Novel Disseisin & No. 110 & \\
\hline \begin{tabular}{|l|} 
Roger Skinner b. Robert Chaplain \\
\end{tabular} & Plaintiff & Diddlebury & Seisin @ Death & No. 214 & \\
\hline \begin{tabular}{|l|} 
Roger Sprengehose \\
\end{tabular} & Court Official & & At Mercy & No. 43 & \\
\hline Roger Spring of Abdon & Pledge & Corfton & Novel Disseisin & No. 105 & \\
\hline Roger Stoker & Victim & Donnington & Murder & No. 733 & Bradford \\
\hline Roger Swift & Defendant & Clive \& Haughton & Nuisance & No. 95 & \\
\hline Roger Tangwar & Accused & & Rape & No. 672 & Wenlock \\
\hline Roger the Parson of Hodnet & Accused & & Murder & No. 823 & Chirbury \\
\hline Roger Tosti & Accused & Field of Millichope & Execution/Murder & No. 656 & Wenlock \\
\hline Roger Walhop & Pledge & Tedstill & Unlawful Entry & No. 566 & Stottesdon \\
\hline Roger Waudin & & & Compromise & No. 83 & \\
\hline Roger Welsh of Burlton & Defendant & Bomere & Novel Disseisin & No. 98 & \\
\hline \begin{tabular}{|l} 
Roger White \\
\end{tabular} & Accused & & Theft & No. 671 & Wenlock \\
\hline Roger Woodrow & Pledge & Bridgenorth & Entry & No. 215 & \\
\hline \begin{tabular}{|l|} 
Roger Young of Felton \\
\end{tabular} & Victim & Ness, Felton \& Shrawardine & Murder & No. 843 & Pimhill \\
\hline Roger, Forester & Victim & Batchcott, Wooferton, Ashford Bowdler \& Overton & Murder & No. 571 & Munslow \\
\hline Roger, Parson of Sheinton & Accused & & Assault & No. 791 & Condover \\
\hline Roger, Parson of Sheinton & Pledge & & Executed & No. 788 & Condover \\
\hline \begin{tabular}{|l|} 
Roger, servant of Parson of Withington \\
\end{tabular} & Victim & & Murder & No. 731 & Bradford \\
\hline S. of Walton & (mention) & & Assault & No. 794 & Condover \\
\hline Saer Mauveysyn & Accused & & Custom \& Services & No. 752 & Bradford \\
\hline Saer Mauveysyn & Plaintiff & Atcham in Berwick & Novel Disseisin & No. 327 & \\
\hline Saer Mauveysyn & & & Plea of Land & No. 197 & \\
\hline Saer of Berwick & Juror & & & No. 906 & Bradford \\
\hline Saer of Huntingfield & Accused & & Default & No. 535 & Overs \\
\hline Sampson Shepherd & Accused & Bridgenorth & Execution & No. 718 & Bradford \\
\hline Seysel & Accused & & Imprisonment & No. 790 & Condover \\
\hline Seysell Gou & Victim & Chapel St. Eldred's \& Bromfield & Murder & No. 575 & Munslow \\
\hline Simon b. Henry Prat & Accused & & Absconded & No. 876 & Bridgenorth \\
\hline Simon Butcher & Accuser & St. Mary's & Assault & No. 901 & Shrewsbury \\
\hline Simon Deuheuwye & Defendant & Bromlow & Dower & No. 149 & \\
\hline Simon Holegod & Defendant & Sheet \& Wettleton \& Stokesay & Seisin @ Death & No. 99 & \\
\hline Simon Memon of Straddle & Accused & Cornewood & Murder & No. 531 & Overs \\
\hline Simon Miller of Broadward & Perp/Nictim & Clungenford, Broadward, Jay \& Beckjay & Murder & No. 489 & Purslow \\
\hline Simon of Colemore & Plaintiff & Astley & Dower & No. 472 & \\
\hline Simon of Colemore & Plaintiff & Colemore & Novel Disseisin & No. 60 & \\
\hline Simon of Coston & Recipient & & Fine & No. 511 & Purslow \\
\hline Simon of Hulle & Pledge & & Custom \& Services & No. 116 & \\
\hline Simon of Overton & Pledge & & \begin{tabular}{|l|} 
Receiving Outlaws \\
\end{tabular} & No. 532 & Overs \\
\hline Simon of Overton & Pledge & & Theft & No. 537 & Overs \\
\hline Simon of Preen & Accuser & & Assault & No. 794 & Condover \\
\hline Simon of Tetsill & Defendant & Hordley & Novel Disseisin & No. 221 & \\
\hline Simon Rate & Defendant & Chetwynd & Novel Disseisin & No. 110 & \\
\hline Simon s. Adam of Hope & Victim & Hope & Murder & No. 527 & Overs \\
\hline Simon s. Philip of Loughton & Plaintiff & Loughton & Novel Disseisin & No. 251 & \\
\hline Simon s. Richard of Bursford & Victim & Burford & Misadventure & No. 530 & Overs \\
\hline Simon the Parson of Donington & Victim & Donington & Murder & No. 809 & Brimstree \\
\hline Simon Wele & Victim & Myndtown & Murder & No. 498 & Purslow \\
\hline Siward Champion & (mention) & Benthall & Entry & No. 115 & \\
\hline Stephen b. Philip of Woodhouse & Defendant & Hordley & Novel Disseisin & No. 221 & \\
\hline \begin{tabular}{|l|} 
Stephen Chamberlain \\
\end{tabular} & Defendant & Middleton & Custom \& Services & No. 350 & \\
\hline Stephen Kede & Accused & Brockton & Theft & No. 811 & Brimstree \\
\hline Stephen Kede & Defendant & Broughton & Seisin @ Death & No. 26 & \\
\hline Stephen Knotte & Pledge & Bridgenorth & Murder & No. 936 & Bridgenorth \\
\hline Stephen of Ashford & Plaintiff & Fennemere & Novel Disseisin & No. 39 & \\
\hline Stephen of Aston & Defendant & Aston & Dower & No. 149 & \\
\hline Stephen of Aston & & & Compromise & No. 212 & \\
\hline Stephen of Bitterley & Court Official & & Perambulation & No. 351 & \\
\hline Stephen of Bitterley & Court Official & Woofferton & Right & No. 332 & \\
\hline Stephen of Bitterley & Court Official & Belswardyne Wood & Tort \& Force & No. 138 & \\
\hline Stephen of Bitterley & Juror & Eyton & Entry & No. 13 & \\
\hline Stephen of Bitterley & Juror & Oxenbold & Entry & No. 30 & \\
\hline Stephen of Bitterley & Juror & The Heath & Entry & No. 114 & \\
\hline Stephen of Bitterley & Juror & Weston & Entry & No. 16 & \\
\hline Stephen of Bitterley & Juror & Wem & Novel Disseisin & No. 48 & \\
\hline Stephen of Bitterley & Juror & Woofferton & Right & No. 332 & \\
\hline Stephen of Bitterley & Pledge & Bitterley & Murder & No. 518 & Overs \\
\hline Stephen of Boscobel & Victim & Claverley & Murder/Imprisonment & No. 629 & Claverley \\
\hline Stephen of Fennemere & Defendant & & Plea of Land & \begin{tabular}{|l} 
No. 477 \\
\end{tabular} & \\
\hline
\end{tabular}




\begin{tabular}{|c|c|c|c|c|c|}
\hline Stephen of Hope Bowdler & Accused & & Default & No. 822 & Chirbury \\
\hline Stephen of Oakley & Defendant & Norton & Seisin @ Death & No. 106 & \\
\hline Stephen of Oakley & Plaintiff & Norton & Entry & No. 310 & \\
\hline Stephen of Smethcote & Victim & Smethcote & Theft & No. 771 & Condover \\
\hline Stephen of St. Albans & Plaintiff & Chirbury & Novel Disseisin & No. 210 & \\
\hline Stephen of Stocks & Accused & Tedstill & Unlawful Entry & No. 566 & Stottesdon \\
\hline Stephen of Westbury & Accused & & Theft & No. 860 & Pimhill \\
\hline Stephen Rowse & Defendant & Clive \& Haughton & Nuisance & No. 95 & \\
\hline Stephen s. Hamon & Defendant & Adderley & Entry & No. 103 & \\
\hline Stephen s. Matilda & Defendant & Hordley & Novel Disseisin & No. 221 & \\
\hline Stephen s. Osbert of Middleton & & & Compromise & No. 127 & \\
\hline Stephen s. Richard of Bishop's Castle & Pledge & Hope Bowdler & Novel Disseisin & No. 46 & \\
\hline Stephen s. Stephen & Accused & & Default & No. 822 & Chirbury \\
\hline Stephen s. Warin & Defendant & Fennemere & Entry & No. 151 & \\
\hline Stephen s. Warin & Defendant & Fennemere & Novel Disseisin & No. 39 & \\
\hline Stephen s. Warin & & & Plea of Land & No. 199 & \\
\hline Stephen s. William Herith & Victim & Alveley \& Nordley & Murder & No. 543 & Alveley \\
\hline Stephen Welsh & Defendant & Sheet \& Wettleton \& Stokesay & Seisin @ Death & No. 99 & \\
\hline Stephen, mason of Eaton & Accused & & Default & No. 517 & Purslow \\
\hline Stirk' of Shrewsbury & Pledge & Foregate & Mort d'Ancestor & No. 274 & \\
\hline Susan Attelegh gd. Richard s. Fulk & Plaintiff & Legh & Entry & No. 333 & \\
\hline Susanna w. Richard of Loppinton \& d. Peter of Aston & Plaintiff & Aston & Seisin @ Death & No. 284 & \\
\hline Swanilde w. Roger Young of Felton & Victim & Ness, Felton \& Shrawardine & Murder & No. 843 & Pimhill \\
\hline Sybil d. Geoffrey of Criddon & Defendant & Deuxhill & Seisin @ Death & No. 42 & \\
\hline Sybil d. Hilary + Richard s. Rose \& w. Adam Berde & Defendant & Woofferton & Seisin @ Death & No. 33 & \\
\hline Sybil Kede d. William Kede & Plaintiff & Broughton & Seisin @ Death & No. 26 & \\
\hline Sybil n. William Porter & Plaintiff & Shrewsbury & Seisin @ Death & No. 101 & \\
\hline Sybil n. William Porter & Plaintiff & Shrewsbury & Seisin @ Death & No. 309 & \\
\hline Sybil of Wigmore & Accused & Friars Minor, Bridgenorth & Theft & No. 867 & Bridgenorth \\
\hline Sybil s. Margaret Brian & Attorney & & Plea of Villeinage & No. 188 & \\
\hline Sybil w. Adam s. Peter & Plaintiff & Claverhall & Novel Disseisin & No. 157 & \\
\hline Sybil w. Henry of Leigh & Defendant & Preston & Entry & No. 235 & \\
\hline Sybil w. Henry of Leigh & Plaintiff & & Entry & No. 9 & \\
\hline Sybil w. Henry of Leigh & & & AppointAttorney & No. 481 & \\
\hline Sybil w. Peter of Calverhall & Plaintiff & Calverhall & Novel Disseisin & No. 74 & \\
\hline Sybil w. Roger of Broom & Victim & & Murder & No. 602 & Munslow \\
\hline Sybil w. William de Gardinis & Attorney & Ruckley & Novel Disseisin & No. 226 & \\
\hline Sybil w. William Okeman & Defendant & Criddon & Dower & No. 307 & \\
\hline Sybil w. William s. Hugh Heylin of Bromlow [Heilyn] & Defendant & Bromlow & Dower & No. 149 & \\
\hline Sybil w. William s. William Wytinou & Plaintiff & Astley & Novel Disseisin & No. 286 & \\
\hline Sybil wd. Ellis s. Hervey of Leighton [Elis/Elias] & (mention) & Leighton & Entry & No. 302 & \\
\hline Sybil wd. Hugh of Criddon & Plaintiff & Criddon & Dower & No. 307 & \\
\hline Sybil wd. Richard English & Plaintiff & Leebotwood & Dower & No. 85 & \\
\hline Sybil wd. Richard English & Plaintiff & Whittingslow & Dower & No. 92 & \\
\hline Tangaret [Angharad] & First Finder & Edstaston & Murder & No. 683 & Bradford \\
\hline Thomas a clerk of Drayton, an outlaw & Accused & Drayton & Murder & No. 801 & Brimstree \\
\hline Thomas Amuret of North Foregate & Pledge & & Murder & No. 892 & Shrewsbury \\
\hline Thomas b. Richard Smith of Claverhall & Accused & & Theft & No. 750 & Bradford \\
\hline Thomas b. Robert of Hawkstone & Defendant & Clive \& Haughton & Nuisance & No. 95 & \\
\hline Thomas Baterel & Pledge & Weston & Seisin @ Death & No. 160 & \\
\hline Thomas Berner & Accused & & Assault & No. 890 & Shrewsbury \\
\hline Thomas Bindefeud & Accused & Cause & Imprisonment & No. 516 & Purslow \\
\hline Thomas Book & Attorney & Marton & Novel Disseisin & No. 112 & \\
\hline Thomas Boray & Defendant & Shrewsbury & Entry & No. 329 & \\
\hline Thomas Borrey & Accused & & Assault & No. 890 & \begin{tabular}{|l|} 
Shrewsbury \\
\end{tabular} \\
\hline Thomas Burnel & Accused & & Rape & No. 672 & Wenlock \\
\hline Thomas Cadigan [Cadwgan] & Defendant & Ridgwardine & Entry & No. 283 & \\
\hline Thomas Cambun & Accused & Stanton & Murder & No. 650 & Stanton \\
\hline Thomas Carter & Defendant & Rodenhurst & Nuisance & No. 22 & \\
\hline Thomas Carter & Defendant & Shrewsbury & Seisin @ Death & No. 309 & \\
\hline Thomas Champion & \begin{tabular}{|l|} 
Witness \\
\end{tabular} & Ludlow & Murder & No. 576 & Munslow \\
\hline Thomas Cleche of The Dean & Pledge & Wenlock & Mort d'Ancestor & No. 89 & \\
\hline Thomas Clerk & Plaintiff & The Heath & Novel Disseisin & No. 88 & \\
\hline Thomas Clerk & Plaintiff & The Heath & Nuisance & No. 169 & \\
\hline Thomas Constantine & Coroner & Fields of Prees Heath & Misadventure & No. 679 & Bradford \\
\hline Thomas Constantine & Coroner & & & No. 484 & \begin{tabular}{|l|} 
Shropshire \\
\end{tabular} \\
\hline Thomas Constantine & Court Official & Eyton & Entry & No. 13 & \\
\hline Thomas Constantine & Court Official & Oxenbold & Entry & No. 30 & \\
\hline Thomas Constantine & Juror & Eyton & Entry & No. 13 & \\
\hline Thomas Constantine & Juror & Oxenbold & Entry & No. 30 & \\
\hline Thomas Constantine & Juror & The Heath & Entry & No.114 & \\
\hline Thomas Constantine & Juror & Weston & Entry & No. 16 & \\
\hline Thomas Constantine & Juror & Wem & Novel Disseisin & No. 48 & \\
\hline Thomas Constantine & & & Appoint Attorney & No. 189 & \\
\hline Thomas Constantine s. Isabel d. Robert de Girros & Plaintiff & Sutton & Entry & No. 64 & \\
\hline Thomas Corbet & (mention) & & Dower & No. 149 & \\
\hline Thomas Corbet & (mention) & Wythigruk' & Theft & No. 813 & Chirbury \\
\hline Thomas Corbet & Accused & Shrewsbury & Imprisonment & No. 738 & Bradford \\
\hline Thomas Corbet & Bailiff & & Imprisonment/Theft & No. 577 & Munslow \\
\hline Thomas Corbet & Defendant & Acton Burnel & Novel Disseisin & No. 231 & \\
\hline Thomas Corbet & Defendant & Alberbury & Novel Disseisin & No. 335 & \\
\hline Thomas Corbet & Defendant & Aston & Seisin @ Death & No. 284 & \\
\hline Thomas Corbet & Plaintiff & & Custom \& Services & No. 289 & \\
\hline Thomas Corbet & Plaintiff & Yockleton \& Amaston & Pracipe in Capite & No. 128 & \\
\hline Thomas Corbet & Sheriff & & Theft & No. 510 & Purslow \\
\hline Thomas Corbet & Sheriff & & & No. 483 & Shropshire \\
\hline Thomas Cotewyn & Accused & Castle Holdgate & Theft & No. 611 & Munslow \\
\hline Thomas Crawe of Priors Lee & Accused & Donnington & Murder & No. 803 & Brimstree \\
\hline Thomas Dod & Defendant & Clive \& Haughton & Nuisance & No. 95 & \\
\hline Thomas Eward & Pledge & Frankwell & Murder & No. 884 & Shrewsbury \\
\hline Thomas Ferraunt & Accused & & Assault & No. 890 & Shrewsbury \\
\hline
\end{tabular}




\begin{tabular}{|c|c|c|c|c|c|}
\hline Thomas Forester & Defendant & Clive \& Haughton & Nuisance & No. 95 & \\
\hline Thomas French & Plaintiff & Tyrley & Novel Disseisin & No. 280 & \\
\hline Thomas French of Shrawardine & Pledge & Tyrley & Novel Disseisin & No. 291 & \\
\hline Thomas Griffin [Gruffydd] & Juror & & & No. 928 & Worfield \\
\hline Thomas Hanaud s. William Hannaud & Plaintiff & Marton & Seisin @ Death & No. 256 & \\
\hline Thomas Harang & Juror & & Judgement & No. 617 & Munslow \\
\hline Thomas Hare of Loppington & Accused & & Theft & No. 860 & Pimhill \\
\hline Thomas Herdsman & Defendant & Chetwynd & Novel Disseisin & No. 110 & \\
\hline Thomas Hopton & Defendant & Hopton & Novel Disseisin & No. 57 & \\
\hline Thomas Hord & Accused & Tedstill & Unlawful Entry & No. 566 & Stottesdon \\
\hline Thomas Hord & Payer & Tedstill & Unlawful Entry & No. 566 & Stottesdon \\
\hline Thomas Hord of Wattlesborough & Pledge & Tedstill & Unlawful Entry & No. 566 & Stottesdon \\
\hline Thomas Mauveysyn & Court Official & Eyton & Novel Disseisin & No. 229 & \\
\hline Thomas Melkere & Accused & & Theft & No. 786 & Condover \\
\hline Thomas Miller of Drayton & Accused & Condover & Murder & No. 709 & Bradford \\
\hline Thomas of Alkington & Court Official & Donnington & Nuisance & No. 331 & \\
\hline Thomas of Ashwood & Victim & & Murder & No. 760 & Edgmond \\
\hline Thomas of Atterley & Accused & & Murder & No. 670 & Wenlock \\
\hline Thomas of Bardley & Pledge & Northwood & Nuisance & No. 87 & \\
\hline Thomas of Beckbury & Plaintiff & Nobold, Beckbury \& Golding & Dower & No. 162 & \\
\hline Thomas of Chipnall & Pledge & Tyrley & Novel Disseisin & No. 280 & \\
\hline Thomas of Enchmarsh & Accused & & Absconded & No. 620 & Munslow \\
\hline Thomas of Enville & Attorney & & Plea of Land & No. 269 & \\
\hline Thomas of Eudes & Defendant & Willaston & Seisin @ Death & No. 213 & \\
\hline Thomas of Garmston & Victim & Garmston & Murder & No. 711 & Bradford \\
\hline Thomas of Geldeford & Juror & & Judgement & No. 617 & Munslow \\
\hline Thomas of Grinshill & Defendant & Clive \& Haughton & Nuisance & No. 95 & \\
\hline Thomas of Hatton & Accused & & Theft & No. 619 & Munslow \\
\hline Thomas of Hereford & Accused & & Judgement & No. 640 & Ludlow \\
\hline Thomas of Hordley & Plaintiff & Hordley & Novel Disseisin & No. 221 & \\
\hline Thomas of Lea & Court Official & & At Mercy & No. 43 & \\
\hline Thomas of Lea & Juror & Eyton & Entry & No. 13 & \\
\hline Thomas of Lea & Juror & Oxenbold & Entry & No. 30 & \\
\hline Thomas of Lea & Juror & The Heath & Entry & No. 114 & \\
\hline Thomas of Lea & Juror & Weston & Entry & No. 16 & \\
\hline Thomas of Lea & Juror & Woofferton & Right & No. 332 & \\
\hline Thomas of Leaton & (mention) & Pontesbury & Fine & No. 831 & Ford \\
\hline Thomas of Leaton, a beadle & Accused & & Custom \& Services & No. 830 & Ford \\
\hline Thomas of Ledwich & Attorney & & Novel Disseisin & No. 10 & \\
\hline Thomas of Lee, Carpenter & Victim & Lee Parva, Ketley, Dawley Panton \& Stirchley & Murder & No. 680 & Bradford \\
\hline Thomas of Leighton & Defendant & Woodhouse & Novel Disseisin & No. 159 & \\
\hline Thomas of Leintwardine & Defendant & Chelmarsh & Novel Disseisin & No. 47 & \\
\hline Thomas of Melleg' & Accuser & & Corruption & No. 649 & Hales \\
\hline Thomas of Monk Hall & Accused & & Theft/Murder & No. 556 & Stottesdon \\
\hline Thomas of Moor & Witness & Castle Holdgate & Murder & No. 591 & Munslow \\
\hline Thomas of Munslow & Victim & & Imprisonment & No. 746 & Bradford \\
\hline Thomas of Munslow & Victim & Betton & Murder & No. 713 & Bradford \\
\hline Thomas of Onneley & Bailiff & Staffordshire & Murder & No. 760 & Edgmond \\
\hline Thomas of Sambrook & & & Appoint Attorney & No. 70 & \\
\hline Thomas of Sambrook & & & Compromise & No. 69 & \\
\hline Thomas of Shireford, Master & Defendant & Wooton & Custom \& Services & No. 249 & \\
\hline Thomas of Shireford, Master & Defendant & & Plea of Debt & No. 346 & \\
\hline Thomas of Shireford, Master & & Legh & Compromise & No. 63 & \\
\hline Thomas of Shireford, Master & & & Compromise & No. 163 & \\
\hline Thomas of Shireford, Master & & & Custom \& Services & No. 478 & \\
\hline Thomas of Shirefore & Defendant & Legh & Entry & No. 333 & \\
\hline Thomas of Willaston & Accused & & Assault & No. 748 & Bradford \\
\hline Thomas of Willaston & Defendant & Sandford & Novel Disseisin & No. 279 & \\
\hline Thomas of Willaston & Plaintiff & Moreton & Novel Disseisin & No. 216 & \\
\hline Thomas of Worthen & Victim & Worthen & Murder & No. 541 & Worthen \\
\hline Thomas of Wyke & Accused & Brockton & Theft & No. 811 & Brimstree \\
\hline Thomas Pede of Acton & Pledge & Down & Novel Disseisin & No. 56 & \\
\hline Thomas Pede of Stanway & Pledge & Adforton & Novel Disseisin & No. 18 & \\
\hline Thomas Provost of Newton & Defendant & Bomere & Novel Disseisin & No. 98. & \\
\hline Thomas Punch & Defendant & Woofferton & Right & No. 332 & \\
\hline Thomas Rabaz & Accused & & Assault & No. 743 & Bradford \\
\hline Thomas Rabaz & Court Official & Eyton & Novel Disseisin & No. 229 & \\
\hline Thomas reeve of Neen & Pledge & Neen Savage & Novel Disseisin & No. 2 & \\
\hline Thomas Russell & Accused & & Absconded & No. 812 & Brimstree \\
\hline Thomas s. Adam & Defendant & Eaton & Nuisance & No. 303 & \\
\hline Thomas s. Adam of Leighton & Pledge & Leighton & Mort d'Ancestor & No. 4 & \\
\hline Thomas s. Alice & Attorney & & & No. 70 & \\
\hline Thomas s. Berner \& b. John & & & Compromise & No. 294 & \\
\hline Thomas s. Berner \& b. John & & & Compromise & No. 324 & \\
\hline Thomas s. David [Dafydd] & Defendant & Clive \& Haughton & Nuisance & No. 95 & \\
\hline Thomas s. David of Leebotwood & Accused & Woodhouse & Murder & No. 778 & Condover \\
\hline Thomas s. Dewynt & Defendant & Bromlow & Entry & No. 250 & \\
\hline Thomas s. Edith of Ledwich & Pledge & Moreton & Novel Disseisin & No. 217 & \\
\hline Thomas s. Eudes & Defendant & Willaston & Seisin @ Death & No. 120 & \\
\hline Thomas s. Hugh & Defendant & Bomere & Novel Disseisin & No. 98. & \\
\hline Thomas s. Madin of Lea & Accused & Hanwood & Murder & No. 828 & Ford \\
\hline Thomas s. Margery of Ledwich & Pledge & Moreton & Novel Disseisin & No. 217 & \\
\hline Thomas s. Nicholas & Accuser & The Heath & Imprisonment/Theft & No. 621 & Munslow \\
\hline Thomas s. of John of Hodnet & Pledge & & Theft & No. 786 & Condover \\
\hline Thomas s. of William Provost & Defendant & Moreton & Novel Disseisin & No. 217 & \\
\hline Thomas s. Osbert of Wollerton & Payer & Wollerton & Trespass & No. 745 & Bradford \\
\hline Thomas s. Peter Champeneis & Defendant & Shrewsbury & Right & No. 278 & \\
\hline Thomas s. Pymme & & & Plea of Villeinage & No. 188 & \\
\hline Thomas s. Reginald & Victim & Garmston & Murder & No. 687 & Bradford \\
\hline Thomas s. Richard the Chaplain & Victim & Westhope, Corfton \& Dinchope & Murder & No. 596 & Munslow \\
\hline Thomas s. Robert & Defendant & Brockton & Novel Disseisin & No. 72 & \\
\hline
\end{tabular}




\begin{tabular}{|c|c|c|c|c|c|}
\hline Thomas s. Robert of Broomcroft & Accused & Kenley & Murder & No. 776 & Condover \\
\hline Thomas s. Robert of Ledwich & Pledge & Moreton & Novel Disseisin & No. 217 & \\
\hline Thomas s. Robert s. Robert & Defendant & Eaton & Nuisance & No. 303 & \\
\hline Thomas s. Robert Syward & Defendant & Clee St. Margaret & Novel Disseisin & No. 78 & \\
\hline Thomas s. Roger & Defendant & Neen Savage & Novel Disseisin & No. 2 & \\
\hline Thomas s. Thomas of Leighton & Defendant & Woodhouse & Novel Disseisin & No. 159 & \\
\hline Thomas s. Walter of Ashford & Accused & Batchcott, Wooferton, Ashford Bowdler \& Overton & Murder & No. 570 & Munslow \\
\hline Thomas s. widow Agnes & Victim & Bourton, Presthope, Patton \& West Bradeley & Murder & No. 660 & Wenlock \\
\hline Thomas s. William & Warrenty & Kenley & Seisin @ Death & No. 55 & \\
\hline Thomas Schire of Wentor & Pledge & Wentnor, Ratlinghope, Medlicott \& Home & Murder & No. 492 & Purslow \\
\hline Thomas Selewy [Selwyn] & Victim & Kenley & Execution/Murder & No. 777 & Condover \\
\hline Thomas Shoemaker & Defendant & & Custom \& Services & No. 116 & \\
\hline Thomas Tacy & Accused & & Theft & No. 904 & Shrewsbury \\
\hline Thomas Tangwar & Accused & & Rape & No. 672 & Wenlock \\
\hline Thomas the reeve of The Heath & Pledge & The Heath & Novel Disseisin & No. 230 & \\
\hline Thomas Thoppe & Defendant & Neen Savage & Novel Disseisin & No. 2 & \\
\hline Thomas Tinker & Victim & Burlton & Murder & No. 852 & Pimhill \\
\hline Thomas Walhop & Pledge & Tedstill & Unlawful Entry & No. 566 & Stottesdon \\
\hline Thomas Wymund & Victim & Stanton & Murder & No. 653 & Stanton \\
\hline Tuthegy, a Welshwoman & Victim & Marton fields & Misadventure & No. 819 & Chirbury \\
\hline Vivian of Rossall & Court Official & & At Mercy & No. 43 & \\
\hline Vivian of Rossall & Juror & Eyton & Entry & No. 13 & \\
\hline Vivian of Rossall & Juror & Oxenbold & Entry & No. 30 & \\
\hline Vivian of Rossall & Juror & The Heath & Entry & No. 114 & \\
\hline Vivian of Rossall & Juror & Weston & Entry & No. 16 & \\
\hline Vivian of Rossall & Juror & Woofferton & Right & No. 332 & \\
\hline Vivian s. Adam of Adderley & Plaintiff & Adderley & Entry & No. 103 & \\
\hline Walter b. Thomas Forester & Defendant & Clive \& Haughton & Nuisance & No. 95 & \\
\hline Walter Balle of Peaton & Pledge & & Theft/Absconded & No. 637 & Corfton \\
\hline Walter Barun & Accused & & Executed & No. 873 & Bridgenorth \\
\hline Walter Benet & Accused & & Theft & No. 721 & Bradford \\
\hline Walter Berner & Defendant & Neen & Novel Disseisin & No. 1 & \\
\hline Walter Bovetun of Tugford & Accused & & Theft & No. 620 & Munslow \\
\hline Walter Chirin & Defendant & Chetwynd & Novel Disseisin & No. 110 & \\
\hline Walter de Clifford & Defendant & Cleobury North & Custom \& Services & No. 207 & \\
\hline Walter de Clifford & Defendant & \begin{tabular}{|l|} 
Diddlebury \\
\end{tabular} & Novel Disseisin & No. 152 & \\
\hline Walter de Clifford & Payer & & Theft/Absconded & No. 637 & \begin{tabular}{|l|} 
Corfton \\
\end{tabular} \\
\hline Walter de Clifford & Plaintiff & & Trespass & \begin{tabular}{|l|l|} 
No. 84 \\
\end{tabular} & \\
\hline \begin{tabular}{|l|} 
Walter de Clifford \\
\end{tabular} & & & Appoint Attorney & No. 201 & \\
\hline Walter de Clifford & & & Appoint Attorney & No. 67 & \\
\hline Walter de Dunstanville & (mention) & Adderley & Entry & No. 103 & \\
\hline Walter de Dunstanville & & & Compromise & No. 101 & \\
\hline Walter de Gardino & Accused & & Theft & No.865 & Bridgenorth \\
\hline Walter Deu [Ddu] & Pledge & Neen & Nuisance & No. 113 & \\
\hline Walter Eylrich & Juror & & Judgement & No. 617 & Munslow \\
\hline Walter Fretel & Attorney & & Custom \& Services & No. 204 & \\
\hline Walter Goldsmith & Pledge & Bridgenorth & Murder & No. 936 & Bridgenorth \\
\hline Walter Grim & Victim & Longnor & Murder & No. 779 & Condover \\
\hline Walter Hakelutel & Accused & & Default & No. 614 & Munslow \\
\hline Walter Haket & Defendant & Egarton in Bromden & Novel Disseisin & No. 255 & \\
\hline Walter Haket & Plaintiff & Wheathill & Novel Disseisin & No. 38 & \\
\hline Walter Haket & Accuser & & Theft & No. 721 & Bradford \\
\hline Walter Honne & Accused & & Absconded & No. 619 & Munslow \\
\hline Walter Nightingale & Plaintiff & Cainham & Mort d'Ancestor & No. 254 & \\
\hline Walter of Bitterley & Accused & Lee Parva, Ketley, Dawley Panton \& Stirchley & Murder & No. 680 & Bradford \\
\hline Walter of Bridgnorth, Master & Defendant & Oldbury & Dower & No. 167 & \\
\hline Walter of Coreley & Victim & & Execution/Murder & No. 522 & Overs \\
\hline Walter of Enville & Accused & & Theft/Absconded & No. 874 & Bridgenorth \\
\hline Walter of Hadnall & Victim & Cotes/Coton & Murder & No. 888 & Shrewsbury \\
\hline Walter of Heathton & Defendant & Draycott & Dower & No. 337 & \\
\hline Walter of Higford & (mention) & Cressage & Wardship & No. 130 & \\
\hline Walter of Higford & Accused & & Default & No. 808 & Brimstree \\
\hline Walter of Hopton & Defendant & Mocktree wood in Shelderton & Custom \& Services & No. 275 & \\
\hline Walter of Hopton & Defendant & Shelderton & Custom \& Services & No. 276 & \\
\hline Walter of Hopton & Attorney & & Plea of Land & No. 189 & \\
\hline Walter of Hopton s. Joan d. Robert de Girros & Plaintiff & Sutton & Entry & No. 64 & \\
\hline Walter of Leighton & Victim & & Murder & No. 807 & Brimstree \\
\hline Walter of Mese, Cook & Accused & Lawton, Little Sutton \& Bitterley & Murder & No. 652 & Stanton \\
\hline Walter of Pedwardine & Plaintiff & Eyton on the the Weald Moors & Dower & No. 144 & \\
\hline Walter of Pendock & Defendant & Moreton & Novel Disseisin & No.217 & \\
\hline Walter of Soulton & Victim & Drayton \& Soulton & Murder & No. 708 & Bradford \\
\hline Walter of Stanlow & Victim & Burcote & Murder & No. 674 & Worfield \\
\hline Walter of Woodhouse & Accused & Bitterley & Murder & No. 518 & Overs \\
\hline Walter of Woodhouse & Victim & & Murder & No. 619 & Munslow \\
\hline Walter of Wottenhull & Accuser & & Assault & No. 748 & Bradford \\
\hline Walter Pacy & Defendant & Moreton & Novel Disseisin & No. 217 & \\
\hline Walter Pacy & Pledge & Moreton & Novel Disseisin & No. 217 & \\
\hline Walter Palmer & Accused & & Custom \& Services & No. 872 & Bridgenorth \\
\hline Walter Palmer, Master & Defendant & Bridgenorth & Novel Disseisin & No. 12 & \\
\hline Walter Parys & Accused & Tugford & Theft & No. 607 & Munslow \\
\hline Walter Peke of Stretton & Pledge & Tedstill & Unlawful Entry & No. 566 & Stottesdon \\
\hline Walter Pelter & Plaintiff & Charlton & Novel Disseisin & No. 141 & \\
\hline Walter Pelter of Charlton & Plaintiff & Charlton & Novel Disseisin & No. 136 & \\
\hline Walter Pinchun & Victim & Mawley, Presleye, Kyneredewell \& Cleobury & Murder & No. 545 & Stottesdon \\
\hline Walter Puttock & Accused & & Theft & No. 786 & Condover \\
\hline Walter s. Alexander s. Walter of Preen & Plaintiff & Preen & Seisin @ Death & No. 241 & \\
\hline Walter s. Alfred \& b. Adam s. Alfred & Plaintiff & Whitton & Seisin @ Death & No. 228 & \\
\hline Walter s. Alice of Norton & Pledge & Pendeston Mill near Higford & Murder & No.806 & Brimstree \\
\hline Walter s. Gilbert of Stockton & Witness & Pendeston Mill near Higford & Murder & No. 806 & Brimstree \\
\hline Walter s. Horner of Stanton & Victim & Lizard Wood in Stanton & Misadventure & No. 804 & Brimstree \\
\hline Walter s. Humfrey, a clerk & Accused & & Absconded & No. 796 & Condover \\
\hline
\end{tabular}




\begin{tabular}{|c|c|c|c|c|c|}
\hline Walter s. leun [leuan] & Juror & & & No. 919 & Corfton \\
\hline Walter s. Ives of Marchamley & Payer & & Trespass & No. 743 & Bradford \\
\hline Walter s. Ives of Peaton & Pledge & & Theft/Absconded & No. 637 & Corfton \\
\hline Walter s. Ives of Peaton & Victim & & Extortion & No. 636 & Corfton \\
\hline \begin{tabular}{|l} 
Walter s. Jareford [Yareford] \\
\end{tabular} & Victim & Stretton & Murder & No. 624 & Stretton \\
\hline Walter s. John of Preen & Plaintiff & Preen & Seisin @ Death & No. 240 & \\
\hline \begin{tabular}{|l|} 
Walter s. John of Ragdon \\
\end{tabular} & (mention) & Prescott & Dower & No. 124 & \\
\hline \begin{tabular}{|l} 
Walter s. Reginald of Chatwell \\
\end{tabular} & Accused & Enchmarsh & Murder & No. 604 & Munslow \\
\hline Walter s. Richard of Wem & Pledge & river Roden & Misadventure & No. 697 & Bradford \\
\hline \begin{tabular}{|l|} 
Walter s. Stephen of Leighton \\
\end{tabular} & Accused & Garmston & Murder & No. 687 & Bradford \\
\hline \begin{tabular}{|l|} 
Walter s. William of Middleton \\
\end{tabular} & Victim & Wyre wood outside Duddlewick & Murder & No. 657 & Wenlock \\
\hline \begin{tabular}{|l|} 
Walter s. William of Peaton \\
\end{tabular} & Victim & & Extortion & No. 636 & Corfton \\
\hline Walter Scariot & Accused & Neen & Murder & No. 524 & Overs \\
\hline Walter Schyre & Victim & Ludlow Market & Murder & No. 582 & Munslow \\
\hline \begin{tabular}{|l|} 
Walter the Chaplain \\
\end{tabular} & Victim & Newport & Murder & No. 700 & Bradford \\
\hline \begin{tabular}{|l|} 
Walter the Provost \\
\end{tabular} & Defendant & Chetwynd & Novel Disseisin & No. 110 & \\
\hline Walter the Smith of Minton & Victim & Stretton & Execution/Murder & No. 622 & Stretton \\
\hline Walter Walhop & Accused & Tedstill & Unlawful Entry & No. 566 & Stottesdon \\
\hline Warin of Soudley, Reeve & Accused & Soudley & Absconded & No. 755 & Bradford \\
\hline Wiliam of Lake & Accuser & & Imprisonment & No. 790 & Condover \\
\hline \begin{tabular}{|l|} 
Wiliam of Leighton \\
\end{tabular} & Pledge & & Theft & No. 793 & Condover \\
\hline \begin{tabular}{|l|} 
Willaim s. Stephen \\
\end{tabular} & Accused & & Default & No. 822 & Chirbury \\
\hline William & First Finder & Clungenford, Broadward, Jay \& Beckjay & Murder & No. 489 & Purslow \\
\hline William Aleyn & Attorney & & & No. 282 & \\
\hline \begin{tabular}{|l} 
William b. Alice wd. Reginald de Gaugy \\
\end{tabular} & (mention) & & Theft/Harbor & No. 863 & Bridgenorth \\
\hline William b. Hoel s. William [Hywel] & Defendant & Woodbatch & Seisin @ Death & No. 299 & \\
\hline William b. Reginald Cambun & Defendant & Chetwynd & Novel Disseisin & No. 110 & \\
\hline William b. Richard Lubbe & Accused & Ludlow & Murder & No. 576 & Munslow \\
\hline William b. Richard Smith of Claverhall & Accused & & Theft & No. 750 & Bradford \\
\hline William b. Wyn Croucher & (mention) & Frankwell & Murder & No. 884 & Shrewsbury \\
\hline William Baril & Accused & & Assault & No. 890 & Shrewsbury \\
\hline William Baril of Shrewsbury & Pledge & Birch & Mort d'Ancestor & No. 97 & \\
\hline William Baryl & & & Plea of Land & No. 482 & \\
\hline \begin{tabular}{|l|} 
William Baryl of Shrewsbury \\
\end{tabular} & Pledge & Hope Bowdler & Novel Disseisin & No. 46 & \\
\hline William Beadle & At Mercy & & & No. 20 & \\
\hline William Beruard & Defendant & Rodenhurst & Nuisance & No. 22 & \\
\hline \begin{tabular}{|l|lll} 
Willam Bird \\
\end{tabular} & Victim & Little Wenlock & Murder & No. 665 & Wenlock \\
\hline \begin{tabular}{|l|} 
William Blanastre \\
\end{tabular} & (mention) & Smethcote & Seisin @ Death & No. 209 & \\
\hline William Blethin [Bleddyn] & Accuser & Bernestre Wood & Assault & No. 613 & Munslow \\
\hline William Blunt & Defendant & Chetwynd & Novel Disseisin & No. 110 & \\
\hline \begin{tabular}{|l} 
William Bonami \\
\end{tabular} & Pledge & Bridgenorth & Murder & No. 936 & Bridgenorth \\
\hline William Bonami & Pledge & & Theft/Harbor & No. 863 & Bridgenorth \\
\hline William Bonet & Defendant & Whitton & Seisin@ Death & No. 228 & \\
\hline William Bordfaxe of Meretown & Pledge & Donnington & Entry & No. 17 & \\
\hline William Bret & Plaintiff & Hope Bowdler & Novel Disseisin & No. 46 & \\
\hline \begin{tabular}{|l|l} 
William Brocher, Hayward of Stapleton \\
\end{tabular} & Accused & Stapleton \& Smethcott & Murder & No. 780 & Condover \\
\hline William Brown & Pledge & & Theft & No. 537 & Overs \\
\hline William Brown of Overton & Pledge & & Receiving Outlaws & No. 532 & Overs \\
\hline William Brown, Brother at Combermere & Accused & & Trespass/Force & No. 742 & Bradford \\
\hline William Bulweyn of Ruyton & Victim & Ness & Murder & No. 845 & Pimhill \\
\hline William Burgeys of Ellerton & Accused & Wellington & Absconded & No. 755 & Bradford \\
\hline William Burnel & Accused & & Executed & No. 788 & Condover \\
\hline William Burnell & (mention) & Ruckley & Novel Disseisin & No. 226 & \\
\hline William Buscer & Plaintiff & Monks' Forgate & Novel Disseisin & No. 61 & \\
\hline William Cadigan [Cadwgan] & Accuser & Shrewsbury & Imprisonment & No. 738 & Bradford \\
\hline William Cadigan [Cadwgan] & Bailiff & & Imprisonment & No. 746 & Bradford \\
\hline William Cadigan [Cadwgan] & Defendant & Ridgwardine & Entry & No. 283 & \\
\hline William Cappe of Clee St. Margaret & Accused & & Theft & No. 620 & Munslow \\
\hline William Catchpole & Pledge & Drayton & Novel Disseisin & No. 27 & \\
\hline William Chaplain & Defendant & The Bold & Dower & No. 211 & \\
\hline William Chaplain & Warrenty & Sutton & Seisin @ Death & No. 292 & \\
\hline William Child & Defendant & Diddlebury & Novel Disseisin & No. 109 & \\
\hline William Child & Pledge & & Fine & No. 577 & Munslow \\
\hline William Chirin & Defendant & Chetwynd & Novel Disseisin & No. 110 & \\
\hline William Cokerel of Weston & Accused & & Default & No. 535 & Overs \\
\hline William Coleman & Accused & & Murder & No. 639 & Ludlow \\
\hline William Coleman & Witness & Ludlow & Murder & No. 576 & Munslow \\
\hline \begin{tabular}{|l} 
William Constantine (prob. Thomas Constantine) \\
\end{tabular} & Coroner & Steplewood & Misadventure & No. 499 & Purslow \\
\hline William Coterel & Defendant & Sheet \& Wettleton \& Stokesay & Seisin @ Death & No. 99 & \\
\hline William Coterel of Ludlow & Juror & & Judgement & No. 617 & Munslow \\
\hline William Couchere & Pledge & & Theft & No. 786 & Condover \\
\hline William Crompe & Accused & & Theft & No. 671 & Wenlock \\
\hline William Curteys of Nash & Accused & Nash & Murder & No. 526 & Overs \\
\hline William Cut & Accused & & Murder & No. 764 & Edgmond \\
\hline William Cuthel & Victim & Frankwell & Murder & No. 891 & Shrewsbury \\
\hline William Daukin & Victim & Stanton & Murder & No. 650 & Stanton \\
\hline \begin{tabular}{|l} 
William de Baskerville, a clerk \\
\end{tabular} & Accused & St. Mary's & Assault & No. 901 & Shrewsbury \\
\hline \begin{tabular}{|l} 
William de Coleville \\
\end{tabular} & Warrenty & Foregate & Dower & No. 298 & \\
\hline \begin{tabular}{|l|} 
William de Furches \\
\end{tabular} & Court Official & & Perambulation & No. 351 & \\
\hline \begin{tabular}{|l} 
William de Furches \\
\end{tabular} & Juror & Eyton & Entry & No. 13 & \\
\hline \begin{tabular}{|l} 
William de Furches \\
\end{tabular} & Juror & Oxenbold & Entry & No. 30 & \\
\hline \begin{tabular}{|l|} 
William de Furches \\
\end{tabular} & Juror & The Heath & Entry & No. 114 & \\
\hline \begin{tabular}{|l} 
William de Furches \\
\end{tabular} & Juror & Weston & Entry & No. 16 & \\
\hline \begin{tabular}{|l|} 
William de Furches \\
\end{tabular} & Juror & Wem & Novel Disseisin & No. 48 & \\
\hline \begin{tabular}{|l} 
William de Furches \\
\end{tabular} & Juror & Woofferton & Right & No. 332 & \\
\hline William de Furches b. Robert de Furches & Victim & & Extortion & No. 636 & Corfton \\
\hline William de Furches of Wollerton & Payer & Wollerton & Trespass & No. 745 & Bradford \\
\hline \begin{tabular}{|l} 
William de Gardinis \\
\end{tabular} & Defendant & Ruckley & Novel Disseisin & No. 226 & \\
\hline William de Gardino & (mention) & & Executed & No. 788 & Condover \\
\hline \begin{tabular}{|l|} 
William de Harcourt \\
\end{tabular} & Defendant & Tong Wood \& Grange @ Lizard & Nuisance & No. 111 & \\
\hline \begin{tabular}{|l} 
William de Pantulf \\
\end{tabular} & Accused & Hatton & Murder & No. 691 & Bradford \\
\hline
\end{tabular}




\begin{tabular}{|c|c|c|c|c|c|}
\hline William de Ross, Master & & & Plea of Utrum & No. 198 & \\
\hline William de Ross, Parson of Diddlebury & Plaintiff & Diddlebury & Novel Disseisin & No. 109 & \\
\hline William de Sollars & & & Plea of Market & No. 201 & \\
\hline \begin{tabular}{|l} 
William de Stutevill \\
\end{tabular} & Accused & & Default & No. 614 & Munslow \\
\hline \begin{tabular}{|l|l} 
William de Stutevill \\
\end{tabular} & Accused & & Default & No. 535 & Overs \\
\hline William Dire & Defendant & Chetwynd & Novel Disseisin & No. 110 & \\
\hline William Dod & Plaintiff & Wooton & Custom \& Services & No. 249 & \\
\hline William Doggefel of Coton [St. Dogmael/Dogvael] & Pledge & Edstaston & Murder & No. 683 & Bradford \\
\hline William Fleming & Plaintiff & Norbury & Novel Disseisin & No. 50 & \\
\hline William Fleming & Warrenty & Prescott & Dower & No. 124 & \\
\hline William Forester & Defendant & Eaton & Nuisance & No. 303 & \\
\hline William French & Plaintiff & Rowton \& Obaston & Nuisance & No. 58 & \\
\hline William French & & & Novel Disseisin & No. 176 & \\
\hline William Gentil & Pledge & Shrewsbury & Novel Disseisin & No. 330 & \\
\hline William Goch & Juror & & & No. 926 & Shrewsbury \\
\hline William Gogy [Goch] & Victim & Stanton \& Westhope & Execution/Murder & No. 594 & Munslow \\
\hline William Golding & Victim & Cound & Misadventure & No. 767 & Condover \\
\hline William Goldsmith & Defendant & Bridgenorth & Entry & No. 308 & \\
\hline William Gongelard & & & Compromise & No. 338 & \\
\hline William Hake & Attorney & & Plea of Land & No. 190 & \\
\hline William Hering & Accused & Wellington & Absconded & No. 755 & Bradford \\
\hline William Hesulfe & Victim & & Extortion & No. 636 & Corfton \\
\hline William Heyrun & Accused & & Absconded & No. 540 & Overs \\
\hline \begin{tabular}{|l|} 
William Hokeman \\
\end{tabular} & Juror & Wooton & Custom \& Services & No. 249 & \\
\hline \begin{tabular}{|l|} 
William Hope \\
\end{tabular} & Pledge & Frankwell & Murder & No. 884 & Shrewsbury \\
\hline William Horderley & Accused & & Default & No. 522 & Purslow \\
\hline William Hubert, Serjeant of Robert de Meysy & Serjeant & Wistanstow & Murder & No. 585 & Munslow \\
\hline William Huner & Defendant & Marton & Novel Disseisin & No. 112 & \\
\hline William Hunter & Defendant & Marton & Novel Disseisin & No. 134 & \\
\hline William Kibin & & & Compromise & No. 153 & \\
\hline William Kimble & Attorney & Whatmore & Novel Disseisin & No. 317 & \\
\hline William Knave & Victim & Longford & Murder & No. 730 & Bradford \\
\hline William Knight & Accused & Cronkhill in Emstrey & Murder & No. 772 & Condover \\
\hline William Knight & Defendant & Bomere & Novel Disseisin & No. 98. & \\
\hline William Kocerel of Weston & Pledge & Bitterley & Dower & No. 131 & \\
\hline William Kylmayn & Victim & & Murder/Harbor & No. 861 & Bridgenorth \\
\hline William Lance & Defendant & Rodenhurst & Nuisance & No. 22 & \\
\hline William Little & Accused & Brockton & Theft & No. 811 & Brimstree \\
\hline William Little of Notton, Brother at Combermere & Accused & & Trespass/Force & No. 741 & Bradford \\
\hline William Long & Bailiff & Pontesbury & Fine & No. 831 & Ford \\
\hline William Lori & Accused & & Default & No. 635 & Corfton \\
\hline \begin{tabular}{|l} 
William Lori of Diddlebury \\
\end{tabular} & Victim & & Extortion & No. 636 & Corfton \\
\hline \begin{tabular}{|l|} 
William Lovekin \\
\end{tabular} & Accused & Bearstone \& Gravenhunger & Murder & No. 702 & Bradford \\
\hline William Makedaunce & Accused & & Murder & No. 760 & Edgmond \\
\hline William Marculf & Pledge & Marculf & Theft & No. 786 & Condover \\
\hline \begin{tabular}{|l} 
William Marshall \\
\end{tabular} & Victim & Newport & Murder & No. 758 & Edgmond \\
\hline William Mauduit & Jailor & Castle Holdgate & Theft & No. 611 & Munslow \\
\hline William Mauduit & Defendant & & Trespass & & \\
\hline \begin{tabular}{|l|} 
William Mauduit of Castle Holdgate \\
\end{tabular} & Plaintiff & Oxenbold & Entry & No. 30 & \\
\hline \begin{tabular}{|l|} 
William Mauduit of Castle Holdgate \\
\end{tabular} & Warrenty & The Heath & Entry & No. 114 & \\
\hline William Mauveysyn & Accused & & Receiving Outlaws & No. 532 & Overs \\
\hline William Mauveysyn & Court Official & Whatmore & Novel Disseisin & No. 317 & \\
\hline William Mauveysyn & Plaintiff & Nash & Novel Disseisin & No. 93 & \\
\hline William Miller & Accused & & Theft/Absconded & No. 633 & Corfton \\
\hline William Morris & Accused & & Theft & No. 539 & Overs \\
\hline William Mortimer & Accused & Bulwardine & Default & No. 631 & Claverley \\
\hline William Mossel & Accused & Burlton & Murder & No. 852 & Pimhill \\
\hline William Nightingale & Defendant & Cainham & Mort d'Ancestor & No. 254 & \\
\hline William of Adney & Victim & Norton fields & Misadventure & No. 805 & Brimstree \\
\hline William of Bicton & Court Official & Bomere & At Mercy & No. 98. & \\
\hline William of Bicton, servant of Abbot of Shrewsbury & Accused & Betton & Murder & No. 713 & Bradford \\
\hline William of Birch & Victim & & Misadventure & No. 902 & Shrewsbury \\
\hline William of Bitterley & Payer & & Fine & No. 882 & Foregate \\
\hline William of Bowdler & & & Novel Disseisin & No. 200 & \\
\hline William of Bretteswald, Brother at Combermere & Accused & & Trespass/Force & No. 741 & Bradford \\
\hline William of Bridgenorth & Accused & & Murder & No. 934 & Bridgenorth \\
\hline William of Brompton & Accused & & Trespass/Assault & No. 741 & Bradford \\
\hline William of Brompton & Accused & & Trespass/Force & No. 742 & Bradford \\
\hline William of Brompton & Attorney & & Plea of Land & No. 197 & \\
\hline William of Brompton & & & Appoint Attorney & No. 197 & \\
\hline William of Burton & Accused & & Absconded & No. 789 & Condover \\
\hline William of Calverhall & Defendant & Calverhall & Novel Disseisin & No. 74 & \\
\hline William of Charlcotte & Defendant & The Bold & Dower & No. 211 & \\
\hline William of Charlcotte & Juror & Lawton & Novel Disseisin & No. 473 & \\
\hline William of Cheswell & Pledge & & Theft/Assault & No. 741 & Bradford \\
\hline William of Child & Court Official & Munslow & & No. 328 & \\
\hline William of Clater & & & Plea of Land & No. 180 & \\
\hline William of Claverhall & Accused/Accuser & & Theft & No. 750 & Bradford \\
\hline William of Claverhall & Defendant & Claverhall & Novel Disseisin & No. 157 & \\
\hline William of Cloverley & Accused & & Trespass/Force & No. 741 & Bradford \\
\hline William of Clunbury & Accused & & Default & No. 635 & Corfton \\
\hline William of Combermere, Baker & Accused & & Trespass/Force & No. 741 & Bradford \\
\hline \begin{tabular}{|l|} 
William of Corelay \\
\end{tabular} & Accused & Hinton, Lilleshall, Brockton \& Little Hales & Murder & No. 686 & Bradford \\
\hline \begin{tabular}{|l} 
William of Coreley \\
\end{tabular} & Pledge & Walford \& Wigmore & Nuisance & No. 270 & \\
\hline William of Corvedale, a clerk & Accused & Westbury & Murder & No. 827 & Ford \\
\hline William of Darliston & Accused & & Theft & No. 750 & Bradford \\
\hline William of Deuxhill & (mention) & Deuxhill & Seisin @ Death & No. 42 & \\
\hline William of Diddlebury, Vicar & Accused & & Default & No. 635 & Corfton \\
\hline \begin{tabular}{|l|l} 
William of Eccleshall \\
\end{tabular} & Pledge & & Fine & No. 610 & Munslow \\
\hline William of Ercall & Defendant & Rodenhurst & Nuisance & No. 22 & \\
\hline \begin{tabular}{|l} 
William of Ercall \\
\end{tabular} & Defendant & Rowton \& Obaston & Nuisance & No. 58 & \\
\hline
\end{tabular}




\begin{tabular}{|c|c|c|c|c|c|}
\hline William of Ercall & & & Appoint Attorney & No. 176 & \\
\hline William of Ercall & & & Compromise & No. 59 & \\
\hline \begin{tabular}{|l|} 
William of Exmouth \\
\end{tabular} & (mention) & & Imprisonment & No. 899 & Shrewsbury \\
\hline William of Eyton & (mention) & Eyton on the the Weald Moors & Dower & No. 144 & \\
\hline \begin{tabular}{|l|} 
William of Felhampton \\
\end{tabular} & Bailiff/Serjeant & Castle Holdgate & Theft & No. 592 & Munslow \\
\hline William of Fenchurch & Accuser & & Receiving Outlaws & No. 532 & Overs \\
\hline William of Ford & Defendant & Weston & Seisin @ Death & No. 160 & \\
\hline William of Gannow & Victim & Espley wood & Misadventure & No. 839 & Ford \\
\hline William of Goldstone & Plaintiff & Tyrley & Novel Disseisin & No. 291 & \\
\hline William of Hagindon & Defendant & Sandford & Novel Disseisin & No. 279 & \\
\hline William of Haleworth & Attorney & & & No. 238 & \\
\hline William of Hampton & Plaintiff & Alveley & \begin{tabular}{|l|} 
Novel Disseisin \\
\end{tabular} & No. 3 & \\
\hline William of Haughton & Defendant & Thakimor & Novel Disseisin & No. 75 & \\
\hline William of Haughton & Defendant & Spoonhill, Manor of & Seisin @ Death & No. 126 & \\
\hline William of Hayton & Pledge & Hopton & Novel Disseisin & No. 57 & \\
\hline William of Hints s. William of Hints & Warrenty & Walford & Entry & No. 90 & \\
\hline William of Hockleton & Accused & & Default & No. 822 & Chirbury \\
\hline William of Hodnet & Payer & & Trespass & No. 743 & Bradford \\
\hline William of Hodnet & Pledge & Ragdon & Novel Disseisin & No. 166 & \\
\hline \begin{tabular}{|l|} 
William of Holdeham \\
\end{tabular} & Juror & Lawton & Novel Disseisin & No. 473 & \\
\hline \begin{tabular}{|l|} 
William of Hope \\
\end{tabular} & Payer & & Fine & No. 511 & Purslow \\
\hline \begin{tabular}{|l} 
William of Ightfield \\
\end{tabular} & Victim & Ightfield & Murder & No. 703 & Bradford \\
\hline William of Ireland & Victim & Westbury & Murder & No. 827 & Ford \\
\hline \begin{tabular}{|l|} 
William of Keuere \\
\end{tabular} & Pledge & Stokesay & Novel Disseisin & No. 15 & \\
\hline \begin{tabular}{|l|} 
William of Kinnersley \\
\end{tabular} & Victim & Newport & Murder & No. 759 & Edgmond \\
\hline William of la Bude & Attorney & & Custom \& Services & No. 204 & \\
\hline \begin{tabular}{|l|} 
William of Lacon \\
\end{tabular} & Defendant & Hawode in Soulton & Novel Disseisin & No. 220 & \\
\hline \begin{tabular}{|l|} 
William of Lacon \\
\end{tabular} & Defendant & Wem & Novel Disseisin & No. 48 & \\
\hline \begin{tabular}{|l|} 
William of Langley \\
\end{tabular} & Pledge & Ruckley & Novel Disseisin & No. 226 & \\
\hline \begin{tabular}{|l|} 
William of Lea \\
\end{tabular} & Accused & Ludlow & Murder & No. 638 & Ludlow \\
\hline \begin{tabular}{|l|} 
William of Ledwich \\
\end{tabular} & Defendant & Cleeton & Seisin @ Death & No. 168 & \\
\hline William of Leidegrane & Juror & Wooton & Custom \& Services & No. 249 & \\
\hline William of Leighton & Pledge & Garmston & Murder & No. 687 & Bradford \\
\hline William of Leighton & Court Official & & At Mercy & No. 43 & \\
\hline William of Leighton & Court Official & The Heath & Entry & No. 114 & \\
\hline William of Leighton & Court Official & Belswardyne Wood & Tort \& Force & No. 138 & \\
\hline \begin{tabular}{|l|} 
William of Leighton \\
\end{tabular} & Juror & Eyton & Entry & No. 13 & \\
\hline William of Leighton & Juror & Oxenbold & Entry & No. 30 & \\
\hline \begin{tabular}{|l|} 
William of Leighton \\
\end{tabular} & Juror & The Heath & Entry & No. 114 & \\
\hline \begin{tabular}{|l|} 
William of Leighton \\
\end{tabular} & Juror & Weston & Entry & No. 16 & \\
\hline William of Leighton & Juror & Wem & Novel Disseisin & No. 48 & \\
\hline William of Leighton & Juror & Woofferton & Right & No. 332 & \\
\hline William of Leighton & Plaintiff & Thakimor & Novel Disseisin & No. 75 & \\
\hline \begin{tabular}{|l|} 
William of Lifford \\
\end{tabular} & Attorney & & Plea of Land & No. 197 & \\
\hline \begin{tabular}{|l|} 
William of Middlehope \\
\end{tabular} & & & Appoint Attorney & No. 198 & \\
\hline \begin{tabular}{|l|} 
William of Milson \\
\end{tabular} & Accused & & Default & No. 822 & Chirbury \\
\hline \begin{tabular}{|l|} 
William of Milson \\
\end{tabular} & Accused & & Default & No. 535 & Overs \\
\hline \begin{tabular}{|l|} 
William of Milson \\
\end{tabular} & Defendant & Milson & Novel Disseisin & No. 258 & \\
\hline William of Minton, Carter & Victim & Ludlow Market & Murder & No. 612 & Munslow \\
\hline William of Moreton & Defendant & Bomere & Novel Disseisin & No. 98. & \\
\hline \begin{tabular}{|l|} 
William of Norton \\
\end{tabular} & Defendant & Norton & Entry & No. 310 & \\
\hline \begin{tabular}{|l|} 
William of Orleton \\
\end{tabular} & Accused & Garmston & Default & No. 751 & Bradford \\
\hline \begin{tabular}{|l|} 
William of Orleton \\
\end{tabular} & Pledge & & Assault & No. 744 & Bradford \\
\hline William of Orleton & Pledge & Preston & Novel Disseisin & No. 107 & \\
\hline William of Overton & Pledge & Sidbury & Novel Disseisin & No. 40 & \\
\hline \begin{tabular}{|l} 
William of Pimley \\
\end{tabular} & Plaintiff & Pimley, Manor of & Novel Disseisin & No. 145 & \\
\hline William of Pimley, Clerk & Accused & Tedstill & Unlawful Entry & No. 566 & Stottesdon \\
\hline William of Pipillinton & Victim & Severn & Misadventure & No. 847 & Pimhill \\
\hline William of Preen & Accused & Preen & Theft & No. 786 & Condover \\
\hline William of Prees & Attorney & Bomere & Novel Disseisin & No. 98. & \\
\hline William of Radecote & Pledge & Woodcote & Mort d'Ancestor & No. 271 & \\
\hline William of Radnor & Pledge & Ludlow & Theft & No. 579 & Munslow \\
\hline \begin{tabular}{|l|} 
William of Ragdon \\
\end{tabular} & Accused & Stretton & Execution/Murder & No. 622 & Stretton \\
\hline William of Ragdon, outlaw & Accused & Longville \& Acton & Murder & No. 586 & Munslow \\
\hline \begin{tabular}{|l|} 
William of Roden \\
\end{tabular} & Plaintiff & Pulley & Novel Disseisin & No. 148 & \\
\hline William of Sandford & Accused & & Theft & No. 750 & Bradford \\
\hline William of Sheinton & Defendant & Cressage & Entry & No. 322 & \\
\hline \begin{tabular}{|l|} 
William of Snitton \\
\end{tabular} & Victim & Snitton, Whitton \& Uppencott & Murder & No. 523 & Overs \\
\hline William of Songare & Defendant & Stanton Lacy & Seisin @ Death & No. 164 & \\
\hline William of Sparchford & Accused & & Default & No. 635 & Corfton \\
\hline William of St. George & Accused & & Theft & No. 567 & Stottesdon \\
\hline William of St. George & Defendant & Neen & Novel Disseisin & No. 34 & \\
\hline William of St. George & Plaintiff & Neen & Novel Disseisin & No. 1 & \\
\hline William of St. George & Plaintiff & Neen Savage & Novel Disseisin & No. 2 & \\
\hline William of St. George & Plaintiff & Neen & Nuisance & No. 113 & \\
\hline William of St. George & Warrenty & Walford & Entry & No. 90 & \\
\hline William of Stapleton & (mention) & Stanton & Murder & No. 653 & Stanton \\
\hline William of Stapleton & Court Official & Eyton & Novel Disseisin & No. 229 & \\
\hline William of Stapleton & & & Plea of Land & No. 190 & \\
\hline William of Styche & Pledge & & Fine & No. 882 & Foregate \\
\hline William of Sutton, servant of Christine of Newport & Accused & Newport & Murder & No. 757 & Edgmond \\
\hline William of Tauton & Attorney & & Custom \& Services & No. 354 & \\
\hline William of Tern & & & Compromise & No. 76 & \\
\hline William of The Down & Court Official & Whatmore & Novel Disseisin & No. 317 & \\
\hline William of The Green, Chaplain & Defendant & Alveley & Novel Disseisin & No. 3 & \\
\hline William of The Hale & Defendant & Chetwynd & Novel Disseisin & No. 110 & \\
\hline William of The Lowe & Court Official & Posenhall & Novel Disseisin & No. 223 & \\
\hline William of The Lowe & Juror & Loughton & Novel Disseisin & No. 251 & \\
\hline \begin{tabular}{|l|} 
William of Walton \\
\end{tabular} & Victim & Walton, Ercall, Wytheford \& Rowton & Execution/Murder & No. 678 & Bradford \\
\hline William of Westwood & Juror & Lawton & Novel Disseisin & No. 473 & \\
\hline \begin{tabular}{|l|} 
William of Whitton \\
\end{tabular} & Accused & Whitton & Absconded & No. 512 & Purslow \\
\hline
\end{tabular}




\begin{tabular}{|c|c|c|c|c|c|}
\hline William of Wilstone & Pledge & Wellington & Theft & No. 761 & Edgmond \\
\hline \begin{tabular}{|l|} 
William of Woodhouse \\
\end{tabular} & Victim & Bitterley & Murder & No. 518 & Overs \\
\hline William of Wootton & Attorney & & & No. 205 & \\
\hline William of Wootton & Attorney & & & No. 238 & \\
\hline William of Wottenhull & Defendant & Sandford & Novel Disseisin & No. 279 & \\
\hline William Okeman & Defendant & Criddon & Dower & No. 307 & \\
\hline \begin{tabular}{|l|} 
William Page \\
\end{tabular} & Attorney & & Dower & No. 183 & \\
\hline William Page & Defendant & Aston & Dower & No. 149 & \\
\hline William Pede & Plaintiff & Down & Novel Disseisin & No. 56 & \\
\hline \begin{tabular}{|l} 
William Peket \\
\end{tabular} & Defendant & Atcham in Berwick & Novel Disseisin & No. 327 & \\
\hline \begin{tabular}{|l|} 
William Poitevin \\
\end{tabular} & Attorney & & Plea of Land & No. 482 & \\
\hline William Provost & Defendant & Bomere & Novel Disseisin & No. 98. & \\
\hline William Pyneleys & Plaintiff & Cressage & Novel Disseisin & No. 91 & \\
\hline William Pynot & Defendant & Bomere & Novel Disseisin & No. 98. & \\
\hline \begin{tabular}{|l|l} 
William Red \\
\end{tabular} & Accused & Tugford & Theft & No. 607 & Munslow \\
\hline \begin{tabular}{|l} 
William Rees [Rhys] \\
\end{tabular} & Plaintiff & Hayton & Novel Disseisin & No. 96 & \\
\hline William Russell & Defendant & Shrewsbury & Entry & No. 6 & \\
\hline William s. Adam & Attorney & & Plea of Land & No. 191 & \\
\hline William s. Adam & Accused & Langley & Theft/Absconded & No. 770 & Condover \\
\hline William s. Adam of Weston & Victim & Weston, Middleton \& Mucklewick & Misadventure & No. 821 & Chirbury \\
\hline William s. Adam s. Brown of Norton & Pledge & & Fine & No. 878 & Bridgenorth \\
\hline \begin{tabular}{|l|} 
William s. Aldith \\
\end{tabular} & Accused & & Theft & No. 671 & Wenlock \\
\hline \begin{tabular}{|l} 
William s. Brice [ap Rhys] \\
\end{tabular} & Defendant & The Bold & Dower & No. 211 & \\
\hline William s. Cecily & Defendant & Woodhouse & Right & No. 344 & \\
\hline \begin{tabular}{|l} 
William s. David [Dafyyd] \\
\end{tabular} & & & Compromise & No. 45 & \\
\hline William s. Geoffrey of Overton & Attorney & & Plea of Land & No. 179 & \\
\hline \begin{tabular}{|l|} 
William s. Geoffrey of Overton \\
\end{tabular} & Defendant & Neen Savage & Novel Disseisin & No. 2 & \\
\hline \begin{tabular}{|l|} 
William s. Gilbert of Stockton \\
\end{tabular} & Accused & Pendeston Mill near Higford & Murder & No. 806 & Brimstree \\
\hline William s. Golenthyche & Plaintiff & Woodbatch & Seisin @ Death & No. 299 & \\
\hline William s. Hamon de Curzun & Accused & & Theft & No. 537 & Overs \\
\hline \begin{tabular}{|l|} 
William s. Hawise of Shyrington \\
\end{tabular} & & & Compromise & No. 163 & \\
\hline \begin{tabular}{|l} 
William s. Hendelot \\
\end{tabular} & Victim & & Extortion & No. 636 & Corfton \\
\hline William s. Henry & Accused & & Theft & No. 786 & Condover \\
\hline \begin{tabular}{|l} 
William s. Henry of Claverhall \\
\end{tabular} & Pledge & Claverhall & Novel Disseisin & No. 157 & \\
\hline William s. Henry of Wyrley & Plaintiff & Calverhall & Novel Disseisin & No. 74 & \\
\hline \begin{tabular}{|l} 
William s. Herbert \\
\end{tabular} & Victim & & Misadventure & No. 553 & Stottesdon \\
\hline William s. Hugh & Accused & Longford, Moreton Say \& Longslow & Murder & No. 701 & Bradford \\
\hline William s. Hugh & Plaintiff & Stanton & Custom \& Services & No. 345 & \\
\hline William s. Hugh & Plaintiff & Tyrley & Novel Disseisin & No. 280 & \\
\hline William s. Hugh & & & Appoint Attorney & No. 282 & \\
\hline William s. Hugh Heylin of Bromlow [Heilyn] & Defendant & Bromlow & Dower & No. 149 & \\
\hline William s. Hugh of Sheinton & Defendant & Cressage & Seisin@ Death & No. 129 & \\
\hline \begin{tabular}{|l|} 
William s. Hugh of Shrawardine \\
\end{tabular} & Pledge & Tyrley & Novel Disseisin & No. 291 & \\
\hline \begin{tabular}{|l|} 
William s. Ithel of Wotherton \\
\end{tabular} & Victim & Wotherton & Misadventure & No. 816 & Chirbury \\
\hline William s. Ivor of Myddle & Defendant & Bomere & Novel Disseisin & No. 98. & \\
\hline William s. John & Plaintiff & The Heath & Novel Disseisin & No. 230 & \\
\hline William s. John & Defendant & The Heath & Novel Disseisin & No. 263 & \\
\hline William s. John & Defendant & The Heath & Nuisance & No. 169 & \\
\hline William s. John & Defendant & The Heath & Novel Disseisin & No. 88 & \\
\hline William s. John & Victim & Longville \& Acton & Murder & No. 586 & Munslow \\
\hline William s. John of Castle Holdgate & Defendant & The Heath & Entry & No. 114 & \\
\hline \begin{tabular}{|l} 
William s. John of Castle Holdgate/The Heath \\
\end{tabular} & Accused & & Imprisonment/Theft & No. 577 & Munslow \\
\hline 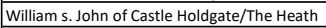 & Accused & & Murder & No. 578 & Munslow \\
\hline William s. John of Castle Holdgate/The Heath & Payer & & Fine & No. 577 & Munslow \\
\hline William s. John of Cound & Accused & & Murder & No. 879 & Foregate \\
\hline William s. John of Darliston & Pledge & Darliston & Theft & No. 786 & Condover \\
\hline William s. John of Hopton & Pledge & Hopton & Novel Disseisin & No. 57 & \\
\hline William s. John of The Heath & Accused & The Heath & Imprisonment/Theft & No. 621 & Munslow \\
\hline \begin{tabular}{|l|ll} 
William s. John of Wall \\
\end{tabular} & Accused/Victim & & Murder & No. 600 & Munslow \\
\hline William s. John s. Walter & Plaintiff & Preen & Seisin @ Death & No. 242 & \\
\hline \begin{tabular}{|l|} 
William s. John Smith \\
\end{tabular} & (mention) & West Wall & Seisin@ Death & No. 262 & \\
\hline William s. Mabel & Accused & & Assault & No. 890 & Shrewsbury \\
\hline William s. Madock of Broughton [Madog] & Accused & Broughton & Murder & No. 502 & Purslow \\
\hline William s. Margaret & Accused & & Murder & No. 740 & Bradford \\
\hline \begin{tabular}{|l|} 
William s. Matilda \\
\end{tabular} & Victim & Westhope, Corfton \& Dinchope & Murder & No. 596 & Munslow \\
\hline William s. Maurice of Pulley & Juror & Ruckley & Novel Disseisin & No. 226 & \\
\hline William s. Maydos & Pledge & The Heath & Imprisonment/Theft & No. 621 & Munslow \\
\hline William s. Nicholas of The Heath & Pledge & The Heath & Imprisonment/Theft & No. 621 & Munslow \\
\hline William s. Osbert & Warrenty & Diddlebury & Seisin @ Death & No. 214 & \\
\hline \begin{tabular}{|l} 
William s. Osbert \\
\end{tabular} & & & Compromise & No. 7 & \\
\hline William s. Pain & Defendant & Leighton & Entry & No. 302 & \\
\hline William s. Parnel & Defendant & Birch & Mort d'Ancestor & No. 97 & \\
\hline William s. Peter & Defendant & Chelmick & Seisin @ Death & No. 52 & \\
\hline William s. Peter & & & Plea of Land & No. 281 & \\
\hline \begin{tabular}{|l|} 
William s. Peter of Shavington \\
\end{tabular} & Plaintiff & Shavington & Novel Disseisin & No. 122 & \\
\hline William s. Philip Miller & Plaintiff & Shrewsbury & Seisin @ Death & No. 340 & \\
\hline William s. Philip of Abcott & Perp/Nictim & Clungenford, Broadward, Jay \& Beckjay & Murder & No. 489 & Purslow \\
\hline \begin{tabular}{|l|} 
William s. Philip of Stapleton \\
\end{tabular} & Defendant & Bomere & Novel Disseisin & No. 98. & \\
\hline William s. Philip of Stapleton & Defendant & Hayton & Novel Disseisin & No. 96 & \\
\hline William s. Philip of Stapleton & & Stapleton & Compromise & No. 170 & \\
\hline William s. Ralph of Preston & Victim & Preston fields & Murder & No. 848 & Pimhill \\
\hline \begin{tabular}{|l} 
William s. Ralph of Sandford \\
\end{tabular} & First Finder & Sandford & Murder & No. 695 & Bradford \\
\hline William s. Ranulf of Posenhall & Defendant & Posenhall & Novel Disseisin & No. 223 & \\
\hline William s. Ranulph of Eyton & Accused & Stanton & Murder & No. 653 & Stanton \\
\hline William s. Redwy & Victim & Coston, Burton' \& Beckbury & Murder & No. 491 & Purslow \\
\hline William s. Reginald of Acton & Warrenty & Prescott & Dower & No. 124 & \\
\hline William s. Richad Herdsman & Pledge & Bridgenorth & Murder & No. 936 & Bridgenorth \\
\hline \begin{tabular}{|l} 
William s. Richard Cuggel of Rossall \\
\end{tabular} & Victim & Rossall & Misadventure & No. 842 & Pimhill \\
\hline William s. Richard of Bletchley & Pledge & Willaston & Novel Disseisin & No. 80 & \\
\hline William s. Richard of Brockton & Pledge & & Theft/Assault & No. 741 & Bradford \\
\hline William s. Richard of Jay & Pledge & Clungenford, Broadward, Jay \& Beckjay & Murder & No. 489 & Purslow \\
\hline
\end{tabular}




\begin{tabular}{|c|c|c|c|c|c|}
\hline William s. Richard of Stanton Lacy & Plaintiff & Stanton Lacy & Seisin @ Death & No. 164 & \\
\hline \begin{tabular}{|l|} 
William s. Richard Pygot \\
\end{tabular} & Plaintiff & Bromlow & Entry & No. 250 & \\
\hline \begin{tabular}{|l|} 
William s. Richard the Chaplain \\
\end{tabular} & Accused & Westhope, Corfton \& Dinchope & Murder & No. 596 & Munslow \\
\hline William s. Robert & (mention) & Neen & Novel Disseisin & No. 1 & \\
\hline William s. Robert Beadle of Preen & Accused & & Assault & No. 794 & Condover \\
\hline William s. Robert of Acton & Accuser & & Theft & No. 793 & Condover \\
\hline William s. Robert of Acton & Pledge & Acton Burnel & Novel Disseisin & No. 231 & \\
\hline William s. Robert of Brockton & Victim & Brockton, Lydbury, Colebatch \& Totterton & Murder & No. 501 & Purslow \\
\hline William s. Robert of Lacon & Pledge & Shavington & Novel Disseisin & No. 122 & \\
\hline William s. Robert of Langley & Pledge & & Rape & No. 672 & Wenlock \\
\hline \begin{tabular}{|l} 
William s. Robert of Worfield \\
\end{tabular} & Victim & Oxenbold & Misadventure & No. 659 & Wenlock \\
\hline \begin{tabular}{|l|} 
William s. Robert Seys \\
\end{tabular} & Accused & Worthen & Murder & No. 541 & Worthen \\
\hline \begin{tabular}{|l} 
William s. Roger \\
\end{tabular} & Plaintiff & Woodhouse & Right & No. 344 & \\
\hline \begin{tabular}{|l|l} 
William s. Roger \\
\end{tabular} & & & Appoint Attorney & No. 206 & \\
\hline William s. Roger of Bagley & Defendant & Bagley & Seisin @ Death & No. 326 & \\
\hline William s. Roger of Leighton & Witness & Garmston & Murder & No. 687 & Bradford \\
\hline \begin{tabular}{|l|} 
William s. Roger of The Down \\
\end{tabular} & Juror & Neen & Novel Disseisin & No. 34 & \\
\hline William s. Roger s. Alewy & Defendant & Bagley & Seisin@ Death & No. 86 & \\
\hline William s. Sabina & Accused & & Default & No. 751 & Bradford \\
\hline \begin{tabular}{|l|l} 
William s. Simon of Tunstall \\
\end{tabular} & Accused & Cleobury North & Murder & No. 558 & Stottesdon \\
\hline \begin{tabular}{|l|} 
William s. Stephan of Walcot \\
\end{tabular} & Victim & Tern & Misadventure & No. 692 & Bradford \\
\hline William s. the Chaplain of Eyton & Pledge & Uppington & Misadventure & No. 681 & Bradford \\
\hline \begin{tabular}{|l} 
William s. the clerk of The Heath \\
\end{tabular} & Pledge & Clee St. Margaret & Novel Disseisin & No. 78 & \\
\hline \begin{tabular}{|l} 
William s. the Priest \\
\end{tabular} & Defendant & Deuxhill & Seisin @ Death & No. 306 & \\
\hline \begin{tabular}{|l|} 
William s. Thomas \\
\end{tabular} & Plaintiff & Norton & Novel Disseisin & No. 49 & \\
\hline \begin{tabular}{|l} 
William s. Thomas of Oldbury \\
\end{tabular} & Victim & Oldbury & Murder & No. 643 & Hales \\
\hline William s. Thomas of Tatlington & Plaintiff & Eudon & Entry & No. 154 & \\
\hline \begin{tabular}{|l} 
William s. Thomas of Wilmington \\
\end{tabular} & Victim & Wilmington & Murder & No. 820 & Chirbury \\
\hline \begin{tabular}{|l|} 
William s. Warin \\
\end{tabular} & Defendant & Cheney Hill & Dower & No. 155 & \\
\hline \begin{tabular}{|l|} 
William s. Warin \\
\end{tabular} & & & Dower/Land & No. 195 & \\
\hline \begin{tabular}{|l|} 
William s. Warin of Leighton \\
\end{tabular} & Victim & & Imprisonment & No. 859 & Pimhill \\
\hline \begin{tabular}{|l|} 
William s. William Cheles \\
\end{tabular} & Plaintiff & Little Sutton & Entry & No. 285 & \\
\hline William s. William Cheles & Plaintiff & Sutton & Seisin @ Death & No. 292 & \\
\hline William s. William Lovekin & Accused & Bearstone \& Gravenhunger & Murder & No. 702 & Bradford \\
\hline \begin{tabular}{|l|} 
William s. William of Bicton \\
\end{tabular} & Accused & & Theft & No. 860 & Pimhill \\
\hline \begin{tabular}{|l|} 
William s. William of Cressage \\
\end{tabular} & & & & No. 72 & \\
\hline \begin{tabular}{|l|} 
William s. William of Edstaston \\
\end{tabular} & Victim & Pimley & Misadventure & No. 694 & Bradford \\
\hline William s. William of Home & Accused & Wentnor, Ratlinghope, Medlicott \& Home & Murder & No. 492 & Purslow \\
\hline \begin{tabular}{|l|} 
William s. William of Ledwich \\
\end{tabular} & Victim & Middleton, Ledwich, Hopton \& The Moor & Murder & No. 587 & Munslow \\
\hline William s. William of Ledwich & Victim & Middleton, Ledwich \& Court of Hill & Murder & No. 520 & Overs \\
\hline \begin{tabular}{|l|} 
William s. William of Peplow \\
\end{tabular} & Pledge & Peplow & Theft & No. 786 & Condover \\
\hline William s. William of Sidbury & Attorney & & Custom \& Services & No. 354 & \\
\hline William s. William s. Philip & Victim & [inside Welshry] & Murder & No. 858 & Pimhill \\
\hline \begin{tabular}{|l|} 
William s. William s. William of Bicton \\
\end{tabular} & Accused & & Theft & No. 860 & Pimhill \\
\hline \begin{tabular}{|l|} 
William s. William Turner \\
\end{tabular} & Plaintiff & Shrewsbury & Novel Disseisin & No. 125 & \\
\hline William s. William Wytinou & Plaintiff & Astley & Novel Disseisin & No. 286 & \\
\hline William s. Wymund & Plaintiff & Walford & Entry & No. 90 & \\
\hline William Sermoner & (mention) & & Dower & No. 149 & \\
\hline \begin{tabular}{|l} 
William Seusot \\
\end{tabular} & Victim & Longville \& Acton & Murder & No. 586 & Munslow \\
\hline \begin{tabular}{|l|} 
William Silion of Longford [Sulien] \\
\end{tabular} & Pledge & Longford & Theft & No. 786 & Condover \\
\hline William Smith & Accused & Longslow, Drayton \& Longford & Theft/Execution & No. 722 & Bradford \\
\hline \begin{tabular}{|l|} 
William Smith of Aston \\
\end{tabular} & Accused & & Default & No. 516 & Purslow \\
\hline \begin{tabular}{|l|} 
William Somerswein \\
\end{tabular} & Victim & fields of Eyton & Murder & No. 696 & Bradford \\
\hline William Sparrow & Defendant & Shrewsbury & Seisin @ Death & No. 309 & \\
\hline \begin{tabular}{|l|} 
William Spich of Muxton \\
\end{tabular} & Accused & Donnington & Murder & No. 733 & Bradford \\
\hline William Spring of Ditton & Accused & Wyre wood outside Duddlewick & Murder & No. 657 & Wenlock \\
\hline William Strike & Accused & & Assault & No. 890 & Shrewsbury \\
\hline William Taylor & Defendant & Woofferton & Seisin @ Death & No. 33 & \\
\hline William the Clerk & Attorney & Pulverbatch & Entry & No. 11 & \\
\hline William the Cook of Brockton & Accused & & Theft & No. 810 & Brimstree \\
\hline \begin{tabular}{|l|} 
William the Reeve of Bearstone \\
\end{tabular} & Victim & Bearstone \& Gravenhunger & Murder & No. 702 & Bradford \\
\hline William Toppe & Victim & Ellerdine \& Muckleton & Misadventure & No. 717 & Bradford \\
\hline \begin{tabular}{|l|} 
William Treng of Boomcroft \\
\end{tabular} & Defendant & Kenley & Seisin @ Death & No. 55 & \\
\hline William Tuppe & Accuser & Sandford & Theft/Assaul & No. 747 & Bradford \\
\hline William Turner & Attorney & & Plea of Land & No. 266 & \\
\hline \begin{tabular}{|l|} 
William Wade of Shrewsbury \\
\end{tabular} & Victim & & Murder & No. 880 & Foregate \\
\hline William Walerand & (mention) & Stapleton & Novel Disseisin & No. 313 & \\
\hline \begin{tabular}{|l|} 
William Walerand \\
\end{tabular} & Defendant & & & No. 150 & \\
\hline \begin{tabular}{|l|} 
William Walerand \\
\end{tabular} & Plaintiff & Pulverbatch & Entry & No. 11 & \\
\hline \begin{tabular}{|l|} 
William Walerand \\
\end{tabular} & Plaintiff & Pulverbatch & Right & No. 475 & \\
\hline \begin{tabular}{|l|} 
William Walerand \\
\end{tabular} & Plaintiff & Pulverbatch & & No. 264 & \\
\hline William Welsh & Attorney & Pulverbatch & Entry & No. 11 & \\
\hline William Welsh & Victim & Isombridge & Misadventure & No. 705 & Bradford \\
\hline \begin{tabular}{|l|} 
William Wenche \\
\end{tabular} & Accused & & Theft & No. 750 & Bradford \\
\hline William Weyte of Bridgenorth & Accused & St. Leonard's Church, Bridgenorth & Murder & No. 870 & Bridgenorth \\
\hline William White & Defendant & Chetwynd & Novel Disseisin & No. 110 & \\
\hline William White & Victim & Bishop's Castle & Misadventure & No. 504 & Purslow \\
\hline \begin{tabular}{|l} 
William Wild of Badger \\
\end{tabular} & Accused & & Execution & No. 667 & Wenlock \\
\hline \begin{tabular}{|l|} 
William Wild of Clunton \\
\end{tabular} & Pledge & & Murder & No. 509 & Purslow \\
\hline William Wood & Victim & Neen & Murder & No. 524 & Overs \\
\hline William Wytemuth & Pledge & Great Sutton & Novel Disseisin & No. 66 & \\
\hline \begin{tabular}{|l|} 
William, Abbot of Combermere \\
\end{tabular} & Accused & & Incitement & No. 741 & Bradford \\
\hline William, Abbot of Combermere & Accused & & Incitement & No. 742 & Bradford \\
\hline Wrennon, a Welshman & Accused & Chapel St. Eldred's \& Bromfield & Murder & No. 575 & Munslow \\
\hline Wyn Croucher & Victim & Frankwell & Murder & No. 884 & Shrewsbury \\
\hline \begin{tabular}{|l} 
Wynn s. Madoc [Wyn] [Madog] \\
\end{tabular} & Victim & Prees & Murder & No. 736 & Bradford \\
\hline \begin{tabular}{|l|} 
Wyot s. Roger of Ightfield \\
\end{tabular} & Accused & & Murder/Absconded & No. 725 & Bradford \\
\hline Yareford of Wolverley & Accused & & Theft & No. 750 & Bradford \\
\hline Yareford s. Ithel & Accused & & Theft & No. 750 & Bradford \\
\hline Yareford Welsh & Victim & Bitterley & Misadventure & No. 519 & Overs \\
\hline Yareford, man of Abbot of Buildwas & Victim & Cause & Imprisonment & No. 516 & Purslow \\
\hline
\end{tabular}




\begin{tabular}{|c|c|c|c|c|c|}
\hline Yewan of Whixal [leuan] & First Finder & Whixall & Murder & No. 720 & Bradford \\
\hline Youan s. Madoc Was [leuan] [Madog] & Accuser & & Murder & No. 753 & Bradford \\
\hline Yowain of Whixall [Owain] & Accused & Whixall & Absconded & No. 755 & Bradford \\
\hline Ythel of Hinton [Ithel] & Accused & Hinton, Brough & Murder & No. 677 & ford \\
\hline
\end{tabular}




\section{APPENDIX FIVE \\ THE ROLL OF THE SHROPSHIRE EYRE OF 1256 WELSH INDIVIDUALS ${ }^{236}$}

Taken from the data compiled from The Roll of the Shropshire Eyre of 1256, Appendix

Five includes only individuals who were Welsh. Whether by name or identifier, these men and women can be considered to be Welsh according to the criteria laid out in Chapter Five.

${ }^{236}$ The Roll of the Shropshire Eyre of 1256. 


\begin{tabular}{|c|c|}
\hline Name & Location \\
\hline Adam Cyrecok/Ceiriog & Stottesdon \\
\hline Adan Wele & Overs Hundred \\
\hline \multicolumn{2}{|l|}{ Agnes w. Robert Welsh } \\
\hline Brice of Cleobury (ap Rhys) & Lawton \\
\hline Brice of Cleobury (ap Rhys) & The Bold \\
\hline Cadigan s. Einion of Hinton & Bradford Hundred \\
\hline Conin of Hope & Cornewood \\
\hline \multicolumn{2}{|l|}{ Dafydd Bollyn } \\
\hline Dafydd s. Alexander of Bradeshull & Tedstill \\
\hline Dafydd s. Henry & Woodhouse \\
\hline Daniel s. Madog Was & Bradford Hundred \\
\hline Einion s. Alexander of Bradeshull & Tedstill \\
\hline \multicolumn{2}{|l|}{ Einion s. Owain } \\
\hline Elias & Munslow Hundred \\
\hline Elias of Berkeford & Berkeford \\
\hline Elias of Stoke & Stoke \\
\hline Elias s. Hugh of Noneley & [inside Welshry] \\
\hline Elias s. Richard & Bradford Hundred \\
\hline \multicolumn{2}{|l|}{ Emeline w. Enion s. Owayn } \\
\hline Gruffydd & Condover Hundred \\
\hline Gruffydd ap Gwenwynwyn & Chirbury Hundred \\
\hline Gruffydd of Ultak & Ultak \\
\hline Gruffydd s.Einion & Ford Hundred \\
\hline Gwyneth d. Roger of Ellastone \& s. Parnel d. Roger of Ellastone & Ellastone \\
\hline Hywel s. Adam & Chirbury Hundred \\
\hline leuan s. Madog Was & Bradford Hundred \\
\hline Isabel d. Iseult & Worthen Manor \\
\hline \multicolumn{2}{|l|}{ Iseult w. Edwin } \\
\hline John Welsh & Hales Manor \\
\hline Kenewrek s. Wyard Little & Bradford Hundred \\
\hline Madog of Sutton & The Heath \\
\hline Nicholas s. Elias of Eaton & Ford Hundred \\
\hline \multicolumn{2}{|l|}{ Nicholas Welsh, Brother } \\
\hline \multicolumn{2}{|l|}{ Osbert s. Heilyn } \\
\hline Philip Welsh & Down \\
\hline Richard s. Einion & Birch \\
\hline Richard s. Griffith & Bradford Hundred \\
\hline Robert s. Robert Welsh & Ragdon \\
\hline \multicolumn{2}{|l|}{ Robert Welsh } \\
\hline Roger s. Elias & Chirbury Hundred \\
\hline Roger Tangwar & Wenlock Manor \\
\hline Saer Mauveysyn & Bradford Hundred \\
\hline
\end{tabular}




\begin{tabular}{|l|l|}
\hline Saer Mauveysyn & Bradford Hundred \\
\hline Saer of Huntingfield & Huntingfield \\
\hline Seysel & Condover Hundred \\
\hline Thomas Gruffydd & Worfield Manor \\
\hline Thomas Tangwar & Wenlock Manor \\
\hline Walter s. leuan & Corfton Manor \\
\hline William Bleddyn & Bernestre Wood \\
\hline William Cadigan & Bradford Hundred \\
\hline William Goch & Liberty Shrewsbury \\
\hline William s. Brice (ap Rhys) & The Bold \\
\hline William s. Dafydd & \\
\hline Yareford s. Ithel & Bradford Hundred \\
\hline
\end{tabular}




\begin{tabular}{|l|l|}
\hline & \\
\hline Type of Case & Case No. \\
\hline Criminal Case & No. 552 \\
\hline Regional Juror & No. 910 \\
\hline Civil Case & No. 165 \\
\hline Civil Case & No. 473 \\
\hline Civil Case & No. 211 \\
\hline Criminal Case & No. 742 \\
\hline Criminal Case & No. 531 \\
\hline Civil Case & No. 200 \\
\hline Civil Case & No. 566 \\
\hline Civil Case & No. 159 \\
\hline Criminal Case & No. 753 \\
\hline Civil Case & No. 566 \\
\hline Civil Case & No. 54 \\
\hline Criminal Case & No. 578 \\
\hline Civil Cases & No. 244 \\
\hline Regional Juror & No. 906 \\
\hline Criminal Case & No. 857 \\
\hline Criminal Case & No. 750 \\
\hline Civil Case & No. 54 \\
\hline Criminal Case & No. 790 \\
\hline Civil Case & No. 822 \\
\hline Criminal Case & No. 524 \\
\hline Civil Case & No. 834 \\
\hline Civil Case & No. 77 \\
\hline Civil Case & No. 822 \\
\hline Criminal Case & No. 753 \\
\hline Criminal Case & No. 542 \\
\hline Civil Case & No. 197 \\
\hline Regional Juror & No. 930 \\
\hline Criminal Case & No. 753 \\
\hline Civil Case & No. 114 \\
\hline Regional Juror & No. 923 \\
\hline Civil Case \\
\hline Civil Case \\
\hline Criminal Case & Nivil Case \\
\hline Criminal Case \\
\hline
\end{tabular}




\begin{tabular}{|l|l|}
\hline Civil Cases & No. 752 \\
\hline Civil Case & No. 535 \\
\hline Criminal Case & No. 790 \\
\hline Regional Juror & No. 928 \\
\hline Criminal Case & No. 672 \\
\hline Regional Juror & No. 919 \\
\hline Criminal Case & No. 613 \\
\hline Criminal Case & No. 746 \\
\hline Regional Juror & No. 926 \\
\hline Civil Case & No. 211 \\
\hline Civil Case & No. 45 \\
\hline Criminal Case & No. 750 \\
\hline
\end{tabular}




\section{APPENDIX SIX \\ THE WELSH ASSIZE ROLL 1277-1284 BY NAME 237}

Appendix Six is made up of a detailed description of every case found in The Welsh Assize Roll 1277-1284. Many of the cases are continuations of claims made earlier in the Assize and for that reason the data is organized by individual. The following compilation and analysis identifies arguments and judgements when available and notes when particular legal issues arose. For example, appeals to Welsh law and questions about the legal statuses of Marcher Baronies, Welsh bastards, and wardships are pointed out. Most of the dates in Appendix Six were calculated by J. C. Davies but those that were not I have calculated with the aid of the regnal year calendars compiled by Chris Philips for his website "Some Notes on Medieval English Genealogy". 238

${ }^{237}$ Davies, The Welsh Assize Roll, 1277-1284: Assize Roll No. 1147.

${ }^{238}$ Chris Phillips, "'A Medieval Engish Calendar" in Some Notes on Medieval English Genealogy," www.medievalgenealogy.org.uk/cal/medcal.shtml. Accessed between 2015-2018. 


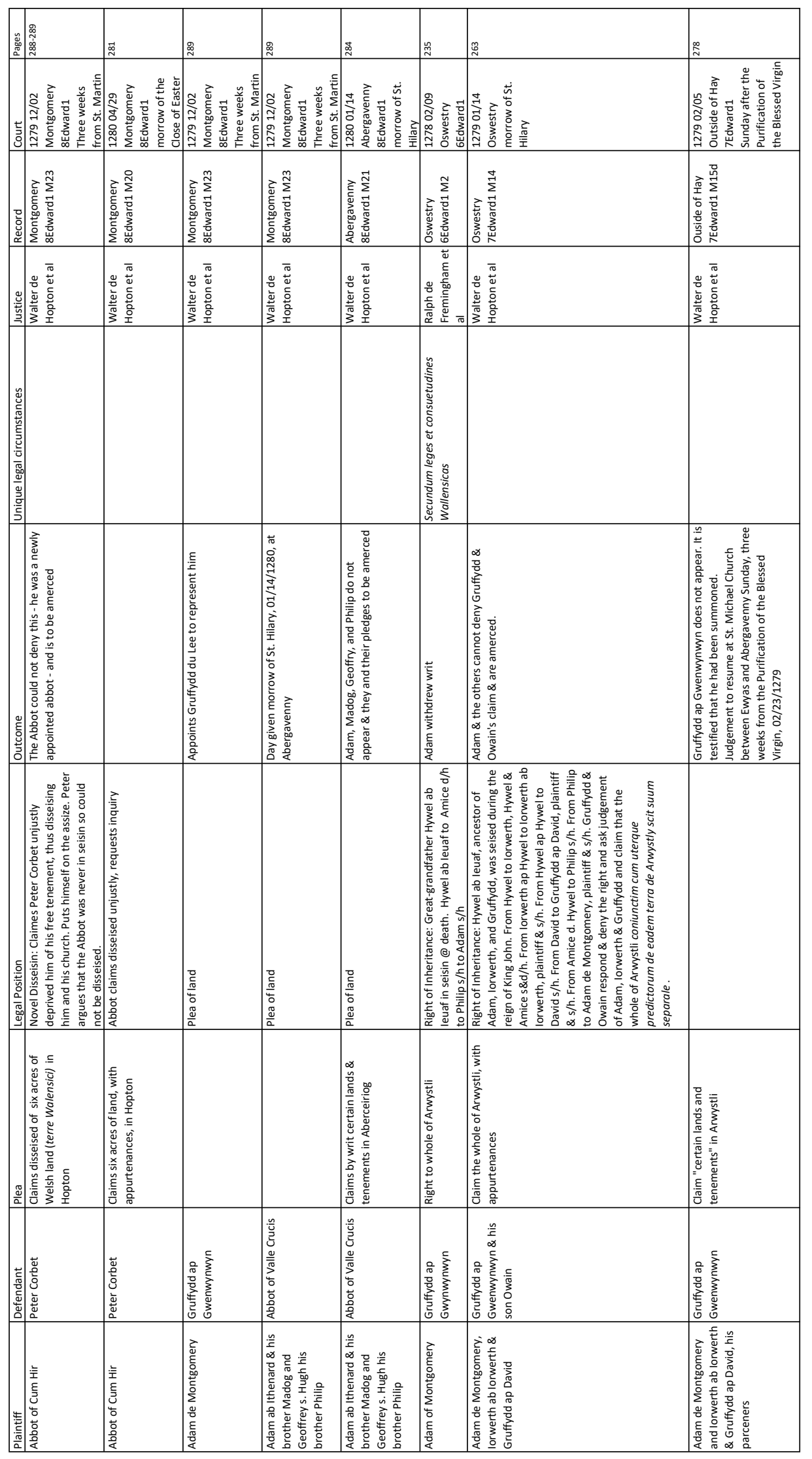




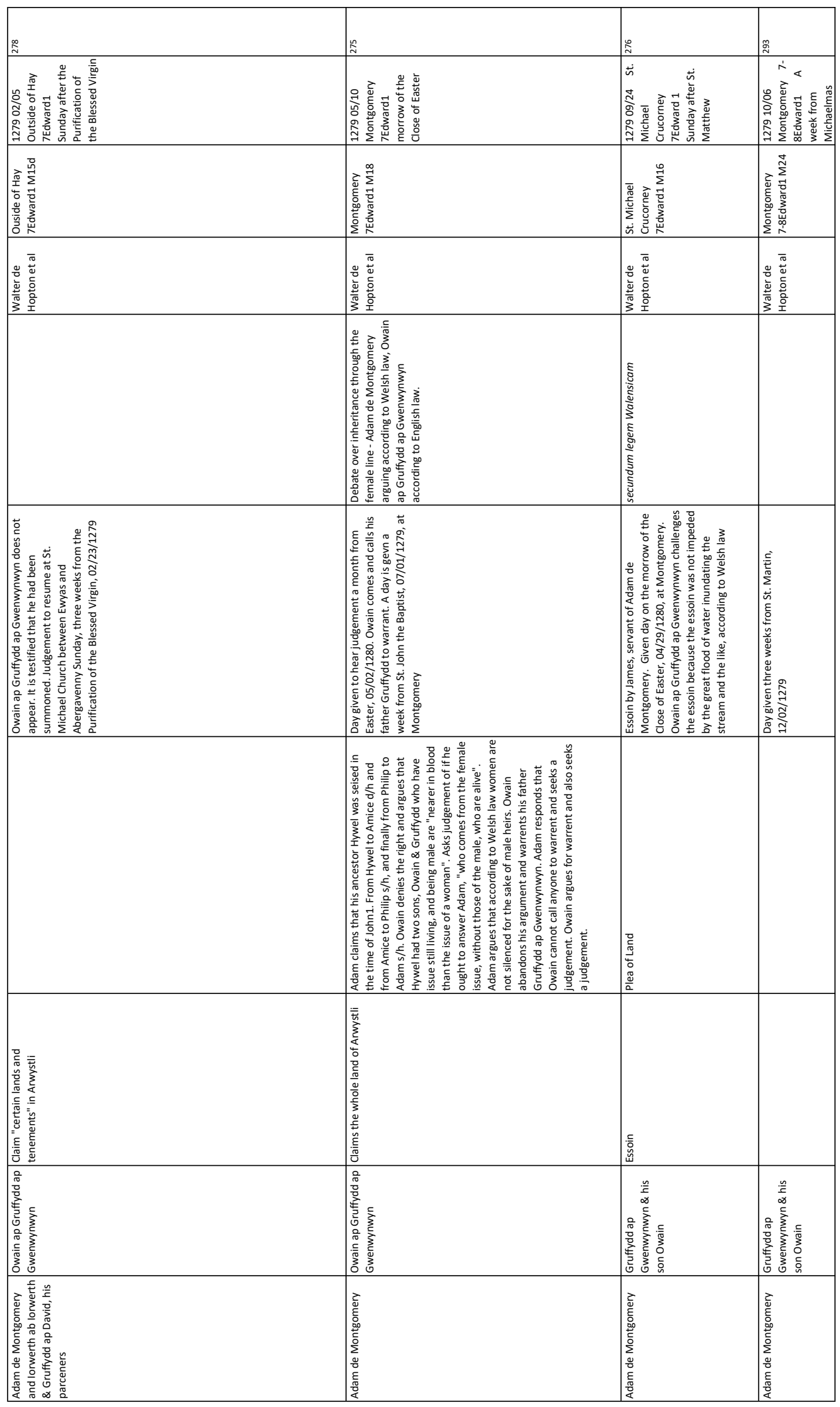




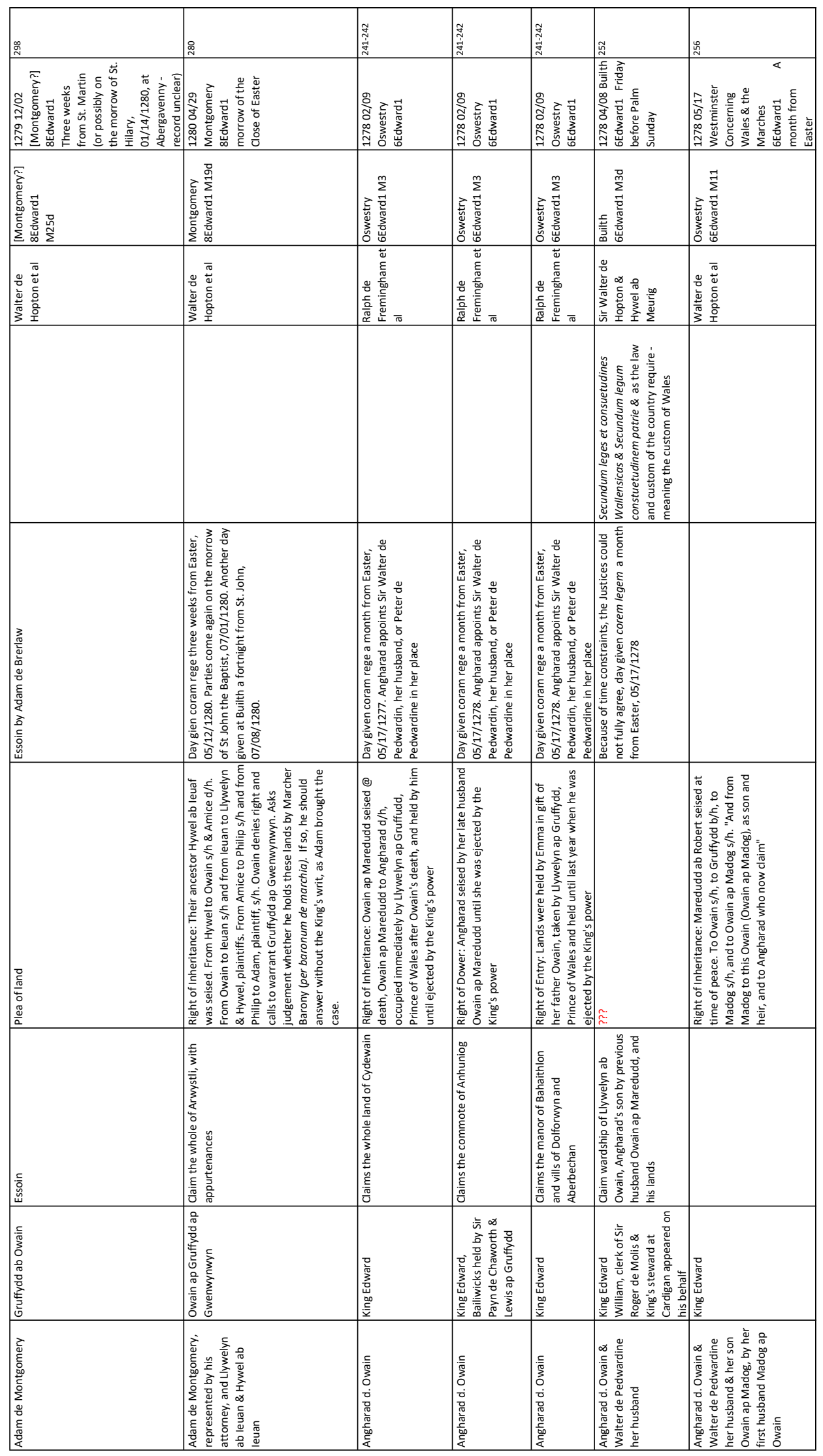




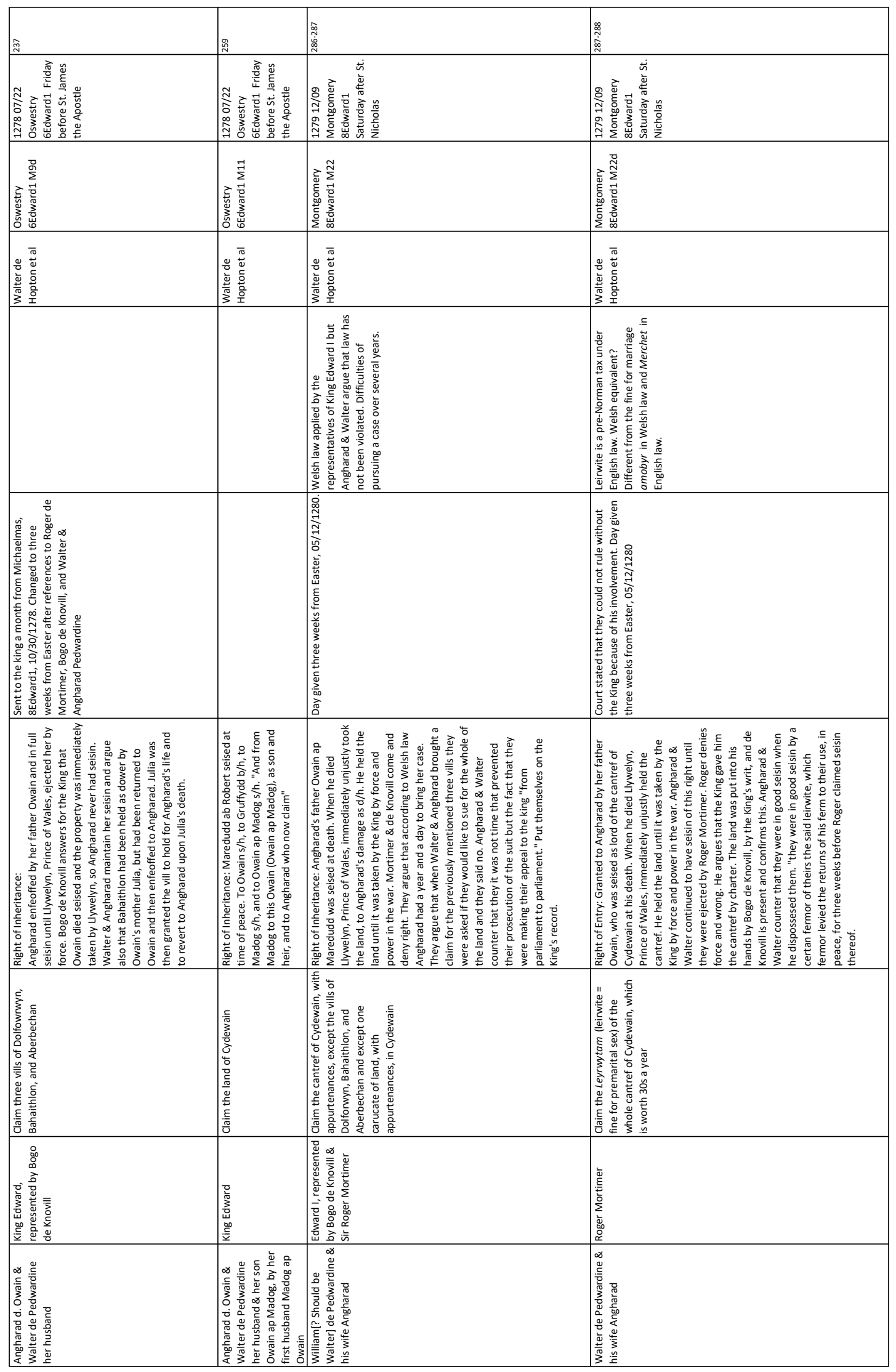




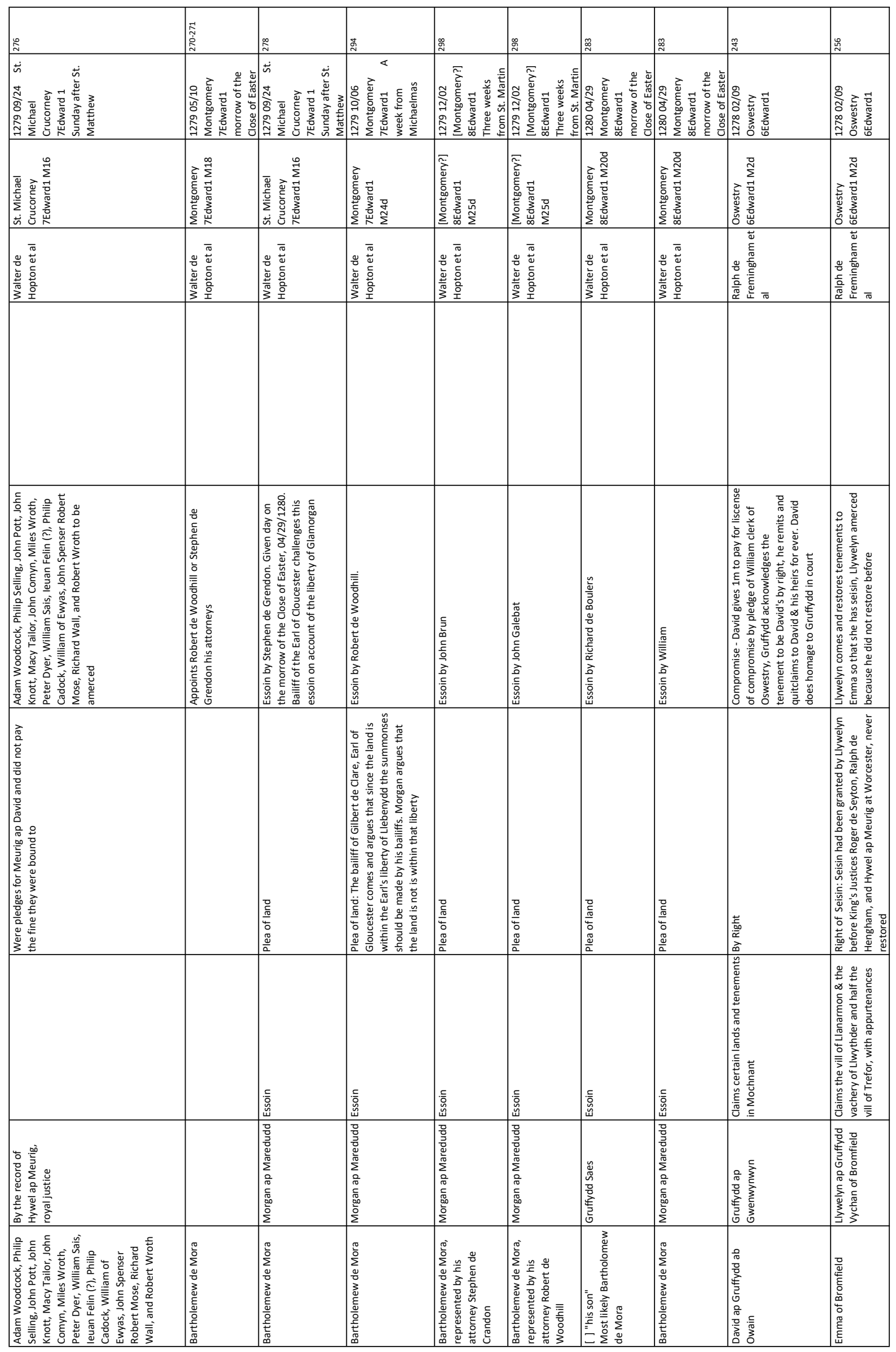




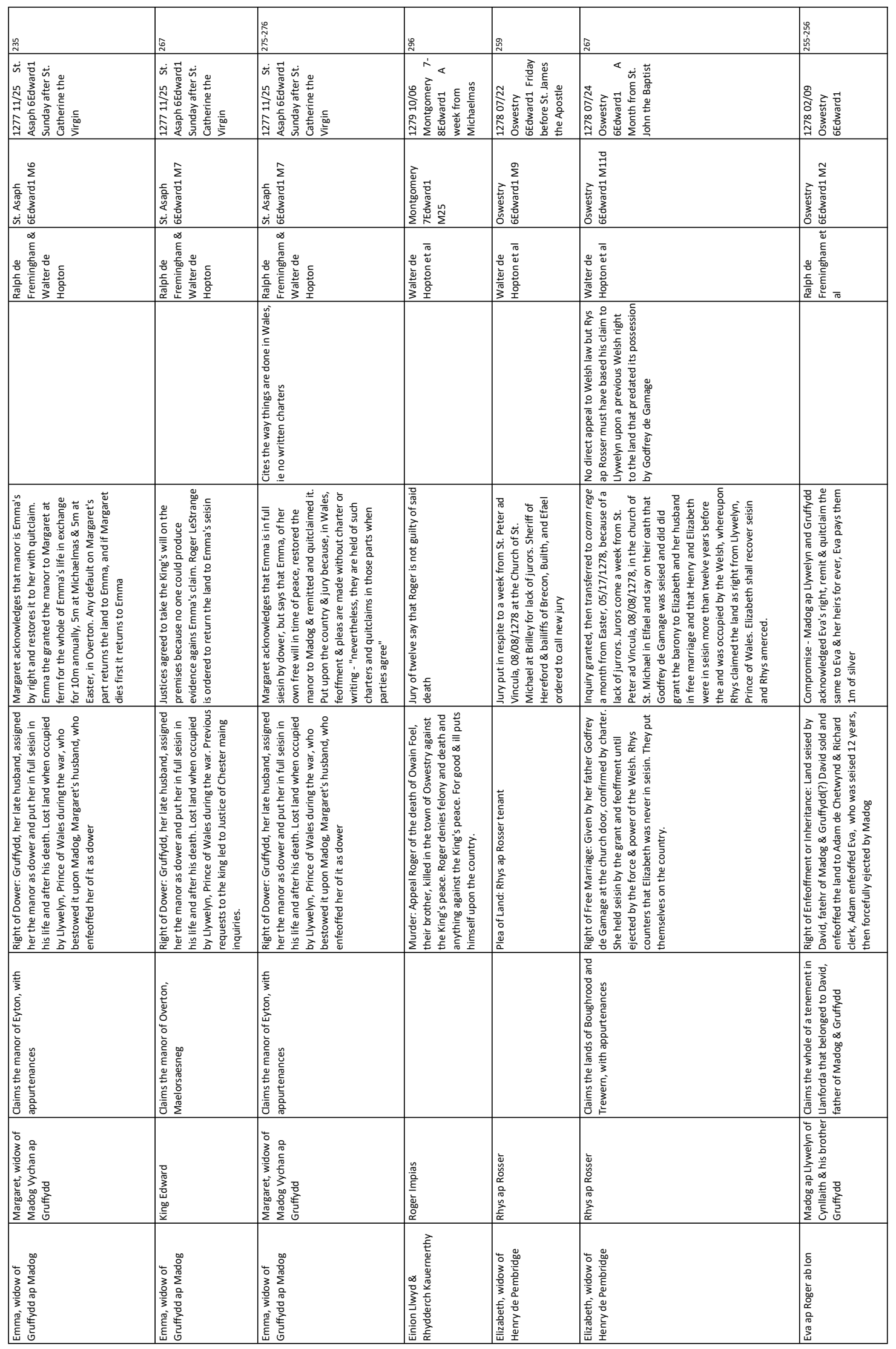




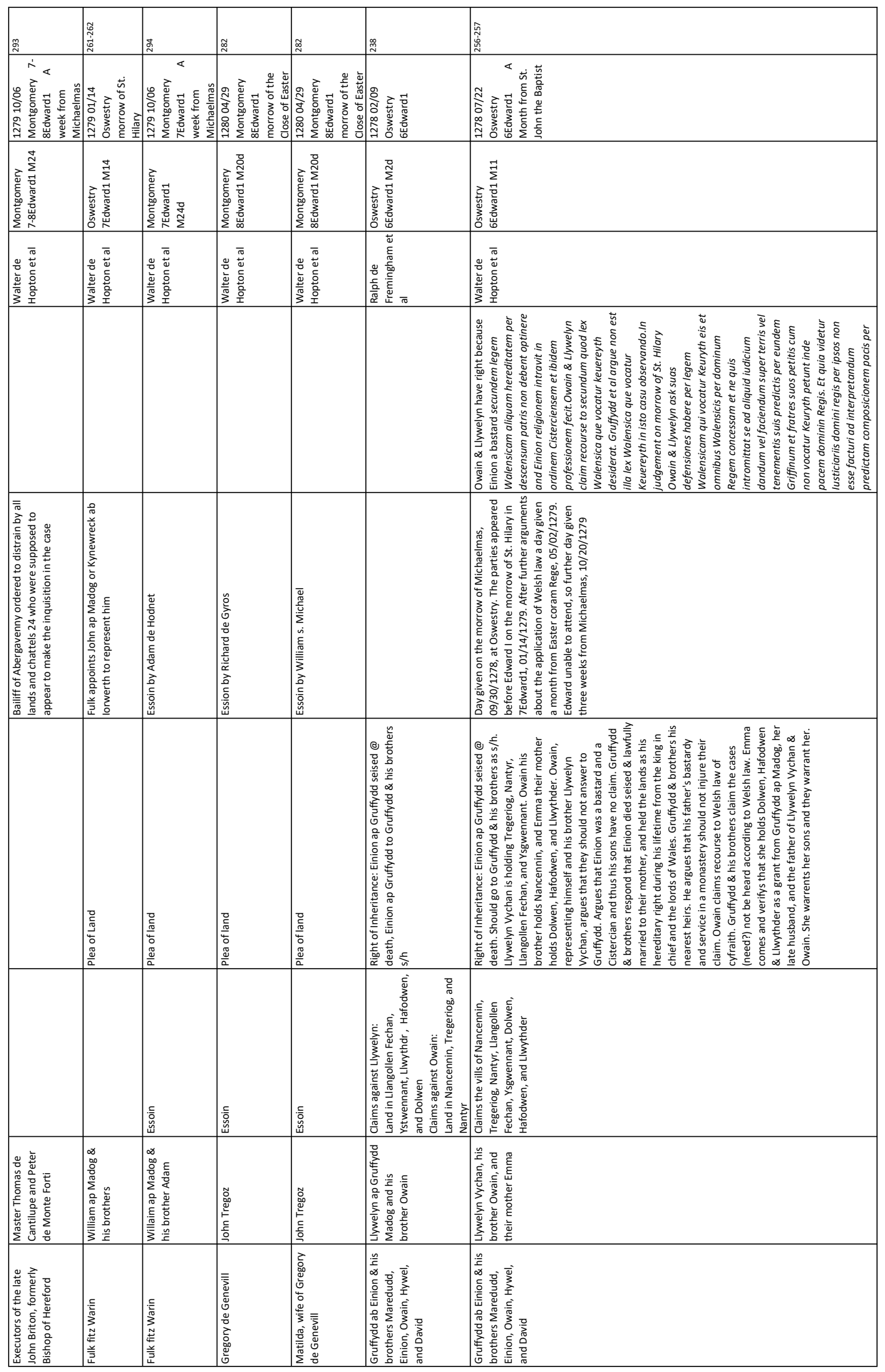




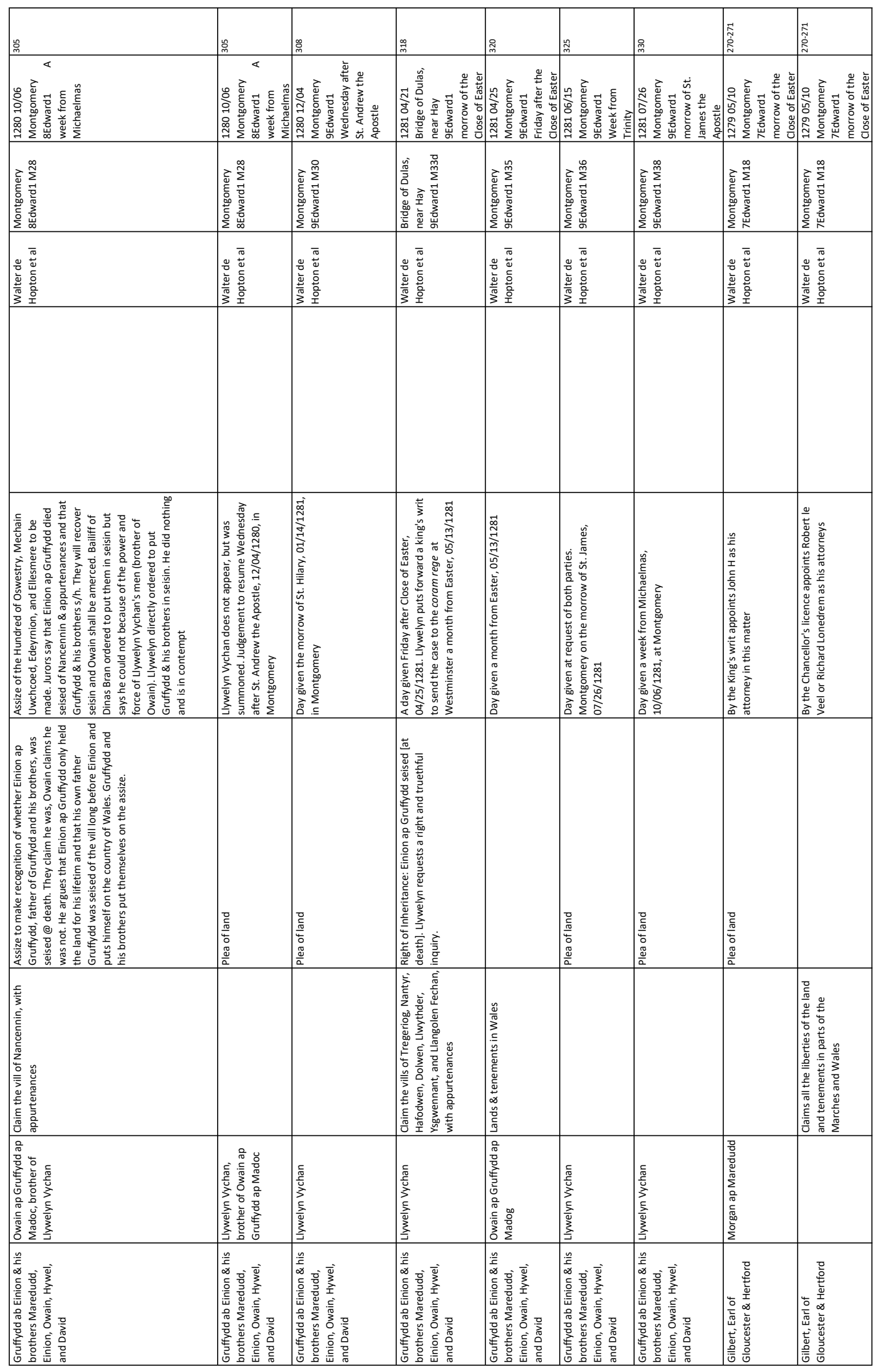




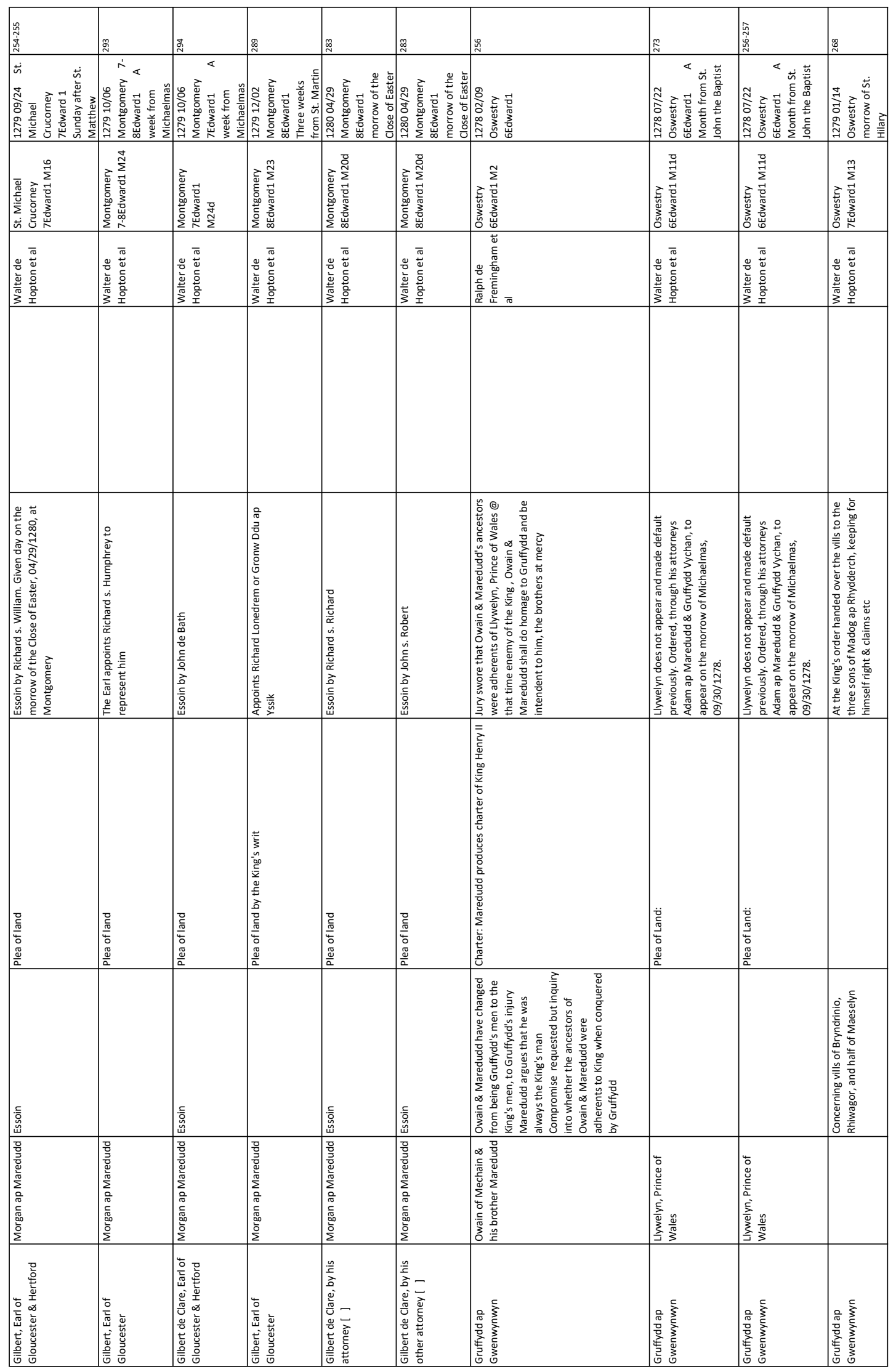




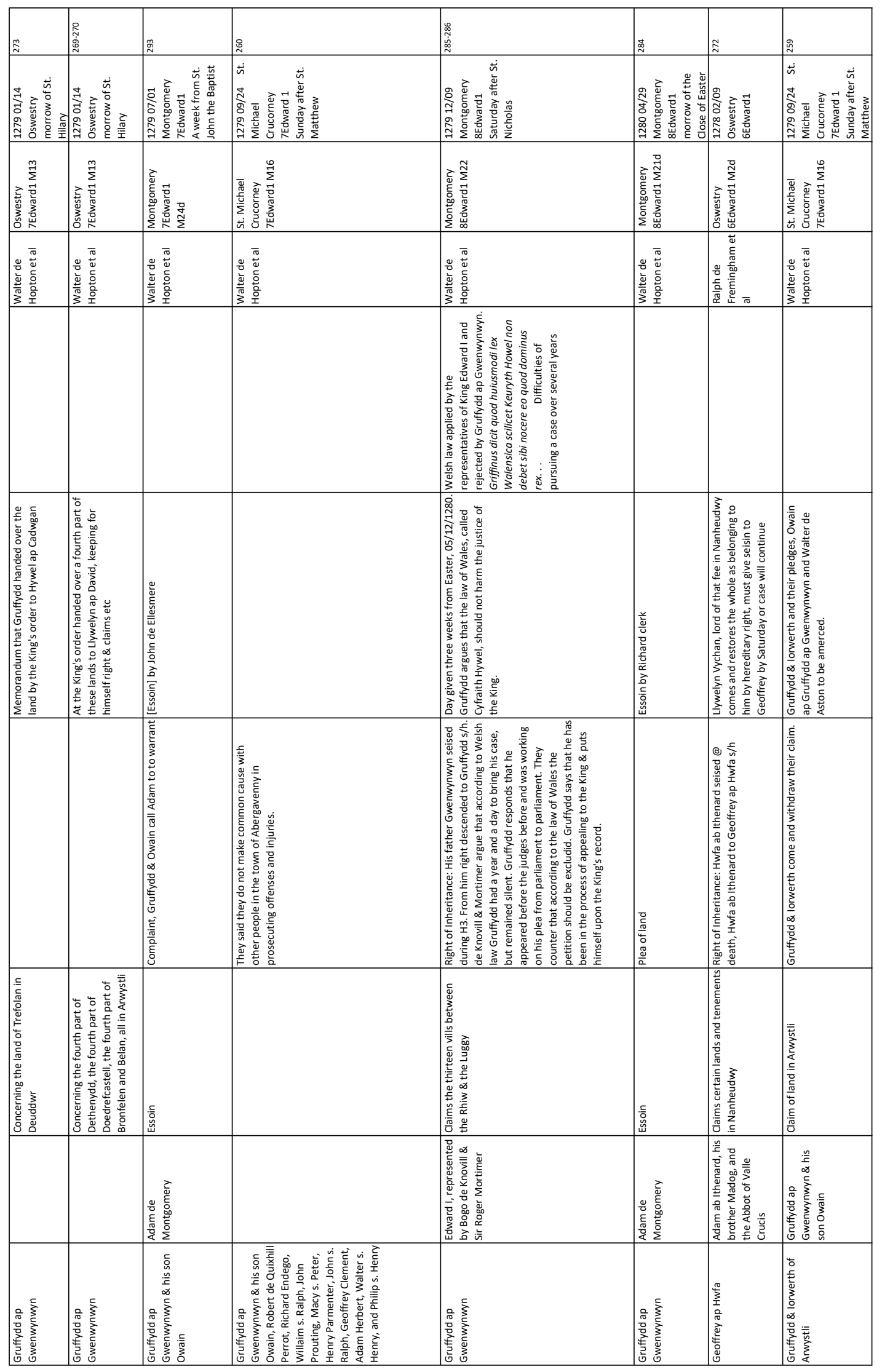




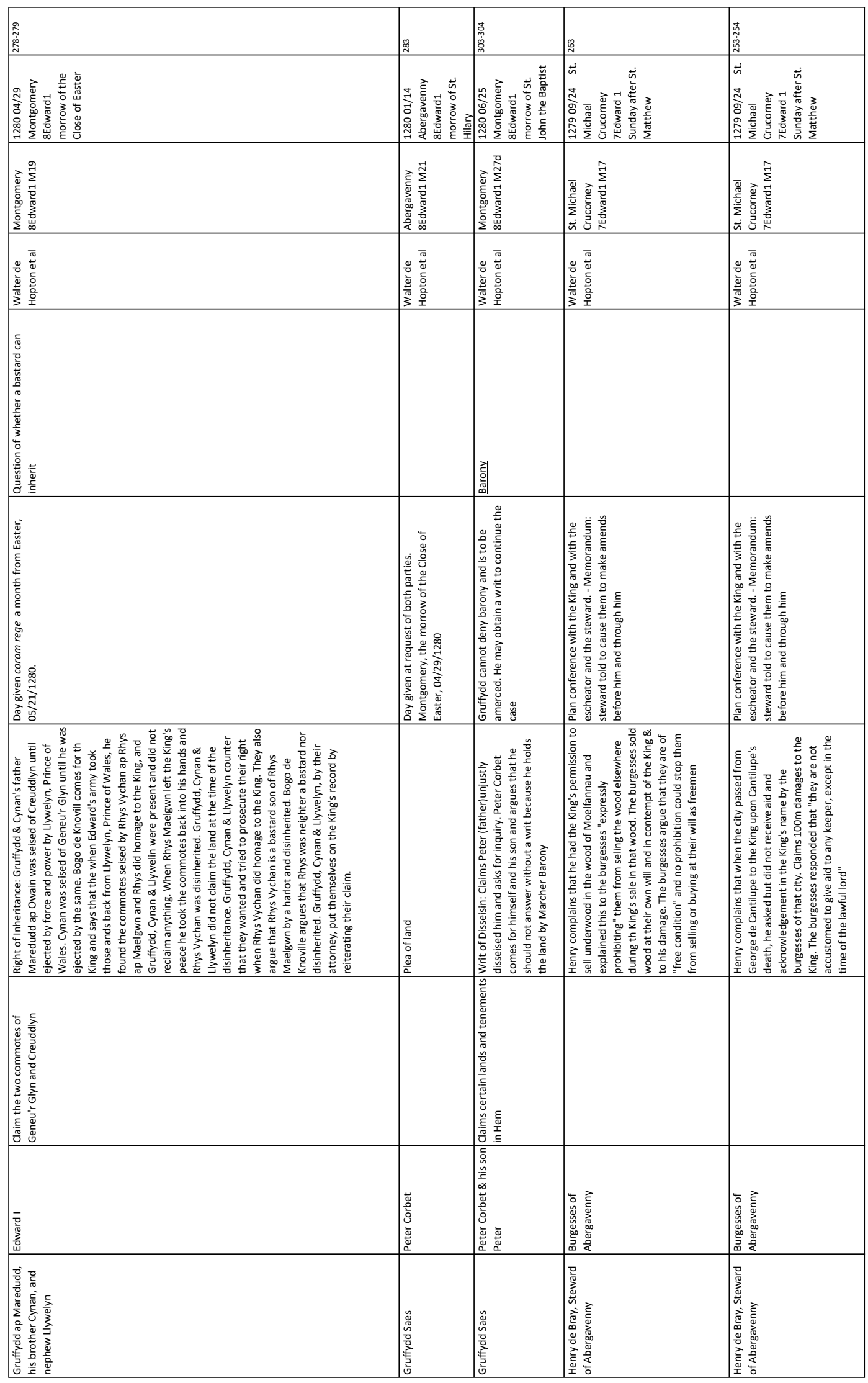




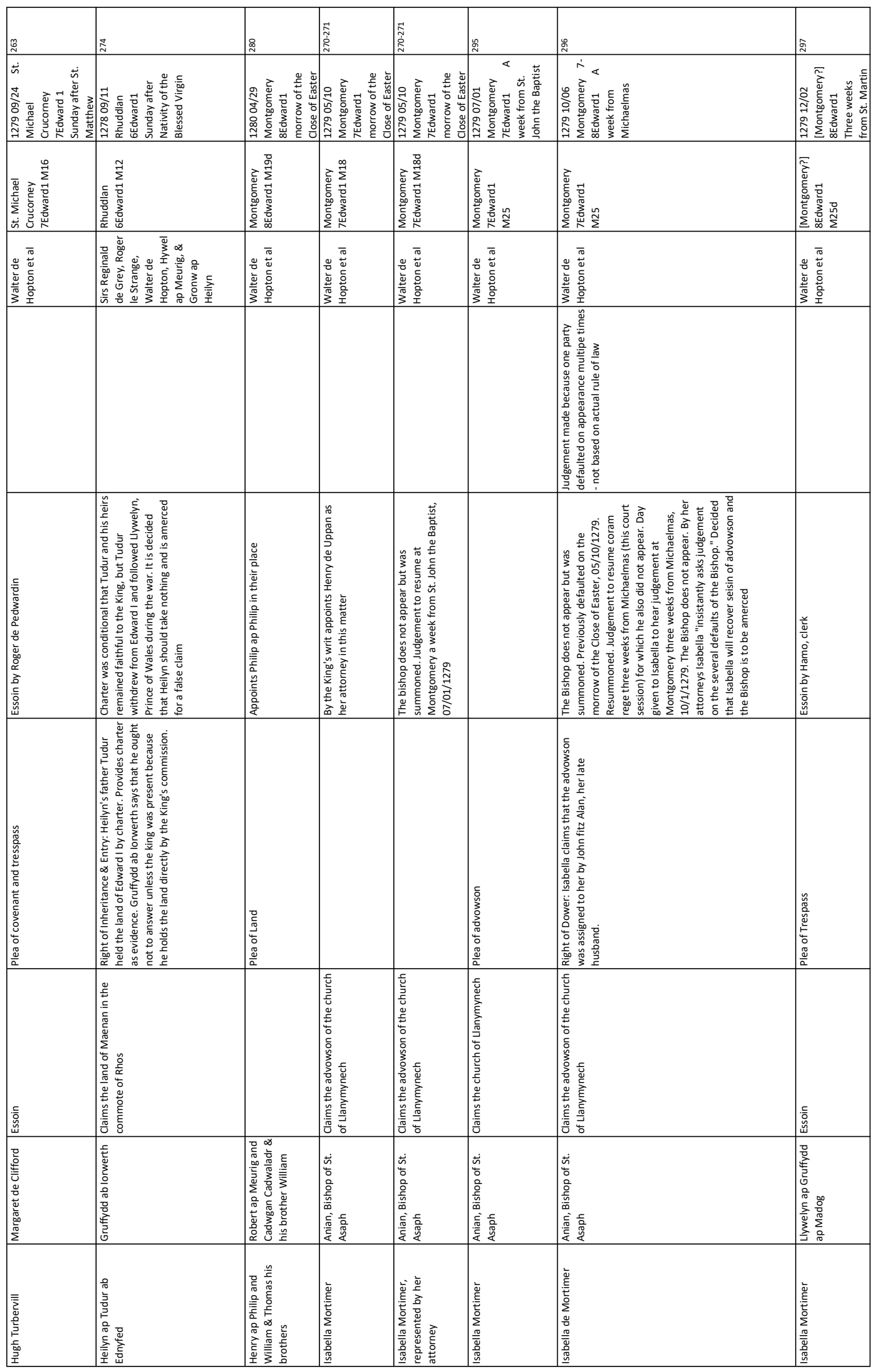




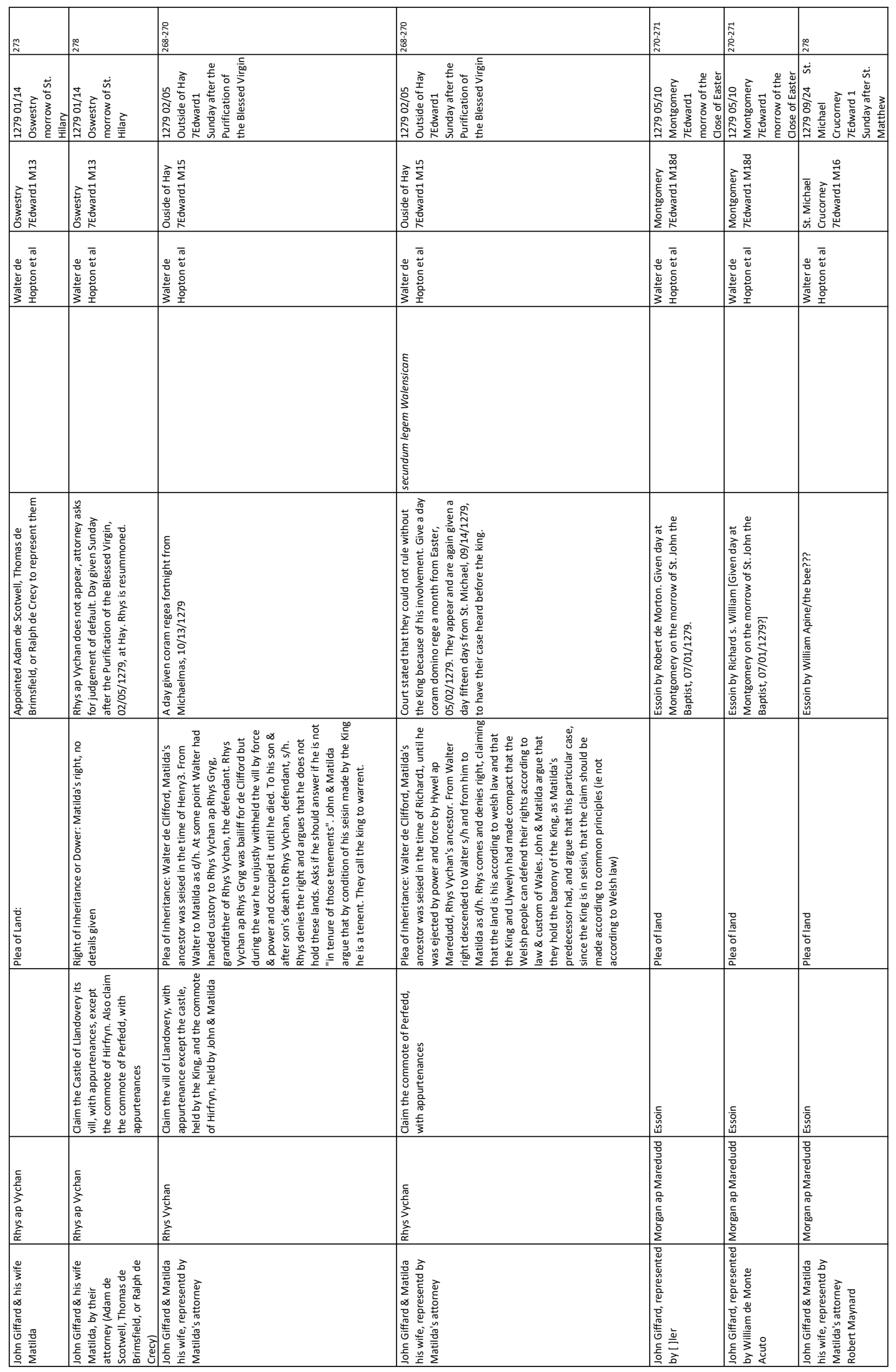




\begin{tabular}{|c|c|c|c|c|c|}
\hline 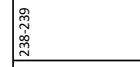 & 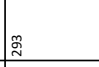 & ळ & ळ & 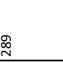 & 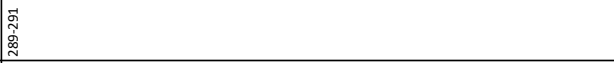 \\
\hline 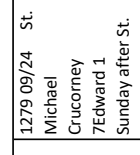 & 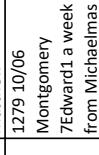 & 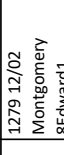 & & & 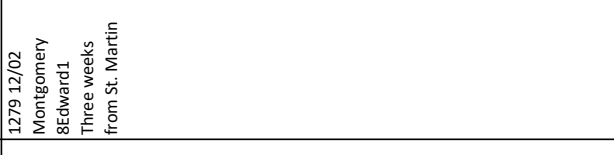 \\
\hline 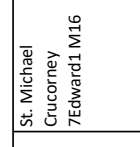 & 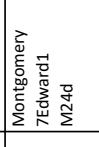 & 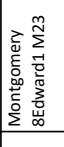 & 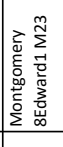 & & 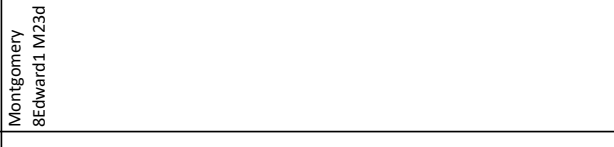 \\
\hline 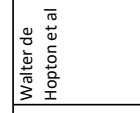 & 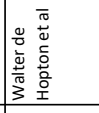 & 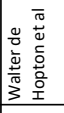 & 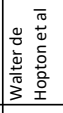 & 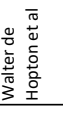 & 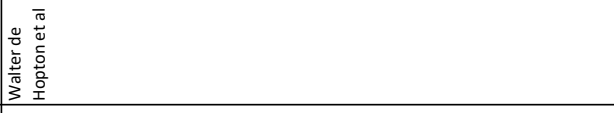 \\
\hline & 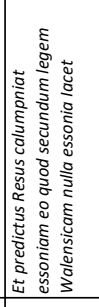 & & & & 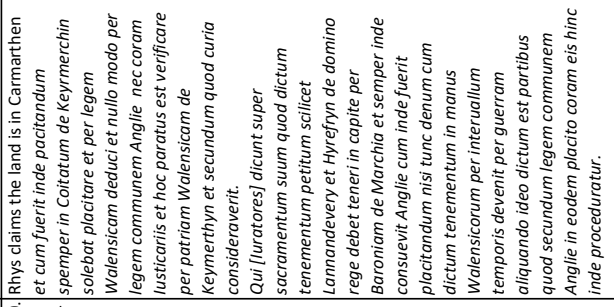 \\
\hline 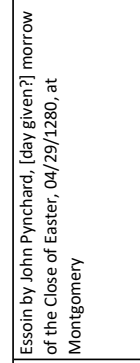 & 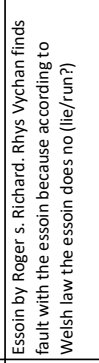 & 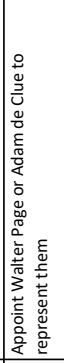 & 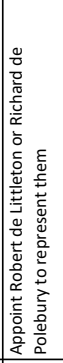 & 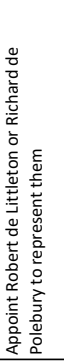 & 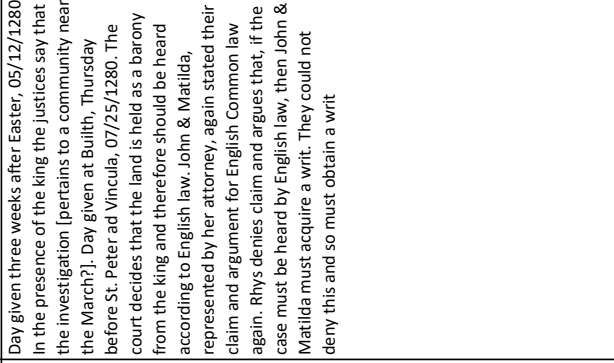 \\
\hline 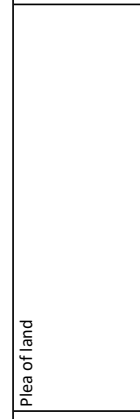 & 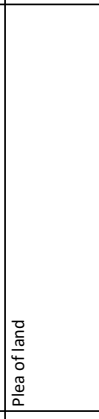 & 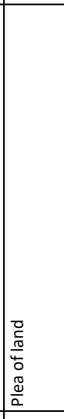 & 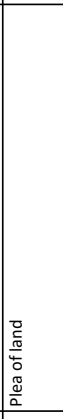 & 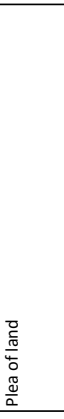 & 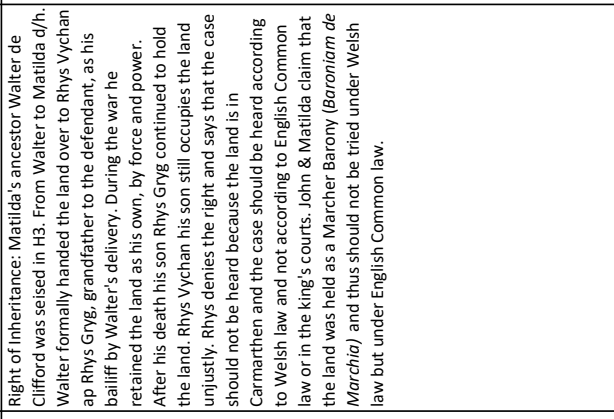 \\
\hline 总 & 涪 & & & & 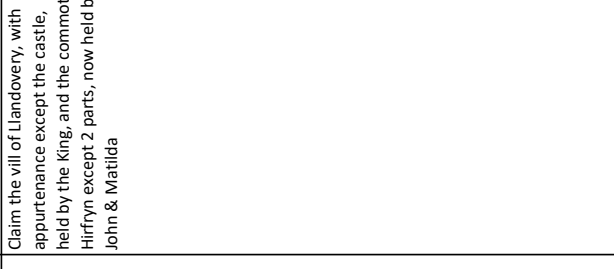 \\
\hline 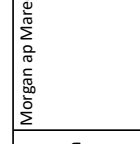 & 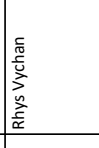 & 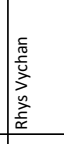 & 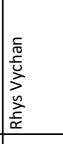 & 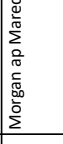 & \\
\hline 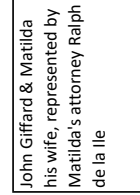 & 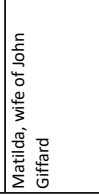 & 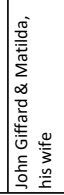 & 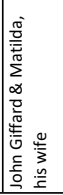 & 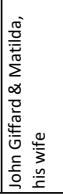 & 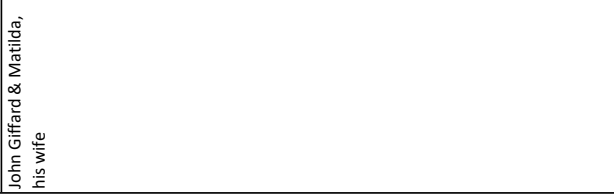 \\
\hline
\end{tabular}




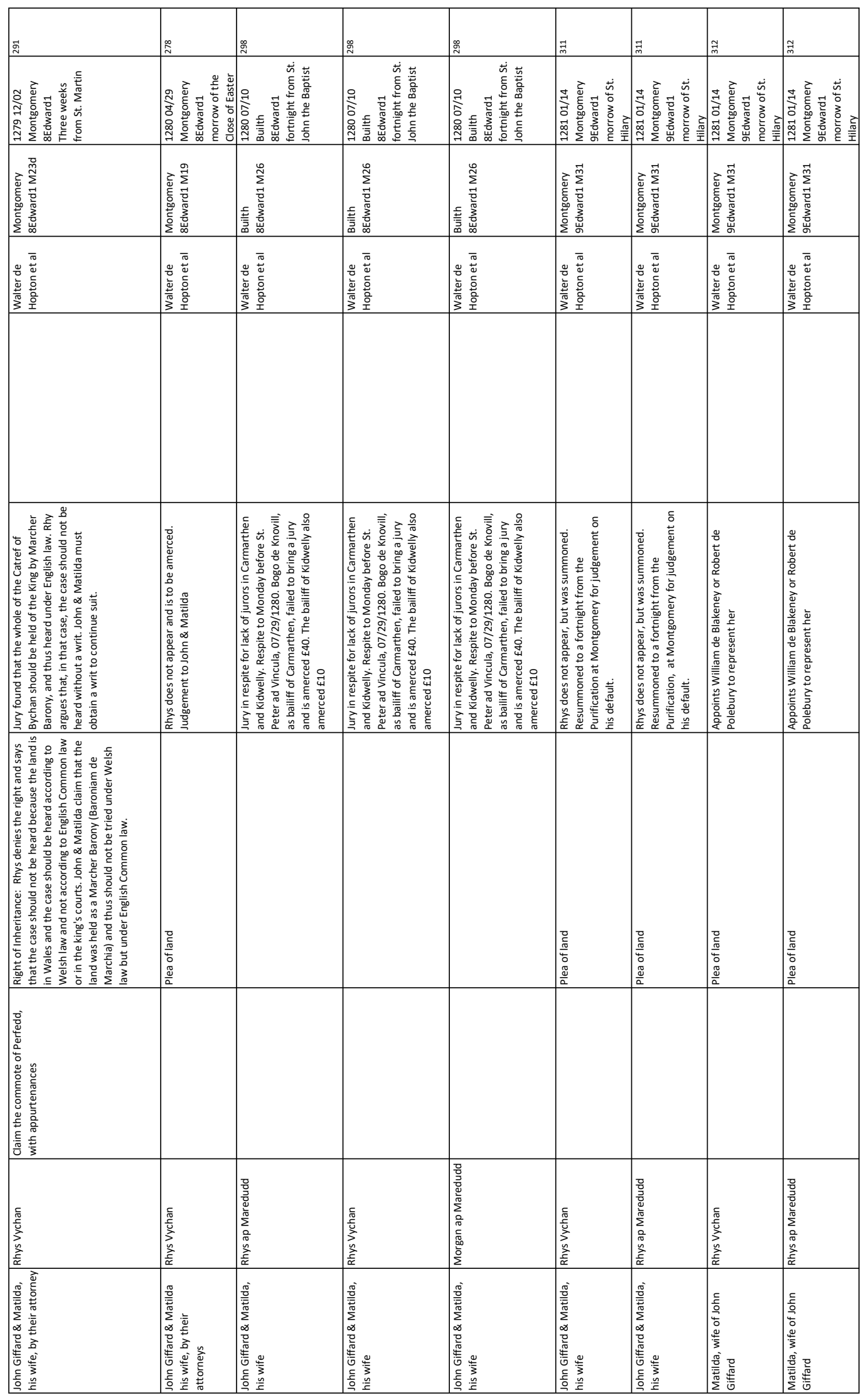




\begin{tabular}{|c|c|c|c|c|}
\hline 䛓 & $\begin{array}{l}\text { 惫 } \\
\text { 萹 }\end{array}$ & 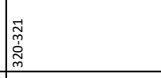 & $\overrightarrow{\tilde{m}}$ & \\
\hline 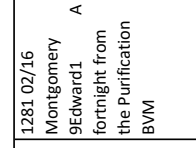 & 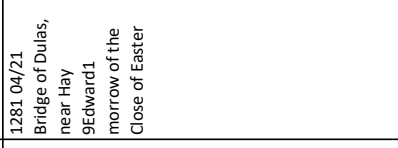 & 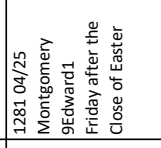 & 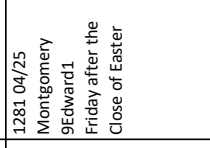 & 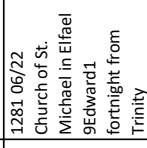 \\
\hline & 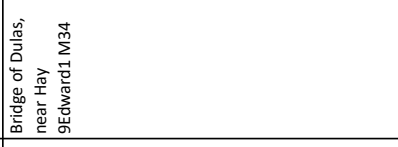 & 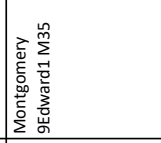 & 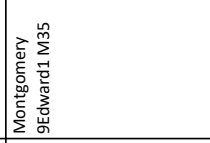 & 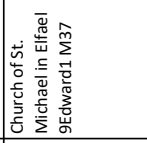 \\
\hline 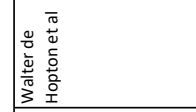 & 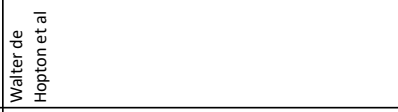 & 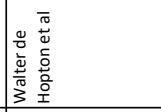 & 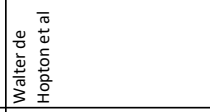 & 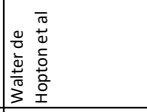 \\
\hline 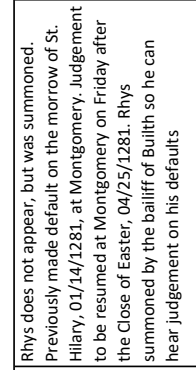 & 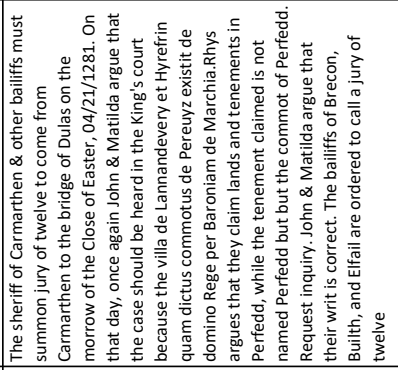 & 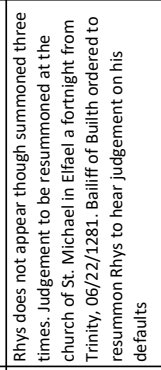 & 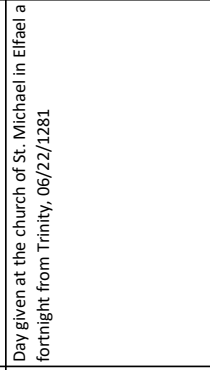 & 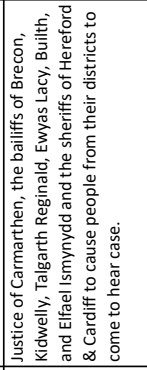 \\
\hline & 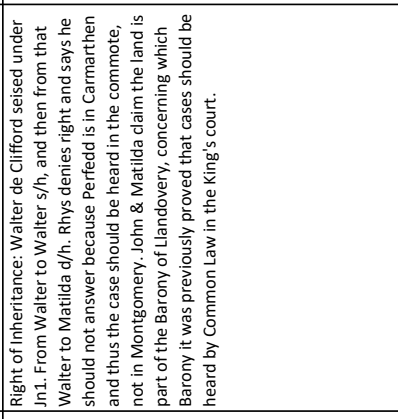 & & 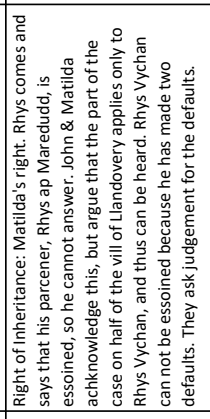 & 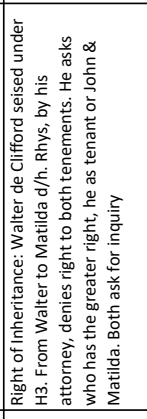 \\
\hline 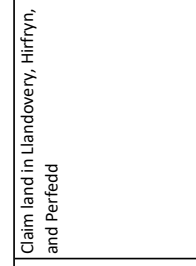 & 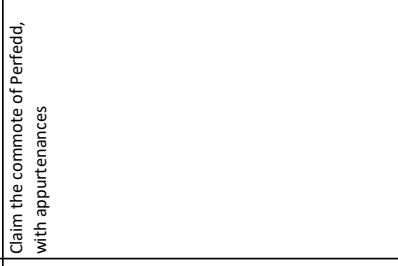 & & 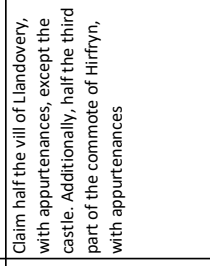 & 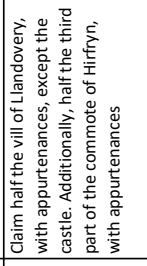 \\
\hline 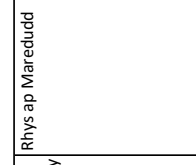 & 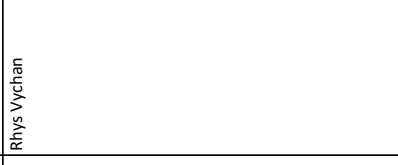 & 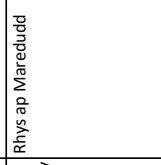 & 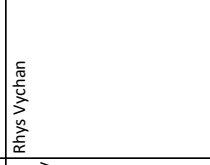 & 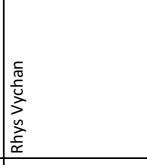 \\
\hline 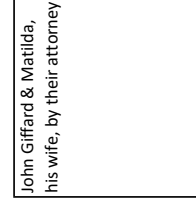 & & 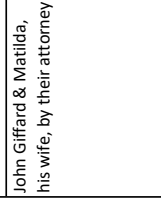 & 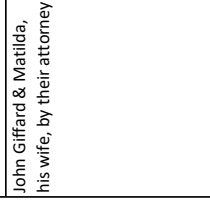 & 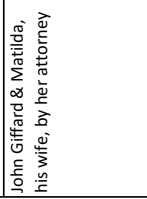 \\
\hline
\end{tabular}




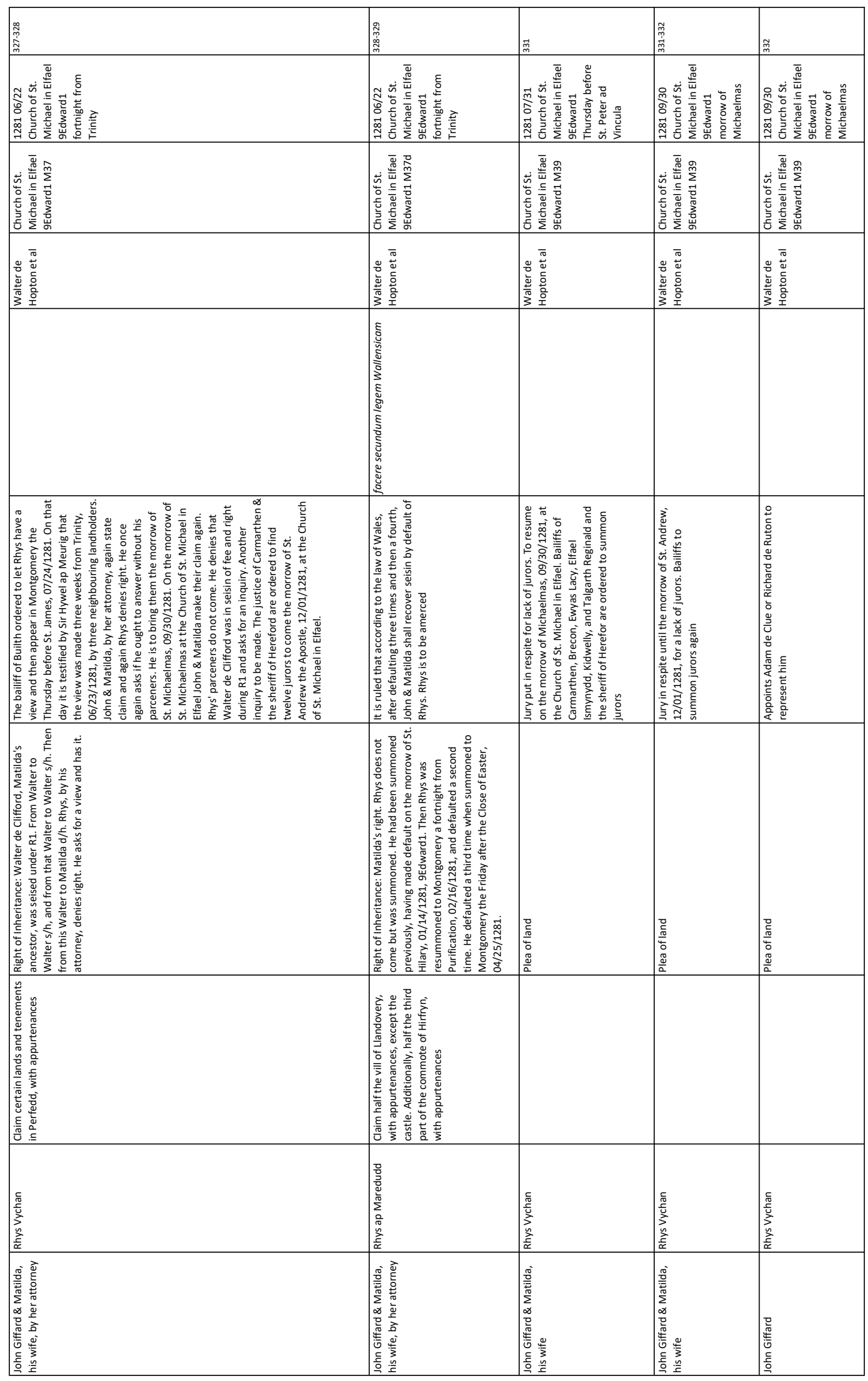




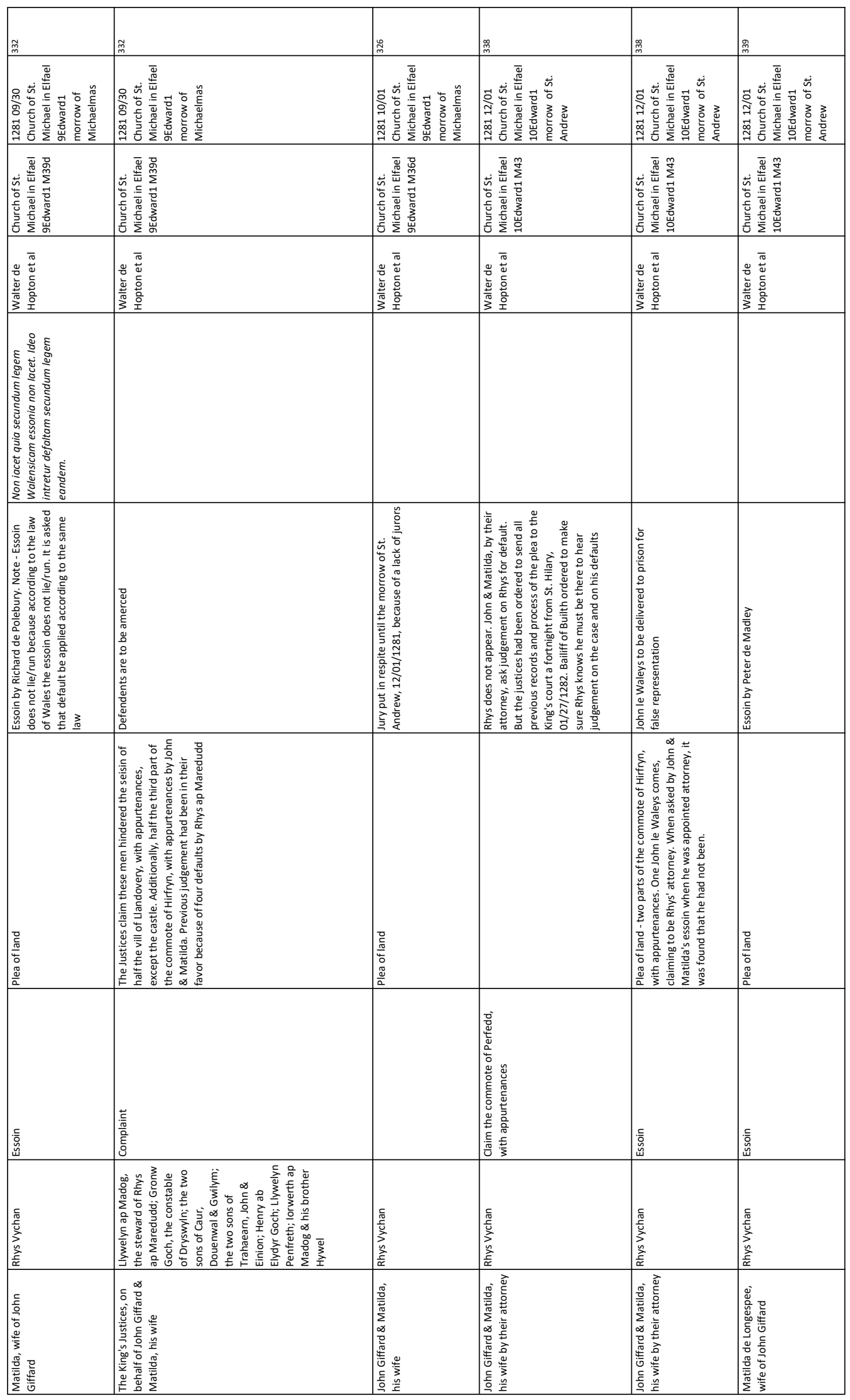




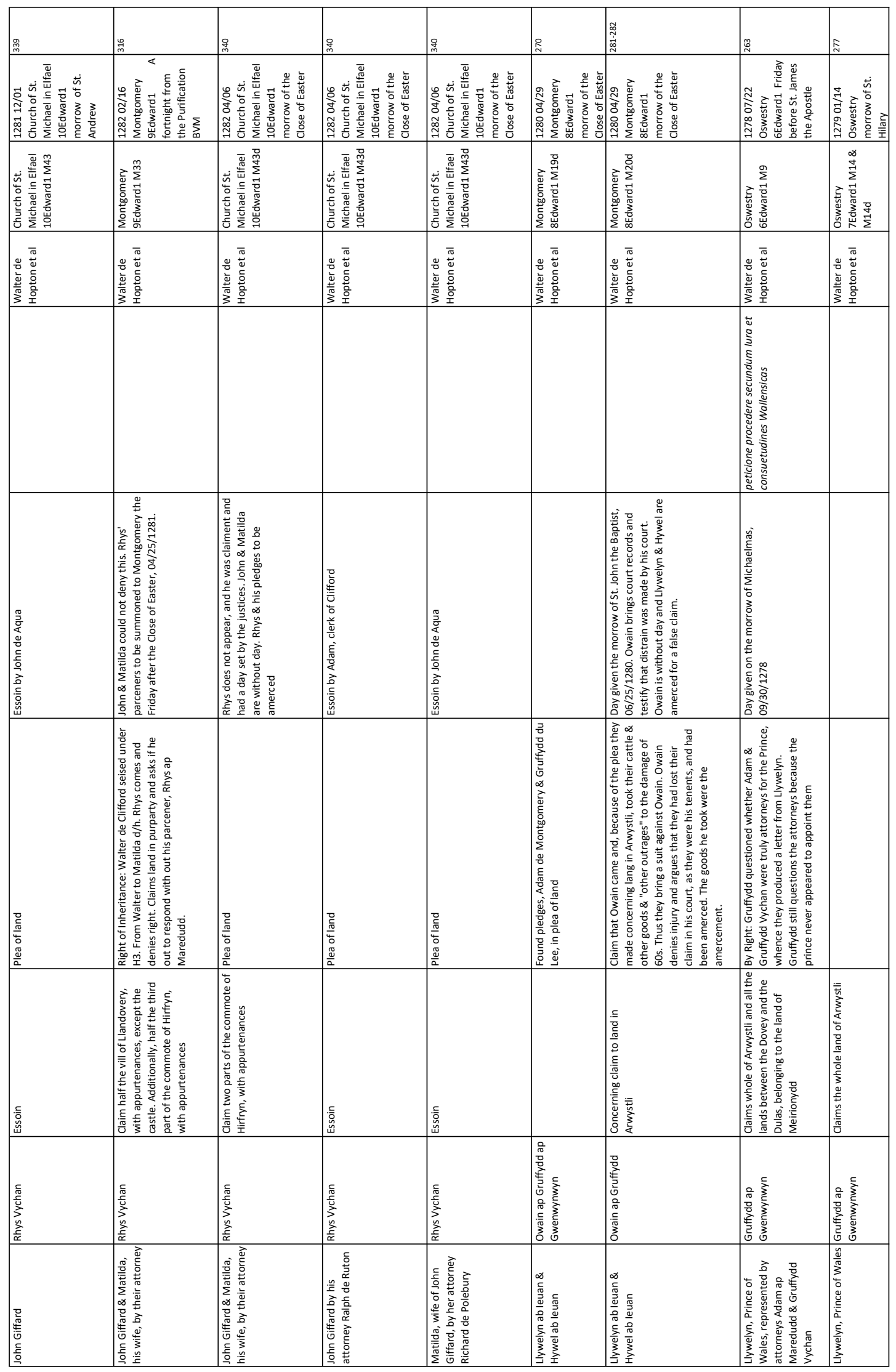




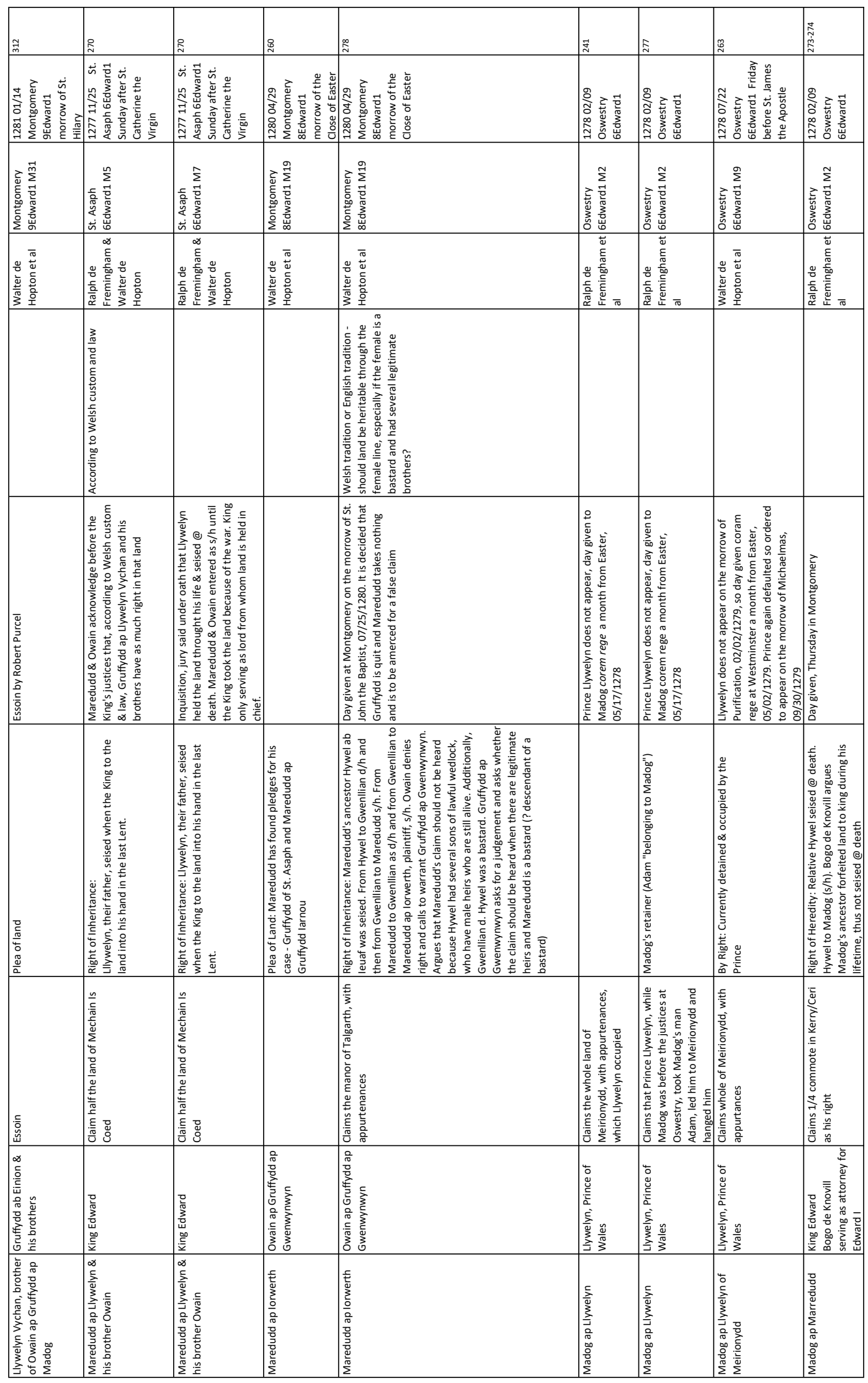




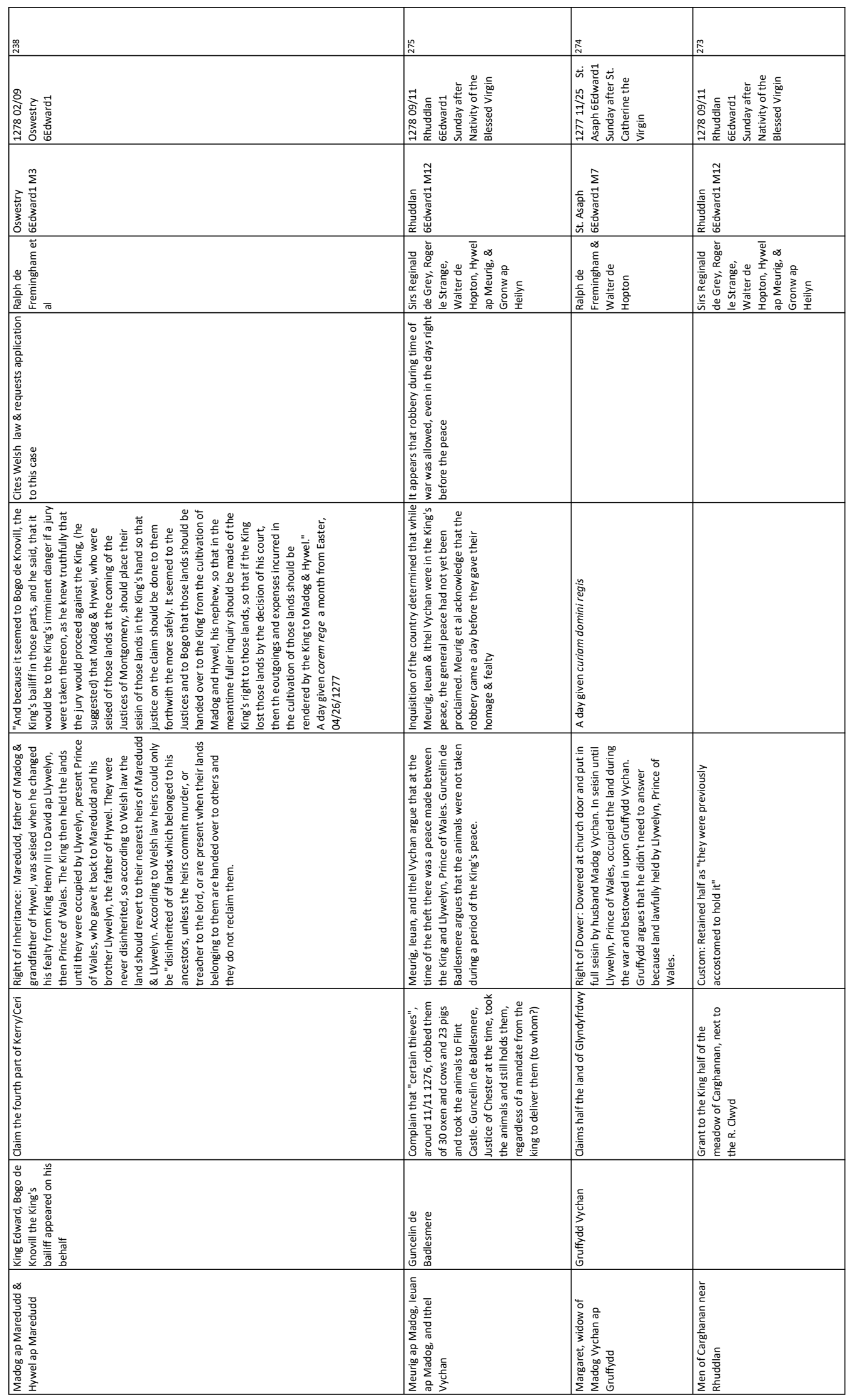




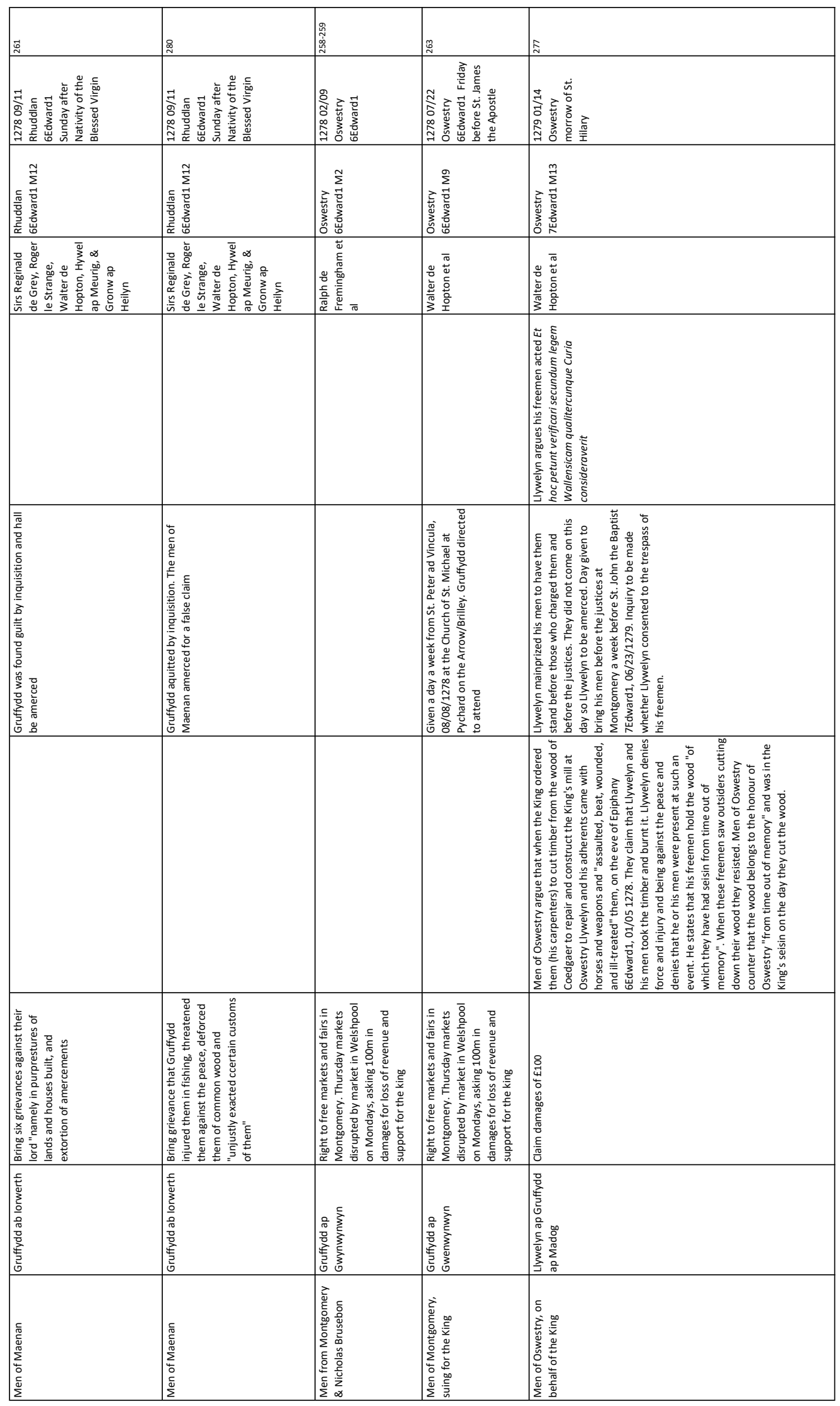




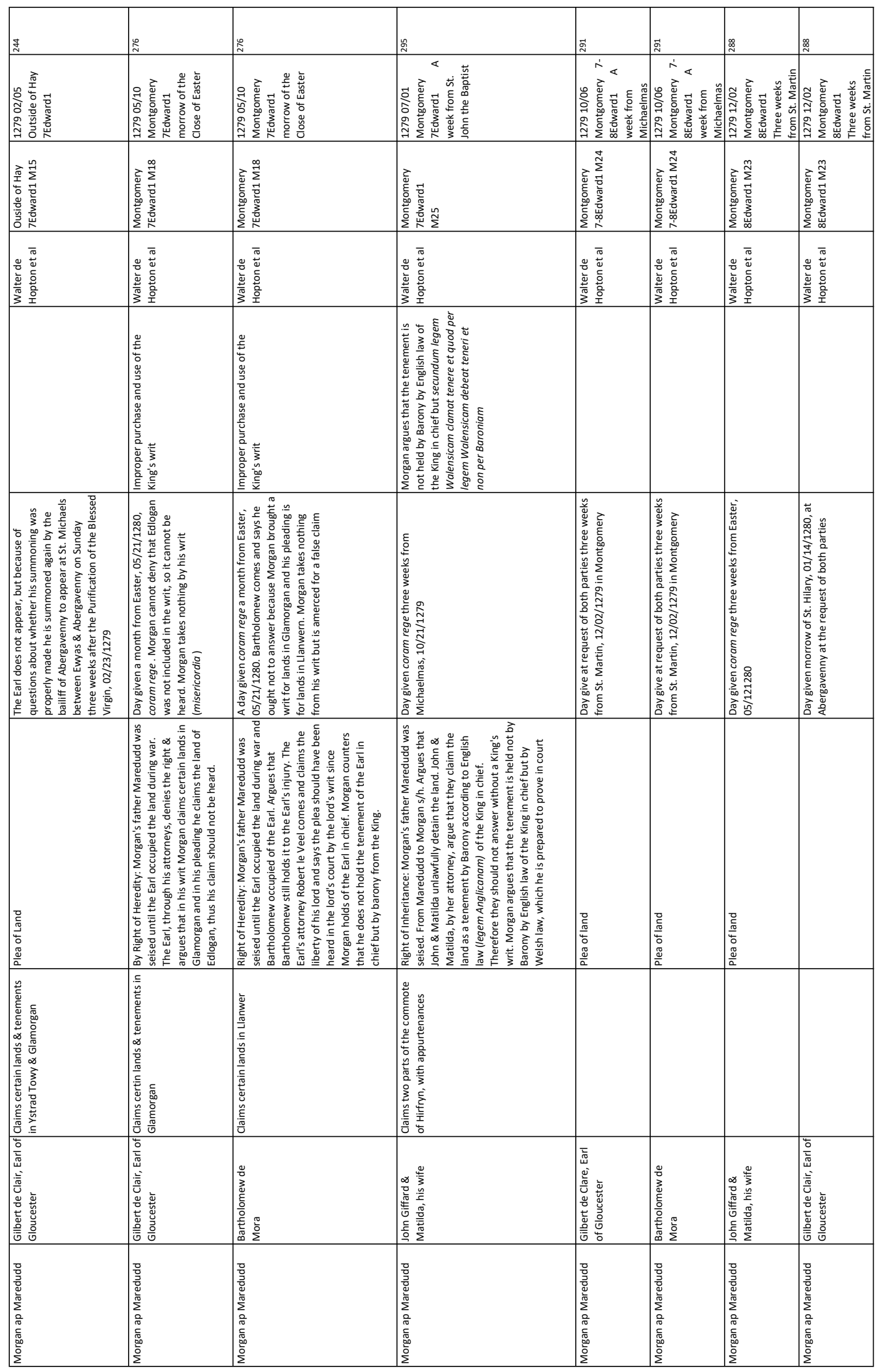




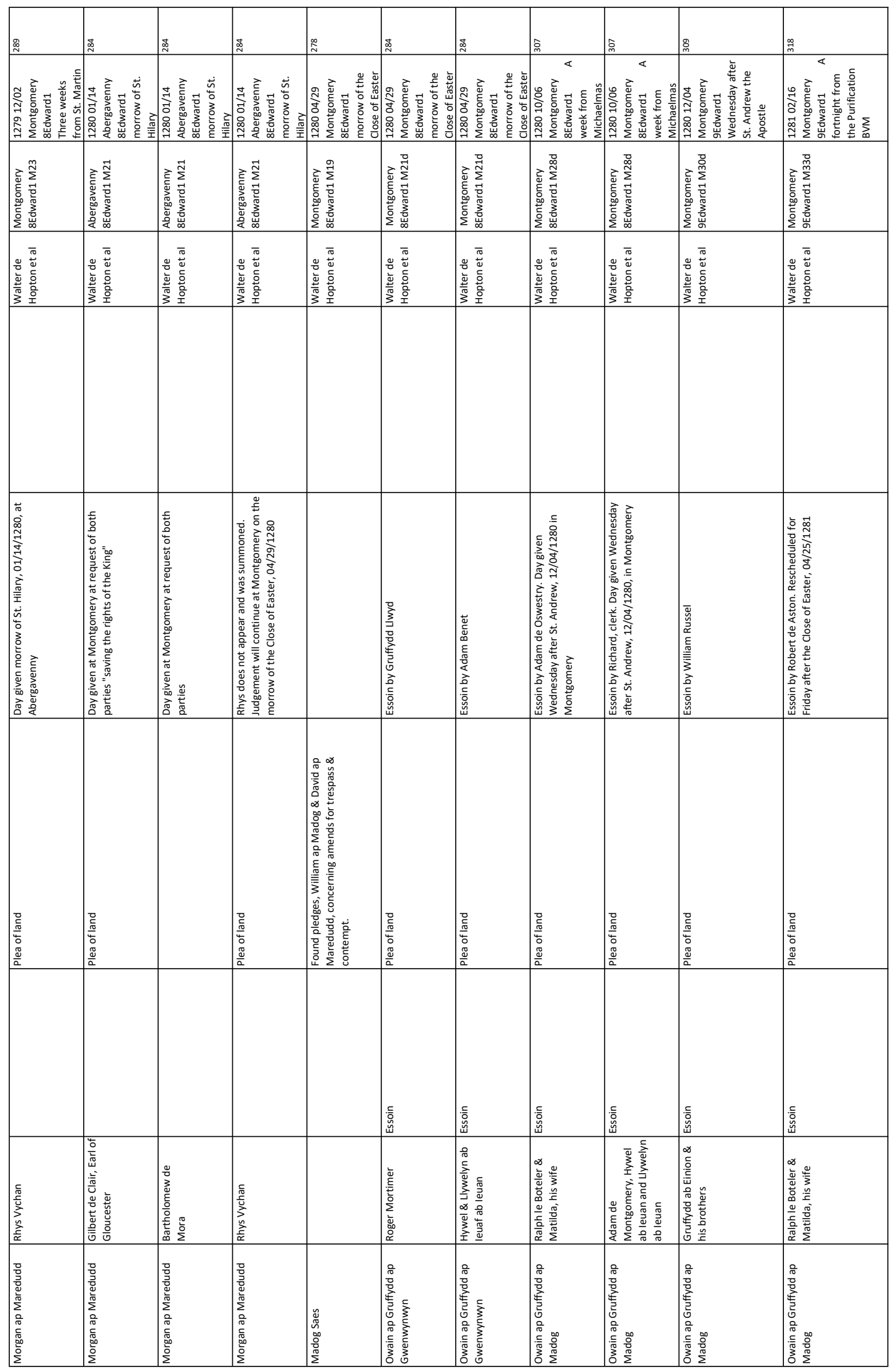




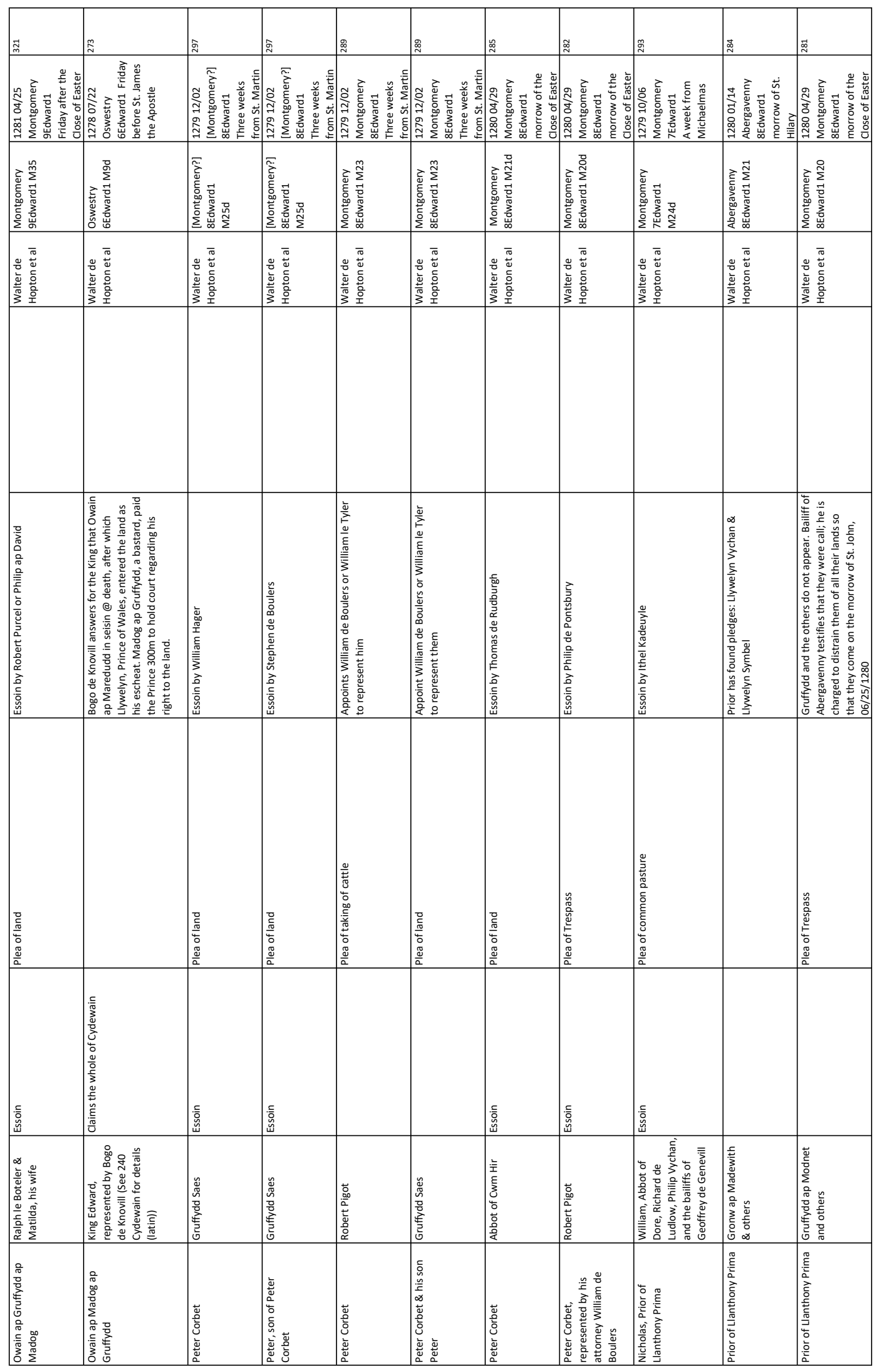




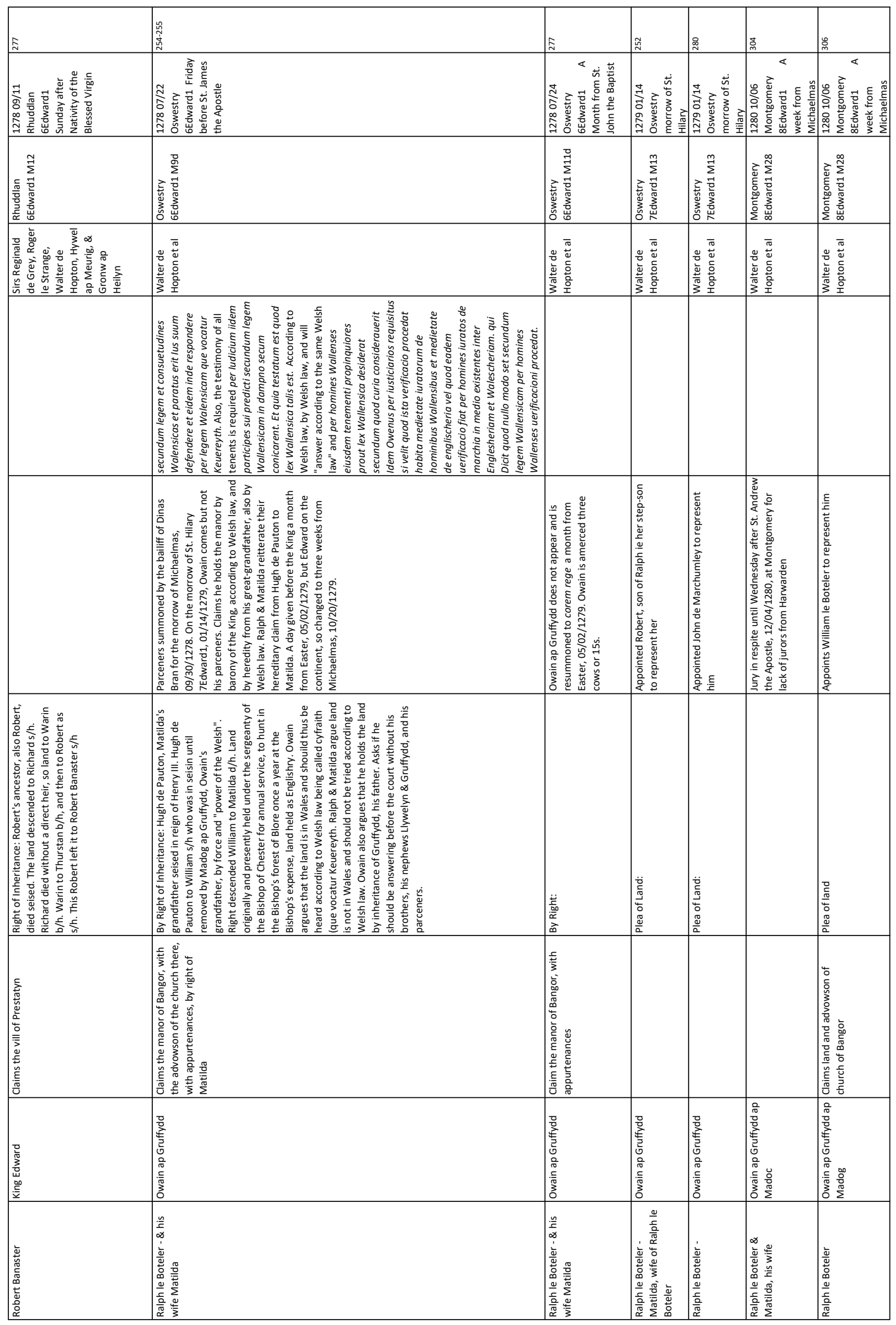




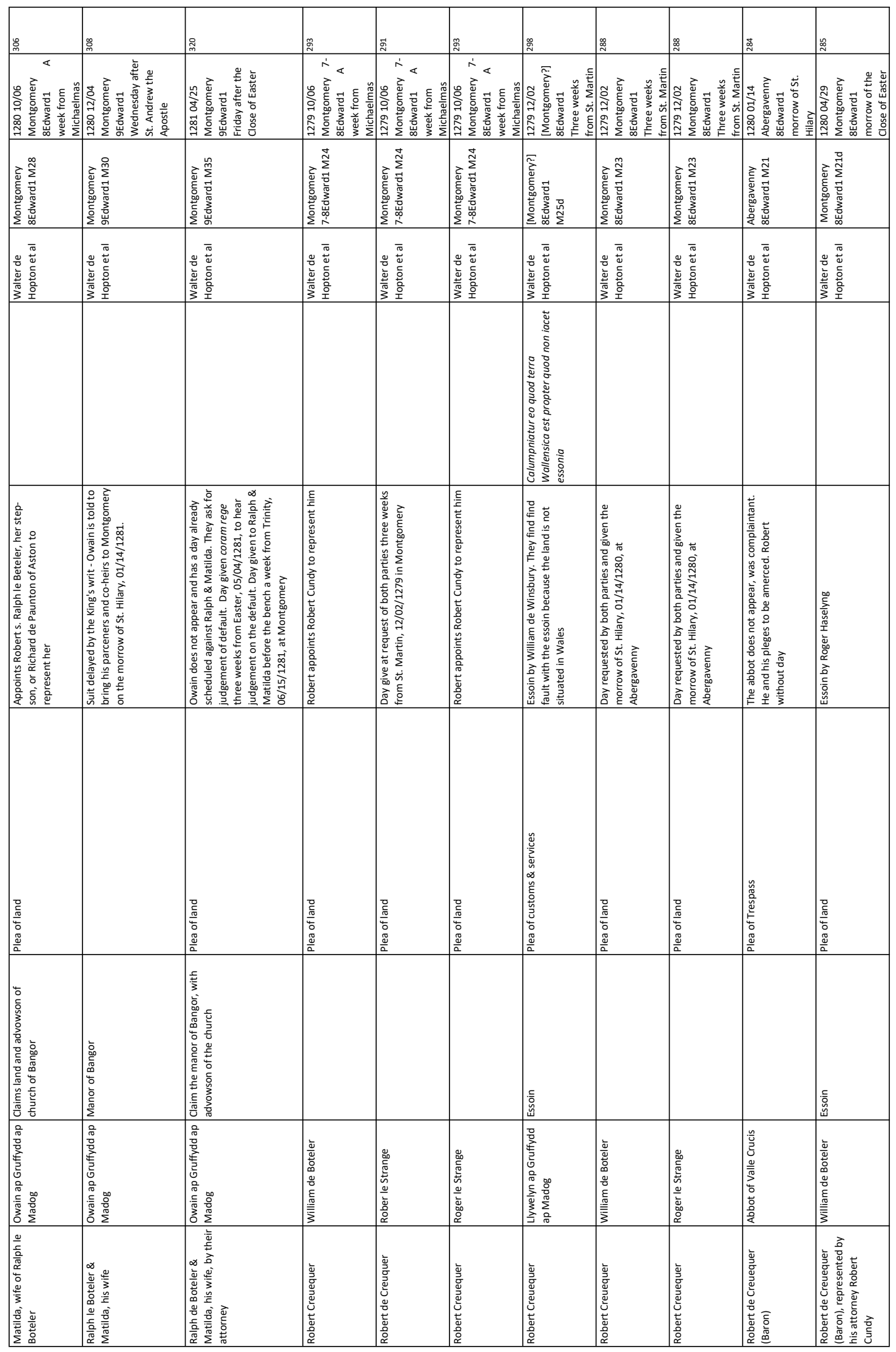




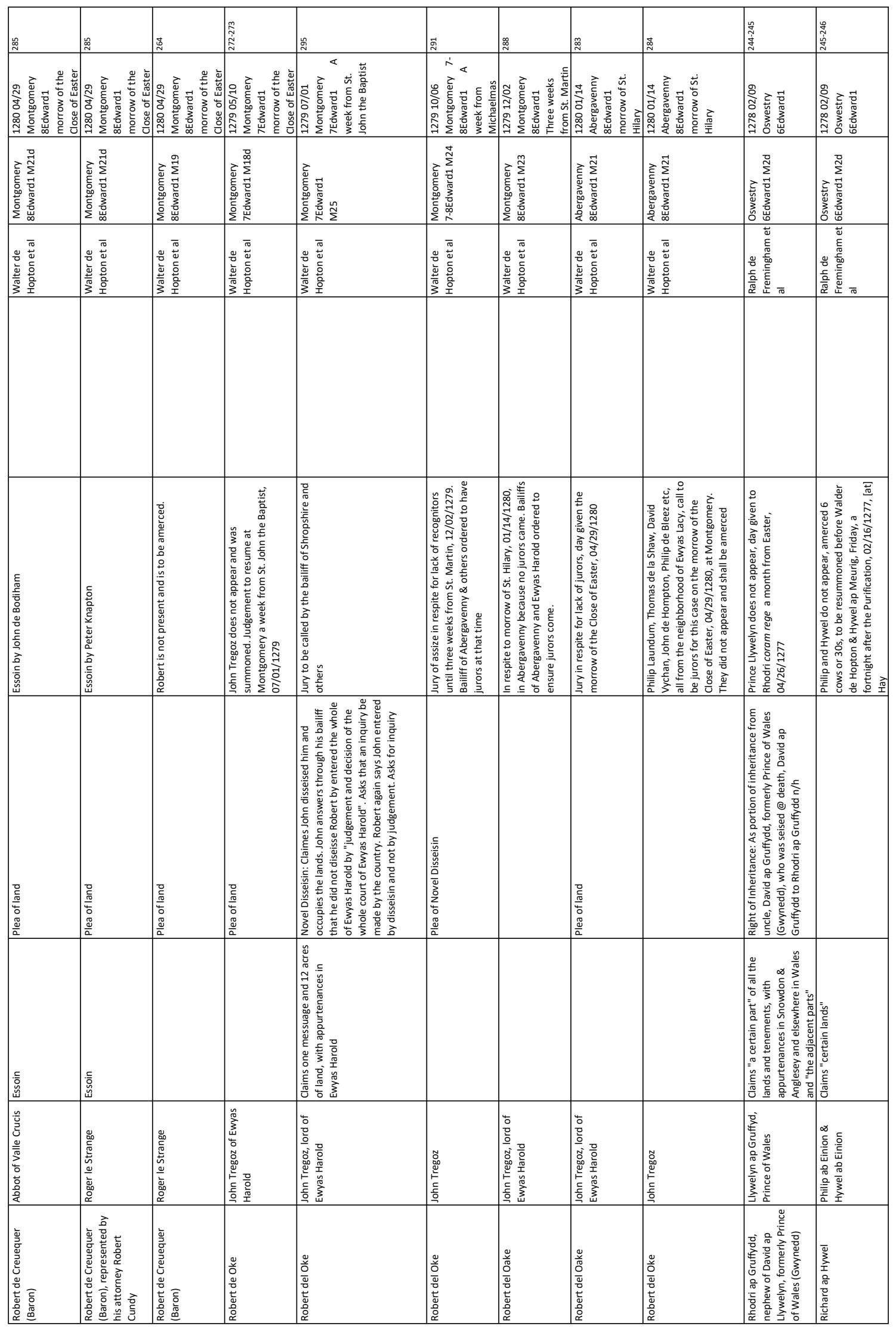




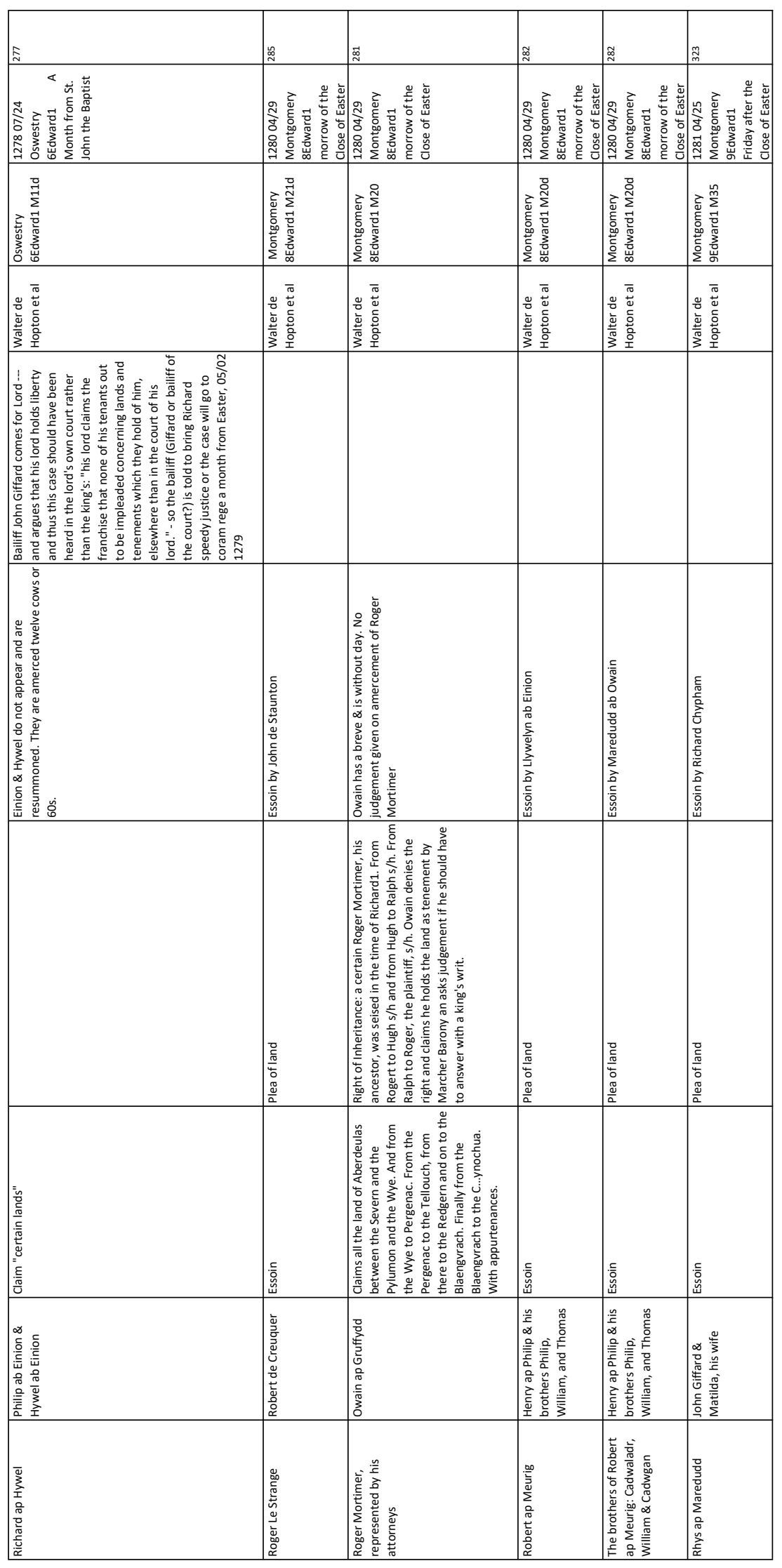




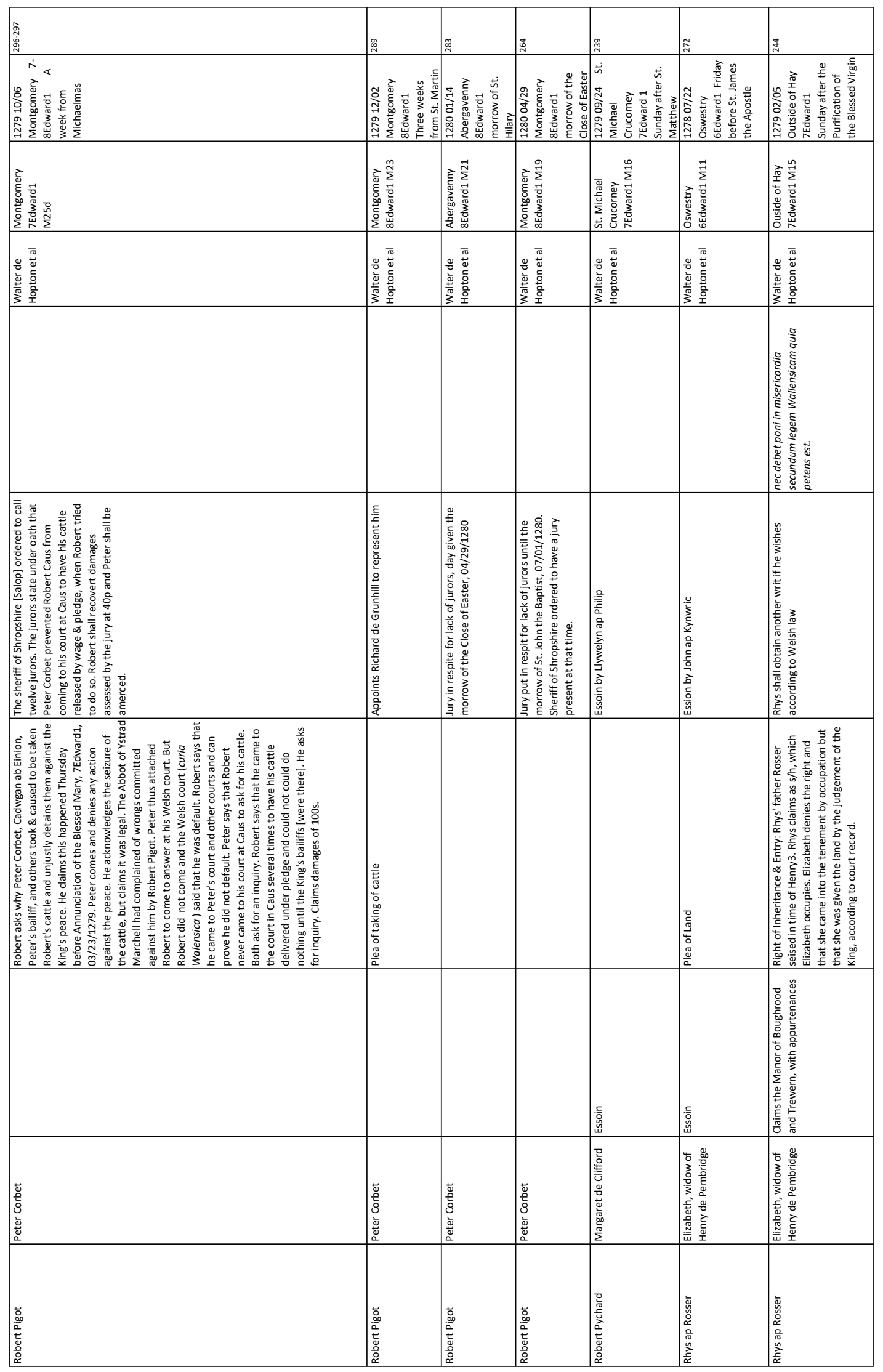




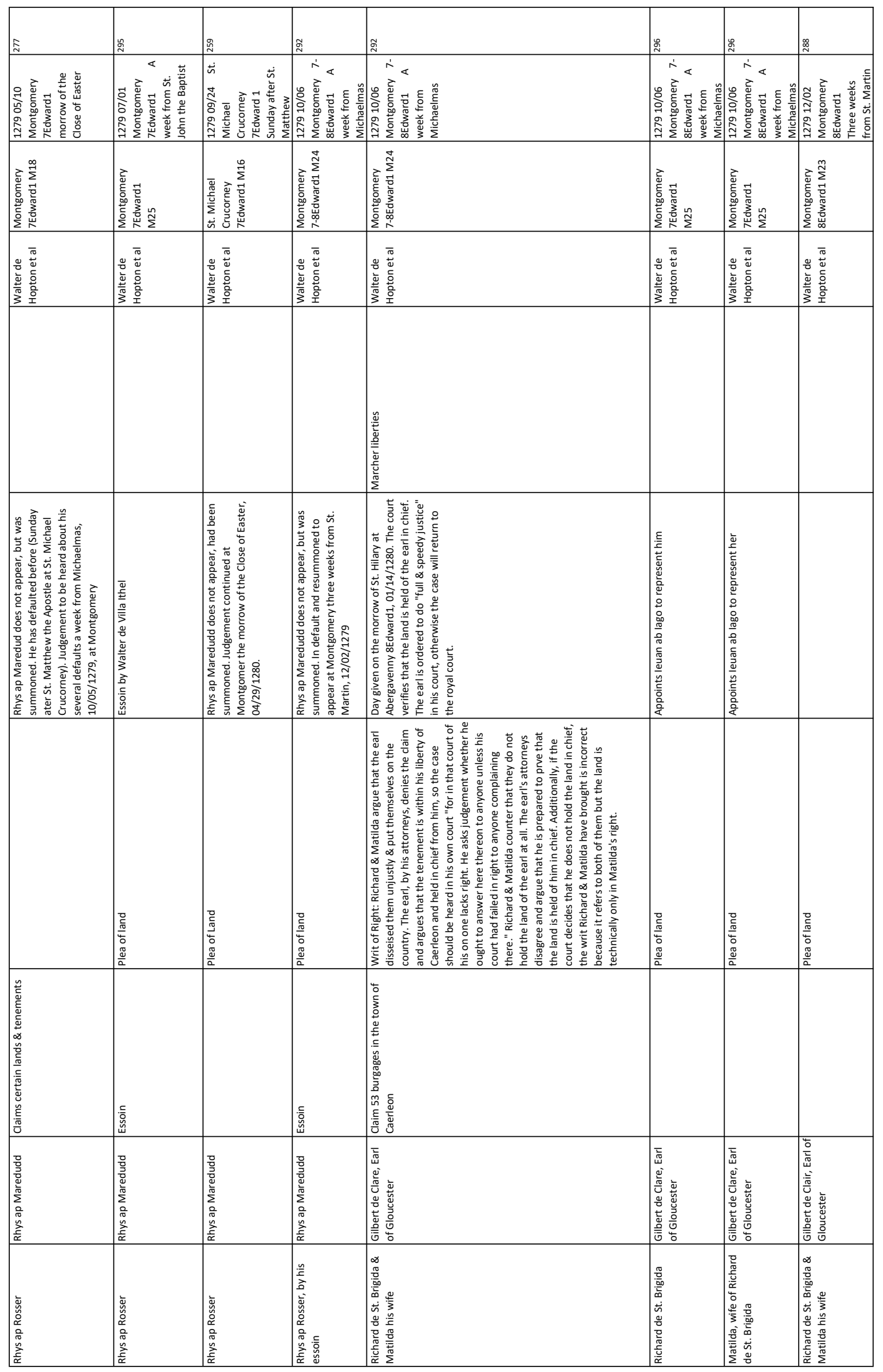




\begin{tabular}{|c|c|c|c|c|c|c|c|c|}
\hline$\vec{n}$ & 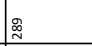 & $\widetilde{\pi}$ & $\approx$ & 암 & $\overrightarrow{m_{m}}$ & 曾 & 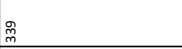 & 嗗 \\
\hline 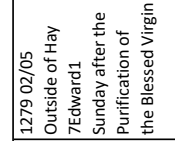 & 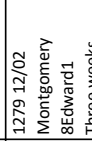 & 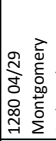 & 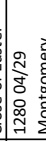 & 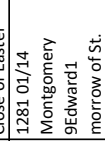 & 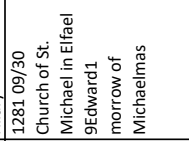 & 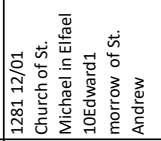 & 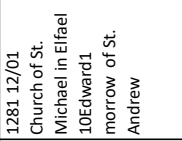 & 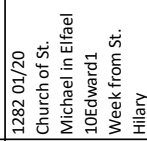 \\
\hline 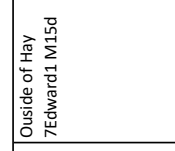 & 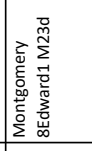 & 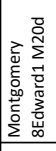 & 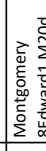 & 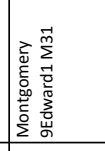 & 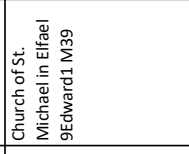 & 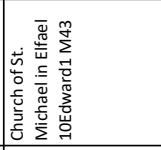 & 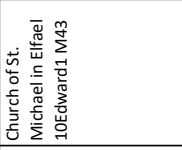 & 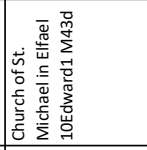 \\
\hline 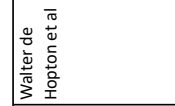 & 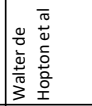 & 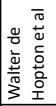 & 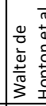 & 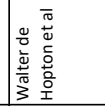 & 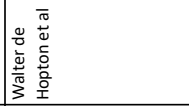 & 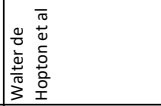 & 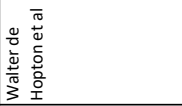 & 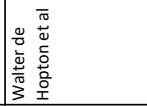 \\
\hline 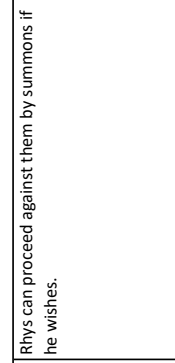 & 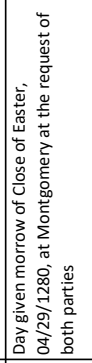 & 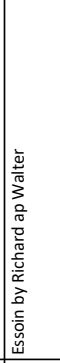 & 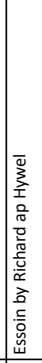 & 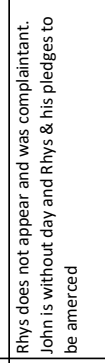 & 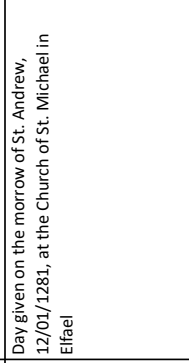 & 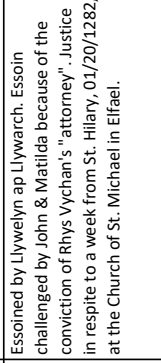 & 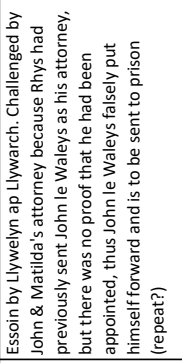 & 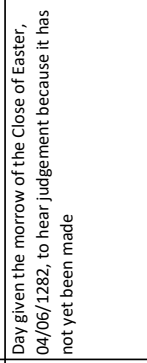 \\
\hline 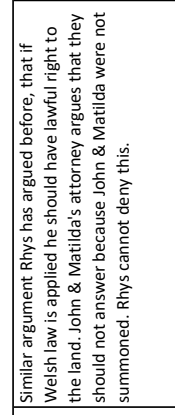 & 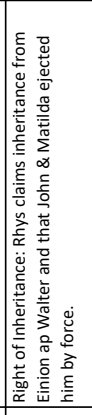 & & 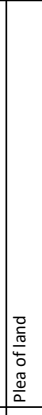 & 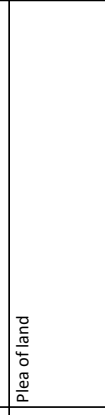 & 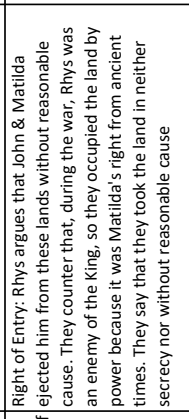 & 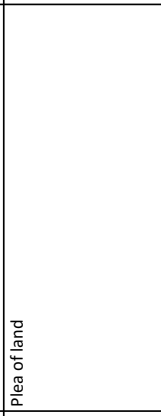 & 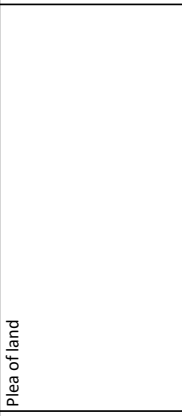 & \\
\hline 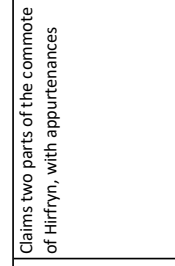 & 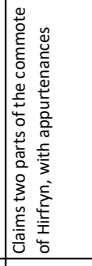 & 聪 & 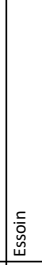 & & 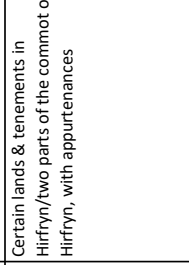 & 僁 & 窎 & \\
\hline 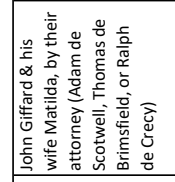 & 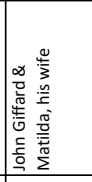 & 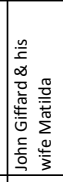 & 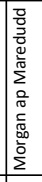 & 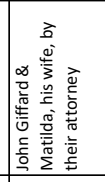 & 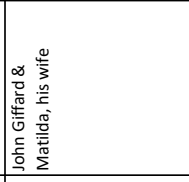 & 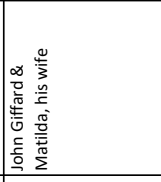 & 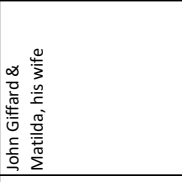 & 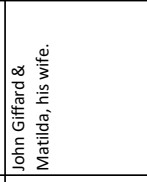 \\
\hline 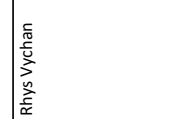 & 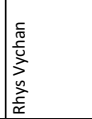 & $\mid$ & 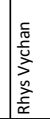 & 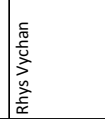 & $\mid$ & $\mid$ & 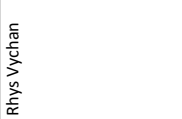 & $\mid$ \\
\hline
\end{tabular}




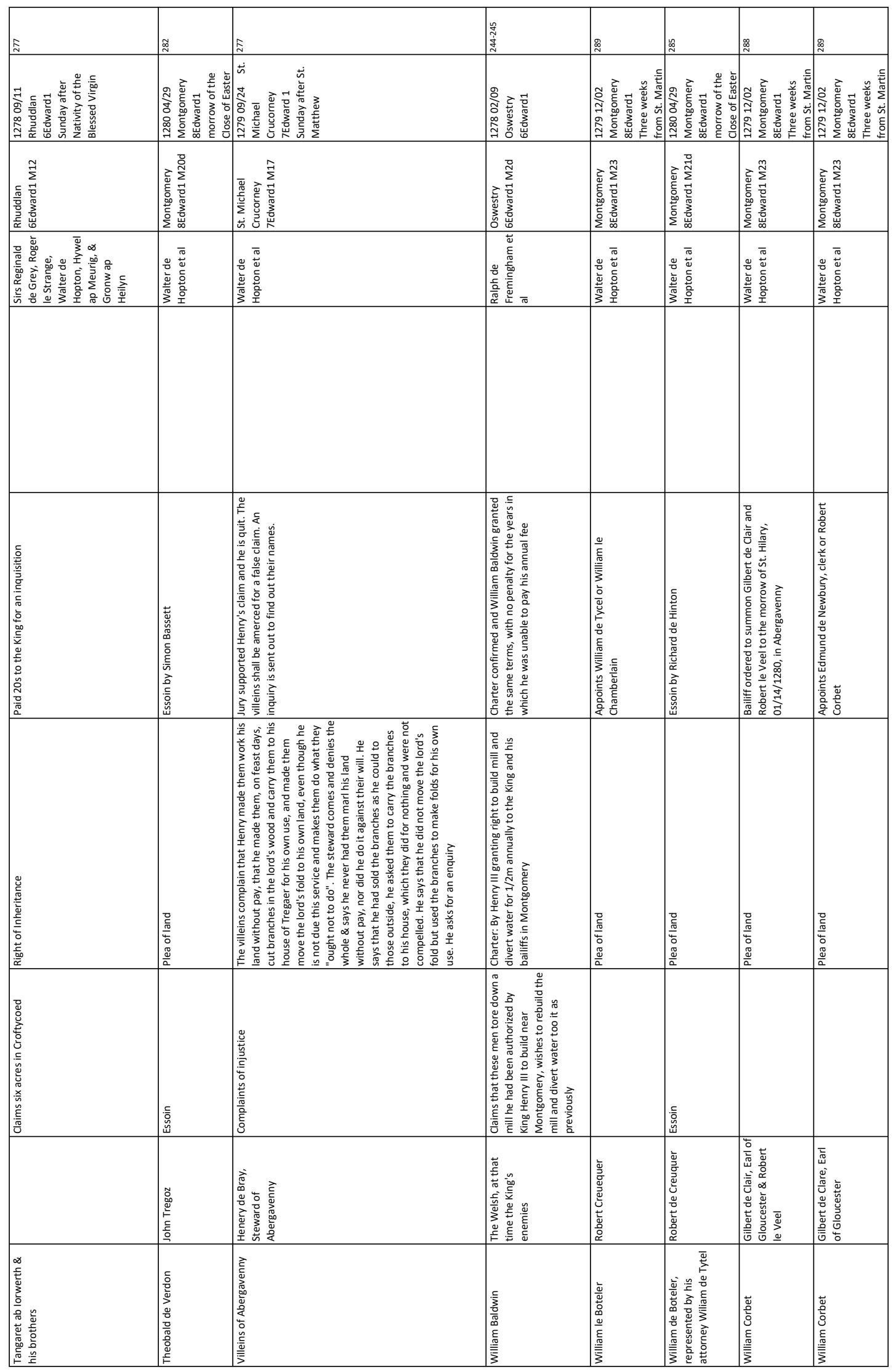




\begin{tabular}{|c|c|c|c|c|c|c|}
\hline 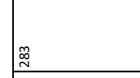 & $\approx$ & $\dddot{n}$ & 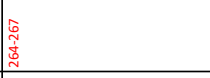 & 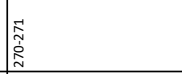 & 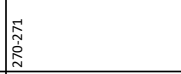 & 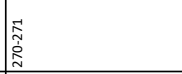 \\
\hline 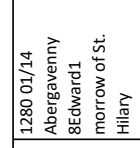 & 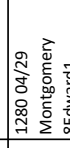 & 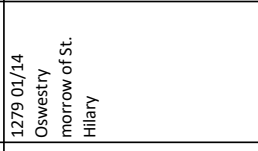 & 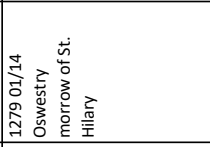 & 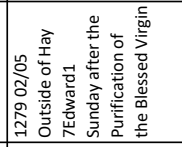 & 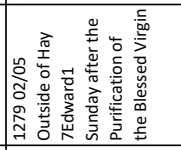 & 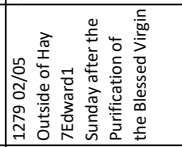 \\
\hline 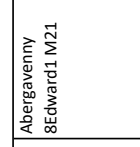 & 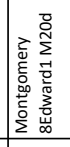 & 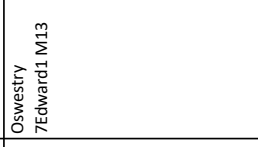 & 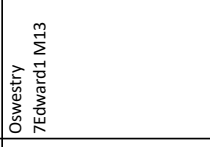 & 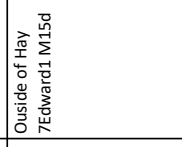 & 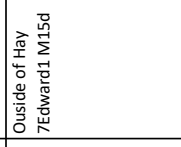 & 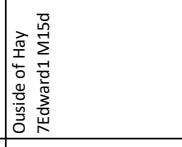 \\
\hline 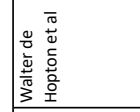 & 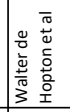 & 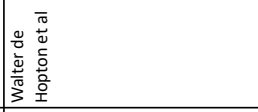 & 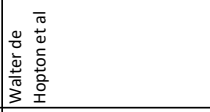 & 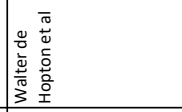 & 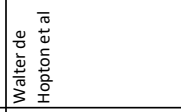 & 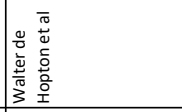 \\
\hline 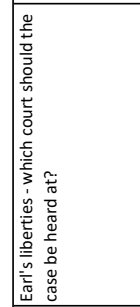 & & & & & & \\
\hline 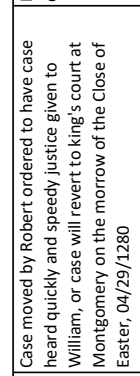 & 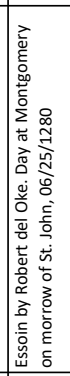 & 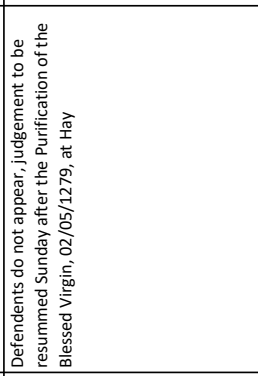 & & 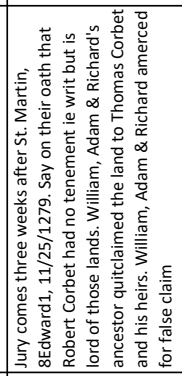 & 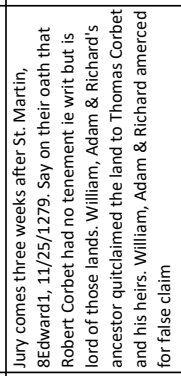 & 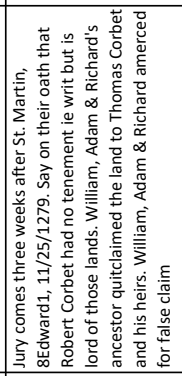 \\
\hline 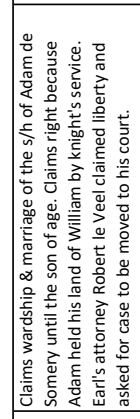 & 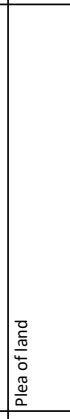 & 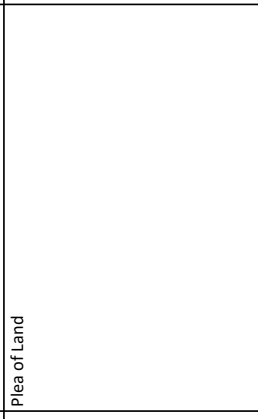 & 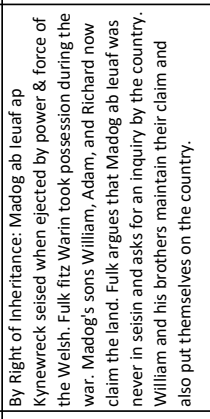 & 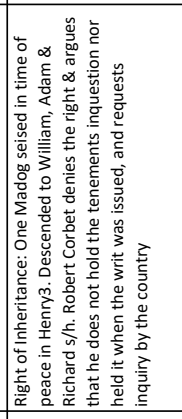 & 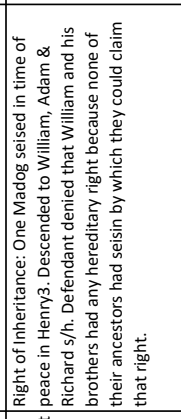 & 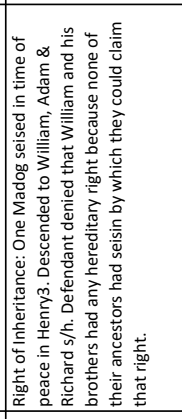 \\
\hline & $\mid \begin{array}{c}\text { 嗢 } \\
\end{array}$ & & 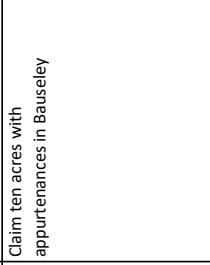 & 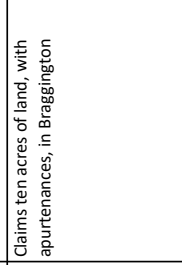 & 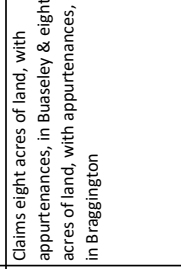 & 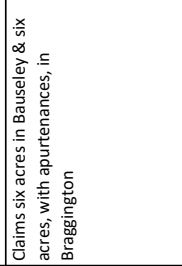 \\
\hline 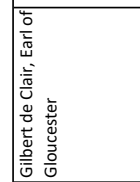 & 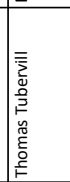 & 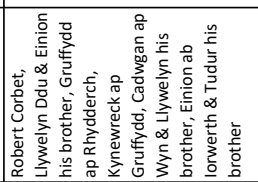 & $\mid$ & 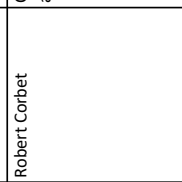 & 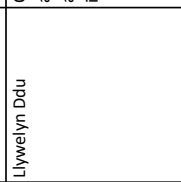 & 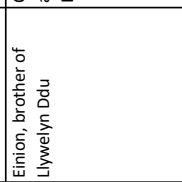 \\
\hline 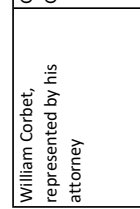 & 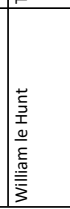 & 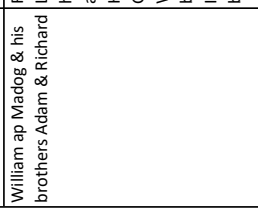 & 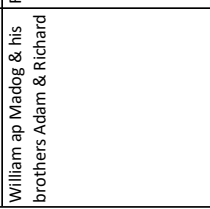 & 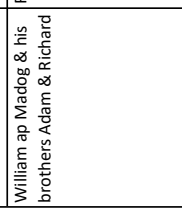 & 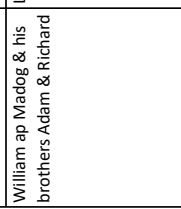 & 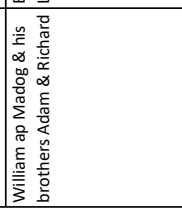 \\
\hline
\end{tabular}




\begin{tabular}{|c|c|c|c|c|c|c|}
\hline 6 & \begin{tabular}{|l}
$\tilde{N}$ \\
$\overline{\tilde{\Sigma}}$ \\
\end{tabular} & 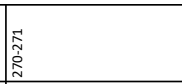 & 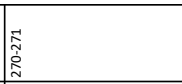 & \begin{tabular}{|l}
$\tilde{\tilde{n}}$ \\
\end{tabular} & 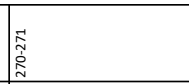 & 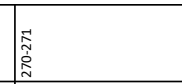 \\
\hline 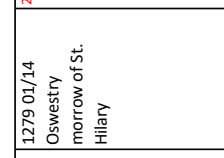 & 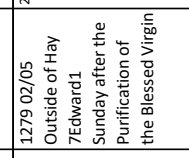 & 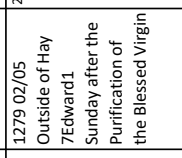 & 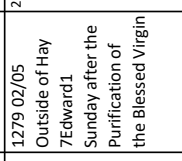 & 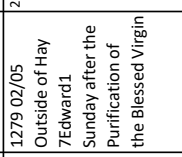 & 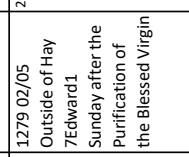 & 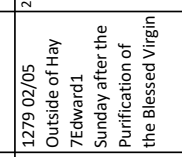 \\
\hline 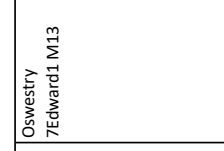 & 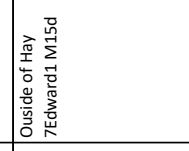 & 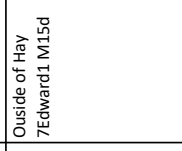 & 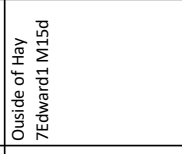 & 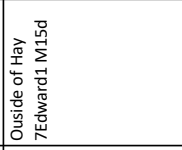 & 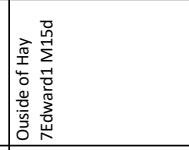 & 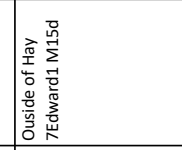 \\
\hline 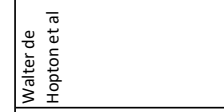 & 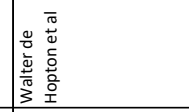 & 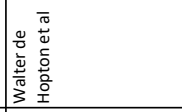 & 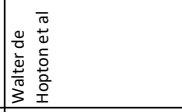 & 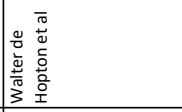 & 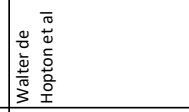 & 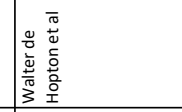 \\
\hline & 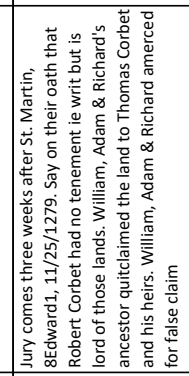 & 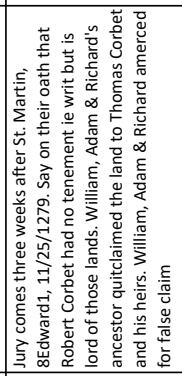 & 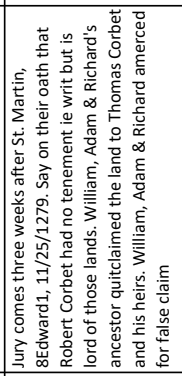 & 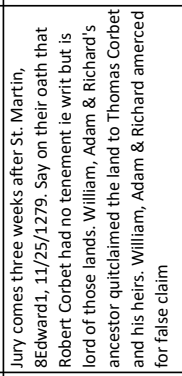 & 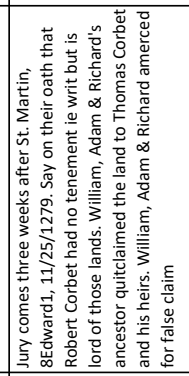 & 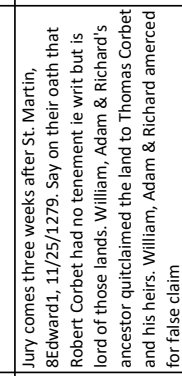 \\
\hline 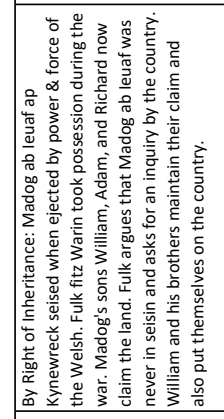 & 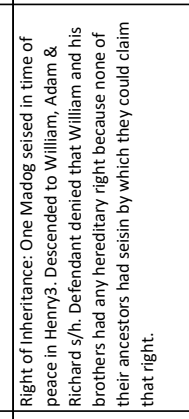 & 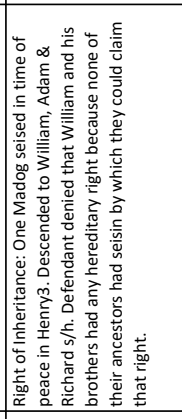 & 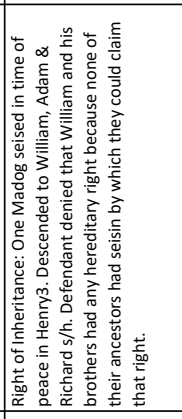 & 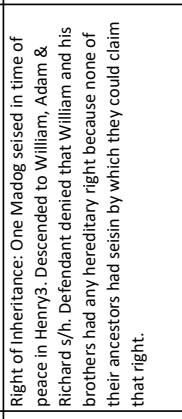 & 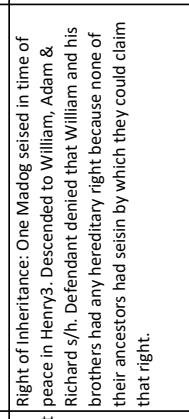 & 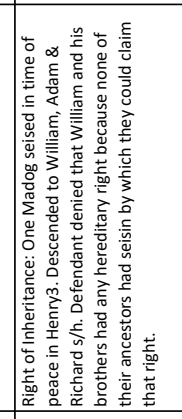 \\
\hline 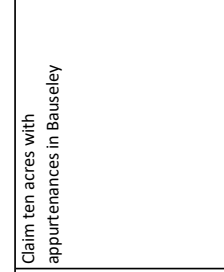 & 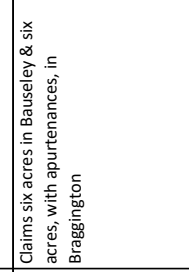 & 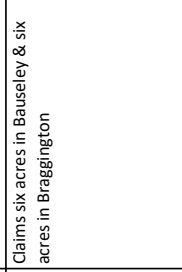 & 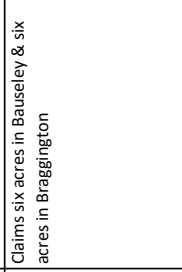 & 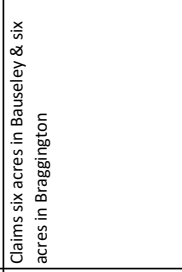 & 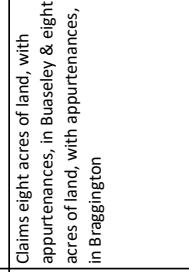 & 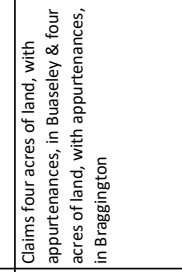 \\
\hline $\mid$ & 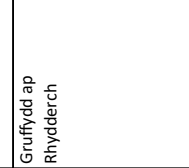 & 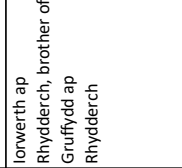 & $\mid$ & & 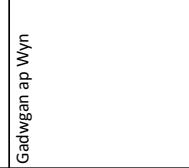 & 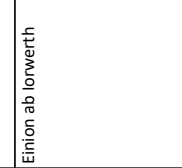 \\
\hline 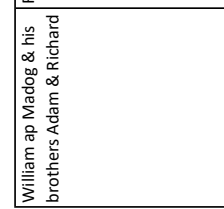 & 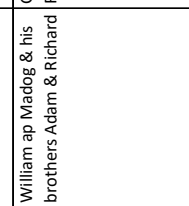 & 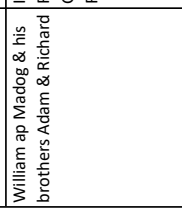 & 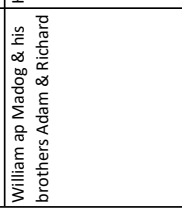 & 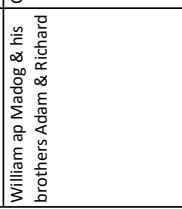 & 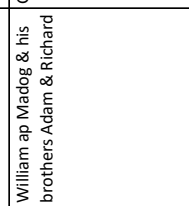 & 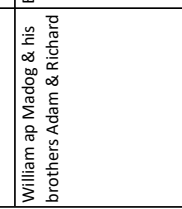 \\
\hline
\end{tabular}




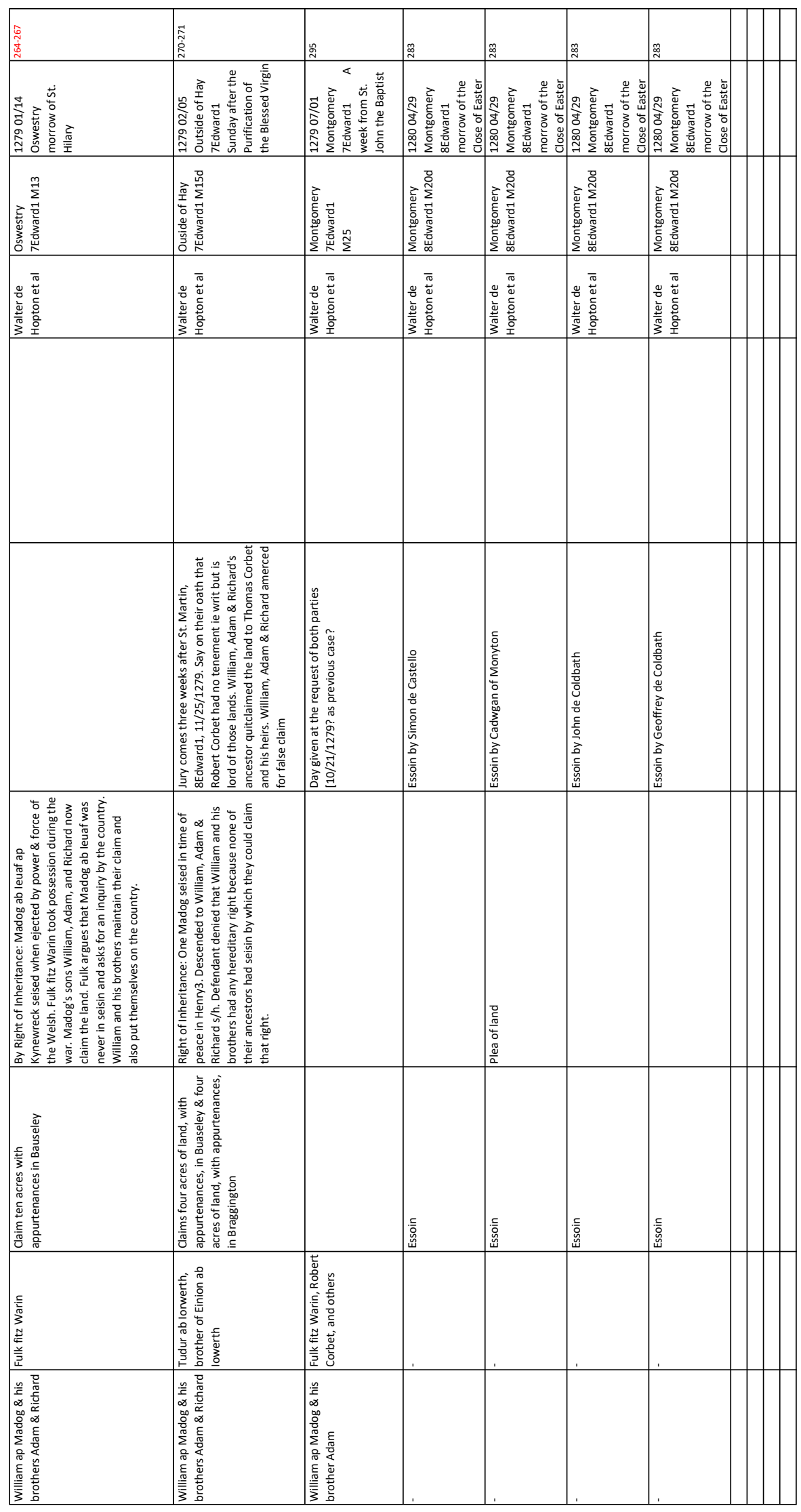




\section{APPENDIX SEVEN \\ THE WELSH ASSIZE ROLL 1277-1884 BY DATE ${ }^{239}$}

Appendix Seven uses the same data collected in Appendix Six, but sorted by date instead of individual. Sorting by date allows for the chronological reading of the proceedings of the assize, something that cannot be done when reading the original membranes in the order they were collected. As Davies points out in his critical edition of the text, the membranes were often sewn together out of order. In this way the original document presents a confusing dialogue in which some cases have been decided before an inquiry has even been requested.

${ }^{239}$ Davies, The Welsh Assize Roll, 1277-1284: Assize Roll No. 1147. 


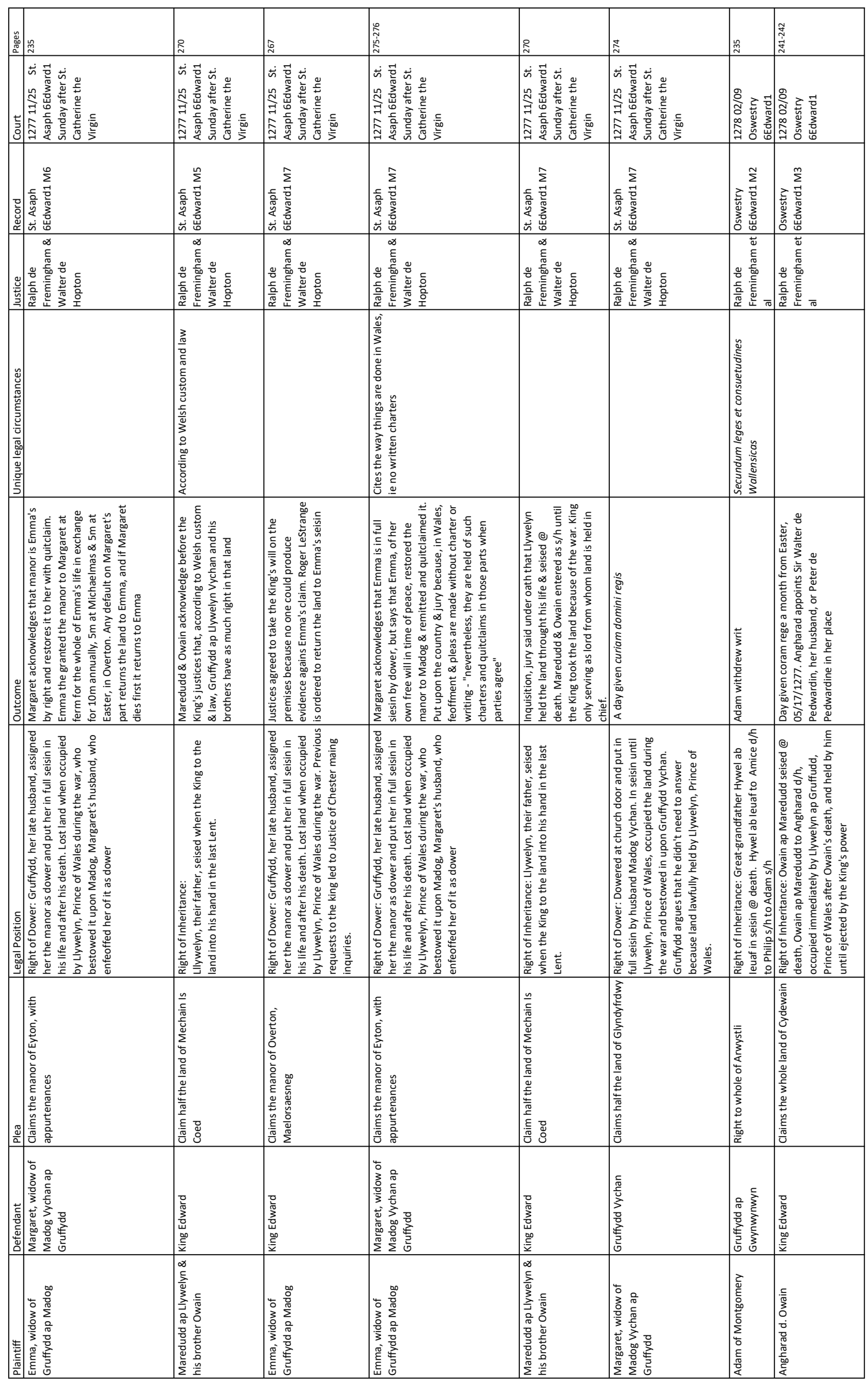




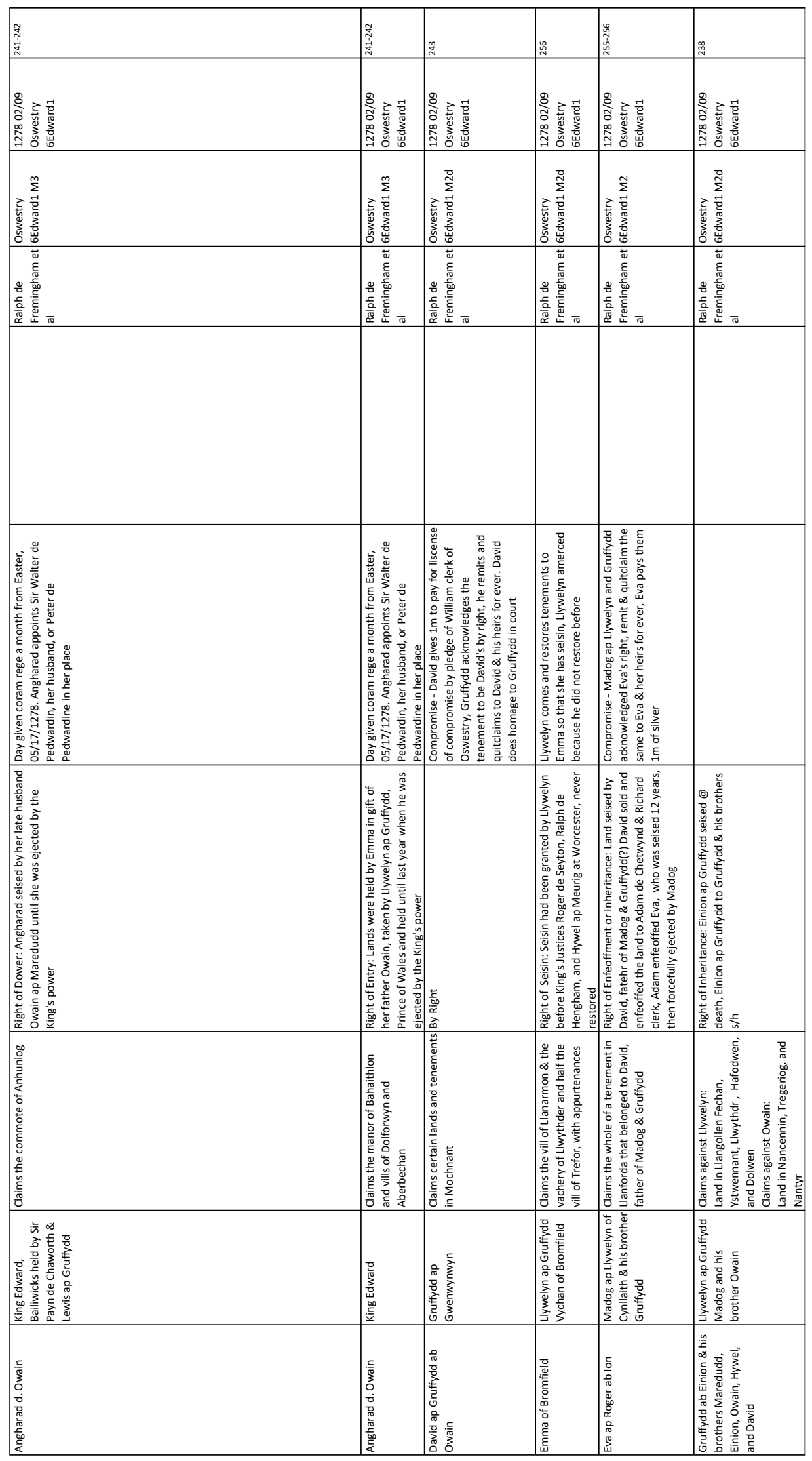




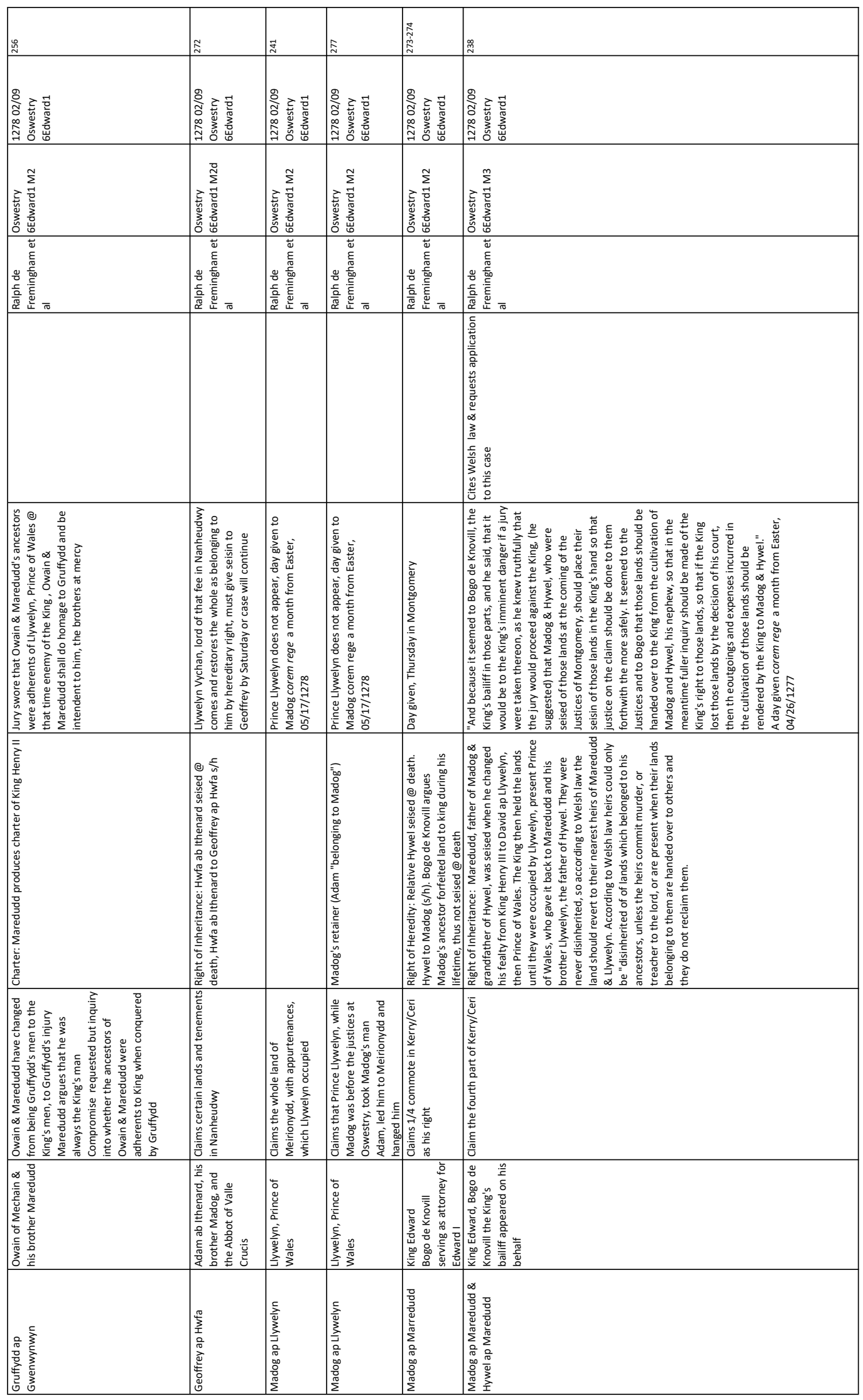




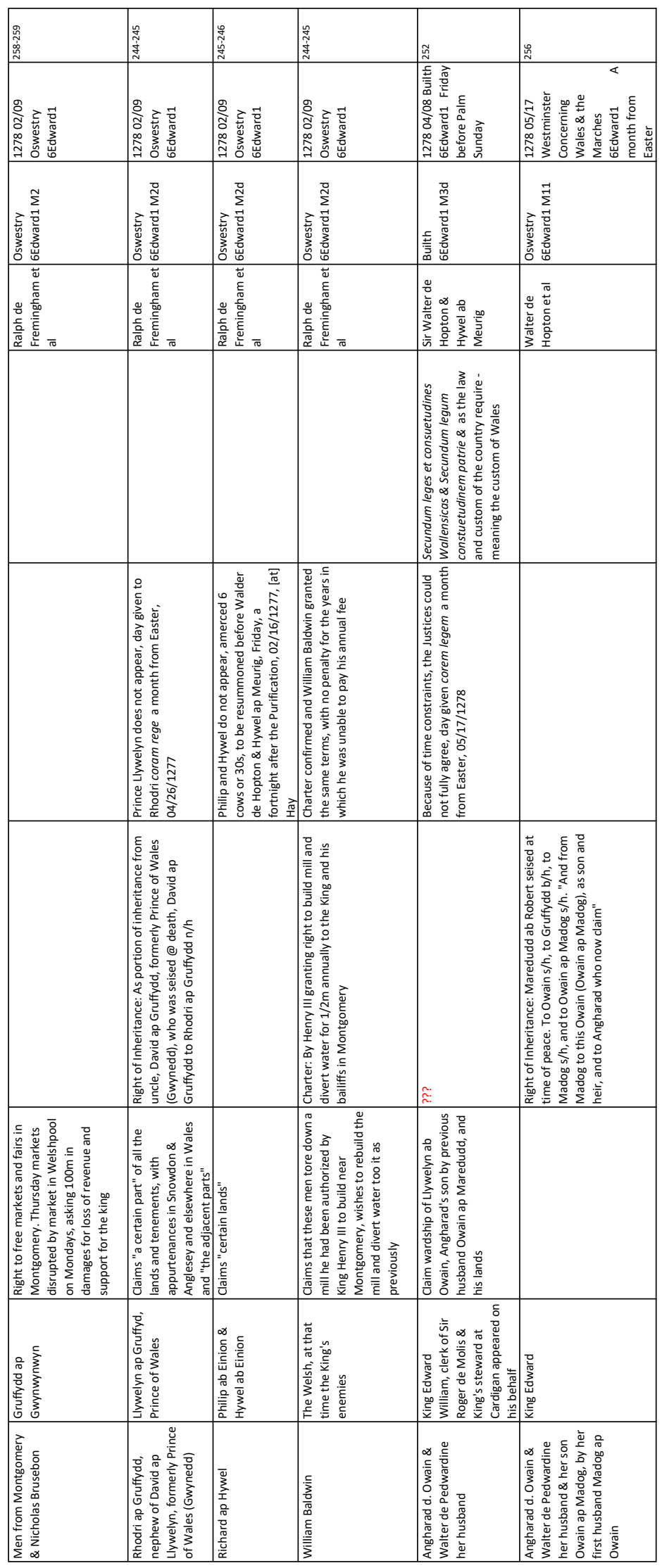




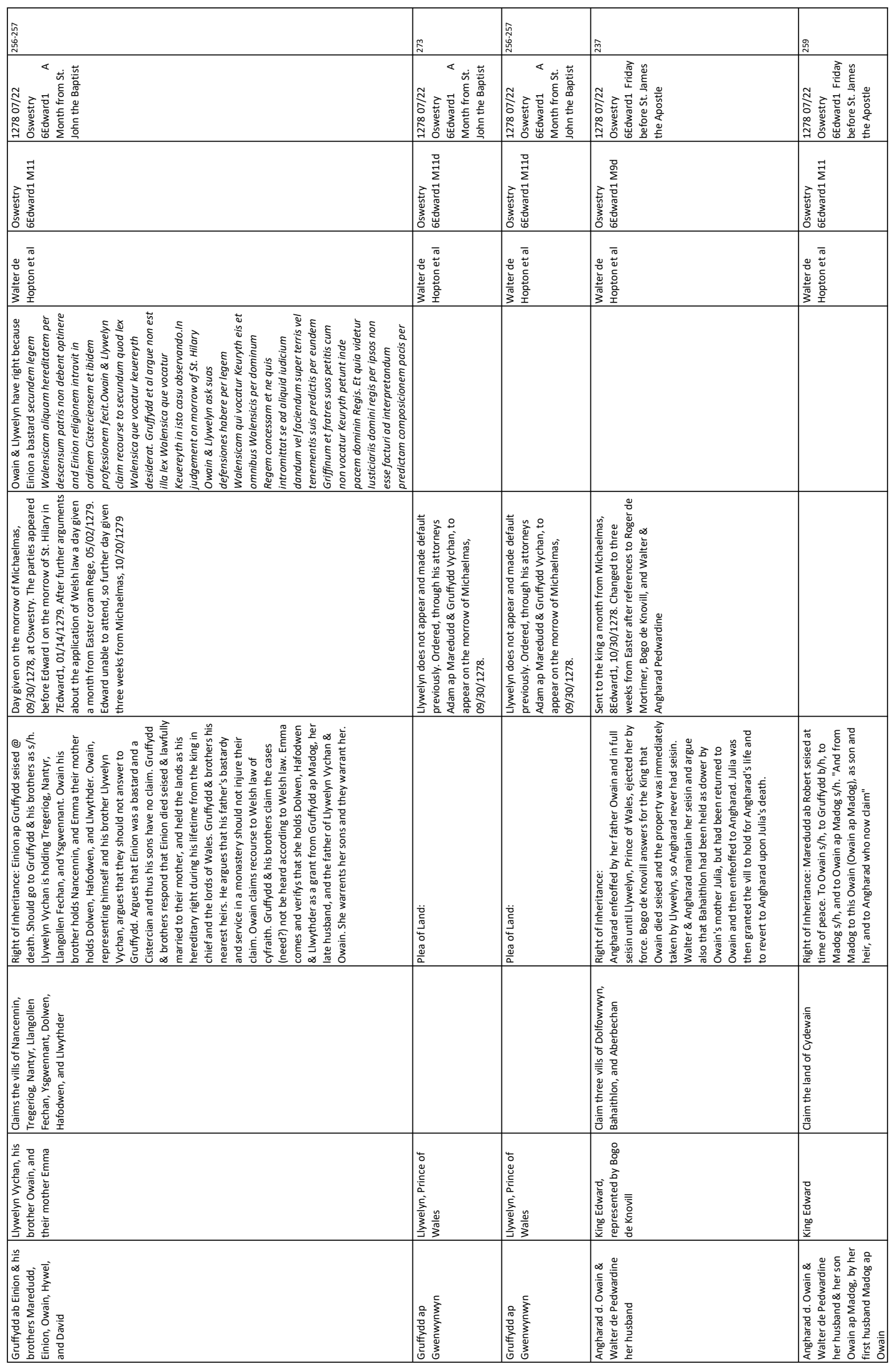




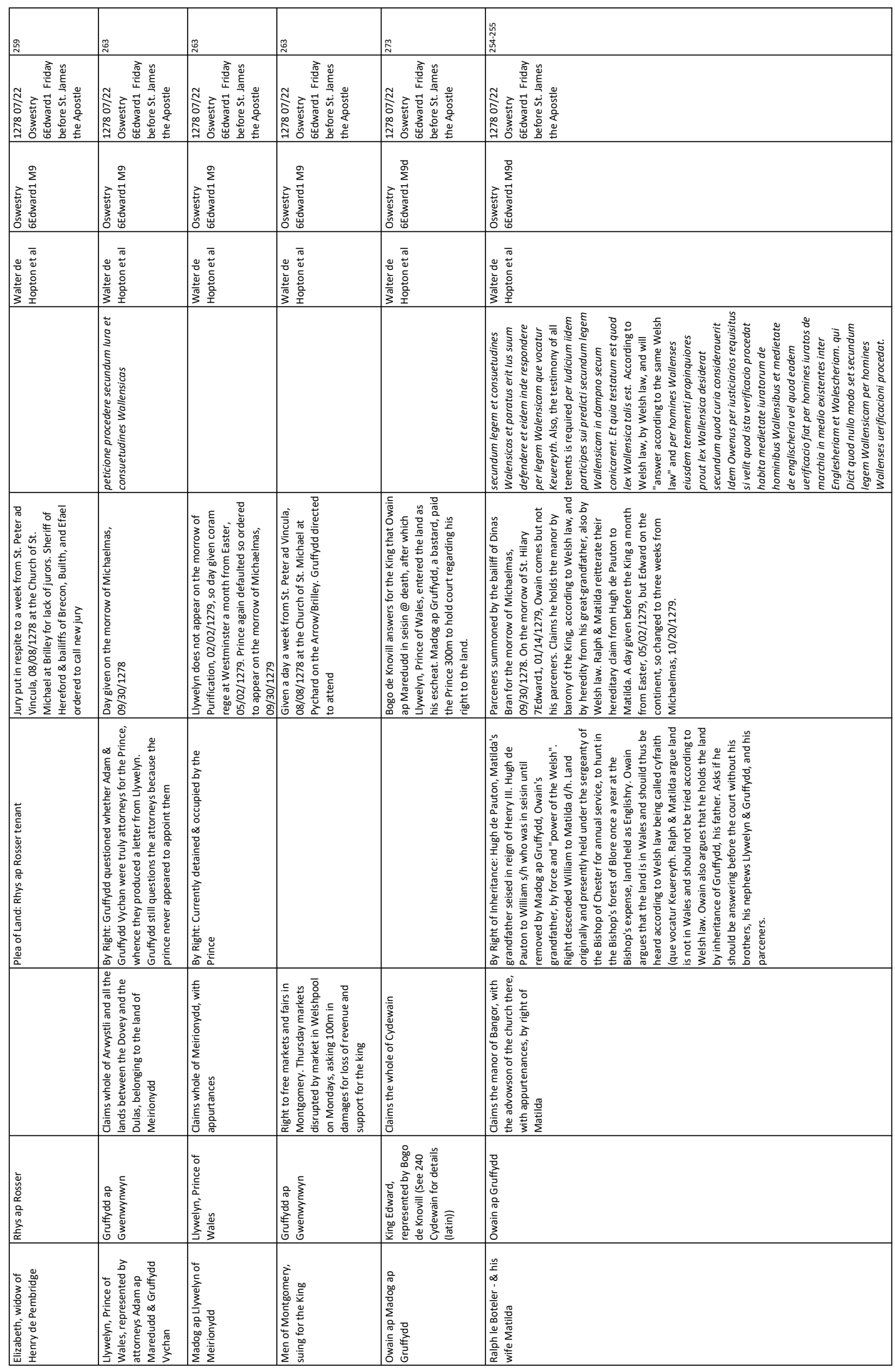




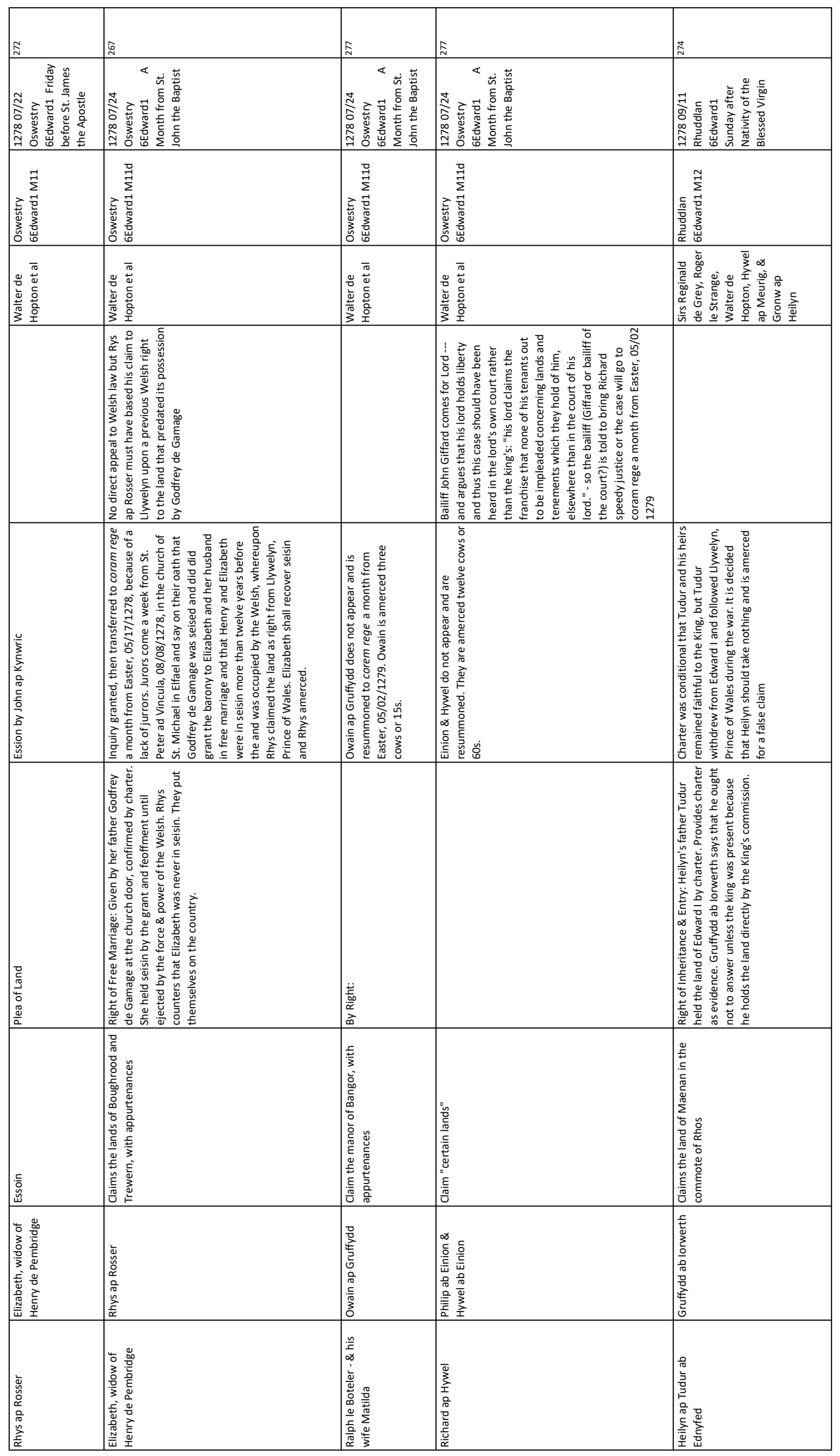




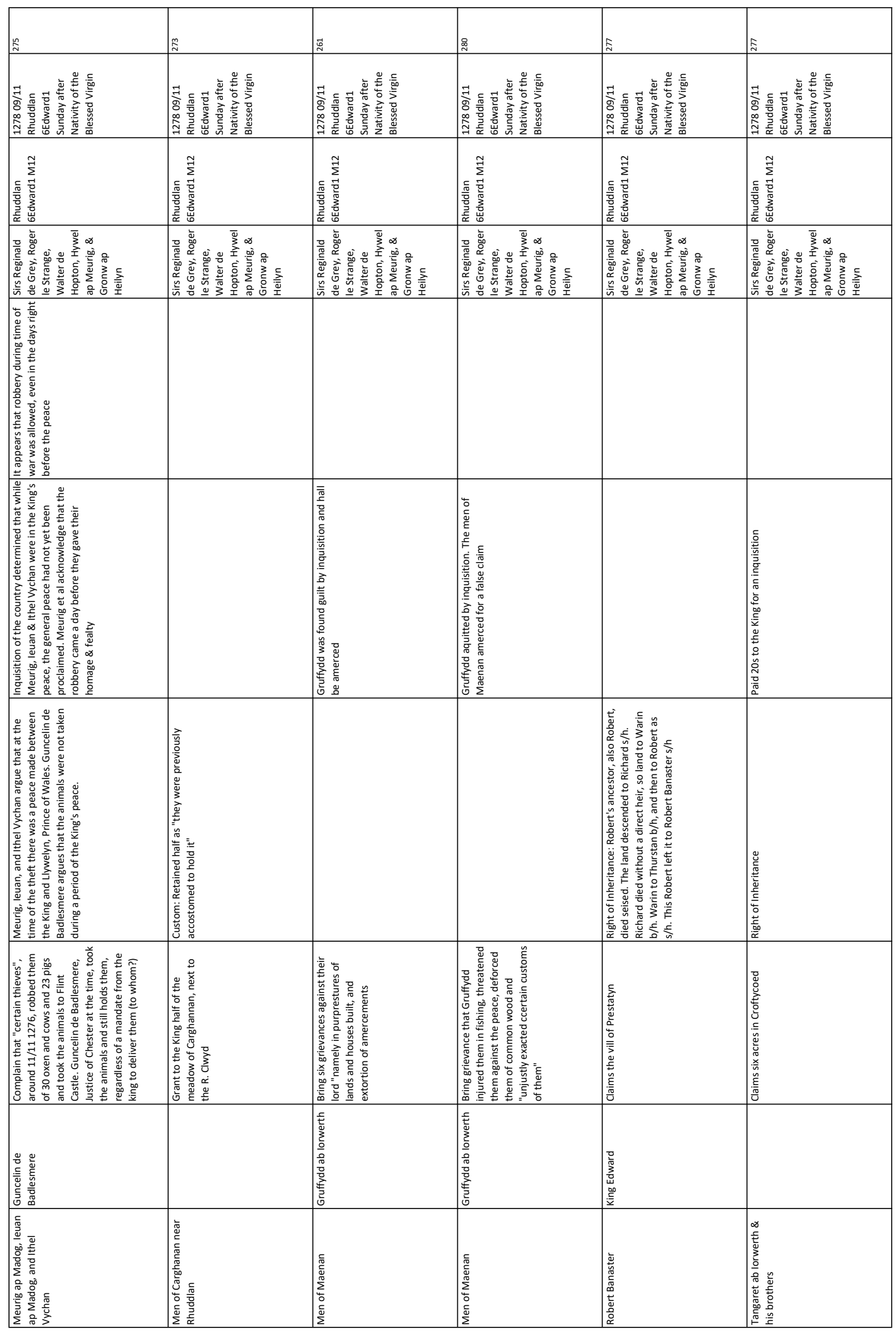




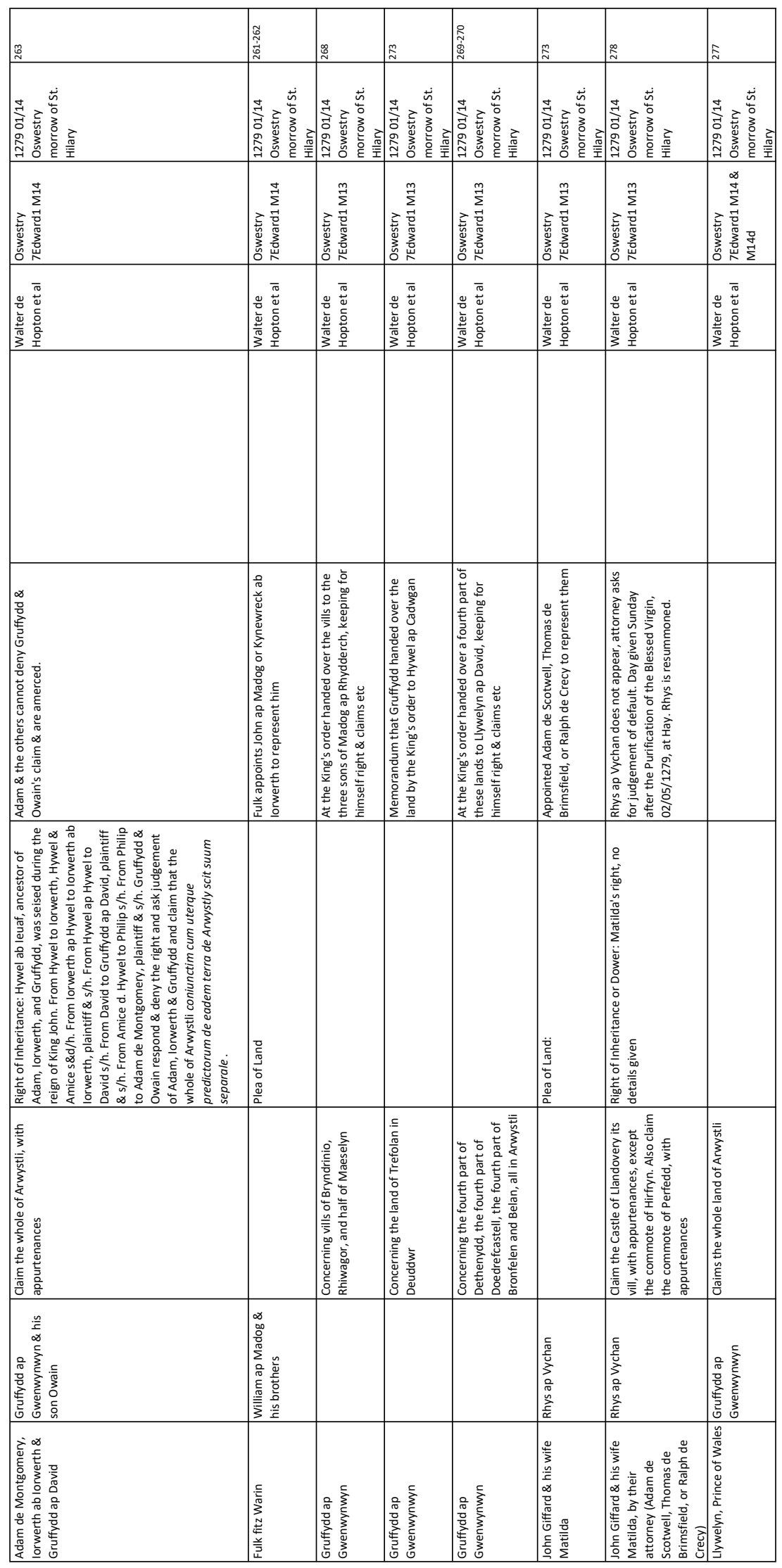




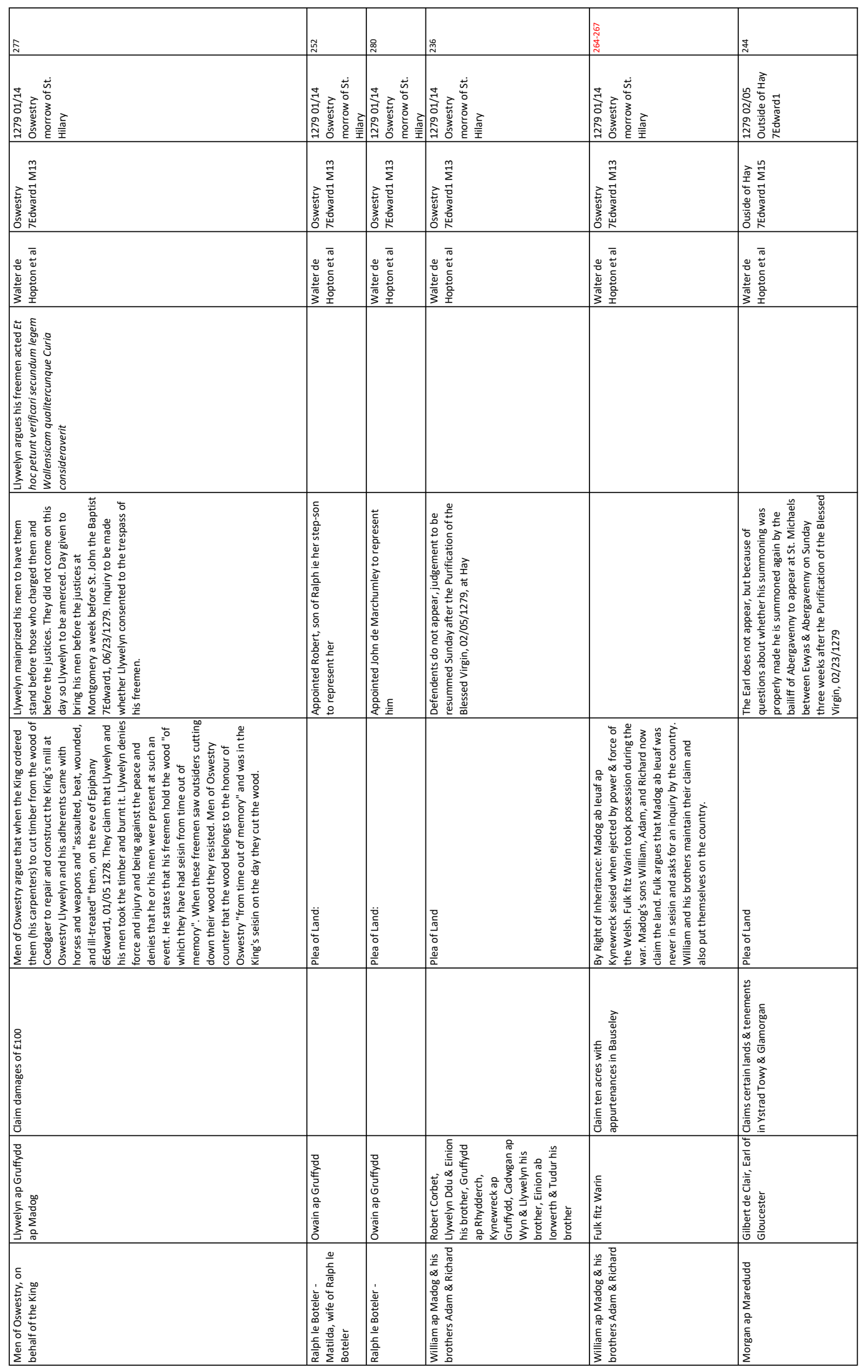




\begin{tabular}{|c|c|c|c|c|c|}
\hline$\stackrel{\infty}{i}$ & 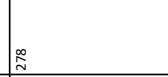 & 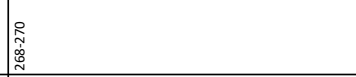 & 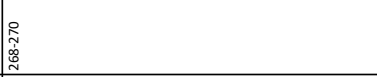 & $\frac{\pi}{2}$ & $\vec{j}$ \\
\hline 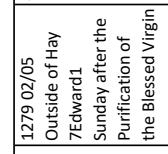 & 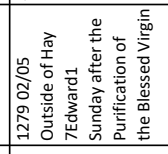 & 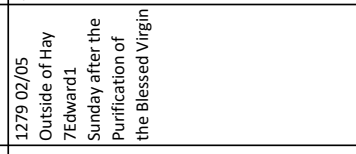 & 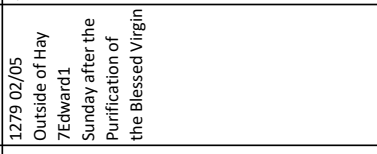 & 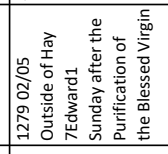 & 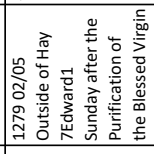 \\
\hline 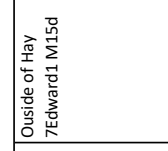 & 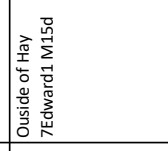 & 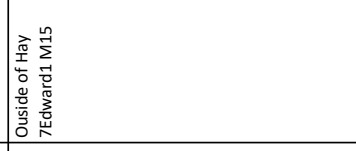 & & 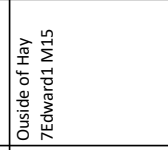 & 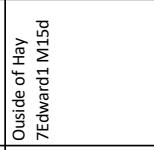 \\
\hline & 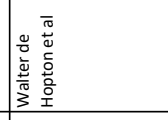 & 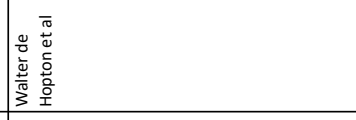 & 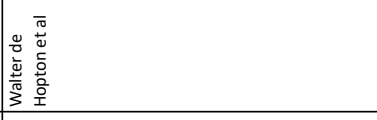 & 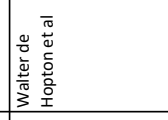 & 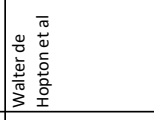 \\
\hline & & & & 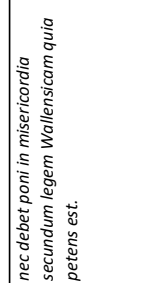 & \\
\hline 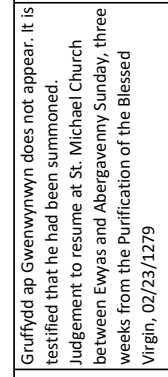 & 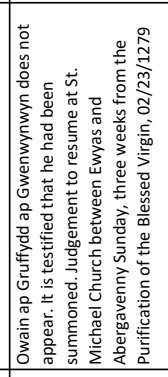 & 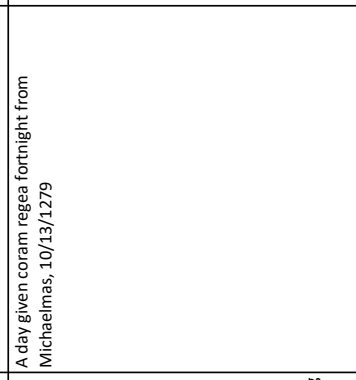 & 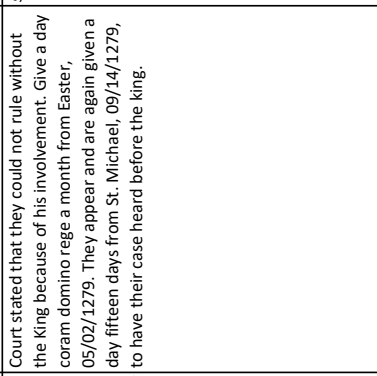 & 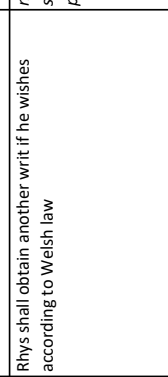 & 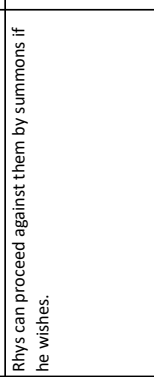 \\
\hline & & 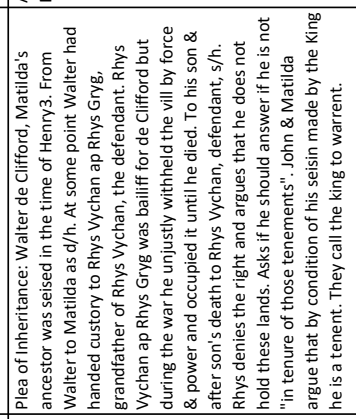 & 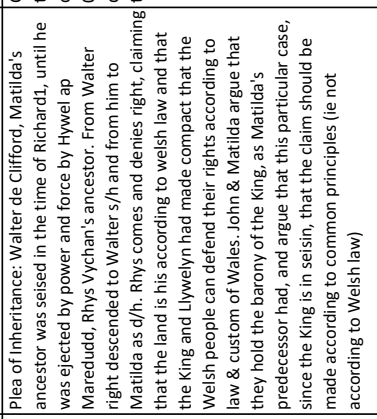 & 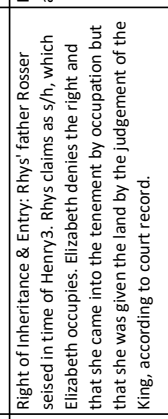 & 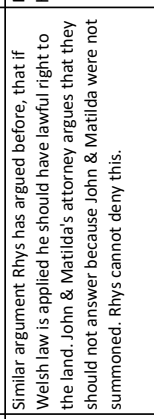 \\
\hline 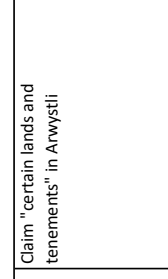 & 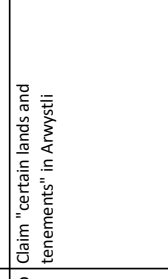 & 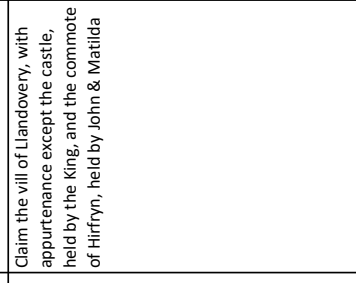 & 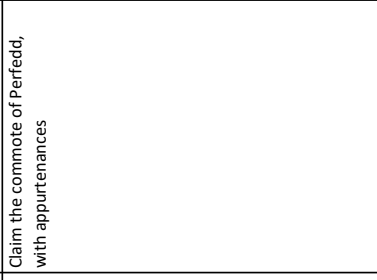 & 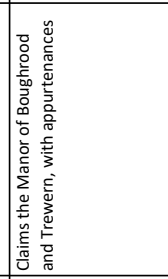 & 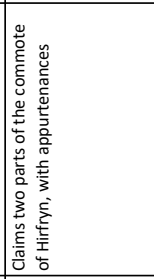 \\
\hline \begin{tabular}{|l}
$\frac{2}{0}$ \\
$\frac{0}{0}$ \\
0 \\
产 \\
\end{tabular} & 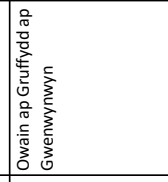 & 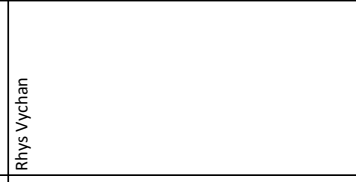 & & 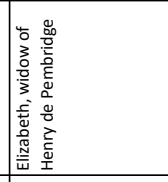 & 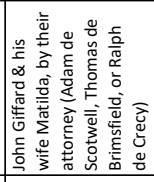 \\
\hline 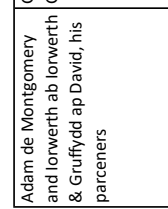 & 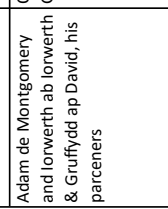 & 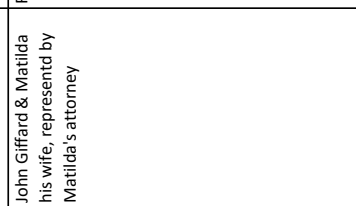 & 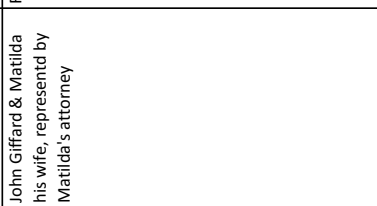 & 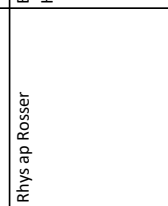 & 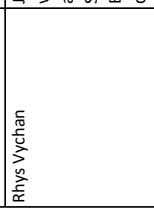 \\
\hline
\end{tabular}




\begin{tabular}{|c|c|c|c|c|c|c|}
\hline & 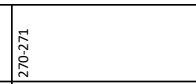 & 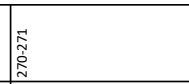 & 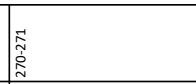 & 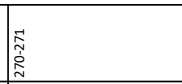 & 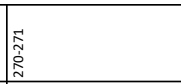 & $\begin{array}{l}\tilde{\tilde{N}} \\
\overline{2}\end{array}$ \\
\hline 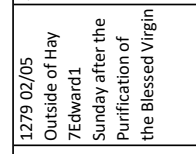 & 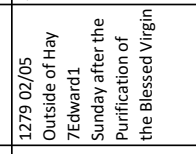 & 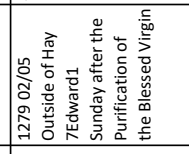 & 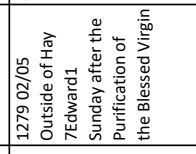 & 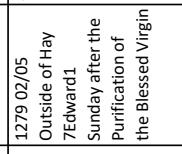 & 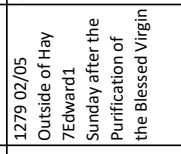 & 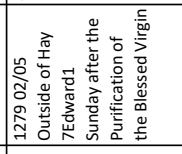 \\
\hline & 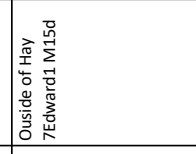 & 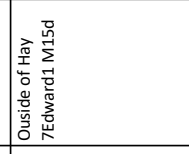 & 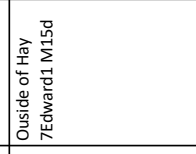 & 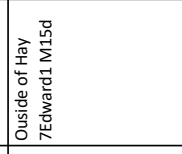 & 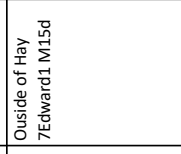 & 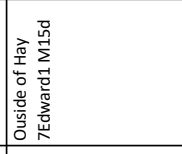 \\
\hline 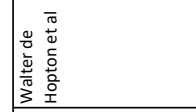 & 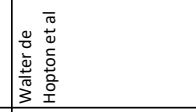 & 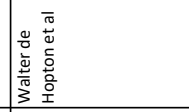 & 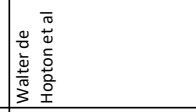 & 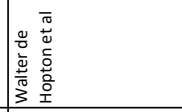 & 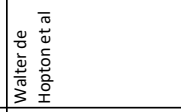 & 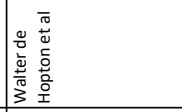 \\
\hline 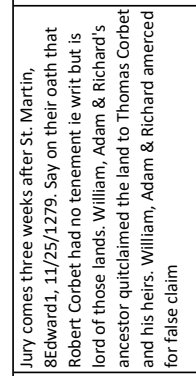 & 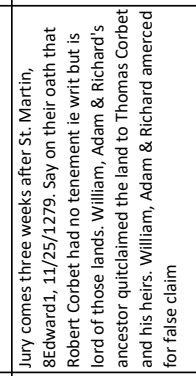 & 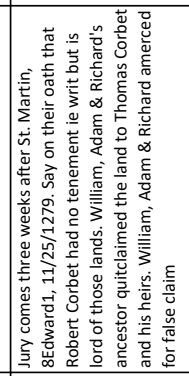 & 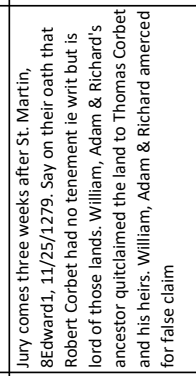 & 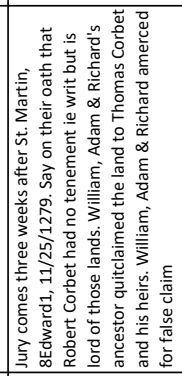 & 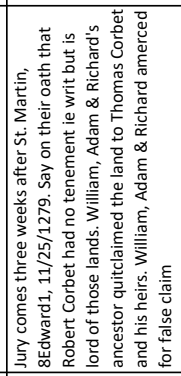 & 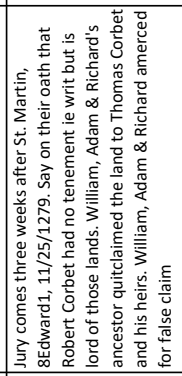 \\
\hline 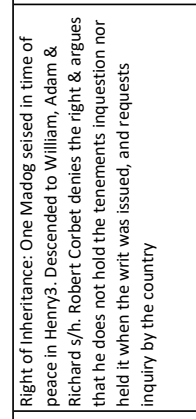 & 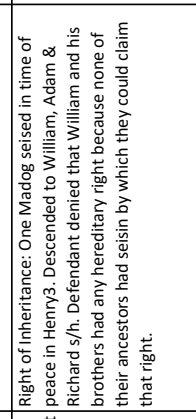 & 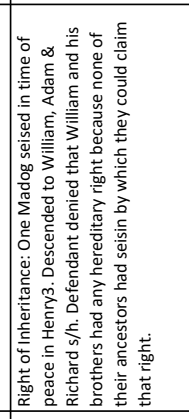 & 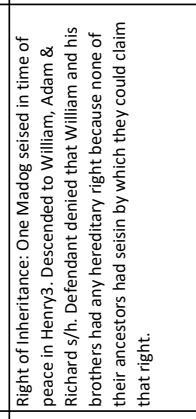 & 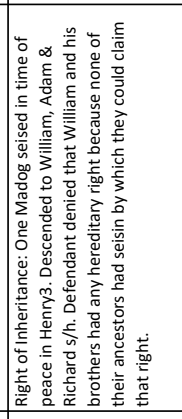 & 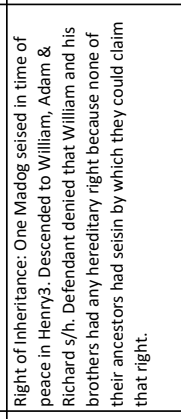 & 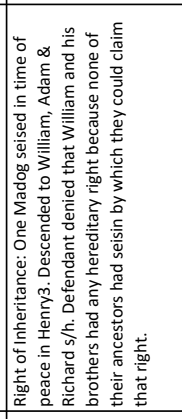 \\
\hline 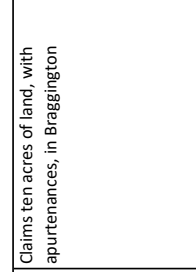 & 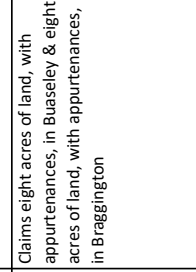 & 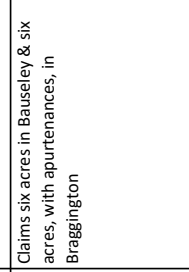 & 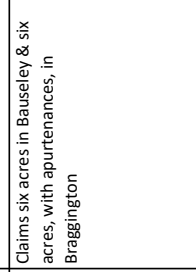 & 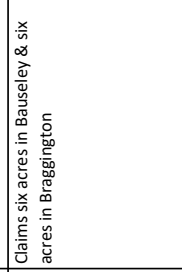 & 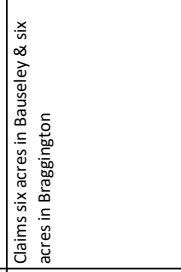 & 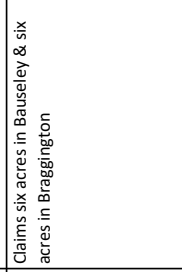 \\
\hline 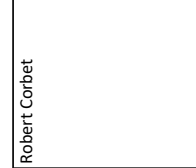 & 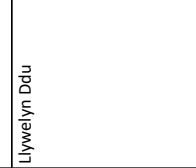 & 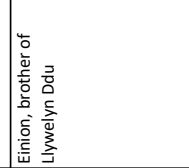 & 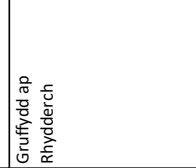 & 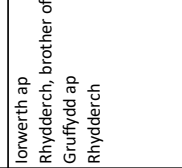 & 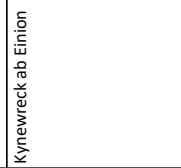 & 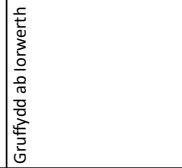 \\
\hline 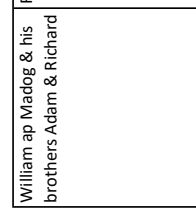 & 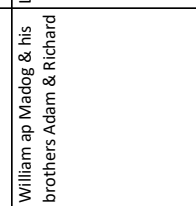 & 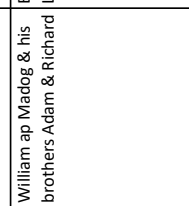 & 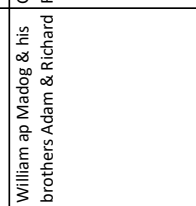 & 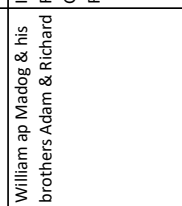 & 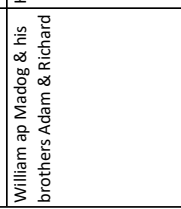 & 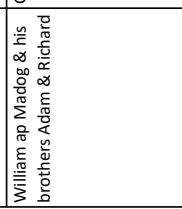 \\
\hline
\end{tabular}




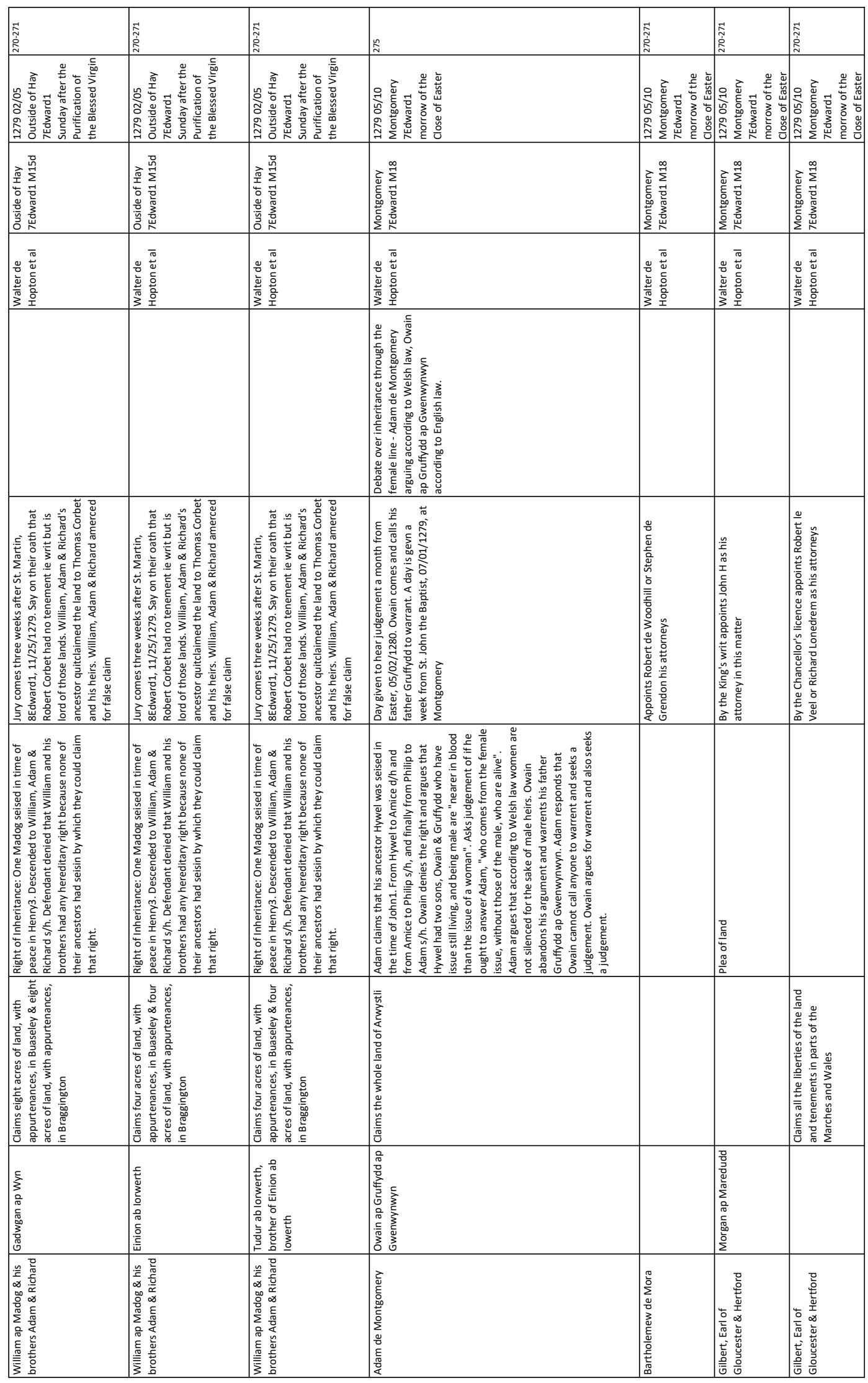




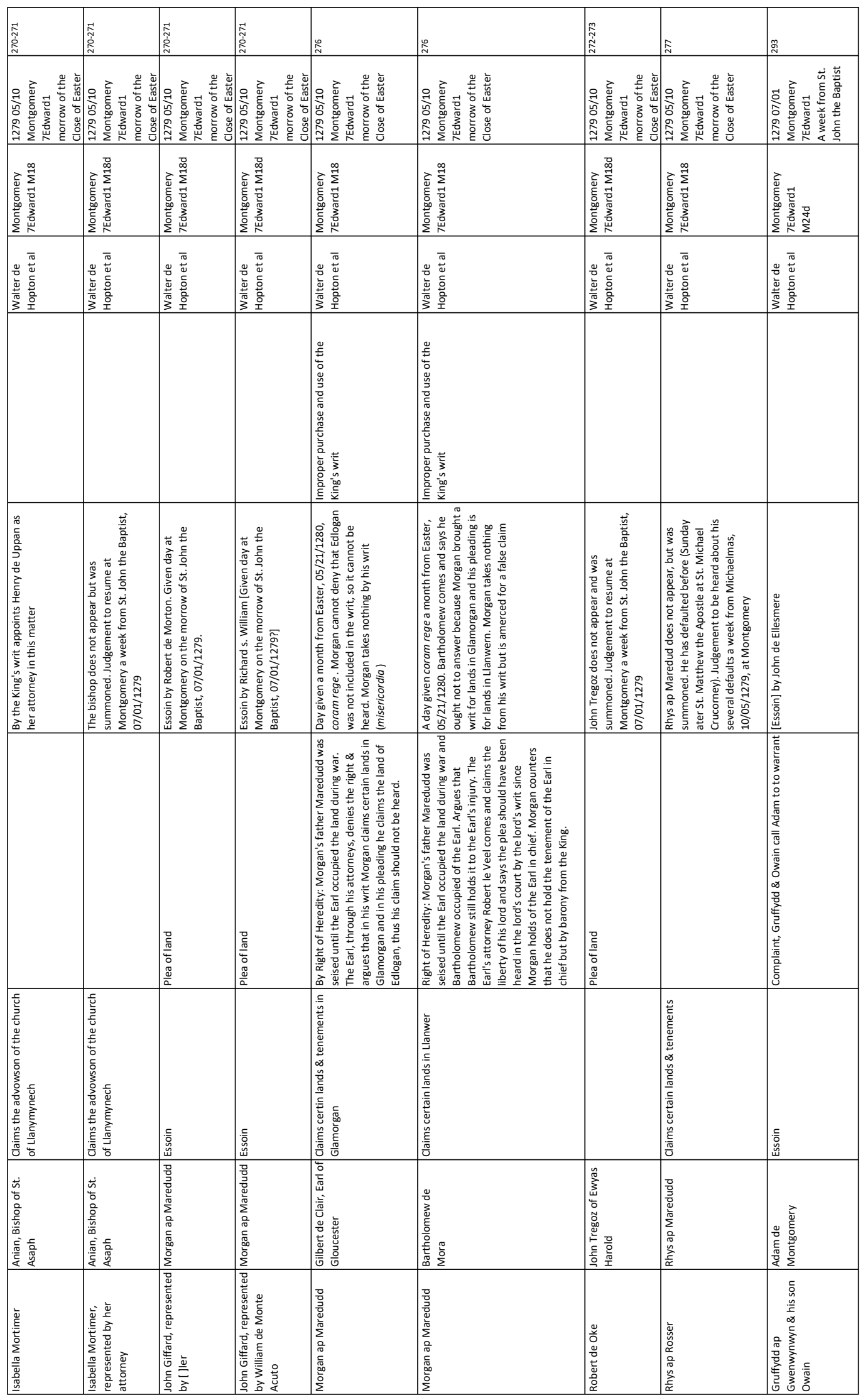




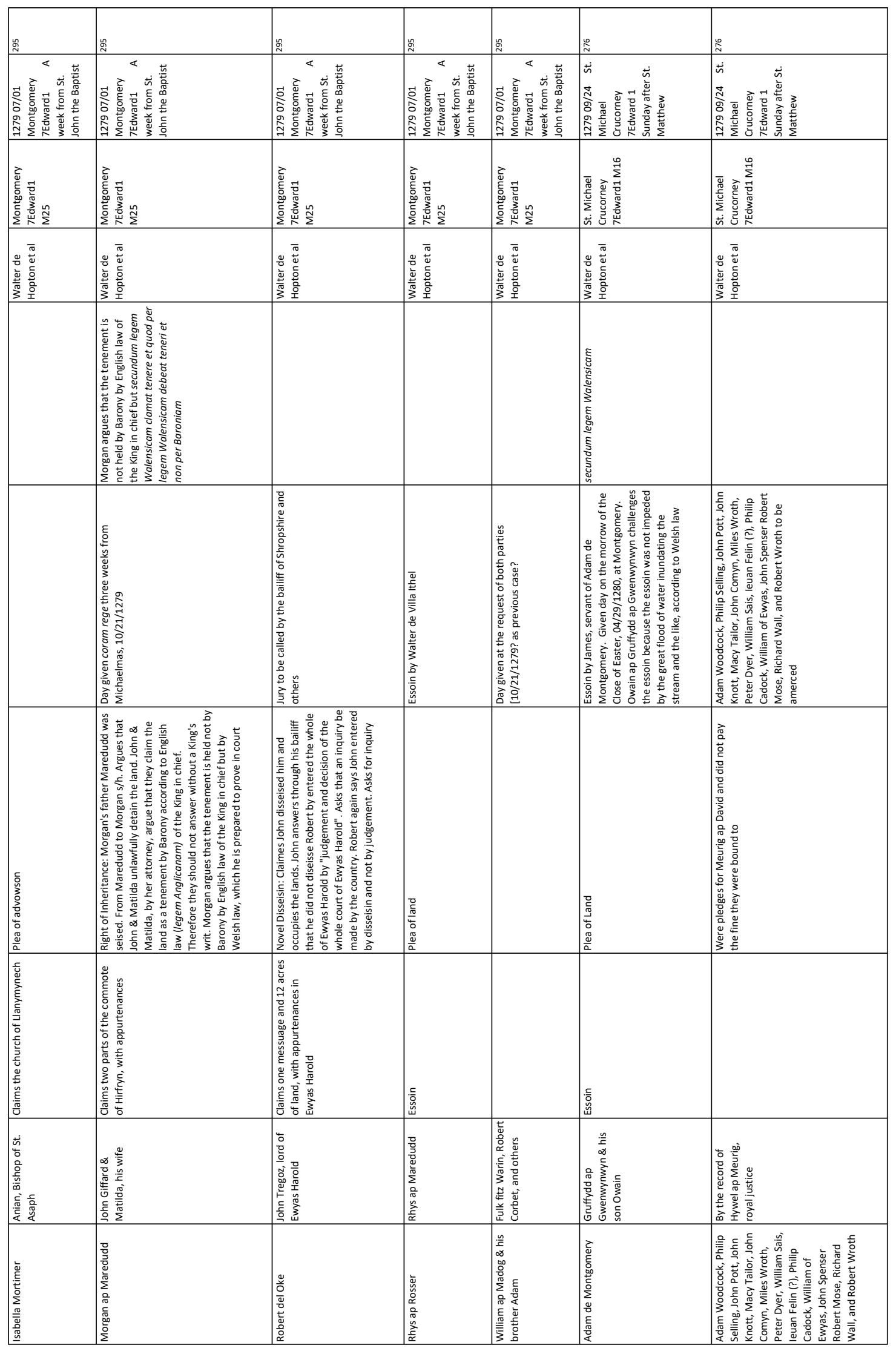




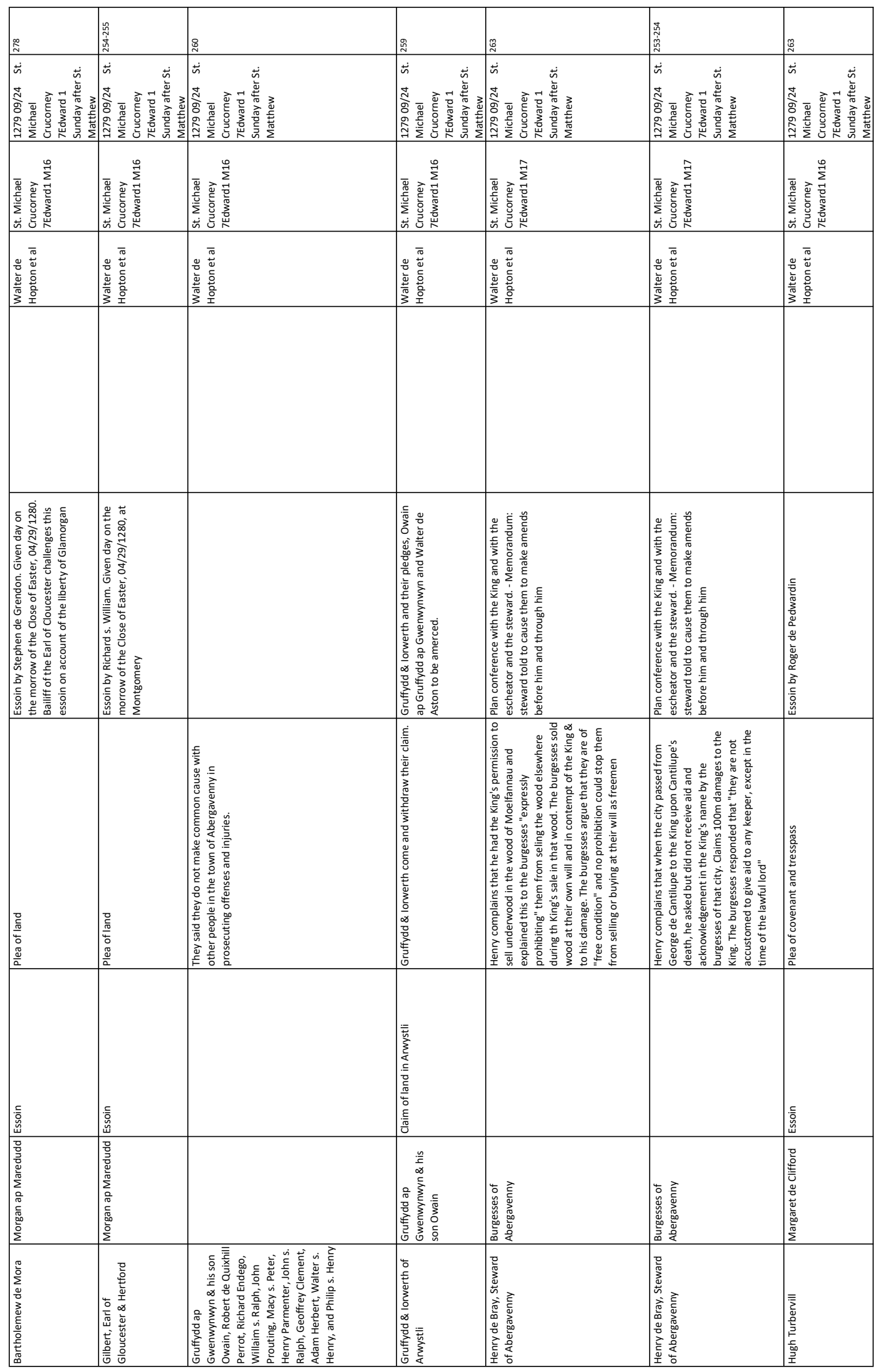




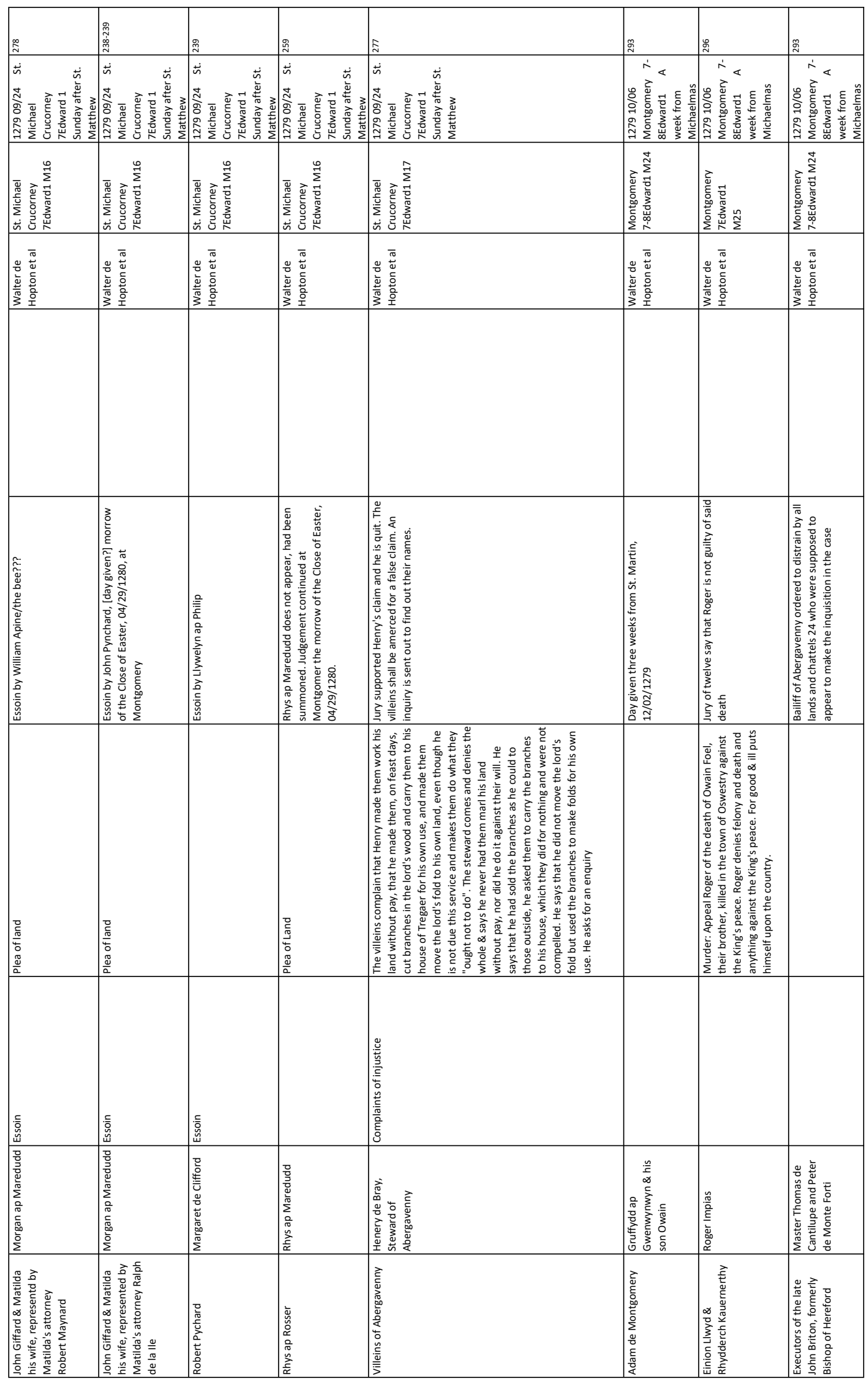




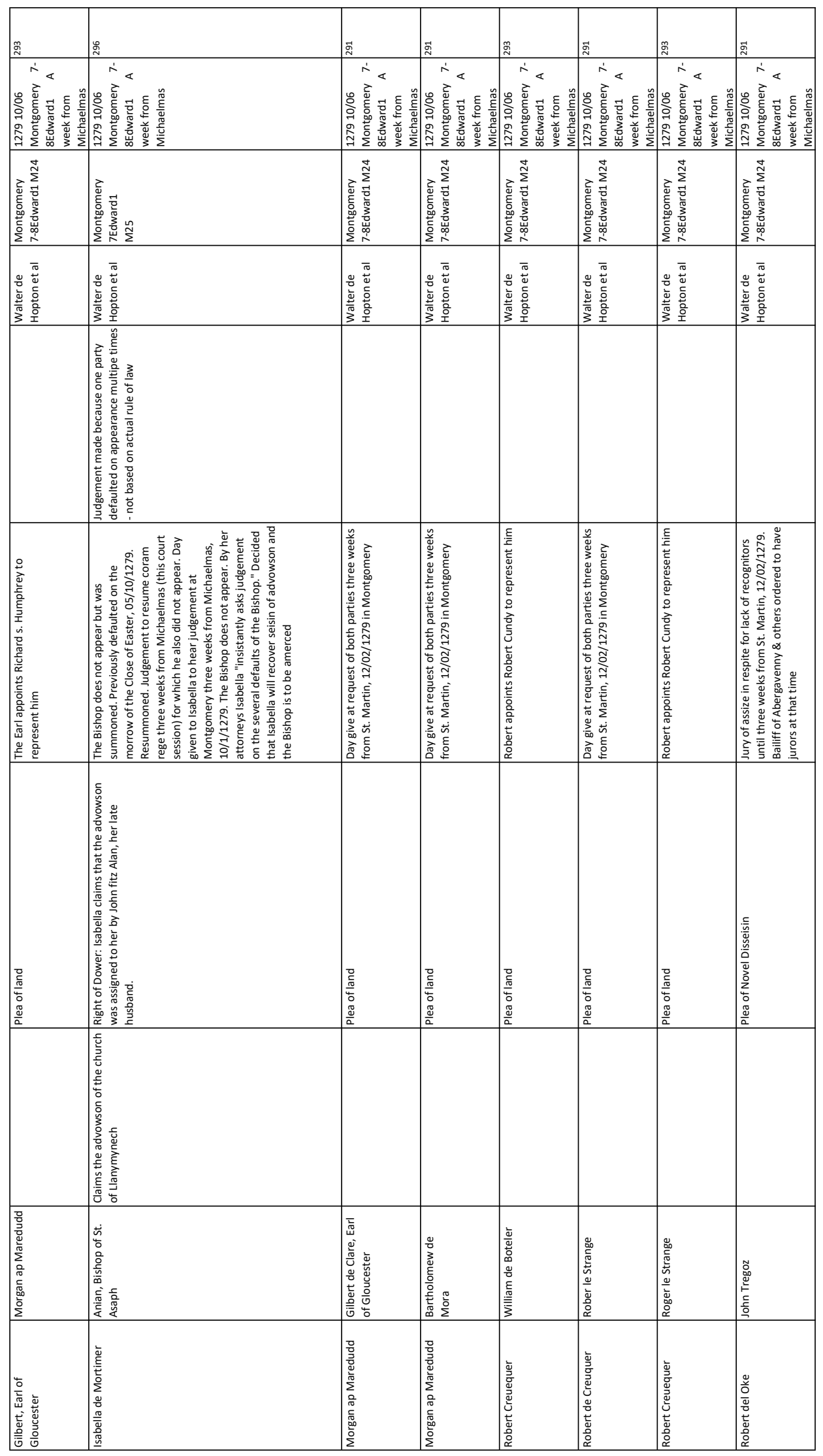




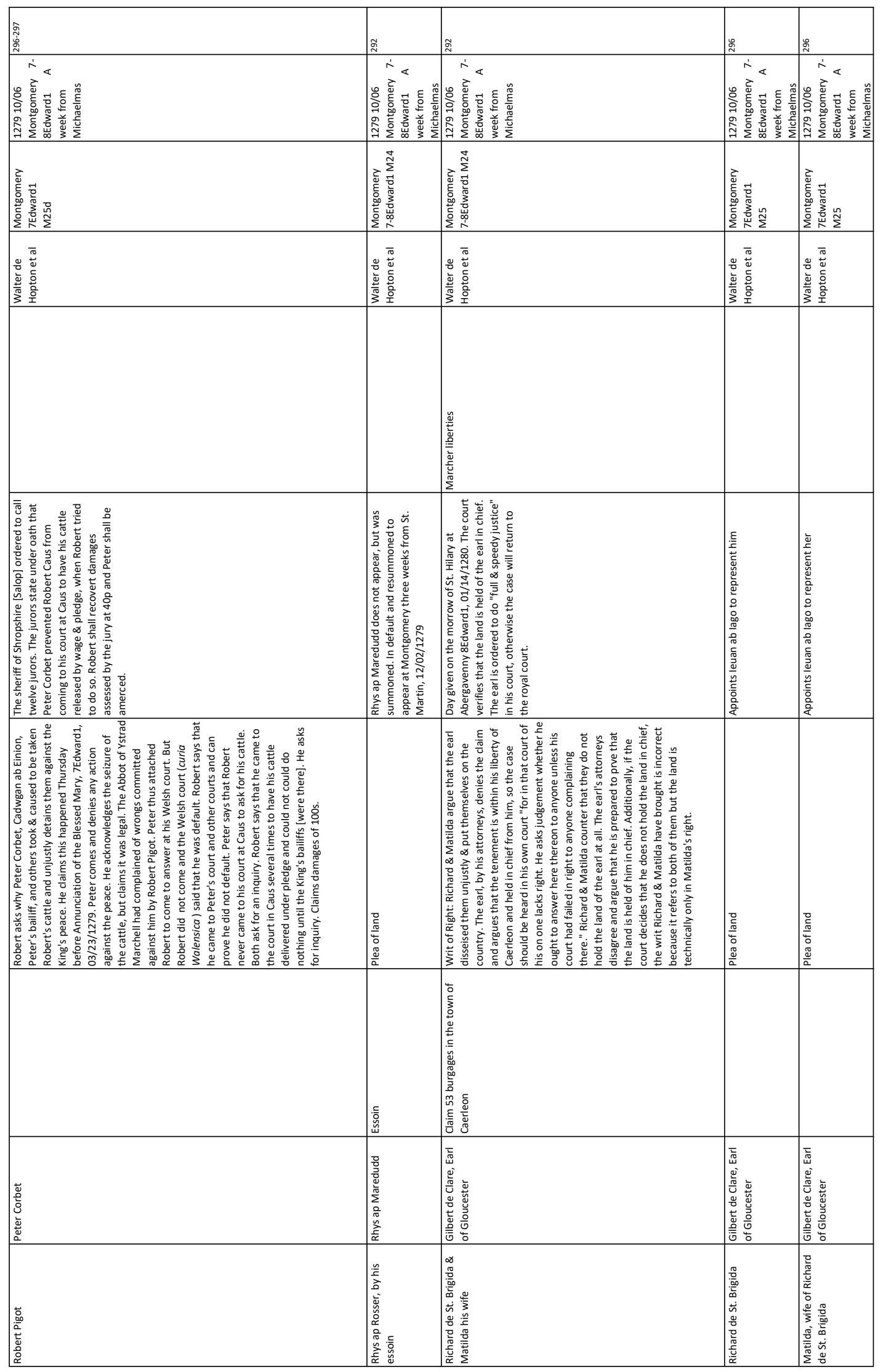




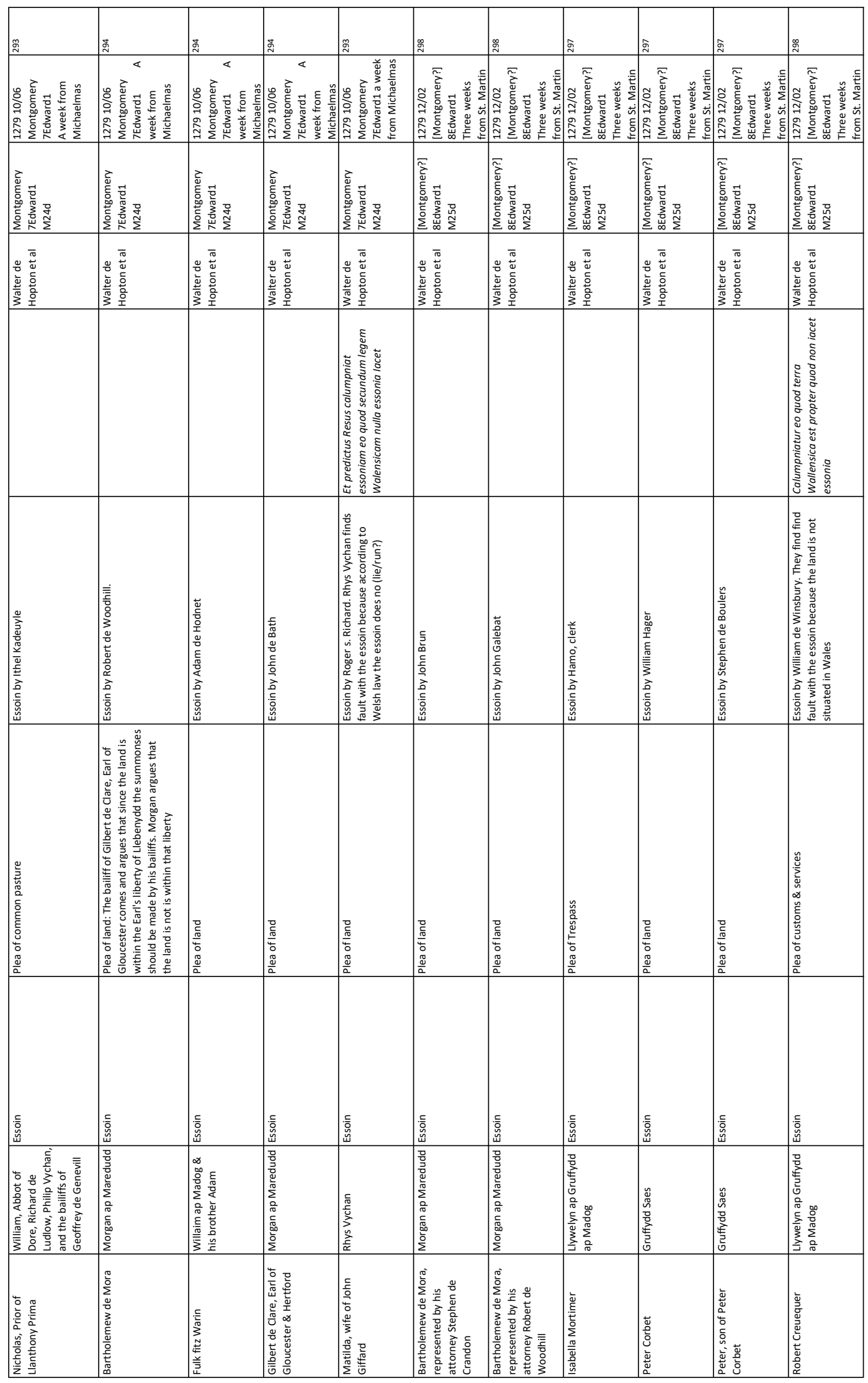




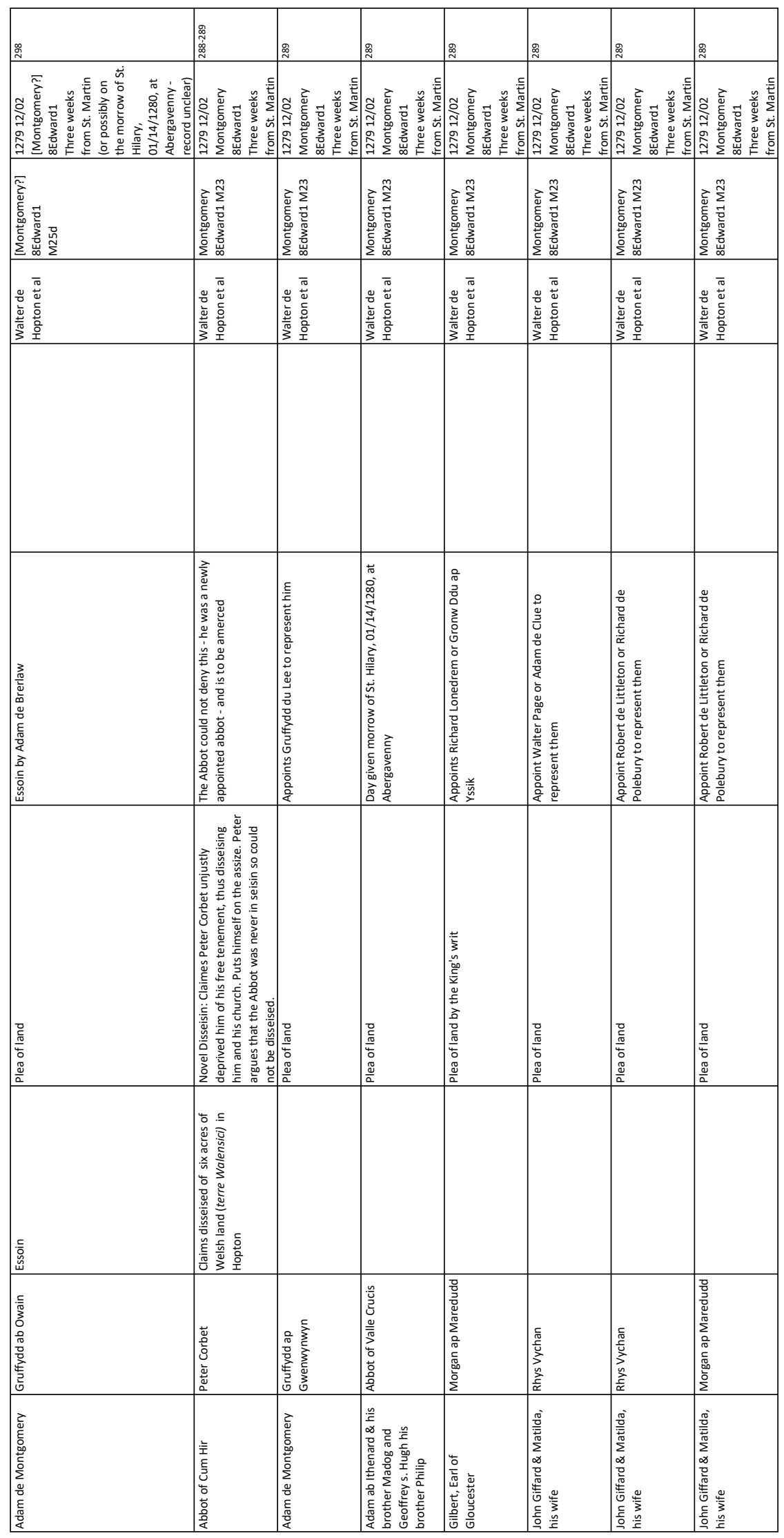




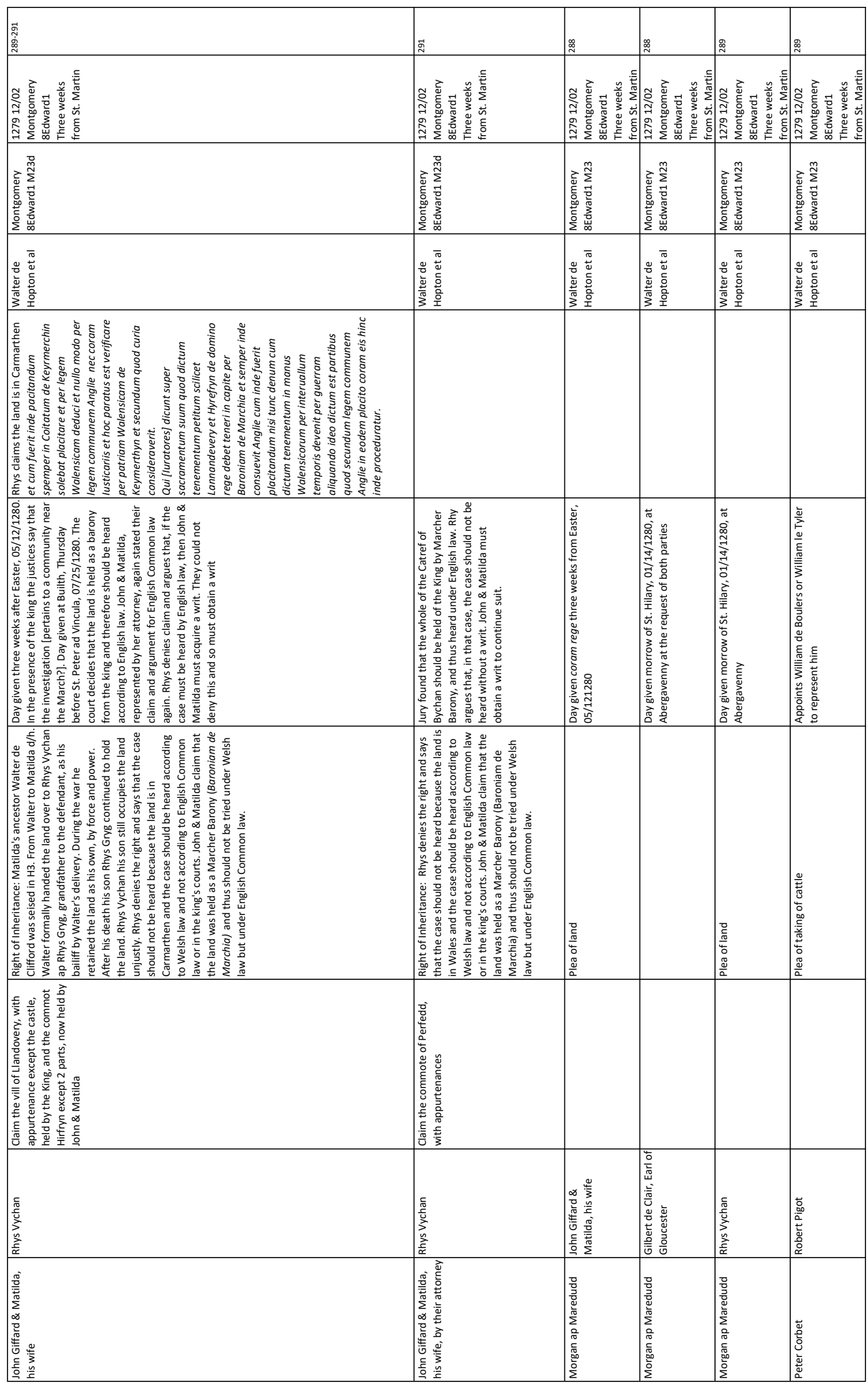




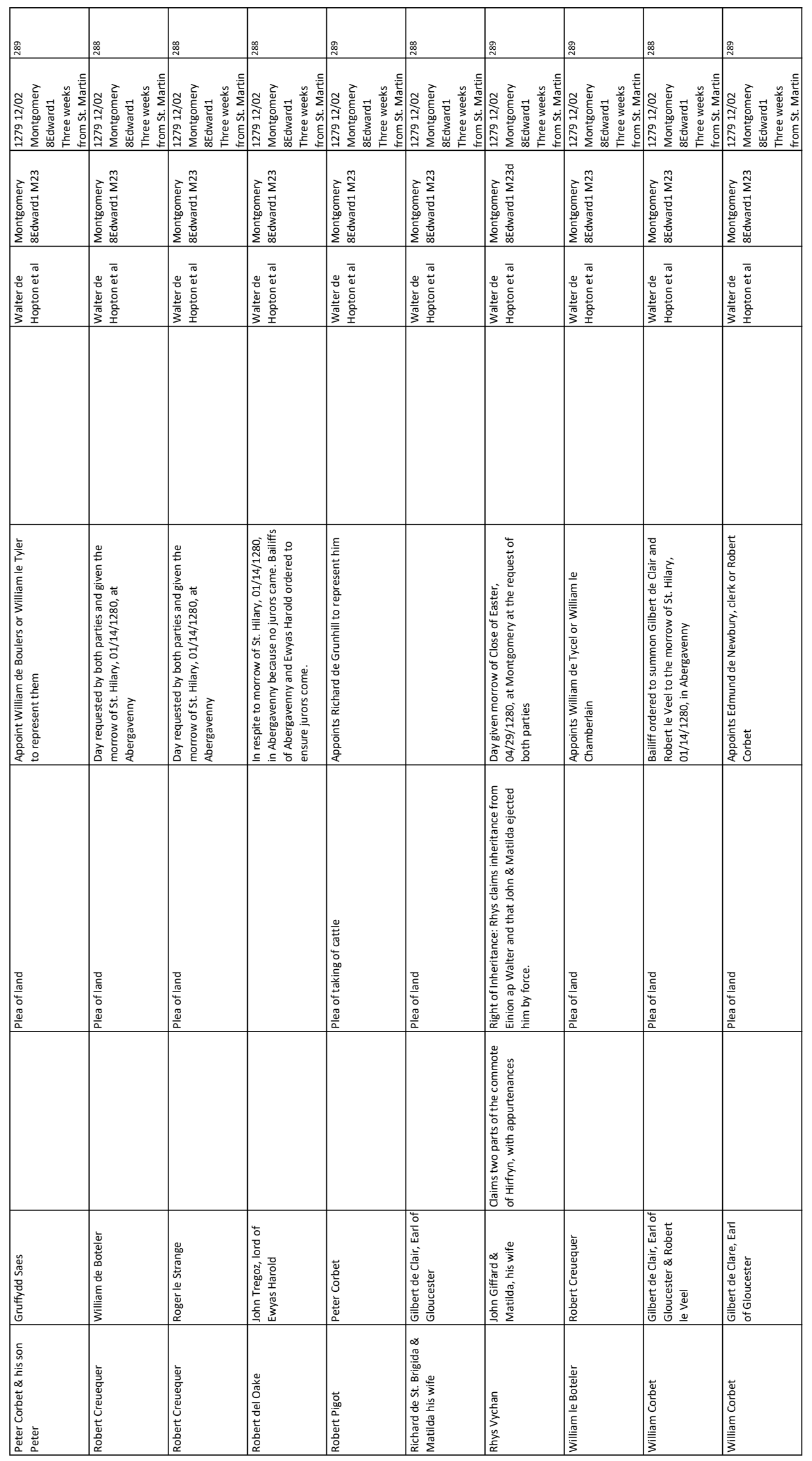




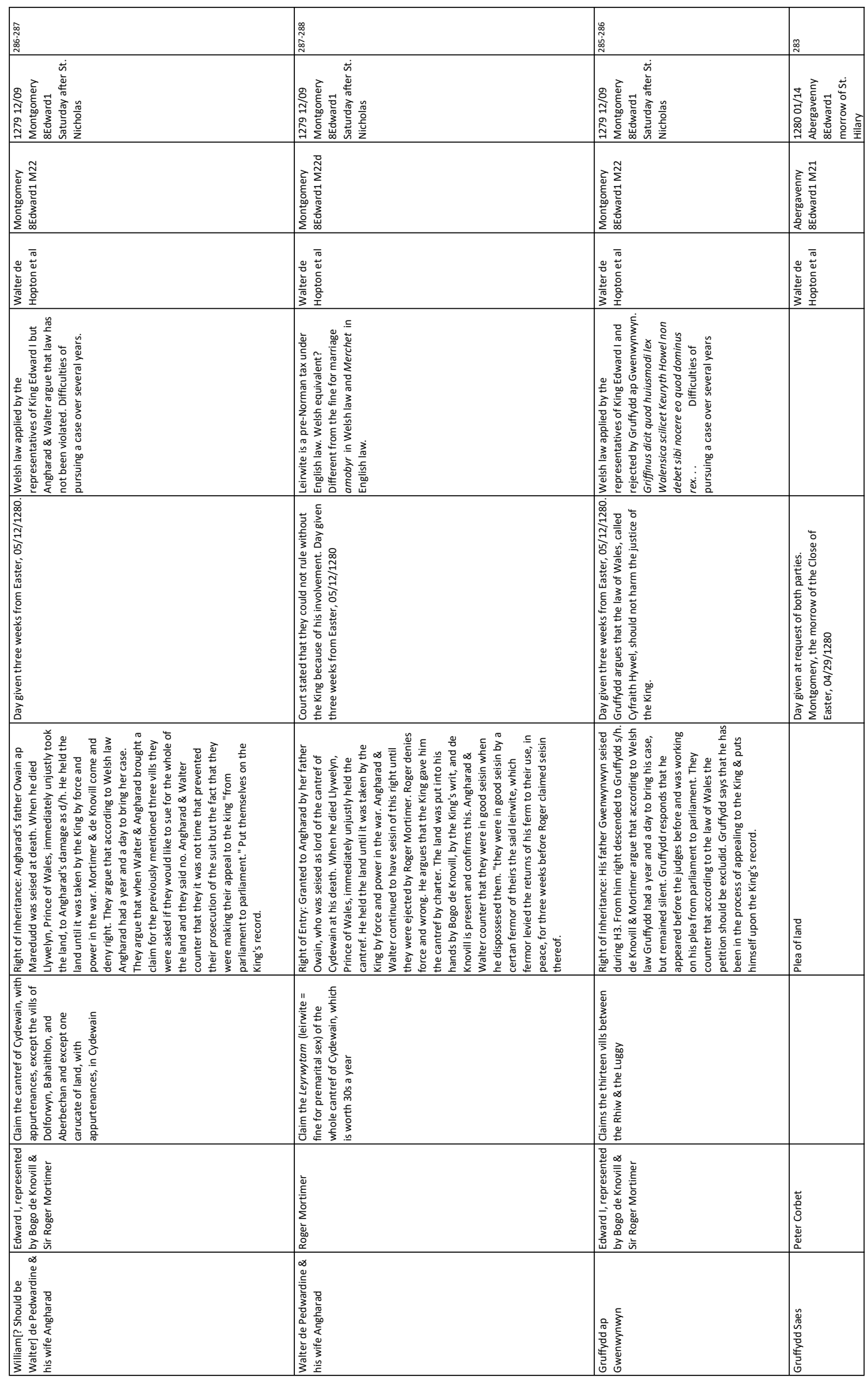




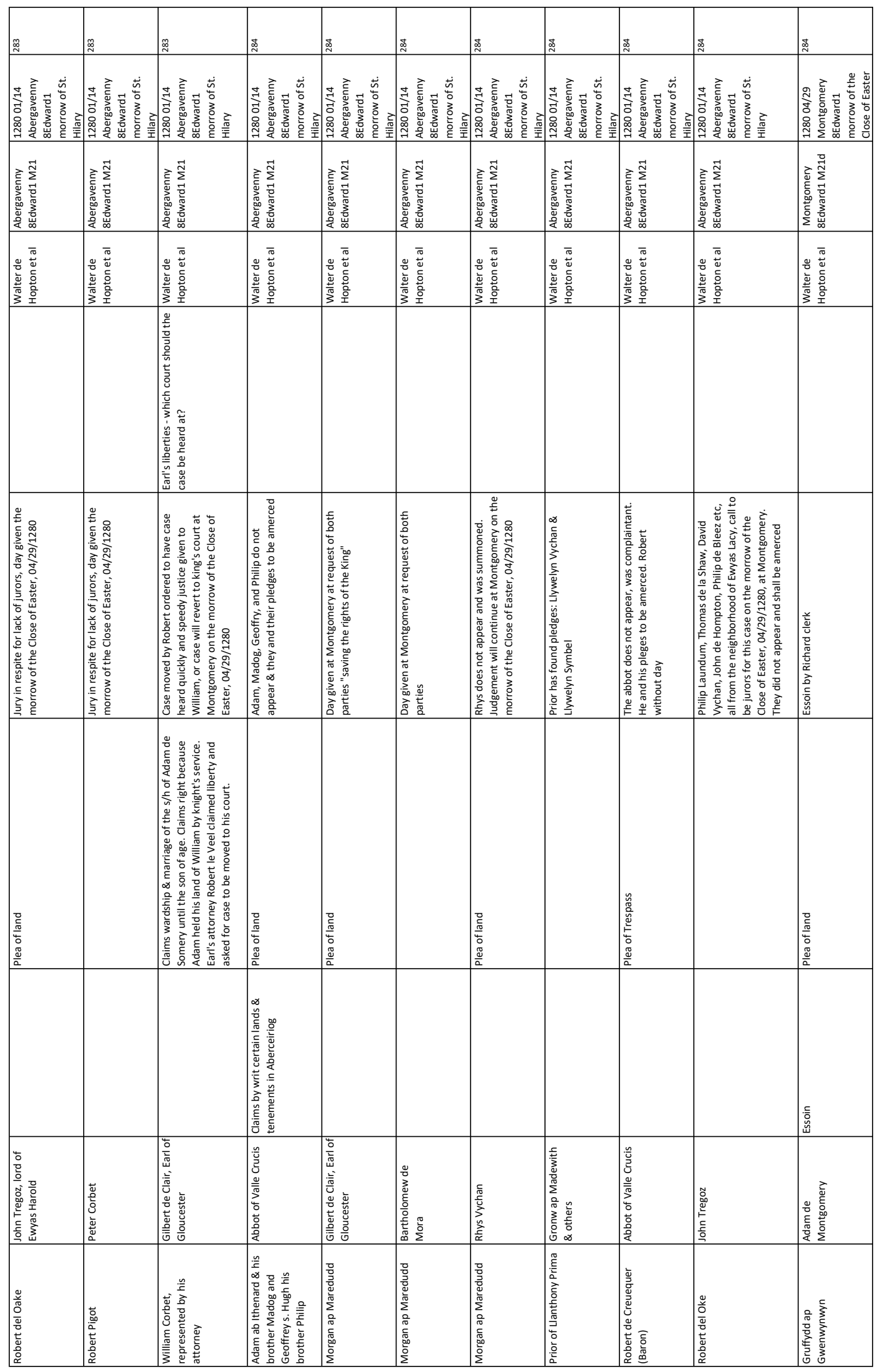




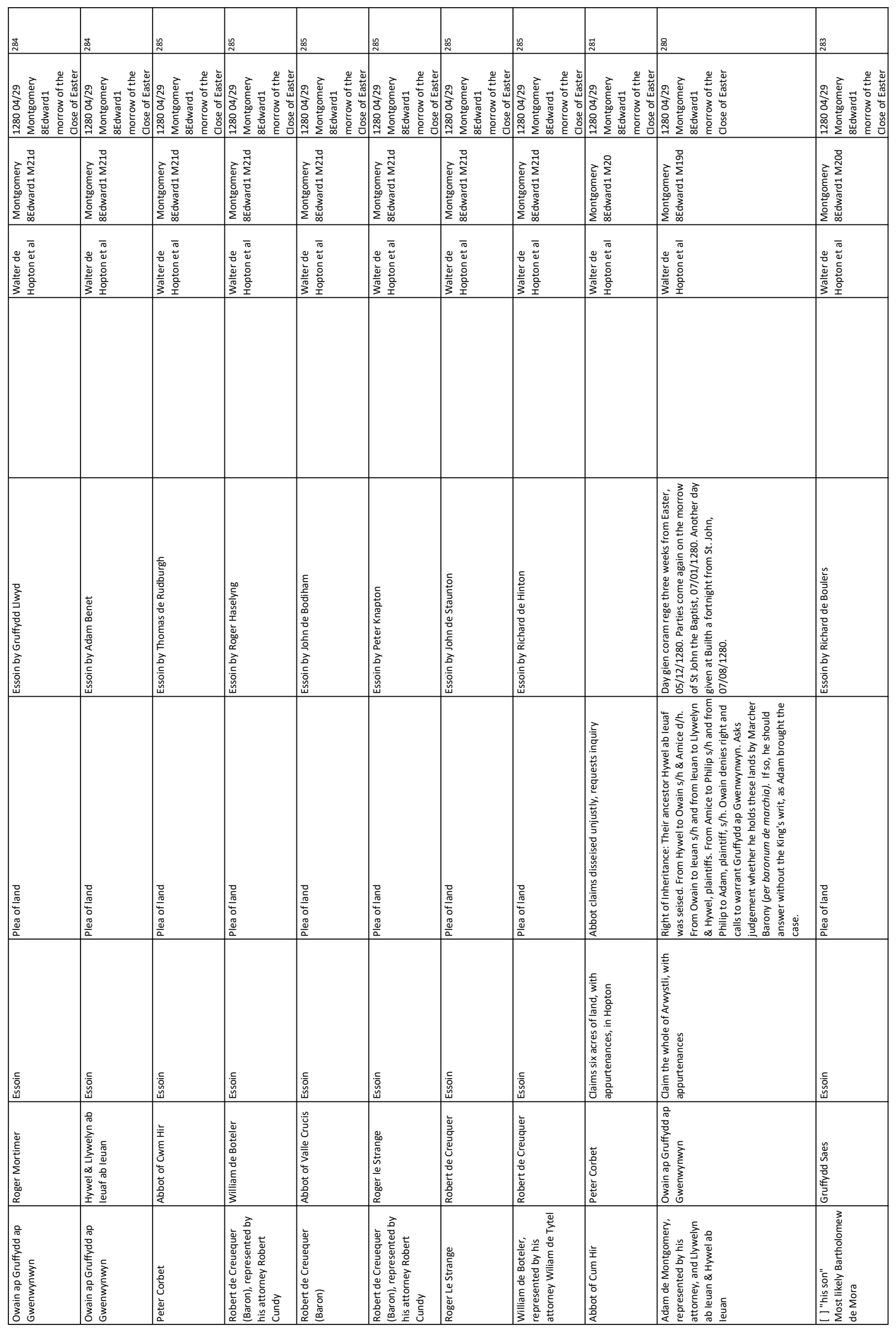




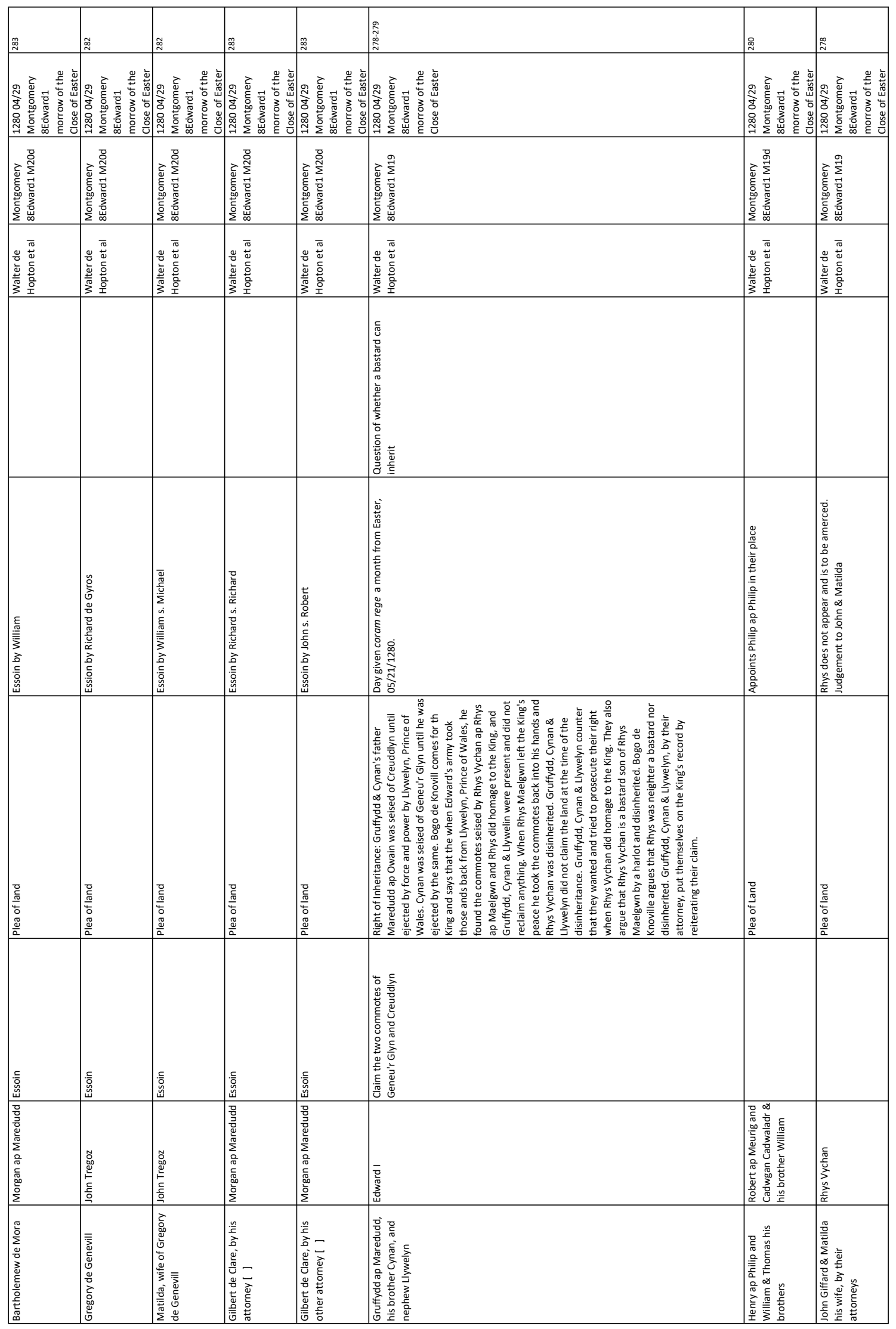




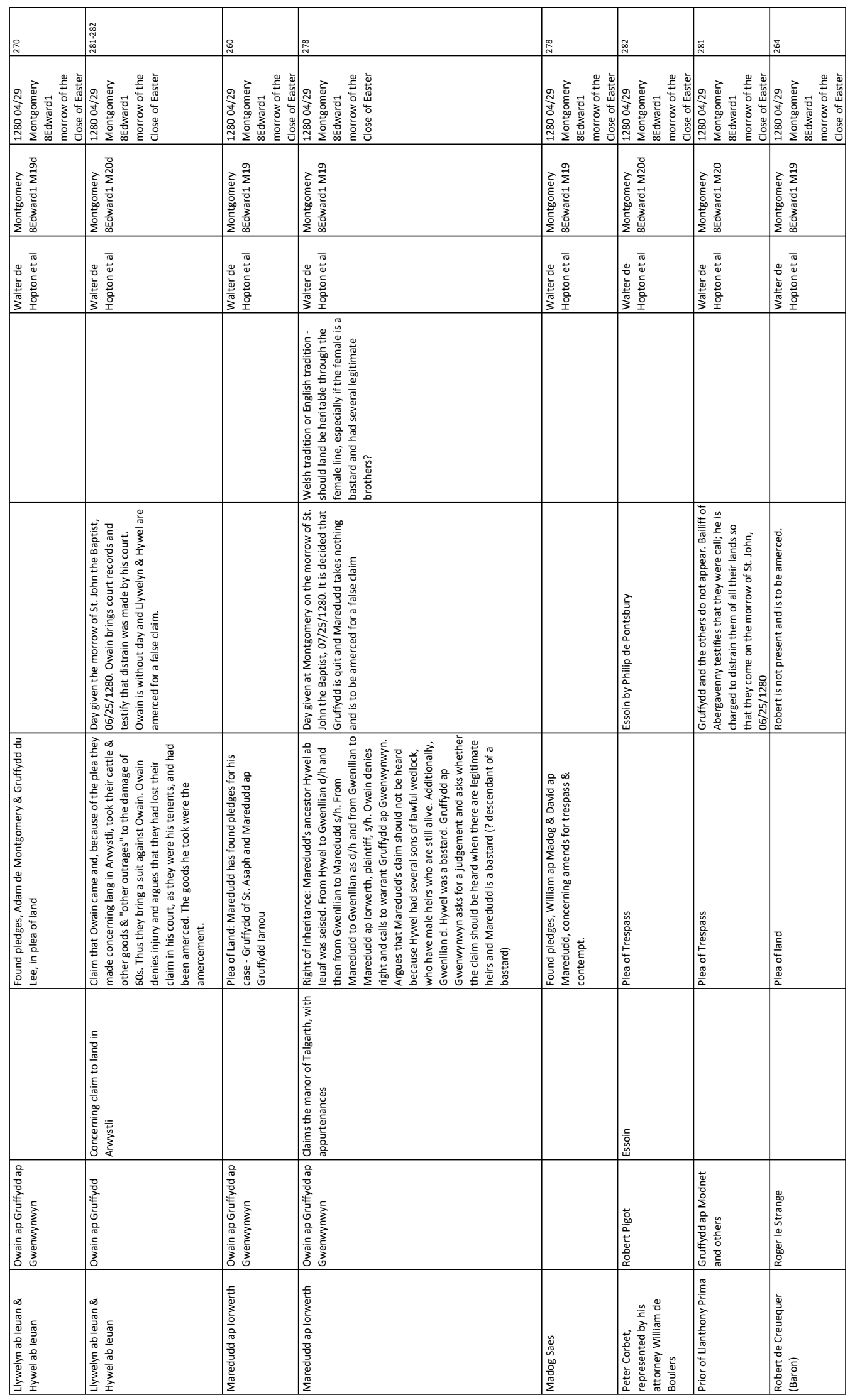




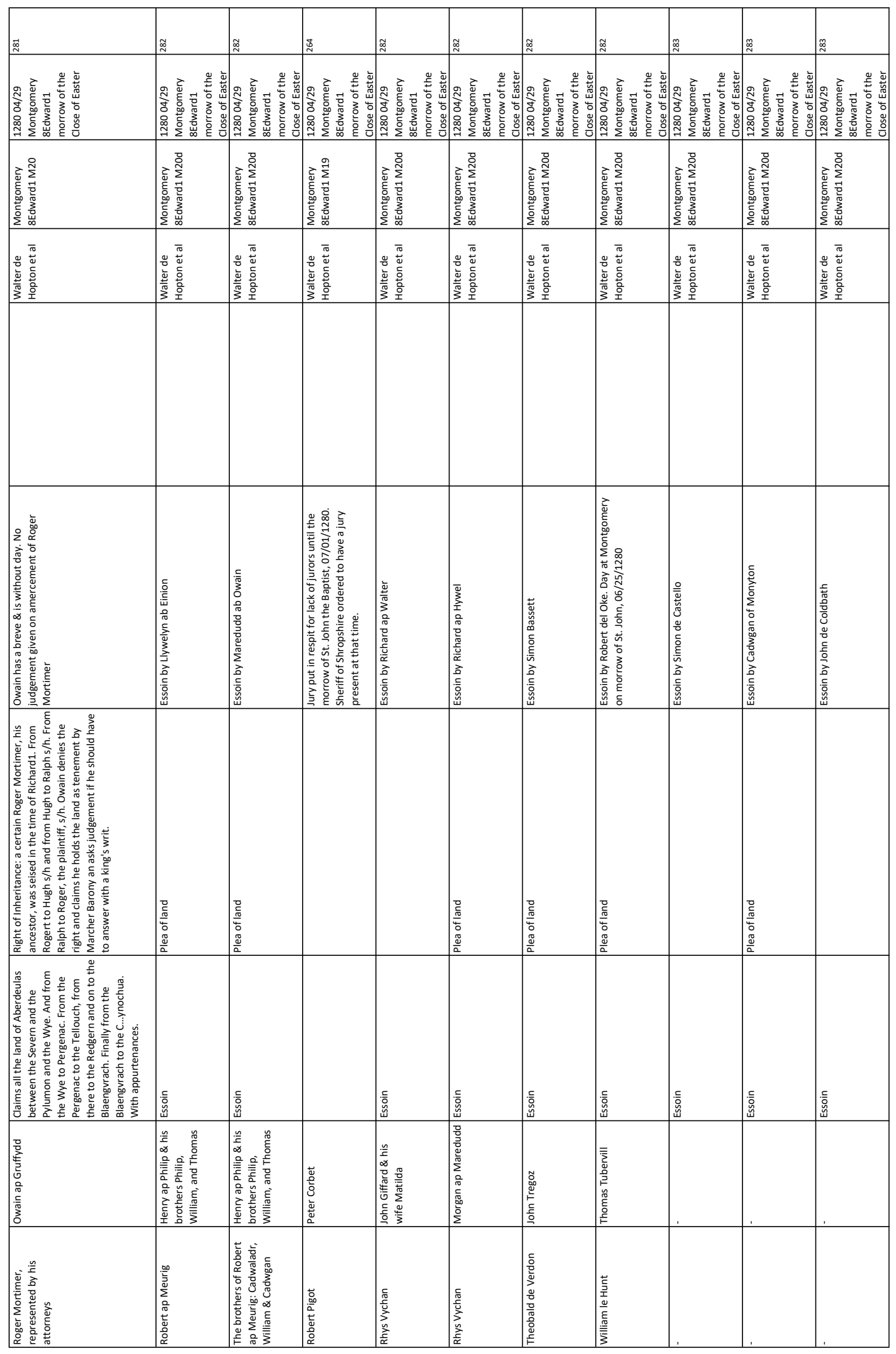




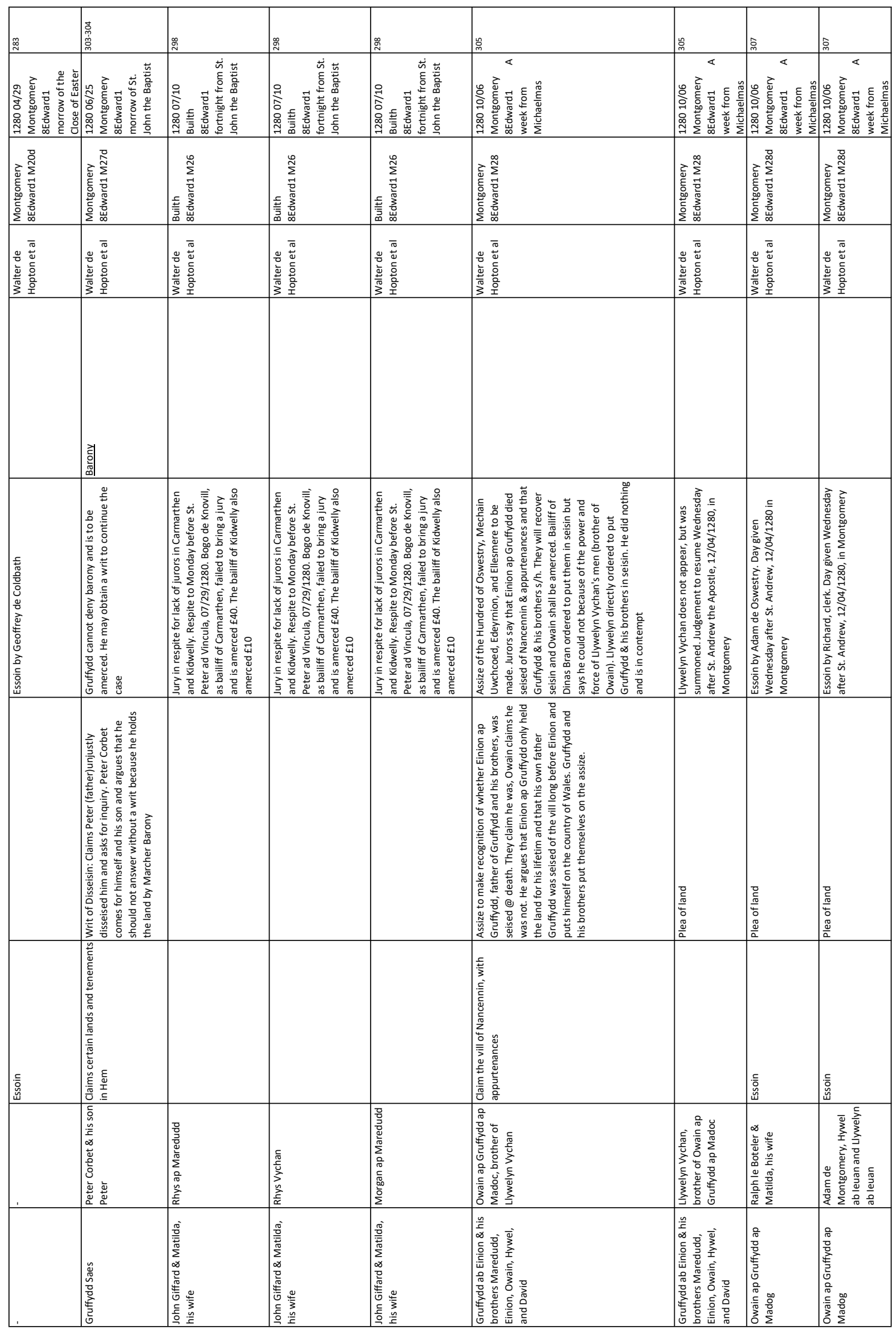




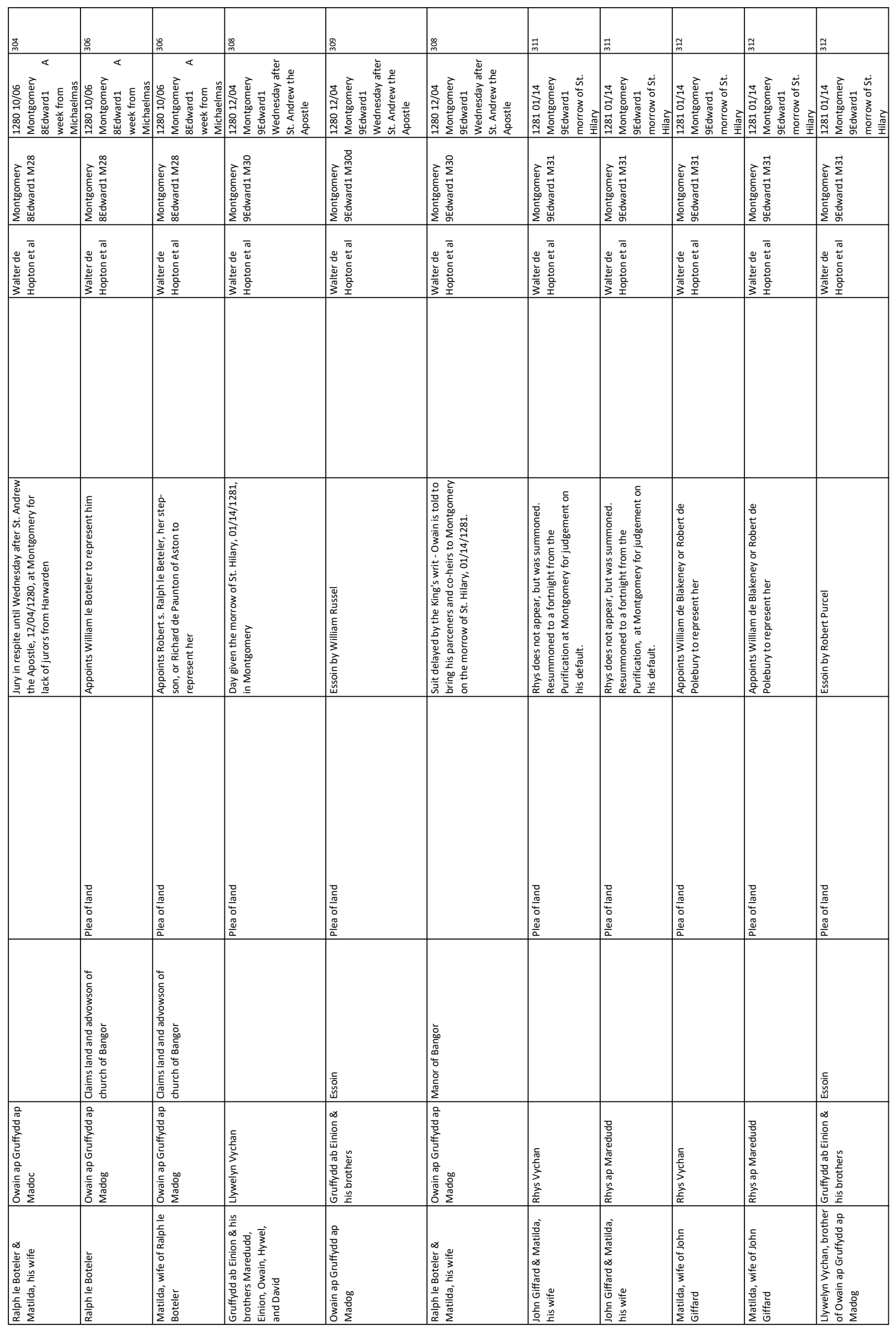




\begin{tabular}{|c|c|c|c|c|c|c|}
\hline 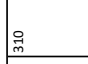 & $\frac{m}{m}$ & $\frac{\infty}{\pi}$ & 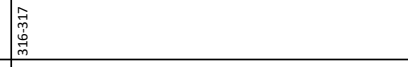 & 㐫 & 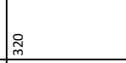 & 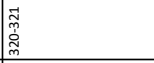 \\
\hline 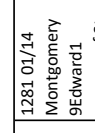 & 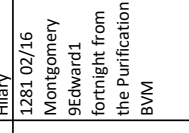 & 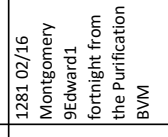 & 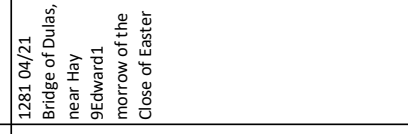 & 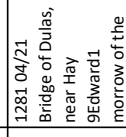 & 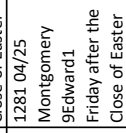 & 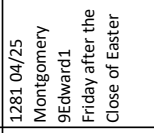 \\
\hline & 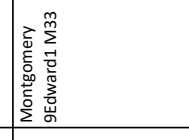 & 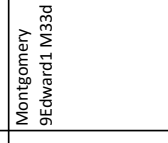 & 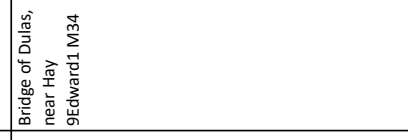 & 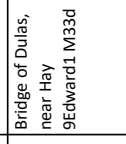 & 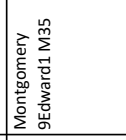 & 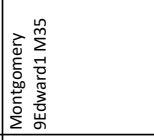 \\
\hline 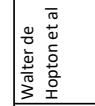 & 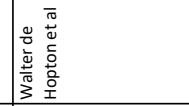 & 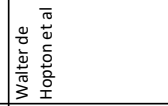 & 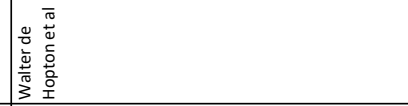 & 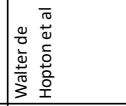 & 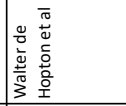 & 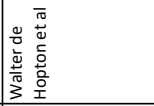 \\
\hline 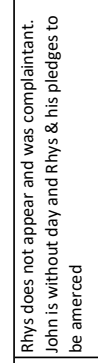 & 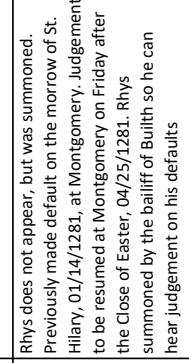 & 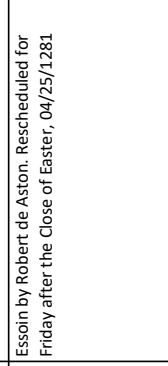 & 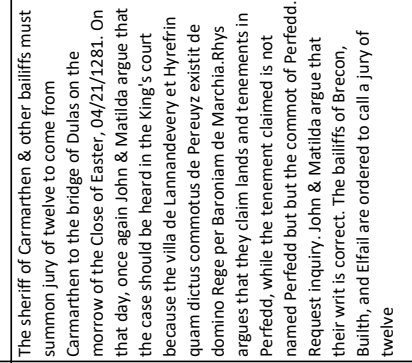 & 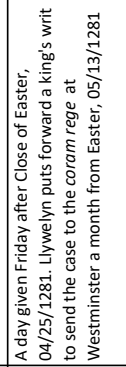 & 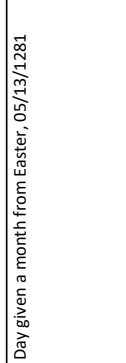 & 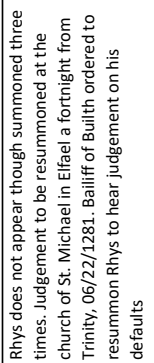 \\
\hline 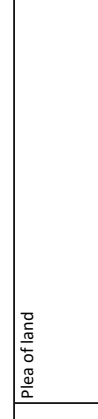 & 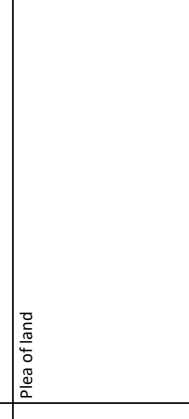 & 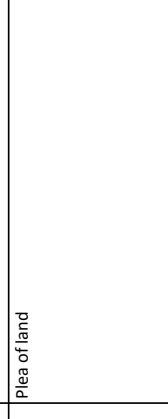 & 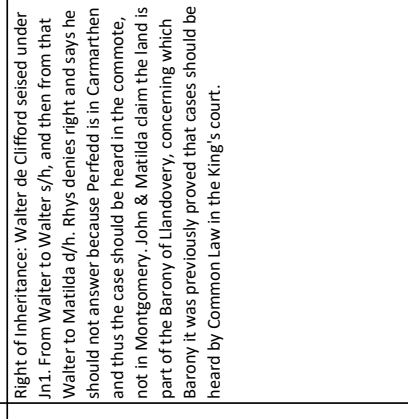 & 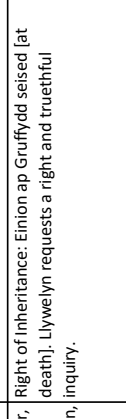 & & \\
\hline & 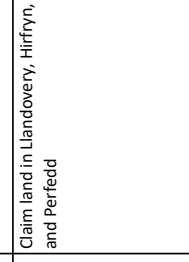 & 嵩 & 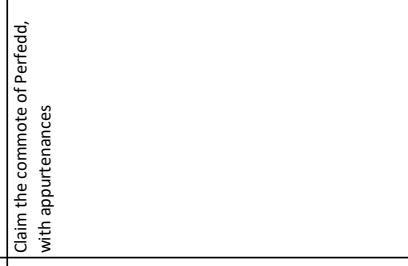 & 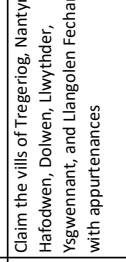 & 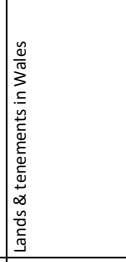 & \\
\hline 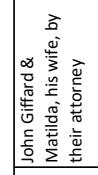 & 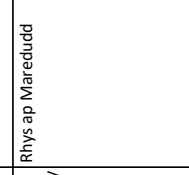 & 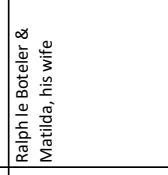 & 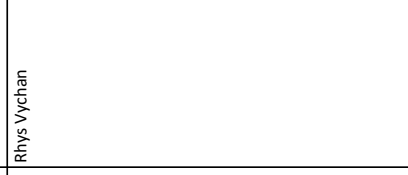 & 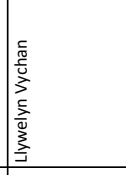 & 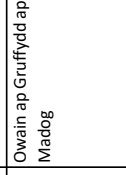 & 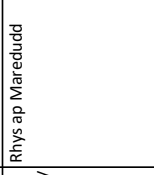 \\
\hline 咅 & 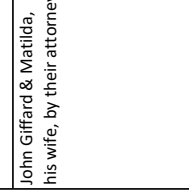 & 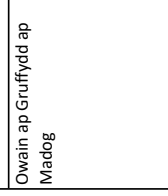 & & 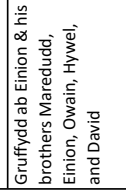 & 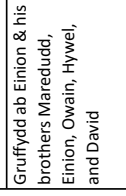 & 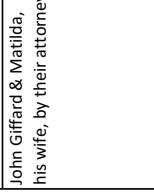 \\
\hline
\end{tabular}




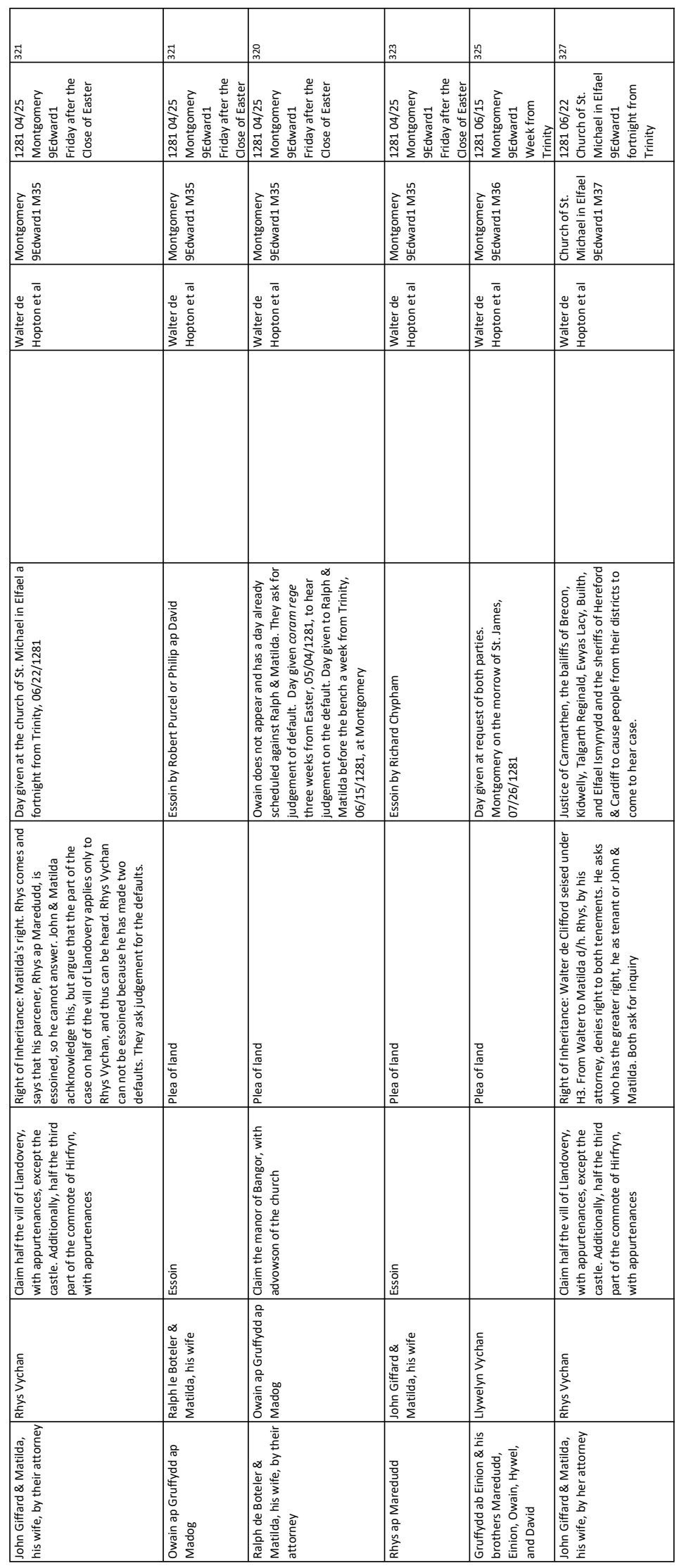




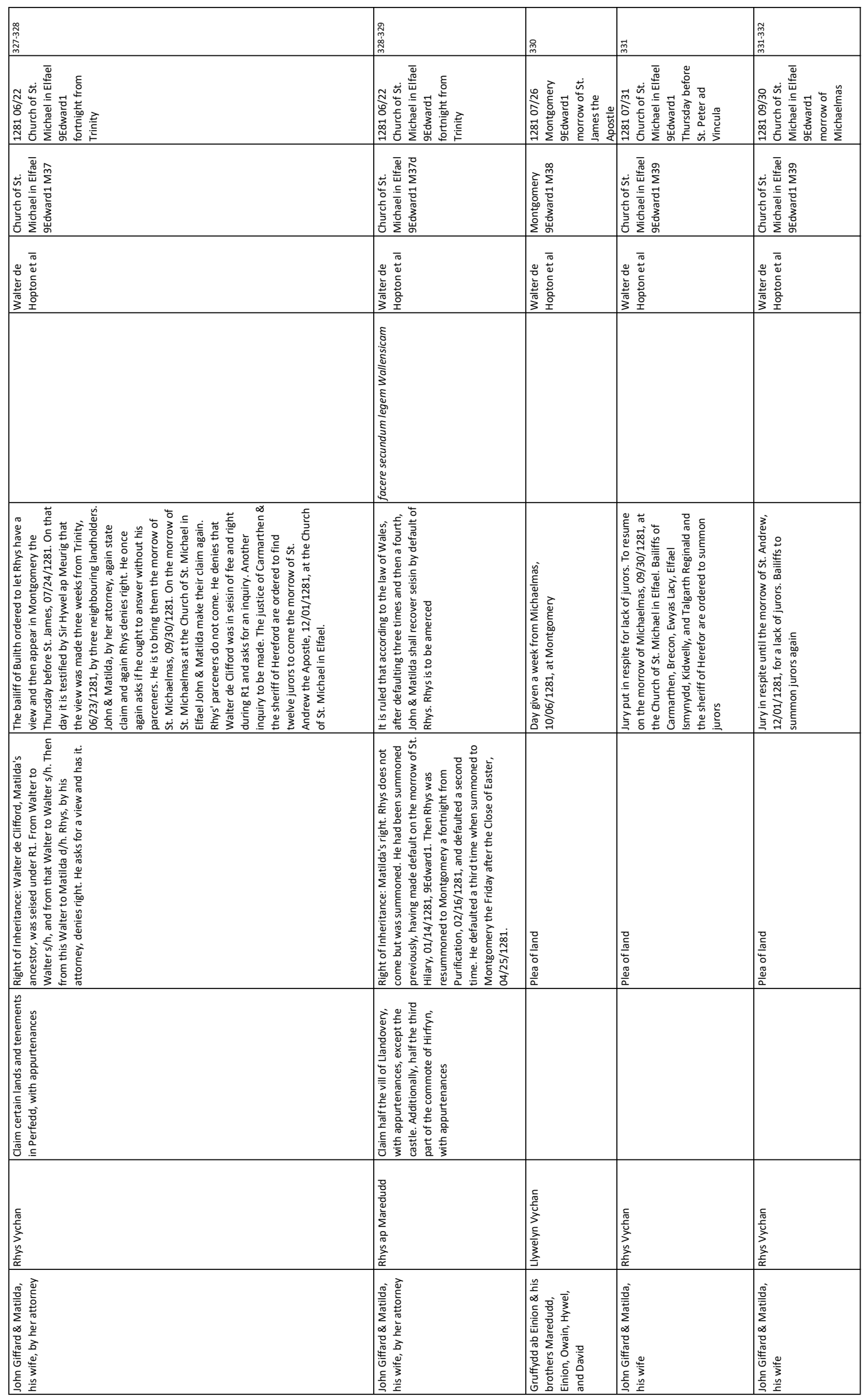




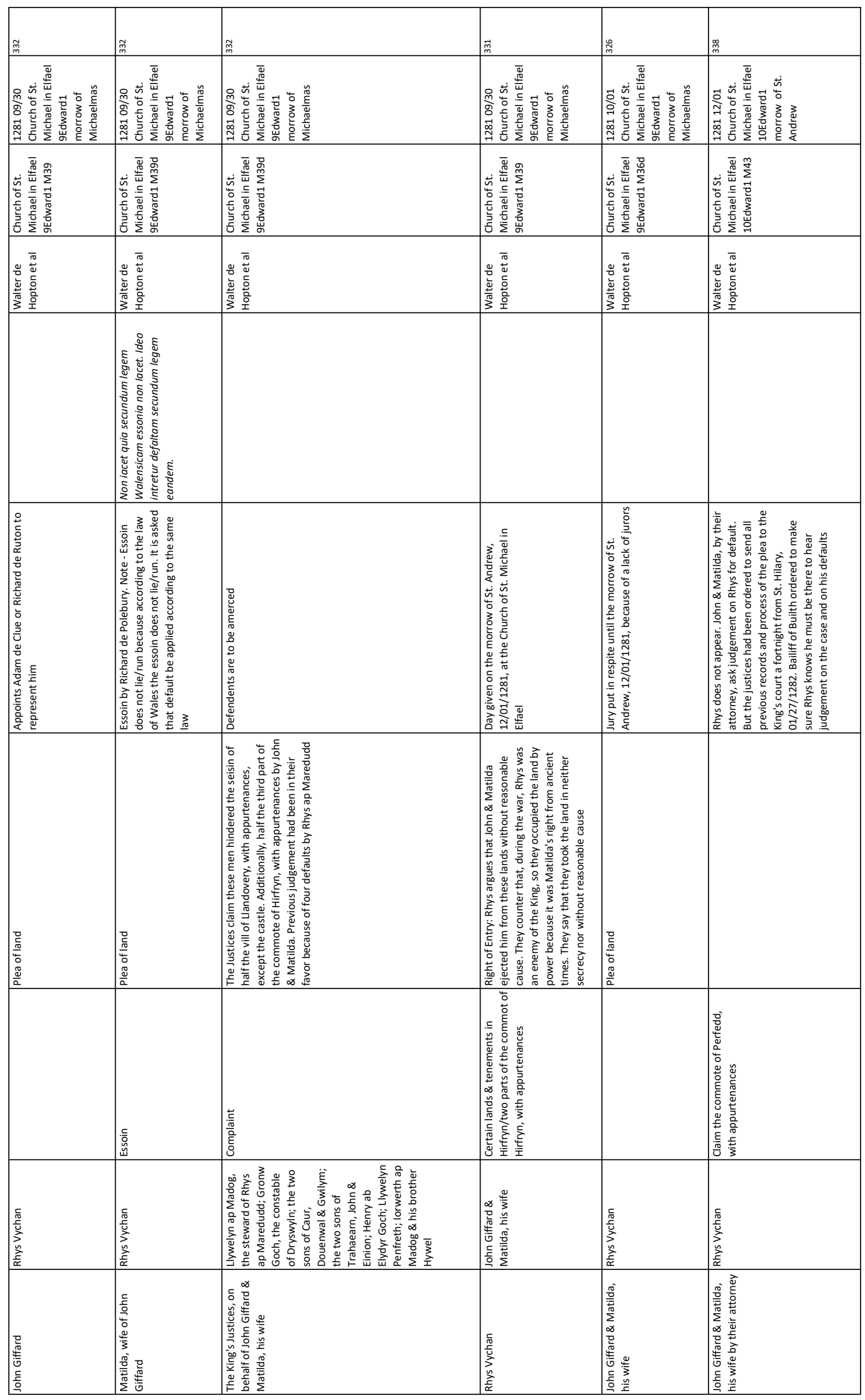




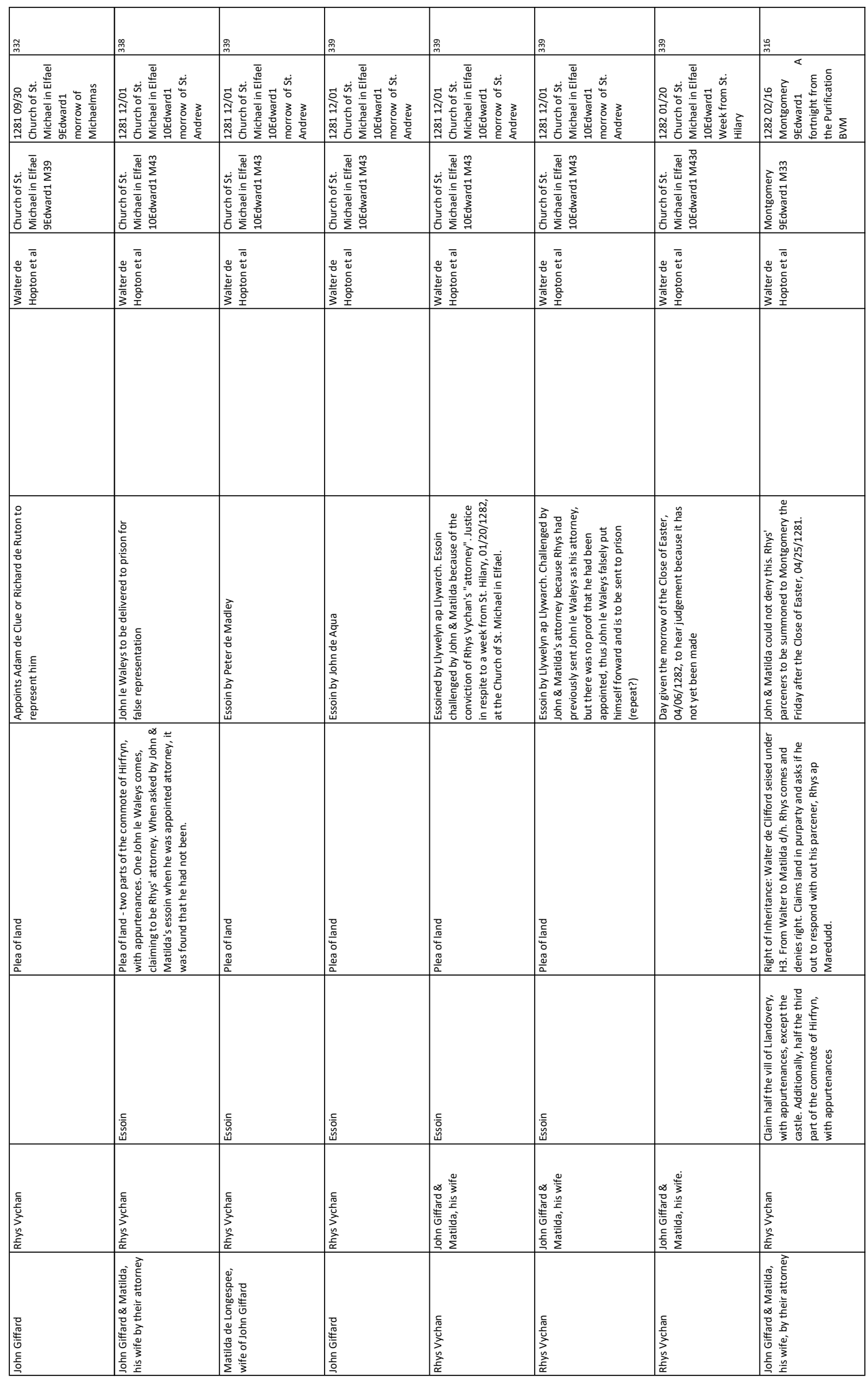




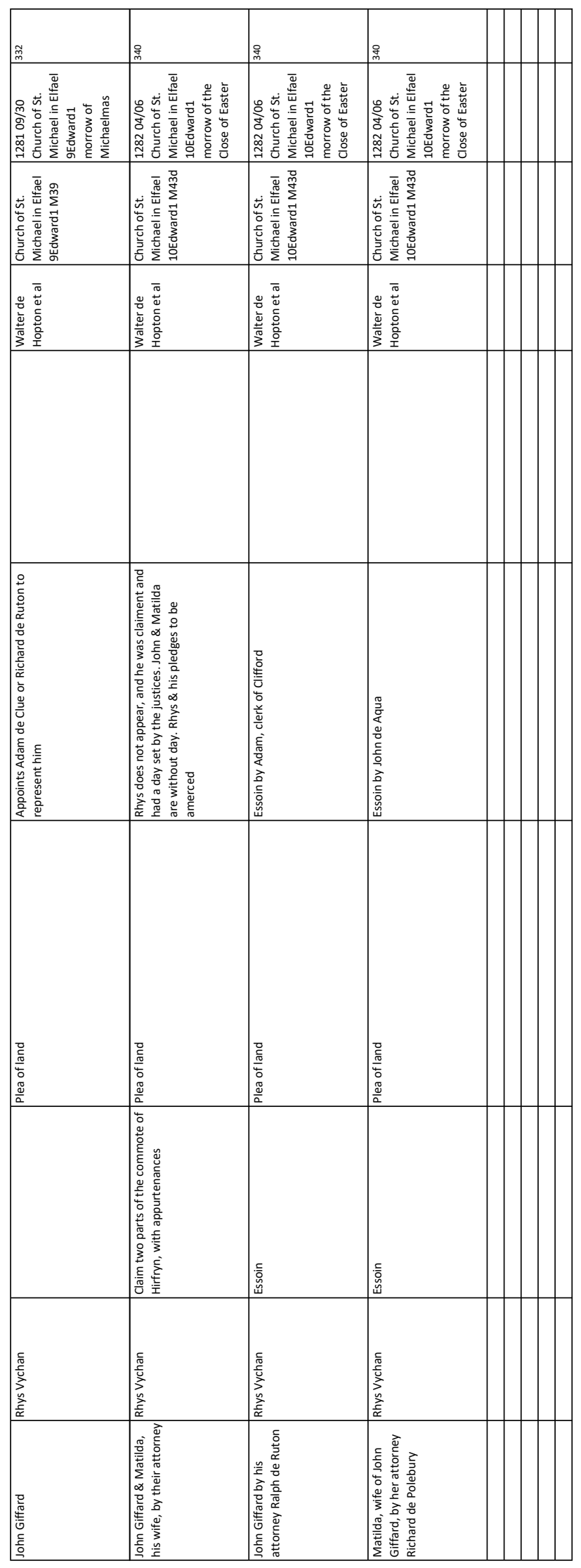




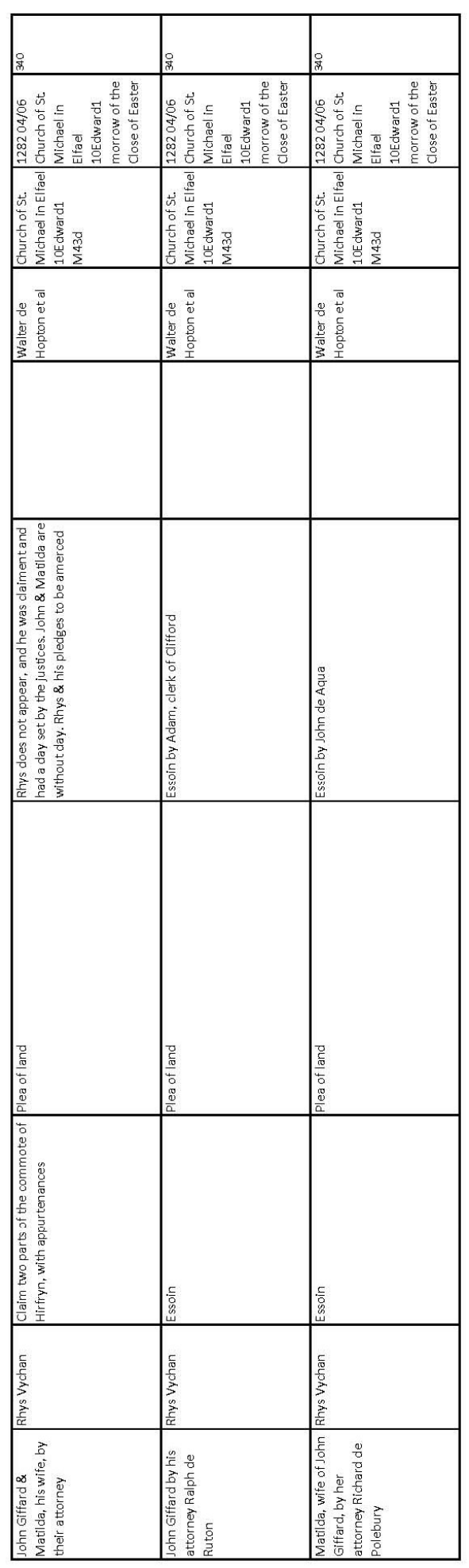




\section{Bibliography}

"\#42 Central Wales, with Dates of Commencement of Registers for Parishes Formed before 1832." Canterbury: The Institute of Heraldic \& Genealogical Studies. 1995.

"\#43 North Wales, with Dates of Commencement of Registers for Parishes Formed before 1832." Canterbury: The Institute of Heraldic \& Genealogical Studies. 1983.

"\#44 South Wales, with Dates of Commencement of Registers for Parishes Formed before 1832." Canterbury: The Institute of Heraldic \& Genealogical Studies. 1998.

Anderson, Benedict. Imagined Communities: Reflections on the Origin and Spread of Nationalism. Revised ed. New York: Verso, 1991.

Anon. "Untitled - a Fragment of a History Written Late in the Thirteenth Century and Possibly Drawn up by One of Archbishop Peckham's Clerks at the Time When $\mathrm{He}$ Was Occupied with the Welsh Negotiations." In Historical Manuscripts Commission Report on Mss. in various collections, 246-50. 1901.

Bartlett, Robert. The Making of Europe: Conquest, Colonization and Cultural Change 950-1350. Princeton: Princeton University Press, 1993.

__ . "Medieval and Modern Concepts of Race and Ethnicity." Journal of Medieval and Early Modern Studies 31 (2001).

Barton, P. G. . "Gruffudd Ap Gwenwynwyn's Trefnant Market 1279-1282." Montgomeryshire Collections 90 (2002): 69-86.

Bartrum, Peter C. Welsh Genealogies: Ad 300-1400. 8 vols Cardiff: University of Wales Press, Board of Celtic Studies, 1974.

"The Bartrum Project." In www.cadair.aber.uk. University of Wales-Aberystwyth.

Beverley Smith, J. . "Judgement under the Law of Wales." Studia Celtica 39 (2005): 63103.

Beverley Smith, Llinos. "A Contribution to the History of Galanas in Late-Medieval Wales." Studia Celtica 43 (2009): 87-94.

—_. "The Statute of Wales, 1284." Welsh History Review 10, no. 2 (1980): 127-54.

Borroff, Marie, ed. Sir Gawain and the Green Knight, Patience, and Pearl: Verse Translation. New York: W. W. Norton \& Company, 2001. 
Bowen, Ivor, ed. The Statutes of Wales. London: T. Fisher Unwin, 1908.

Brut Y Tywysogion: The Gwentian Chronicle of Caradoc of Llancarvan. London: J. R. Smith, 1862. Electronic Book, not in copywrite. http://www.archive.org/details/brutytywysogiong00cararich.

Calendar of Charter Rolls Henry Iii-Edward I Ad 1257-1300. Vol. 2, London: Public Records Office, 1906.

Calendar of Charter Rolls Henry Iii Ad 1226-1257. Vol. 1, London: Public Records Office, 1903.

Cartwright, Jane. "The Desire to Corrupt: Convent \& Community in Medieval Wales." In Medieval Women in Their Communities, edited by Watt, 20-48. Toronto: University of Toronto Press, 1997.

- Feminine Sanctity and Spirituality in Medieval Wales. Cardiff: University of Wales Press, 2008.

Cavell, Emma. "Aristocratic Widows and the Medieval Welsh Frontier: The Shropshire Evidence: The Rees Davies Prize Essay." Transactions of the Royal Historical Society 17, no. ArticleType: research-article / Full publication date: 2007 / Copyright (C) 2007 Royal Historical Society (2007): 57-82.

—. "Noblewomen in Shropshire and the Adjacent March of Wales, 1150-1350." Unpublished Dissertation: Balliol College Oxford. 2006.

Chapman-Stacey, Robin. "Divorce, Medieval Welsh Style." Speculum Oct (2002): 110727.

—_. "Learning to Plead in Medieval Welsh Law." Studia Celtica 38 (2004): 107-23.

Charles-Edwards, T. M. . Early Irish and Welsh Kinship. New York: Clarendon, 1993.

Cohen, Jeffrey Jerome. "Race." In A Handbook of Middle English Studies, edited by Marion Turner: John Wiley \& Sons, 2013.

Davies, J. Conway, ed. The Welsh Assize Roll, 1277-1284: Assize Roll No. 1147, History $\&$ Law Series, vol. VII. Cardiff: Board of Celtic Studies University of Wales, 1940.

Davies, John Reuben. "The Cult of Saints in the Early Welsh March: Aspects of Cultural Transmission in a Time of Political Conflict." In The English Isles: Cultural Transmission and Political Conflict in Britain and Ireland, 1100-1500, edited by S. Duffy and S. Foran, 37-55. Dublin: Four Courts Press, 2013.

_. "Old Testament Personal Names among the Britons: Their Occurrence and Significance before the Twelfth Century." Paper presented at the 18th Annual 
Conference of the Society for Name Studies in Britain and Ireland, Falmouth, 2009.

Davies, R. R. "Colonial Wales." Past \& Present, no. 65 (1974): 3-23.

- Conquest, Coexistence, and Change: Wales, 1063-1415 [in English]. The History of Wales, [V. 2]. Oxford; [Cardiff]: Clarendon Press ; University of Wales Press, 1987.

- Domination and Conquest : The Experience of Ireland, Scotland, and Wales, 1100-1300 [in English]. Cambridge; New York: Cambridge University Press, 1990.

- The First English Empire: Power and Identities in the British Isles 1093-1343. New York: Oxford University Press, 2000.

—. "The Identity of 'Wales' in the Thirteenth Century." In From Medieval to Modern Wales: Historical Essays in Honour of Kenneth O. Morgan and Ralph A. Griffiths, edited by Davies \& Jenkins. Cardiff: University of Wales Press, 2004.

- Lordship \& Society in the March of Wales, 1282-1400. Oxford: Oxford University Press, 1978.

_ Williams Lecture 1973." Transactions of the Honorable Society of Cymmrodorion (1974/1975): 32-56.

Emanuel, Hywel David. The Latin Texts of the Welsh Laws [in English]. Cardiff: Wales U.P., 1967.

Evans, E. Estyn. "An Essay on the Historical Geography of the ShropshireMontgomeryshire Borderland." Montgomeryshire Collections 40 (1923): 242-71.

Eyton, R. W. Antiquities of Shropshire. 8 vols Shiffnal: John Russell Smith 1854-1860.

The Oxford Dictionary of Saints. 5th revised ed. 2011.

Gerald of Wales. "The Journey through Wales and the Description of Wales." In Gerald of Wales: The Journey through Wales and The Description of Wales, edited by Lewis Thorpe. New York: Penguin. 1978.

Given, James. "The Economic Consequences of the English Conquest of Gwynedd." Speculum 64, no. 1 (1989): 11-45.

Goldenberg, David M. . "The Development of the Idea of Race: Classical Paradigms and Medival Elaborations, a Review of Ivan Hannaford Race: The History of an Idea in the West." International Journal of the Classical Tradition (Spring 1999): 56170 . 
Golding, Brian. Conquest and Colonization: The Normans in Britain, 1066-1100. British History in Perspective. edited by Jeremy Black. Rev. ed. Basingstoke: Palgrave, 2001.

Griffiths, Ralph Alan. "Owain Glyndwr and the Seige of Coity Castle, 1404-1405." Morgannwg: Transactions of the Glamorgan Local History Society 45 (2001): 528.

Hammond, Matthew. "Introduction: The Paradox of Medieval Scotland, 1093-1286." In New Perspectives on Medieval Scotland, edited by Matthew Hammond, 3-49. Woodbridge: The Boydell Press, 2013.

, ed. New Perspectives on Medieval Scotland, 1093-1286. Woodbridge: The Boydell Press, 2013.

Harding, Alan, ed. The Roll of the Shropshire Eyre of 1256. London: Selden Society, 1981.

Heng, Geraldine. "The Invention of Race in the European Middle Ages I: Race Studies, Modernity, and the Middle Ages." Literature Compass 8, no. 5 (2011): 315-31.

Holden, Brock. Lords of the Central Marches: English Aristocracy \& Frontier Society 1087-1265. Oxford: Oxford University Press, 2008.

Howe, Nicholas. "Introduction." In Visions of Community in the Pre-Modern World, edited by Nicholas Howe. Notre Dame: University of Notre Dame Press, 2002.

Hudson, John. The Formation of the English Common Law : Law and Society in England from the Norman Conquest to Magna Carta. Medieval World. London; New York: Longman, 1996.

-. Land, Law, and Lordship in Anglo-Norman England. Oxford Historical Monographs. New York: Oxford University Press, 1994.

- Land, Law, and Lordship in Anglo-Norman England. Oxford: Oxford University Press, 1997.

Huntingdon, Henry of. The Chronicle of Henry of Huntingdon: Comprising the History of England, from the Invasion of Julius Caesar to the Accession of Henry Ii. Also, the Actsof Stephen, King of England and Duke of Normandy. London: H. G. Bohn, 1853. Electronic Book - Not in Copywrite. http://www.archive.org/details/chroniclehenryh01 foregoog.

Jenkins, Dafydd. "The Administration of Law in Medieval Wales: The Role of the Ynad Cwmwd (Judex Patrie)." In Lawyers and Laymen, edited by B. Walters. Cardiff: University of Wales Press, 1986. 
, ed. The Law of Hywel Dda: Law Texts from Medieval Wales, Translated and Edited, The Welsh Classics: Gomer Press, 1986.

Jenkins, Dafydd, and Morfydd E. Owen. The Welsh Law of Women : Studies Presented to Professor Daniel A. Binchy on His Eightieth Birthday, 3 June 1980 [in English]. Cardiff: University of Wales Press, 1980.

Johns, Susan M. Gender, Nation and Conquest in the High Middle Ages : Nest of Deheubarth. Gender in History. New York: Palgrave Macmillan, 2013.

Jones, Heather. "Comparing Historic Name Communities in Wales: Some Approaches and Considerations." In Studies on the Personal Name in Later Medieval England and Wales, edited by Dave Postles \& Joel T. Rosenthal, 211-76. Kalamazoo: Medieval Institute Publications, 2006.

Jones, W. Sinclair. "Caus Castle's Historic Associations." Montgomeryshire Collections 38 (1917): 261-68.

Julian Jones, Melissa. "Family Strategy or Personal Principles? The Corbets in the Reign of Henry lii." Paper presented at the Authority and Resistance in the Age of Magna Carta Conference, Aberystwyth and Lampeter, 2013, 2015.

Klandermans, P. G. "Presidential Address - Identity Politics and Politicized Identities: Identity Processes and the Dynamics of Protest." Political Psychology 35, no. 1 (2014): 1-22.

Lieberman, Max. The Medieval March of Wales: The Creation and Perception of a Frontier, 1066-1283. New York: Cambridge University Press, 2010.

Lozovsky, Natalia. "Geography and Ethnography in Medieval Europe: Classical Traditions and Contemporary Concerns." In Geography and Ethnography, Perceptions of the World in Pre-Modern Societies, edited by Kurt and Richard Talbert Raaflaub, 311-29. Chichester: Wiley-Blackwell, 2010.

Maitland, Sir Frederick Pollock and Frederic William. The History of English Law before the Time of Edward I. 2nd Edition, Liberty Press Reprint ed. Vol. 1, Cambridge: Cambridge University Press, 1898.

- The History of English Law before the Time of Edward I. 2nd Edition, Liberty Fund Reprint ed. Vol. 2, Cambridge: Cambridge University Press, 1898.

Mann, Kevin. "'The March of Wales"." Welsh History Review 18, no. 1 (1996): 1-13.

Martin, Charles Trice, ed. Registrum Epistolarum Fratris Johannis Peckham, Archiepiscopi Cantuariensis. 3 vols. Vol. 2. London: Longman, 1882-1885.

Mitchell, Linda Elizabeth. Joan De Valence : The Life and Influence of a ThirteenthCentury Noblewoman. The New Middle Ages. 
- Portraits of Medieval Women : Family, Marriage, and Politics in England, 1255-1350. New Middle Ages. 1st ed. New York: Palgrave Macmillan, 2003.

Mooers Christelow, Stephanie. "Name and Ethnicity in Anglo-Norman England." In Studies on the Personal Name in Later Medival England and Wales, edited by Dave Postles \& Joel T. Rosenthal, 341-71. Kalamazoo: Medieval Institute Publications, 2006.

Murphy, Kenneth. "The Rise and Fall of the Medieval Town in Wales." In Towns in Decline, Ad 100-1600, edited by T. R. Slater, 193-213. Burlington: Ashgate, 2000.

Owen, D. Huw. "The Middle Ages." In Settlement and Society in Wales, edited by D. Huw Owen, 199-223. Cardiff: University of Wales Press, 1989.

_. "Tenurial and Economic Developments in North Wales in the Twelfth and Thirteenth Centuries." Welsh History Review 6 (1972): 117-42.

Phillips, Chris. "'A Medieval Engish Calendar" in Some Notes on Medieval English Genealogy." www.medievalgenealogy.org.uk/cal/medcal.shtml.

Pierce Jones, T. . "Social \& Historical Aspects of the Welsh Laws." Welsh History Review (1963): 33-49.

Pike, Luke Owen. "Chronicles \& Memorials of Great Britain and Ireland During the Middle Ages." In Dear Books of the Reign of King Edward III Year XV London: HM Stationary Office, 1891.

Postles, Dave. "Identity and Identification: Some Recent Research into the English Medieval "Forename"." In Studies on the Personal Name in Later Medieval England and Wales, edited by Dave Postles \& Joel T. Rosenthal, 29-62. Kalamazoo: Medieval Institute Publication, 2006.

Power, Daniel. The Norman Frontier in the Twelfth and Early Thirteenth Centuries. Cambridge Studies in Medieval Life and Thought. Cambridge ; New York: Cambridge University Press, 2004.

Roberts, Sara Elin. "More Plaints in Medieval Welsh Law." Studia Celtica 48 (2014): 171-99.

Roberts, Sara Elin \& Jones, Bryn. "Cyfraith Hywel." In http://cyfraithhywel.cymru.ac.uk/en/index.php: Research funded by the University of Wales, Website by Coleg Cymraeg Cenedlaethol. 2010-2011.

Gis Visualizer www.gpsvisualizer.com/map_input.

Searle, Eleanor. Predatory Kinship and the Creation of Norman Power, 840-1066. Berkeley: University of California Press, 1988. 
The Shropshire Gazetteer: With an Appendix Including a Survey of the County, and Valuable Miscellaneous Information, with Plates. Wem: T. Gregory, 1824.

Spurgeon. "Gwyddgrug Castle (Forden) and the Gorddwr Dispute in the Thirteenth Century." Montgomeryshire Collections 57, no. 2 (1962): 125-36.

Thomas, Archdeacon. "The Gorther." Montgomeryshire Collections 38 (1917): 185-212.

Wade-Evans, Arthur Wade, ed. Welsh Medieval Law: Being a Text of the Laws of Howel the Good, Namely the British Museum Harleian Ms. 4353 of the 13th Century, with Translation Introduction, Appendix, Glossary Index, and a Map. Oxford: Clarendon Press, 1909. Reprint, University of Toronto Libraries.

Wales, Gerald of. "The Journey through Wales and the Description of Wales." In Gerald of Wales: The Journey through Wales and The Description of Wales, edited by Lewis Thorpe. New York: Penguin. 1978.

Watt, Diane, ed. Medieval Women in Their Communities. Cardiff: University of Wales Press, 1997.

"Welsh Names (Traditional)." http://www.namenerds.com/welsh/trad2.html.

Williams, Glanmor, and R. R. Davies. Welsh Society and Nationhood : Historical Essays Presented to Glanmor Williams [in English]. Cardiff: University of Wales Press, 1984. 
Alexis Miller was born in Port Angeles, Washington in 1981. She spent her childhood in the Pacific Northwest in Portland, OR and Walla Walla, WA, where she attended high school. Her journey to become a medievalist began in her first quarter of college. She was assigned Amy Kelly's Eleanor of Aquitaine and the Four Kings in a class that discussed the role and reality of heroes. She earned a bachelor's degree from Pacific Union College in California in 2003 and immediately began a year-and-a-half term as a volunteer teacher on Majuro, Marshall Islands. When she returned to the United States she earned a Masters of Arts in Teaching and taught secondary social studies for three years before being accepted into the graduate program at the University of Missouri. She graduated with a PhD in Medieval History in May, 2018. 